\title{
FEIÇÕES MINERALÓGICAS DE ROCHAS LAMPROFÍRICAS MESOZÓICAS DA PROVÍNCIA ALCALINA CENTRAL, PARAGUAI ORIENTAL
}

JAIME LEONARDO BÁEZ PRESSER

Orientador: Prof. Dr. Excelso Ruberti

TESE DE DOUTORAMENTO

COMISSÃO JULGADORA

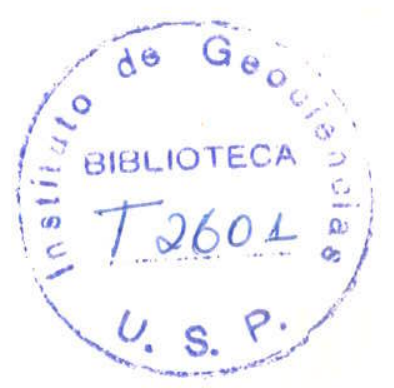

Nome

Assinatura

Presidente: Prof. Dr. Excelso Ruberti

Examinadores: Prof. Dr. Celso de Barros Gomes

Prof $^{\text {a. }}$ Dr $^{\text {a. }}$ Eleonora Maria G. Vasconcellos

Prof ${ }^{\text {a }} \mathrm{Dr}^{\mathrm{a}}$ Mabel Norma Costas Ulbrich

Prof ${ }^{\text {a. }}$ Dr. Marta Silvia Maria Mantovani

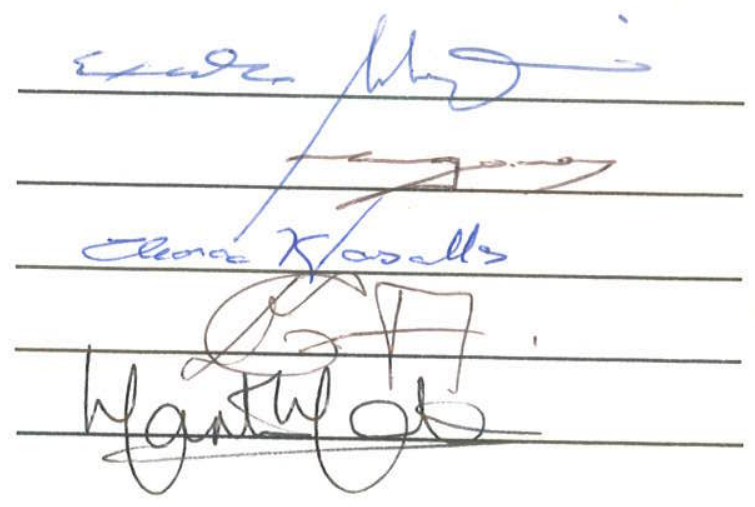

SÃO PAULO

1998 


\title{
UNIVERSIDADE DE SĀO PAULO \\ INSTITUTO DE GEOCIENCIAS
}

\section{FEIÇŌES MINERALÓGICAS DE ROCHAS LAMPROFÍRICAS MESOZÓICAS DA PROVINCIA ALCALINA CENTRAL, PARAGUAI ORIENTAL}

\author{
Jaime Leonardo Báez Presser
}

Orientador: Prof. Dr. Excelso Ruberti

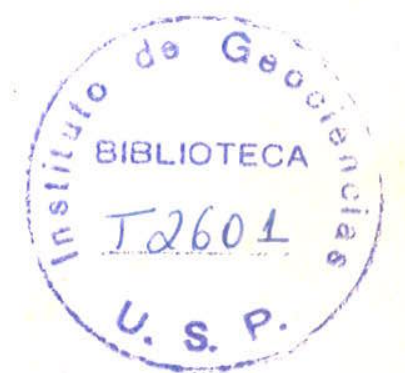

TESE DE DOUTORAMENTO

Programa de Pós-Graduação em Mineralogia e Petrologia

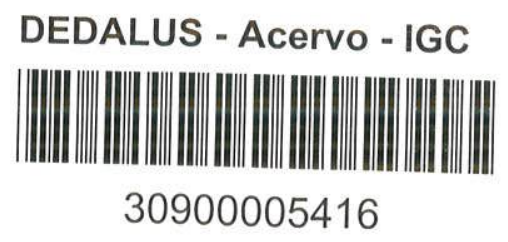




\section{CAPÍTULO 1}

Pagina 1, Parágrafo 3, línha 8 ; trocar associan-se, por associadas,

$3,1,7$; perovsquita, por perovskita,

$5,1,9$; flogopita-kinoshitalita., por flogopita-kinoshitalita,

$14,1,1$; breha-lava, por brecha-lava,

17, Recálculo catiónico, por Recálculo catiônico.

\section{CAPÍTULO 2}

36, 3, 7; Feições sugeririam, por Feições que sugeririam, pseudomorfos,

$55,3,3$; piroxênio e pseudomorfos, por piroxênio mica e

56, 3, 1; Debe-se, por Finalmente com relação às intrusões deve-se,

$65,1,1$; políticos, por pelíticos,

32, De esquerda a direita, as Figuras são: a, b, c.

\section{CAPÍTULO 3}

$82,1,3 ; \quad(0.00-0.08)$ e $\mathrm{Cr}_{2} \mathrm{O}_{3}$, por (0.00-0.08), $\mathrm{Cr}_{2} \mathrm{O}_{3}$,

$84,3,4$; existe existindo, por existindo,

$88,3,4$; analcima>, por analcima,

92, 1, 7; Tabela 3-3., por Tabela 3-3 que permitem,

A2),

98, 1, 1; têm composição (apêndice A2), por são flogopitas (apêndice

ocorrem em,

$98,1,9$; frequentemente ocorrendo, por e frequentemente também

102, 3, 2; Ymi-1, por Yzu-1,

$104,1,5$; segundo o esquema, por segundo zeólitas,

$104,1,7$; diques o denominador comum, por diques, neles sendo o denominador comum,

106, 3, 5;

$108,1,3$

$113,1,2$

$113,1,5$

do centro em para, por do centro para,

lamelas de ilmenita, por lamelas de hematita,

são apresentam, por apresentam

e em outros, por e outros,

116, 2 após Yzu-6 apagar estão enriquecidos em moléculas de diopsídio,

119, 1, 9; Velde, 1986; Cancarix, em Venturelli et al. 1984; Jumilla, em

Venturelli et al, 1991) e, por Velde, 1986); Cancarix, em Venturelli et al. (1984);

Jumilla, em Venturelli et al, (1991) e,

$119,3,1$

$125,1,6$ caraterizam, por caraterizar,

$125,5,1$; perosquita, por perovskita,

Tabela 3-3. Numa, por Tabela 3-3, que numa, 
129, 2, 3; Ti de Fe, por Ti e de Fe,

$131,2,17$; e os teores, por com teores,

131, 2, 18; possuí alto teor, por alto teor,

trata-se de uma,

134, 1, 2; trata-se de uma, por como observado em cristais de leucita,

134, 5, 6; Espanha), por Espanha.,

$138,4,5$; lamproítos, por "lamproítos" e lamprófiros por "lamprófiros",

140,3 ; apagar última linha.

42, 2, 7; (Shang et al., por Zhang et al.,

147,2

Em (a), por Em (b),

$148,1,12$; lamprófiros, por "lamprófiros",

$150,3,16$; lamproítos, por "lamproítos".

\section{CAPÍTULO 4}

$161,4,1$; No G-11, por No G2,

165,1 , -hematia, por hematita,

$168,3,1$; Nos concentrados são, por Nos concentrados abundam,

Referência: Atkinson et al. (1984), Inserir nas "Referências": ATKINSON, W.J.; HUGHES, F.E. \& SMITHM C.B. 1984. A Review of the kimberlitic Rocks of Western Australia. In: KORNPROBST (ed.), Kimberlites and Related Rocks, p. 195-224. Elsevier Press., New York.

\section{CAPÍTULO 5}

$172,1,6 ; \quad$ Como Finnerty (1989), por Finnerty (1989)

$178,3,1, \quad$ Doroshev \& Turkin (1982) e Turkin et al. (1983), por Doroshev \& Turkin (1982) in Brey et al. (1991) e Turkin et al. (1983) in Brey et al. (1991).

\section{CAPÍTULO 6}

$190,1,4 ; \quad$ temeperaturas, por temperaturas,

195, 2, 4; melor, por melhor,

202, 1, 13; esteas, por estas,

$204,1,6 ; \quad$ com, por como,

206, $4 \quad$ como em 3-2, por legenda como em 3-2,

210, 2, 6; este, por neste,

212,3 ; apagar última linha,

$214,4,3$; a moderados (Yzu-2), por a moderados (Yzu-6),

pressão, $216,2,11$; a pressão subestimação da, por a subestimação da

222, 1, 2; $\quad$ grupo, por grupo III (plagileucito),

$223,2,2$; evento térmico na, por evento térmico (subdução) na,. 
Apêndlice A11, Tabela de análises qứmicas dos cristais de diamante e zarcão pertencentes aos pipes YMI-1 (1-7) e YMI-8 (10-22). Observou-se nos cristais $2,3,12,13,21$ e 22 flourescência azul cobalto.

$\begin{array}{ccc}\begin{array}{c}\text { n. de } \\ \text { anal. }\end{array} & \mathrm{SiO}_{2} & \mathrm{ZrO}_{2} \\ \mathbf{1} & 0,22 & \\ \mathbf{2} & 1,12 & \\ \mathbf{3} & & \\ \mathbf{4} & 0,73 & \\ \mathbf{5} & 0,11 & \\ \mathbf{6} & 6,57 & \\ \mathbf{7} & \underline{37,36} & \\ & & \\ \mathbf{1 0} & \underline{37,72} & 1,01 \\ \mathbf{1 1} & 0,56 & 0,32 \\ \mathbf{1 2} & 0,26 & 0,14 \\ \mathbf{1 3} & 2,03 & 69,12 \\ \mathbf{1 4} & \underline{31,11} & 0,02 \\ \mathbf{1 5} & 0,03 & 1,03 \\ \mathbf{1 6} & 0,4 & 0,34 \\ \mathbf{1 7} & 1,02 & 0,33 \\ \mathbf{1 8} & 0,31 & 0,17 \\ \mathbf{1 9} & 3,16 & 1 \\ \mathbf{2 0} & 0,38 & 0,04 \\ \mathbf{2 1} & 0,09 & \\ \mathbf{2 2} & 0,17 & \\ \mathbf{2 3} & 0,03 & \\ \mathbf{2 4} & 0,17 & \\ \mathbf{2 5} & 8,39 & \end{array}$




$$
\begin{aligned}
& \text { "Buscarrei refúgio em Buddhat } \\
& \text { - a mente onisciente de Shaldham } \\
& \text { - suar infinitar sabharma }
\end{aligned}
$$

Procur - aqueles que treingm e no Sariagh emsinamemitos,

$$
\text { e no Sanghat }
$$

Assim, por farei por completo messas trem os ensinamentos dele.

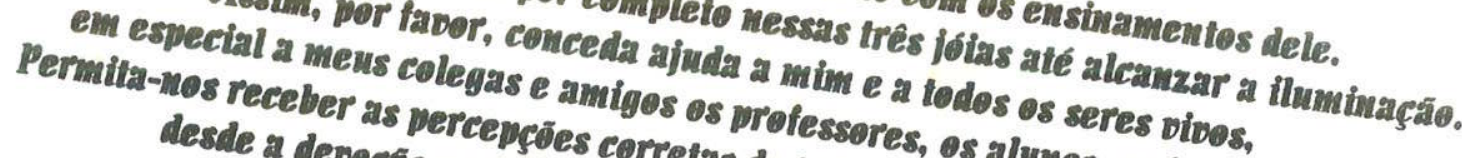
descle a depos percepcées corretas de todoes, os alumos, os tivos,

a devofrato ao Guru atte a reas de todos os pontos do os funcionaírios.

$$
\text { igcato fingal do pleno despertar" graduado, }
$$

Ta ya tha om muni man 


\section{Agradecimentos}

A consecução deste projeto de pós-graduação (nivel doutorado) em toda sua extensão tornou-se factivel graças à inestimável cooperação de instituições e pessoas, prestadas na forma de auxílios financeiros e de serviços, e de pequenos e grandes gestos de colegas e amigos prestados através de uma desinteressada cooperação

obrigado!l!

desta forma deixo aqui registrado a cada um em especial muitissimo

À Fundacão de Amparo à Pesquisa do Estado de São Paulo-FAPESP, através do projeto "Petrologia e geoquímica de rochas alcalinas" (Proc. 97/01210-4),

Conselho Nacional de Desenvolvimento Científico e Tecnológico-CNPg (três anos de bolsa) e

Coordenação de Aperfeicoamento de pessoal de nivel Superior-CAPES (um ano de bolsa), pela assistência financiera que possibilitou a concretização desta tese.

Aos Professores Celso de Barros Gomes, Cláudio Ricomini, Umberto G. Cordani, Horstpeter H. Ulbrich, Marta Mantovani, Jorge Bittencourt e A. Romalino Fragozo Cesar que aportaram contribuições a este trabalho.

À Professora Gianna Garda receba pelas sugestões e inestimáveis contribuições a este trabalho muitiiiissimoooooo obrigado!!!.

Ao Professor Excelso Ruberti, orientador desta tese, receba pelas contribuições pequenas e grandes deste cinco anos de trabalho conjunto um obrigado do tamanho do sol!!!!

Aos colegas do departamento (DMP) e amigos do IGc, pela inestimável ajuda, recebam com carinho meus agradecimentos!

Patricia e William, a vocês, pela imensa amizade e ajuda constante. o mais gentil e carinhoso obrigado!!!. 


\section{ÍNDICE}

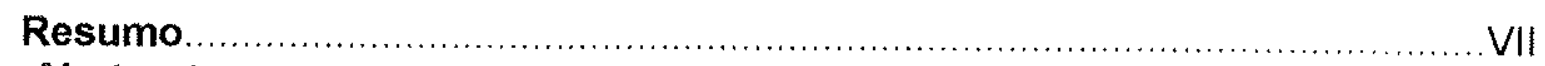

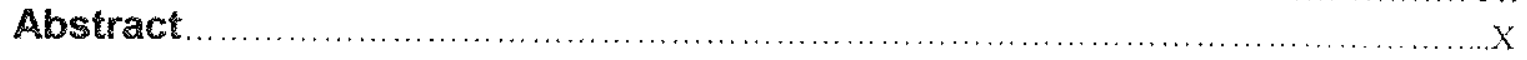

Introdução ao problema.

\section{CAPITULO I - Introdução ao probiema}

Objetivos

Localização da área.

Métodos Utilizados ................................................................. 13

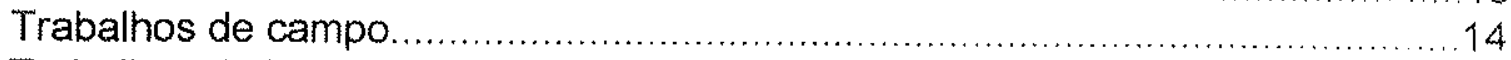

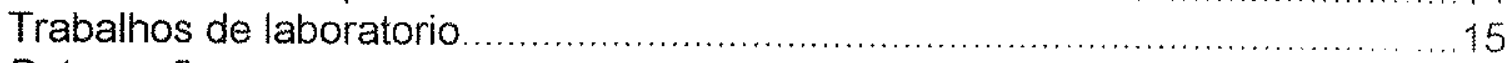

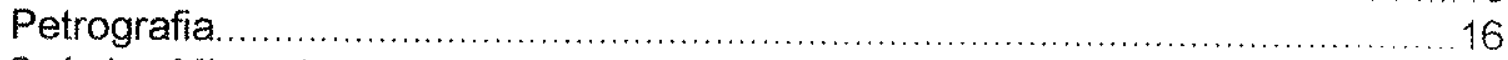

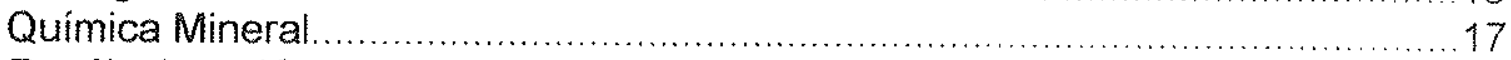

Recálculo catiónico mineral e classificações............................................. 17

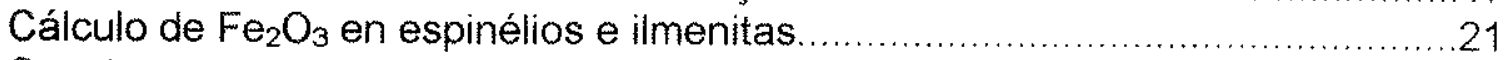

Constantes e razões........................................................................... 22

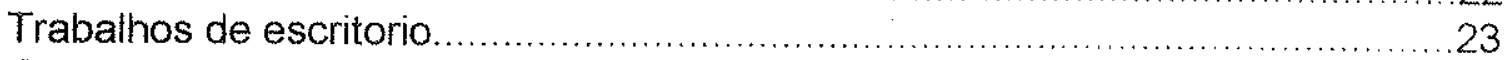

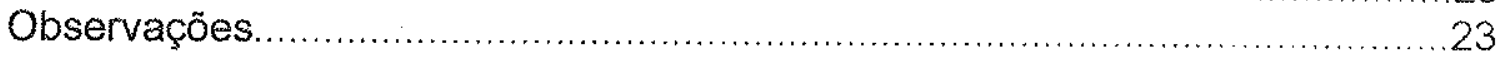

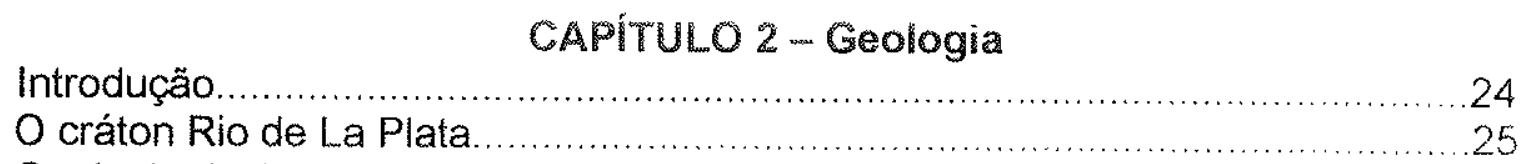

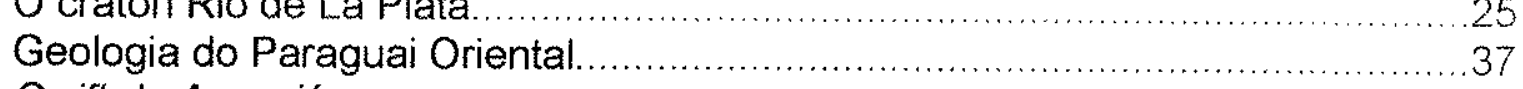

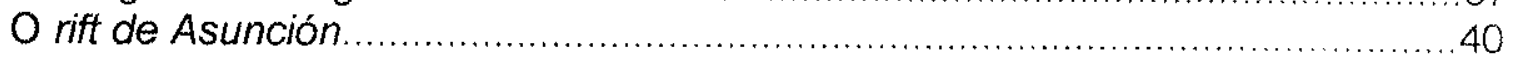

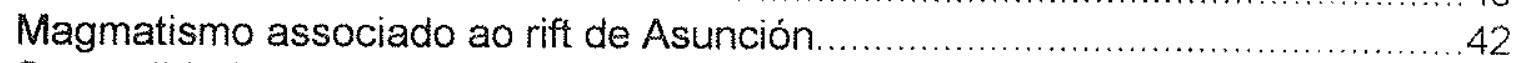

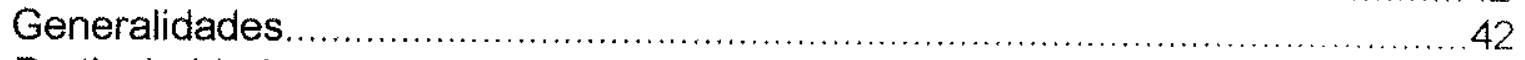

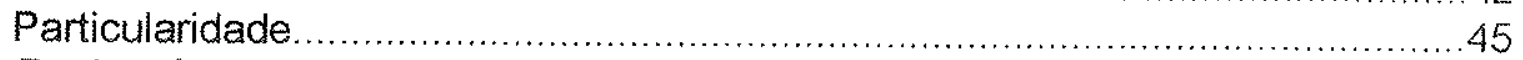

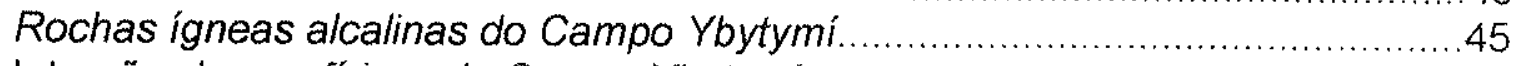

Intrusões lamprofíricas do Campo Ybytymí .............................................46

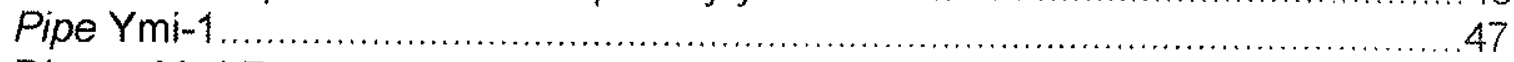

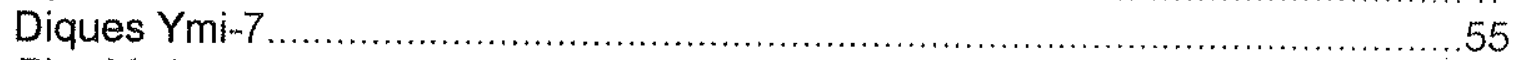

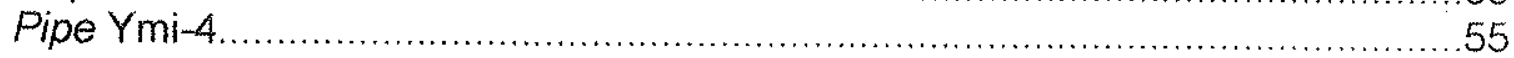

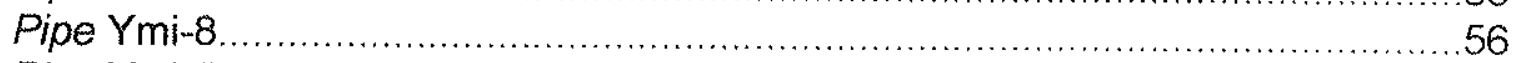

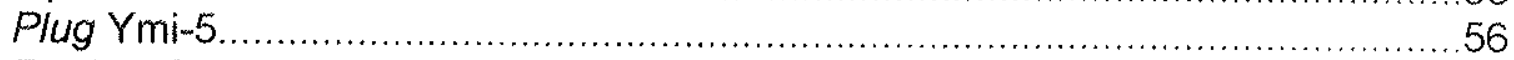

Rochas ígneas alcalinas do Campo Ybytyruzú.............................................59

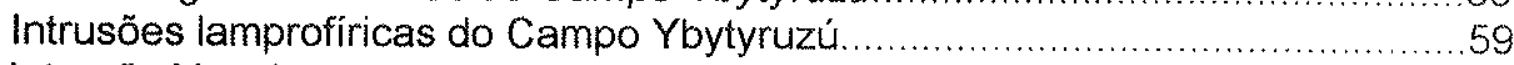

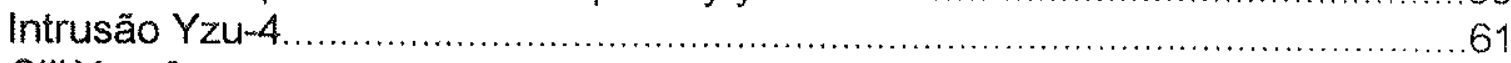

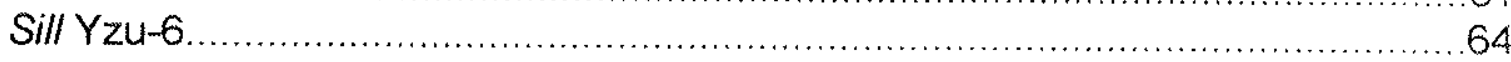

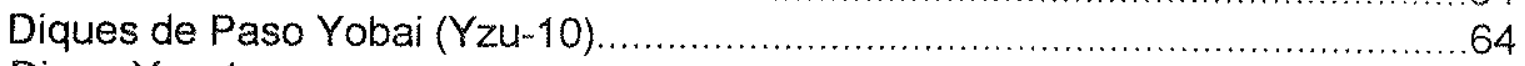

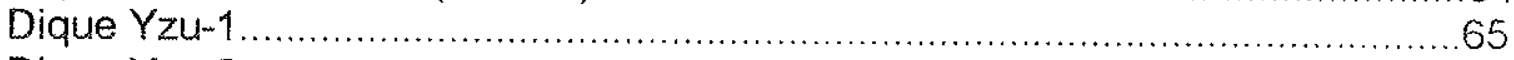

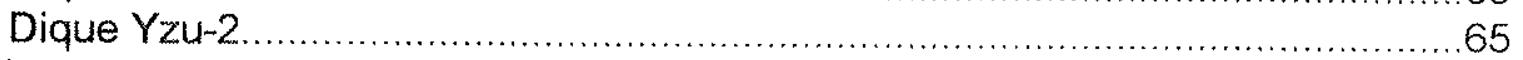

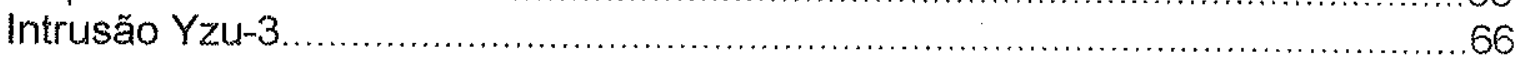




\section{CAPÍTULO 3 - Petrografia e química mineral}

Introdução

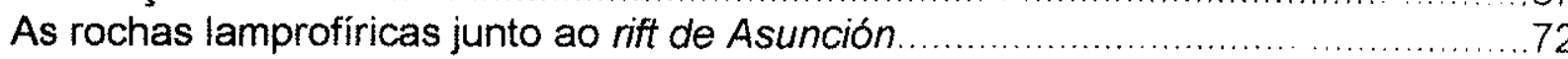

"Lamprófiros".

Olivina "lamprófiros"

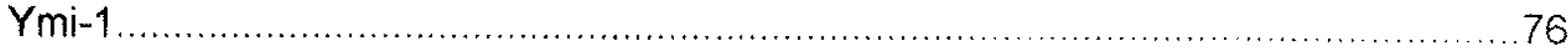

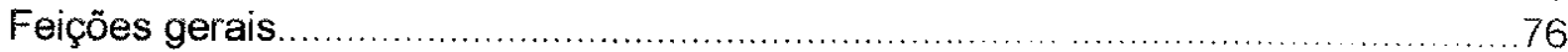

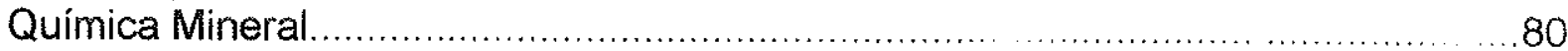

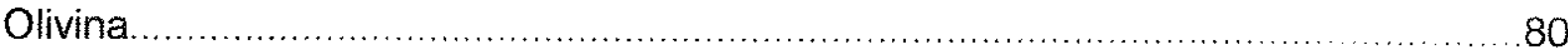

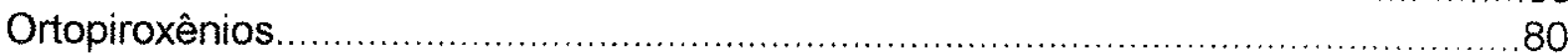

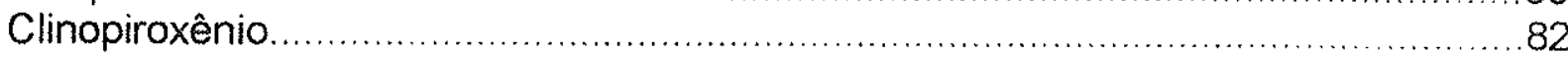

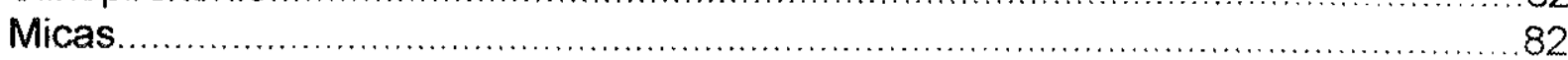

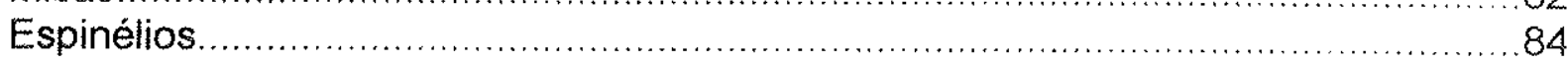

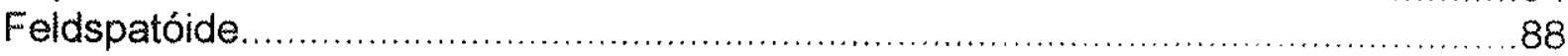

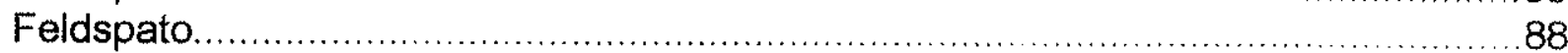

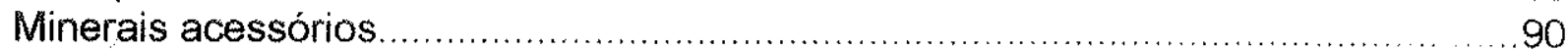

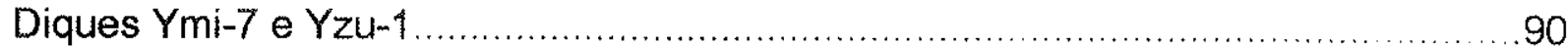

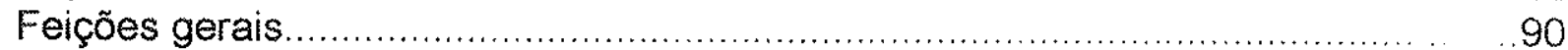

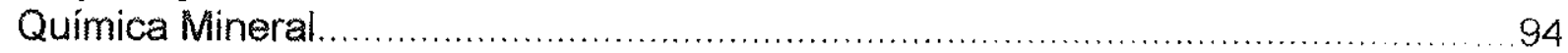

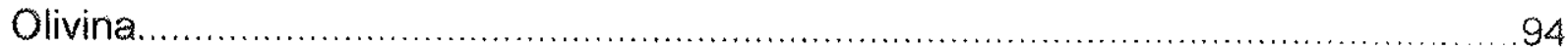

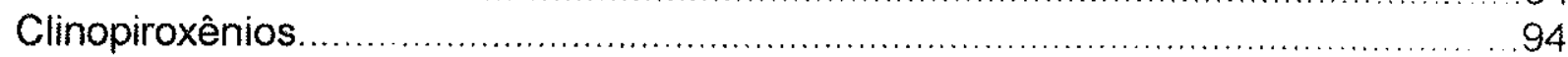

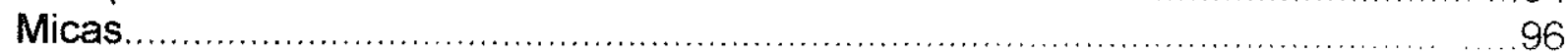

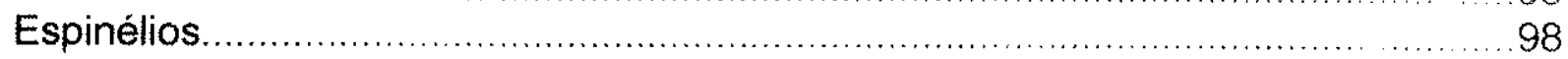

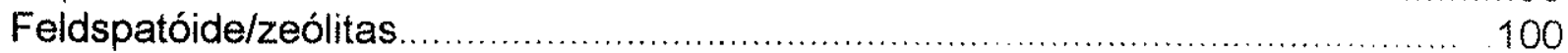

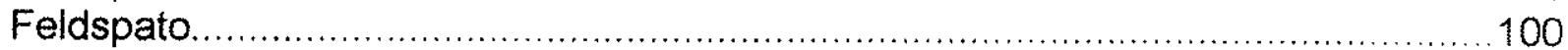

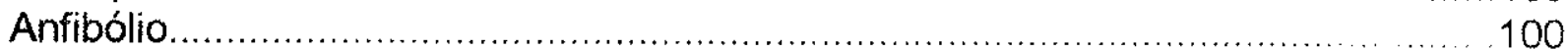

Mica "lamprófiros"

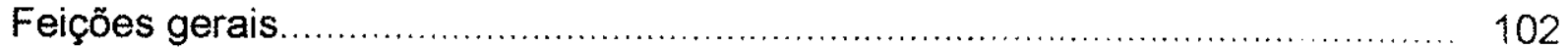

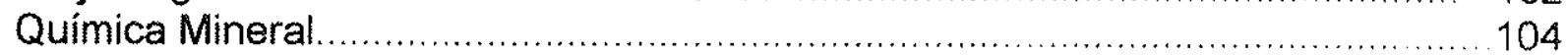

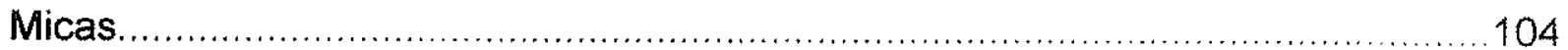

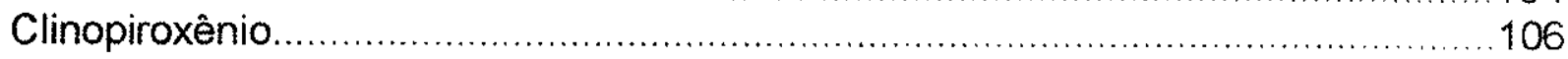

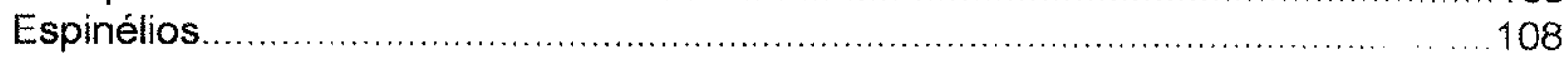

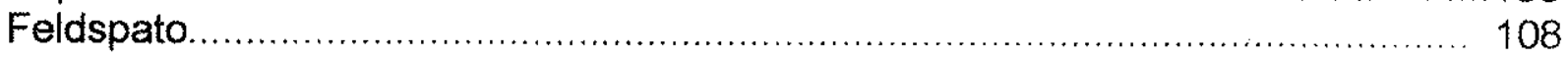

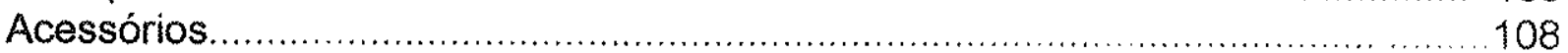

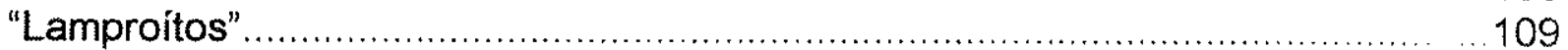

Mica "Lamproítos" ......................................................................... 111

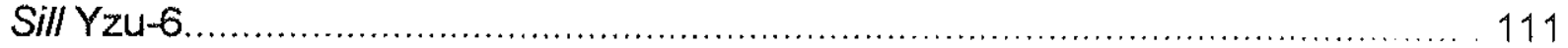

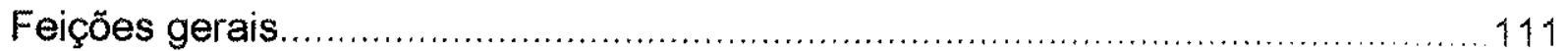

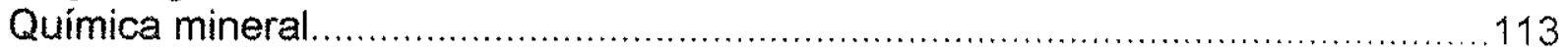

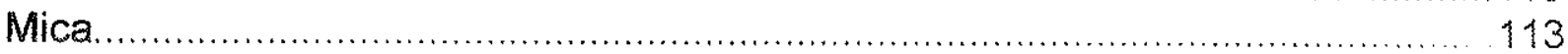

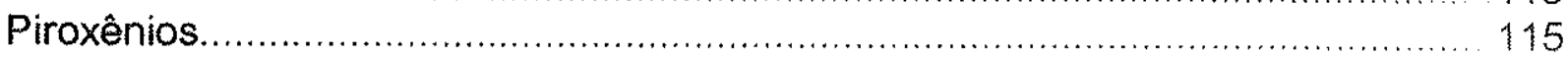

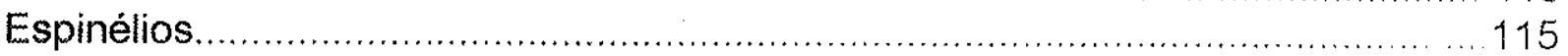

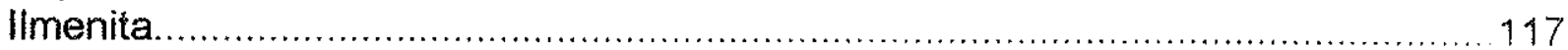

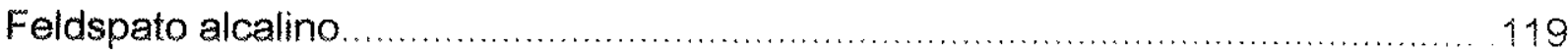




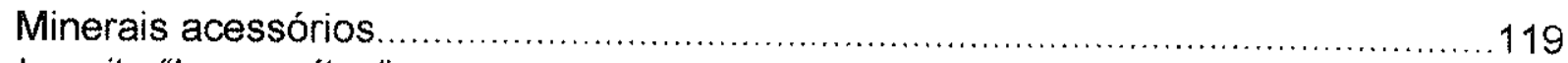

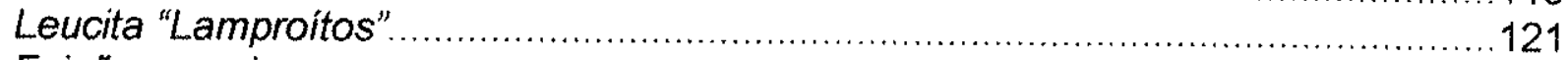

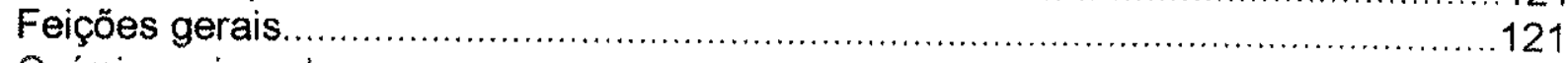

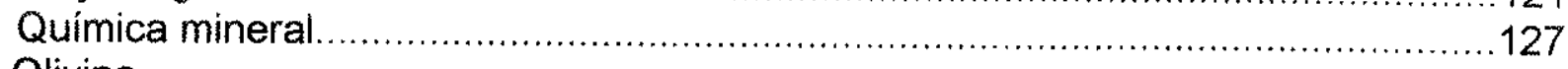

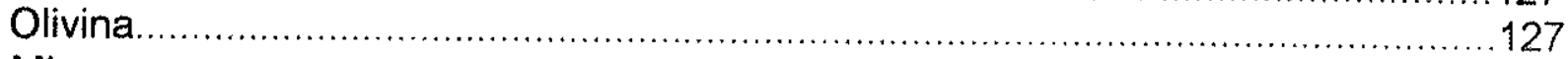

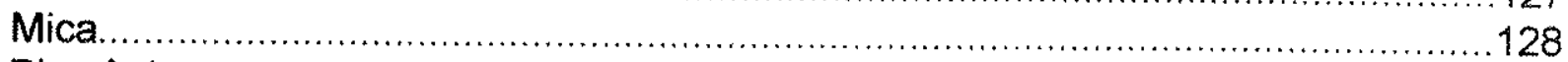

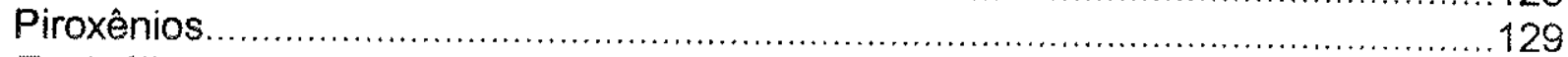

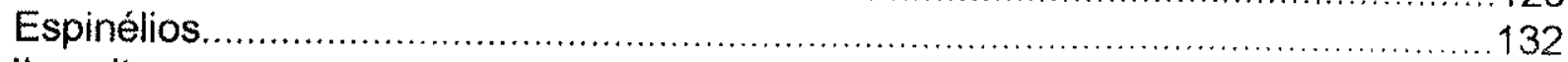

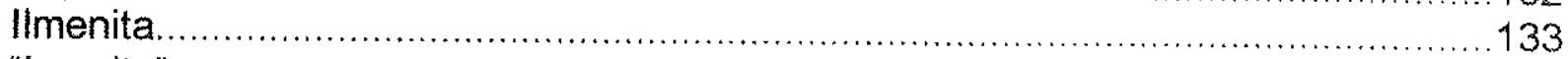

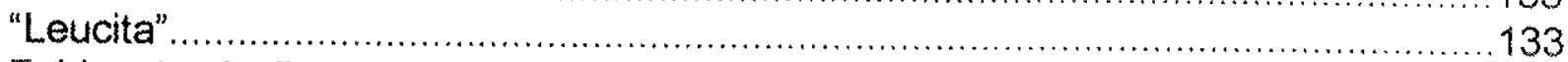

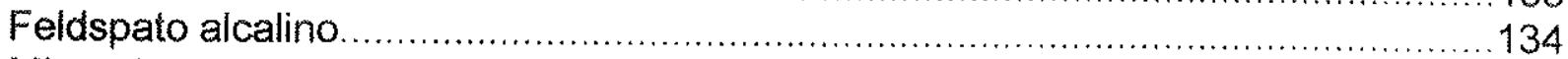

Minerais acessórios ......................................................................... 135

Solução Sólida, Substituições em Micas,

Piroxênios, Espinélios e Feldspatos.................................................. 136

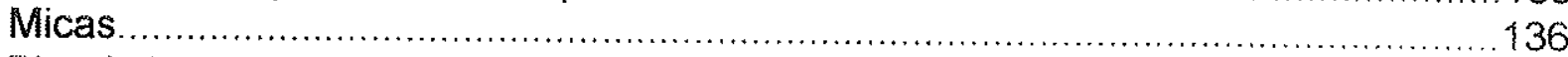

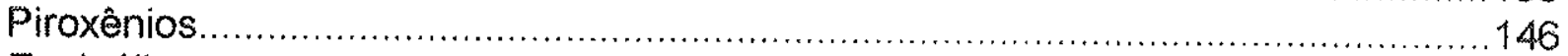

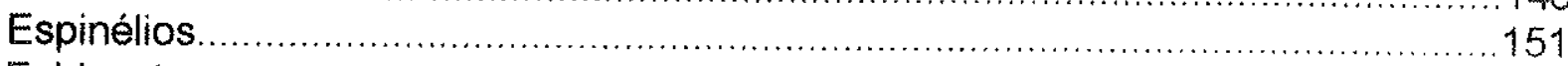

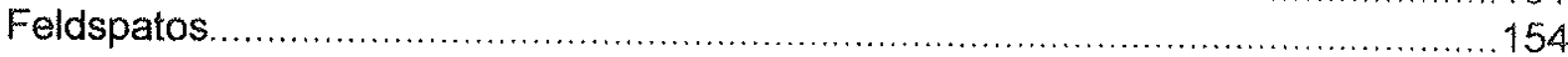

CAPITULO 4 - Potencial Econômico

Pipe Ymi-1

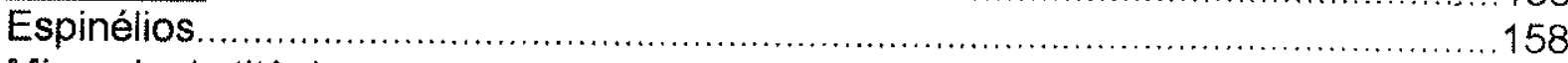

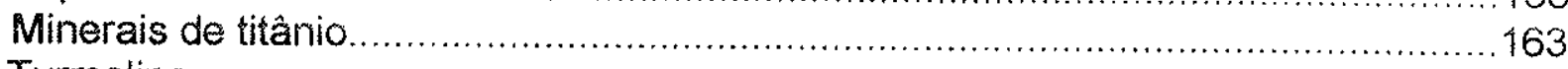

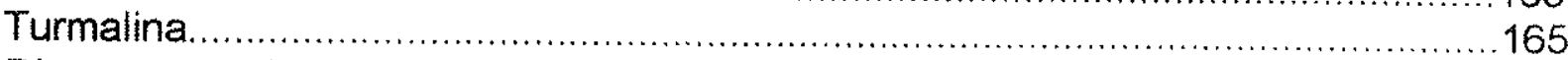

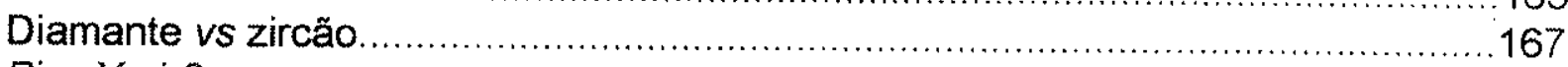

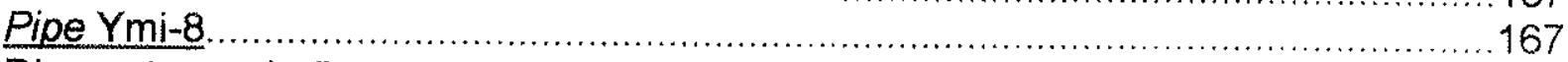

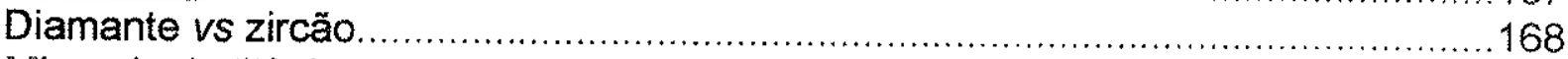

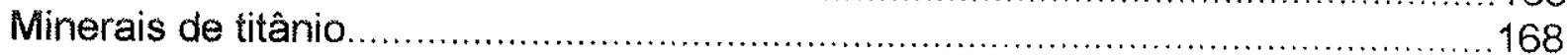

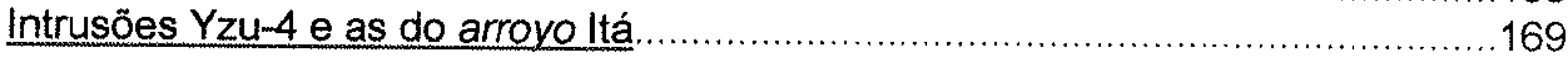

Termobarometria

CAPÍTULO 5 - Considerações Físico-Quimicas dos Pipes

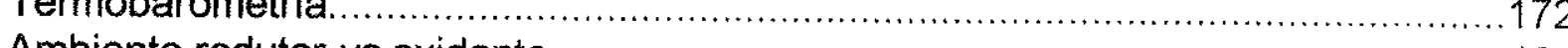

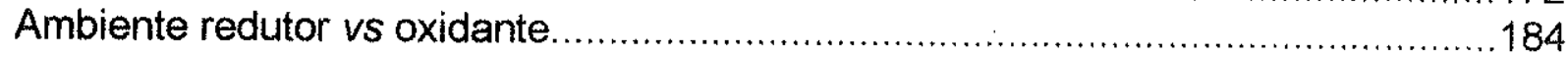

CAPÍTULO 6 - Consideraçöes e conclusões

Aspectos geodinâmicos sobre o assoalho da Bacia do Praná:

- Paraguai Oriental.

Relaçōes geodinâmicas com relação as intrusões estudadas...................................197

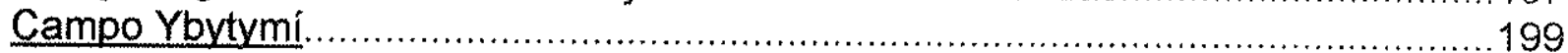

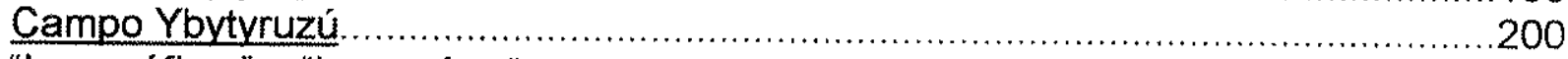

"Lamprófiros" e "lamproitos" vs outras rochas alcalinas:

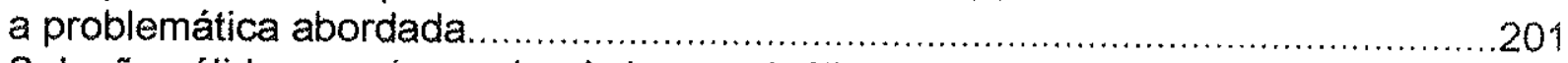

Solução sólida em micas, piroxênios, espinélios e feldspatos ..............................211

Condições termodinámicas acusadas nas rochas estudadas.................................215

Potencial económico que as rochas estudadas sugerem .....................................217 


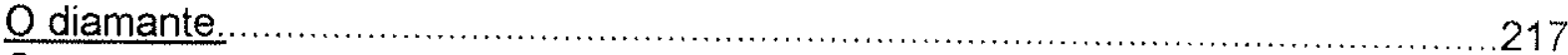

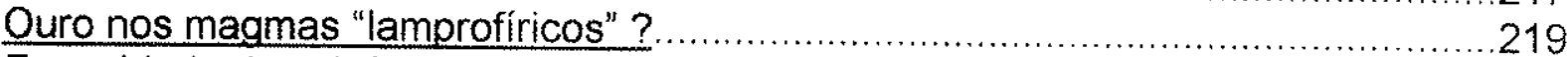

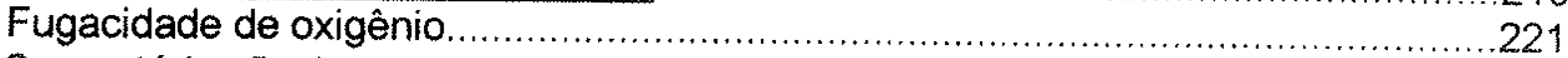

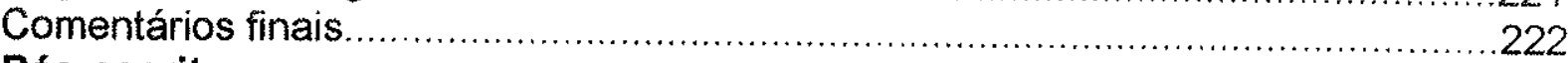

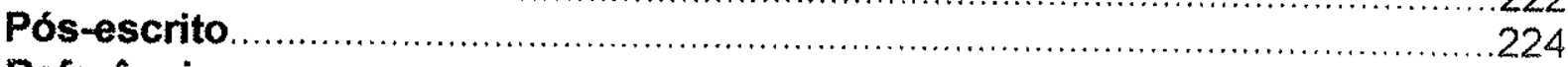

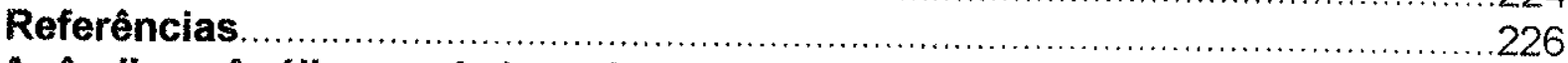

Apêndice -Análises químicas dos minerais.

dos "lamprófiros" e dos "lamproítos"

\section{Figuras}

Figura 1-1 Toponimia e localização dás áreas estudadas

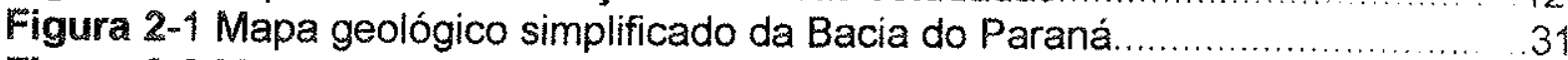

Figura 2-2 Mapa geológico geotectónico esquemático da Bacia do Paraná.............32

Figura 2-3 Mapa gravimétrico do embasamento da Bacia do Paraná....................33

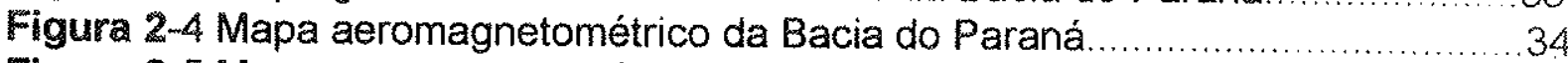

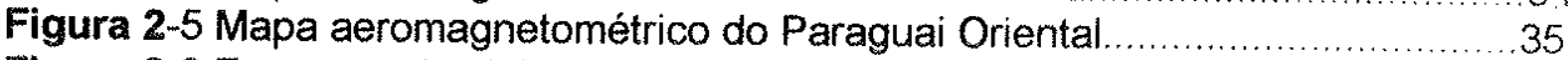

Figura 2-6 Esquema simplificado das unidades gelógico-estruturais

no Paraguai Oriental e as províncias alcalinas.

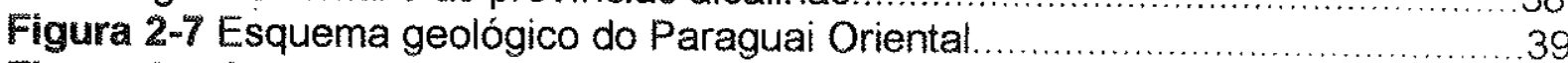

Figura 2-8 Corpos de rochas alcalinas no rift de Asunción...................................48

Figura 2-9 Mapa litológico do Valle de Acahay e vizinhanças..................................49

Figura 2-10 O pipe Ymi-1 na área de Kiritó.................................................. 54

Figura 3.1 Nomenclatura dos espinélios no prisma multicomponente ......................68

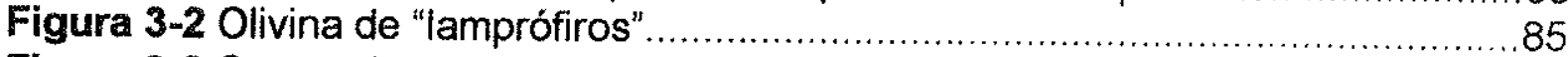

Figura 3-3 Composição dos piroxênios de "lamprófiros"

no diagrama de classificação do IMA.

Figura 3-4 Enriquecimento em termos de Ti e Al

nos piroxênios dos "lamprófiros".

Figura 3-5 Classificação das micas

no diagrama Flogopita-Anninta-Eastonita-Siderofilita.

Figura 3-6 Diagrama de variação Al vs Ti e Al vs Fe

das micas das rochas lamprofíricas.

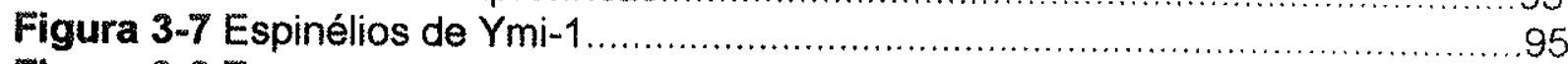

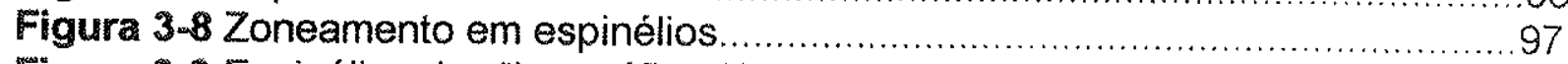

Figura 3-9 Espinélios dos "lamprófiros" Ymi-4, Ymi-7 e Yzu-1 ...................................99

Figura 3-10 Feldspatos dos "lamprófiros".................................................. 101

Figura 3-11 Anfibólios nos "lamprófiros" .................................................... 103

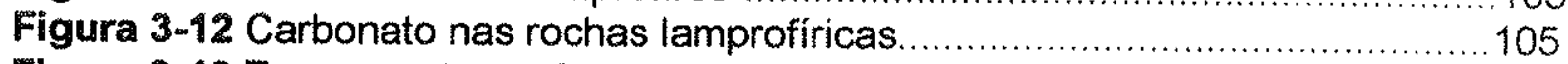

Figura 3-13 Zoneamento em fenocristais de mica.......................................... 107

Figura 3-14 Olivina dos "lamproitos".......................................................... 114

Figura 3-15 Piroxênio dos "lamproítos" ....................................................... 116

Figura 3-16 Enriquecimento em Ti vs Al em piroxênio dos "lamproítos" .................118

Figura 3-17 Espinélios dos "lamproítos"..................................................... 120

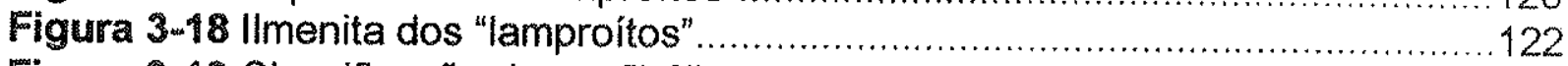

Figura 3-19 Classificação dos anfibólios que ocorrem nos "lamproítos"...............124 
Figura 3-20 Feldspato dos "lamproitos".

Figura 3-21 Relação entre os sítios catiônicos nas micas

dos "lamprófiros" e dos "lamproítos"

Figura 3-22 Substituições em micas dos "lamprófiros" e "lamproitos" .......................139

Figura 3-23 Substituições do Ti nas micas ......................................................141

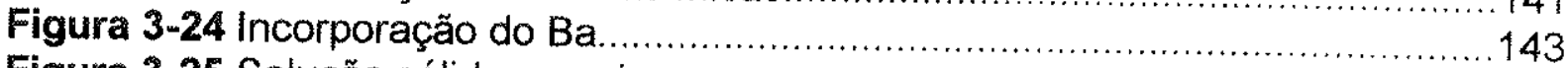

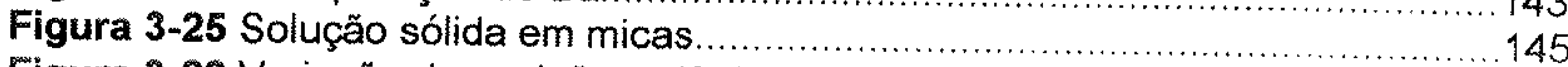

Figura 3-26 Variação da posição catiônica em piroxênios

de "lamprófiros" e "lamproítos".

Figura 3-27 Distribuiçäo catiônica em piroxênios de "lamprófiros" e "lamproitos" ... 149

Figura 3-28 Campo dos espinélios em "lamprófiros" e "lamproítos" ...................... 152

Figura 3-29 Diferença entre os espinélios em função de

log. Al2O3-demais óxidos nas rochas potássicas do rift de Asunción...

Figura 4-1 Xenocristais e cristais magmáticos de espinélio

Figura 4-2 Espinélios da fácies do diamante de espinèlio................................160

Figura 4-3 Mineraios da facies do diamante ..............................................162

Figura 4-4 imenita de titanio ............................................................... 164

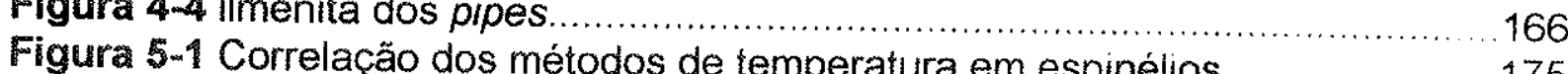

Figura 5-2 Histogramao dos métodos de temperatura em espinélios .....................175

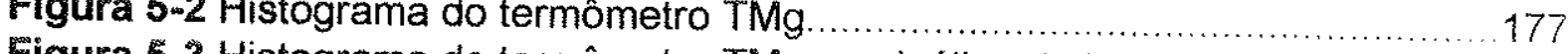

Figura 5-3 Histograma do termômetro TMg: espinélios do Paraguai......................179

Figura 5-4 P-T em espinélios..................................................................... 181

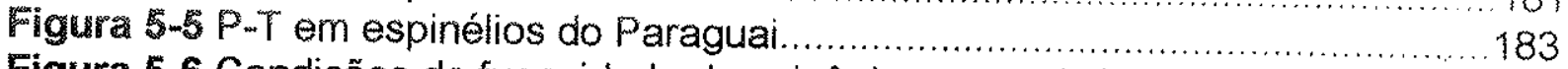

Figura 5-6 Condições de fugacidade de oxigênio nos espinélios ............................... 185

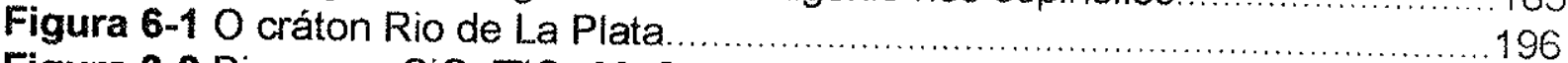

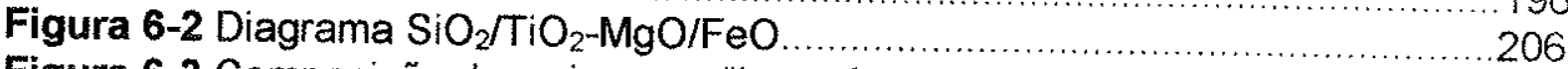

Figura 6-3 Composição das micas em "lamprófiros" e "lamproítos" .............................208

\section{Fotografias}

Fotografia 1 Imagem (falsa cor) da borda W do rift de Asunción...........................51

Fotografia 2 Cópia da fotografia aérea 1:50.000 do __.......................................52

Fotografia 3 Paisagem sobre o pipe Ymi-1 ..........................................................53

Fotografia 4 Poço de inspeção na fácies epiclastica situado a SW do pipe Ymi-1...53

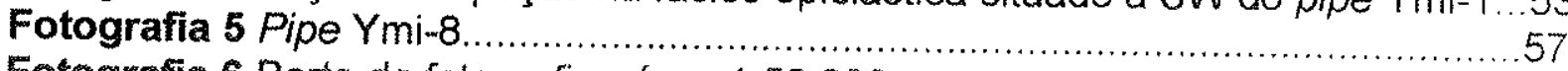

Fotografia 6 Parte da fotografia aérea 1:50.000 _

Fotografia 7 Imágem de satélite, branco e preto (canal 5),

do bloco Oriental do rift de Asunción.

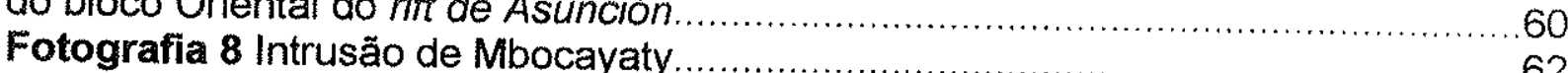

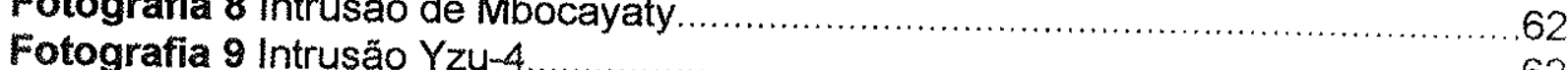

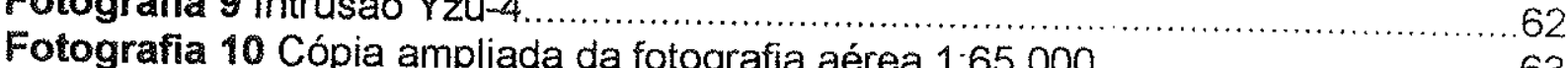

Fotografia 10 Cópia ampliada da fotografia aérea 1:65.000__.......................63

Fotomicrografia

Fotomicrografia 2 Detalhes texturais dos "lampón. ............................................77

Fotomicrografia 3 Fenos texturais dos lamprófiros ........................................79

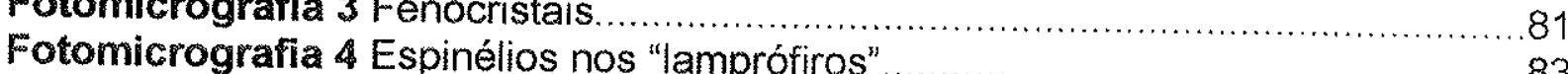

Fotomicrografia 5 "Lamprotos 
Fotomicrografia 6 "Lamproíto" Yzu-2

Fotomicrografia 7 Minerais pesados do pipe Ymi-1 ...........................................157

Fotomicrografia 8 Concentrado de minerais pesados do arroyo ltá (YZu-10) ......170

\section{Tabelas}

Tabela 1-1 Comparação entre as variedades de rochas "lamprofíricas",

kimberlitos, orangeítos e lamproítos.

Tabela 1-2 Minerais comuns em kimberlitos, orangeitos, lamproitos e lamprófiros cálcio-alcalinos, alcalinos e ultramáficos

Tabela 2-1 Características geológicas dos crátons, conforme Brito-Neves (1995)...25 Tabela 2-2 Algumas características geofísicas dos crátons, conforme Brito-Neves (1995)

Tabela 2-3 ldades dos corpos intrusivos das três regiões

Tabela 2-4 Intrusões lamprofíricas relacionadas e/ou que ocorrem junto ao rift de Asunción.

Tabela 3-1 Composição quimica do grupo dos espinélios.

Tabela 3-2 Dados geoquímicos das rochas potássicas a ultrapotássicas vinculadas com o rift de Asunción

Tabela 3-3 Análises modal estimada dos "lamprófiros" e "lamproitos" 


\section{Resumo}

O presente trabalho tem por objetivo primordial a caraterização, com base em dados petrográficos e de química mineral, das rochas "lamprofíricas" do Mesozóico ( 130 Ma.) que ocorrem na Província Alcalina Central do Paraguai CentromOriental. Os estudos da petrografia e química mineral, centralizaram-se em alguns corpos dispostos em dois campos separados: Campo Ybytymí a oeste -Ymi-1, Ymi-4, Ymi-5, Ymi-7 e Ymi-8; Campo Ybytyryzú a leste -Yzu-1, Yzu-2, Yzu-3 e Yzu-6. Um grupo adicional de corpos (Yzu-4, Yzu-10) é apresentado em uma descrição preliminar das feições minerais e petrográficas macroscópicas.

Os dados gravimétricos definiram para o assoalho da Bacia do Paraná, o cráton Rio de La Plata, um mosáico de blocos soldados por cinturões. O fragmento do embasamento exposto a $W$ do Paraguai, conhecido como Alto de Caapucú, os dados geocronológicos são escassos (0.5m0.78 $G a$ a $2.1 \mathrm{Ga}$ ), e esta corresponde porção $W$ do cráton Rio de la Plata. Os dados sísmicos apontaram para o Paraguai Oriental e regióes vizinhas do Brasil hipocentros profundos, evidenciando assim sismicidade típica de zonas de baixo fluxo de calor, comparáveis com regiões cratônicas do escudo canadense. Estes dados identificaram também profundidades de Moho oscilando entre 38 e $48 \mathrm{~km}$. Já os dados de fluxo térmico superficial $\left( \pm 40 \mathrm{mWm}^{-2}\right)$ definem um fluxo de calor também característico de regiões cratônicas.

Dentre os blocos gravimetricamente definidos no cráton Rio de La Plata, destaca-se o bloco Paranapanema, estrutura definida como um bloco que possui uma litosfera espessa e resistente (crátonic-like block), com largura em torno de $1600 \mathrm{~km}$ e espessura variável de $\sim 300$ a $600 \mathrm{~km}$. Este bloco adentra-se por vários quilômetros no território paraguaio e hospeda na sua borda o rift de Asunción, i.e. um rift pericratônico. Associados a esta estrutura ocorrem os corpos do Campo Ybytymí e Ybytyruzú

Na borda pericratônica do bloco a $W$, entre as intrusões do Campo Ybytymí ocorrem:

O pipe Ymi-1, que possui forma grosseiramente bilobulada a irregular e dimensões de $2050 \mathrm{~m}$ por 1200 e $880 \mathrm{~m}$. Onde ocorrem sedimentos vulcano-epiclásticos em topografia planoondulada onde obtebe-se concentrados de minerais pesados como picro-cromila, cromita, magnetitas, pseudobrookita, ilmenita, rutilo, rutilo de $\mathrm{Nb}$ (niobífero), turmalina, diamante, zircão, piroxênio e traços de granada. E plug de rochas sub-vulcânicas porfiríticas escuras e diques interiores (Ymi-1/d) e exteriores (Ymi-1c) ao pipe possuindo a mesma composição petrográfica: uma variedade de lamprófiro picrítico (olivina 10 a $25 \%$ ) cálcio-alcalino ("kentallemito") composto de fenocristais/microfenocristais de olivina ( $\mathrm{F}_{922-75}$ ), diopsídio (titanífero-aluminoso), flogopita (titanifera-aluminosa, Ymi 1c), hornblenda magnesiana e cromita, imersos em uma matriz fina de sanidina (sódica em parte), magnetita titanifera magnesiana, magnetita titanífera, diopsídio (titanífero-aluminoso), flogopita-biotita (titanífera), carbonato e acessórios de apatita, plagioclásio, hornblenda magnesiana, eckermanita, analcima e rutilo.

Vários diques, com possança decimétrica, paralelos segundo E-W (Ymi-7) de uma variedade de lamprófiro cálcio-alcalino ("kentallemito") com micro-xenólitos peridotíticos, formada por fenocristais/microfenocristais de olivina ( $\mathrm{F}_{3558}$ ), diopsídio (titanífero-aluminoso), hornblenda e flogopita (titanifera-aluminosa) imersos em uma matriz fina essencialmente de sanidina, magnetita titanifera magnesiana, magnetita titanífera, diopsidio (titanífero-aluminoso), analcima, homblenda e acessoriamente apatita, mica e carbonato.

O pipe Ymin têm cerca de $1258 \mathrm{~m}$ de comprimento e possue forma bilobulada. Que conta com fácies de lava de coloração roxa, fortemente vesiculada, de aspecto lamprofírico, cortadas por fácies de brecha (autolitica de conducto) e alguns diques de rocha algo vesiculada de aspecto lamprofírico. As rochas compõem-se de uma variedade de lamprófiro cálcio-alcalino formado por fenocristais/microfenocristais de olivina serpentinizada, flogopita (titanífera-aluminosa), diopsídio (titanífero-aluminoso) e magnetita titanífera magnesiana imersos em uma matriz muito

$$
\text { is axtensono }
$$


fina a fina formada de sanidina, magnetita titanífera e acessórios de diopsidio (titaniferoaluminoso), apatita, carbonato e zeólitas. Os lamprófiros desta inurusão são variedades melhor definidos como minette.

O pipe Ymi-8, apresenta-se nas fotografias aéreas como uma estrutura bilobulada com comprimento de 2750 por $1250 \mathrm{~m}$ (lóbulo $\mathrm{N}$ ) e $1150 \mathrm{~m}$ (lóbulo $\mathrm{S}$ ). Onde ocorrem predominantemente sedimentos vulcano-epiclásticos e ocorreriam fácies sub-vulcânicas (plug). A sua caraterização foi preliminarmente definida como um lamprófiro comparável ao Ymi-1, com base na suite de minerais pesados (pseudobrookita, ilmenita, rutilo, zirção, diamante $e$ traços de espinélio, piroxênios e granadas).

O plug Ymi-5, representa uma variedade de lamproito transicional (entre lamproíto e plaguileucíto), uma intrusão com diâmetro de $200 \mathrm{~m}$. Esta uma rocha basaltóide cinza, fortemente porfiritica, com feno-megacristais branco a turquesa esbranquiçados de glomérulos de "leucita" pseucomorfisada, junto a diopsídio (titanífero a titanado-aluminoso), olivina (serpentinizada) e magnetita titanífera magnesiana, imersos em uma matriz fina de sanidina (rica em Ba), diopsidio (titanifero-aluminoso a pobre em Al), magnetita titanífera, biotita (titanífera-pobre em $\mathrm{Al}$, a aluminosa e rica em $\mathrm{Ba}$ ), com acessórios de apatita, perovskita $\mathrm{e}$ anfibólio (potássico-titanífero). A rocha representa um olivina sanidina diopsidio leucita lamproito.

No segmento Oriental, junto ao bloco Paranapanema, encontram-se as intrusões do Campo Ybytyruzú entre as quais ocorrem:

O dique Yzu-1, que possue possança decimétrica e compõe-se de uma rocha porfirítica com aspecto basaltóide bastante fresca. Trata-se de um lamprófiro picritico (olivina $\sim 15 \%$ ) calcio alcalino ("kentallemito") com fenocristais de olivina (Fo89-75), diopsídio (pobre em Al) e flogopita (titanifera-aluminosa) imersos em matriz formada por analcima, sanidina (rica em Fe)anorfoclásio, magnetita titanffera magnesiana, magnetita titanffera e acessórios de apatita $e$ carbonato.

A intrusão Yzu-4 têm forma de pipe e compõe-se de dois fácies petrográficas: uma lamprofirica e outra basaltóide. A suite de minerais pesados apresentam ilmenita, piroxênios, espinélios e mica.

O conjunto de diques Yzu-10, com possança decimétricas a métricas, têm marcado carater lamprofírico e frequentemente encontram-se alterados, associa-se a filóes de quartzo aurifero, que se concentram nos rios da região junto a minerais pesados como ilmenita, zircão, espinélios, granada e ilmenita.

O dique Yzu-2, é representado por uma variedade de lamproíto ${ }_{s s} \mathrm{com}$ possança decimétrica, possuindo abundantemente pontilhados de leucita pseudomorfiçada de cor branco beje acompanhados por fenocristais de olivina (FO ${ }_{85-81}$ ), diopsidio (pobre em Al) e flogopita (titanifera) imersos em matriz fina de sanidina (rica em $\mathrm{Fe}$ ), flogopita-biotita (titanifera-pobre em $\mathrm{Al}$ ), diopsídio (pobre em Al), magnetita titanifera magnesiana, ilmenita e acessórios de eckermatita ferrosa (potássica-titanífera) e apatita. Trata-se de um olivina-sanidina-flogopita-diopsídio-leucita lamproito.

A intrusão Yzu-3 (Mbocayaty) é formada lavas brechosas porfíriticas escuras, de aspecto basaltóide, com uma aparente direção de fluxo segundo NNE. São variedades de lamproíto ${ }_{s s}$ com fenocristais/microfenocristais de olivina ( $\left.\mathrm{Fo}_{83-81}\right)$, diopsídio (pobre em $\mathrm{Al}$ ), "leucita" $\mathrm{e}$ ilmenita, imersos em uma matriz fina formada por sanidina (em parte rica em Fe), flogopita (titanífera-pobre em Al), diopsídio (pobre em Al), magnetita titanífera magnesiana e acessórios de apatita e anfibólio (tianífero-potássico). Representam um olivina-flogopita-sanidina-diopsídioleucita lamproíto.

O sill Yzu-6, compõe-se de um lamproíto com possança decimétrica, cinza esverdeado com fenocristais/microfenocristais de flogopita (titanifera), diopsidio (pobre em Al) e ilmenita imersos 
em matriz média formada de sanidina (rica em $\mathrm{Fe}, \mathrm{Ba}$ e $\mathrm{Na}$ ), flogopita-biotita (titanifera), anfibólio e acessórios de ilmenita, apatita, carbonato e rutilo/priderita (?). Correspondem a um diopsídio-flogopita-sanidina lampróĺto.

Também neste trabalho discutem-se as relações de solução sólida que caracterizam as micas, os piroxênios, os espinélios e os feldspatos estudados nos dois grupos de rochas.

Dados geotérmicos (Termômetro $\mathrm{TMg}$ ) obtidos em xenocristais de espinélios dos corpos Ymi 1 e Yzu-1 assemelham-se em muito aos obtidos em espinélios de kimberitos da plataforma Siberiana; i.e. fluxo de calor $\sim 30-40 \mathrm{mWm}^{-2}$. Xenocristais de espinélio nos que ao ser aplicado a variação do barômetro de Doroshev (o valor de $\mathrm{C} \#$ multiplicado pelo teor de $\mathrm{Cr}_{2} \mathrm{O}_{3}$ ) permitiram estimar a profundidade de formação/proveniência, para os magmas lamprofíricos picríticos cálcio-alcalino, correspondente em torno de 10 a $50 \mathrm{Kbrs}$. Essas feições termo-barométricas sugerem que esses magmas picríticos (Ymi-1 e Yzu-1) amostraram peridotitos de um manto litosférico profundo cratonizado, que no Jurássico ( $\sim 130 \mathrm{Ma})$ possuía o gradiente geotérmico de $\approx 35 \mathrm{~mW} / \mathrm{m}^{2}$.

Nos diagramas Ci\# vs $\mathrm{Fe}^{2+} \#$ e $\mathrm{MgCr}_{2} \mathrm{O}_{4}-\mathrm{MgAl}_{2} \mathrm{O}_{4}-\mathrm{MgFe}_{2} \mathrm{O}_{4}$ muitos xenocristais de espinélios de Ymi-1 e algumas inclusões de espinélio em olivinas de $Y z u-1$ ocuparam campos de espinélios de peridotitos da fácies diamantíferas e/ou associadas ao diamante. Esse fato sugere que eles teriam sidos arrancados das raizes do manto peridotítico cratonizado da facies do diamante e trazidos pelo magma até a superfície.

Os xenocristais de espinélio de $Y$ mi-1 no diagrama $\mathrm{Fe}^{3+} /\left(\mathrm{Fe}^{3+}+\mathrm{Fe}^{2+}\right)$ vs CH indicaram condições de formação abaixo do tampão QFM com concentrações elevadas das inclusões e alguns espinélios dos concentrados no tampão Q-1 e microfenocristais, dos concentrados e de algumas inclusões fugacidade ainda menor, i.e., <t+1 a $1+2$. Valores desta fugacidade de oxigênio são muito favoráveis formação do diamante nas raízes cratônicas. As inclusões de espinélio em olivinas de $Y z u-1$ e $Y$ mi-1 formaram-se num ambiente com tampão Q-1 a 1+2 o que indica em favor de condições de transporte com fugacidade de oxigênio favoráveis para a preservação do diamante.

Grãos de ilmenitas de Ymi- 1 e Ymi-8, foram também analisadas no sistema $\mathrm{MgTiO}_{3}-\mathrm{FeTiO}_{3}-$ $\mathrm{Fe}_{2} \mathrm{O}_{3}$ observando-se que elas apresentam condições de oxidação/redução em torno do tampão $10^{\circ}$ ( $\sim$ buffers wustita-magnetita). Este dado também reforça o que já foi concluido com relação aos espinélios, ou seja, um ambiente relativamente redutor indicando positivamente para a preservação de diamante. Nesse contexto das informações o diamante poderia estar presente nos corpos estudados

$\mathrm{Na}$ região associada s intrusões do arroyo Itá (Campo Ybytyruzú) onde descobriram - se partículas de Au, é uma área muito rica em rochas lamprofíricas assim indicando ser um campo excelente para se pensar numa ligação genética entre as rochas lamprofíricas e as ocorrências de Au. 


\section{Abstract}

Mesozoic "lamprophyric" rocks from the Ybytymi and Ybytyryzú fields of the Central Alkaline Province of Central-Eastern Paraguay are here characterized based on petrographic data and mineral chemistry. The Province lies along the Asunción Rift, situated at the border of the Paranapanema Block, part of the Rio de La Plata Craton.

The bodies from the Ybytymi Field, western portion of the pericratonic border of the Paranapanema Block, are: 1) Ymi-1 pipe, with volcanic-epiclastic sediments (containing picrochromite, chromite, magnetite, pseudobrookite, ilmenite, rutile, $\mathrm{Nb}$-bearing rutile, tourmaline, diamond, zircon, pyroxene and traces of garnet as heavy mineral assemblage), plug and associated dikes ( $Y \mathrm{mi}-1 / \mathrm{d}$ and $\mathrm{Ymi}-1 \mathrm{c})$, which constitute calc-alkaline picritic lamprophyres (kentallenite), composed of pheno/microphenocrysts of olivine, (titaniferous-aluminous) diopside, phlogopite, magnesian hornblende and chromite, in a fine-grained matrix made of (sometimes sodic) sanidine, magnesian titaniferous magnetite, titaniferous magnetite, (titaniferous-aluminous) diopside, (titaniferous) phlogopite-biotite, carbonate and accessory apatite, plagioclase, magnesian hornblende, eckermanite, analcime and rutile; 2) several $\mathrm{E}$-W-trending, peridotitic-microxenolith-bearing dikes (Ymi-7) of kentallenite-type, composed of pheno/microphenocrysts of olivine, (titaniferous-aluminous) diopside, homblende and (titaniferous-aluminous) phlogopite in a fine-grained matrix made essentially of sanidine, magnesian titaniferous magnetite, titaniferous magnetite, (titaniferousaluminous) diopside, analcime, hornblende and accessory apatite, mica and carbonate; 3) the Ymi-4 pipe, made of a lava facies, crosscut by a conduit breccia facies and slightly vesiculated, lamprophyric dikes, being a variety of calc-alkaline lamprophyre (minette), composed of serpentinized pheno/microphenocrysts of olivine, (titaniferous-aluminous) phlogopite, (titaniferous-aluminous) diopside and magnesian titaniferous magnetite in a very fine- to fine-grained matrix made of sanidine, titaniferous magnetite and accessory (titaniferous-aluminous) diopside, apatite, carbonate and zeolites; 4) the Ymi-8 pipe, with predominant volcanic-epiclastic sediments and subordinated plugs, similar to Ymi-1 regarding the heavy mineral assemblage (pseudobrookite, ilmenite, rutile, zircon, diamond and traces of spinel, piroxene and garnet); 5) the Ymi-5 plug, a transitional lamproite (olivine-sanidine-diopside "leucite" lamproite) with abundant pheno/megacrysts of pseudomorphosed leucite, together with (titaniferous to titaniferous-aluminous) diopside, (serpentinized) olivine and magnesian titaniferous magnetite in a fine-grained matrix made of (Ba-rich) sanidine, (titaniferousaluminous to Al-poor) diopside, titaniferous magnetite, (titaniferous, Al-poor to aluminous, Ba-rich) biotite and accessory apatite, perovskite and (potassic-titaniferous) amphibole.

The intrusions from the Ybytyruzú Field, in the eastern portion close to the Paranapanema Block, are: 1) the Yzu-1 dike, a fresh, porphyritic basaltoid rock classified as a picritic, calc-alkaline lamprophyre (kentallenite), with $15 \%$ of olivine phenocrysts, (Al-poor) diopside and (titaniferouswaluminous) phlogopite in a matrix made of analcime, (Fe-rich) sanidine - anorthoclase, magnesian titaniferous magnetite and accessory apatite and carbonate; 2 ) the pipe-like Yzu-4 intrusion, with a lamprophyric and a basaltoid facies and a heavy mineral assemblage composed of ilmenite, piroxene, spinel and mica; 3) altered, lamprophyric Yzu-10 dikes, associated to auriferous quartz lodes, which concentrate in the rivers of the region together with ilmenite, zircon, spinel, garnet and ilmenite; 4) the Yzu-2 lamproitic dike (olivine-sanidine-phlogopite-diopside-"leucite" lamproite), made of abundant microphenocrysts of pseudomorphosed leucite, together with olivine, (Al-poor) diopside and (titaniferous) phlogopite in a fine-grained matriz made of (Fe-rich) sanidine, (titaniferous, Al-poor) phlogopite-biotite, (Al-poor) diopside, magnesian titaniferous magnetite, ilmenite and accessory (potassic-titaniferous) ferrous eckermanite and apatite; 5) the Yzu-3 body (Mbocayaty), formed by porphyritic breccioid lavas of basaltoid aspect (olivine-phlogopite-sanidine-diopside-"leucite" lamproite), with micropheno/phenocrysts of olivine, (Al-poor) diopside, pseudoleucite and ilmenite, in a fine-grained matrix made of (sometimes Fe-rich) sanidine, (titaniferous, Al-poor) phlogopite, (Alpoor) diopside, magnesian titaniferous magnetite and accessory apatite and (titaniferous-potassic) amphibole; 6) the Yzu-6 sill (diopside-phlogopite-sanidine lamproite), composed of pheno/microphenocrysts of (titaniferous) phlogopite, (Al-poor) diopside and ilmenite in a mediumgrained matrix made of (Fe-Ba-Narrich) sanidine, (titaniferous) phlogopite-biotite, amphibole and accessory ilmenite, apatite, carbonate and rutile/priderite (?).

Geothermometric data from Ymi-1 and Yzu 1 spinel xenocrysts are very similar to those from the Siberian Platform kimberlites, i.e. $-30-40 \mathrm{~mW}^{-2}$ heat flow (TMg thermomeler). A variation of Doroshev's barometer ( $\mathrm{Cr} \#$ multiplied by the $\mathrm{Cr}_{2} \mathrm{O}_{3}$ content), when applied to the same Ymi- 1 and Yzu-1 spinel xenocrysts, allowed the formation/provenance depth of the calc-alkaline, picritic, 
lamprophyric magmas to be estimated as equivalent to $10-50 \mathrm{~Kb}$. These data suggest that $\mathrm{Ymi}-1$ and Yzu-1 sampled peridotites from a cratonized, deep lithospheric mantle, which had a $\sim 35 \mathrm{~mW} / \mathrm{m}^{2}$ geothermal gradient in the Jurassic $(130 \mathrm{Ma})$.

In the $\mathrm{C} \#$ vs. $\mathrm{Fe}^{2+} \#$ and $\mathrm{MgCr}_{2} \mathrm{O}_{4}-\mathrm{MgAl}_{2} \mathrm{O}_{4}-\mathrm{MgFe}_{2} \mathrm{O}_{4}$ diagrams, many $\mathrm{Ymi}-1$ spinel xenocrysts and some Yzu-1 spinel inclusions in olivines plot in the fields of spinels from peridotites of the diamondiferous facies and/or associated with diamond. This fact suggests that that they were pulled away from the roots of the cratonized peridotitic mantle of the diamondiferous facies and brought by the magma to the surface.

The $\mathrm{Fe}^{3+} /\left(\mathrm{Fe}^{3+}+\mathrm{Fe}^{2+}\right)$ vs. Cr\# diagram indicated for $\mathrm{Ymi}-1$ spinel xenocrysts conditions of formation below the QFM buffer, with high concentration of inclusions and some spinels from the concentrates falling in the Q-1 buffer, and microphenocrysts from concentrates and some inclusions plotting in even lower oxygen fugacity fields, i.e. $<1+1$ to $1+2$. These fugacity values correspond to very favorable conditions for the formation of diamond in the cratonic roots. Spinel inclusions in olivines from Ymi-1 and Yzu-1 were formed in a Q-1 to $1+2$ buffer environment, which corroborates to transport conditions corresponding to oxygen fugacities favorable to the preservation of diamond.

$\mathrm{Ymi}-1$ and $\mathrm{Ymi}-8$ ilmenite grains were also analysed in the $\mathrm{MgTiO}_{3}-\mathrm{FeTiO}_{3}-\mathrm{Fe}_{2} \mathrm{O}_{3}$ system, yielding oxidation/reduction conditions around the $10^{-6}$ buffer (wustite-magnetite), which corroborated to a relative reducing environment, favorable to the preservation of diamond.

The Arroyo Itá region (Ybytyruzú field), where particles of Au were found, crosscut by lamprophyric rocks, is a possible field to study the genetic link between lamprophyric rocks and Au occurrences. 


\section{CAPÍTULO 1}

\section{Introdução ao problema}

Convencionalmente são referidas como rochas potássicas aquelas que possuem a razão molar $\mathrm{K}_{2} \mathrm{O} / \mathrm{Na}_{2} \mathrm{O}$ em torno ou algo maior que 1 e com o teor em $\mathrm{MgO}>3 \%$, sendo que a restrição no conteúdo de $\mathrm{MgO}$ é imposto para assim excluir algumas rochas, como alguns traquitos, dacitos, e riólitos, que possuem elevada razão $\mathrm{K}_{2} \mathrm{O} / \mathrm{Na}_{2} \mathrm{O}$ como resultado dos processos normais de evolução magmática, assim não implicando numa natureza potássica do magma parental do qual eles teriam derivado (Peccerillo, 1992).

Os esquemas de classificação traçados em torno das rochas potássicas (Sahama 1974; Barton 1979; Mitchell 1985; Foley et al., 1987 e Peccerillo 1992 entre outros), consideram dois tipos principais de rochas potássicas: as rochas shoshoniticas (potássicas a meso-potássicas) e as rochas ultrapotássicas (rochas com alto potássio). No entanto, os termos potássicos ou ricos em potássio freqüentemente são empregados para caraterizar tanto as rochas shoshoniticas como as rochas ultrapotássicas.

Rochas shoshoníticas, são as rochas menos enriquecidas em potássio. Elas possuem 2-3\% de potássio e ostentam a razäo $\mathrm{K}_{2} \mathrm{O} / \mathrm{Na}_{2} \mathrm{O}$ em torno da unidade. Tais rochas possuem tipicamente alto $\mathrm{Al}_{2} \mathrm{O}_{3}\left(14-20 \%\right.$ ), baixo $\mathrm{TiO}_{2}(<1.2-1.3 \%)$ e, num intervalo máfico, elevado conteúdo de $\mathrm{CaO}(10-12 \%)$. A suíte de rochas shoshoníticas compreende basaltos shoshoníticos, latitos, e traquitos a riolitos. São rochas máficas a intermediárias na sua composição, assim oscilando de algo subsaturadas a supersaturadas em sílica (Peccerillo, 1992). Esta suite constitui um grupo de rochas que estão associam-se com vulcânicas cálcio-alcalinas ao longo de zona de placas convergentes (Morrison, 1980).

Foley et al. (1987) definem as rochas ultrapotássicas como sendo aquelas rochas que possuem razão $\mathrm{K}_{2} \mathrm{O} / \mathrm{Na}_{2} \mathrm{O}>2$ e valores de $\mathrm{K}_{2} \mathrm{O}$ e $\mathrm{MgO}>3 \%$. Elas incluem um 
amplo intervalo composicional podendo reconhecer e separar três grupos bem definidos de "rochas ultrapotássicas end member".

Grupo 1: são as rochas que ocorrem como pipes, lavas, tufos e corpos hipoabissais (diques, plugs) e que possuem natureza ultramáfica a máfica. Dentre os grupos de rochas ultrapotássicas, este grupo é o mais enriquecido em potássio e empobrecido em $\mathrm{Na}_{2} \mathrm{O}$, possuindo de 36 a $60 \%$ de $\mathrm{SiO}_{2},<14 \%$ de $\mathrm{Al}_{2} \mathrm{O}_{3},<10 \%$ de $\mathrm{CaO}$ e razão $\mathrm{K}_{2} \mathrm{O} / \mathrm{Al}_{2} \mathrm{O}_{3}>0.6$ (sendo comumente perpotássicas $\left(\mathrm{K}_{2} \mathrm{O} / \mathrm{Al}_{2} \mathrm{O}_{3}>1\right.$ ). Este grupo é equivalente ao "Leucite Hills type" de Barton (1979) e ao grupo orendítico de Sahama (1974), recebendo o nome de lamproítos (Foley et al., 1987; Foley, 1992). Standard members são os lamproitos de W-Austrália e o vulcão de Gaussberg, Antártica. Contudo, observou-se que as feições quimicas de algumas ocorrências de lamproítos possuem $\mathrm{K}_{2} \mathrm{O} / \mathrm{Na}_{2} \mathrm{O}<2$, como constatado em algumas rochas de Jumilla, Espanha (Salvioli-Mariani \&Venturelli 1996); Smoky Buttle, USA (Mitchell et al., 1987); Kapamba, Zambia (Scott-.Smith et al., 1989). Esta mesma feiçăo leva a observar que a razão $\mathrm{K}_{2} \mathrm{O} / \mathrm{Al}_{2} \mathrm{O}_{3}$ é inferior a 0.6. Giampaolo et al. (1997) estudando a série de rochas coletadas na seqüência de lavas do Lago Bracciano (Roma, Italia), encontraram progressiva analcimiticação nas rochas à expensas da leucita, o que se reflete num incremento progressivo do $\mathrm{Na}$ em detrimento do $\mathrm{K}$, $\mathrm{Ca}$ e $\mathrm{Mg} ; \mathrm{Fe}$ permanece constante porém aumentando o teor do $\mathrm{Fe}^{2+}$. Estas feições levam a crer que os valores anômalos, nas rochas ultrapotássicas em geral, das razões $\mathrm{K}_{2} \mathrm{O} / \mathrm{Na}_{2} \mathrm{O}<2$ e $\mathrm{K}_{2} \mathrm{O} / \mathrm{Al}_{2} \mathrm{O}_{3}<0.6$ devem-se a processos de zeolitização (Mitchell et al., 1987; Venturelli et al., 1991). Isto necessariamente leva a caraterizar erroneamente muitas rochas ultrapotássicas como potássicas (p/ex. Foley, 1992). Os lamproítos mostram marcado enriquecimento de elementos terras raras leves (LREE) em relação aos pesados (HREE), com La/Yb elevado; assim como também de elementos LIL sobre os elementos HFS, com Ba/Yb elevado (Bergman, 1987; Mitchel \& Bergman, 1991 e Foley et al., 1987). Woolley et al. (1996) observaram que os lamproítos são rochas caraterizadas pela presença, em quantidades variáveis (5$90 \%$ ), das seguintes fases minerais primárias: (1) fenocristais de flogopita titanífera (2-10\% de $\left.\mathrm{TiO}_{2}\right)$ pobre em $\mathrm{Al}\left(5-12 \%\right.$ de $\left.\mathrm{Al}_{2} \mathrm{O}_{3}\right) ;(2)$ tetraferriflogopita titanifera (5$10 \%$ de $\mathrm{TiO}_{2}$ ) poiquilítica na matriz; $(3)$ richterita titanífera $\left(3-5 \%\right.$ de $\left.\mathrm{TiO}_{2}\right)$ e potássica $\left(4-6 \%\right.$ de $\left.\mathrm{K}_{2} \mathrm{O}\right)$; (4) olivina forsterítica; (5) diopsídio pobre em $\mathrm{Al}\left(<1 \%\right.$ de $\left.\mathrm{Al}_{2} \mathrm{O}_{3}\right)$ e $\mathrm{Na}$ 
( $<1 \%$ de $\left.\mathrm{Na}_{2} \mathrm{O}\right)$; (6) leucita não estequiométrica rica em Fe (1-4\% de $\left.\mathrm{Fe}_{2} \mathrm{O}_{3}\right)$, e (7) sanidina rica em $\mathrm{Fe}$ (tipicamente $1-5 \%$ de $\mathrm{Fe}_{2} \mathrm{O}_{3}$ ). Ressalta-se que a presença das faces mencionadas não requer uma ordem preferencial para classificar uma rocha como lamproíto. Nenhum dos minerais necessariamente deve ser dominante, e assim, junto a dois ou três outros minerais maiores presentes, basta para determinar o nome petrográfico. Fases menores e acessórios comuns incluem a priderita, wadeita, apatita, perovsquita, cromita magnesiana, cromita magnesiana titanifera $e$ magnetita magnesiana titanifera; menos comum, porém, carateristicamente presentes encontram-se, jeppeita, armalcolita, shcherbakovita, ilmenita e enstatita. A presença dos minerais listados a seguir elimina qualquer rocha do grupo dos lamproítos: plagioclásio primário, melilita, monticellita, kalsilita, nefelina, feldspato alcalino rico em $\mathrm{Na}$, sodalita, noseana, hauyna, melanita, schorlomita ou kimzeyita. Hogarth (1997) estudando alguns lamproitos de Napoleon Bay (Isla de Baffin) descreve kalsilita e nefelina como fases minerais de substituição e como minerais de contato; ver também o trabalho de Scott-Smith et al. (1989).

Grupo 11: são as rochas da série de lavas "Katungito, mafurito e ugandito" encontradas no leste Africano (Toro-Ankole, Standard members do grupo). Elas possuem $\mathrm{SiO} 2<46.0 \%, \mathrm{Al}_{2} \mathrm{O}_{3}<14 \%, \mathrm{CaO}>10 \%$ e a razão $\mathrm{K}_{2} \mathrm{O} / \mathrm{Al}_{2} \mathrm{O}_{3}<0.9$. Desvios destes valores podem ocorrer em virtude de processos de alteração tardia, como por exemplo analcimitização. Foley et al. (1987) sugerem para este grupo de rochas o nome kamafugitos em concordância com Sahama (1974). Similarmente aos lamproitos mostram marcado enriquecimento de LREE sobre HREE (La/Yb moderado a alto) e de LILE sobre HFSE (Ba/Yb alto). Conquanto sejam fortemente subsaturadas em sílica, apresentam kalsilita e/ou melilita junto com leucita. Entre os máficos incluem olivina forsterítica, diopsidio-salita aluminosos e titanados (ex. Mitchell \& Bergman, 1991). Podendo também estar presente a monticellita, a flogopita e a perovskita (Peccerello, 1992).

Grupo III: são rochas de uma série bem conhecida representada pelos leucitatefritos, leucititos e leucita fonólitos. Estas rochas são tipicamente encontradas na Província Magmática Romana Itália Central(-Standard members do grupo)(Peccerillo \& Manetti, 1985; Peccerillo, 1994) e em alguns vulcões da Indonésia (Stolz et al.,1988; Leterrier et al., 1990). Estas rochas apresentam conteúdos de $\mathrm{SiO}_{2}$ 
que variam dos 42 aos $63 \%$ (i.e., rochas máficas à intermediárias), estando enriquecidas, quando comparadas com os dois grupos anteriores, em $\mathrm{Al}_{2} \mathrm{O}_{3}(>11 \%)$, empobrecidas em $\mathrm{TiO}_{2}$ (geralmente $<1.2 \%$ ) e possuem razão $\mathrm{K}_{2} \mathrm{O} / \mathrm{Na}_{2} \mathrm{O}<0,5$. As rochas máficas deste grupo possuem alto teores em $\mathrm{CaO}$ (tipicamente entre 10-13\%) e $\mathrm{Na}_{2} \mathrm{O}(\sim 2-3 \%)$. Valores mais elevados do $\mathrm{Na}$ sobre o $\mathrm{K}$ que vá também acompanhado de perdas de $\mathrm{Mg}$ e $\mathrm{Ca}$, deve-se a processos de alteração. De forma geral o grupo apresenta a menor razão $\mathrm{La} / \mathrm{Yb}$ e $\mathrm{Ba} / \mathrm{Yb}$, destacando-se nele uma marcada anomalia negativa em $\mathrm{Nb}$, como propriamente observada em rochas relacionadas a processos de subdução. (Foley et al., 1987). Para este grupo foram propostos os nomes: rochas ultrapotássicas do tipo Provincia Romana (Barton. 1979; Foley et al., 1987; Peccerillo, 1992) e plagileucito (Foley, 1992). Este grupo encontra-se associado com outras rochas vulcânicas menos enriquecidas em potássio pelo sendo freqüentemente referidas como "série potássica" comparativamente, elas lembram os shoshonitos (Peccerillo 1992). As faces minerais félsicas típicas encontradas nas rochas máficas às evoluidas são: leucita, plagioclásio e sanidina rica em $\mathrm{Na}_{2} \mathrm{O}$ e pobre em $\mathrm{Fe}_{2} \mathrm{O}_{3}$, além de nefelina frequentemente intersticial. Diopsidio (rica em $\mathrm{Al} e$, geralmente pobre em Ti) é a fase máfica comum, encontrada junto a proporções menores a traços de olivina, flogopitabiotita (que mostra um trend de enriquecimento em Al-Ti e Al-Fe diretamente proporcional, cf. Mitchell \& Bergman 1991.), anfibólio pargasítico, magnetita titaniffera, haüina e apatita.

Rochas ultrapotássicas volumetricamente mais importantes são aquelas com feições químicas entre lamproítos e plagileucitos sendo mais raro de observar aquelas com feições entre lamproitos e kamafugitos; essas rochas formam o Grupo IV ou Grupo transicional Foley et al (1987). Este tipo de rocha encontra-se frequentemente associado a lamproítos e/ou plagileucitos e/ou kamafugitos (Foley, 1992). Segundo Foley et al. (1987), os grupos das rochas ultrapotássicas não incluem alguns magmas "kimberlitóides" como o são os kimberlitos orangeitos e algumas minettes.

Mitchell (1995a) mostra que kimberlitos são o grupo de rochas potássicas e ultrabásicas ricas em voláteis (dominantemente $\mathrm{CO}_{2}$ ) comumente mostrando distintiva textura inequigranular resultante da presença de macrocristais (ocasinalmente megacristais) imersos em matriz de granularidade fina. A assembléia 
de megacristais/macrocristais consiste de cristais de olivina anhedral, ilmenita magnesiana, piropo titanífero pobre em $\mathrm{Cr}$, diopsídio pobre em $\mathrm{Cr}$ (freqüentemente subcálcico), flogopita, enstatita e cromita pobre em Ti. Os macrocristais de olivina são caraterísticos de todos os kimberlitos, porém não dos fraciònados. A matriz contém uma segunda geração de olivina euhedral que ocorre junto com um u mais de um dos minerais primários: monticellita, flogopita, perovskita, espinélio (solução sólida de ulvoespinélio magnesiano-cromita magnesiana-ulvoespinélio-magnetita), apatita e serpentina. Resulta que a maioria dos kimberlitos contém micas poiquiliticas tardias da série flogopita-kinoshitalita. sulfetos niquelifero e rutilo são os minerais acessórios comuns. É comum a sustituição de olivina, flogopita, monticellita e apatita formadas inicialmente por serpentina deutérica e calcita. Os membros evoluidos do grupo podem ser pobres o isentos de macrocristais e/ou ser compostos da segunda geração de olivina, calciła, serpentina e magnetita, junto à quantidade menor de flogopita, apatita e perovskita. Kimberlitos não contém diopsídio primário; sua presença representa uma fase secundária de cristalização induzida pela assimilação de xenólitos silicáticos.

Ainda segundo Mitchell (1995a) orangeitos são o clã de rochas ultrapotássicas peralcalinas ricas em voláteis (dominantemente $\mathrm{H}_{2} \mathrm{O}$ ), caraterizadas pela presença de macrocristais e microcristais de flogopita em matriz contendo flogopita a tetraferriflogopita. Macrocristais arredondados e cristais euhedrais de olivina são comum porém não sempre como constituintes maiores. As fases caraterísticas da matriz säo: diopsídio geralmente zonado e capeado por aegirina titanifera; espinélios de composição variando de cromita magnesiana a magnetita titanífera; perovskita rica em REE e Sr; apatita rica em $\mathrm{Sr}$; fosfatos ricos em REE (monazita, daqingshanita); titanatos de $\mathrm{K}$ e $\mathrm{Ba}$ correspondentes ao grupo da hollandita; triskaidecatitanatos de $\mathrm{K}\left(\mathrm{K}_{2} \mathrm{Ti}_{13} \mathrm{O}_{27}\right)$; rutilo de $\mathrm{Nb}$; e ilmenita manganesífera. A matriz pode conter ainda calcita, dolomita, ancylita e outros carbonatos de terras raras, witherita, norsethita e serpentina. Membros evoluidos do grupo possuem sanidina e richterita potássica. Silicatos de Zr (wadeita, zircão, granada kinzeyitica e silicatos Ca e Zr) são comuns como minerais tardios da matriz. Barita é comum como mineral secundário ou deutérico. Os orangeitos se diferenciam dos kimberlitos pela ausência 
de monticellita, espinélio magnesiano e micas da série da flogopita-kinoshitalita rica em Ba.

Woolley et al. (1996) definem os lamprófiros como sendo rochas ígneas mesocráticas a melanocráticas, geralmente subvulcânicas, com textura panidiomónfica e abundantes fenocristais máficos de mica escura e/ou anfibólio proporções menores de piroxênio e olivina, imersos em matriz dos mesmos minerais, e feldspato, este geralmente feldspato alcalino. Com base na associação petrológica das rochas igneas e nos ambientes tectônicos onde eles ocorrem, Rock (1977; 1984; 1987; 1989 e 1991) divide os lamprófiros em três Grupos: cálcio-alcalinos (acompanhados de granitóides post-orogênicos e em associação com rochas alcalinas meso-potássicas), alcalinos (acompanhados de rochas alcalinas e carbonatitos em ambientes continentais de intraplaca) e ultramáficos (com similares feições de associação e tectônica a do grupo anterior). A Tabela 1-1 confronta a mineralogia dos três grupos citados e dos kimberitos/orangeítos e lamproitos

Lamprófiros cálcio-alcalinos são aqueles mesocráticos, em parte saturados em sílica, potássicos a mesopotássicos $(\mathrm{Na} /=\mathrm{K})$ possuindo composições intermediárias $\left(\mathrm{SiO}_{2} \sim 53 \%\right)$. Os fenocristais predominantes são hornblenda e/ou flogopita-biotita; a matriz é formada por feldspatos e ocasinalmente quartzo. O grupo acha-se subdividido nas variedades Rock (1984; 1991): kersantitas, vogesitas, esperssartitos e minettes.

Lamprófiros alcalinos são mesocráticos a quase ultramáficos, subsaturados e quimicamente similares a basanitos hidratados (com $\mathrm{SiO}_{2}$ geralmente $<45 \%$ ). Os fenocristais predominantes são olivina rica em $\mathrm{Mg}$, anfibólios titaníferos (p/ex. kaersutita), piroxênios titanados e flogopita-biotita titaniferas; sua matriz constitui essencialmente de feldspatóide que podem estar acompanhado por pequenas proporções de feldspatos. Neste grupo são reconhecidos as seguintes variedades Rock (1987, 1991): monchiquitos, camptonitos e sannaitos.

Lamprófiros ultramáficos são rochas ultrabássicas (com $\mathrm{SiO}_{2}$ geralmente <35\%) e com indice de cor $>90$ ou muito próximo a ele. Possem fenocristais de olivina muito rica em Mg, flogopitas, (e por vezes) diopsidio e anfibólios titaniferos; a matriz constitui essencialmente de carbonato, perovskita, feldspatóide e/ou melilita. São 
reconhecidas as seguintes variedades Rock (1989; 1990): damkjernito, alnoito, ouachitito, ailiquito e polzenito.

Woolley et al. (1996) recomendam para classificação geral dos lamprófiros seja consultado Le Maitre et al. (1989); e, para detalhes na descrição, aquela segundo Rock (1991).

Conquanto que neste trabalho estudaram-se um grupo de ocorrências de rochas lamprofíricas que aparentam lamprófiros cálciomalcalinos, de ambiente de rochas alcalinas, os lamprófiros cálcio-alcalinos e alcalinos serão definidos com base ao Glossário dado por Rock (1991), Dessa maneira, pretende-se que o leitor conte com - auxílio do trabalho citado em mãos para acompanhar a caraterização das rochas estudadas.

Monchiquito: variedade principal de lamprófiro alcalino compõe de combinações de fenocristais de olivina forsterítica, kaersutita, titanaugita e titanobiotita em uma matriz reunindo os mesmos minerais, exceto olivina, com nefelina (nefelinamonchiquito), analcima (analcima-monchiquito) e/ou vidro (hialo-monchiquito). Porém sem nenhum feldspato modal. A localidade tipo de lamprófiro reside na Serra Monchique, Algarve, Portual,; onde foi definido por Weveke em 1880 e redefinido por Caçador \& Rosenbusch (1890).

Camptonito: variedade principal de lamprófiro alcalino, compõe de combinações fenocristais de olivina forsterítica, kaersutita, e titanaugita (augita titanada conforme IMA) imersos em matriz dos mesmos minerais, exceto olivina, com plagioclásio, e por vezes subordinado feldspato alcalino e feldspatóides. A localidade tipo dessa variedade esta em Campton Falls, New Hampshire, E.U.A.; foi denominado por Hawes em 1878 e redefinido por Rosenbusch.

Sannaito: variedade secundária de lamprófiro alcalino compõe de combinações de fenocristais de olivina forsterítica, kaersutita, titanaugita e titanobiotita (bitotia titanífera conforme IMA) em uma matriz dos mesmos exceto olivina, com feldspato alcalino e plagioclásio e subordinadamente feldspatóides. A localidade tipo encontrase em Sanna, Noruega; foi denominado por Brogger (1921).

Minette: um lamprófiro cálcio-alcalino que consiste de fenocristais de phogopita/biotita, com subordinado anfibólio cálcico ou alcalino, olivina forsterítica ou 
clinopyroxênio diopsídico, em matriz formada pelos mesmos minerais e feldspato alcalino e plagioclásio subordinado.

Vogesito: variedade rara de lamprófiro cálcio-alcalino que consiste de fenocristais de hornblenda cálcica, com ou sem phogopita/biotita subordinada, olivina forsterítica ou clinopiroxênio diopsídico, mergulhados em matriz constituida pelos mesmos minerias além de feldspato alcalino e subordinado plagioclásio. A localidade tipo situa-se em Mtns.Vosges , França; tendo sido denonominado por Rosenbusch em 1887.

Kersantito: um lamprófiro cálcio-alcalino que consiste de fenocristais de flogopita/biotita, com ou sem hornblenda cálcica subordinada, olivina forsterítica ou clinopiroxênio diopsídico, em uma matriz constituida pelos mesmos minerias além de plagioclásio e subordinado feldspato alcalino. A localidade tipo está em Kersanton, Brittany, França,; foi denominado por Delesse em 1851.

Spessartito: um lamprófiro cálcio-alcalino que consiste de fenocristais de hornblenda cálcica, com ou sem phlogopita/biotita subordinada, olivina forsterítica ou clinopiroxênio diopsídico, em uma matriz constituida pelos mesmos minerias além de plagioclásio e subordinado feldspato álcalino. A localidade tipo está em Spessar, Alemanha.

Appinito: Originalmente definido por Muralha \& Maufe em 1916 como "equivalentes plutônicos de vogesito e eperssartito com hornblenda". Desde então são referidos a micro-intrusões sem conexões com rochas vitreas, portadores de hornblenda, cuja composição varia de gabbro para monzogabbro, diorito, syenito e granodiorito.

O termo appinitico geralmente é usado para indicar a presença de hornblendas euhedrais grossa e associações com appinito mais básico. Aqui foi restringido para equivalentes granulares grossos, ricos em $\mathrm{K}$, de vogesitos e spessartitos maficos, que consistue essencialmente de abundante hornblenda prismática $\%$ clinopiroxênio, em matriz de plagioclásio * feldspato alcalino, etc. Os appinitos do tipo de Appin, Argyll (Escócia), são predominantemente gabróicos, mas muitos contêm biotita e são mais ricos em $\mathrm{K}$ que gabbros normais. 


\begin{tabular}{|c|c|c|c|c|c|}
\hline $\begin{array}{l}\text { MINERAL } \\
\text { (em \%) }\end{array}$ & L-CAL. & L-AL. & L.UL & KIMB/ORANG & LAMPROITOS \\
\hline anfibólio & 20 a 40 & 2 a 5 & $<35$ & $<5$ & $<25$ \\
\hline Flog.-Biot. & 20 a 40 & 2 a 30 & 5 a 70 & $<40$ & $<25$ \\
\hline clinopiroxênio & $<25$ & 20 a 50 & $<50$ & só em Or. & $<50$ \\
\hline teldspatos & 33 a 67 & 25 a $50^{\text {** }}$ & $<5$ & só em Or. & $<50$ \\
\hline feldspatoldes & $<5^{*}$ & $<15$ & $<35$ & só em Or. & $>20$ \\
\hline granada (mel) & ausente $^{*}$ & $<5$ & $<25$ & ausente $^{*}$ & ausente* \\
\hline vidro & $<5$ & $<30$ & $<20$ & ausente $^{*}$ & $<50$ \\
\hline mellitita & ausente* & ausente* & $<35$ & ausente $^{*}$ & ausente* \\
\hline monticelfita & ausente ${ }^{*}$ & ausente ${ }^{*}$ & $<25$ & $<25$ & ausente $^{*}$ \\
\hline olivina & $<10$ & $<10^{* * *}$ & $<50$ & 25 a 75 & $<60$ \\
\hline quantzo & $<10^{*}$ & ausente* & $\begin{array}{l}\text { ausent } \\
\mathrm{e}^{*}\end{array}$ & ausente & $<10$ \\
\hline plagioci. & comum & comum & comum & ausente* & ausente* \\
\hline
\end{tabular}

Legenda: "pela definiçăo; **pela definição $=0$ em monchiquitos, e $<25$ em comuláticos; ***mais alto em variedades picriticas. Lamprófiros: L-CAL: cáicio-alcalino; L.AL: alcalino e L-UL: uliramáfico. Kim, kimberlito e Orag, orangeito.

Tabela 1-1. Comparação entre as variedades de rochas "lamprofíricas", kimberlitos, orangeitos e lamproítos. Fontes dos dados: Rock (1991); Mitchell (1995 a-b) e Mitchell \& Bergman (1991).

Kentallemito: rocha rica em $\mathrm{K}$ e $\mathrm{Mg}$ que pertence a suíte de appinita. É denominado geralmente de olivina monzonito e picrito shoshonítico; sendo, no entanto biotitaolivina-monzogabbro na nomenclatura de Streckeisen (1976), equivalente plutônico de espessartito e vogesito. Uma variedade de rocha que caracteriza distintamente duas gerações de olivina forsteritica, onde a primeira apresenta-se substituida nas bordas por pyroxênios, phlogopita ${ }^{ \pm}$hornblenda. A localidade tipo acha-se em Kentallen, Appin, Argyll, Escócia; foi denominado por Teall em 1897 (Colina \& Kynaston 1900). 


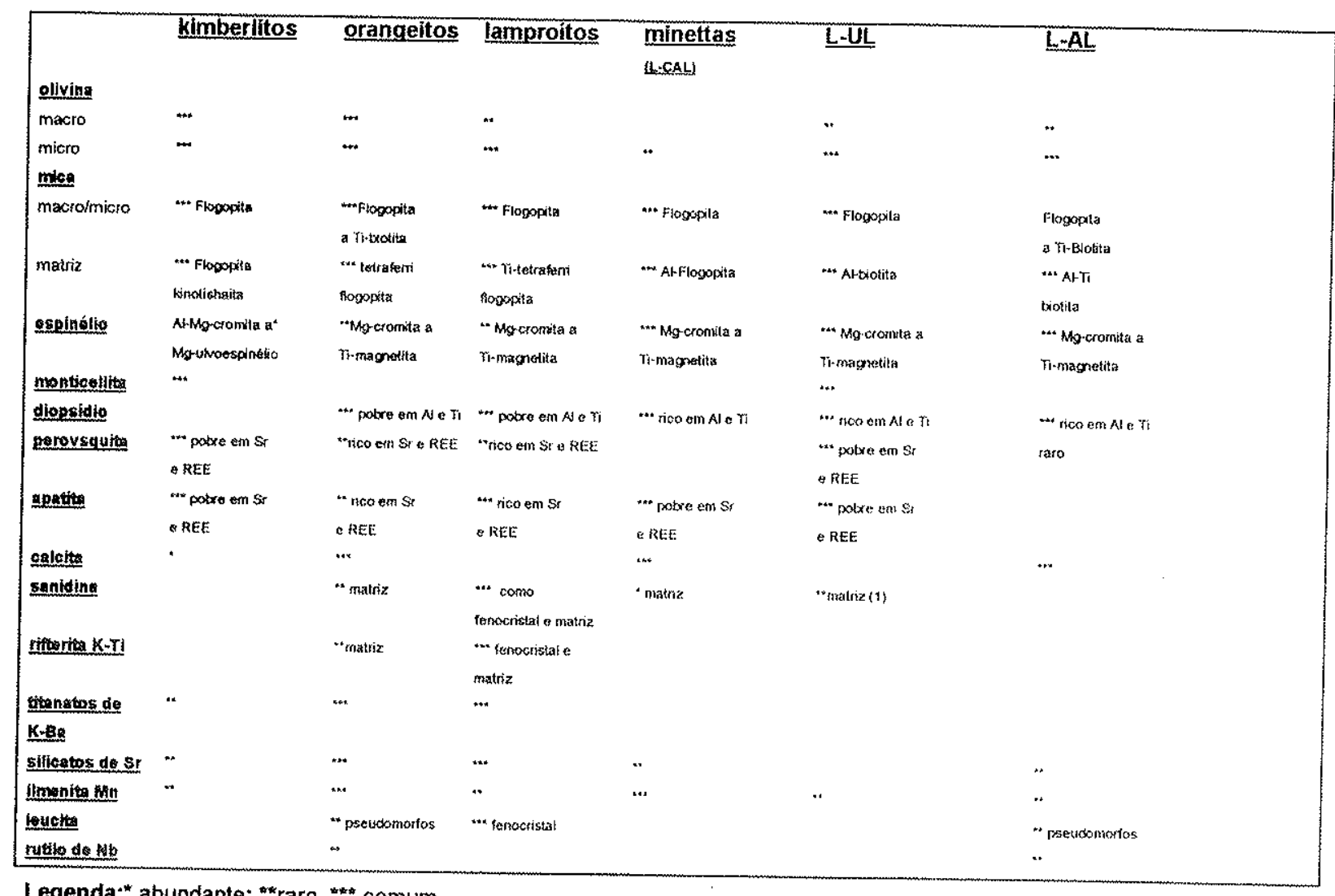

Legenda:* abundante; **aro *** comum.

Tabela 2-2. Minerais comuns em kimberlitos, orangeítos, lamproitos e lamprófiros cálcio alcalinos, alcalinos e uliramáficos. Fontes dos dados: Mitchell (1986 e 1995a); Mitchell \& Bergman (1991); Rock (1991).

\section{Objetivos}

O presente trabalho tem por objetivo primordial a caraterização, com base em dados petrográficos e de química mineral, das rochas "lamprofíricas" do Mesozóico ( 130 Ma.) que ocorrem junto às rochas basaltóides potássicas na Província Alcalina Central do Paraguai Centro-Oriental. Para este fim, os estudos da petrografia e química mineral, centraram em alguns corpos magmáticos com feições de rocha lamprofírica espalhados em dois campos separados: Campo Ybytymí a oeste, com 
os corpos de Ymi-1, Ymi-4, Ymi-5, Ymi-7 e Ymi-8 e, Campo Ybytyryzú a leste, com os corpos Yzu-1, Yzu-2, Yzu-3 e Yzu-6. Um grupo adicional de corpos (Yzu-4, Yzu10) é apresentado em uma descrição epreliminar das sua feições minerais e petrológicas macroscópicas. Como objetivo adicional, faz-se necessário uma discussão sobre sua colocação no ambiente tectônico e sua instalação estrutural no contexto tectônico identificado. Além disso dedicaram-se algumas linhas dos capitulos para estudar o potencial das informações relevantes aos dados termodinâmicos que possam evidenciar algumas fases minerais. Finalmente, foi observado atentamente os aspectos do potencial econômico que as rochas assinalam.

Cabe asinalar que no decorrer dos capitulos desta tese, as rochas estudadas serão referidas genericamente pelo termo textural rochas "lamprofiricas"

\section{Localização da área}

Na Figura 1-1 apresenta-se a localização da área de estudo, situada entre as latitudes: $25^{\circ} 30^{\circ} \mathrm{S}$ e $26^{\circ} 00^{\prime} \mathrm{S}$ e as longitudes $55^{\circ} 45^{\prime} \mathrm{W}$ e $57^{\circ} 30^{\prime} \mathrm{W}$. A área acha-se comprendida pelas folhas topográficas 1:250000 de Asunción e Villarrica. O acesso à area se faz pela rodovia $n^{\circ} \mathrm{I}$ de Asunción a Carapeguá, e daí tomando a rodovia $n^{\circ}$ IX de Carapeguá a La Colmena. Já a parte oriental se faz pela rodovia $n^{\circ} \|$ de Asunción a Cnel. Oviedo, entrando sentido sul na rodovia $n^{\circ}$ IV de Cnel. Oviedo a Mbocayaty; deste último local segue pela estrada sentido leste para Col. Independencia.

\section{Trabalhos anteriores}

Informações sobre aspectos gerais da geologia do Paraguai são sintetizados no Projeto PAR 83/005 (1986). Presser (1992) levanta alguns aspectos da geologia da Folha La Colmena (1:50000) no centro/borda da porção W do rift de Asunción (RA). Orué (1996) faz um apanhado dos aspectos geológicos vinculados com a colocação 

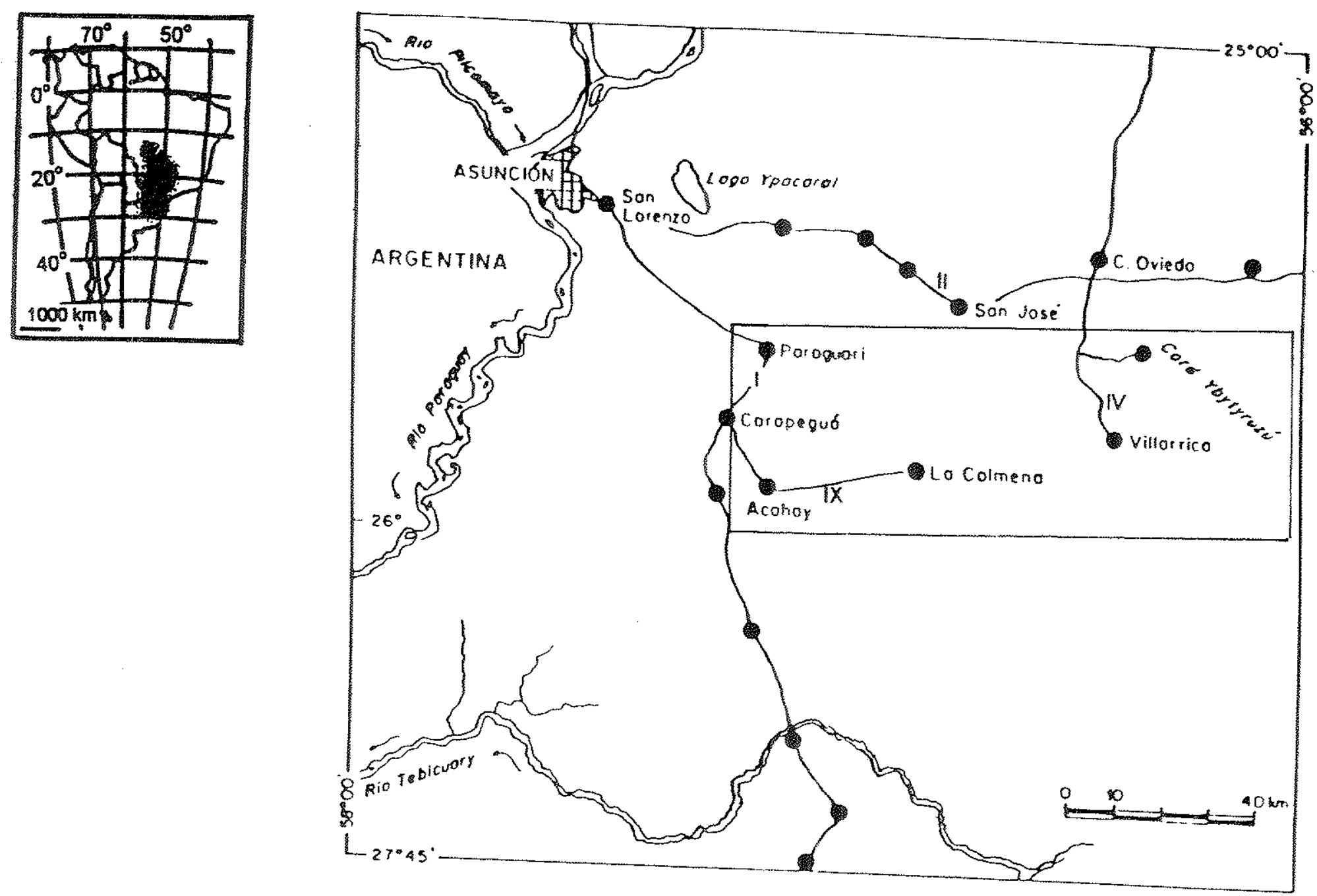
Figura 1-1. Toponimia e localização das áreas estudadas (retángulo). A esquerda em pontilhado a Bácia do Paraná. Em romano os $n^{\circ} S$ das
rodovias $(1, \|, N$ e IX). 
dos magmas alcalinos que ocorrem nas distintas províncias alcalinas do Paraguai. 0 primeiro trabalho, de classificação petrográfica e petroquímica das rochas vulcânicas de Sapucai (Figura 1-1) deve-se a Palmieri (1971, publicado em Palmieri \& Arribas, 1975). Muitos anos depois Bitschene (1987) re-acende o interesse pelas rochas alcalinas mesozóicas, sobretudo as vinculadas com o chamado rift de Asunción (RA). Com este trabalho são conhecidos os mais completos dados petroquímicos (elementos maiores e traços junto a isótopos de $\mathrm{Sr}$ e idades radiométricas $\mathrm{K} / \mathrm{Ar}$ ) da região. Bitschene (1987) foi também o primeiro a referir à presença de rochas ultrapotássicas (lamproitísche ganggesteine phonolithe, trachyte) na cordillera del Ybytyryzú (Bitschene et al., 1986).

Anos depóis seguiram-se os trabalhos de Presser (1991; 1994) reportando a ocorrência de lamproítos e pipes diamantíferos no R.A; Velázquez (1992) que aporta novos dados de geocronologia sobre o magmatismo desta região; Presser (1992) que apresenta dados da geologia e petrografia pertecentes a uma porção do Campo magmático Ybytymi; Comin-Chiaramonti et al. (1992) com dados petroquímicos e de química mineral caraterizaram as rochas vulcânicas do Campo Ybytymí como sendo similares a que ocorrem na Província magmática Romana.

Trabalhos recentes em Comin-Chiaramonti \& Gomes (1996) reunem, extensamente, dados petrográficos, de química mineral, petroquímicos (elementos maiores e traços junto a isótopos de $\mathrm{Sr}$ e $\mathrm{Nd}$ ) e geocronológicos do vasto número de ocorrências de rochas alcalinas potássicas (vulcânicas e plutônicas) do RA e regiões vizinhas. Estes trabalhos foram sintetizados num artigo de Comin-Chiaramonti et al. (1997)

\section{Métodos utilizados}

Os métodos utilizados comprenderam trabalhos de campo, de laboratório e de escritório. 


\section{Trabalhos de campo}

Foram mapeados quatro pipes, uma intrusão de breha-lava, um plug, alguns diques e um sill, utilizando-se como base as cartas topográficas do Instituto Geográfico Militar na escala 1:50.000, as Folhas La Colmena e Acahay e 1:250.000 as folhas Asunción e Villarrica; e algumas fotografias aéreas (1:50.000) que cobrem a folha La Colmena e regiões vizinhas. Somaran-se os mapas geológicos 1:500.000 (T.A.C., 1981) e os publicados nos trabalhos de Bitschene (1987) e Presser (1992). Acrecentaram-se para os trabalhos regionais (ex. tectônicos) imagens satélites em várias escalas e tipos.

A amostragem totalizou aproximadamente 60 espécimes, incluindo rochas frescas de pipes, plugs, sills e diques, amostras de furo de sondagem executados em 2 pipes e amostras de superficie e sedimentos de corrente colhidas em afloramentos e corregos que cortam os pipes ou associados a eles.

Os trabalhos de campo foram realizados em várias etapas distribuídas como segue: *1990 excurções do programa de mestrado, sob à orientação do Prof. Dr. H.G.J.H. Ulbrich, aos pipes Ymi-1, Ymi-4 e Ymi-8 e o plug Ymi-5, sendo a amostragem realizada com a colaboração do Geólogo Adolfo Baez;

*03/93 excurção do programa de pesquisa sobre responsabilidade do Prof. Dr. R.N. Thompson, às regiões do Campo Ybytymí (Ymi-1, Ymi-4 e Ymi-5) e as do Campo Ybytyruzu (Yzu-1, Yzu-2, Yzu-3 e Yzu-6);

*01/95 excurção do programa de doutoramento, sob à orientação do Prof. Dr. Excelso Ruberti, as regiões do Campo Ybytymi (Ymi-1 e Ymi-8, entre outros);

*08 a 10/97 Campo Ybytyruzú, regiöes de Mbocayaty-Col. Independencia e vizinhanças (Yzu-10), com a colaboração dos Srs. B. Gonzales, N. Gonzales, Amarilla, F. Gayoso e E. Bogarim. 


\section{Trabalhos de laboratório}

Neste item contempla-se a separação de minerais pesados, a petrografia, a química mineral e o tratamento dos resultados da química mineral.

\section{Separação de minerais pesados}

Foram amostrados 3 furos de sondagem em 2 pipes, com profundidades entre 1 e 2 $m$ com a finalidade de obter-se material vulcânico inquebrantado de 30 a $60 \mathrm{~kg}$ : ele encontrando-se totalmente alterado. A este somou-se, separadamente, $100 \mathrm{~kg}$ de sedimentos de corrente.

No laboratório de tratamento de amostras do DMP/IGc/USP algumas amostras foram secadas à temperatura ambiente, como também em estufa com $T<100^{\circ} \mathrm{C}$. Os diferentes volumes de amostras já secas, foram peneiradas para a retirada das frações entre 0.5 e $0.25 \mathrm{~mm}$ para seu processamento com líquidos densos. A partir dessas frações obtebe-se um primeiro concentrado separado com bromofórmio. $\mathrm{O}$ concentrado foi examinado em lupa binocular, para separar os grãos de turmalina para montagens de seções polidas. Um segundo concentrado obteve-se com iodeto de metileno, concentrando-se grãos de espinélio, ilmenita, rutilo, zirção e "diamante". Foram separados e fotografados os concentrados obtidos com auxilio de uma lupa binocular Zeiss do laboratório de óptica do IGc/USP. O material restante foi atacado com ácido HF (conc.) durante 07 a 10 dias e em ocasiöes diversas também com HF+solução levemente alcalina., para diluição maior dos silicatos com feições parecidas ao diamante. O resíduo limpo foi empregado para montagem de seções polidas.

Com auxílio de uma microssonda eletrônica marca JEOL SUPERPROBE 8600 s com cinco espectrometros contendo os cristais WDS LIF, TAP, PET, STE, as seções previamanete cobertas com película de carbono foram analizadas seguindo as condições de trabalho seguintes: potencial de aceleração $15 \mathrm{kv}$; corrente da amostra $20 n A$ e tempo de interação 10 a 30 segundos.

*O programa utilizado para análises de silicatos (ex. turmalinas), e em grande número de amostras também para minerais óxidos, determinou os seguentes óxidos: 
$\mathrm{SiO}_{2}, \mathrm{TiO}_{2}, \mathrm{Al}_{2} \mathrm{O}_{3}, \mathrm{Cr}_{2} \mathrm{O}_{3}, \mathrm{FeO}, \mathrm{NiO}, \mathrm{MnO}, \mathrm{MgO}, \mathrm{CaO}, \mathrm{BaO}, \mathrm{Na}_{2} \mathrm{O}$ e $\mathrm{K}_{2} \mathrm{O}$.

*O programa utilizado especialmente para análises de óxidos forneceu:

$\mathrm{SiO}_{2}, \mathrm{TiO}_{2}, \mathrm{Al}_{2} \mathrm{O}_{3}, \mathrm{Cr}_{2} \mathrm{O}_{3}, \mathrm{FeO}, \mathrm{NiO}, \mathrm{MnO}, \mathrm{MgO}$ e $\mathrm{ZnO}$.

*O programa utilizado para análises de zircões forneceu:

$\mathrm{SiO}_{2}, \mathrm{ZrO}_{2}$ e $\mathrm{TR}_{2} \mathrm{O}_{3}$ (Ce, Nd, Pr, La, Eu, Sm, Nb, Y, Gde Th).

Os dados foram corrigidos para radiação de fundo, drift e efeitos de matriz ZAF pelo programa de uso interno do laboratório.

\section{Petrografia}

Foram confeccionadas aproximadamente 65 seções delgadas no laboratorio de laminação do IGc/USP. Dessas algumass pertecem a amostras de pipes, plugs e diques estudados no programa de mestrado (1987-1992) sob orientação do Prof. Dr. H.G.J.H. Ulbrich. Os estudos petrográficos foram conduzidos com auxilio de um microscópios Zeiss do laboratório de óptica do IGC/USP para descrição, contagens de pontos (10 amostras com 500 a 1000 pontos por seção) e fotografia das lâminas

Porquanto que o grupo das rochas estudadas neste trabalho caem dentro das chamadas rochas incomuns os enmarcos para uma clássificação nem sempre são de tarefa fácil. A literatura especializada (Rock, 1991; Mitchell \& Bergman 1991; Mitchell, 1995a) mostra que tanto as feições químicas de rocha como de minerais os limítes geoquímicos entre os grupos de rochas (p/ex. entre as ultrapotássicas) se sobrepõem esto resultando muitas vezes em confusões na caraterização adequada.

Como tarefa de rotina deste trabalho, a caraterização petrográfica das rochas estudadas seguiram-se os procedimentos:

*a determinação do nome petrográfico com base a predominância de um ou mais mineral, conforme sugerido pelo IUGS (cf. Wolley et al. 1996);

*a seguir se buscou a caraterização mineral, através de análises químicas visando aprimorar a determinação petrográfica;

"posteriormente as rochas foram comparadas com rochas similares descritas na literatura; 
*finalmente, procedeu-se a uma caraterização aprimorada das rochas estudadas. $E$ num capítulo fianal tenta-se uma caraterização definitiva.

\section{Quimica mineral}

Foram confeccionadas 37 seções delgadas polidas no laboratório de tratamento de amostras da microssonda eletrônica do IGc/USP. Dessas, foram selecionadas 35 seções para microanálises na microssonda eletrônica nas condições de trabalho já comentadas no item anterior. Desse trabalho resultaram cerca de 50 a 100 análises por seção obtidos nos minerais principais dessas rochas.

\section{Recálculo catiónico mineral e classificações}

Olivina, piroxênio, mica (flogopitas e biotitas), anfibólios, feldspatos e feldspatóides foram tratados (recalculos e classificaçäo) no programa Minpet2.0 (Copyright 1988 1994 by Linda R. Richard).

*Olivinas foram normalizadas para 4 oxigênios e classificados em função das variáveis $\mathrm{mg \#}=\left(\mathrm{Mg} /\left(\mathrm{Mg}+\mathrm{Fe}^{2+}\right)\right.$ vs $\mathrm{Fe \#}=\left(\mathrm{Fe}^{2+} /\left(\mathrm{Fe}^{2+}+\mathrm{Mg}\right)\right.$ num diagrama binário que separa os campos do forsterita-crysolita-hyalosiderita-hortonolita-ferro hortonolitafayalita.

*Piroxênios foram recalculados segundo o esquema de Yoder \& Tilley (1962, citado em Minpet 2.0), sendo normalizados para 6 oxigênios e recalculados para quatro cations empregando-se o método de balanço de carga para o calculo do $\mathrm{Fe}^{3+}$. Já os cations foram locados no sítio estrutural conforme as recomendações do IMA e os end menbers foram recalculados empregando o método de Cawthorn \& Collerson (1974, citado em Minpet 2-0). No apêndice mostram-se os end members e os valores requeridos para a classificação. Nos casos em que os piroxênios apresentaram valores elevados de $\mathrm{Ti}$ empregaran-se os prefixos titanífero (titaniam) quando $\mathrm{TiO}_{2}$ $>2 \%$ e titanado (titam) quando $\mathrm{OTiO}_{2}$ situo-se entre 1-2\%. De modo similar quando $\mathrm{Al}_{2} \mathrm{O}_{3}>2 \%$ emprego-se o termo aluminoso. 
*Micas foram normalizadas para 22-oxigênios considerando que a microssonda eletrônica não permite analizar $\mathrm{OH}$ e que não foi analizado $\mathrm{F}$ e $\mathrm{Cl}$. Com base ao recalculo que realiza o programa Minpet 2.0 foram obtidos o número de cations Si, $\mathrm{Fe}^{2+}, \mathrm{K}, \mathrm{Al}^{\mathrm{iv}}, \mathrm{Cr}, \Sigma_{-} \mathrm{T}, \mathrm{Al}^{\mathrm{Vl}}, \mathrm{Mg}, \mathrm{Ti}, \mathrm{Ca}$, e $\mathrm{Na}$. Elas foram classificadas, após uma primeira separação baseada na razão $\mathrm{Mg}: \mathrm{Fe}=2: 1$ (Deer et al., 1966) i.e., $\mathrm{Fe} / \mathrm{Mg}<0.5$ =flogopitas e Fe/Mg>0.5 =biotitas. As que em função do valor do Fe\# vs Al, foram lançadas num diagrama binário que contempla os campos da flogopita-annitaeastoniamsiderofilita. Assim eles, também foram classificadas com base no diagrama ternário Mg-Al-Fe (Rock, 1984) que contempla os mesmos end members. Empregouse os prefixos titanífero quando $\mathrm{TiO}_{2}>2 \%$ e aluminoso quando o $\mathrm{Al}^{\mathrm{VI}}$ esta presente neste mineral.

Anfibólios foram normalizados para 21 oxigênios, tendo em vista que a microssonda eletrônica não analisa $\mathrm{OH}$ e que não foram dosados $\mathrm{Cl}$ e $\mathrm{F}$ com o cálculo dos cátions TSi, TAI, TFe ${ }^{3}$ Sum_T, CCr, CFe ${ }^{3}, \mathrm{Cti}, \mathrm{CMg}, \mathrm{CFe}^{2}, \mathrm{CMn}, \mathrm{CCa}, \Sigma \mathrm{CBMg} B F e^{2}, \mathrm{BMn}$, $\mathrm{BCa}, \mathrm{BNa}, \Sigma \mathrm{BACa}, \mathrm{ANa}, \mathrm{AK}, \Sigma \mathrm{A}$. O recalculo catiônico foi realizado empregando a opção $\mathrm{Fe}$ como $\mathrm{Fe}^{2+}$. As classificações foram feitas conforme Hawthorne (1981, in Minpet 2.0) que procede, em primeiro lugar em separar-los em 4 maiores grupos de anfibólios: grupo $\mathrm{BCa}+\mathrm{BNa}-\mathrm{BNa}=$ anfibólios de Fe-Mg-Mn, anfibólios cálcicos, anfibólios sódico-cálcicos e anfibólios alcalinos.

O recálculo cationnico e classificação que o Programa Minpet 2.0, na versão 19881994, empregou baseia-se no esquema dado por Leake (1978); recentemente o IMA (Leake et al., 1997) introduziu algumas modificações neste esquema de classificação. Levando em consideração as novas recomendações do IMA, como tarefa de rotina se procedeu da seguinte forma:

$\Downarrow$

locar os anfibólios

*nos diagramas de classificação geral (BNa-BCa+BNa),

$\Downarrow$

deles separadamente analizar

*nos diagramas dos anfibólios de Fe-Mg-Mn (Mg\#-TSi); 
*nos diagramas do grupo cálcico com ANa+AK<0.5; Ti<0.5 (Mg\#-TSi);

$\Downarrow$

"nos diagramas do grupo sódico cálcico com ANa+AK<0.5 (Mg\#-TSi);

$\Downarrow$

"nos diagramas do grupo alcalino com ANa+AK>0.5 $\left(\mathrm{MgHF}^{3+}-\mathrm{Fe}^{3+} /\left(\mathrm{Fe}^{3+}+\mathrm{CAl}\right)\right.$.

A partir destes diagramas de classificação se adapataram as modificaçōes introduzidas pelo IMA ao esquema de Leake (1978), por exemplo os anfibólios alcalinos agora denominados de sódicos). Os anfibólios caracterizados como sódicos segundo Leake et al., (1997), por exemplo os de Yzu-2 e Ymi-1, foram assim classificados seguindo o fluxograma de classificação abaixo:

"Selecionaram-se

anfibólios com $\mathrm{Na}_{\mathrm{B}}>1.50 ;\left(\mathrm{Mg}+\mathrm{Fe}^{2+}+\mathrm{Mn}^{2+}\right)>2.5$;

$\left(\mathrm{Al}^{\mathrm{V}}\right.$ ou $\left.\mathrm{Fe}^{3+}\right)>\mathrm{Mn}^{3+} ; \mathrm{Li}<0.5 ;\left(\mathrm{Mg}\right.$ ou $\left.\mathrm{Fe}^{2+}\right)>\mathrm{Mn}^{2+}$

separados todos os anfibólios de Yzu-2 e Ymi-1 (10.c.001)

$\Downarrow$

*quando Mg\# 0.5-1.0

se $(\mathrm{Na}+\mathrm{K})_{A}<0.50$

ou

se $(\mathrm{Na}+\mathrm{K})_{\mathrm{A}}>0.50$

$\Downarrow$

glaucofana

eckermanita

nyboita

$\left(\mathrm{Al}^{\mathrm{V}}>\mathrm{Fe}^{3+}\right)$

riebekita magnesiana

arfvedsonita magnesiana

ferrinyboita

$\left.(\mathrm{A})^{\mathrm{VI}}<\mathrm{Fe}^{3+}\right)$

"porém se o Mig\# 0.0-0.5

$\Downarrow$

glaucotana ferrosa

eckermanita ferrosa

ferronyboita

$\left(\mathrm{Al}^{\mathrm{VI}}>\mathrm{Fe}^{3+}\right)$ 
riebekita

arfvedsonita ferri=ferronyboita

$\left.(A)^{\mathrm{VI}}<\mathrm{Fe}^{3+}\right)$

Conquanto que os valores de $\mathrm{Fe}^{3+}$ sejam geralmente $<0.00$, foram caraterizados como eckermanita ferrosa em Yzu-2 e eckermanita (Mg\#>0.5) em Ymi-1. Outros detalhes podem ser obtidos em Leake et al. (1997).

São classificados como rifterita alguns anfibólios de Yzu-2 quando têm os cations recalculados com a opção $15-\mathrm{NK}$ ou $13 \mathrm{CNK}$; enquanto que na opção $\mathrm{Fe}^{2+}$ (medido como $\mathrm{FeO}$ ) são classificadas como eckermanita ferrosa.

São também aplicados prefixos adicionais aos nomes dados pelos diferentes esquemas de classificação:

potássico: $K>0.50$ (todos os grupos);

sódico: Na>0.50 (somente no Grupo de Mg-Fe-Mn);

titanifero (titano): Ti>0.50 (todos os grupos com exceção da kaersutita).

No esquema de classificação dos anfibólios de Mg-Fe-Mn (Mg-Fe-Mn-Li) de Leake et al. (1997) foram suprimidos diversos nomes, seguindo as recomendações do IMA:

os nomes: magnésio antofilita por antofilita;

magnésio cummintonita por cummingtonita;

hornblenda tremolítica por magnésiohornblenda;

hornblenda actinolitica por magnésiohornblenda

fero-actinolita hornblenda por ferrohornblenda

Tschermakitic hormblenda por tschermakita

Ferro-tschermakitic hornblenda por ferrotschermakita. Estes critérios serão levados em consideração no decorrer do presente trabalho.

*Feldspatos foram normalizados para 32-oxigênios e classificados em função dos valores moleculares de Or (ortoclásio)-Ab (albita)-An (Anortita). Muitos feldspatos alcalinos apresentaram também elevados tenores de $\mathrm{Fe}_{2} \mathrm{O}_{3}$ e/ou elevados teores de $\mathrm{BaO}$, apesar disso eles foram recalculados com os procedimentos empregados para os feldspatos comuns (Or-Ab-An). Contudo nas caraterizações daqueles com teores elevados em $\mathrm{Fe}_{2} \mathrm{O}_{3}(>1 \%)$ e $\mathrm{BaO}(>1 \%)$ acrecentou-se os prefixos rico em ferro 
e/ou rico em bário em lugar de expresar-thes em termos das moléculas de feldspato férrico ou hyalofana.

*Feldspatóides foram todos padronizados como tratando-se de leucita, i.e. com base a 6-oxigênios. Para classificações (leucita e analcimas) foram considerados os tenores em potássio e sódio.

* Carbonatos foram classificados com base no diagrama Calcita-Magnesita-Siderita (Rock, 1991), i.e. valores moleculares dos óxidos CaO-MgO-FeO presentes nos carbonatos.

*Espinélios, após cálculo do $\mathrm{Fe}_{2} \mathrm{O}_{3}$ (ver item seguinte), os dados foram lanzados nos siguintes diagramas:

- diagramas binários: Cr\# vs Fe\# empregado sobretudo para caraterizar espinélios ricos em $\mathrm{Cr}$; Ti\# vs Fe\# empregados para caraterizar sobretudo espinélios ricos ern Ti ;

- diagramas ternários: 2Ti-Cr-Al para caraterizar os mesmos espinélios ricos em Ti; $\mathrm{MgFe}_{2} \mathrm{O}_{4}-\mathrm{MgAl}_{2} \mathrm{O}_{4}-\mathrm{MgCr}_{2} \mathrm{O}_{4}$ para caraterizar os mesmos espinélios ricos em $\mathrm{Cr}$ e $\mathrm{MnFe}_{2} \mathrm{O}_{4}-\mathrm{MnAl}_{2} \mathrm{O}_{4}-\mathrm{Mn}_{2} \mathrm{O}_{4}$ para caraterizar espinélios ricos em $\mathrm{Mn}$ (espinélios correntemente não considerado nos diagramas acima citados). Nestes últimos adicionou-se os adjetivos rico em manganês, quando $\mathrm{MnO}>2 \%$ e manganesífero quando o MnO 1-2\%. Estes procedimentos seguem as recomendações de Deer et al. (1966), Mitchell (1986; 1995), Mitchell \& Bergman (1991), Haggerty (1994). Detalhes da caraterização são discutidos no Capítulo 3.

IImenitas, após cálculo de $\mathrm{Fe}_{2} \mathrm{O}_{3}$ (ver item seguinte), os dados foram lançados nos diagramas ternários $\mathrm{TiO}_{2}-\mathrm{Fe}_{2} \mathrm{O}_{3}-\mathrm{FeO}, \mathrm{Fe}^{3+}-\mathrm{Mg}^{-\mathrm{Fe}^{2+}}$ (1) e $\mathrm{Mg}-\mathrm{Fe}^{2+}-\mathrm{Mn}$ (2) para fins de resaltar a predominância dos componentes moleculares finais:

hematita-geykelita-ilmenita (1) e geykelita-ilmenita-pyrofanita (2)

\section{Cálculo de $\mathrm{Fe}_{2} \mathrm{O}_{3}$ em espinélios e illmenitas.}

As análises realizadas na microssonda eletrônica fornecem valores do ferro como $\mathrm{FeO}_{\mathrm{t}}$ (ferro total). A grande maioria dos espinélios, como também a grande maioria 
das ilmenitas, representam soluções sólidas de componente finais (end members) (Haggerty, 1976). Em espinélios e ilmenitas, por exemplo, é imperativo recalcular os valores de $\mathrm{Fe}_{2} \mathrm{O}_{3}$ tendo em conta que eles têm importância fundamental no cálculo dos componente moléculares finais presentes nos espinélios e também nas ilmenitas (Haggerty, 1994).

Para o recálculo do $\mathrm{FeO}$ e $\mathrm{Fe}_{2} \mathrm{O}_{3}$, a partir de $\mathrm{FeO}$ total analizado, o método mais aceito pelos pesquisadores é aquele de Finger (1972). Este método foi revisado especificamente para os espinélios e as ilmenitas por Lucas et al. (1989).

No presente trabalho adotou-se o método de finger (1972) para a estimativa do $\mathrm{Fe}_{2} \mathrm{O}_{3}$ presente nos espinélios (525-recálculos) e ilmenitas/pseudobrooquita/rutilos (164-recálculos). Os dados foram listados em planilhas do programa Exel-6 e 7 os espinélios foram normalizados para 32 oxigênios e perfazendo um total de 24 cátions, enquanto que as itmenitas e outros titanatos similares foram normalizados para 3 oxigênios.

Como as planilhas foram montadas com base ao exemplo de Lucas et al. (1989); é encontrado na página 320 :

Calculate weight $\% \mathrm{Fe}_{2} \mathrm{O}_{3}$ :

$Y /(Z+Y) \times A \times B=\quad$ esta fórmula encontra-se errada e debe ser substituida por $Y /(Z+Y) \times C \times B=$

Quando empregomse este mesmo método para o recálculo do $\mathrm{Fe}_{2}$ e $\mathrm{Fe}_{3}$ em pseudobrookitas, a $\Sigma$ de anions sobrepasaba 4 e assim o método não permitia 0 recálculo. Para dar uma saída emprego-se o recurso de sustrair 1 da $\Sigma$ de anios.

\section{Constantes e razões}

No texto, quando necessário foram empregadas constantes para o cálculo de elemento a partir do óxido medidos nos diferentes minerais analizados. As constantes são:

$\mathrm{SiO}_{2} \times 0.4674=\mathrm{Si}, \quad \mathrm{TiO}_{2} \times 0.5995=\mathrm{Ti} \quad \mathrm{Al}_{2} \mathrm{O}_{3} \times 0.5293=\mathrm{Al}, \mathrm{Fe}_{2} \mathrm{O}_{3} \times 0.6994=\mathrm{Fe}^{3+}$, $\mathrm{FeO} \times 0.7773=\mathrm{Fe}^{2+}, \mathrm{MnO} \times 0.7745=\mathrm{Mn}, \mathrm{MgO} \times 0.6031=\mathrm{Mg}, \mathrm{CaO} \times 0.7147=\mathrm{Ca}$, 
$\mathrm{Na}_{2} \mathrm{O} \times 0.7419=\mathrm{Na}, \quad \mathrm{K}_{2} \mathrm{O} \times 0.8302=\mathrm{K}, \quad \mathrm{P}_{2} \mathrm{O}_{5} \times 0.4364=\mathrm{P}, \quad \mathrm{BaO} \times 0.8957=\mathrm{Ba}$, $\mathrm{Cr}_{2} \mathrm{O}_{3} \times 0.6842=\mathrm{Cr}, \quad \mathrm{NiO} \times 0.7857=\mathrm{Ni}$.

As razões empregadas no texto foram as seguintes:

$m g \#=M g /\left(M g+\mathrm{Fe}^{2+}\right), \mathrm{Fe \#}=\mathrm{Fe}^{2+}\left(\mathrm{Fe}^{2}+\mathrm{Mg}\right), \mathrm{Fe}^{3 \#}=\mathrm{Fe}^{3+} /\left(\mathrm{Fe}^{3+}+\mathrm{Fe}^{2+}\right), \mathrm{Cr} \#=$ $\mathrm{Cr} /(\mathrm{Cr}+\mathrm{Al}) \in \mathrm{Ti}=\mathrm{Ti} /(\mathrm{Ti}+\mathrm{Cr}+\mathrm{Al})$.

\section{Trabalhos de escritório}

Os trabalhos de escritório compreendem o tratamento dos dados da química mineral utilizando-se os programas Exel 6.0 e 7.0 e Minpet 2 e 2.0 compativeis com o programa Windows 95; a redaçäo do texto em Word for Windows 7.0

\section{Observações}

-No texto palavras em outros idiomas estão declinadas, ex. pipe.

-Quando empregado entre aspas (ex. "lamprófiro") pretende-se dar ao termo uma conotação de caráter temporário ou com o intuito de agrupar, por exemplo rochas com feições similares. 


\section{CAPÍTULO 2 \\ GEOLOGIA}

\section{Introdução}

Cráton é definido como a parte relativamente estável do continente, ou do interior da placa continental, não afetada pela atividade tectônica de suas margens. Como condições básicas nos crátons são necessárias: estabilidade relativa, antigüidade e transitoriedade, espessura litosférica privilegiada e baixo fluxo térmico (Brito-Neves, 1995). As Tabelas 2-1 e 2-2 fornecem esquematicamente algumas das feições gerais dos crátons. Levando em consideração as idades que podem ser reconhecidas e agrupadas nos crátons, Janse $(1985,1994)$ os divide em três maiores blocos:

1-Archon -rochas do embasamento com idade do Arqueano, que tem como seu último evento termal a idade de $2500 \mathrm{Ma}$.

2-Proton -rochas do embasamento com idade do Proterozóico tardio a médio (2500$1600 \mathrm{Ma}$ ), e que têm Como seu último evento termal a idade de $1600 \mathrm{Ma}$.

3-Tecton -rochas do embasamento com idade do Proterozóico tardio (1600-800 Ma), e com idade do último evento termal de $800 \mathrm{Ma}$.

Crátons são reconhecidos nas Américas, Europa, Asia, África, Ártico (p/ex. Canadian Shielf), Antártica e Austrália, e sua distribuição pode ser encontrada em Janse (1994).

Na Plataforma Sul-Americana, considerada como totalmente formada no evento Pan Africano (Almeida et al., 1984; Schobbenhaus \& Campos, 1984) são reconhecidos 4 crátons: Amazónico, São Luís, São Francisco e Rio de la Plata (Almenida 1971, 1978; Brito-Neves \& Cordani 1991; Brito-Neves et al. 1996; Janse 1985; Svisero 1994; Tompkins 1994; Trompette 1994). 


\section{CARACTERISTICAS GEOLOGICAS GERAIS}

a) Fraçăo/parte relativamente estável, isostaticamente positiva da lifosfera continental (> 100

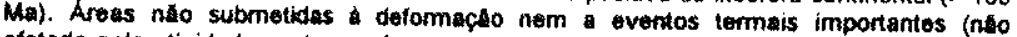
afetede pela atividade comempordnea das bordas das placas itostericas, ou muto pouco afeteda).

b) Caracterizam-se por areas de litosfora continental muito espess $(300-400 \mathrm{~km}, 450 \mathrm{~km})$ com material sílicico ne ordem de $40 \mathrm{~km}$.

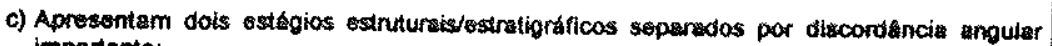
importante:

Coberturas $\quad 0.7 \mathrm{~km} \quad=$ Bacias Sedimentares

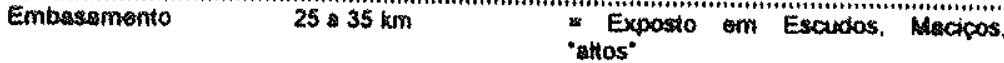

a) As características de estabilidede, antiguidade transitoriodade relativas s\$o requisitos. A natureza transitória no tempo deve sempro edicioneda:

Do quom? Quando? Que ciclo?

6) O zoneamento tecub́nico do craton dove distinguir nucteos mais estaveis ("Full cratonic areas"), das áress marginais a/ou correóres intemos de deformacto em condicbes cratónicas (Antepais, "Fonsiand")

1) Quanto a ldade. $16 \mathrm{~m}$ sido distinguidos precariamente os critons e plataformas:

Velhas ou Verdadairas * Estruturas Pro-Cambrianas predominantes

Lovens ou Pseuctopiataformas a Pos-proterozdicas (discutiveis)

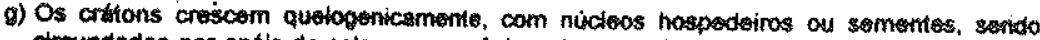

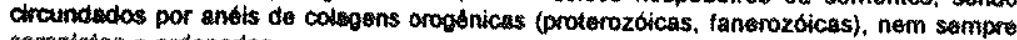
complestas ondenades.

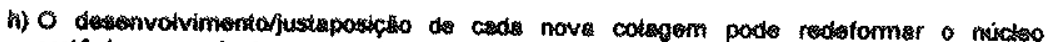

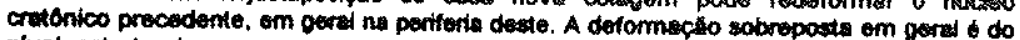
nived estrutural raso a pouco penetrativa (Gemmanotipo), excepcioneimente dixctil penetrotivi (atpinotipo), "regenerando" o criton.

1) A definicllo dos limites dos crtions veril com a escole tectonica (fixdstes" $x$ "plequistes",

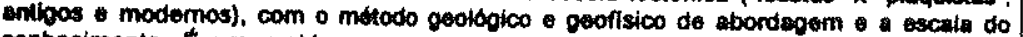
conhecimento. E um problem que curoce reavaliacso sempre, com o prooresso do contrectmento.

1) Em termos de tipos crustais continendais, express 40 globel atual dos dominios cratonicos 6 majoriteria com de cerce de: $23 \%$ em area $47 \%$ em volume

He proposta de comissto especifica de luGS para utilizar os termos:

cration * domínios de embasamento consolidado nos cictos pro-cambrianos ("valho")

plataforma $=$ dominio de embasamento corsolidado mo final do Pro-Cambriano/Eopialoozóico.

Has, em geral, proposta náo seguida.

Tabela 2-1. Características geológicas dos crátons, conforme Brito-Neves (1995).

\section{O cráton Rio de La Plata}

O cráton Rio de La Plata foi definido por Almeida et al. (1973) englobando a porção Uruguai e os arredores da Serra de Tandil na Argentina. Posteriormente, foi estendido rumo ao norte (Fragoso-Cesar \& Soliani, 1984) para incluir, sucessivamente: as janelas de Rivera, ao oeste, e Acegúa, a leste, localizados no interior da Bacia do Paraná, próximas à fronteira Uruguai-Brasil; leste do Rio Grande 
a) Espassuras litosfericas muito elevadas, $300-400 \mathrm{~km}$ (Tectosfera), com Zona de Baixa Votocidade ausente ou presente a grandes profundidades e pobremente definida. Existe uma relaço estreita entre a espessura da tectosfera o a idade. estando as zonas mais espessas sob os núcieos cratónicos, acompanhando o movimento das massas continentais.

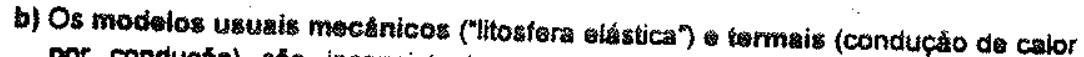
por conducfo) sto inconsistentes para explicar as profundas "assinaturas" sismologicas abuixo dos critons. Estas raizes profunoas, basandas m - vidéncias sismológicas, petrológicas, isotópicas gooquimica sáo em favor de um reservatiório mentatico de baixa densidade ("depleted" por varias razbes). distinto deques das faizas móveis o de outros tipos crustajs.

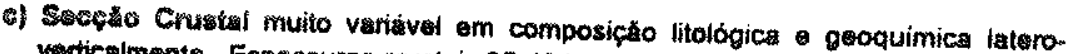
verticalmonte. Espossuras crustajs $35.40 \mathrm{~km}$.

d) Pont sismico com modolos usualmente varivivis com comada sedimentar $\left(0 \mathrm{a.6 \textrm {km }}, V_{p}=2-4 \mathrm{~km} / \mathrm{s}\right)$. camada superior (10 a $\left.25 \mathrm{~km}, V_{p}=6-6,2 \mathrm{~km} / \mathrm{s}\right)$, camade inferior $\left(16-30 \mathrm{~km}, V_{\beta}=6,5-6,2 \mathrm{~km} / \mathrm{s}\right)$. Moho $=$ Refletor variavel de intensidade carater, muito simples a muito
complexo

-) Stsmicidade. Paqueno número de torremotos ratos, atguns concontrados longo de zonas de faithas, outros distribuidos esparsamente. Baixa magnitude em orel, excopcionaimente de grandes magnitudes.

n "Stras" "Em garal estagio do "stross" comprassivo horizontst dominante.

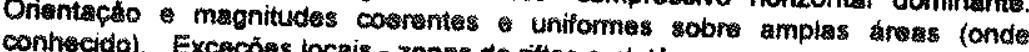
contrecido). Excepós locais - zonas de rittos platós - com zonas de extenstio!

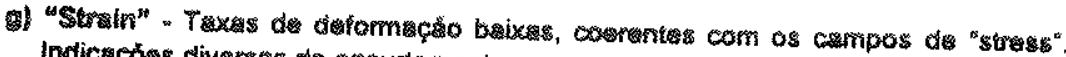
Indicacos diversas de encurtamento nos campos compressivos.

h) Fontes do "stross" - Apesar do pequeno número de dados há boa correlaçáo mundial entre os carmpos de "strass" a trama de velocidade absoluta das placas. A rede de forcas nas zonas dos limites das placas ("ridgo push". "slab pull", trench suction") outros oriundos das relacoles litosfera/astenosfera) sáo as
principais fontes renovávais.

1) Fluxo Tómico, os valores msis baixos monos variáveis entro os tipos crustais em goral, a saber.

Domínios Arquesno-Proterozdico Antigo: $20 \pm 8$ - $48 \pm 18 \mathrm{mWm}^{-2}$

$\begin{array}{ll}\text { Dominios Proterozóico Superior: } & 41 \pm 10 \mathrm{mWm}^{2} \\ \text { Dominios Paidozóicos (Jovens): } & 50 \pm 5 \mathrm{mWm}^{2} \\ & 62 \pm 20 \mathrm{mWm}^{2}\end{array}$

Nas zonas ativadas de riftes e piatós os valores so elevam bastante entre 60 $107 \mathrm{mWm}^{\prime 2}(1,5$ ou $2,88 \mathrm{HFU})$.

O Fiuxo térmico, portanto. crosec com o decrescimo om idade do úlímo maior ovento termal que afotou a regiaso.

1) Os gradientes portermicos sob os crátons șo os mais fracos, do modo qua a curva de temperatura com profundidade mostre sempre as menores inclinacoes. Com a espessura da tectosfera aumenta com a idade da crosta, paraielamente a isto vai diminuir tambem o fluxo de calor.

Estruturas compressionais (mais raras) requerem altas taxas do fluxo térmico a/ou esforcos mais elevados do que aqueles gerados nos limites do placas, muito euperions aqueles gersdos por simples "ridge push".

1) Resistaneia Mectnies - Estruturas axtensionais dentro do cráton săo possiveis

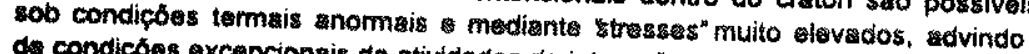
de condicoes excepcionais da atividades de interafso de placas.

m) Anomalias Magnotomstricas - Padrbas amplos de anomalias rotacionais, com amplitudes de algumss cantenas de gammas, larguras de 10 a $100 \mathrm{~km}$ comprimento de centenas de mitharse do quilometros. Varizival basatante com as

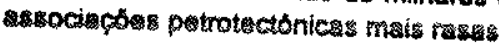

ni Anomallas Cravimetricas - Cancterizados por amplas anomatias regionais de 10 a -50 mgal, com scontuadas anomalias locais. Valores mais elevedos entre tipos crustais continentais (exceto mares interiones).

Tabela 2-2. Algumas carateristicas geofísicas dos crátons, conforme Brito-Neves (1995) 
do Sul ou bloco Taquarembó, e os blocos Encruzilhada e São Gabriel; e finalmente, no norte, o bloco cratônico chamado de Luís Alves (Trompette, 1994). Entretanto Soliani (1986) comenta que os blocos Encruzilhada e São Gabriel representam embasamento polimíctico reativado, o cinturão Dom Feliciano, no Brasiliano. Por outro lado também Kaul, (1980) questiona a incorporação do bloco cratônico Luís Alves, uma vez que este articulado ao bloco Angolano do Cráton do Congo, hipótese esta de difícil comprovação. Segundo Trompette (1994) é tomado como mais razoável de assumir que o Cráton Congo-Zaire acaba por baixo dos sedimentos da bacia costeira Angolana.

Desta forma, o termo Cráton Rio de La Plata, apesar dos problemas ainda existentes na sua definição, é empregado no sentido de Trompette (1994) incluindo as áreas a partir de Serra Tandil, na Argentina até o bloco Luís Alves, no Brasil . Conforme Mantovani et al. (1987) o Cráton Rio de La Plata registra como eventos termais de acresção que oscilam do Arqueano (3.3 Ga.) ao Proterozóico médio (1.3 Ga), i.e. Arcon a Tecton segundo a nomenclatura de Janse (1994).

O Cráton Rio de La Plata, está bem representado no Uruguai (Dalla Salda et al., 1988; Hallinan et al., 1993; Trompette, 1994, Fragoso Cesar \& Machado, 1997; Cingolani et al., 1997), sendo contornado á ESE pelo cinturão Dom Feliciano (Basei, 1985; Trompette, 1994; Chemale et al., 1997); e sens limites a WNW então encoberto sob as rochas sedimentares da Bacia do Paraná (Trompette, 1994). Aqui o cráton consiste de uma ampla associação de Terrenos do Arqueano, soldados por faixas móveis mais novas. Os terrenos do Arqueano ( $>2 \mathrm{Ga}$ ) incluem complexos de rochas granitóides com ithas de diversa litologias de rochas metamóficas conhecidos como Terrenos de Piedra Alta (Cingolani et al. 1997) ou também Como Terreno Tijucas (Fragoso Cesar \& Machado, 1997, ver também Chemale, Jr. et al., 1997). O Terreno Nico Pérez, englobam áreas granulíticas e áreas gnáissico-granito-migmatíticas e que sofreram retrabalhamneto no Brasiliano (cf. Hallinan et al., 1993) sendo também considerados como terrenos muito antigos, i.e. Terrenos Arcon. Entre os terrenos antigos se conhecem três maiores faixas móveis: Faixa San José, Faixa Montevideo e Faixa Arroyo Grande (Cingolani et al., 1997). Eles são compostos por rochas metasedimentares com intercalações de rochas metavulcânicas. (Trompette, 1994) i.e. Terrenos Proton. Segundo Fragoso-Cesar \& Machado (1997) os terrenos a leste estão representados por faixas de granitóides 
Neoproterozóicas ( 0.8-0.55 Ga) Dalla Salda et al. (1988), Cingolani et al. (1997), i.e. Terrenos Tecton. Esta mesma feição pode ser observado também nos crátons de São Francisco (Texeira, 1992), Amazônico (Colombo 1996), como também em crátons de outras partes do mundo (ex. Kaminsky et al., 1995; Helmstaedt \& Gurney, 1995; White et al., 1995) i.e. pedacos de Terrenos Arcon ficaram entre eles soldados por faixas Proton e Tecton e, ao conjunto consolidado referência-se como cráton.

$\mathrm{Na}$ parte norte do Uruguai e no Brasil ocorrem duas janelas do embasamento antigo, Rivera A Acegúa compostas de granito-gnaisses (2272 $\pm 33 \mathrm{Ma}$ ) intrudidos por granitóides brasilianos (580-690 Ma): (Soliani, 1986). No Rio Grande do Sul tem-se encontrado o bloco Taquarembo, consistindo maiormente de granulitos Transamazônicos 1980 a $2370 \mathrm{Ma}$, com idade Pb/Pb 2541士167-169 Ma, indicando a existência de um pequeno núcleo arqueano (Trompette, 1994), i.e.Terrenos Arcon. Juntando-se a eles, entre os estados de Santa Catarina e Paraná, são encontrados três maiores domínios tectônicos (Basei et al., 1992): Luis Alves (2.3-3.1 Ga), Curitiba (2.3-2.8 Ga) e Paranaguá ( 1.97 Ga)(Basei et al., 1997; Siga Jr. et al., 1997; Harara et al., 1997). Estes últimos são terrenos compostos por rochas granitóide cálcio-alcalinos e gnaisses, e rochas de complexo granulítico (Trompette, 1994). Domínios entre os quais se conhecem terrenos de "faixas móveis" do Proterozóico como a Faixa Ribeira (Cordani et al., 1984; Brito-Neves \& Cordani, 1991; Quintas 1995) com idades de 1.08-2.2 Ga, que estão compostas por rochas metamórficas de diversas litologias e metavulcânicas, sendo polissíclicos e estiveram reativados na orogenia Brasiliana como mostrado pelas intrusões granitóide de Cunhaporanga (dos Reis Neto, 1994;) Três Corregos (dos Reis Neto, 1994; Guimarães, 1995) e os da cinturão Dom Felicinano, que cavalga sobre a margem sul do bloco Luís Alves (Mantovani et al., 1991; Basei, 1985; Basei et al., 1997). Observa-se neste domínio que a transição é gradual como está indicado pelas largas falhas que algumas vezes se associam com bacias molássicas (Trompette, 1994). Extremo que, embora nas opiniões de Trompette (1994) permaneça ambigua e hipotética a significância geotectônica (por exemplo do maciço Luis Alves) em conexão com o Cráton Rio de la Plata; aqui também, tanto para este bloco como para os blocos Curitiba e Paranaguá, como mostrado no Uruguai, pode-se pensar como que tratan-se de pedaços do embasamento com raizes Arqueanas que estão soldados por "faixas" de terrenos Proterozóicos; no caso do Luis Alves e 
Curitiba.....terrenos Arcon e Paranaguá e o Cinturão Ribeira.... Terrenos Proton e a do cinturão costeiro Dom Felicinano do Brasiliano que "envolve" os pacotes Arcon e Proton, Terrenos Tecton.

No Sul, o cráton Rio de la Plata reaparece na Argentina nas Serras de Tandil, onde teria sido provavelmente alçado por falhas. Este embasamento Arqueano do ciclo Transamazônico (2200 Ma, Echeveste et al., 1997) esta exposto por cima de $200 \mathrm{~km}$ através de numerosas pequenas ilhas, que raramente excedem os $50 \mathrm{~km}^{2}$ de extensão. Sendo que, esquematicamente o cráton, nestes domínios, consiste de duas maiores unidades. A primeira unidade composta de rochas metamórficas de diversas litologias e rochas metavulcânicas perto da cidade de Tandil. A segunda unidade consiste de migmatitos e rochas granitóides (Trompette, 1994). Ambas as séries foram afetadas por séries tecto-metamórficas elou eventos magmáticos, maiormente radiometricamente definidos, oscilando entre 2150 (Suite cálcio-alcalina, Echeveste et al., 1997) e 1520-1700 Ma (Trompette, 1994; Echeveste et al., 1.997.) com a última orogenia (?) perto do $900 \mathrm{Ma}$ (Trompette 1994), i.e. Terrenos Proton. Este representando a orogenia Transamazônica, sendo interpretado por Ramos et al. (1989) em termos da tectônica de placas, que, durante o Proterozóico Médio e inicio do Proterozóico superior, segiuu a granitização, alguns deles associando-se, provavelmente, com eventos orogênicos (Trompette, 1994) i.e. Terrenos Tecton. Aqui também como comentado com relação aos terrenos do Uruguai e os terrenos de Rio Grande do Sul, Santa Catarina e Paraná, os domínios do cráton Rio de la Plata possuem pedaços de blocos Arqueanos "emvolvidos/soldados" por faixas Proterozóicas; e em seus limites registrando eventos tecto-termais do Brasiliano. Segundo Trompette (1994) este embasamento ficou "tampado" por cobertura da seqüência subhorizontal, a FormaçãoTinta ou Grupo Tandil .

O fragmento do embasamento exposto na região de Assunção (Paraguai) corresponderia a porção W do cráton Rio de La Plata (p/ex. Cordani et al., 1984; Trompette, 1994). Os dados geocronológicos para as rochas expostas nesta região são escassos (Comte \& Hasui, 1971; Bitschene, 1987 e referências).

Os dados geofísicos, encontrados em diversos meios (p/ex. Quintas, 1995; Milani, 1997; Berrocal \& Fernandes, 1996; Snoke \& Janes, 1997) para a Bacia do Paraná, considerada como assentada sobre o cráton Rio de la Plata, mostram a distribuiçăo de diversos elementos crustais que constituem o assoalho e emolduram esta bacia 
(Figuras 2-3, 2-4 e 2-5). A Figura 2-3 mostra que o Bloco Paranapanema do Cráton Rio de La Plata se estende por boa parte do Paraguai Oriental. Na região de Asunción (Paraguai), porção oeste do cráton Rio de la Plata (Trompette, 1994), ocorre o chamado Alto de Caapucú (cf. Proyecto PAR 83/005, 1986), constituido por rochas cristalinas de diversas litologias e também rochas riolitóides e rochas granitóides (cf. Kanzler, 1986) com idades referidas ao cilco Brasiliano (800-500 Ma) (ct. Comte \& Hasui 1971; Bitschene \& Lippolt 1986; Kanzler 1986; Benites com. Pess. 1997), i.e. Terrenos Tecton. Entretanto metaquarzitos da cidade San Miguel forneceram idades $(\mathrm{U} / \mathrm{Pb})$ de $\sim 2.1 \mathrm{Ga}$ (Bitschene comunicação pessoal, 1993). Rochas sedimentares da Bacia do Paraná delimitam tanto a norte como a leste as rochas do Alto de Caapucú, onde os afloramentos do Bloco Paranapanema (Figura 2-3) estão mascarados pela Bacia do Paraná, dando-se assim uma regiăo do tipo plataforma, como é comum de observar na maioria das regiões cratônicas (cf. comentários de Janse, 1994). Neste terreno, na sua borda e entrando em parte, situam-se os afloramentos das rochas que aqui são estudadas (Figuras 2-1, 2-2, 2-3 e 2-5).

Complementando as informações comentadas é encontrado que os diversos poços, dentre eles mais de uma centena já perfurados em busca de petróleo na Bacia do Paraná (Figura 2-2), amostraram porções encobertas do cráton, permindo obter suas idades (Cordani et al., 1984; Ramos, 1988), as quais associada aos dados geofísicos, evidenciam um mosaico de diferentes unidades geotectônicas da Bacia do Paraná (Milani, 1997) e pelo mesmo do Cráton Rio de La Plata, i.e. blocos Arqueanos colados por "faixas" mais jovens; elou Arcons soldados por faixas Protons e Tectons.

Milani (1997) comenta as informações aeromagnetométricas sobre a Bacia do Paraná e elas estão reproduzidas nas Figuras 2-4 e 2-5. Segundo o citado autor, as informações aeromagnetométricas (Figura 2-4) mostram feições lineares orientadas a NE-SW na porção central da Bacia do Paraná; que Marques et al. (1993) as interpretaram que a conformação destas anomalias aeromagnetométricas, com grandes comprimentos de onda, denotam fontes profundas, ligadas à trama do embasamento da bacia. Milani (1997) destacou uma importante feição linear orientada a NE..SW a que pode ser observada no mapa aeromagnetométrico do Paraguai (Figura 2-5), separando áreas com distintas assinaturas nas informações 


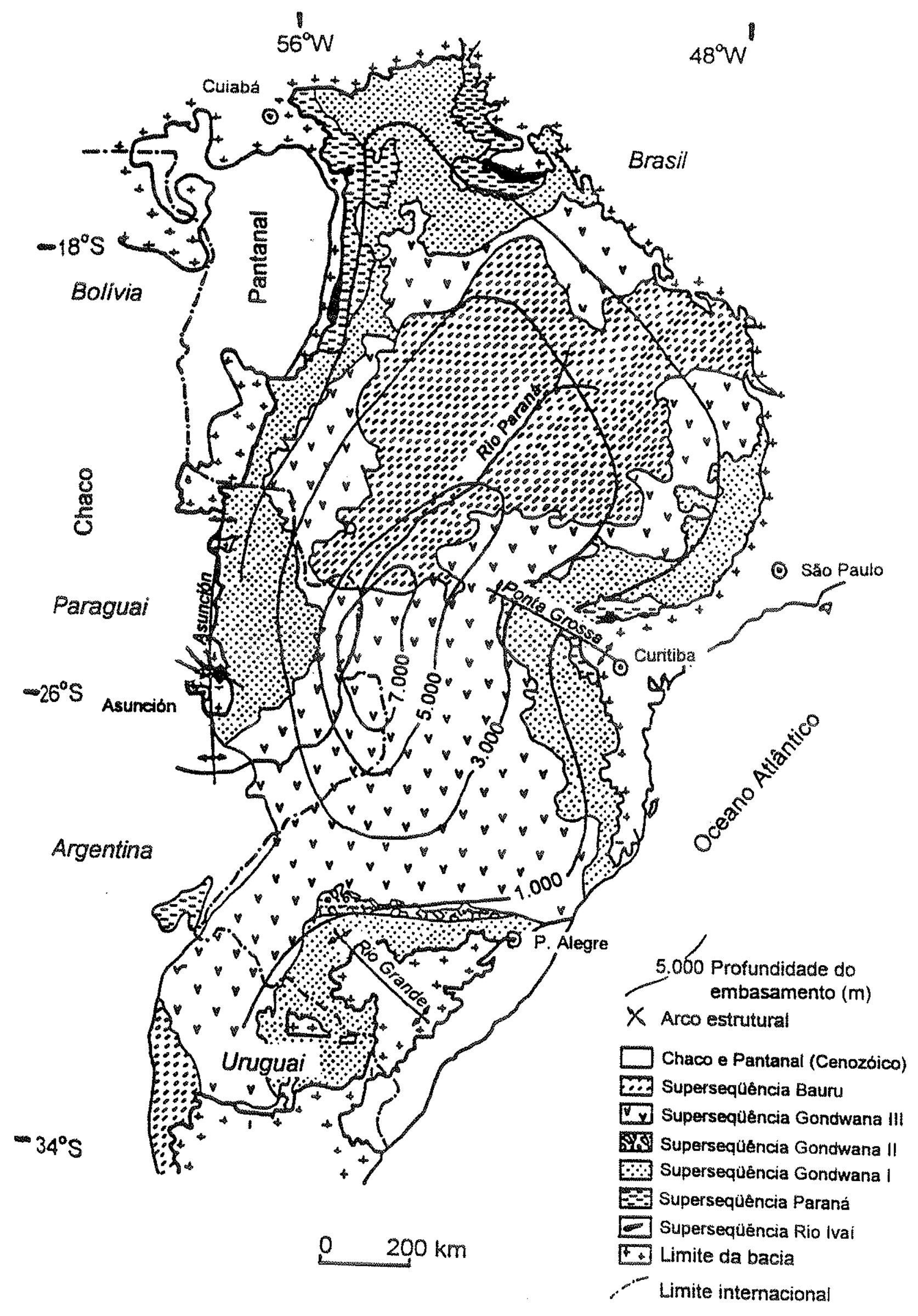

Figrura 2-1. Mapa geológico simplificado da Bacia do Paraná. com referências geográficas e profundidade do embasamento como mostrado por Milani (1997). O rombo. no Paraguai. representa a area de trabalho 


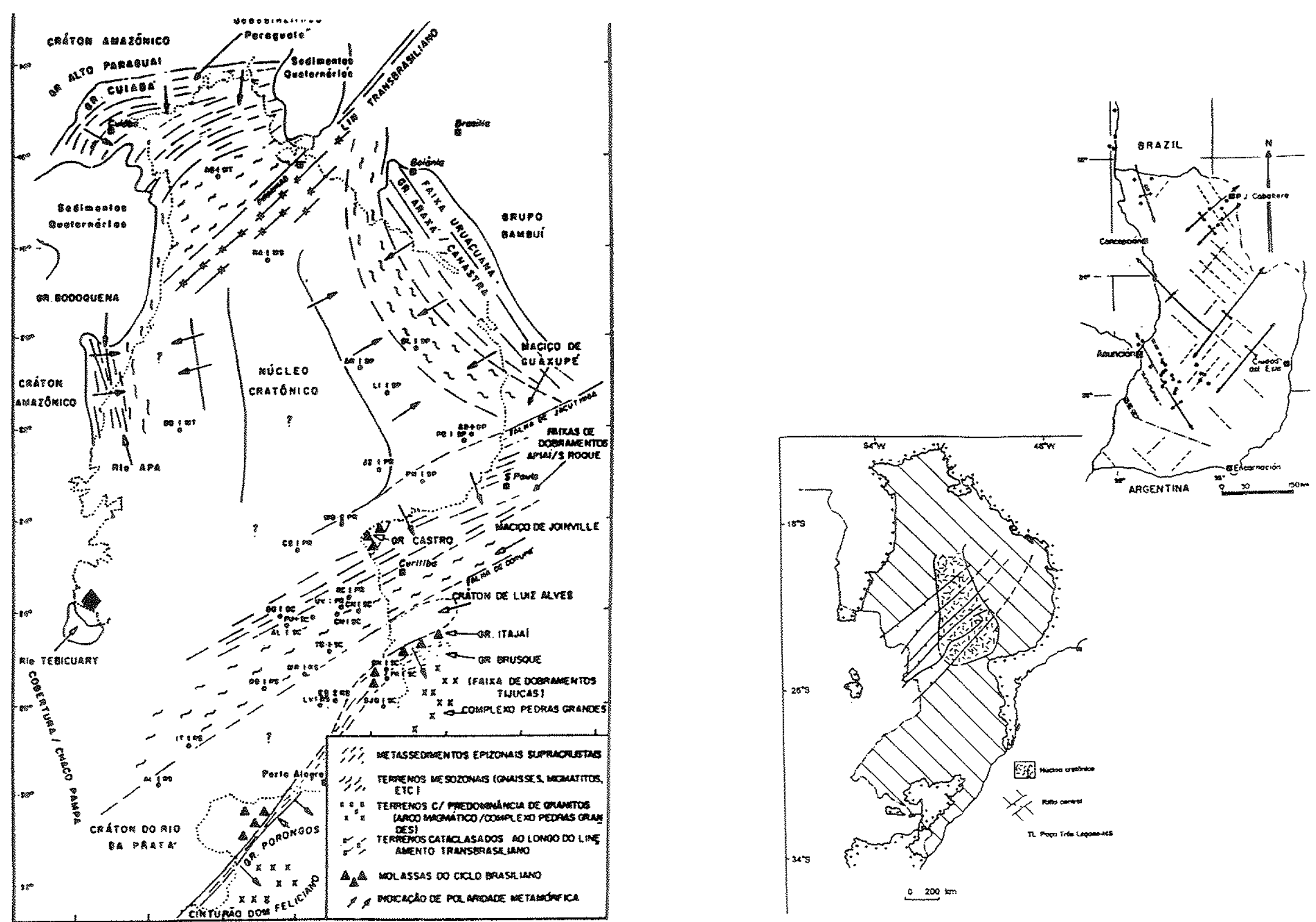

Figura 2-2. Mapa geológico-geotectônico esquemático da Bacia do Paraná. (a), conforme apresentado pot Cordani et al. (1984), que se confronta con o caraterizado rift central de Marques et al. (1993) e os elementos tectônicos (simplificados) do Paraguai Oriental (c) como encontrado em Livieres \& Ouade (1986). Notar que o rift central de Marques et al. (1993) e os altos cntre as cidades de Asunción e P.J. Caballero, no Paraguai Otiental, coincidem. mostrando que se tratam do mesmo elemento estrutural 


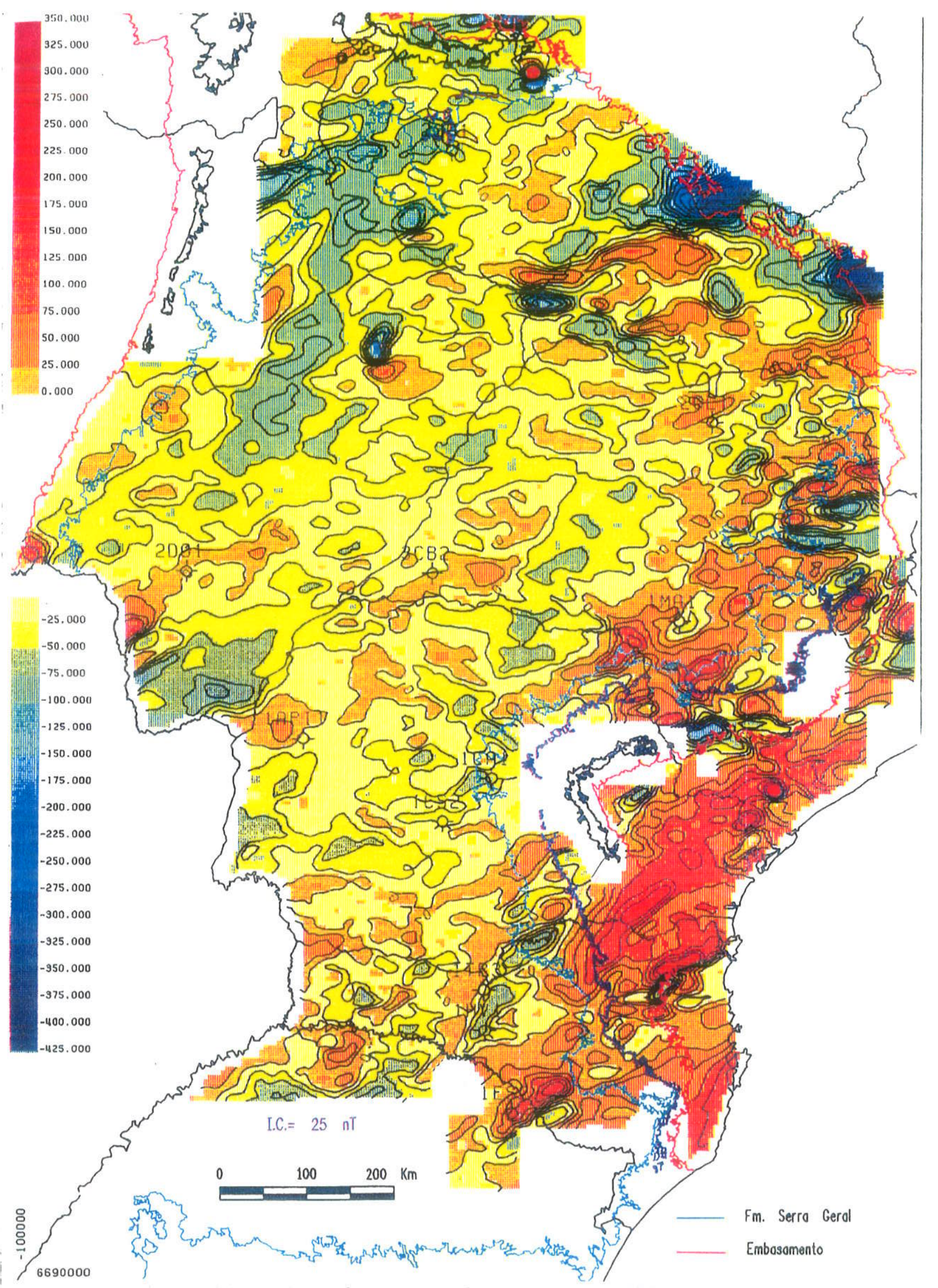

Figura 2-4. Mapa aeromagnetométrico da Bacia do Paraná como apresentado em Milani (1997) que empregou o trabalho de Marques et al. (1993). Compare-se como as configurações das anomalias magnéticas traçam e acompanham a configuração do Craton Rio de La Plata (Figura 2-3). Na figura posterior apresenta-se os dados aeromagnéticos do Paraguai. 


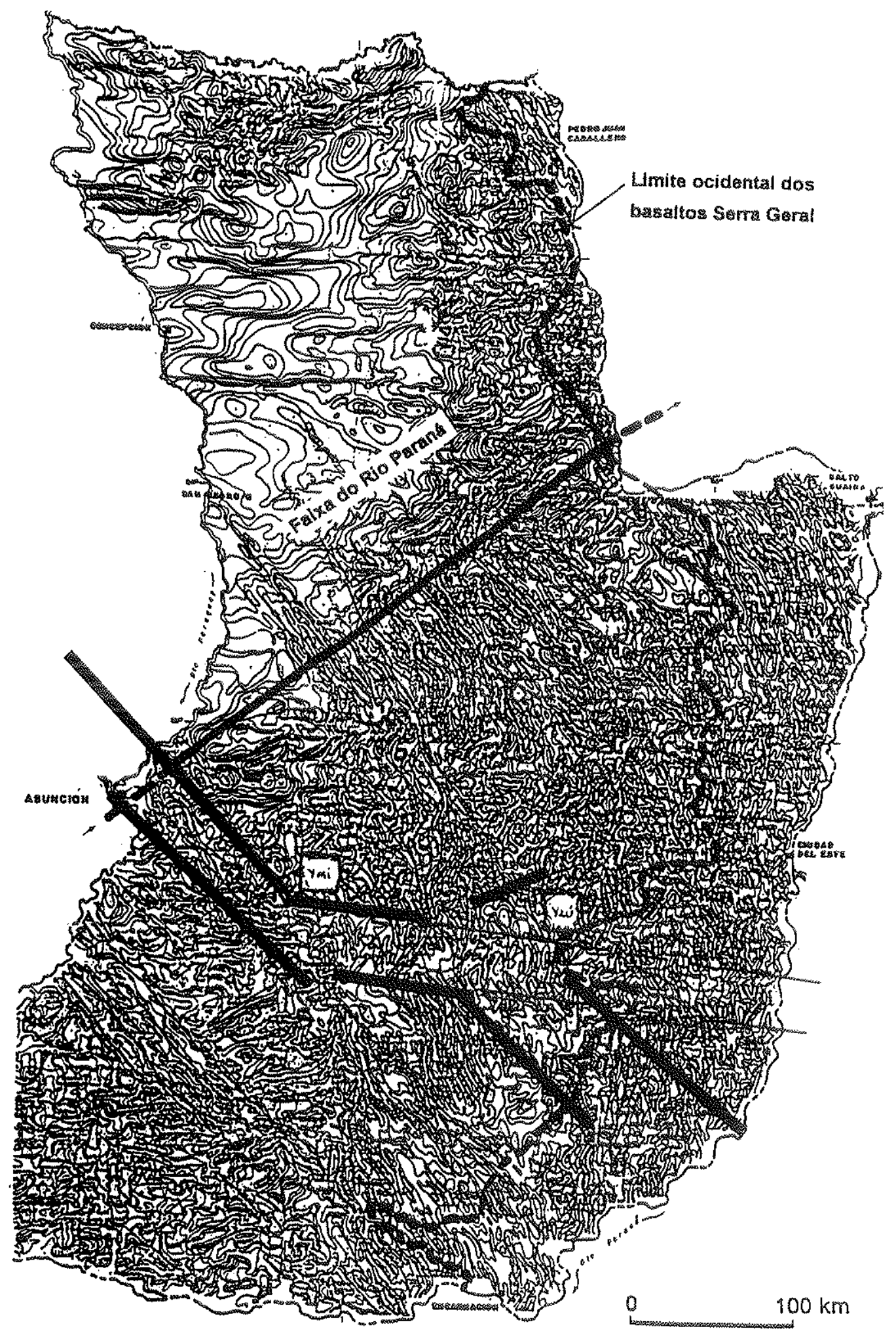

Tigura 2-5. Mapa aeromagnético do Paraguai Oriental (Geoconsultores, 1995 e extraído de Milani, 1997). Neste mapa, segundo Milani (1997) destacan-se dois domínios de assignatures aeromagnéticas diferentes, limitadas por uma marcante feiça linear orientada a NEWW, que consituc no Paraguai o prolongamento do rift Central de Marques et al. (1993). Em destaque o rift de Asunción como delineado por Degrafr (1985) e mostrado em Drueker \& Gay (1987). Comparar esta figura com as figuras $2-2,2-3$ e 2.4 Ymi = Campo Ybytymí e Yzu = Campo Ybytyruzú. 
de tal ferramenta geofísica potencial, as que sugerem estar provavelmente inseridos no contexto de uma faixa de dobramento brasiliana que se extenderia entre a cidade de Asunción (Paraguai) e o poço Três Lagoas (MS-Brasil). Esta estrutura foi denominanda de faixa móvel do Rio Paraná, conceito que segundo esse autor aparentemente conciliaria um amplo conjunto de informações geológicas e geofísicas nas quais se incluem os dados relativos tanto à natureza e às idades das rochas do embasamento da Bacia do Paraná quanto aos trends segundo os quais estes litotipos se distribuem em superfície. A Figura 2-6 confronta as informações cronotectônicas apresentadas por Cordani et al. (1984) com as informações estruturais do Paraguai Oriental (Livieres \& Quade (1986) e com os dados estruturais modelados por Marques et al. (1993) para o centro da Bacia do Paraná. Os lineamentos NE-SW, referidos como altos com diferentes nomes em Livieres \& Quade (1986) no Paraguai Oriental coincidem geográficamente com o rift Central de Marques et al. (1993). Milani (1997) comenta:

"Como consequéncia, o "núcleo cratônico"da Bacia do Paraná desaparece; a faixa móvel do Rio Paraná justapõe dois domínios possivelmente correspondentes a terrenos ou microplacas brasilianas, o bloco do Rio Aporé e o bloco do Rio Paranapanema".

Uma leitura do trabalho de White et al. (1995) permite observar que os "kimberlitos" diamantíferos e econômicos ocorrem em terrenos formados por nucleos Arqueanos (microplacas Archon) soldadas por faixas móveis do Proterozóico Inferior (Proton) ao Superior (Tecton) =plataformas ou cratons muitos deles com uma raiz litosférica profunda. Nestes domínios tectônicos o emprego de dados geofísicos mostram trends de estruturas lineares que se associam com falhas transformantes ou paleorifts (ver Morgan, 1995). Feições sugeririam para o rift Central de Marques et al. (1993) uma posição intra-pericratônica; intracratônico embora que corte o núcleo cratônico de Cordani et al., (1984) e pericratônica conquanto que se prolonga pela região de faixa móvel Paraguai. No Capítulo 6 são levantadas e discutidas mais demoradamente os aspectos relevantes ao aquí levantado. 


\section{Geologia do Paraquai Oriental}

No Paraguai Oriental as unidades morfoestruturais relevantes são os altos de Rio Apa e Caapucú, que juntos seriam parte do Arco de Assunção (Figura 2-6). As rochas nesses altos, nas suas bordas leste, norte e sul estão capeadas por camadas de sedimentos continentais a marinhos, Paleozóicos a Permiano, e basaltos continentais de derrames mesozóicos, em parte intercalados, com sedimentos continentais. Estas unidades em sua maioria são pertencentes à Bacia do Paraná, Figuras 2-1 e 2-7.

A despeito de algumas complicações de caráter localizado (ex. áreas de rift), a sedimentação na Bacia do Paraná no Paraguai Oriental inicia-se com sedimentos clásticos grossos (níveis basais) a finos (niveis do teto) continentais a marinholitorâneos do Siluriano; Grupos Caacupé e Itacurubí espalhados segundo a orientação N-S nestas bordas da bacia, esto acontecendo sobretudo ao redor do Alto de Caapucú; unidades sedimentares que se depositaram segundo mergulho regional de $\sim 5^{\circ}$ em direção a leste. Após um hiato estratigráfico, depositam-se espalhadas pela bacia em dominios mais a leste, (Figura 2*7) sedimentos de várias litologias clásticas de origem glácio-fluvial, os Grupos Cnel. Oviedo a sul e Aquidaban a norte, ambos do Carbonifero. Sotopostos a estes últimos, depositaram-se sedimentos clásticos a químicos com diferentes granulometrias sendo eles principalmente continentais de idade permiana, Grupo Independencia (com as Formações Pañetey e Tacuary). No início do Mesozóico, e acompanhando camadas do teto do Grupo Independencia, sedimentos clásticos eólico-fluviais depositaram-se na bacia, i.e. a Formação Misiones (Figura 2-7). Basaltos continentais de de derrame com idade Triásica $(\sim 135 \mathrm{Ma})$, pertencentes a Formacão Alto Paraná, derramaram-se em vários centros (Figura 2-7). Ao redor das bordas e penetrando, em parte, as bordas da bacia, efusões e intrusões de rochas alcalinas potássicas com baixo Ti (Gibson et al., 1996) (Províncias alcalinas Norte e Central) instalam-se no Mesozóico tardio ( 130 Ma, Comin-Chiaramonti \& Gomes, 1996). Finalmente observa-se a deposição, erosão de diferentes unidades em micro-bacias, algumas delas resultado da tectónica de rift (ex. Formações Acaray e Patiño) (Projeto PAR 83/005, 1986; Presser, 1992; Fulfaro, 1996). 


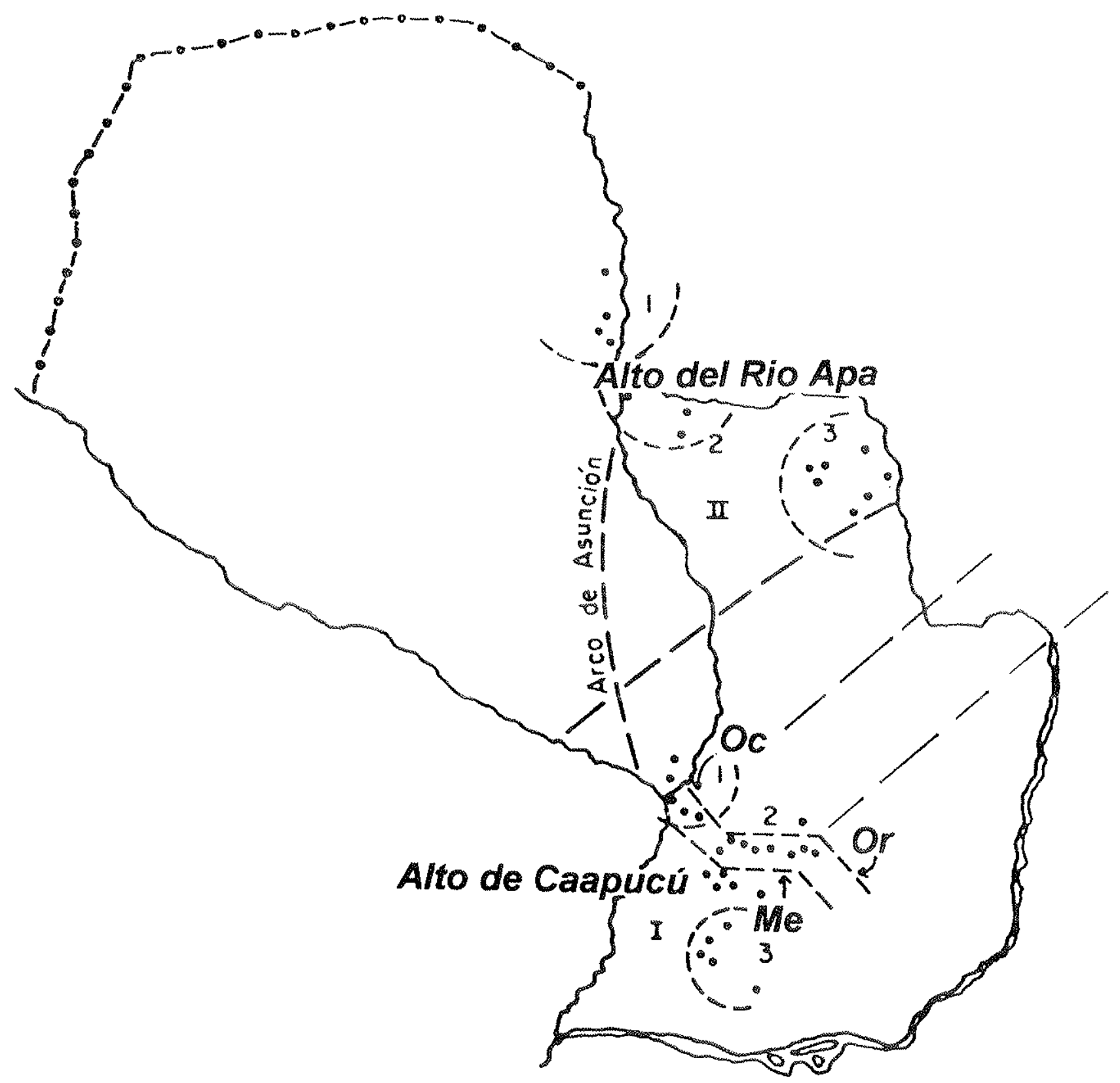

Figura 2-6. Esquema simplificado das unidades geológico-estruturais no Paraguai Oriental e as provincias alcalinas. As linhas tracejadas paralelas indicam aproximadamente o rift de Asuncion, com suas partes Oriental (or), Média (Me) e Ocidental (oc). I: Provincia alcalina Norte. com as subprovincias Alto Paraguay (I). Rio Apa (2) e Amambay (3); Mr: Provincia alcalina Central. com as subprovincias Asunción (1), Guairámparaguarí (2) e Misiones (3). Para outras divisões consultar Gomes et al. (1996) e Velázquez et al. (1996). As linhas paralelas NE-SW corresponderiam ao rift Central de Marques ei al. (1993). 


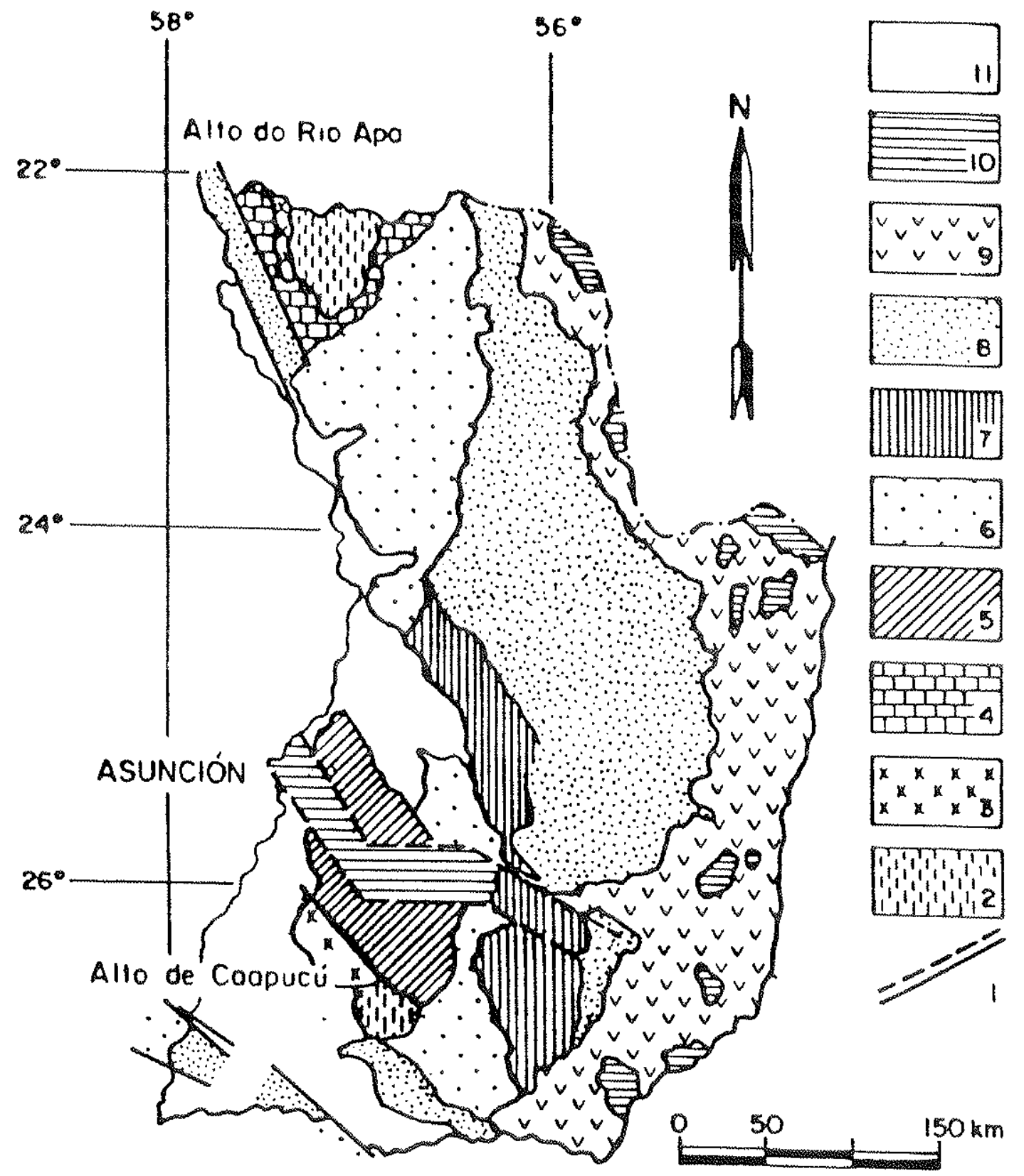

Figura 2.7. Esquema geológico do Paraguai Oriental. Lenda: 1: falhas (propostas e verificadas): 2: rochas do embasamento pré-cambriano (Precámbrico Norte e Sur); 3: rochas igneas pré-cambrianas; 4: Grupo ltapucumi: 5 : Grupos Caacupé e Itacurubí. indiferenciados (Siluriano): 6: Formações Coronel Oviedo (à sul) e Aquidaban (à norte)(Carbonífero a Permiano); 7: Grupo İndependencia (Permiano Superior); 8: Formação Misiones (Triásico a Jurássico); 9: Formação Alto Paraná (Cretáceo); 10 Formaçōes terciárias indiferenciadas; 11: depósitos recentes e subrecentes. Fonte: Livieres \& Quade (1987). com modificações. Para localização de algumas manifestações alcalinas ver Figuras 2.8 e 2.9 e Fotografias 1 e 7 . 


\section{O rift de Asunción (RA)}

Arcos da borda da Bacia do Paraná, como Asunción (Figura 2-6) no Paraguai (Almeida, 1983) foram sujeitos no Mesozóico a uma intensa reativação de falhas e fraturas de trend N-S, NW-SE (Almeida, 1983) e E-W, e NE-SW ao que se associaram magmatismo toleítico e alcalino (Figuras 2-2 e 2-7). Como comentado em itens anteriores o Alto de Caapucú, tido como conformando ao Arco de Assunção (Almeida, 1983.; Projeto PAR 83/005, 1986), representaria a borda TectonProton do Cráton Rio de La Plata (Figuras 2-3 e 2-7) e em parte também esta estrutura representaria nas cercanias da cidade de Paraguari-Assunção (Figura 2-8; 6-1) regióes de faixa móvel. As estruturas NW-SE foram no Paraguai reconhecidas através de estudos geofísicos (Degraff et al., 1981; Degraff, 1985; Drueker \& Gay, 1987 e ver também Milani, 1997 e referências) e estudando imagens satélites e fotografias aéreas que mostram lineamentos e diques com esta direção (p/ex. Drueker \& Gay, 1987; Presser, 1992). Lineamentos NE-SW (Figuras 2-2, 2-3, 2-4, 2 5 e 2-6), que parecem ser herança do Megaciclo Brasiliano (p/ex. Schobenhaus, 1984), no Paraguai foram denominados de anticlinais (Liviers \& Quade, 1987) e também de Faixa do Rio Paraguai (Milani, 1997). Distensão crustal com rumo NESW, considerados como geneticamente relacionados à separação dos continentes do $W$ do continente Gondwânico e a abertura do Atlântico Sul, são tidos também como responsáveis pela geração dos trends de estruturas NW-SE (cf. Comentários em Gomes et al., 1996). Fúlfaro et al. (1982, em Gomes et al., 1996) consideram que a formação dos arcos NW-SE começaram no Devoniano e atingiram sua máxima expressão no Jurássico-Triássico.

A complexa estrutura, no Paraguai Centro-Oriental, com duas porções NW-SE e uma E-W (Figuras 2-5 a 2-8) foi reconhecida por Degraff (1985) e também por Degraff et al. (1981) ao que denominou-se de rift de Asunción, uma estrutura de 25$40 \mathrm{~km}$ de comprimento e $\sim 200 \mathrm{~km}$ de largura com preenchimento por sedimentos em torno de $2500 \mathrm{~m}$ (Degraff, 1985). Observando a geometria do rift (ex. Figura 2-5) percebe-se, de forma simples, que ele possue geometria muito característica, mostrando forma $z$ deitado, estando formado por três segmentos: o ocidental (Asunción), de percurso NW-SE; o central (Acahay) de rumo E-W, e o oriental (Ybytyruzú), outra vez com direção NW..SE (Figuras 2-5 a 2-8), que desaparece por 
baixo das coberturas da Bacia do Paraná; o último sendo o menos conhecido dos três (Ulbrich \& Presser, 1992; Presser, 1992).

Neste rift desenvolveu-se sedimentação em domínios geográficos aparentemente isolados da influência da sedimentação da bacia do Paraná. Presser (1992) descreve na parte $W$ do segmento central do rift, três unidades sedimentares que preenchem $a$ fossa do rift, as que informalmente chamou-as de U1 (basal, pelítica-arenosa, com espessura máxima de $50 \mathrm{~m}$ e apresentando caules silicificados de possiveis samambaias), U2 (arenosa, espessura máxima de $100 \mathrm{~m}$ ) e U3 (superior, com conglomerados de matriz de areia média a grossa, espessura mínima $165 \mathrm{~m}$ ). Observou-se que a unidade U1 à $\sim 10 \mathrm{~km}$ SE da cidade de Sapucai (Figura 2-8) depositoumse sobre conglomerados grossos e quartzosos. A este conjunto de sedimentos atribuiu-se idade Permiana Superior (Presser, 1992) e assim equivalente a Formação San Miguel do Grupo Independencia. Este pacote sedimentar foi afetado posteriomente pelo magmatismo alcalino Mesozóico (cf. Tabela 2-3).

Nas proximidades da cidade La Colmena e aredores (Figura 2-8) ocorrem sedimentos (arenitos conglomeráticos médios a grossos cujos seixos pelo geral, constituidos por rochas regionais e, também arenitos com alguns seixos centimétricos) pós magmáticos atribuidos por Presser (1992) como pertencentes à Formação Patiño. Este grupo de sedimentos que até agora foram descritos como relacionados ao rift e encontrados na cordillera de Ybytymi e redores (Figura 2-8) representaria um primeiro domínio geográfico de sedimentacão.

O segmento oriental do rift sendo o menos conhecido dos três segmentos teria levado a muitos autores ( $p / e x$. Presser, 1992) a traçar limites hipotéticos da falha/sistema de falhas da borda oriental do rift (Figuras 2-5 a 2w8); esta borda é traçada acompanhando a Cordillera del Ybytyruzú (Figuras 2-8). Nesta borda na que Bitschene (1987), Cuadricula 41 (1966), T.A.C. (1981) e Projecto PAR 83/ 005 (1986) observaram a ocorrência de sedimentos pertencentes ao Grupo Independencia (Permiano) sobretudo nas proximidades das cidades de Mbocayaty, Villarrica, M.J. Troche, Colonia Independencia (ver Figuras 2-8 e 2-9).

No Grupo Independencia foram destacadas pelo Projeto PAR 83/005 (1986) duas formações:

- Formacão San Miquel, que compreende arenitos intercalados com siltitos, arenitos sílticos, diamictitos e lutitos com o aparecimento, local, de cherts oolitícos- 
pisolíticos, arenitos carbonáticos e calcarenitos. Segundo T.A.C: (1981) os sedimentos desta formação depositaram-se em concordância com os sedimentos da Formação Coronel Oviedo. Neste citado trabalho salienta-se que existe um contato transicional com a Formação Taquary, sotoposta.

- Formacão Taquary: compreendendo uma seqüência de arenitos sílticos, lutitos, arenitos finos, calcarenitos e estratos com arenitos calcáreos (Cuadricula 41 , 1966; T.A.C., 1981; Projecto PAR 83/005, 1986; Bitschene, 1987). Cuadricula 41 (1966) e posteriormente Herbst (1975) citam a presença, na Formação Taquary, de uma flora característica formada por troncos silicificados eqüivalentes a Osmudites brasiliensis, encontrado na Formação Estrada Nova do Permiano no Brasil (Presser 1992). O Projecto PAR 83/005 (1986) opina que esta formação é coberta concordantemente pela Formacão Misiones, a qual é atribuida idade Permiana Superior-Jurássica Inferior. Outros aspecto e outras considerações relevantes ao Grupo Independencia poderam ser encontrados em Orué (1996).

Este grupo de sedimentos encontrados junto a cordillera del Ybytyruzú e redores representaria o segundo domínio geográfico de sedimentacão, fato que levaria necessariamente a reconhecer a presença de sedimentos permianos dentro do rift (?). Entretanto o pacote sedimentar do último domínio atribuem-se como de ambientes de uma sedimentação na bacia do Paraná ( $p /$ ex. Projeto Par 83/005, 1986).

\section{Magmatismo associado ao rift de Asunción}

\section{Generalidades}

Na cordillera del Ybytyruzú as observações levantadas pelo T.A.C. (1981), Projecto PAR 83/005 (1986) e Bitschene (1987) levaram a reconhecer derrames de basaltos continentais (Suite de vulcanismo toleítico; Formacão Alto Paraná, com 135 Ma; cf. Conte \& Hasui, 1971; Bitschene, 1987) em suas formas extrusivas e equivalentes hipoabissais que invadem as unidades do Grupo Independencia e invadem/intercalam-se com arenitos da Formação Misiones. Nos domínios da cordillera de Ybytymi, segundo o encontrado em Presser (1992) e também nos trabalhos encontrados em Comin-Chiaramonti \& Gomes (1996), ocorrem alguns diques de diabásio da suíte também similar a encontrada nos domínios do Campo 


\begin{tabular}{|c|c|c|c|}
\hline $\begin{array}{l}\text { AREA } \\
\text { Norte }\end{array}$ & TIPOS DE ROCHA & NDADE & REFERENCIAS \\
\hline $\begin{array}{l}\text { C. Boggiani, Pao de Açu- } \\
\text { car, Fecho dos Morros }\end{array}$ & $\begin{array}{l}\text { Nefelina sienitos, sienitos. traquitos, fonc- } \\
\text { litos }\end{array}$ & $\begin{array}{l}240-250 \mathrm{Ma} \\
\text { (KAr, RbiSt, Ar/Ar) }\end{array}$ & Velázquez (1995). Gomes et al (1996) \\
\hline \multicolumn{4}{|l|}{$\frac{\text { Nordeste }}{\text { Chiriguelo, A. Gasory }}$} \\
\hline $\begin{array}{l}\text { Chiriguelo, A. Gasory. } \\
\text { C. Guazú, A. Blanco }\end{array}$ & $\begin{array}{l}\text { shonkinito, silico-carbonatito, } \\
\text { traquitos, lamprófiros }\end{array}$ & $\begin{array}{l}117-145 \mathrm{Ma} \\
\quad(\mathrm{K} / \mathrm{At})\end{array}$ & Mariano (1978). Eby \& Mariano (1986) \\
\hline \multicolumn{4}{|l|}{$\frac{\text { Centro-leste }}{\text { Mbocayaty }}$} \\
\hline $\begin{array}{l}\text { Col. Independencia } \\
\text { C. Aguapety P., Mbocayaty, } \\
\text { Cord. del Ybytyruzú, } \\
\text { c. Km 23, C. Sta. Helena }\end{array}$ & $\begin{array}{l}\text { tefritóides, lamprófiros. lamproitos. shon- } \\
\text { kinitos, nefelina sienitos }\end{array}$ & $\begin{array}{l}128-131 \mathrm{Ma} \\
(\mathrm{K} / \mathrm{Ar})\end{array}$ & Bitschere (1987) \\
\hline $\begin{array}{c}\text { Sapukai } \\
\text { Potrero Ybaté }\end{array}$ & & & \\
\hline $\begin{array}{l}\text { a-Sapukai. Potrero Ybaté. } \\
\text { C. Achay, C Sto Tonás. } \\
\text { E. las Rosas, Arrua-i } \\
\text { b-Sapukai, C. Gimenez }\end{array}$ & $\begin{array}{l}\text { tefritóides, traquibasaltoides, lamprófros, } \\
\text { fonolitos, traquitos, gabroides alc., sienitói- } \\
\text { des }\end{array}$ & $\begin{array}{c}98-138 \mathrm{Ma} \\
\text { (K/Ar) }\end{array}$ & $\begin{array}{l}\text { Palmieri \& Arribas (1975). Velázquez (1992) } \\
\text { Gomes et at (1996) }\end{array}$ \\
\hline $\begin{array}{l}\text { b-Sapukai, C. Gimenez } \\
\text { Asunción }\end{array}$ & fonolitoides & $\begin{array}{l}66 \mathrm{Ma} \\
\text { (KIAr) }\end{array}$ & Velázquez el al (1992). Gomes et al 11906 \\
\hline $\begin{array}{l}\text { C. Lambare. C. Tacumbù. } \\
\text { C. Neemby. C confuso, } \\
\text { C. Verde. V. Hayes, T Nueba } \\
\text { R. castillo, C Patiño, Limpio }\end{array}$ & nefelinitos fonditos & $\begin{array}{l}60-38 \mathrm{Ma} \\
\text { (K/Ar) }\end{array}$ & Bitschene $(1987\}$ \\
\hline
\end{tabular}

Tabela $2-3$. Idades dos corpos intrusivos das três regiỏes (Norłe, Nordeste e Centro-leste) alcalinas no Paragual (cf. Comin-Chiaramonti \& Gomes, 1996). 
Ybytyruzú. Os diques estão cortando granitóides do Grupo Caapucú (Pré-Cámbrico Superior) e sedimentos do Grupo Caacupé de idade Silúrico (Presser 1992) (Figuras 2-8 e 2-9) que ocorrem nas bordas a Sul e a Norte do segmento Central do rift. Com exceção de um dique alterado reconhecido por Presser (1992) no vale do rift do segmento Central, inexistiriam lavas/diques de composição toleítica da Formação Alto Paraná dentro da zona abatida do rift (i.e. vale do rift = Valle de Acahay).

Por outro lado, conforme Gomes et al. (1996) no Paraguai são conhecidas três maiores regiões de ocorrência de rochas alcalinas: ao norte, e nordeste, ambas encontradas dentro da província alcalina Norte, e no centro-leste, esta encontrada nos domínios da província Central. Nessas regiões as determinações radiométricas (predominantemente realizadas pelo método $\mathrm{K} / \mathrm{Ar}$ ) reunem as intrusões em três grupos cronológicos bem definidos, sintetizado na Tabela 2-3. As rochas mais antigas ( 240 Ma) são encontradas ao norte do Paraguai (p/ex.Velázquez, 1995 e referências). Um grupo de em torno dos $130 \mathrm{Ma}$, compreende o amplo número de ocorrências distribuídas ao nordeste ( $p / e x$. Livieres, 1987) e a área centro-leste (p/ex. Bitschene, 1987) do Paraguai Oriental (Figuras 2-2, 2-6, 2-8 e 2-9). Um grupo mais jovem, reconhecido só na área central, engloba as ocorrências de fonólitos sódicos e nefelinitos terciários (70-39 Ma) (Bitschene, 1987; Bitstchene \& Presser, 1990; Gomes et al., 1996 e referências) (Figura 2-6)

Com relação a Província Central é hoje conhecida uma vasta literatura sobre a ocorrências de rochas alcalinas do cronomgrupo de $130 \mathrm{Ma}$, como encontradas na (Figuras 2-8 e 2-9). Alguns desses centros de ocorrências foram objeto de numerosos trabalhos de caráter cientifico (p/exs. De Min, 1993; Comin-Chiaramonti \& Gomes, 1996 e referências) e econômico (p/ex. Presser, 1991) que contribuíram substancialmente para um melhor nível de entendimento de sua evolução dentro de um contexto petrológico. Contudo, são escassos os trabalhos que contam com estudos sistemáticos e detalhados (ex. Comin-Chiaramonti et al, 1992 e em parte também De Min, 1993). A maioria dos publicados são ainda preliminares (p/ex. Presser, 1994; ver também Comin-Chiaramonti \& Gomes, 1996) ou eles visam aspectos de caraterização global (Comin-Chiaramonti et al., 1996 a-b) e assim podem ser englobados mais como trabalhos de referencias.

Verifica-se que as rochas ígneas alcalinas do Mesozóico (Tabela 2-3) da província Central estão amplamente distribuidas nos três segmentos do rift de Asunción. As 
idades radiométricas (Comte \& Hasui, 1971; Palmieri \& Arribas, 1975; Bitschene, 1987; Velázquez, 1992; Comin-Chiaramonti \& Gomes, 1996) obtidas nestas rochas (vulcânicas e intrusivas) distribuem-se sobretudo em dois maiores campos de intrusões dentro do rift: Campo Ybytymi e Campo Ybytyruzú (Figura 2-8); apontando para uma colocação em torno de 138-98 Ma (Tabela 2-3).

Contudo, na provincia Central as rochas possuem uma diversidade petrográfica muito grande. São encontrados desde basaltos alcalinos da série dos tefritos com leucita a fonolitos com leucita, basaltos alcalinos da série dos traquibasaltos a traquitos, "lamproítos", mela leucita fonolitos, "lamprófiros" (cálcio-alcalinos, alcalinos e ultramáficos), ijolitos, nefelina sienitos, sienitos alcalinos, shonkinitos, gabros alcalinos, entre outros como pode ser constatado em Palmieri \& Arribas (1975); Bitschene (1987); Velázquez (1992); Presser (1991; 1992; 1994; 1996); CominChiaramonti et al. (1992); os trabalhos encontrados em Comin-Chiaramonti \& Gomes (1996).

Como se observa por exemplo em Palmieri \& Arribas (1975), as rochas alcalinas do Mesozóico que ocorrem no Campo Ybytymí apresentam marcado caráter potássico. Já em Bitschene (1987) são apresentados aprimorados dados do magmatismo do Campo Ybytyruzú também potássico. O magmatismo de ambos os campos são comagmáticos (ver Tabela 2-3) e serão ainda comentados, brevemente, seus aspectos geoquímicos, no Capítulo seguinte.

\section{Particularidades}

\section{Rochas igneas alcalinas do Campo Vbytymi}

As rochas alcalinas estão amplamente distribuidas no Campo Ybytymí (Figuras 2-8 e 2-9); este campo situa-se no segmento Central do rift. O magmatismo manifiesta-se na forma de coberturas de piroclastos e de lava, condutos epiclásticos/brecha (pipes), plugs, diques isolados, enxame de diques ring-dyke e sills, possuindo composições variadas: basaltóides com leucita a fonólitos e traquitos, "leucita lamproíto", lamprófiros ultramáfico e cálcio-alcalinos e também rochas intrusivas da série dos gabroides alcalinos a sienitóides alcalinos e ijolitos (Eckel, 1959; Putzer, 1962; Palmieri \& Arribas, 1975; Velázquez, 1992; Presser, 1991; 1992 e 1994; De Min 1993; Comin-Chiaramonti \& Gomes, 1996). 
Dentro deste segmento do rift destacam-se no extremo norte um denso enxame de diques (Enxame Ybytymí) com rumo médio de N50\% $\sim 70 \mathrm{~km}$, (Presser, 1992 e 1994). No centro-sul do mesmo segmento do rift aparecem pipes, plugs, e alguns diques portadores de xenocristais e/ou microxenólitos do manto, assim como também plugs de rochas fonolitóides ( $68 \mathrm{Ma}$ ) com claras assinaturas químicas (expresso, por exemplo, pelos valores dos isótopos de $\mathrm{Sr} / \mathrm{Sr}$ e $\mathrm{Nd} / \mathrm{Nd}$, cf. Velázquez, 1992; Comin-Chiaramonti \& Gomes, 1996) de material proveniente de um manto profundo (p/ex. C. Medina, C. Gimenez, C. Yariguá entre outros)( Velázquez, 1992 e referências citadas); parecem estar vinculadas com falhas abissais E-W e outras NW-SE e EN-SW, (Figura 2-8 e Fotografia 1), e que também mostrariam um domínio ocupado por falhas profundas (até lithosfericas?). No presente trabalho são estudados alguns pipes, plugs e diques de rochas lamprofíricas que ocorrem neste campo, sendo que eles são abordados em detalhe.

\section{Intrusces lamprofincas do Campo Ybytym}

Foram estudadas várias intrusões, no campo Ybytymi. Três delas correspondem aos pipes (Ymi-1, Ymi-4 e Ymi-8), a um plug (Ymi-5) e o restante a alguns diques (ex. Ymi-7). Outras ocorrências de rochas lamprofíricas, apesar de originalmente amostradas, como os derrames basaltóides que ocorrem a norte do cerro Acahay, os piroclastos e os derrames das localidades de Kirito (Presser, 1992) e derrames do C. Porteño, entre outras (Figura 2-8, Tabela 2-4) neste trabalho foram deixadas de lado porque ao serem petrográficamente examinadas, elas mostraram tratar-se de rochas basaltóides, já estudadas nesta província por De Min (1993); Comin-Chiaramonti \& Gomes (1996) e Comin-Chiaramonti et al. (1997). Acreditando-se que novas contribuições em relação às rochas basaltóides aportariam muito pouco ao já levantado pelos acima referidos autores, optou-se por enfocar os trabalhos sobre as ocorrências de rochas com afinidades "lamprofíricas".

Como passo inicial deve ser comentado que o conjunto das intrusões alcalinas dos segmentos Central e Oriental do rift, representadas na Figura 2-8 e 2-9, seguem lineamentos de fratura que localmente seriam as responsáveis pela colocação dos diferentes corpos magmáticos. Os traços E-W em combinaçäo com os traços NE-SW apresentam-se como direções importantes no Campo Ybytymi, enquanto que os traços E-W e NW-SE apresentan-se destacados no Campo Ybytyruzú. 


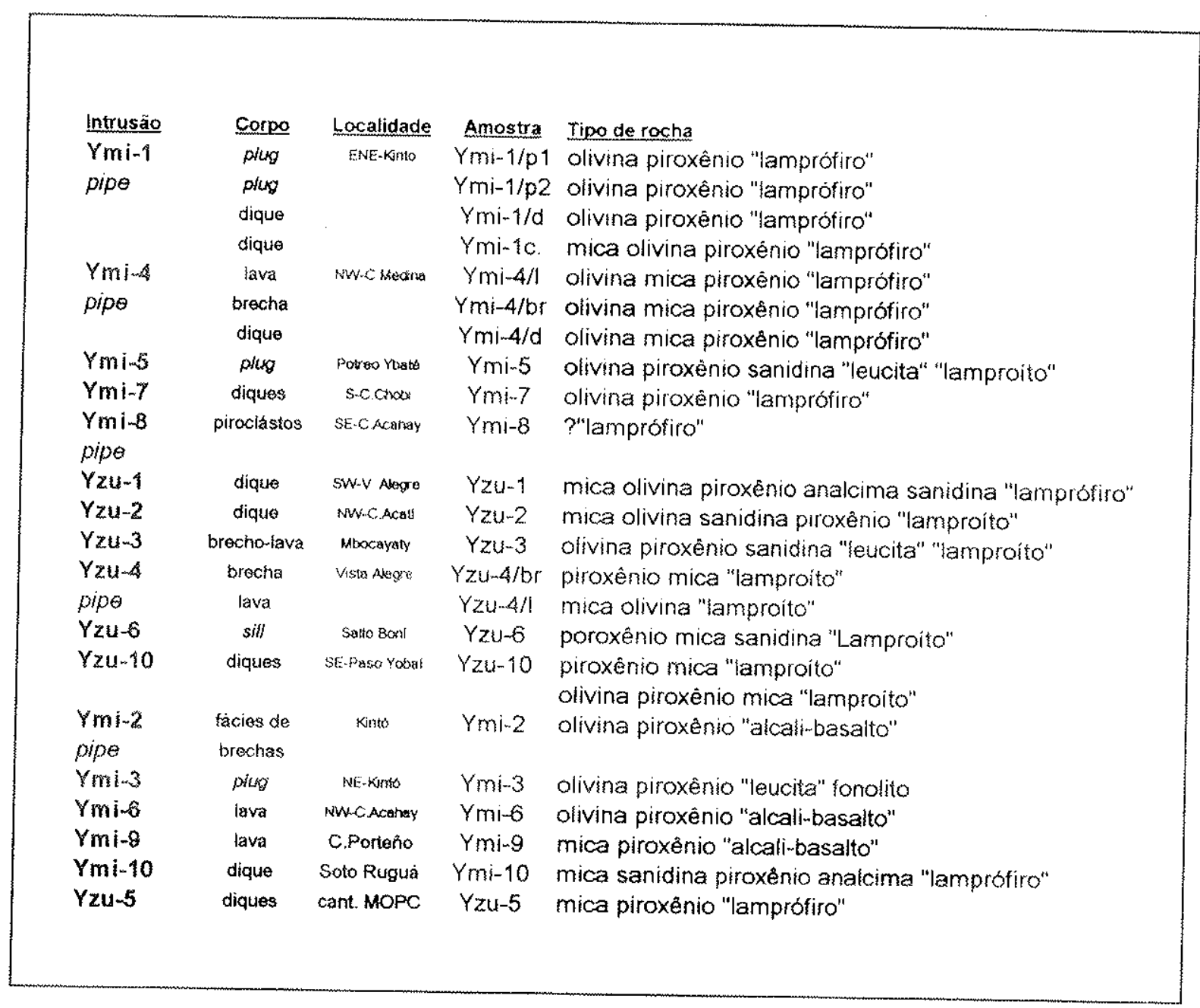

Tabela 2-4. Intrusões lamprofíricas relacionadas e/ou que ocorrem junto ao rift de Asunción.

\section{Pipe Ymi-1}

Este corpo foi originalmente reconhecido por Presser (1992) referindo-se a ele como conduto "lamproítico" Dom Eladio 1; Fotografia 1, 2, 3 e 4; ver reproduçäo na Figura 2-10. Como se observa na Figura 2-8 a intrusão colocou-se sobre linhas de fratura EW e NE-SW. Na fotografia 2 e no mapa da Figura 2-10 fica evidênciada a forma irregular a grosseiramente bilobulada do corpo, sendo que o seu tamanho é de cerca de $2050 \mathrm{~m}$ por $1200 \mathrm{~m}$ (lóbulo leste) a $880 \mathrm{~m}$ (lóbulo oeste). O pipe corta a sedimentos das unidades clásticas finas a grossas U1-U3 (Presser, 1992) sendo ele cortado por alguns delgados diques com rumo E-W e NW-SE (Fotografias 1e 2). 


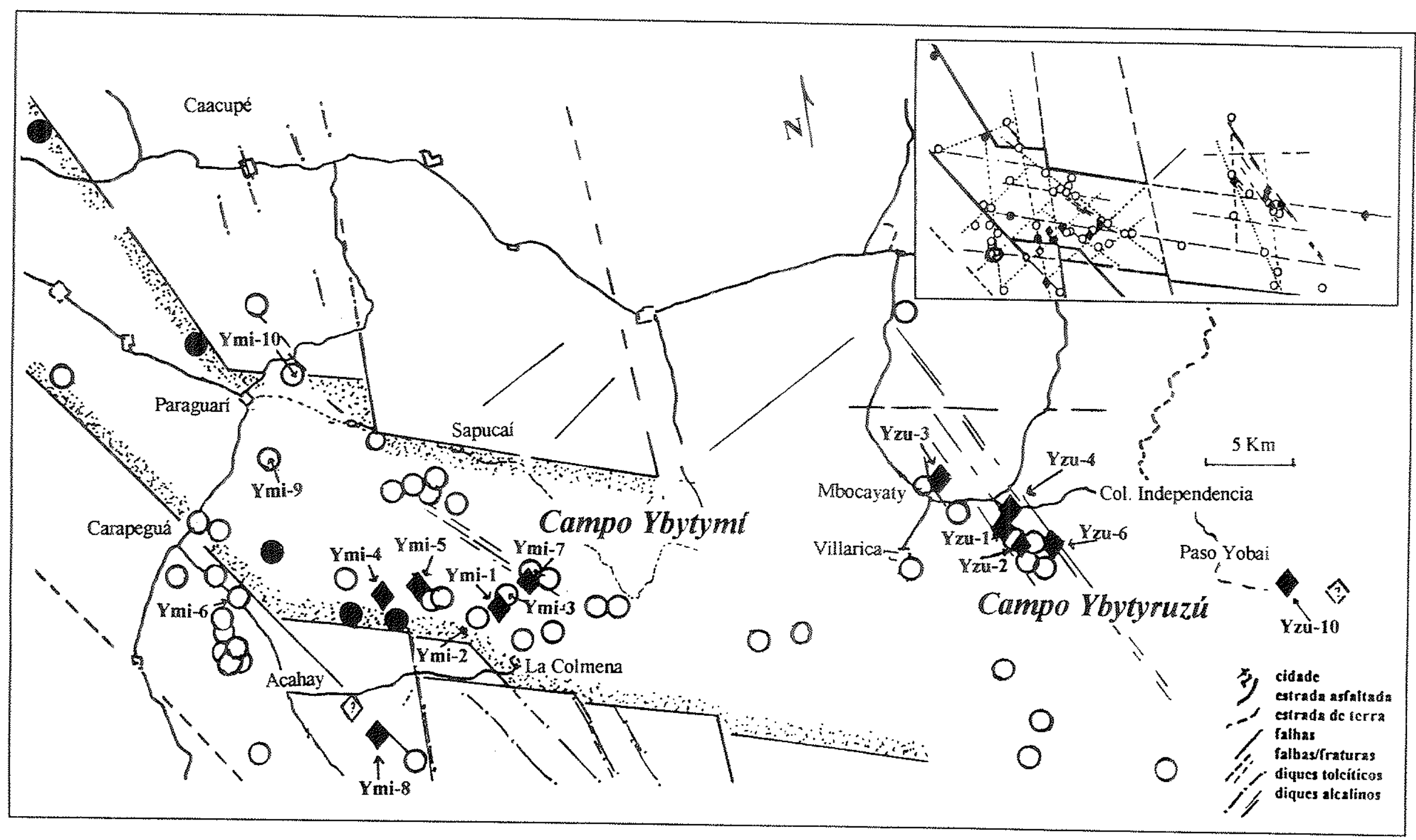

Figura 2-8. Corpos de rochas alcalinas no rift de Asunción. Aqui são destacados os corpos de rochas "lamprofiricas" que foram estudados neste trabalho e os diferentes intrusivos associados ao rift. Em rombos cheios as rochas "lamprofiricas" estudadas, em circulo vazio outras litologias alcalinas ( $\sim 30 \mathrm{Ma})$ e em circulo cheio fonolitóides de $-68 \mathrm{Ma}$ e nefelinitos de $-45 \mathrm{Ma}$ (cf. Velázquez, 1992 e Comin-Chiaramonti \& Gomes, 1996). Na borda superior direita esquema de anisotropia das encaixantes dos corpos intrusivos alcalinos no rif. No Campo Ybytymi as intrusäes encaixaran-se segundo os traços E-W, N-S, NE-SW (anisotropia do megaciclo Brasiliano?) e secundariamente NW-SE; já no campo Ybytynuzu as intrusðes encaixaram-se segundo os traços E-W, NW-SE e secundariamente N-S. Para dados da geologia consultar a figura seguinte. 


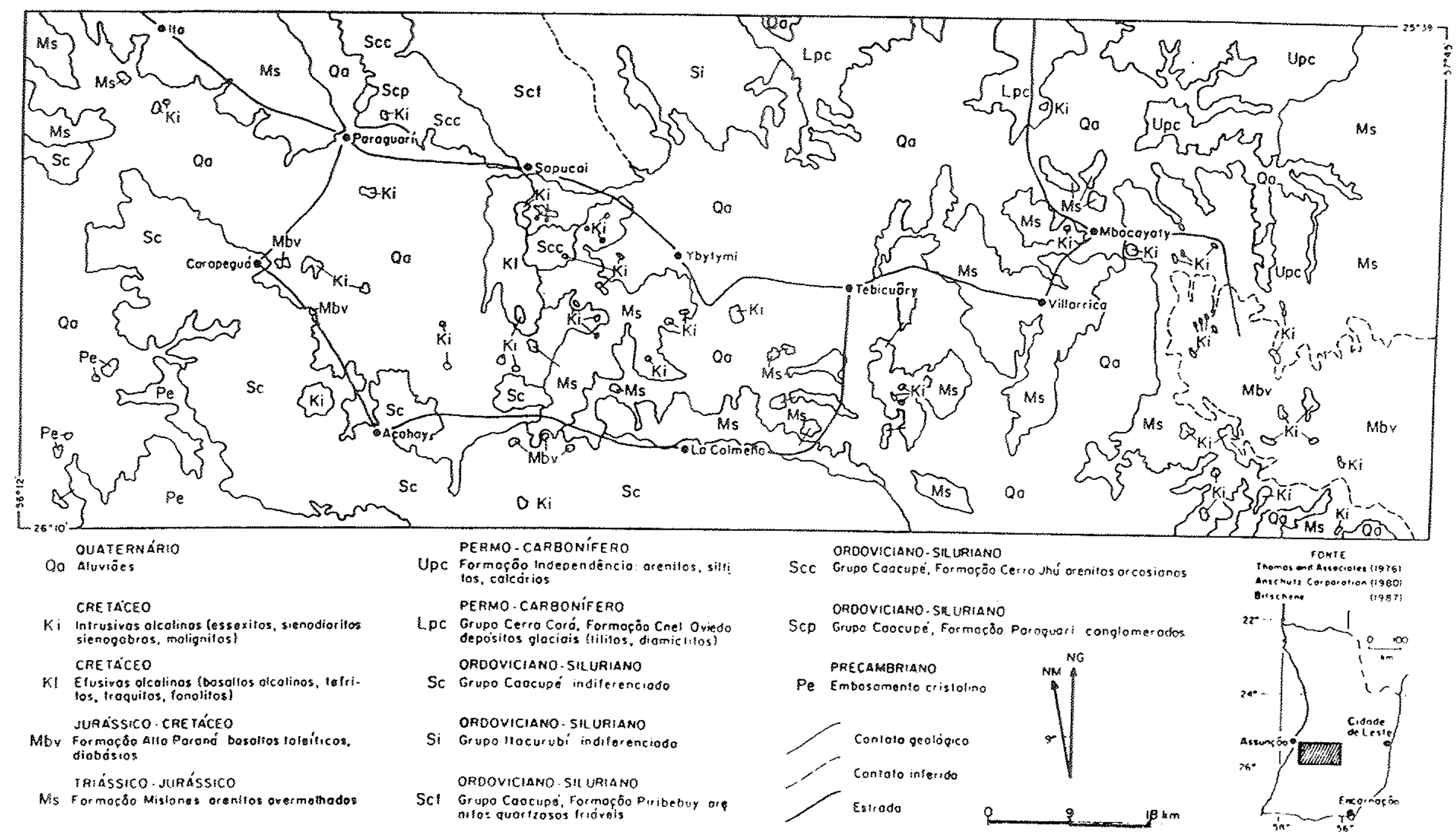

Figura 2-9. Mapa litológico do I alle de Acahave virinhanças. Mapa compilado por Velázquez (1992) com basc nos dados de Anschutz. Co. (1981). Bitschenc (1987) c tambćm Thomas and Associates (1976. cilado cm Velázquez, 1992). Na figura Ms. cm dirę̧ro a W a partir da cidade de Villarrica corresponden a sedimentos de precncinmento de rift $\mathrm{c}$ pós riff do rift de Asunción. como no caso do pacote permiano da Cordillera de lbuttum e dos arenitos do (erro l'alacios (ao W da cidade de Paraguarí). 
Este corpo como os outros pipes foram estudados através da observação de campo auxiliado pelas fotografias aéreas e mapas topográficos (1:50.000). Nesta estrutura e na de Ymi-8 (item adiante) foram feitos poços de inspeção (Fotografia 4). Conforme o levantamento geológico no seu lóbulo oeste reconheceram-se um pequeno afloramento da fácies hipoabissal; um plug destacado no campo pelo suave ressalto topográfico, e aqui são encontrados blocos de rocha porfirítica fresca de cor cinza escuro a algo alteradas (assim apresentando cores cinza amarronzados) com feno/megacristais de olivina e de piroxênio em matriz algo fina de aspecto basaltóide. O resto da estrutura aparece coberta por solo que the transmite uma topografia plano ondulada onde cresce a vegetação rasteira (Fotografia 3), que contrasta com a vegetação mais volumosa e arbórea das bordas do pipe.

Foram reconhecidas, a partir de poços de inspeção (uns deles com $\sim 2 \mathrm{~m}$ ) realizados a SW (Fotografia 4) no lóbulo leste, afloramentos de rochas sedimentares clásticas, onde se reconhece sedimentos argilosos cinza beje ricos em seixos de quartzo bem arredondado e areia quartzosa fina a grossa. Do material amostrado e lavado com líquidos densos obtiveram-se concentrados de minerais pesados, os que sugerem que se trata de fácies epiclástica do pipe. Este conjunto de dados mineralógicos seräo abordados mais pormenorizadamente em capítulos posteriores.

Amostraram-se também vários diques decimétricos, encontrados em blocos/matações alinhados dentro desta estrutura. Alguns destes diques são estudados nos detalhes da química mineral (Ymi-1 d). Contudo dois diques bem diferenciados que cortam as fácies a leste do pipe (Fotografia 2) ocorrem como rocha porfiritica fresca de cor cinza escuro, com feno/megacristais de olivina e de piroxênio que estão mergulhados em uma matriz de aspecto basaltóide algo fina. Outro dique foi amostrado a leste do conduto, (Fotografia 2), apresentandomse como um dique decimétrico em zig-zag que corta a sedimentos finos U1 (Presser, 1992). Trata-se de uma rocha porfiritica de marcado aspecto lamprofírico cinza escuro com fenocristais de olivina, piroxênio e mica escura em uma matriz basaltóide fina.

A julgar pela exposições de ilhas dos sedimentos das encaixantes dentro do pipe, apresentando-se claramente sem pertubações tectônicas, este corpo teria sofrido avançada erosão. 


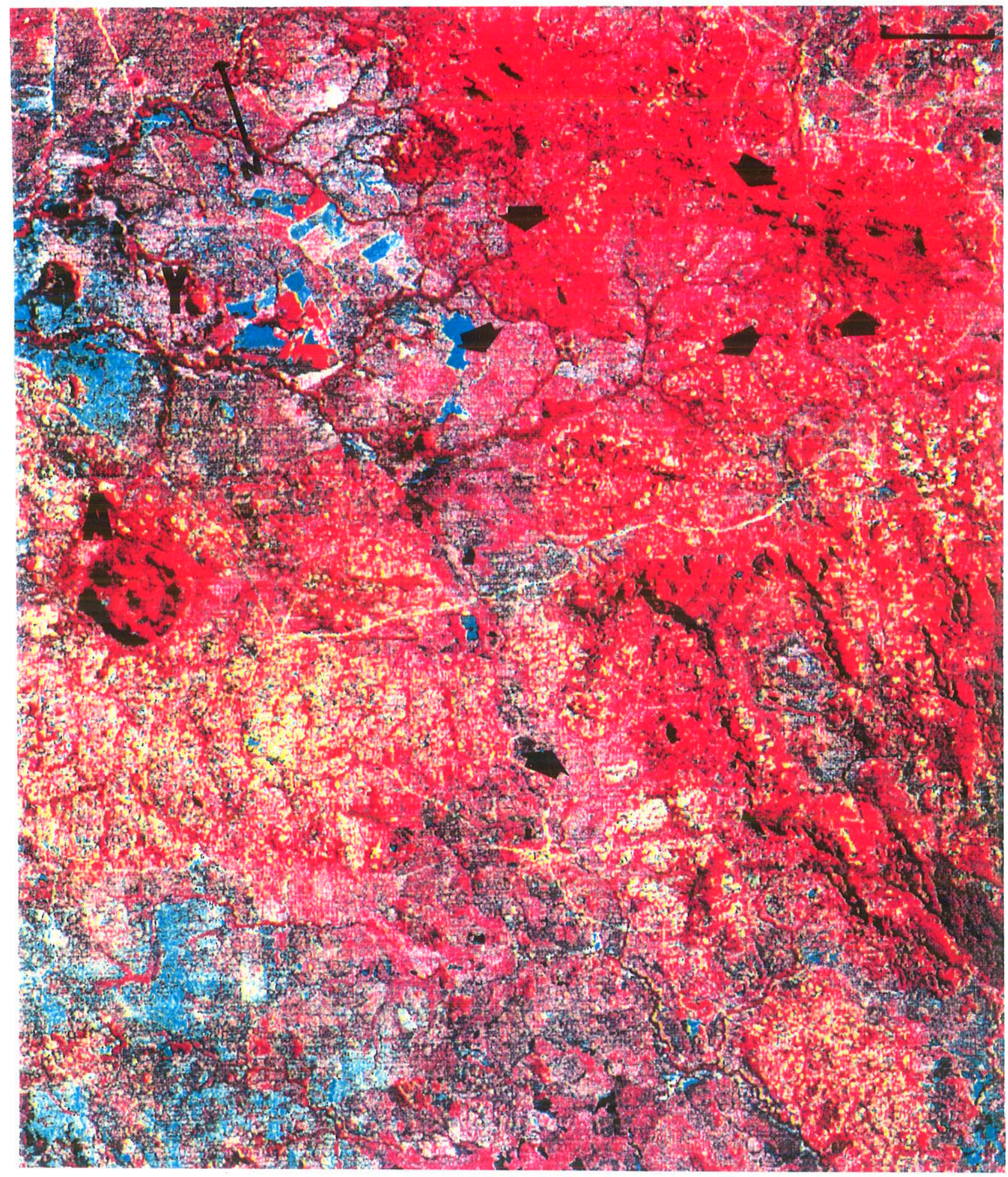

Fotografia 1. Imagem (falsa cor) da borda W do rift de Asunción. São destacados, pelas setas, os corpos estudados neste trabalho, assim como também outras intrusões alcalinas do Mesozóico bem conhecidas (ex. C. Acahay, A) e do Terciário (ex. C. Yariguaá, Y). 


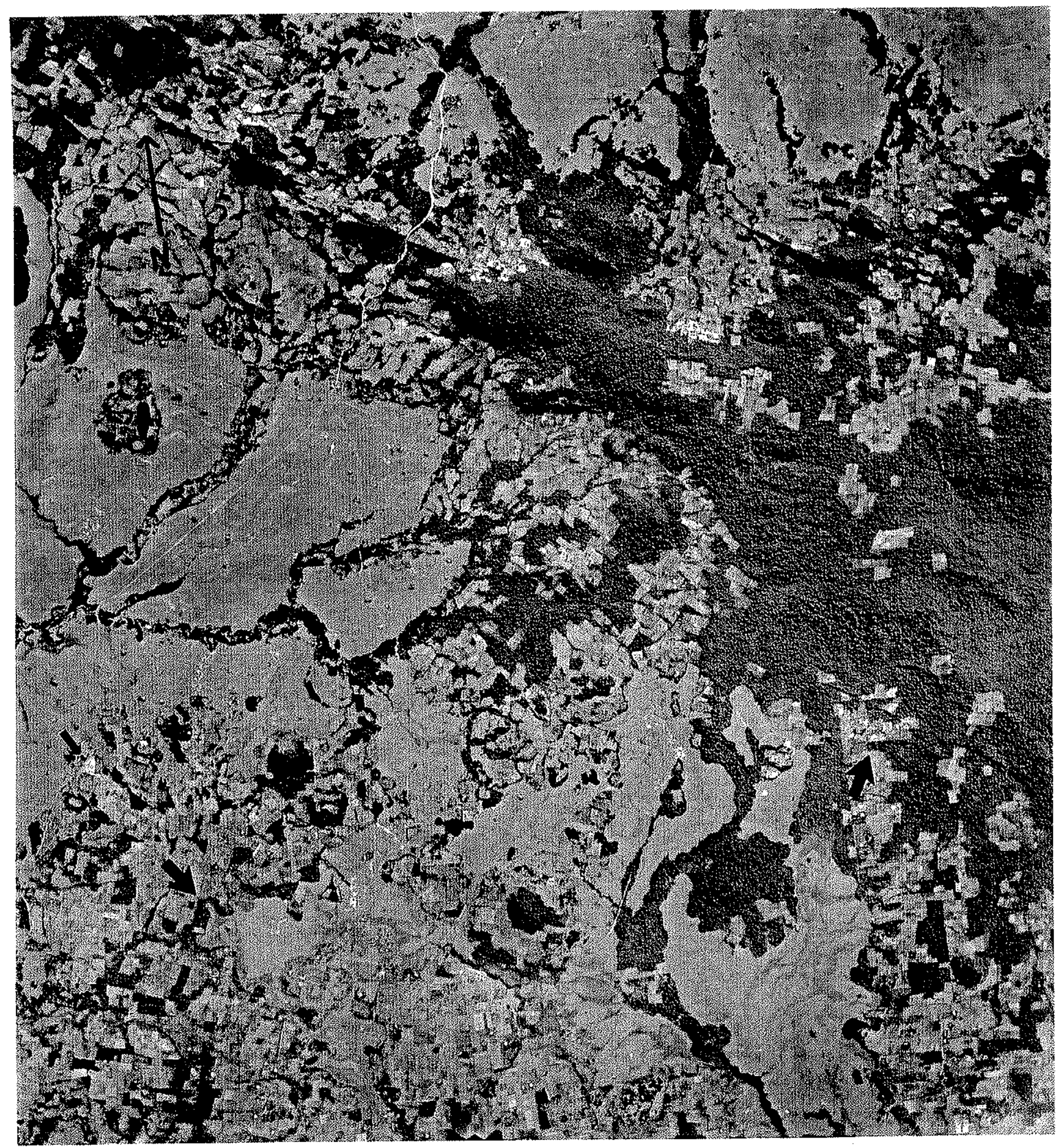

Fotografía 2. Cópia da fotografia aérea 1:50.000 do I.G.M. (Paraguai) onde são destacados, pela setas, o pipe Ymi-1 e, pouco mais acima (seta menor) o dique Ymi-1c; e a NE os diques E-W Ymi-7. A N, traços NW-SE diques alcalinos do enxame Ybytymí (Presser, 1992). $2 \mathrm{~cm}$ na fotografia $=1000 \mathrm{~m}$. 


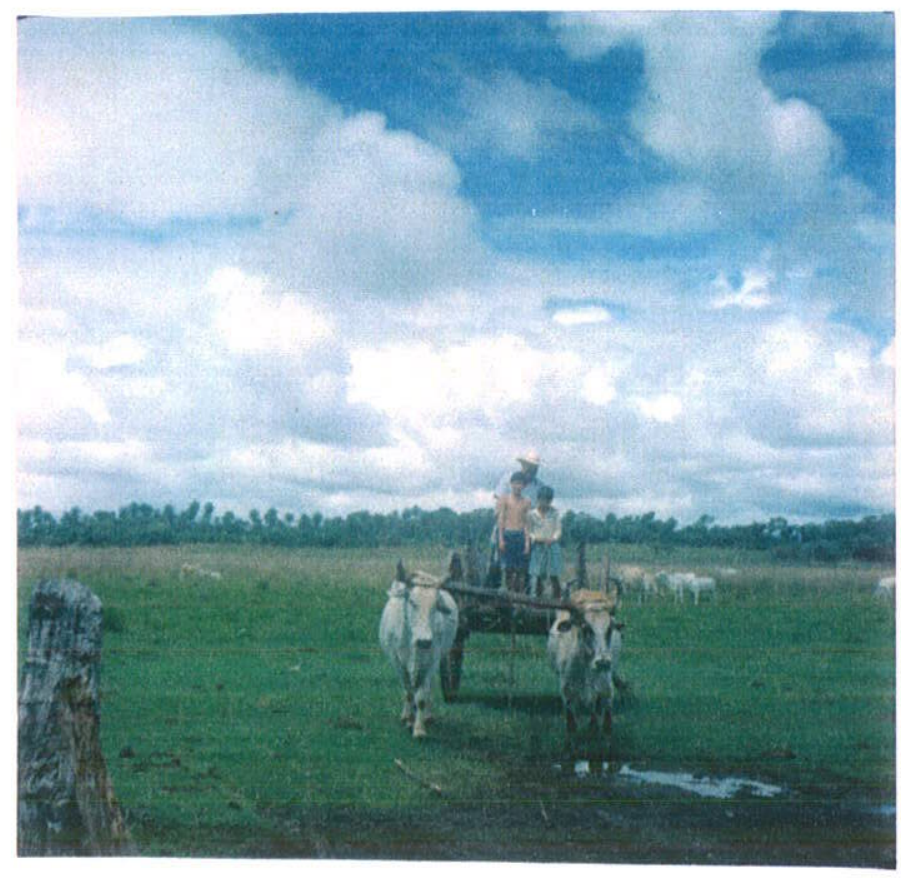

Fotografia 3. Paisagem sobre o pipe Ymi-1. Observar o relevo plano e sem vegetação dentro do pipe.

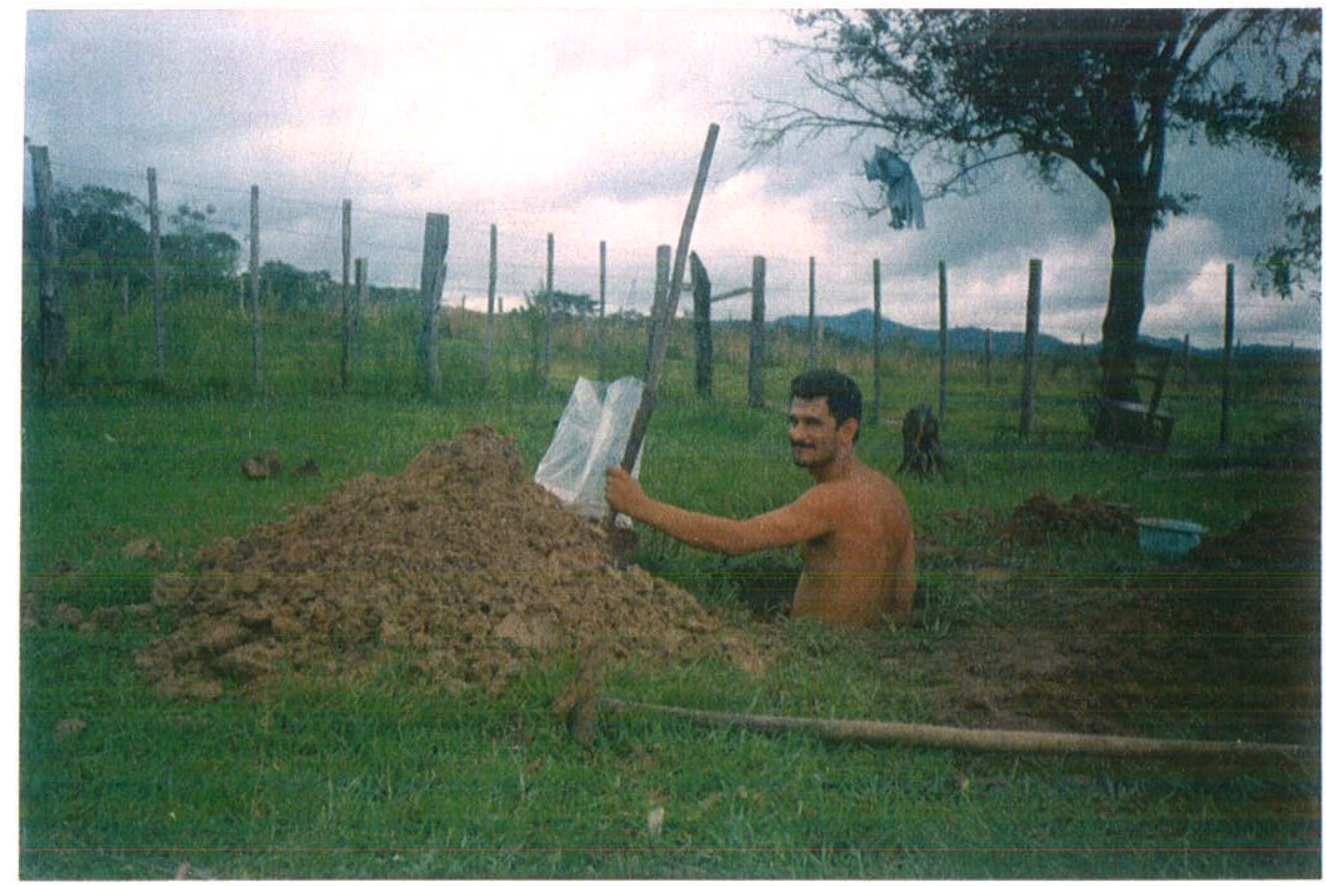

Fotografia 4. Poço de inspeção na fácies epiclástica situado a SW do pipe Ymi-1 


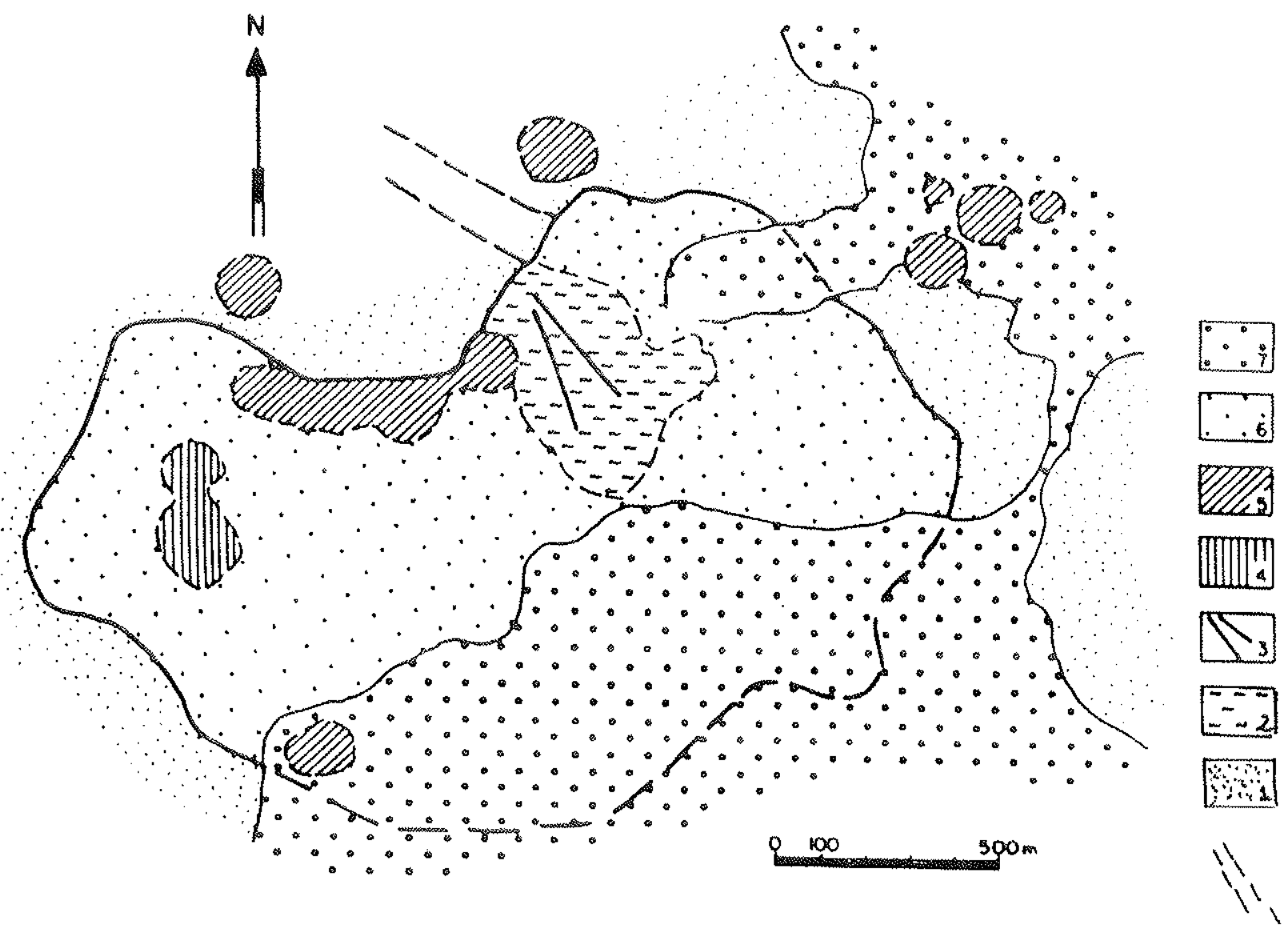

Figunra 2.10. O pipe Ymiّ1 na área de Kiritó. campo Ybytymi. Lenda: tracejado paralelo: fotolineamentos (fraturas?); 1: rochas sedimentares permianas; 2: rochas sedimentares finas da base do pipe: 3: diques "lamprofíricos": 4: fácies hipoabissal (p/ug) de rochas "lamprofinica"; 5: estruturas circulares observadas em fotografias aéreas ("basaltos alcalinos"/ "lamprófiros": 6: solo de cobertura: 7: depóssitos quatemários/recentes. Os contatos assinalados, tanto das formaçōes como das estruturas, são todos aproximados ou inferidos. 


\section{Diques Ymi-7}

São encontrados dentro da borda centro-sul de aparente estrutura circular na região do cerro ChobímCañada (Presser 1992) um conjunto de diques métricos paralelos a E-W (Fotografia 2) encaixados nos sedimentos U2 (Presser 1992). Aqui traços E-W junto com outros que possuem rumo NE-SW parecem ter desempenhado um papel de destaque na colocação destes diques, como também na colocaçã̃o da intrusão Ymi-1 (Figura 2-8). Ymi-7 constituem diques de rocha porfiritica fresca de cor preta algo esverdeada, com feno/megacristais (milimétricos a centimétricos) de piroxênio verde e fenocristais de olivina acompanhada de enclaves angulosos (milimétricos a centimétricos) de rocha peridotítica. Eles estão colocados em uma matriz de aspecto basaltóide. Detalhes petrográficos e de química mineral de um destes diques são encontrados no capítulo 3.

\section{Pipe Ymi-4}

Esta estrutura, descrita em Presser (1992) como Dú 2, possui conforme fotografias aéreas, forma bilobulada. Apresenta um tamanho menor quando comparado com Ymi-1, com $\sim 1258 \mathrm{~m}$ de comprimento; o seu contorno encontra-se ocultado pela cobertura do solo e lavas basaltóides com leucita da Formação Sapucai, assim dificultando a observação direta das relações do pipe com as encaixantes (Presser 1992).

No centro da estrutura ficam expostas rochas da fácies hipoabissal, representadas por lavas vesículadas (preenchidas por zeólitas) cinza-roxo, algo alteradas e de marcado aspecto lamprofírico, com fenocristais de piroxênio e pseudomorfos de olivina em uma matriz fina de aspecto fonolitóide. Pela sua vez, as lavas estão cortadas por fácies de brecha autolítica com clástos angulosos predominando dimensões centimétrica, porém algo mais maciças e algo alteradas e sustentadas por matriz magmática da mesma composição. As lavas estão cortadas por diques decimétricos (rumo NW-SE) da mesma composiçäo diferindo das litologias anteriores, por serem algo mais maciços e menos alterados. A eles associam-se outros diques de composições basaltóides com fenocristais de leucita e micapseudomórfica, cortando as lavas em rumo NE-SW. Detalhes da química mineral e da petrografia são dados no capítulo 3 . 


\section{Pipe Ymi-8}

Esta estrutura, destaca-se pela forma bilobulada (Fotografia 5 e 6 ), sendo seu comprimento de $\sim 2750 \mathrm{~m}$ e contando com dois lóbulos, um deles de $\sim 1250 \mathrm{~m}$ de largura a norte e outro menor de $\sim 1150 \mathrm{~m}$ de largura a sul (Fotografia 5 e 6). Possue em superficie forma plana que esta quebrantada, no lóbulo sul, por uma lombada suave de forma triangular (Fotografia 5 e 6). Neste corpo não foram observados exposições de rocha magmática, porém num furo de inspeção ( $2 \mathrm{~m})$ praticado no lóbulo sul obtiveram-se materiais argilosos de cor cinza-ocre, onde identificaram-se alguns seixos de quartzo (milimétricos) e areia fina a média também quartzosa que ao ser lavadas com líquidos densos forneceram suite de minerais pesados de afinidade magmática (ver Capítulo 4). Esta feição, como levantado já em referência a Ymi-1, testemunham uma fácies epiclástica comum aos pipes magmáticos. Esta intrusão instalou-se em encaixantes de rochas sedimentares do Grupo Siluriano (Fm. Tobati) flanco sul do rift; que segundo Presser (1992) trata-se de um bloco abatido a W, num fenômeno estrutural que teria facilitado a colocação de outros corpos alcalinos (Figura 2-8) como o C. Acahay (ring dyke de $5 \mathrm{~km}$ de diâmetro). Este conjunto de intrusões fundamentalmente parece estar vinculado com traços NW-SE e de certa forma também com aqueles de rumo NE-SW (Figura 2-8).

\section{Plug Ymi-5}

Estrutura originalmente descrita por Presser (1991) e detalhada em Presser (1992 e 1994). Este corpo intrusivo se encaixou nos basaltóides da Formação Sapucai. As fotografias aéreas sugerem uma forma circular de $\sim 200 \mathrm{~m}$ de diâmetro (plug). No campo, a estrutura esta mascarada pelo relevo deprimido, que possibilita o desenvolvimento de solo e o abatimento de blocos basaltóides das encaixantes. Corresponde a uma rocha vulcânica marcadamente porfirítica com feno/megacristais de "leucita" de cor branco a turquesa pálido e feno e microfenocristais de piroxênio escuro o olivina serpentinizada em uma matriz de aspecto basaltóide, contendo algumas amigdalas de zeólita branca.

Deve-se mencionar que diques de natureza lamprofírica (i.e. "lamprófiros" com fenocristais de mica) do enxame de diques Ybytymi (Presser 1992, 1994) mostram preferência pelas fácies sedimentares onde abundam os sedimentos mais finos (p/ex. argiláceos). Outra observação a apontar é a preferência destes diques a 


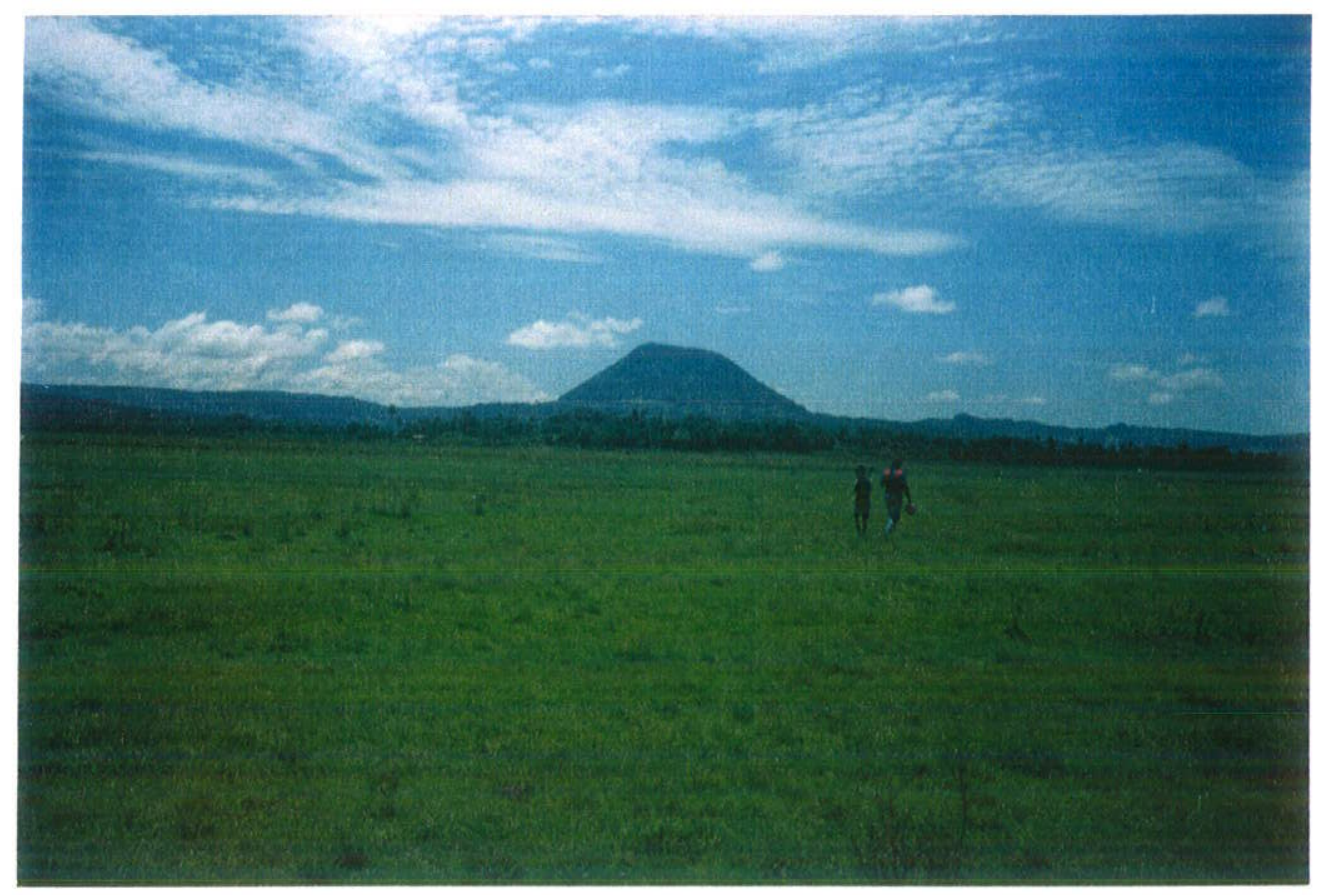

Fotografia 5. Pipe Ymi-8. Este corpo mostra marcadamente o relevo plano que esta sobrelevado no fundo por uma leve ondulação na topografia, a qual corresponderia a fácies magmática (plug) como descrito na literatura (ex. Mitchel \& Bergman 1991). No fundo, o morro cônico representa o C. San José (alcalino gabróide, cf. Presser 1992). 


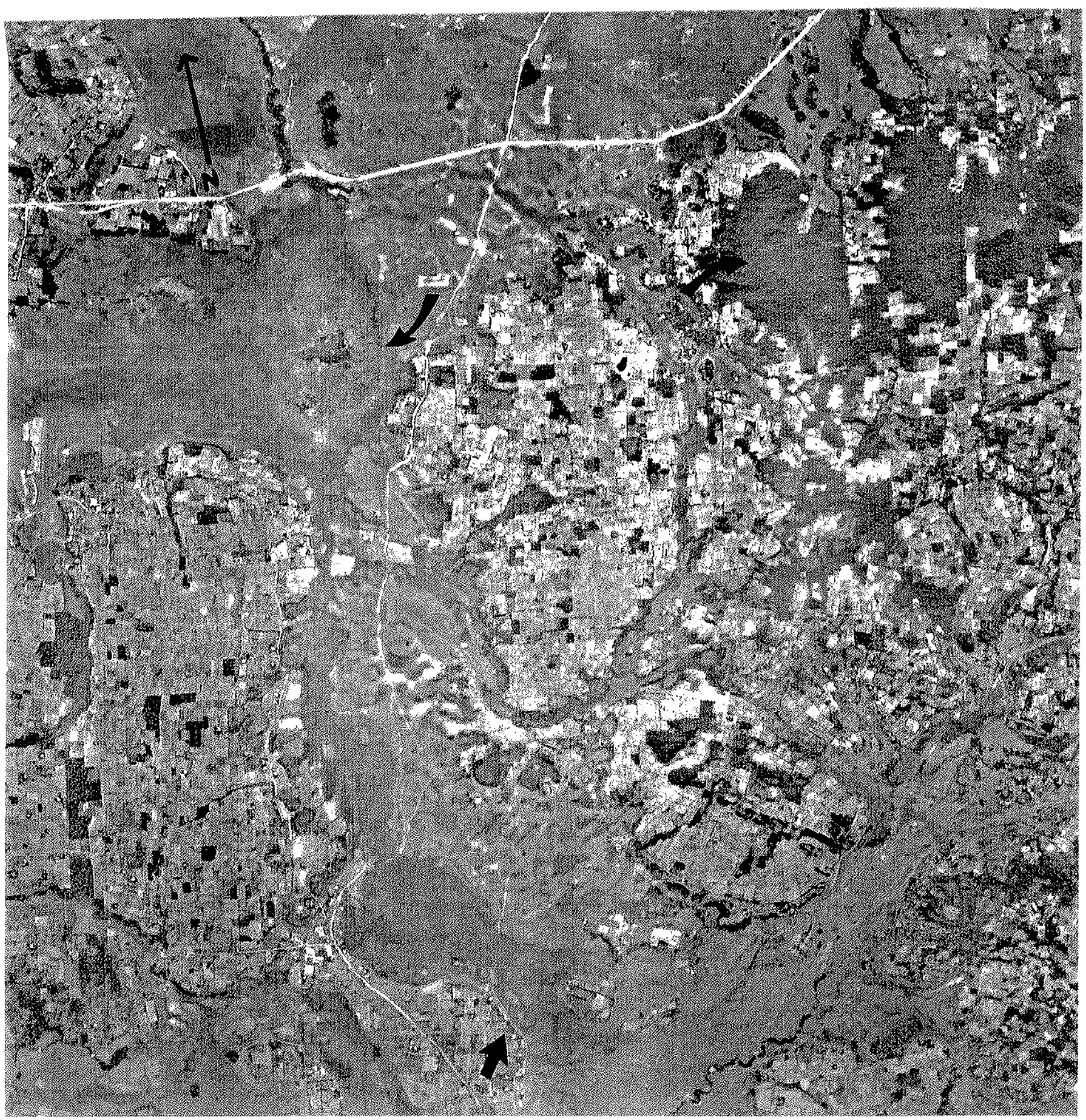

Fotografia 6. Parte da fotografia aérea 1:50.000 (I.G.M. - Paraguai) onde é mostrado pela seta o pipe Ymi-8 $(\sim 2750 \mathrm{~m})$. Outros suspeitos pipes a $\mathrm{N}$ são mostrados pelas setas curvas. 
ocupar fendas com orientação N-S, relegando-se à rochas de dique de composições diferentes à outras direções prefênciais (p/ex MW-SE).

\section{Rochas igneas alcalinas do Campo Ybytyruzú}

No segmento oriental do rift se destaca a elevada topografia da Cordillera del Ybyíyruzú contrastando em $\sim 700 \mathrm{~m}$ acima do nivel topográfico médio do valle de Acahay. Aqui ocorrem centros de efusões e intrusões de diques de composição toleítica que estão cortados por diques, enxame de diques (Enxame Ybytyruzú com rumo NW-SE, Figuras 2-8 e 2-9), plugs e stocks de rochas alcalinas Mesozóicas $(\sim 130 \mathrm{Ma}$, Tabela 2-3). As ocorrências mais conhecidas são:

- intrusões a NNE: Aguapety-portón, Mbocayaty, Capitindy, Melgarejo, Vista Alegre, entre outras (Figura 2-8 e 2-9);

- intrusões a SSW: C. Sta. Helena, C. km 23, etc. (Figura 2-8 e 2-9).

Estudos petrográficos iniciados com Eckel (1959) levaram ao reconhecimento, neste dominio, de rochas gabróides e rochas sienitóides alcalinas e de "lamproítos", rochas lamprofíricas e basaltóides com "leucita" ver Putzer (1962), Bitschene (1987), CominChiaramonti \& Gomes (1996).

De forma general, como constata-se na Fotografia 2-7, 2-8 e 2-9, as intrusões instalaran-se segundo traços/combinação de traços E-W e NW-SE e segundo falha $\sim N-S$.

\section{Intruscos lamprofinicas do Campo Vbytyruzú}

Foram reconhecidos no campo Ybytyruzú duas intrusões de brecha (Yzum3 e Yzu-4), um sill e vários diques e enxame de diques possuindo aspecto de rochas lamprofíricas (Yzú-1 e YZu-2). Algumas intrusões das muitas encontradas na borda norte da cordillera del Ybytyruzú, sucintamente apontadas na Tabelas 2-3 e 2-4 são aqui estudadas e outras são estudadas em Bitschene (1987) e Comim-Chiaramonti \& Gomes (1996), Figuras 2-8 e 2-9. A Fotografia 7 mostra a orientação estrutural das intrusões a norte da cordillera del Ybytyruzú:

- lineamento NW-SE bem marcado (ex. enxame de diques Ybytyruzú, Presser 1994), que estão marcados como linhas de traços na Figura 2-8;

- por vezes o lineamento dado pela/s provável/eis falha/s abissal/is) N-S (ex. Yzu-1, Yzu-2 e Yzu-4). Outros diques encontrados a leste da cordillera (Paso Yobai, 


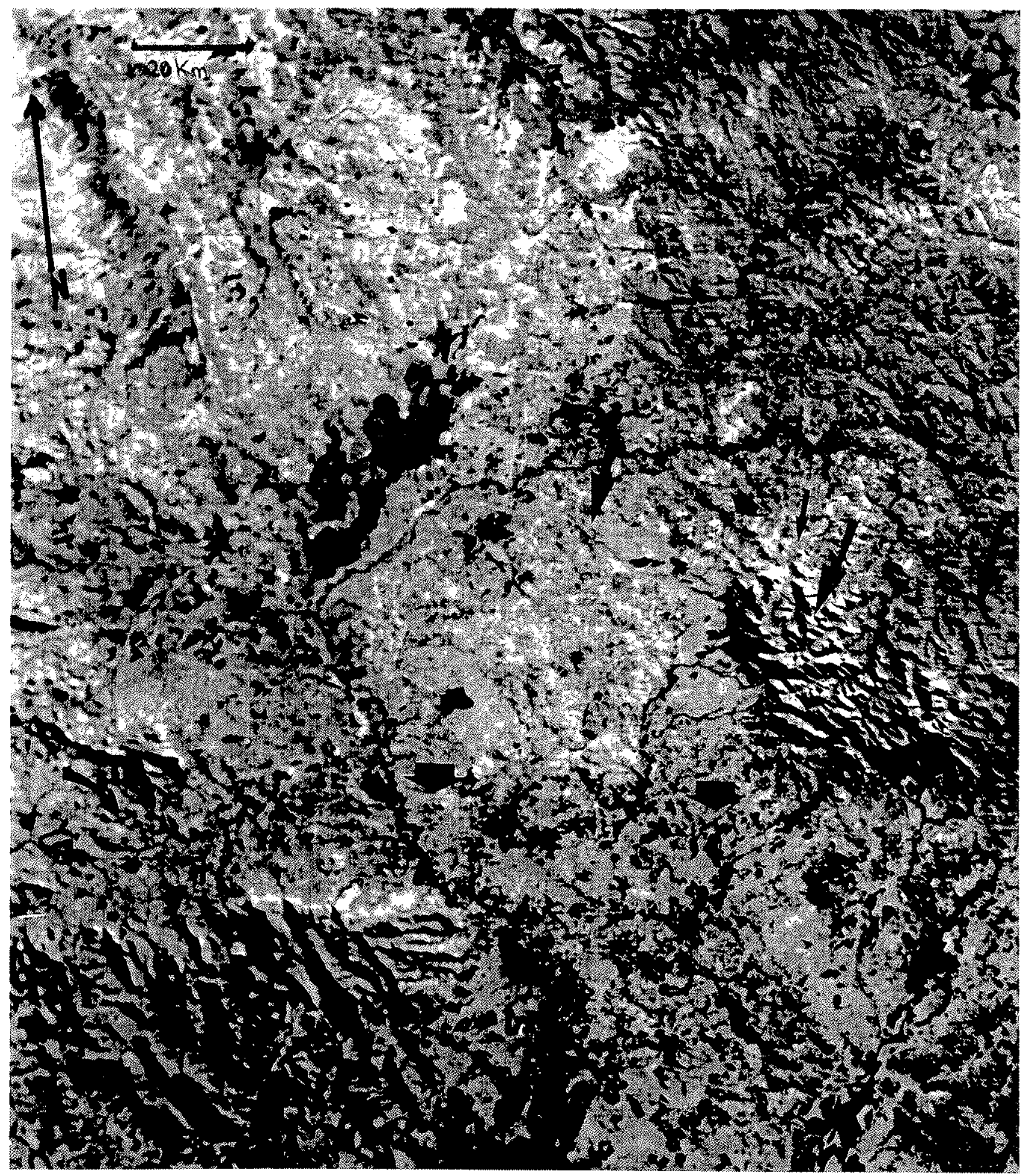

Fotografia 7. Imagem de satélite, branco e preto (canal 5), do bloco Oriental do rif de Asunción. Estäo apontadas os enxame de diques alcalinos (NW-SE, pela seta); as intrusões alcalinas citadas no texto, que da esquerda à direita são: Yzu-3, Yzu-2 Yzu-4, Yzu-2Nzu-6 e Yzu-10. Notar os lineamentos com rumo E-W (ex. Setas paralelas), N-S, NW-SE e menos comum os NE.SW. 
Figura 2-8), seguem rumo N-S e associam-se com zonas de fraturas E-W, NS, NW-SE e mais raramente também NE-SW, (medidas em encaixantes do Grupo Independencia).

De forma geral, como pode ser constatado na fotografia 7 e nas Figuras 2-8 e 2-9 as intrusões instalaram-se segundo linha de traços/conjunção de linhas de traços $E-W$, NW-SE e N-S. O conjunto de linhas de traços E-W, que entende-se como falhas abissais, correspondem à zona de lineamento $E-W$. Conforme indicado na Figura 2 8 , se estende a W até o campo Ybytymi e o Rio Paraguay, juntando-se a leste com o lineamento do Rio Uruguai.

\section{Intrusão Yzum}

Este corpo foi descrito por Bitschene (1987) referindo-se a ele como fono-lamproito. A intrusão possue algumas dezenas de metros $(<50)$ de largura e forma geométrica similar a uma taça de champagne. Esta encaixada em sedimentos do Grupo Independencia (Bitschene, 1987). Nela são reconhecidas duas fácies diferentes de rocha:

1- fácies de brecha micácea que ocupa o conduto da intrusão, prolongando-se para leste onde é coberta por lavas.

2- fácies de lava, que se apresenta pseudo estratificada rumo a leste (Fotografia 9).

Esta intrusão lembra condutos (pipes) lamproíticos.

A fácies de brecha micácea corresponde a uma rocha vulcânica de textura lamprofírica marrom esverdeada, brechóide autolitica (segundo fragmentos angulosos de rocha de aspecto lamprofírico rica em feno/microfenocristais de mica pseudomexagonal, raros pseudomorfos de olivina milimétrica e pseudomorfos de piroxênio), acompanhada por enclaves das rochas encaixantes (sedimentares e ígneas) de dimensões centimétricas possuindo formas arredondadas a angulosas sustentados em matriz da mesma composição carregada de clástos de areia fina a grossa quartzosa.

A fácies de lava corresponde a uma rocha vulcânica de cor cinza amarronzado a esverdeado, porfirítica com abundantes fenocristais de piroxênio prismático verde milimétrico, olivina pseudomónfica sub milimétrica a milimétrica e, microfenocristais de mica castanha. Ocorre junto a eles escassos fragmentos angulosos autoliticos 


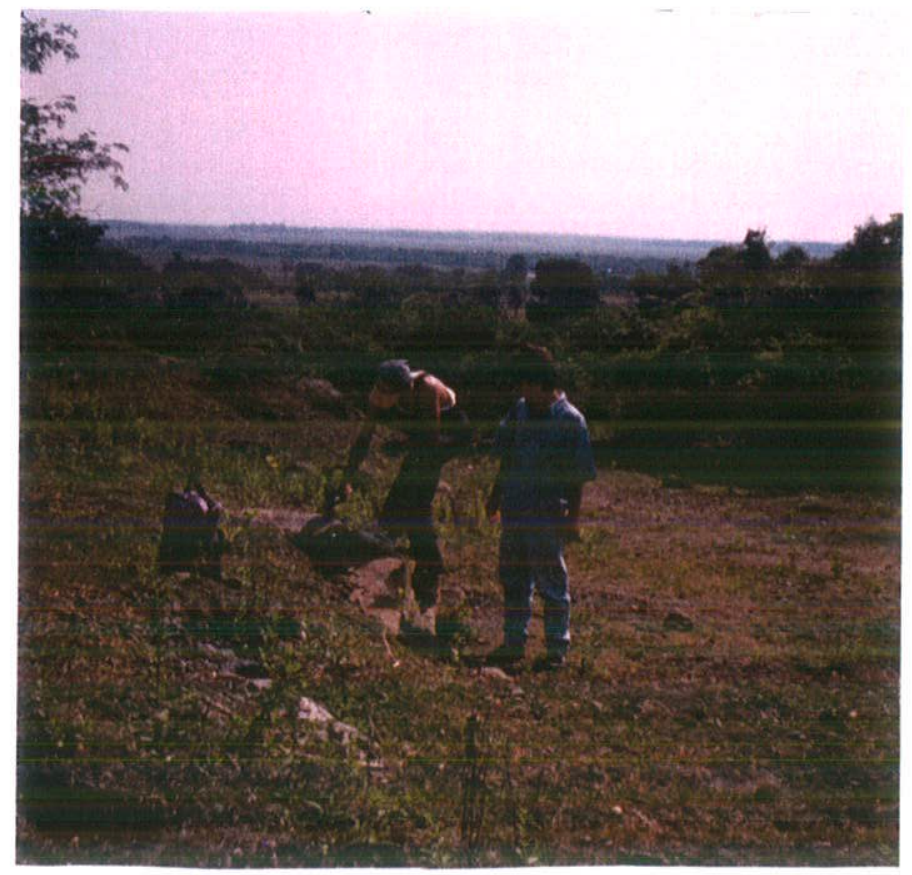

Fotografia 8. Intrusão de Mbocayaty. Aqui os observadores examinam exposições da brecha rica em fenocristais de "leucita"(Yzu-4), exposta no contato (em direção ao observador) com encaixante um shonkinito (cf. Putzer 1962).

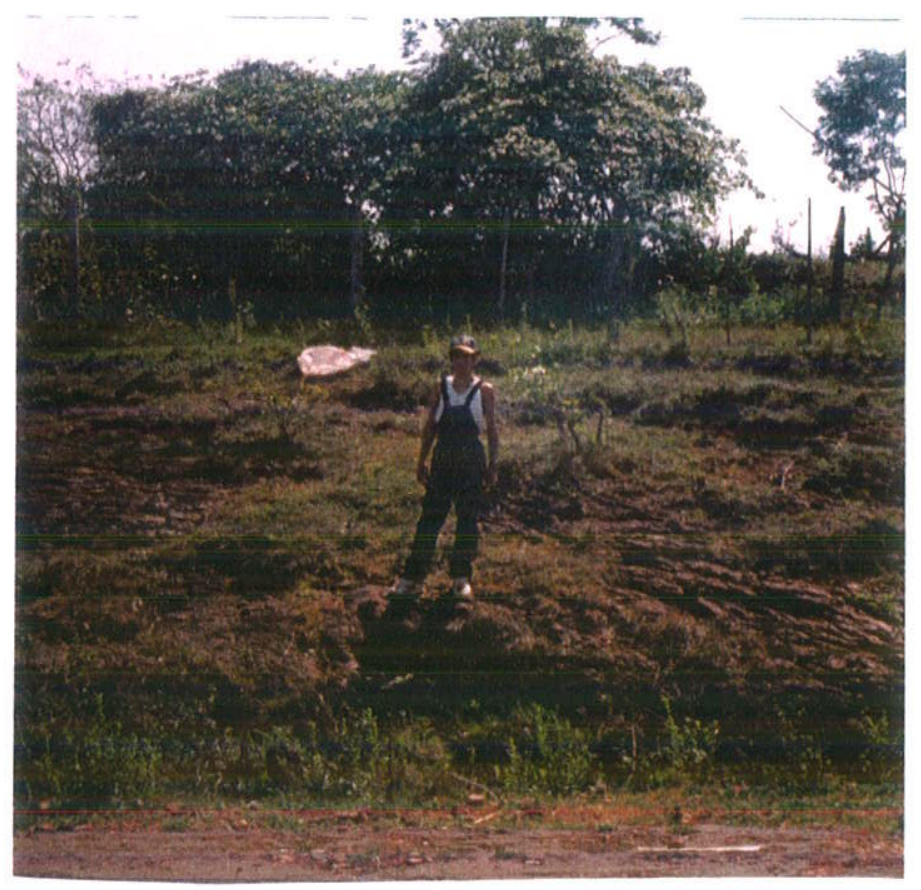

Fotografia 9. Intrusão Yzu-4. Fácies de brecha com mica (esquerda da foto até o observador) invade (?) fácies de "lava" (a direita da foto junto ao observador). 


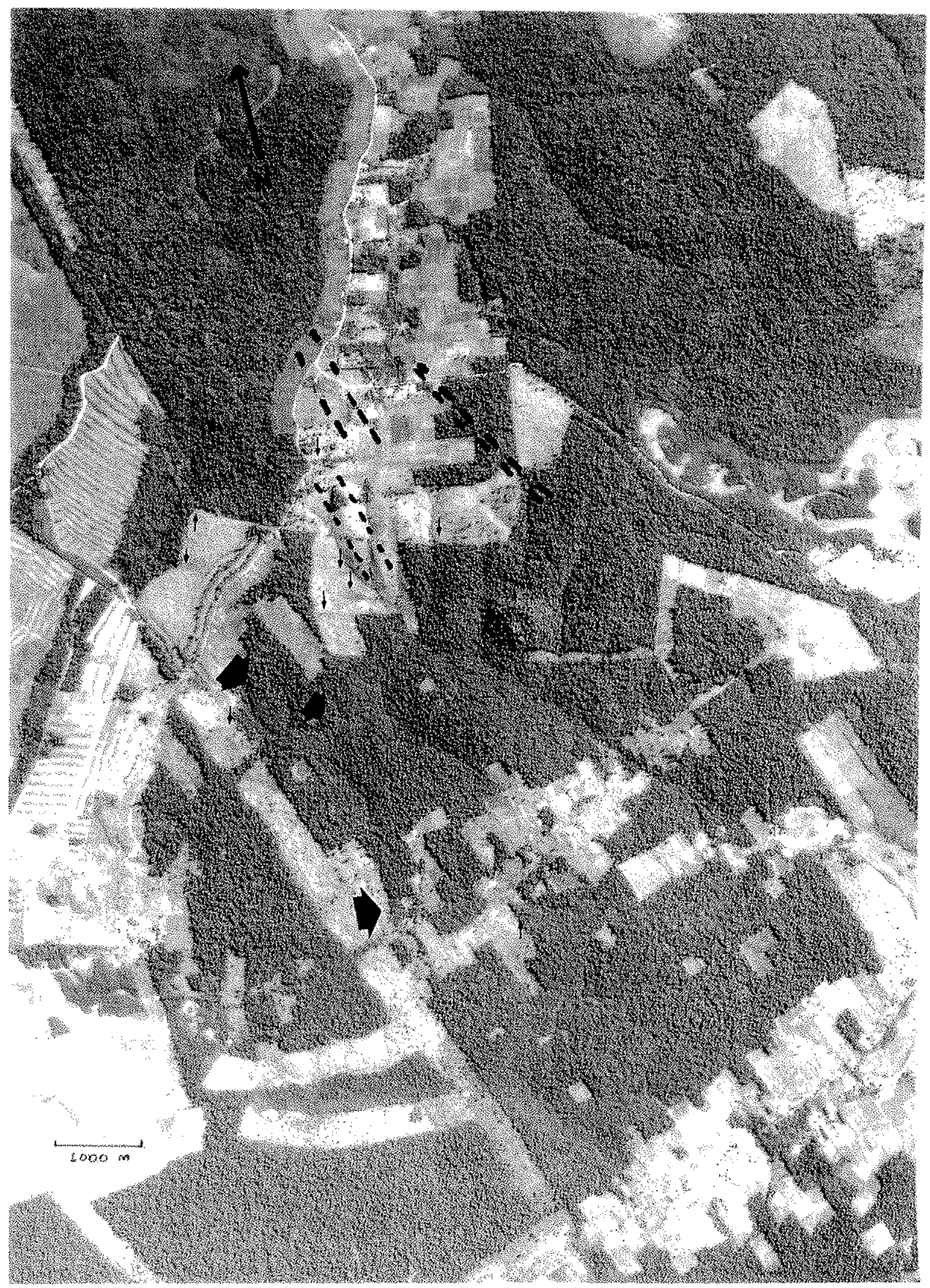

Fotografia 10. Cópia ampliada da fotografia aérea 1:65,000 do I. G.M. (Paraguai) a $\sim 10 \mathrm{Km}$ SW da cidade Paso Yobai, onde são mostrados os diques "lamprofiricos" (scas) Yzu-10 (rumo N-S), que ocorren associados com veios/filǒes de quartyo aurífero (rumo $\mathrm{E}-\mathrm{W}$, em selas pequenas). Em linhas de traços alguns diques de diabásio toleítico (Serra Genal ou fin. Allo Paraná, no Paraguai); litologias encaixadas em sedimentos do Grupo Independencia (Permiano). 
possuindo vesículas milimétricas preenchidas por zeólitas. A matriz é muito fina e alterada.

\section{Sill Yzu-6}

Bitschene (1987) descreve este sill, que está colocado entre os arenitos da Formaçäo Misiones (arenitos cor bege claro), como rocha de natureza sienitoide (malignito melanocrático/shonkinito porfiritico). Observações de detalhe mostram que o corpo tratamse de um dique-sill, máximo de um metro de espessura, colocado numa fratura subvertical que se abre em direção leste num sill que ficou exposto na base da queda da água conhecida como salto Boni ( $50 \mathrm{~m}$ de queda, Bitschene 1987.). $\mathrm{O}$ sill é composto por uma rocha vulcânica porfirítica com marcada textura lamprofírica, dada pela presença de fenocristais milimétricos de mica, piroxênio e microfenocristais de ilmenita imersos em uma matriz microgranular algo alterada com abundantes amígdalas de carbonato milimétricos a centimétricos e enclaves de rochas sedimentares texturalmente finas. São apresentados os detalhes petrográficos e de química mineral no Capitulo 3.

\section{Diques de Paso Yobai (Yzu-10)}

Na porção distante $10 \mathrm{~km}$ a SE da cidade de Paso Yobai, na Compañía Unidas (Figura 2-8 e Fotografia 10) ocorrem jazidas de ouro onde este autor esteve pesquisando durante os meses de agosto a outubro (1997). Esta pesquisa levou a observar que diques decimétricos a métricos de rochas de aspecto lamprofírico ocorrem associados a diques de diabásio da Formação Alto Paraná (Serra Geral no Brasii), de possança decimétrica junto a filöes de quartzo (alguns auríferos) centimétricos a métricos (?). Esses litotipos encontam-se encaixados em sedimentos (pelíticos a arenitos quartzosos/oolíticos a pisolíticos) portadores de caules de madeira silicificada, atribuídas ao Grupo Independencia.

As informações geológicas coligidas no campo permitiram observar que:

- os diques de diabásio toleítico, maciço, de cor preto cortam sedimentos (pelitos e arenitos) do Grupo Independencia segundo NW-SE;

- os diques de rocha vulcânica, parcial a totalmente alterada, com forte aspecto lamprofírico dado pela presença de microfeno a megacristais (até centimétricos) de mica e pseudomorfos de piroxênio e microfenocristais de olivina; numa matriz de 
textura muito fina a fina; cortam sedimentos politicos do Grupo Independencia segundo N-S, NNW-SSE.

- filöes de quartzo aurífero com vários centímetros de espessura aparecem em zonas de fraturas decimétricas com rumo E-W e ENE-WSW, instalando-se nos sedimentos areníticos do Grupo Independencia. Aqui também, como verificado no Campo Ybytymi, os diques das intrusões lamprofíricas micáceas encontram-se preferencialmente encaixados em sedimentos finos.

Nos sedimentos de leito do córrego (arroyo) Itá ocorrem blocos de rochas fonolíticas porfiriticas (fenocristais de olivina e feldspato) e rochas traquitóides frescas. Estas litologias de afindades tipicamente alcalina ainda não foram descritas na literatura. Observamse um provável plug, colocado perto de onde foram encontrados estes blocos; possivelmente seja sua fonte (Fotografia 10).

\section{Dique Yzu-}

A oeste da intrusầo Yzu-4, junto à base do flanco NW-SE da borda da cordillera del Ybytyruzú (Figura 2-8) ocorre um dique decimétrico de rocha vulcânica, de cor cinza escuro, porfirítica com fenocristais de piroxênio, olivina fresca/pseudomorfizada, milimétrica e, ocacionalmente mica escura mergulhados em matriz de aspecto basaltóide muito fina. O dique encontra-se encaixado em sedimentos do Grupo Independencia. Ele ocorre no flanco a leste de uma faixa rica em diques alterados de "lamprófiros" com mica oreintados segundo NW-SE, pertencentes ao enxame Ybytyruzú (Figura 2-8 e Fotografia 7)

\section{Dique $\mathrm{Yu}-2$}

Na porção sul da intrusão Yzu-4, no extremo norte da cordillera del Ybytyruzú, e vinculado ao lineamento N-S (Figura 2-8 e Fotografia 7), encontram-se blocos alinhados aparentemente cortando as lavas da Formação Alto Paraná. Trata-se de uma rocha vulcânica cinza, fortemente porfirítica, rica em pontilhados branco-beje de fenocristais de "leucita" (sub milimétrica) e microfenocristais de piroxênio escuro, olivina submilimétrica e subordinada mica castanha; encontram-se imersos em matriz muito fina de aspecto basaltóide. Detalhes petrográficos e da química mineral são proporcionados no capítulo 3. 


\section{Intrusão Yzu-3}

Esta intrusão aflora na antiga pedreira da cidade de Mbocayaty e foi originalmente descrito por Eckel (1959) como rochas sienitóide, sendo posteriormente revisada por Putzer (1962). No entanto, coube a Bitschene (1987) notificar nesta localidade a presença de rochas vulcânicas intrusivas nos sedimentos do Grupo Independencia. A oeste ocorre um stocks com fácies de rochas plutônicas máficas, cortadas na sua borda leste por rochas vulcânicas. Estas rochas vulcánicas possuem aspecto brechoide, clasto-matriz sustentada (Fotografias 7 e 8 ) composta por fragmentos milimétricos a decimétricos de rocha basaltóides porfirítica contendo fenocristais milimétricos de olivina, piroxênio e abundante "leucita", em matriz magmática basaltóide porfirítica com fenocristais de olivina, piroxênio e "leucita". Entre os clástos de rocha magmática observam-se alguns com vesiculas milimétricas preenchidas por zeólitas (fragmentos vesiculados). Estas rochas dão a impressão de tratar-se de brechas autolíticas de frente de lava, nas quais se nota um aparente fluxo de derrame rumo a NE, com aspectos similares às descritas por Presser (1992) junto ao cerro Medina na Formação Sapukai. No capitulo 3 descreve-se uma amostra coletada nos primeiros metros junto à parede de contato com as rochas sienitóides.

Este conjunto de rochas vulcânicas e plutônicas são cortadas por diques decimétricos, quase todos alterados, de composição basaltóide com leucita (rumo $\mathrm{N} 45^{\circ} \mathrm{W}$ ) e lamprofíricas micáceas (rumo N-S).

Em relação ao Campo Ybytymí, no Campo de Ybytyruzú o trabalho não é fácil devido à presença de bosques que dificultam a coleta de amostras frescas. Entretanto, em comum com as do Campo Ybytymi o enxame de diques Ybytyruzú é rico em rochas lamprofíricas. Porém no Campo Ybytyruzú predominam os mica piroxênio "lamprófiros" perante outras litologias de rochas alcalinas (mais heterogeneas no Campo Ybytymi). Neste trabalho de tese são abordados um reduzido número das intrusões deste campo, pelo que informações adicionais, em termos da geologia, petrografia, química de rocha e química mineral poderão ser complementados com os trabalhos de Bitschene (1987), De Min (1993) e Comin-Chiaramonti \& Gomes (1996). 


\section{CAPÍTULO 3}

\section{Petrografia e Química Mineral}

\section{Introdução}

Do grupo de rochas estudadas o espinélio é a face mineral mais comum presente em todas elas. Como os espinélios nem sempre são tarefa fácil de ser abordados e corretamente caraterizados, pretende-se a seguir dar algumas informações sobre os espinélios. A utilidade, das linhas apresentadas em relação a este mineral, será avaliadas em seguida nas descrições da química mineral; no capítulo final, os espinélios novamente são abordados, constituindo-se uma nova oportunidade para o contato do leitor com as linhas de baixo.

A fórmula estrutural dos espinélios é $\mathrm{R}^{2+}\left(\mathrm{R}^{3+}\right)_{2} \mathrm{O}_{4}$ e formam uma extensiva e intermutual série de solução sólida, onde raramente ocorrem como espécies naturais de uma composição pura de end members (Deer et al., 1962).

Este conjunto de minerais forma um GRUPO que pode ser subdividido em três séries, conforme os ions trivalentes $\mathrm{Al}^{3+}, \mathrm{Fe}^{3+}$ e $\mathrm{Cr}^{3+}$ (Tabela 3-1), que estiverem presentes: SÉRIE DO ESPINÉLIO $\left(R=A I^{3+}\right)$, SÉRIE DA MAGNETITA $\left(R=F e^{3+}\right)$ e SÉRIE DA CROMITA $\left(\mathrm{R}=\mathrm{Cr}^{3+}\right)$. Os membros das séries diferenciam-se entre si segundo o elemento que se apresenta como cátion $\mathrm{R}^{2+}$ predominantemente: $\mathrm{Mg}, \mathrm{Fe}$, Zn, Mn, Ni, Co, Ge e Cu (Deer et al., 1962; Haggerty 1976). As composições desses 


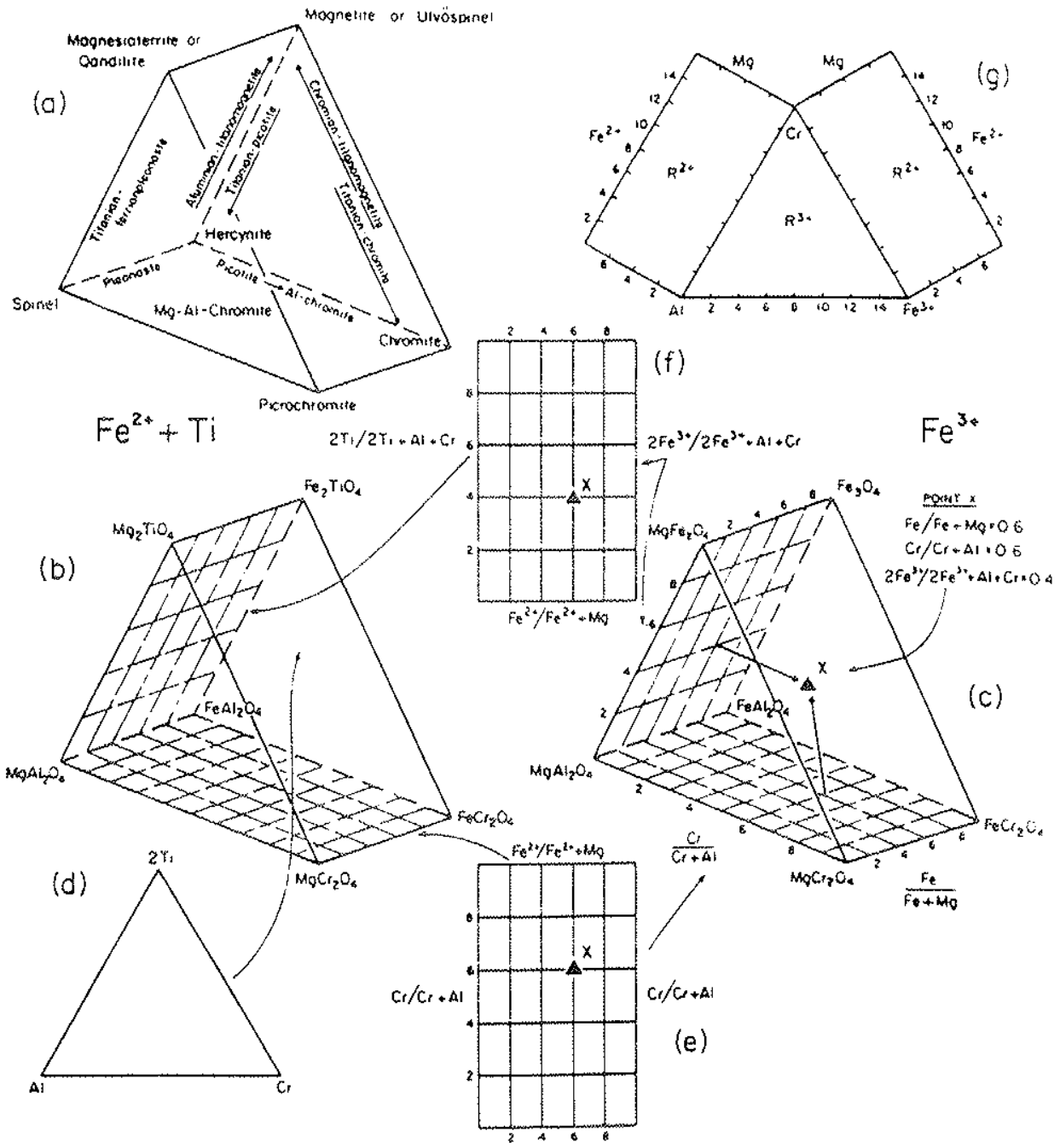

Figura 3-1. Nomenclatura dos espinélios no prisma multicomponente. A base do prisma é tida como dos espinélios normais e os flancos dos espinélios inversos. Espinélios inversos são divididos em $\mathrm{Fe}^{2+} \mathrm{Mg}_{\mathrm{g}}+\mathrm{Fe}^{2+}$ (b), e $\mathrm{Fe}^{2+} \mathrm{Mg}+\mathrm{Fe}^{3+}$ (c). O ternário do extremo esquerdo dos prismas possuem $\mathrm{Mg}$ como elemento comum, o ternário direito $\mathrm{Fe}^{2+}$ como elemento comum. Pelo prisma divalente, $\mathrm{Ti}, \mathrm{Fe}^{2+}$ e $\mathrm{Mg}$ são as variáveis (b); onde o prisma trivalente (c) as variáveis são $\mathrm{Fe}^{3+}$, $\mathrm{Al} \mathrm{e} \mathrm{Cr}$. Conquanto $\mathrm{Fe}^{2+} \mathrm{e} \mathrm{Mg}$ são fatores comuns para cada um dos ternários. o raio mostrado em (e) define a variação ao longo da base do prisma. A projeção empregada é mostrada em (d) e (f) porém a projeção mais empregada é a base do prisma dos espinélios (e). Estes prismas (b) e (c) são conhecidos como o prisma dos espinélios modificado de Johnson que é algo diferente do prisma de Parlov em (g). No prisma de Parlov, faz-se projeção indiretamente no ternário empregando componentes trivalentes. e em seguida lançam-se as mesmas análises que são transferidos ao retânguio da esquerda se $\mathrm{Al}>\mathrm{Fe}^{3+}$, ou ao retângulo da direita se $\mathrm{Fe}^{3+}>\mathrm{Al}$; este segundo lançamento é especifico para ions divalentes. Os valores da escala representam o numero de cátions em coordenação tetraédrica e octaédrica da fórmula dos espinélios que se baseia em 32 oxigênios e 24 cations (Haggerty, 1991). 
minerais podem ser projetados no sistema multicomponente dos espinélios, representados por um prisma modificado de Johnston na Figura 3-1 (cf Deer et al., 1962; Haggerty 1975, 1976, 1991, 1994).

Espinélios com estrutura normal são aqueles em que $\mathrm{R}^{2+}$ é de coordenação tetraédrica e $R^{3+}$ de coordenação octaédrica $\left(8 R^{2+}\right.$ em $A, 16 R^{3+}$ em $\left.B\right)$, tendo como exemplo o espinélio $\left(\mathrm{Mg}^{\mathrm{IV}}\left(\mathrm{Al}_{2}\right)^{\mathrm{V} / \mathrm{O}_{4}}\right)$. Estes incluem as espécies como a hercinita $\left(\mathrm{Mg}^{\mathrm{IV}}\left(\mathrm{Cr}_{2}\right)^{\mathrm{Vl}} \mathrm{O}_{4}\right)$, a cromita $\left({ }^{\mathrm{V}} \mathrm{Fe}^{2+}\left(\mathrm{Cr}_{2}\right)^{\mathrm{IV}} \mathrm{O}_{4}\right)$ e a magnésio cromita $\left(\mathrm{Mg}^{\mathrm{IV}}\left(\mathrm{Cr}_{2}\right)^{\mathrm{VI}} \mathrm{O}_{4}\right)$, que estão representadas na base do prisma multicomponente dos espinélios (Figura 3-1).

Espinélios com estrutura inversa são aqueles em que as posições $\mathrm{R}^{2+}$ e $\mathrm{R}^{3+}$ estão preenchidos tanto como ions em coordenação tetraédrica como octaédrica $\left(8 \mathrm{R}^{3+} \mathrm{em}\right.$ A, $8 R^{2+}+8 R^{3+}$ em B) (Deer et al. 1966). Neles podem ocorrer deficiências de cations. Como exemplo encontram-se a magnetita $\left({ }^{\mathrm{IV}} \mathrm{Fe}^{3+}\left(\mathrm{Fe}^{3+} \mathrm{Fe}^{2+}\right)^{\mathrm{V} /} \mathrm{O}_{4}\right)$ e ulvöespinélio $\left({ }^{I V} \mathrm{Fe}^{2+}\left(\mathrm{VFe}^{2+} \mathrm{Ti}\right)^{V /} \mathrm{O}_{4}\right)$. São espinélios que no prisma multicomponente estão representados em suas bordas (Figura 3-1). O mineral maghemita $\left(y-\mathrm{Fe}_{2} \mathrm{O}_{3}\right)$ possuem estrutura dos espinélios no qual se dá a substituição $2 \mathrm{Fe}^{3+}=\mathrm{Fe}^{2++} \mathrm{Ti}^{4+}$ (Deer et al., 1966).

$\mathrm{Na}$ série dos espinélios, o espinélio $\left(\mathrm{MgAl}_{2} \mathrm{O}_{4}\right)$ sensu stricto, seguido da hercinita $\left(\mathrm{FeAl}_{2} \mathrm{O}_{4}\right)$, é o mais comum, existindo uma série de substituição contínua entre o espinélio e a hercinita. Espinélios onde $\mathrm{Fe}^{2+}$ substitui o $\mathrm{Mg}$ na proporção $\mathrm{Mg}: \mathrm{Fe}^{2+}=3$ a 1 recebem o nome de pleonasto ou ceilonita. Zn pode substituir o Mg dando uma série isomorfa do espinélio gahnita $\left(\mathrm{ZnAl}_{2} \mathrm{O}_{4}\right)$; este espinélio com $\mathrm{Zn}$ recebe o nome de gahnoespinélio ou espinélio de $\mathrm{Zn}$. O íon $\mathrm{Al}$ pode ser substituido pelo $\mathrm{Cr}$, gradando à série da Cromita (cromita magnesianawcromita); o nome picotita restringe-se a hercinitas com apreciável substituição do Al pelo $\mathrm{Cr}$. Galaxita $\left(\mathrm{MnAl}_{2} \mathrm{O}_{4}\right)$ é um raro exemplar desta série e a substituição se dá como $\mathrm{Mn}=\mathrm{Fe}^{2+}$ e $\mathrm{Al}=\mathrm{Fe}^{3+}$ (Deer et al., 1966)

$\mathrm{Na}$ Série da Magnetita, a magnesioferrita ( $\left.\mathrm{Mg} \mathrm{Fe} \mathrm{Fe}^{3+} \mathrm{O}_{4}\right)$, magnetita $\left(\mathrm{Fe}^{2+} \mathrm{Fe}^{3+} \mathrm{O}_{4}\right)$ e maghemita $\left(y-\mathrm{Fe}_{2} \mathrm{O}_{3}\right.$ ), o uivöespinélio $\left(\mathrm{Fe}^{2+} \mathrm{TiO}_{4}\right)$, a rranklinita $\left(\mathrm{ZnFe}{ }^{3 *} \mathrm{O}_{4}\right)$, a jacobsita $\left(\mathrm{MnFe}{ }^{3+} \mathrm{O}_{4}\right)$ e a trevorita $\left(\mathrm{NiFe}^{3+} \mathrm{O}_{4}\right)$ são as variedades comuns; apesar da 


\begin{tabular}{|c|c|c|c|}
\hline $\begin{array}{l}\text { Cátios A2t } \\
\mathrm{Mg}\end{array}$ & $\begin{array}{l}\text { Série do Espinélio }(B=A \mid 3+) \\
\text { espinélio (MgA|2O3) }\end{array}$ & $\begin{array}{l}\text { Série da Wagnetita }(B=F e 3+) \\
\text { magnesioferrito (MgFe2O4) }\end{array}$ & $\begin{array}{l}\text { Série da Cromita }(B=C r 34) \\
\text { megnésiocromito }(\mathrm{MgCr} 204)\end{array}$ \\
\hline $\mathrm{Fe}$ & herchnito (FeAl2O3) & magnetita $\{\mathrm{Fe} 2 \mathrm{Fe} 304\}$ & cromita $(\mathrm{FeCr} 204)$ \\
\hline $\mathrm{Zn}$ & gahnito $(Z n A 1204)$ & frankinita (ZnFe2O4) & \\
\hline Mn & galaxito (MnA12O4) & Lacobsito (MnFe2O4) & manganocromita $\langle(\mathrm{Mn}, \mathrm{Fe})(\mathrm{Cr}, \mathrm{V}) 2 \mathrm{O} 4\rangle$ \\
\hline Ni & & frevorito (NiFe204) & nicromita ((Ni,Co,Fe)(Cr.Fe,Al)2O4) \\
\hline co & & & cocromita $((\mathrm{CO}, \mathrm{Ni}, \mathrm{Fe})(\mathrm{Cr}, \mathrm{A}) 2 \mathrm{2O})$ \\
\hline Ge & & brunogiento (Ge $\mathrm{Fe} 2+y(\mathrm{Fe} 2 \mathrm{O} 4)$ & \\
\hline $\mathrm{Cu}$ & & cruproespinéligat (CuFe2+1F 204) & \\
\hline
\end{tabular}

Tabela 3-1. COMPOSIÇÃO QUIMICA DO GRUPO DOS ESPINELLIOS 
magnesioferrita ser difícil de analisar por ocorrer com hematita; as maghemitas, metaestáveis, gradam para hematita, e só são identificadas em magnetitas com excesso de $\mathrm{Fe}_{2} \mathrm{O}_{3} ;$ o ulvöespinélio ocorre como blebs em magnetita ou pseudobrookita. As demais espécies da série são raras (Deer et al., 1966).

$\mathrm{Na}$ Série da Cromita reconhecem-se só duas espécies: a magnesiocromita $\left(\mathrm{MgCr}_{2} \mathrm{O}_{4}\right)$ e a cromita $\left(\mathrm{FeCr}_{2} \mathrm{O}_{4}\right)$, sendo que a primeira recebe também o nome de picrocromita. Entre ambos existe substituição continua do $\mathrm{Mg}$ pelo $\mathrm{Fe}^{2+}$ ou o inverso. Além disso dá-se apreciável substituição do $\mathrm{Cr}$ pelo $\mathrm{Al}$ e pelo $\mathrm{Fe}^{3+}$. São também conhecidas cromitas com Zn (Deer et al., 1966). Arbitrariamente, para se diferenciar uma da outra adota-se, neste trabalho, o valor do $\mathrm{mg} \#(\mathrm{Mg} /(\mathrm{Mg}+\mathrm{Fe}))$, sendo $\mathrm{mg} \#$ entre 50-100 para picrocromitas e $<$ mg\# 50 para as cromitas.

Os end members $\mathrm{MgAl}_{2} \mathrm{O}_{4}$ (espinélio) $-\mathrm{FeAl}_{2} \mathrm{O}_{4}$ (hercinita) $-\mathrm{MgCr}_{2} \mathrm{O}_{4}$ (picrocromita)$\mathrm{FeCr}_{2} \mathrm{O}_{4}$ (cromita) representam o grupo predominante de espinélios no manto superior. Estas variedades, no prisma multicomponente ocupam sua base e eles possuem a estrutura dos espinélios normais, composição que, desta forma, pode ser expressado em termos de mg\# vs $\mathrm{Cr}$, que é a base tanto para os espinélios "oxidados" (magnetita-magnesioferrita), como a base dos espinélios "redusidos" (qandilita-ulvöespinélio) (Haggerty 1991, 1994).

Os end members $\mathrm{MgAl}_{2} \mathrm{O}_{4}-\mathrm{FeAl}_{2} \mathrm{O}_{4}-\mathrm{MgTiO}_{4}$ (reunidos sob o nome coletivo de titanomagnetitas) $-\mathrm{Fe}_{2} \mathrm{TiO}_{4}$ (ülvoespinélio), são end members muito diferenciados da série e podem ser representados em diagramas binários em termos dos valores das rações de Ti\# $(=\mathrm{Ti} /(\mathrm{Ti}+\mathrm{Cr}+\mathrm{Al}))$ vs $\mathrm{Fe \#}\left(=\mathrm{Fe}^{2+} /\left(\mathrm{Fe}^{2+}+\mathrm{Mg}\right)\right.$ ) (Mitchell \& Bergman 1991), que são úteis sobretudo para expressar aqueles espinélios como o ülvoespinélio e titanita magnesifera $\left(\mathrm{Mg}_{2} \mathrm{TiO}_{4}\right)$. Já os espinélios vistos como a magnetita e magnesioferrita se representam melhor em diagramas binários em termos das razões Fe $\mathrm{e}^{3+}$ vs Fe\#, ver por exemplo Haggenty $(1975,1976,1991,1994)$.

Menos comunmente representam-se nos diagramas ternários a magnetita/ulvoespinélio-cromita-hercynita, em função dos valores 2Ti-Cr Al. O seu lado oposto é o prisma formado pelo qandilito-magnésiocromita-espinélio (Figura 3-1) 
e corresponde aos espinélios inversos. 2Ti-Cr-Al será empregado neste trabalho para representar as chamadas "magnetitas" em preferência ao diagrama binário

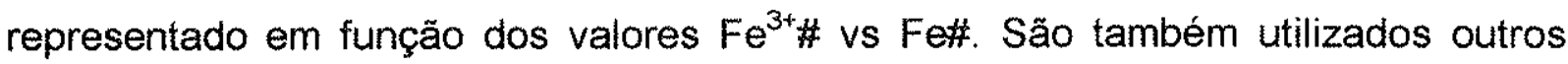
diagramas ternários de representação como $\mathrm{MgFe}_{3} \mathrm{O}_{4}-\mathrm{MgCr}_{2} \mathrm{O}_{4}-\mathrm{MgAl}_{2} \mathrm{O}_{4}$ (Foley 1985); este é útil sobretudo para end members da série da cromita. No presente trabalho será empregado junto ao diagrama binário mg\# vs Cr\# para caraterizar espinélios cromíferos. Finalmente espinélios ricos em $\mathrm{Mn}$ ( $\mathrm{MnO}>1 \%$ ), que pertecem comumente à série da magnetita, podem ser representados também em diagramas ternários do tipo $\mathrm{MnFe}_{3} \mathrm{O}_{4}-\mathrm{MnCr}_{2} \mathrm{O}_{4}-\mathrm{MnAl}_{2} \mathrm{O}_{4}$; neste trabalho também será empregado como ferramenta de caraterização dos espinélios ricos em moléculas de jacobsita.

\section{As rochas lamprofíricas junto ao rift de}

\section{Asunción}

Neste capítulo serão tentativamente caraterizados através da petrografia do estudo da química mineral de algumas intrusões de rochas lamprofíricas encontradas como rochas associadas aos basaltóides potássicos/ultrapotássicos do tipo Província Romana (Comin-Chiaramonti et al., 1992). Algumas delas já foram estudadas (Ymi-1, Ymi-5, Yzu-1 e Yzu-3, Gibson et al. 1996; Comin-Chiaramonti et al., 1992; De Min, 1993) e outras novas serão tratadas aqui. Quando possivel, tentar-se-á, com base em critérios petrográficos e da química mineral, alcançar uma caraterização petrológica das ocorrências estudadas e, ainda que preliminar, o nome da rocha vem entre aspas, por exemplo olivina piroxênio "lamprófiro". Contudo, a correta caraterização mineralógica, conforme as recomendações do IMA, seja por comparações das feições dos minerais analisados e os encontrados em outras rochas incomuns (lamprofíricas e/ou basaltóides potássicas), seja através das feiçöes de enriquecimento nos diferentes elementos, através das análises das posições cationicas, entre outros elementos que puderam ser encontrados nos minerais analizados, antecederam uma caraterização definitiva das rochas estudadas. 


\begin{tabular}{|c|c|c|c|c|c|c|c|c|c|c|}
\hline $\begin{array}{l}\text { Annosere } \\
\text { Antitien }\end{array}$ & $\begin{array}{c}935 O B 24 \\
1\end{array}$ & $\begin{array}{c}\text { Codri-M } \\
2\end{array}$ & $\begin{array}{c}\text { NYGr } \\
3\end{array}$ & $\begin{array}{c}3151 \\
4\end{array}$ & $\begin{array}{c}D 12(515) \\
5\end{array}$ & $\begin{array}{c}93 S O B 152 \\
1\end{array}$ & $\begin{array}{c}9350 B 39 \\
1\end{array}$ & $\begin{array}{c}935 O B 61 \\
1\end{array}$ & $\begin{array}{c}9350 \mathrm{~S} 109 \\
1\end{array}$ & $\begin{array}{c}48 P S 262 \\
5\end{array}$ \\
\hline locattrapio & Poworo ra & Yo. & Anow. & whaxaysery & c. restmáá & Krato & nonoto & cmos. & Seaced & socomy \\
\hline \multicolumn{11}{|l|}{ Elomontos } \\
\hline 202 & 47,28 & 48,32 & 50,13 & 48,2 & 50,83 & 49,8 & 48,19 & 49,23 & 47,88 & 50,31 \\
\hline Tice & 2,27 & 1,69 & 5,23 & 1,92 & 2 & 1,27 & 1,69 & 1,48 & 2,04 & 1,61 \\
\hline 1202 & 15,97 & 15,16 & 6,26 & 40,35 & 10,95 & 12,34 & 12,24 & 10,88 & 14,43 & 12,96 \\
\hline+100 & $10,85^{\circ}$ & $8,29^{*}$ & 2,03 & 4,98 & 4,68 & 9,7 & 9,64 & 9,75 & 11,51 & 5,86 \\
\hline P.203 & & & 7,09 & 5,42 & 3,9 & & & & & 2,11 \\
\hline wato & 0,19 & 0,12 & 0,18 & 0.2 & 0,13 & 0,15 & 0,15 & 0,15 & 0,18 & 0,13 \\
\hline so & 4,15 & 6,49 & 9,09 & 10,91 & 7,53 & 11,86 & 8,77 & 11,35 & 5,58 & 7,44 \\
\hline cao & 9,3 & 8,98 & 5,23 & 7,93 & 7,5 & 8,59 & 9,93 & 9,23 & 8,98 & 8,13 \\
\hline Hazo & 1,68 & 1,1 & 0,63 & 2 & 4,5 & 2,95 & 2,35 & 2,9 & 3,81 & 3,03 \\
\hline 200 & 5,55 & 9,64 & 10.11 & 5,84 & 3,5 & 3,1 & 5,15 & 3,27 & 4,05 & 4,44 \\
\hline 200 & 0,88 & 0,2 & 0,98 & 0,59 & 0,47 & 0,49 & 0,54 & 0,41 & 0,62 & 0,47 \\
\hline Yots & 98,12 & & & 99,91 & 99,73 & 100,25 & 98,65 & 98,65 & 99,08 & 99,34 \\
\hline Lor & 4,56 & & & 1,61 & 3,74 & 3,16 & 2,67 & 9,18 & 2,51 & 2,85 \\
\hline 2 & 2078 & 715 & 8900 & 1440 & 2410 & 1050 & 1144 & 1743 & 1307 & 1606 \\
\hline $\mathrm{cr}$ & 66 & 122 & & 850 & 455 & 904 & 300 & 906 & 54 & 445 \\
\hline an & 22,4 & & & & & 15,5 & 9,9 & 14,2 & $\{9,1$ & \\
\hline$m$ & 8,5 & & & & & 6,04 & 5,35 & 3,83 & 6,84 & \\
\hline $\mathrm{Hb}$ & 62,3 & 12,3 & 99 & 51 & 55 & 29,6 & 32,9 & 30,5 & 49,2 & 39 \\
\hline 糟 & 36 & 60 & & 291 & 88 & 298 & 101 & 262 & 39 & 119 \\
\hline Po & 18,6 & & & & & 10,3 & 18,3 & - & 13,9 & \\
\hline Rs & 87 & 337 & 191 & 189 & 56 & 34 & 63 & 31 & 102 & 80 \\
\hline se & 94,3 & & & & & 24,5 & 20,7 & 25 & 25,6 & \\
\hline 8 & 1865 & 437 & 1706 & 1368 & 1652 & 1356 & 1483 & 1311 & 1346 & 1550 \\
\hline พัะ & 4,10 & & & & & 2,41 & 2,07 & 2,26 & 2,92 & \\
\hline $\mathrm{r}$ & 11,63 & 2,2 & 77 & & & 7,94 & 8.52 & 8,17 & 10,42 & \\
\hline$v$ & 3,62 & 0,2 & 3 & & & 1,99 & 2,3 & 2,51 & 2,18 & \\
\hline$v$ & 314 & & & & & 264 & 271 & 244 & 296 & \\
\hline $\mathbf{Y}$ & 27.1 & 16 & 15 & 17 & 21 & 14,9 & 19,5 & 12,5 & 24,1 & 17 \\
\hline 2 & 100 & & & & & 73 & 78 & 73 & 87 & \\
\hline$z r$ & 445 & 102 & 918 & 386 & 340 & 261 & 257 & 254 & 339 & 298 \\
\hline L.: & 132 & 20,4 & 148 & 121 & 154 & 76 & 74 & 72 & 76 & 82 \\
\hline co & 237 & 60,6 & 208 & 239 & 265 & 147 & 126 & 148 & 478 & 147 \\
\hline Wd & 121.78 & 29,3 & 98 & 79 & 104 & 69,4 & 63,36 & 69,25 & 65,94 & 50 \\
\hline $8 m$ & 15,33 & 8,9 & 10,94 & & & 9,29 & 8,14 & 7,99 & 10.4 & \\
\hline Eu & 3,6 & 3,8 & 2,89 & & & 2,41 & 2,14 & 2,62 & 2,73 & \\
\hline 6 & - & 5,7 & 1,01 & & & - & - & - & 10,4 & \\
\hline$w$ & 1,35 & & 0,11 & & & 0,77 & 0,83 & $1,0.4$ & 1,15 & \\
\hline Ho & 0,98 & & & & & 0,84 & 0,79 & 0,62 & 0,9 & \\
\hline Tเw & - & & & & & $\cdot$ & - & - & - & \\
\hline ro & 2,46 & 0.27 & & & & 1,4 & 1,67 & 0,94 & 1,82 & \\
\hline Lu & 0,29 & 0,05 & & & & 0,16 & 0,22 & 0,13 & 0,23 & \\
\hline 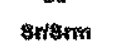 & 0,707205 & & & & & 0,707236 & 0,707527 & 0,707366 & 0,707006 & \\
\hline Memam & 0,511928 & & & & & 0,511861 & 0,511812 & 0,51172 & 0,511946 & \\
\hline anton & 0,706938 & & & & & 0,70657 & 0,707229 & 0,707093 & 0,70657 & \\
\hline Adratat & 0,511859 & & & & & 0,511859 & 0,511656 & 0,511787 & 0,511859 & \\
\hline redouspal & 1235 & & & & & 1358 & 1375 & 1400 & 1411 & \\
\hline
\end{tabular}

Tabela 3-2. Dados geoquimicos das rochas potássicas a ultrapotássicas vinculadas comorift de Asunción. Fontes: $1=$ Gibson et al. (1996); $2=$ Comin-Chiaramonti et al. (1993); $3=$ Presser (1994); 4=De Min (1993); 5=Comin-Chiaramonti \& Gomes (1996). 
Conforme comentado no capitulo anterior, no presente trabalho dar-se-á ênfase ao estudo das rochas lamprofíricas. Estas rochas são divididas, a seguir, em dois grandes grupos petrográficos preliminares; (1) "lamprofíros", e (2) "lamproítos". Esta divisão permite facilitar as descrições da petrografia e da química mineral em grupos "familiares" de rocha.

No Capítulo anterior foram apontadas as variedades de rochas que são estudadas neste trabalho. Elas foram referidas como lamprofiricas, pois apresentavam como denominador comum a textura porfirítica com marcado idiomorfismo dos fenocristais.

Preliminarmente, se fazem necessários alguns comentários referentes à geoquímica do magmatismo alcalino dos campos Ybytymi e Ybytyruzú. Menciono-se que CominChiaramonti et al. (1992), De Min (1993) e Comin-Chiaramonti \& Gomes (1996) reuniram um vasto acervo de dados geoquimicos, geocronológicos e da química mineral do magmatismo alcalino dos campos Ybytymi e Ybytyruzú. De conformidade com os dados disponiveis nestes trabalhos e os encontrados em Bitschene (1987), Comin-Chiaramonti et al. (1992) e Gibson et al. (1996) pode-se destacar alguns aspéctos relevantes dessas rochas:

*Os teores em potássio variam de 3 a $9 \%$ com $\mathrm{K}_{2} \mathrm{O} / \mathrm{Na}_{2} \mathrm{O}$ de $<1$ a 47 , mostrando claramente o caráter potássico a muito rico em potássio.

${ }^{*} \mathrm{O}$ grande volume de rochas potássicas em que se observam teores de $\mathrm{K}_{2} \mathrm{O}>3 \%$, $\mathrm{MgO}>3$ e $\mathrm{K}_{2} \mathrm{O} / \mathrm{Na}_{2} \mathrm{O}$ entre $>2$ e 47 que evidenciam 0 caracter de rochas ultrapotássicas. Segundo Comin-Chiaramonti et al. (1992) estas rochas adequam-se ao Grupo III das rochas ultrapotássicas, i.e. plagileucitos (Comin-Chiaramonti et al., 1996). Neste grupo foram reconhecidas duas grandes suites de rochas potássicas (Comin-Chiaramonti et al., $1996 \mathrm{a}-\mathrm{b}$ ): basanito-tefrito-fonotefrito-fonólito e basalto alcalino-traquibasalto-traquiandesito-traquifonólito/traquito. As variações composicionais dão-se em termos de $\mathrm{K}_{2} \mathrm{O} / \mathrm{Na}_{2} \mathrm{O}=2$ ( $\mathrm{K}$ dominantes) a $\mathrm{K}_{2} \mathrm{O} / \mathrm{Na}_{2} \mathrm{O}>2$ (HK importantes) que ocorrem junto a um outro tipo litogeoquímico de caráter transicional a potássico que denominaram de transicional (tK). Apesar disso, Giampaolo et al. (1997) observaram, ao estudar algumas rochas da Província 
Romana (Lago Bracciano), que ocorrem trocas geoquímicas do potássio pelo sódio + $\mathrm{H}_{2} \mathrm{O}$ em lavas com fenocristais de leucita; observação similar pode também ser vista em Gupta \& Yagi (1980) e Mitchell et al. (1987). Estas feições chamam a atenção sobre o acento ou não do procedimento de separação dos grupos transicionais a ultrapotássicos adotado por Comin Chiaramonti et al. (1996) com relação as rochas do rift de Asunción. Assim, também a composição isotópica de $\mathrm{Sr}_{\mathrm{m}}$ nestas rochas potássicas varia de 0.70700 a 0.71018 e a razão isotópica em $\mathrm{Nd}_{\mathfrak{m}}$ varia de 0.511660 a 0.511195 (Bitschene 1987; Gibson et al., 1996 e Castorina et al., 1996). Além desso quando se consideram nestas rochas as elevadas razões em Ba/Yb (até 2649) e em La/Yb (até 105) observa-se-á que as rochas potássicas do Paraguai diferem-se dos plagileucitos da localidade Stand member (Província Romana e Indonésia, em Foley et al., 1987) pois apresentam teores elevados em $\mathrm{TiO}_{2}(0.66-2.30)$ e moderados a altos em Nb (18-69) aproximando-se bem mais aos lamproitos, como indicado por Bitschene (1987) e Presser \& Bistchene (1990), do que aos plagileucitos e basaltóides afins associados, como propoem Comin-Chiaramonti \& Gomes (1996). Entretanto isto comentado só aponta algumas complexidades do magmatismo do RA.

\begin{tabular}{|c|c|c|c|c|c|c|c|c|c|c|c|c|c|}
\hline Amostra & $\begin{array}{l}\text { Ymi- } \\
1 / p 1\end{array}$ & $\begin{array}{l}\text { Ymi } \\
1 / p_{2}\end{array}$ & $\begin{array}{c}Y \operatorname{Ymi} \\
1 / d\end{array}$ & $\begin{array}{c}\text { Ymi- } \\
\text { 1.c }\end{array}$ & $\underset{7}{Y \operatorname{mi}-}$ & $\begin{array}{c}\text { Yzu- } \\
1\end{array}$ & $\begin{array}{l}\text { Ymi- } \\
4 / \text { br }\end{array}$ & $\begin{array}{c}Y \text { mi- } \\
4 / 1\end{array}$ & $\begin{array}{c}Y \mathrm{mi}- \\
4 / \mathrm{d}\end{array}$ & $\underset{5}{Y \mathrm{mi}}$ & $\begin{array}{c}\text { Yzun } \\
2\end{array}$ & $\begin{array}{c}\text { Yzum } \\
3\end{array}$ & $\begin{array}{c}\text { Yzu- } \\
6\end{array}$ \\
\hline Olivina & $\bar{X} \bar{X}$ & $\overline{\mathbf{X} X \mathbf{X}}$ & $\mathbf{X X X}$ & $\mathrm{X}$ & $X$ & $\overline{X X}$ & $x$ & $\bar{x}$ & $\bar{x}$ & $x$ & $\bar{X}$ & $x$ & \\
\hline Piroxênio & $X x x$ & $X x x$ & $X \times x$ & $x X x$ & $X \times x$ & $X x x$ & $X X x$ & $X X X$ & $X X x$ & $X x x$ & $X x x$ & $x \times x$ & $X$ \\
\hline Espinélio & $x x$ & $X x$ & $X x$ & $x x$ & $x x$ & $x x$ & $X x$ & $X x$ & $X x$ & $x \times x$ & $x x x$ & $x \times x$ & $x x$ \\
\hline Mica & $x$ & $x$ & $x$ & $X x$ & $x$ & $x$ & $x x$ & $x X$ & $x x$ & $x$ & $X x x$ & $x$ & $X x x$ \\
\hline Carbonato & $x$ & $x$ & $x$ & & $x$ & $x$ & $x$ & $x$ & $x$ & & & & $x$ \\
\hline Foide & $x x$ & $x x$ & $x x$ & $x$ & $x$ & $x x x$ & $x$ & $x$ & $x$ & $X X X$ & $x X$ & $X x$ & \\
\hline Felds. Alc. & $x x$ & $x x$ & $x x$ & $x x$ & $x x$ & $x$ & $x x$ & $x x$ & $x x$ & $x x$ & $x x$ & $x x$ & $x \times x$ \\
\hline Apatita & $x$ & $x$ & $x$ & $x$ & $x$ & $x$ & $x$ & $x$ & $x$ & $x$ & $x$ & $x$ & $x$ \\
\hline Himenita & & & & & & & & & & & $x$ & $x$ & $x$ \\
\hline
\end{tabular}

Tabela 3 3. Análises modal estimada dos "lamprófiros" e "lampróltos". X, fenocristal/microfenocristal; $x$, matriz; XXX, muito abundante (olivinas em Ym-1 variam de $10-25 \%$ e portanto comportammse como "picritos"); XX, abundante; $X$, presente $(<10 \%$ a traços $)$. 


\section{"Lamprófiros"}

São estudadas separadamente as seguintes variedades petrográficas: I- os "lamprofiros" com fenocristais de olivina e piroxênio ou "lamprofíros" com fenocristais de mica, olivina e piroxênio (OLIVINA "LAMPRÓFIROS"); II- "lamprofíros" com fenocristais de mica e piroxênio (MICA "LAMPRÓFIROS"). Os criterios sobre uma caraterização correta e precisa conforme preconizada na literatura (ex. Rock 1991) serão seguidos nos subitens.

\section{Olivina "lamprófiros"}

As intrusöes de Ymi-1 (pipe), Ymi-7 e Yzu-1 (diques) são "lamprofíros" caraterizados por possuir como denominador comum, em maior ou menor proporçäo, fenocristais de olivina e piroxênio. Por questōes práticas descrevem-se separadamente as rochas da intrusão Ymi-1, das intrusões Ymi-7 e Yzu-1.

\section{Ymi-1}

\section{Feições gerais}

Gibson et al. (1996) forneceram os dados químicos de um dos diques interiores (Don Eladio 93SOB152) e do dique exterior ao pipe (Kerito 93SOB39), caraterizando rochas potássicas $\left(\mathrm{K}_{2} \mathrm{O} / \mathrm{Na}_{2} \mathrm{O}>1-2\right)$, ricas em MgO (8-12\%), $\mathrm{Ni}(101-298)$ e $\mathrm{Cr}(300-$ 904) e com moderados teores em $\mathrm{TiO}_{2}(1.2-1.7 \%)$ e $\mathrm{CaO}(8-10 \%)$; estas feiç̃es geoquímicas as colocam como uma das mais primitivas rochas do Mesozóico encontradas no rift de Asunción (Tabela 3-2). Considerando que se trata de um "lamprófiro", este prestar-se-á à comparação com os monchiquitos (Rock, 1987) e os vogesitos (Rock, 1984); porém, os vogesitos diferem dos monchiquitos por apresentar teores em $\mathrm{SiO}_{2}$ (cf. Rock 1991) mais parecidos aos valores encontrados nos diques de Ymi-1 (48-50\%). Outros dados geoquímicos são apresentados na Tabela 3-2. 

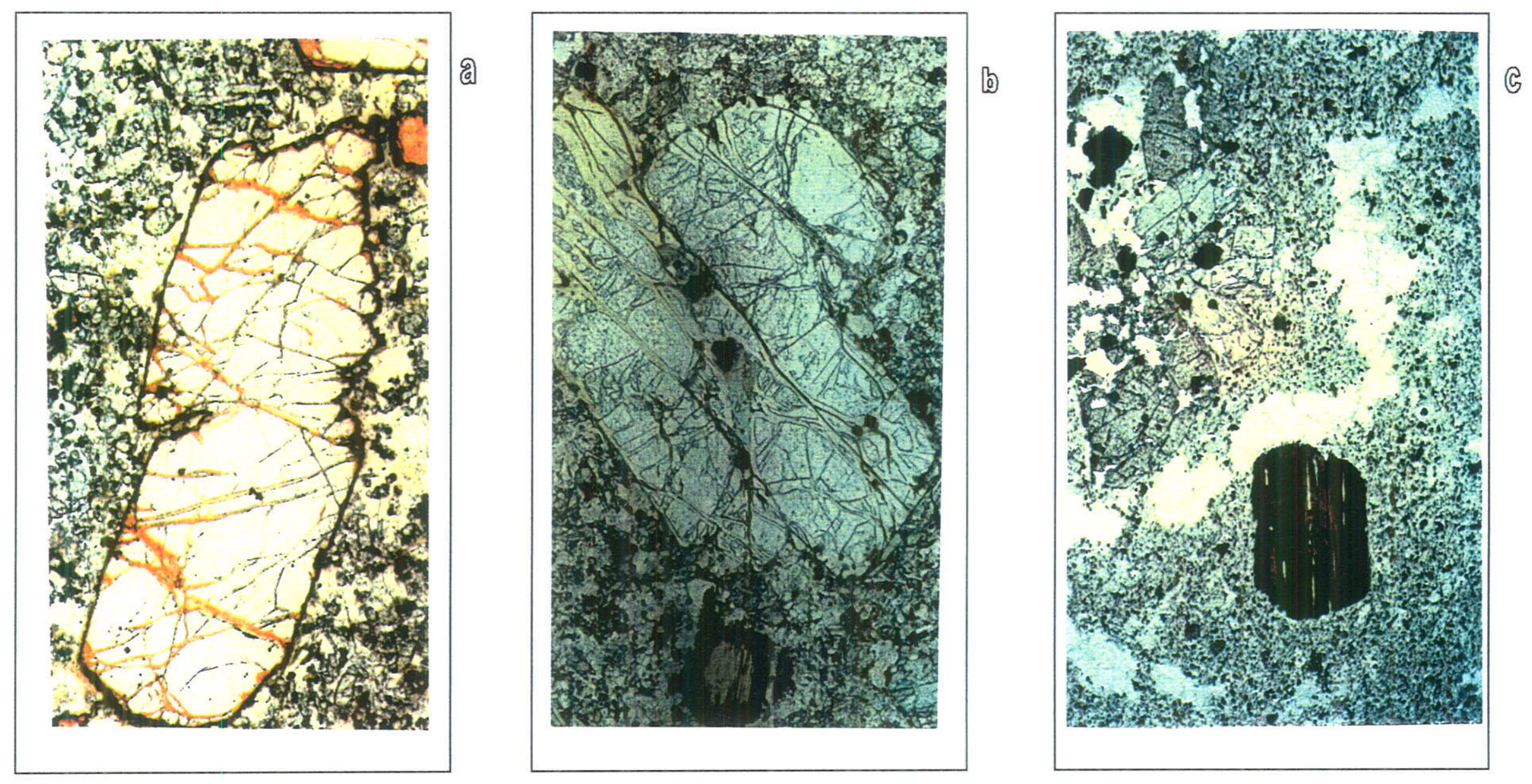

Fotomicrografia 1. Fenocristais em "lamprófiros". (a) Ymi-1, olivina de $\sim 3 \mathrm{~mm}$ mostrando no lado superior direito bordas dog-tooth. (b) Yzu-1, olivina parcialmente serpentinizada de $\sim 3 \mathrm{~mm}$ mostrando inclusões de espinélio; na parte inferior, microfenocristal de mica com bordas de opacos. (c) Ymi-4, fenocristais de mica $(\sim 1 \mathrm{~mm})$ junto a piroxênios agrupados com espinélios. Áreas irregulares de cor branco são de zeólita. Fotografias com polarizador inferior. 
Como comentado no Capitulo anterior, as fácies magmáticas que foram reconhecidas nesta intrusão pertecem a plugs e diques. Tanto as rochas dos diques que cortam o pipe (i.e. diques interiores) como as rochas dos plugs não apresentam diferenças texturais e modais que justifiquem abordagens separadas sendo assim descritas coletivamente.

As rochas possuem estrutura maciça e são ricas em fenocristais/megacristais de olivina avermelhada (milimétrica) alotriomórfica, e de piroxênio verde escuro euhedral $(1.5 \mathrm{~mm})$, que localmente pode apresentar-se como cristais glomerulares; sustentados em matriz algo fina. No dique Ymi-1.c a rocha apresenta feições distintas. É caracterizada por uma rocha fresca de cor cinza escura, estrutura maciça, que possui fenocristais de olivina avermelhada (sub milimétrica a milimétrica) subidiomórfica, piroxênio verde escuro prismático (milimétrico) e mica castanha escura (milimétricas) pseudo-hexagonais, sustentados por matriz basaltóide fina e maciça.

Ao microscópio apresentam-se como rochas marcadamente portiriticas, em parte seriadas, onde seus fenocristais de piroxênio e olivina (Fotomicrografia 1) e subordinadamente cromita (Fotomicrografia 4), mica, e esporádicamente ortopiroxênios são preferencialmente euhedrais, possuindo dimensões submilimétricas (ex. cromitas) a centimétricos (macrocristais, ex. piroxênios). Raros fenocristais de anfibólio amarronzado também foram encontrados. Sustentamos uma matriz intergranular a panidiomórfica fina $(<0.1$ a $0.2 \mathrm{~mm})$, composta depiroxênio, espinélio, mica e, intersticialmente, analcima, e minerais máficos às vezes incluindo poiquiliticamente feldspato alcalino (Fotomicrografia 2). Como minerais acessórios foram identificados carbonato, apatita (acicular), rutilo de $\mathrm{Nb}$ (similar ao encontrado nos concentrados e apresentado no apêndice), e anfíbólios marrom escuros. Em alguns diques (ex. Ymi-1c) ocorrem traços de plagioclásio. Na Tabela 3-3 são apresentadas as proporções modais das fases minerais presentes. As rochas do plug podem ser caraterizadas como feldspatóide-feldspato alcalino-olivina-piroxênio "Iamprófiro" picrítico, considerando que olivina modal esta presente em quantidades entre $>10$ e $25 \%$. Essa mineralogia asemelha-se a monchiquitos picríticos (Rock, 1991) de Wandagee (Jaques et al., 1989)(Wan) como também aos lamprófiros 

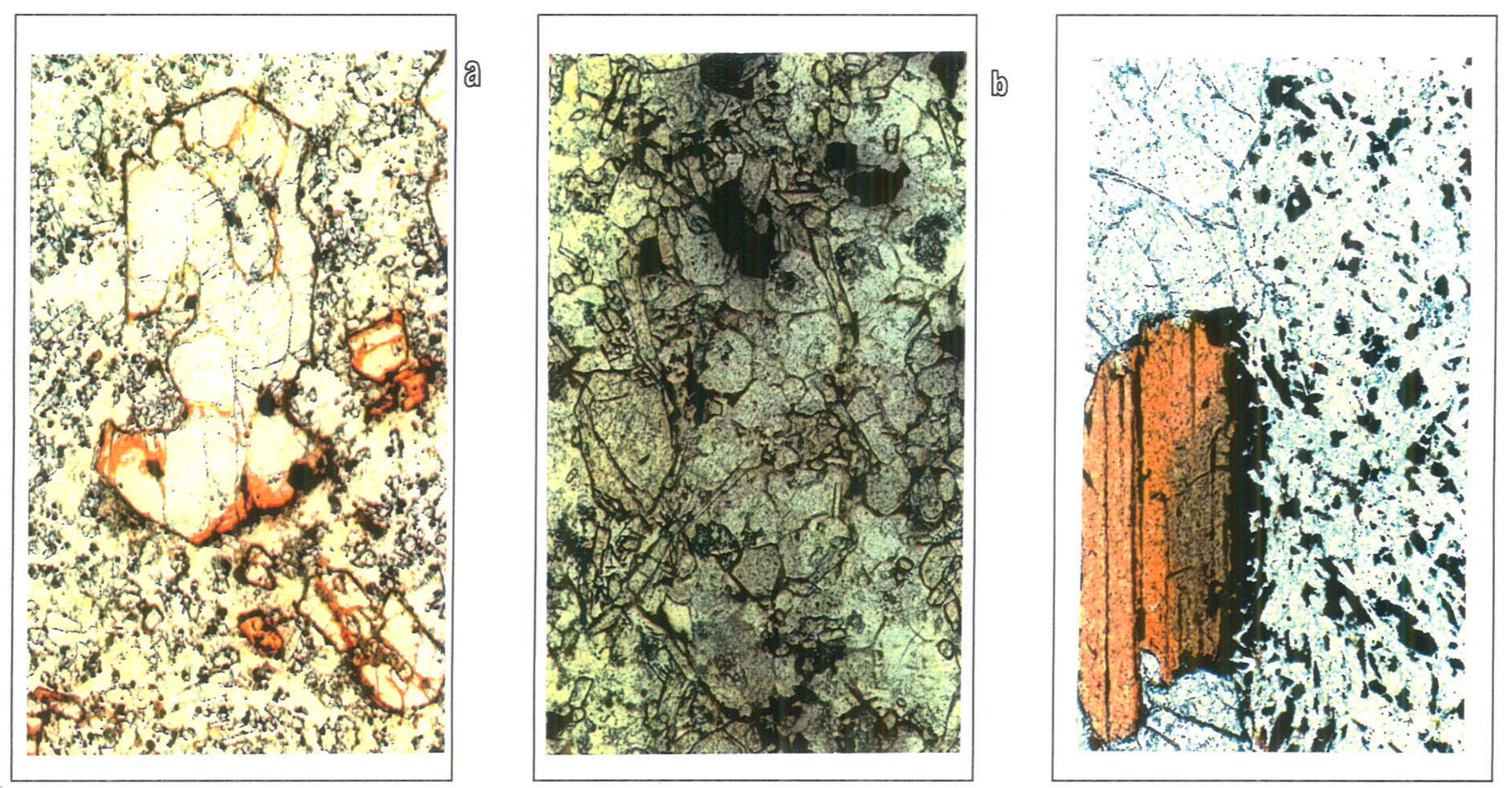

Fotomicrografia 2. Detalhes texturais dos "lamprófiros". (a) Ymi-1, matriz branca rica em analcima e feldspato (branco turvo) junto ao piroxênio, espinélios e mica intersticial (fenocristal de Olv. 1.6 mm). (b) Yzu-1, analcima arredondada (branca) junto a espinélio (opacos $\sim 0.10 \mathrm{~mm}$ ) e piroxênio esverdeado. (c) Ymi-4, microfenocristal $(\sim 0.6 \mathrm{~mm})$ de mica com bordas de espinélio. Observe-se o feldspato ripíforme (microtextura traquitóide) que ocorre entre espinélios. As três fotografias em polarizador inferior. 
picríticos de São Sebastião e arredores ( $\underline{\mathbf{S S}}$ ) (Garda, 1995). As rochas dos diques podem ser caracterizadas como feldspatóide-feldspato alcalino-olivina-piroxênio "lamprófiro" picrítico (com olivina modal $>20 \%$ ) e olivina-mica-feldspatóide-feldspato alcalino-piroxênio "lamprófiro".

\section{Química mineral}

As análises químicas dos elementos maiores e alguns menores dos principais minerais são apresentados nas tabelas do Apêndice, nas que se consta também as fórmulas estruturais. Os dados foram tratados, como se verá no decorrer deste capítulo, em diversos diagramas.

\section{Olivina}

Ocorre ( $>10$ a $25 \%$ modal) tanto nos plugs como nas rochas de diques, na forma de cristais euhedrais (preferentemente no dique Ymi-1.c, aqui $<10 \%$ modal) a anhedrais com dimensões tipicamente de 1 a $2 \mathrm{~mm}$ atingindo ocasionalmente $\sim 6 \mathrm{~mm}$ (macrocristais) sendo mais raros de observar os de tamanho submilimétrico euhedrais. Em geral são frescos a algo alterados (iddinsita e/ou serpentina) nas bordas/fraturas (Fotomicrografias 1). Alguns cristais apresentam as bordas serrilhadas lembrando assim a microtextura dog-tooth descrita nos olivina lamproítos por Mitchell \& Bergman (1991); em outros cristais é mais comum de se observar fenômenos de engolfamento, i.e. cristais que evidenciam corrosão. Microinclusões de cromita anhedrais (cor vermelho sangue) a subhedrais (opacos) abundam na maioria dos cristais (Fotomicrografia 4).

A composição das olivinas (apêndice A1) varia de $\mathrm{FO}_{74}$ a Fo92 (Figura 3-2) e correspondem à forsterita-crysolita, zonadas com o centro variando de Fo82-91 $e$ borda de $\mathrm{Fo}_{81}{ }^{-92}$. O zoneamento é também evidenciado em termos dos elementos $\mathrm{Ni}$ e $\mathrm{Ca}$, com o $\mathrm{NiO}$ variando de $0.0-0.49$ no centro a $0.04-0.40 \%$ nas bordas e o $\mathrm{CaO}$ oscilando de 0.11-0.33 no centro a $0.14-0.32 \%$ nas bordas (Figura $3-2 \mathrm{c}$ ).

\section{Ortopiroxênios}

Este mineral é encontrado como microfenocristais euhedrais (i.e. magmático) de cor algo amarronzada e com fraco pleocroísmo. Em alguns cristais observou-se a presença de inclusões de olivina e de espinélio (cromitas). Os cristais ocorrem alterados nas bordas e fraturas e, assim, ao ser analisados na microssonda 

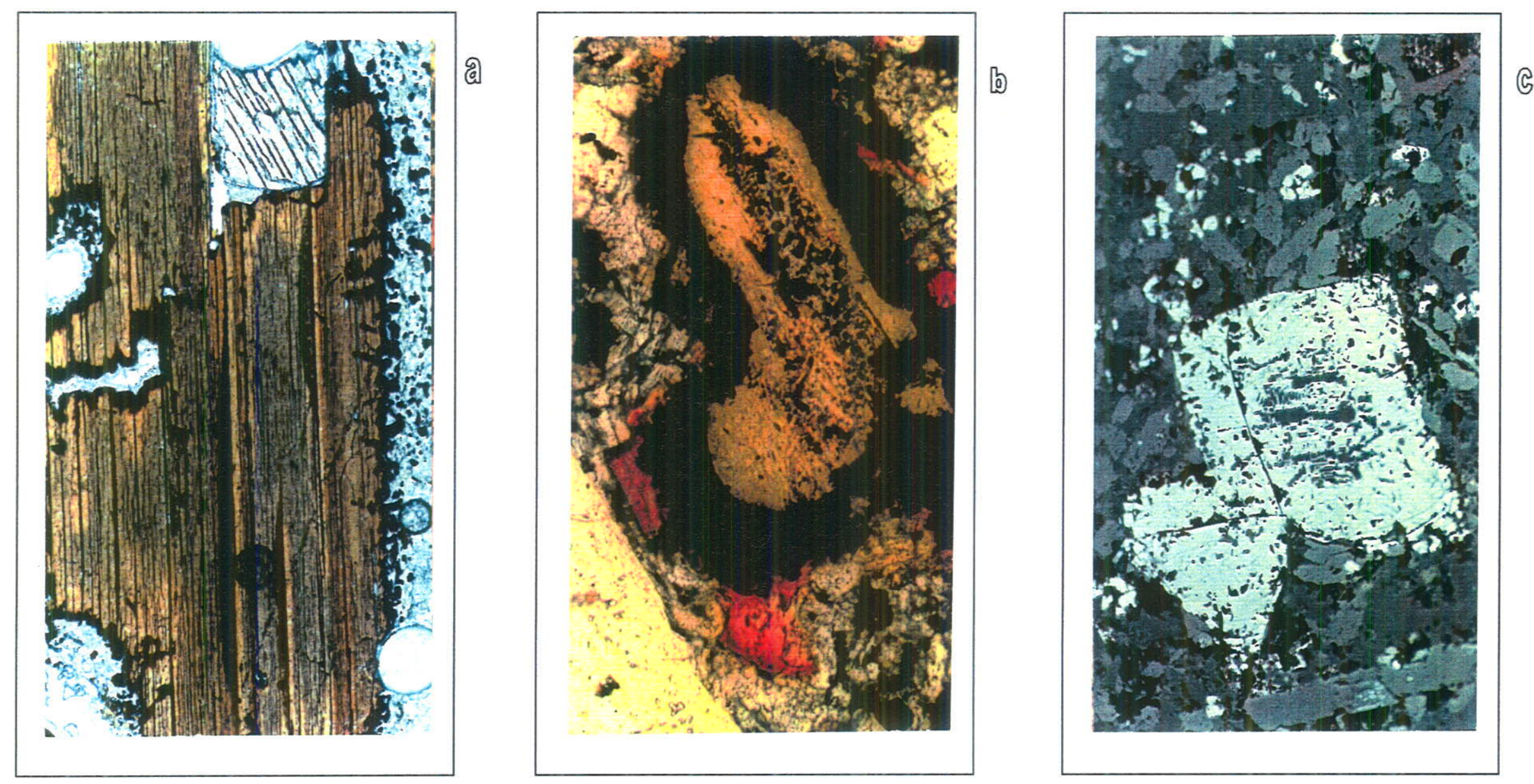

Fotomicrografia 3. Fenocristais. (a) campo $0.84 \mathrm{~mm}$, mica amarronzada subidiomórfica com bordas e engolfamentos devido à corrosão (Ymi-4); na borda inclusão parcial de piroxênio. (b) microfenocristal $(\sim 0.8 \mathrm{~mm}$ ) de flogopita corroída e pseudomorfizada nas bordas por espinélios (Yzu-2). (c) microfenocristal ( 0.3 mm) de magnetita magnesiana titanífera (cinza escuro) em microtextura do tipo cross-arm em hospedeiro de magnetita titanífera (prata cinzento) (Ymi-5). Fotos (a) e (b) luz transmitida e (c) luz refletida. 
eletrônica, eles forneceram análises parciais (cf. apêndice A3). Eles variam: aparentemente, de $\mathrm{En}_{73}$ a $\mathrm{En}_{80}$ apresentando baixos teores em $\mathrm{Al}_{2} \mathrm{O}_{3}(0.06-0.16 \%)$, $\mathrm{TiO}_{2}(0.00-0.08 \%)$ e $\mathrm{Cr}_{2} \mathrm{O}_{3}(0.01-0.12 \%)$ e $\mathrm{NiO}(0.25-0.45 \%)$. Nas rochas alcalinas, o ortopiroxênio magmático é conhecido só em lamproítos.

\section{Clinopiroxênios}

Os clinopiroxênios ocorrem abundantemente (30 a 35\% modal) nos plugs e nos diques, como fenocristais prismáticos comumente de $2 \mathrm{~mm}$, podendo atingir até 10 $\mathrm{mm}$ (macrocristais). Eles se apresentam como cristais isolados (monocristais e/ou cristais simetricamente geminados) a agrupados e interpenetrados, incolores, algo esverdeados/amarronzados apresentando zoneamento oscilatório a oscilatório setorial muito fina (visivel só com ambos os polarizadores). Em alguns cristais observaram-se inclusões de olivina anedral (fresca a serpentinizada anhedral) e/ou de espinélios. Na matriz, os cristais apresentam-se algo mais esverdeados, possuindo formas prismáticas ou mais raramente anhedrais.

Composicionalmente (apêndice A3) são diopsídios (Figura 3-3) ricos em $\mathrm{Al}_{2} \mathrm{O}_{3}$ (1.40$5.81 \%$ no centro a $1.08-5.89 \%$ na borda/matriz $=$ aluminosos $), \mathrm{TiO}_{2}(0.05-1.88 \%$ no centro a $0.25-2.02 \%$ na borda/matriz que, conforme recomendações do IMA, permite acrescentar o adjetivo titanífero) e pobres em $\mathrm{Na}_{2} \mathrm{O}(0.21-0.53$ centro a $0.19-0.61 \%$ borda/matriz). Tratamse de um diopsídio titanífero aluminoso. Mostram zoneamento, que torna-se evidente pelas variações nos teores de $\mathrm{Al}$ e $\mathrm{Ti}$ aumentando do centro para a borda (Figura 3-4: a-Ymi-1; b-Ymi-7, Yzu-1; c-Ymi-4). Esse tipo de enriquecimento também foi observado por Cundari et al. (1996) nas rochas potássicas da Província alcalina Central do Paraguai. Os lamprófiros estudados apresentam-se com deficiências na razão Ti/Al quando comparadas àquelas estudadas por Cundari et al. (1996).

\section{Micas}

Fenocristais submilimétricos a milimétricos $(<5 \mathrm{~mm})$ de mica ocorrem no dique Ymi$1 \mathrm{C}(<5 \%$ modal) na forma de cristais ora euhedrais apresentando fina a delgada 
อ

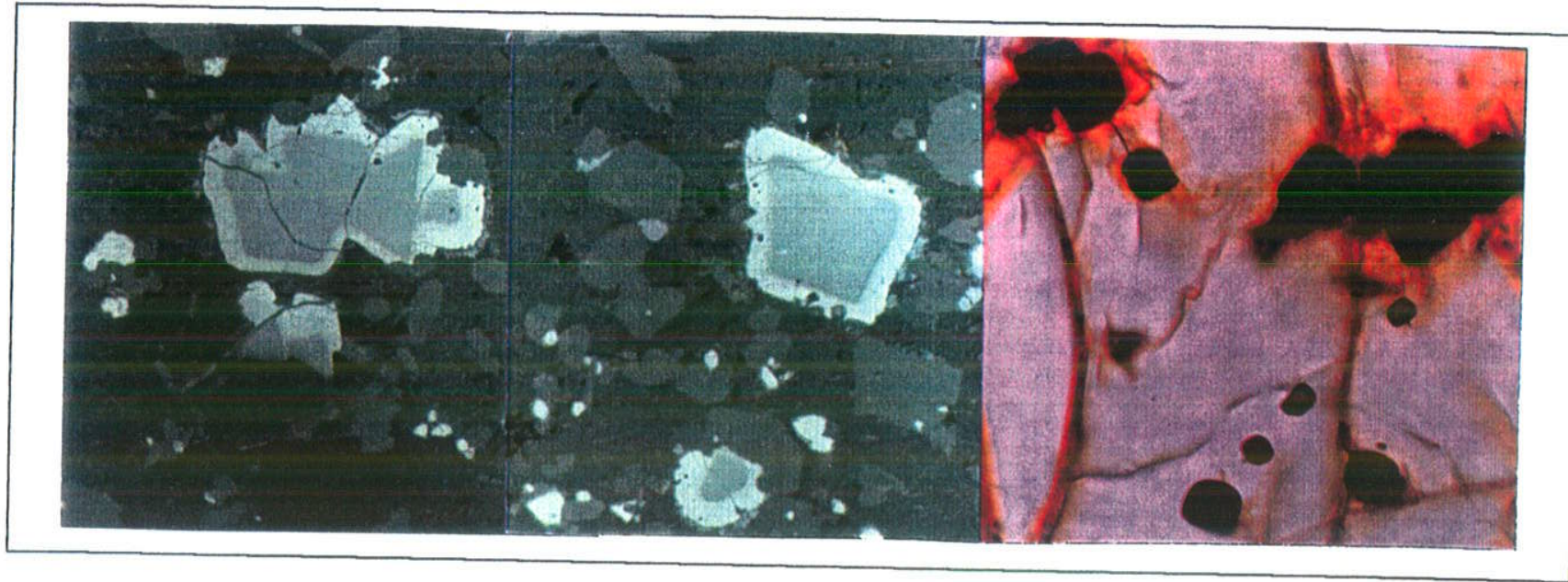

(⿹)

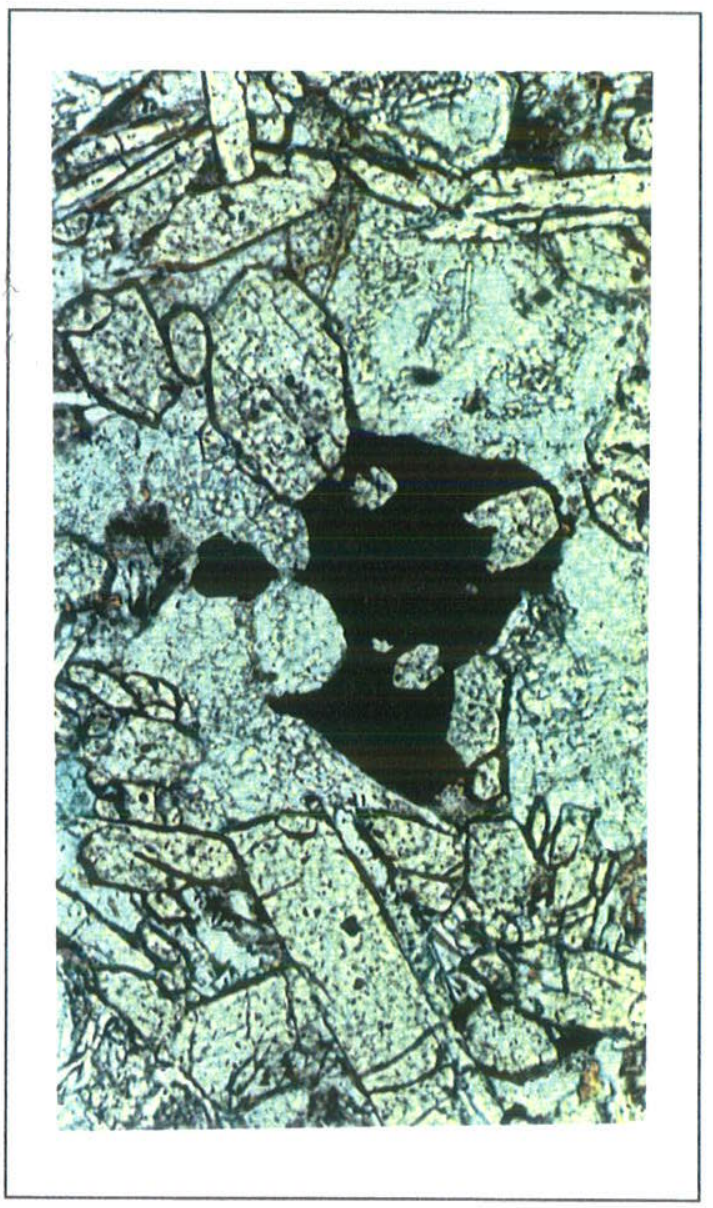

C

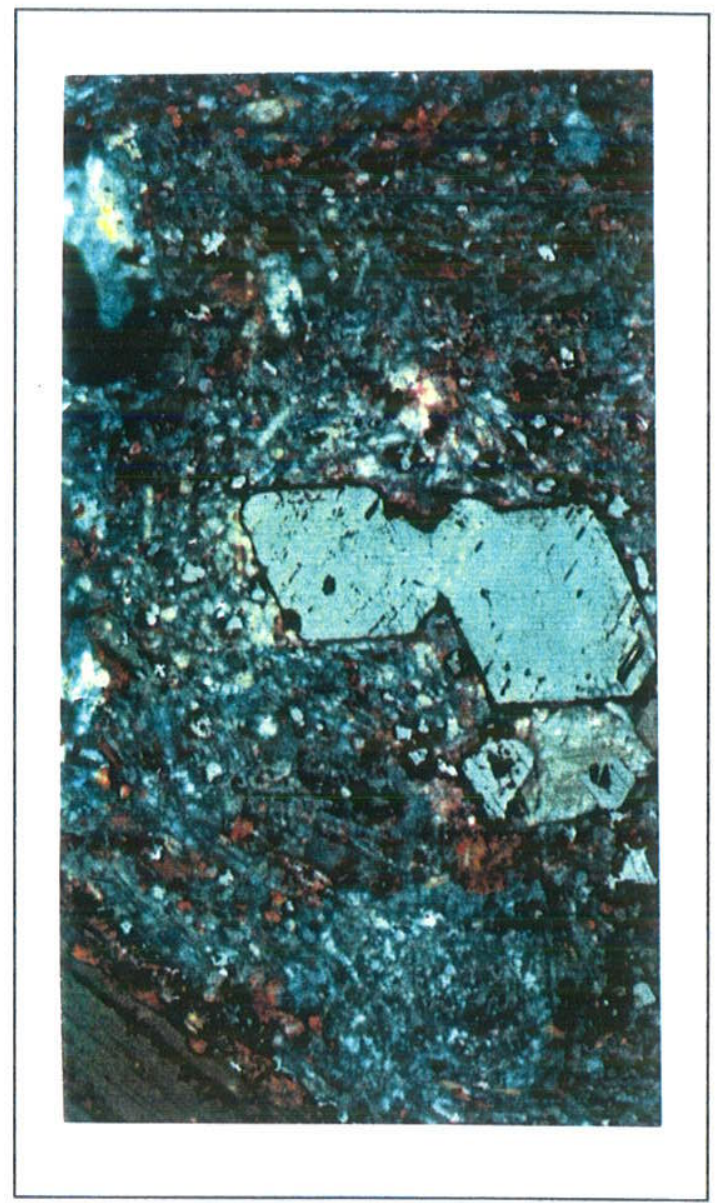

Fotomicrografia 4. Espinélios nos "lamprófiros". (a) Ymi-1, dois microfenocristais à esquerda $(\sim 0.5 \mathrm{~mm})$ de cromita (cinza) contornados por magnetita magnesiana titanífera (prata cinzento); à direita inclusões $(\sim 0.01$ $\mathrm{mm}$ ) vermelho escura de cromita em olivina. (b) Yzu-1, espinélio na matriz $(\sim 0.1 \mathrm{~mm})$ poiquilítico segundo clinopiroxênios (relevo alto). (c) Ymi-4, microfenocristais $(\sim 0.3 \mathrm{~mm})$ de magnetita titanífera. Fotos (c) e (a), luz refletida; (b) luz transmitida, polarizador inferior. 
borda de opacos (corrosão parcial), ora anhedrais exibindo uma grossa a muito grossa borda de opacos (profunda corrosão e substituição por opacos). Estas micas apresentam pleocroísmo que varia do amarelo mel a marrom avermelhado. Foram observadas nestes cristais inclusões de olivina e espinélio. Em diques e plugs interiores do pipe, as micas ocorrem na matriz, em tenores modais de até $3 \%$. Apresenta-se na forma de cristais intersticiais anhedrais a tabulares com pleocroísmo amarronzado a amarelo mel. Ocasionalmente incluem poiquiliticamente cristais de espinélio.

A composição (apêndice A2) varia de flogopita a biotitas (Figura 3 5). Os fenocristais de Ymi-1c., são todos flogopitas, com mg\# que variável de 0.79 a $0.81, \mathrm{Cr}_{2} \mathrm{O}_{3}$ de 0.3 a $1.6 \%, \mathrm{Al}_{2} \mathrm{O}_{3}$ de 14.6 a $15.8 \%$ (aluminosa) e $\mathrm{TiO}_{2} 3.2$ a $3.8 \%$ (titaniferas). Quimicamente os fenocristais são flogopitas titaniferas aluminosas com crômio similares a algumas flogopitas ocorrem em lamproitos de Leucite Hill (Mitchell \& Berman, 1991). Já nas micas da matriz das rochas de Ymi-1 (plugs e diques) observa-se que mgł apresenta variações de 0.67 a 0.73 (com um cristal possuindo valores de 0.87) e de 0.54-0.67. Essas micas possuem $\mathrm{Cr}_{2} \mathrm{O}_{3} 0.00$ a $0.28 \%, \mathrm{Al}_{2} \mathrm{O}_{3}$ 11.54 a $14.75 \%$ (subaluminosas a aluminosas em parte) e $\mathrm{TiO}_{2}$ de 2.74 a $6.75 \%$ (titanifera). Quimicamente são flogopitas titaniferas e biotitas titaníferas, como freqüentemente descritas nos lamprófiros cálcio alcalinos (Rock, 1984; 1991) e também em alguns lamproítos (Mitchell \& Bergman, 1991).

\section{Espinélios}

São encontradas, nos plugs e diques nos interiores do pipe, três assembléias texturais distintas de espinélio: como inclusões microscópicas (Fotomicrografia 4), microfenocristais (Fotomicrografia 4.), e como componentes da matriz (Fotomicrografia 2). Além disso, existe existindo ainda outra assembléia encontrada na fácies epiclástica e no leito de córregos, que serão tratados no capítulo seguinte. Nas rochas magmáticas foram reconhecidas microfenocristais $(0.3-0.35 \mathrm{~mm},<1 \%$ modal) zonados (Fotomicrografias $4 a$, lado direito e meio) segundo um centro cinza grosso capeado por uma borda fina, a algo grossa, de cor prateada. 

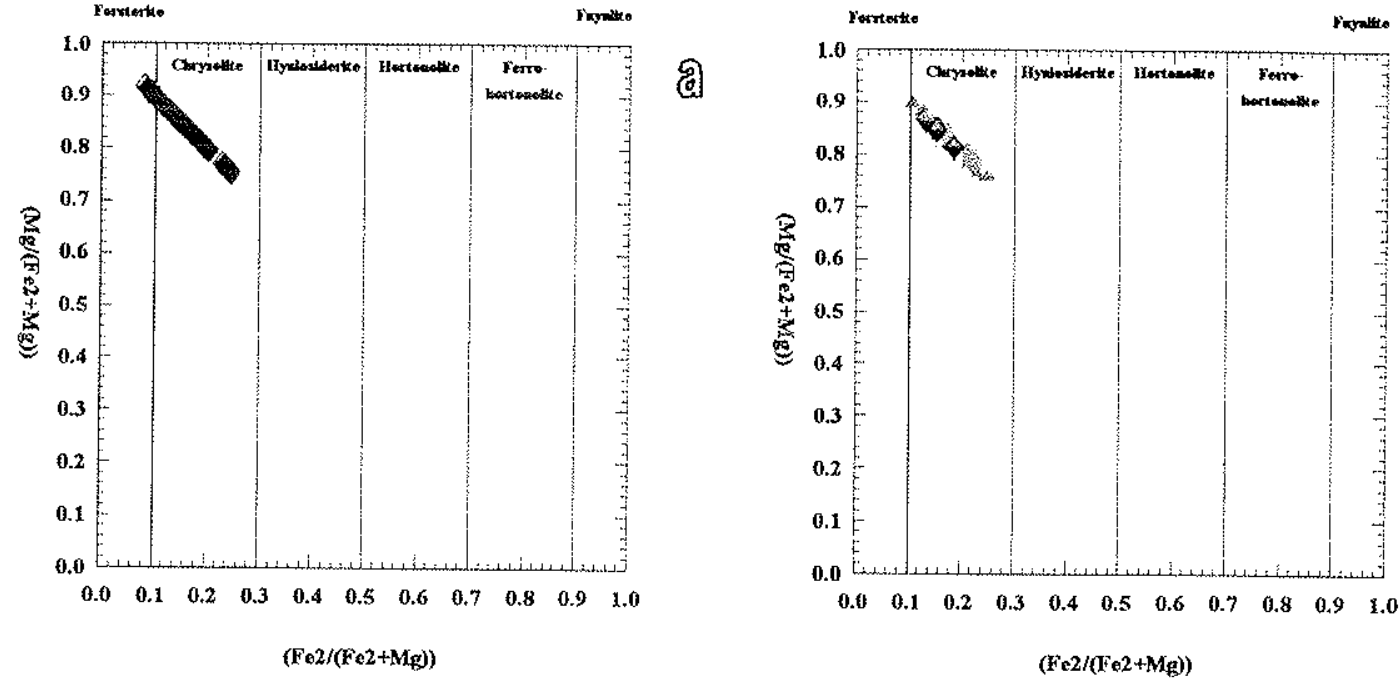

b

g

(Fe2/(Fe2+Mg)
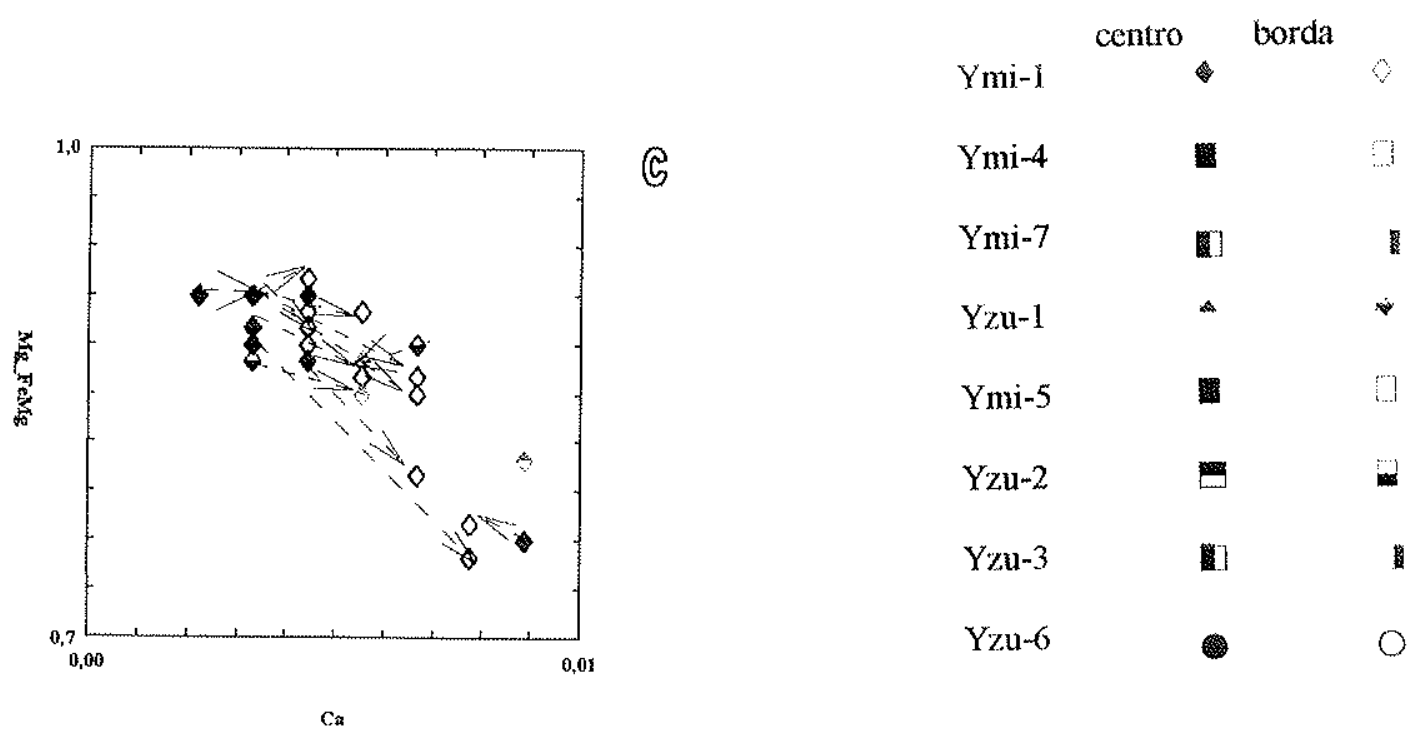
As inclusões em minerais máficos (preferencialmente em olivina) apresentam-se na forma de diminutos $( \pm 0.1 \mathrm{~mm}$ ) cristais opacos (idiomórficos) a translúcidos (de cor vermelha), geralmente arredondados.

$\mathrm{Na}$ matriz os espinélios ( $\pm 8 \%$ modal) apresentam-se como cristais interpenetrados com formas irregulares a cúbicas, às vezes parcial a totalmente inclusos nos cristais de mica.

Quimicamente (apêndice A4), sua composição forma parte da série da cromitamagnetita-espinélio; quando considerado o teor de titânio é possivel separar um grupo com $\mathrm{TiO}_{2}<2 \%$ e um outro com $\mathrm{TiO}_{2}>2 \%$. Os cristais com $\mathrm{TiO}_{2}<2 \%$ serão melhor estudados no Capítulo seguinte. Com base a razäo cr\# as cromitas com $\mathrm{TiO}_{2}>2 \%$ podem ser separadas, em dois grupos: cromitas-cromitas magnesianas $\left(\mathrm{Cr}_{*}>50\right)$ e espinélios-herciniticos $(\mathrm{C} \#<50)$. Os espinélios ricos em crômio ocorrem como inclusões, como microfenocristais e como cristais mais abundantes das fácies epiclásticas do pipe. O diagrama das Figuras 3-7 (a) mostra o trend composicional destes espinélios ressalta a riqueza nas moléculas de picro-cromita e cromita Conforme a nomenclatura de Mitchell \& Bergman (1991) (ver também Mitchell, 1995) esses espinélios são: l-cromita (predominantemente cromitas) titanifera magnesiana $\left(\mathrm{TiO}_{2} 2-10.91 \%\right.$, e $3-22 \% \quad \mathrm{Al}_{2} \mathrm{O}_{3} ; 16-46 \% \quad \mathrm{Cr}_{2} \mathrm{O}_{3}<1.7 \% \mathrm{MnO} ; 1.12 \%$ $\mathrm{MgO} ; 0.01-0.2 \% \mathrm{NiO} e$ até $0.26 \%$ de $\mathrm{ZnO}$ ). Esta variedade de espinélio é reconhecida como pertencendo ao trend magmático de kimberlitos (magnesian ulvöespinel trend, Mitchell, 1986). As variedades pobres em crômio são reconhecidas na matriz ou nas bordas dos microfenocristais. A Figura 3-8 (a) mostra a variação quimica do núcleo até a borda dos microfenocristais. Na Figura 3-7 (b) observa-se que a suíte dos espinélios mostra-se concentrada em dois campos distintos: um com baixo Ti\# que corresponde aos ricos em $\mathrm{Cr}$; outro com médio a alto Ti\#, que corresponde aos espinélios pobres em Cr. Nesta última suite observa-se um trend composicional que é em parte contínuo com as cromitas titaniferas magnesianas (Figuras 3-7 (a) e (b)), caraterizando segundo nomenclatura de Mitchell \& Bergman (1991) e Mitchell (1995a) os termos magnetita titanifera magnesiana (MgO>1\% e $\mathrm{Cr}_{2} \mathrm{O}_{3}>1 \%$ ) e magnetita titanífera ( $\mathrm{MgO}<1 \%$ e $\left.\mathrm{Cr}_{2} \mathrm{O}_{3}<1 \%\right)$, ambos apresentando variaçóes de $10-25 \%$ de $\mathrm{TiO}_{2}, 1-19 \%$ de $\mathrm{Al}_{2} \mathrm{O}_{3},<2.0$ de $\mathrm{MnO}, 0.02-0.19$ de $\mathrm{NiO}$ e até 

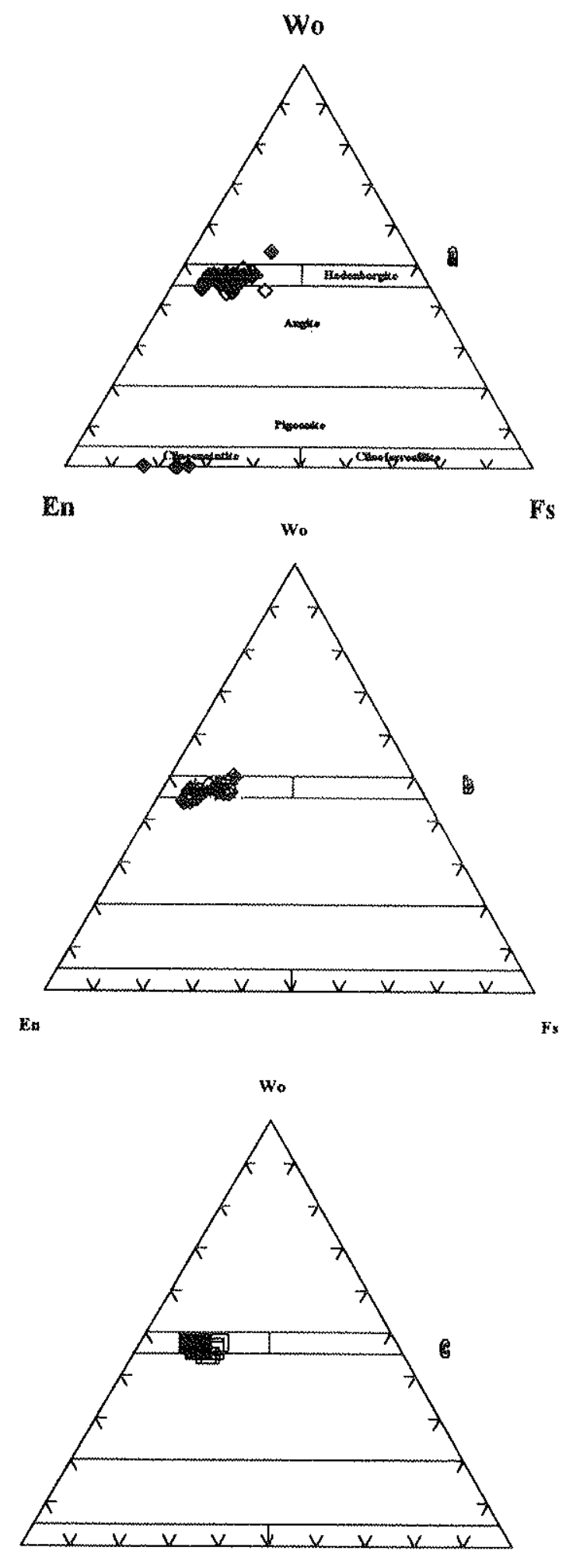

En

Fs

Figura 3-3. Composiçæo dos piroxênios de "lamprófiros" no diagrama de classificação do IMA (Morimoto, 1989) (a) Ymi-1; (b) Ymi-7 e Yzu-1 e; (c) Ymi-4. Simbologia como em 3-2. 
0.29 de Zno. No sistema ulvoespinélio-cromita-hercynita (Figura 3-7 (c)) os espinélios desta intrusão seguem um trend paralelo ao que pode ser encontrado em lamproítos. Nos grupos pobres em Cr é também freqüente encontrar teores elevados em MnO (0.3 a 2\%, ricos em manganes); a Figura 3-7 (d) ressalta os teores elevados nas moléculas de jacobsita e galaxita. São variedades de espinélios freqüentemente presentes em rochas lamprofíricas (cf. Garda, 1995) e basaltóides potássicas tipo Província Romana (cf. De Min, 1993; Cundari et al., 1996), do tipo magnetita titanifera magnesiana e magnetita titanifera ricas em manganes (em parte).

\section{Feldspatóide}

Os feldspatóides ocorrem na matriz (11-21\% modal) dos plugs e diques como cristais intersticiais freqüentemente anhedrais incolores a marrom-esbranquiçados devido a alterações insipientes. Alguns cristais mostram inclusões aciculares de "apatita".

Os dados químicos (apêndice A6) mostram composição de analcima> Possuem teor de sódio e potássio e $\mathrm{Fe}_{2} \mathrm{O}_{3}<1 \%$, assemelhantes aos a feldspatóides que ocorrem em lavas ultrapotássicas tipo Província Romana (cf. Gupta \& Yagui, 1980) e nos lamprófiros (cf. Rock, 1991).

\section{Feldspatos}

Junto aos feldspatóides, os feldspatos são abundantes (12-32\% modal como esperado de se encontrar em lamprófiros, como por exemplo os cálcio alcalinos). $\mathrm{Na}$ matriz, ocorrem como cristais tabulares a anhedrais (intersticiais), incolores limpidos a algo turbos (por alteração). Em rochas de diques interiores observam-se cristais com geminação em grade muito fina (anortoclásio); já nos diques de Ymi-1c, observa-se a presença de traços de plagioclásio tabular.

A Figura 3-10 exibe o campo de variação composicional dos feldspatos de Ymi-1. São sanidinas e algumas delas, a julgar pelos teores elevados em sódio, podem ser ainda denominadas de sanidinas sódicas. Andesina (Figura 3-10 (a)) ocorre em alguns diques (ex. Ymilc). De modo geral os feldspatos possuem teores baixos a moderados de $\mathrm{Fe}_{2} \mathrm{O}_{3}$ (até $1.33 \%$ ) e de $\mathrm{BaO}$ (até $0.87 \%$ ). Essas feições são 

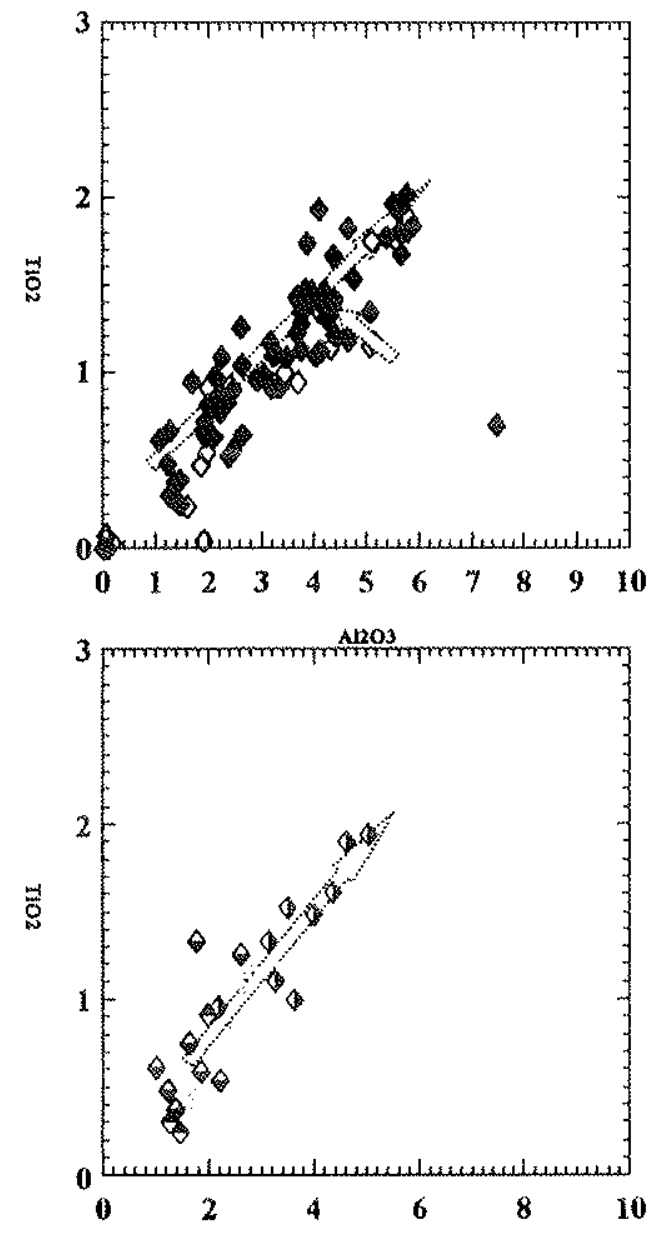

B

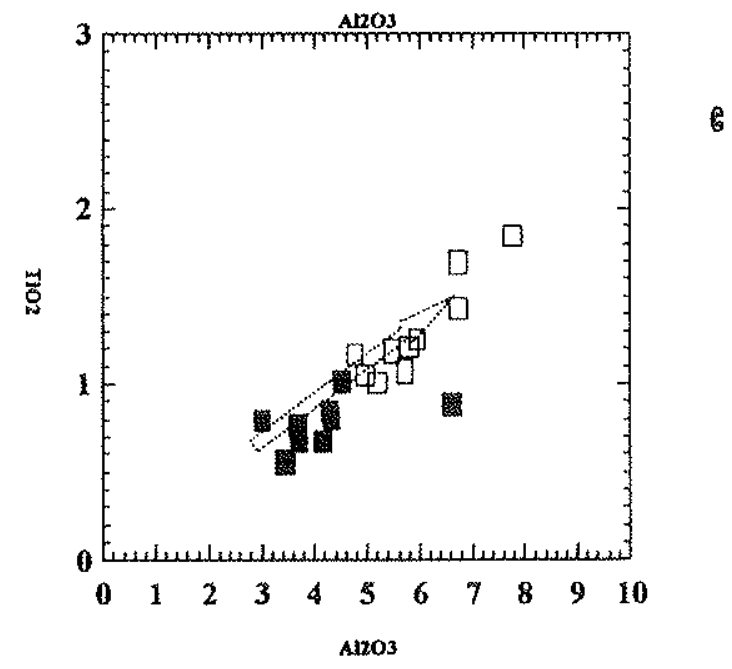

Figura 3-4 Enriquecimento em termos do Ti e Al nos piroxênios dos "lamprófiros". Enriquecimento diretamente proporcional, em Ymi-1 (a); em Ymi-7 e Yzu-1 (b); e em Ymi-4 (c). Tipo de enriquecimento que também observado por Cundari et al. (1996) nas rochas potássicas da Província alcalina centro Oriental do Paraguai. Os "Lamprofiros" estudados apresentam"Se com algumas diferênças na razão Ti/Al quando comparadas àquelas de Cundari et al. (1996). As setas indicam direção na zoneamento, do centro em direção a borda. Simbologia como em 3-2 
comumente observadas nos feldspatos que ocorrem em algumas variedades de lamprófiros (cf. Rock, 1991 e referências).

\section{Minerais acessórios}

Os principais minerais acessórios encontram-se na matriz e são representados por: rutilo de $\mathrm{Nb}$ (apêndice A8); carbonatos ricos em Mg e Fe (21-33\% de MgO e 21$27 \%$ de FeO) (apêndice A9 e Figura 3 12) e apatita. Além desses acessórios podem ainda ocorrer anfibólios de caracter potássicos $(K>0.25)$, titaníferos $(\mathrm{Ti}>0.25)$ ou sódicos $(>0.25)$, representados por eckernmanita $\left(\mathrm{Fe}^{3+}<\mathrm{Al}\right)$ hormblenda magnesiana e grunerita (apêndice A5 e Figura 3-11). Foi analizado apenas um fenocristal de anfibólio com dimensão milimétrica (apêndice) encontrando uma composição de hornblenda magnesiana. Como minerais secundários ocorrem a cummingtonita a cummingtonita magnesiana (apêndice)

As feições mineralógicas caraterizadas nas rochas da intrusão Ymi-1 permitem definir as siguientes variedades petrográficas:

analcima sanidina olivina diopsídio "lamprófiro" picrítico nos plugs e alguns diques; e

olivina flogopita analcima sanidina diopsídio "lamprófiro no dique Ymi-1c. São similares aos monchiquitos de Wan (Jaques et al., 1989) e SS (Garda, 1995).

\section{Diques Ymi-7 e Yzú-1}

\section{Feições gerais}

O dique Ymi-7 é muito parecido aos diques interiores encontrados em Ymi-1; são rochas porfiríticas que possuem estrutura maciça a algo orientada, com feno/megacristais de piroxênio (milimétricos a centimétricos) prismáticos verde esmeralda a verde escuro, e de olivina (sub milimétricos a milimétricos) subidiomórfica incolor (às vezes confunde-se com pequenos enclaves angulosos sub centimétricos a centimétricos de rocha peridotítica) inmersos em uma matriz fina 

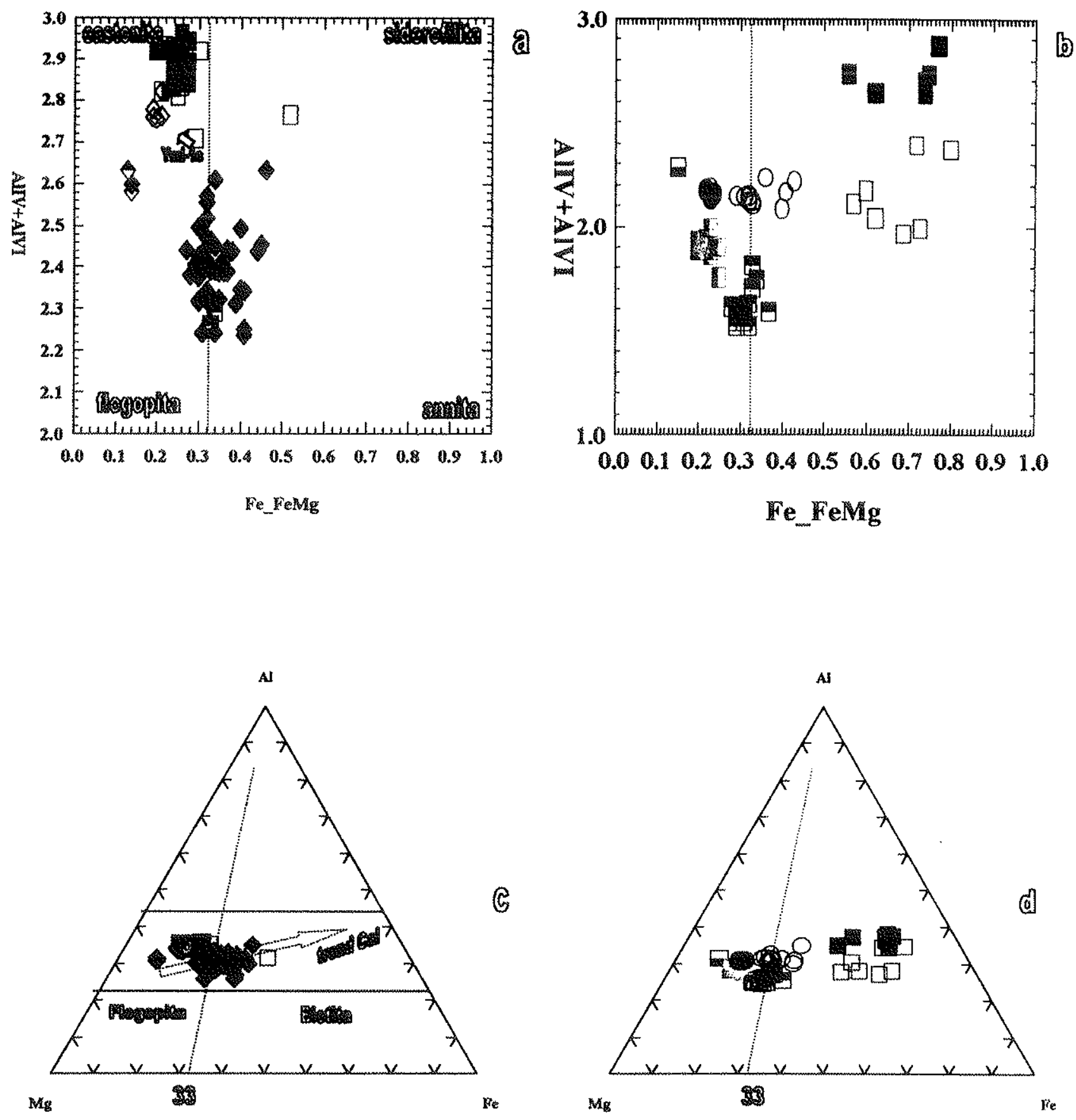

Figura 3-5. Classifícação das micas no diagrama Flogopita-Annita -Eastonita-Siderofilita. (a) e (b) micas dos "lamprófiros" e dos "lamproitos" no diagrama $\mathrm{Al}$ (IV+V) vs Fe\# (conforme Minpet 2.0, parcialmente modificado para incluir as micas com deficiência de $\mathrm{Al}^{\mathrm{V}}$ ); Fe\# separam flogopitas (Fe\#<33) das biotitas (Fe\#>33). (c) e (d) como em (a) e (b) porém classificadas no sistema Al-Mg-Fe (Rock, 1984; 1991; Mitchell, 1995a). O trend Cal (lamprófiros cálcio alcalinos) e o limite flogopita biotita (33, na base da figura) como tracado por Rock (1984). Legenda como em 3-2. 
escura de aspecto basaltóide. Ao microscópio possuem textura porfiritica seriada, em parte com abundantes fenocristais de piroxênio subhedral a euhedral e microfenocristais de olivina euhedrais a cristais maiores anhedrais, alguns apresentando sinais de deformação (xenocristais). Mais raramente aparece a mica como cristais corroídos. A matriz é fina $(\sim 0.3 \mathrm{~mm})$, intergranular, formada por piroxênio, espinélio, mica, felúspato alcalino, analcima e acessoriamente apatita junto com traços de plagioclásio. Os dados modais achan-se dispostos na Tabela 3-3. Os dados permitem caraterizá-las como um olivina feldspatóide-feldspato alcalinopiroxênio lamprófiro.

Yzu-1 trata-se de uma rocha vulcânica cor cinza escuro, maciça, porfiritica comfenocristais prismáticos de piroxênio esverdeado milimétrico, feno/megacristais de olivina fresca/pseudomorfizada idiomórfica $e$, raros cristais subhidiomórficos de mica castanha escura, contidos em uma matriz fresca de aspecto basaltóide.

Yzu-1 foi também estudado por Gibson et at. (1996) (Colonia Independencia $83 S O B 61$ ). Os elementos químicos estäo na Tabela 3-2 e permitem apontar feições como: rocha rica em $\mathrm{K}_{2} \mathrm{O}(3.27 \%), \mathrm{Na}_{2} \mathrm{O}$ (2.90\%), $\mathrm{MgO}$ (11.35\%), Ni (262) e $\mathrm{Cr}(906)$; razões moderadas de $\mathrm{Ba} / \mathrm{Yb}$ (1854) e La/Yb (77); razões isotópicas de $\mathrm{Sr} / \mathrm{Sr}$ (0.707366) e Nd/Nd (0.511720) similares às apontadas por Bitschene (1987) e Comin-Chiaramonti et al. (1997) nas rochas potássicas a ultrapotássicas vinculadas ao rift de Asunción. Essas feições são muito similares as do dique de Ymi-1 e desse modo Yzu-1 apresenta feições químicas de uma rocha primitiva.

Ao microscópio a textura é porfirítica, algo seriada, com fenocristais de piroxênio prismático e olivina tabular a poligonal, que ocorre com dimensóes submilimétricas (microfenocristal) milimétricas. Menos freqüentemente ocorrem fenocristais de mica subhedral a anhedral, submilimétrica a milimétrica, parcial a totalmente pseudomorfizada pelos opacos, acusando assim corrosão e instabilidade no magma hospedeiro. A matriz é fina $(<0.5 \mathrm{~mm}) \mathrm{com}$ marcada textura panhidiomórfica, estando formada por abundantes cristais arredondados de analcima glomerulofídica entre os quais ocorrem na forma de ilhas piroxênio e espinélio intercalados por ripas de feldspato alcalino e traços de carbonato. Apatita é um accessório freqüente. Os 

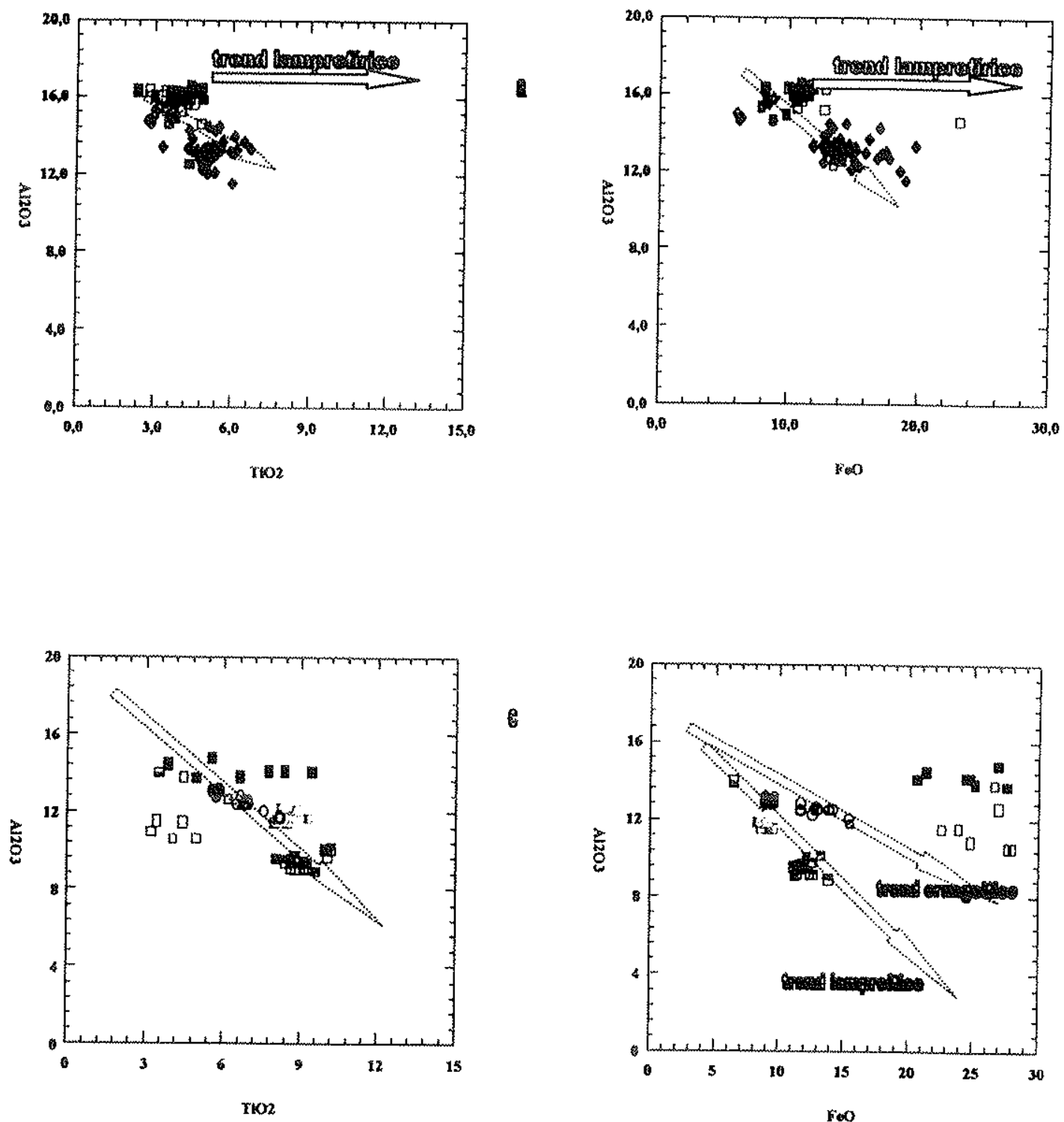

Nigura 3-6 Diagrama de variacão Al us Ti e Al us Fe das micas das rochas lamprofíricas. "Lamprófiros" (a) e (b), mostram tendencia de enriquecimento comum de observar em lamprófiros (Rock et al., 1992) e em rochas ultrapotássicas tipo Província Romana (Mitchell \& Berman, 1991) (como o trend lamprofirico), Ymi-1 parecese com lamproítos. "Lamproítos" (c) e (d), mostram um trend de enriquecimento (indicado pela seta) próprio dos lamproítos (Mitchell, 1985; 1995a-b; Mitchell \& Bergman, 1991; Rock el al., 1992). Yzu-6 (em d) parece acusar um trend que se observa em orangeítos (Mitchell, 1995a). Por outro lado, algumas das micas de Ymi-5 mostram um trend de enriquecimento como mostrado pelas micas de Ymi 4 (comparar com b). Simbologia como em 3-2. 
dados modais (Tabela 3-3) permitem definir a rocha de Yzu-1 como um feldspato alcalino-olivina-piroxênio-feldspatóide lamprófiro.

\section{Química minera!}

\section{Olivina}

Em Ymi-7 a olivina ( $10 \%$ modal) exibe cristais submilimétricos a milimétricos, geralmente euhedrais, ou milimétricos subhedrais a anhedrais, ambos frescos a algo serpentinizados nas bordas e/ou nas fraturas. Em alguns cristais maiores anhedrais observaram-se sinais de esforço. Nestes diques ocorrem microxenólitos peridotíticos, permitindo interpretar os cristais com sinais de deformação como um produto da fragmentação destes xenólitos (i.e. xenocristais de olivina). Em Yzu-1 a olivina (Fotomicrografia 1) apresenta-se ( 15\% modal) como fenocristais milimétricos a megacristais tabulares a algo poligonais, freqüentemente alterados nas bordas e fraturas a totalmente pseudomorfizados pela serpentina. Como observado nas olivinas de Ymi-1, as olivinas de Yzum-1 possuem abundantes inclusões microscópicas de cromita.

Em Yzu-1 as olivinas apresentan-se zonadas (apêndice A1), com variações de Fo80. 88 no centro a Fo ${ }_{81-87}$ na borda; no diagrama da Figura 3-2 são crysolita. Em Ymi-7, as olivinas analizadas apenas nas porções centrais apresentam composição Fo79-84. e igualmente representam crysolitas (Figura 3-2). Nas duas intrusões as olivinas apresentam teores moderados de $\mathrm{CaO}$ (0.23 a 0.32\% em Ymi-7; e 0.0-0.46\%, centro e 0.23-0.32\% borda, em Yzu-1) (Figura 3-2). Estas olivinas são menos primitivas (NiO entre 0.00-0.15\% em Ymi-7 e 0.01-0.34\% no centro para 0.15-0.20\% na borda em Yzu-1) com relação ao global das olivinas analisadas em Ymi-1 (plugs e diques interiores).

\section{Piroxênios}

Clinopiroxênios proeminentes, comumente milimetricos a centimétricos na forma de cristais prismáticos isolados ou interpenetrados incolores a fracamente esverdeados- 
Gris
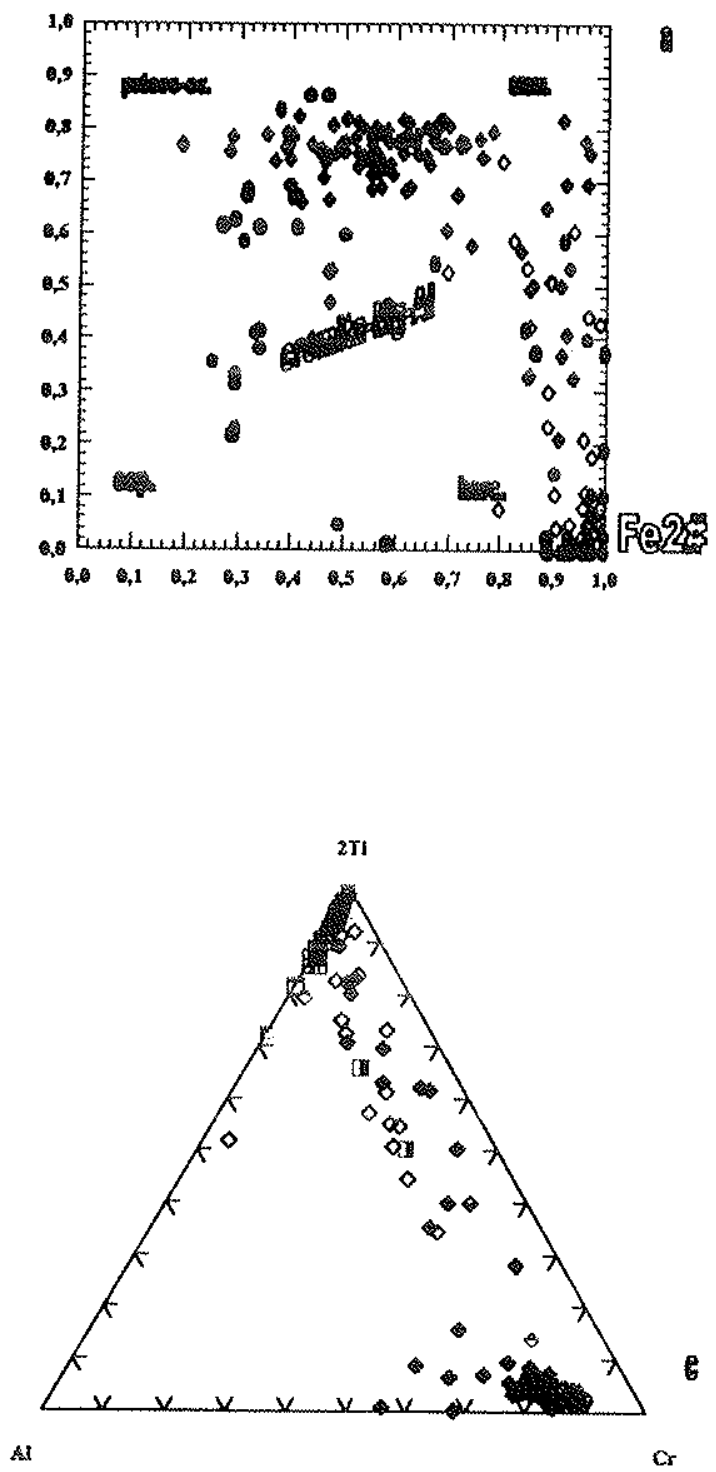

Thes
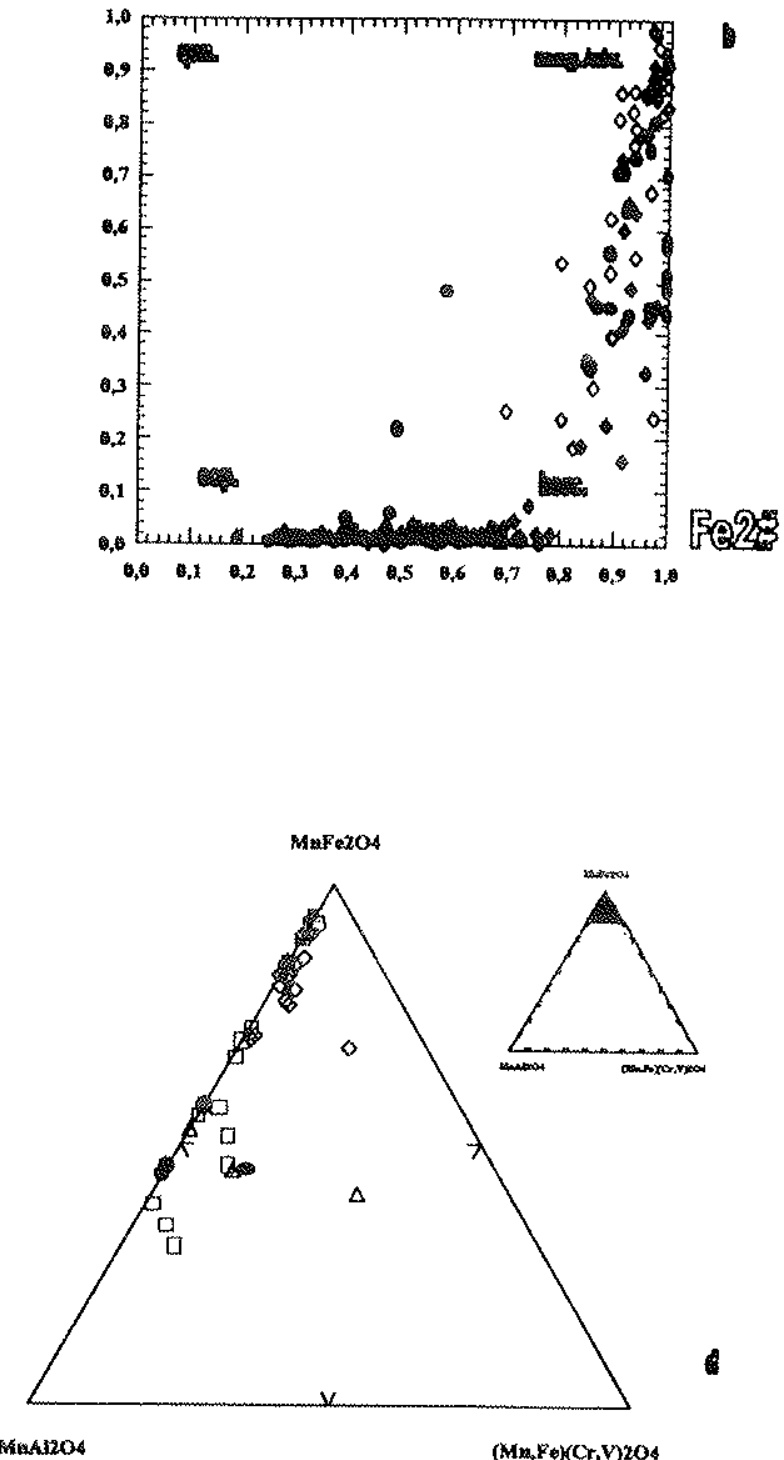

Tigura 3-7. Espinélios em Ymi-1. (a) sistema Cromita magnesiana (picro-cr.)-Cromita (crom.)-Hercynita (herc.) Espinélio (esp.), os espinélios de Ymi-l mostram um trend entre a cromita magnesiana-cromitahercynita. Espinélios de Wandagee (Jaques et al., 1989) e de São Sebastião e arredores (SP) (Garda, 1995)(ambos em círculo) foram lançados para comparaçóes. (b) sistema qandilito(qan.)-magnetitaulvóespinélio(mag/ulv.)-espinélio(esp.)-hercynita(herc.) (Mitchell \& Bergman, 1991). Nesta figura aprecia-se como os espinélios dos "lamprófiros" traçam um caminho muito similar ao traçado pelos lamproitos (cf. Mitchell, 1985). (c) sistema ulvóespinélio (2Ti)-cromita (Cr)-hercynita (Al)(cf. Figura 3-1) no qual os espinélios de Ymiml traçam um trend paralelo ao traçado pelos lamproitos (cf. Figura 3-17), porém em Ymi-1 observa-se maior enriquecido nas moléculas de hercynita. (d) espinélios de todos os "lamprófiros" estudados com $\mathrm{MnO}>1 \%$ no sistema jacobsito $\left(\mathrm{MnFe}_{2} \mathrm{O}_{3}\right)$-manganocromita $(\mathrm{Mn}, \mathrm{Fe}),\left(\mathrm{Cr}, \mathrm{V}_{2} \mathrm{O}_{4}\right.$-galaxito $\left(\mathrm{MnAl}_{2} \mathrm{O}_{4}\right)$, mostrando-se enriquecidos em jacobsito e galaxito. Simbologia como em 3-2. 
amarronzados, são observados em Ymi-7. Apresentando zoneamento setorial a irregular nas bordas. Alguns dos cristais euhedrais (megacristais) se mostram quebrados, lembrando a trituração metamórfica. Em Yzu-1, os piroxênios são fenocristais de menor proporção modal ao encontrado em Ymi-7. Eles apresentamse como cristais prismáticos de alguns milimetros, incolores a levemente esverdeados e algo zonados nas bordas. Em ambos os diques, a matriz compöe-se de piroxênios idiomórficos com tonalidades algo esverdeadas.

Os piroxênios de Ymi-7 têm composiçäo variada (apêndice A3, Figura $3-3(b)$ ) com teores médios em $\mathrm{Al}_{2} \mathrm{O}_{3}$ (1.56 a $3.18 \%$ no centro a 2.21 a $5.06 \%$ na borda e matriz aluminosos), moderados em $\mathrm{TiO}_{2}(0.39-1.18 \%$ centro a $0.96-1.95 \%$ borda e matriz, que conforme recomendações do IMA, são titaniferos) e baixos em $\mathrm{Na}_{2} \mathrm{O}(<0.55 \%)$. A sua composição quimica corresponde a um diopsidio titanítero aluminosos .Por sua vez, os piroxênios de Yzu-1 (apêndice A3 e Figura $3-3$ (b)) apresentam teores baixos de $\mathrm{Al}_{2} \mathrm{O}_{3}$ (1.27-2.02\% no centro a $1.03-2.63 \%$ na borda e matriz aluminosos, em parte), $\mathrm{TiO}_{2}(0.25-0.91 \%$ centro a $0.38-1.33 \%$ na borda e matriz; conforme recomendaçốes do IMA, säo titaniferos, em parte) e de $\mathrm{Na}_{2} \mathrm{O}(<0.51 \%)$. Este tipo de piroxênio é algo similar aos piroxênios observados em Ymi-7 e correspondem a um diopsidio titaniero a algo aluminoso. Em ambas ocorrencias pode ser observado enriquecimento do Ti sendo diretamente proporcional ao Al (Figura 3-4 (b)) e, desta forma, os piroxênios de Ymi-7 são similares com relação aos piroxênios de Ymim1 Essas feições são comuns de piroxênios de lamprófiros. Os piroxênios de Yzu-1 apresentam feicões químicas bastante semethantes àquelas dos lamproitos, o que será melhor discutida em parágrafos seguintes.

\section{Micas}

Nos dois diques foram registrados raros microfenocristais de mica amarronzada com raco pleocroísmo (marrom a amarelo mel) e estando parcial ou totalmente pseudomonizadas nas bordas pelos opacos. Na matriz ocorrem raros cristais irregulares nas rochas de Ymi-7; apresentam as mesmas carateristicas opticas dos fenocristais. 

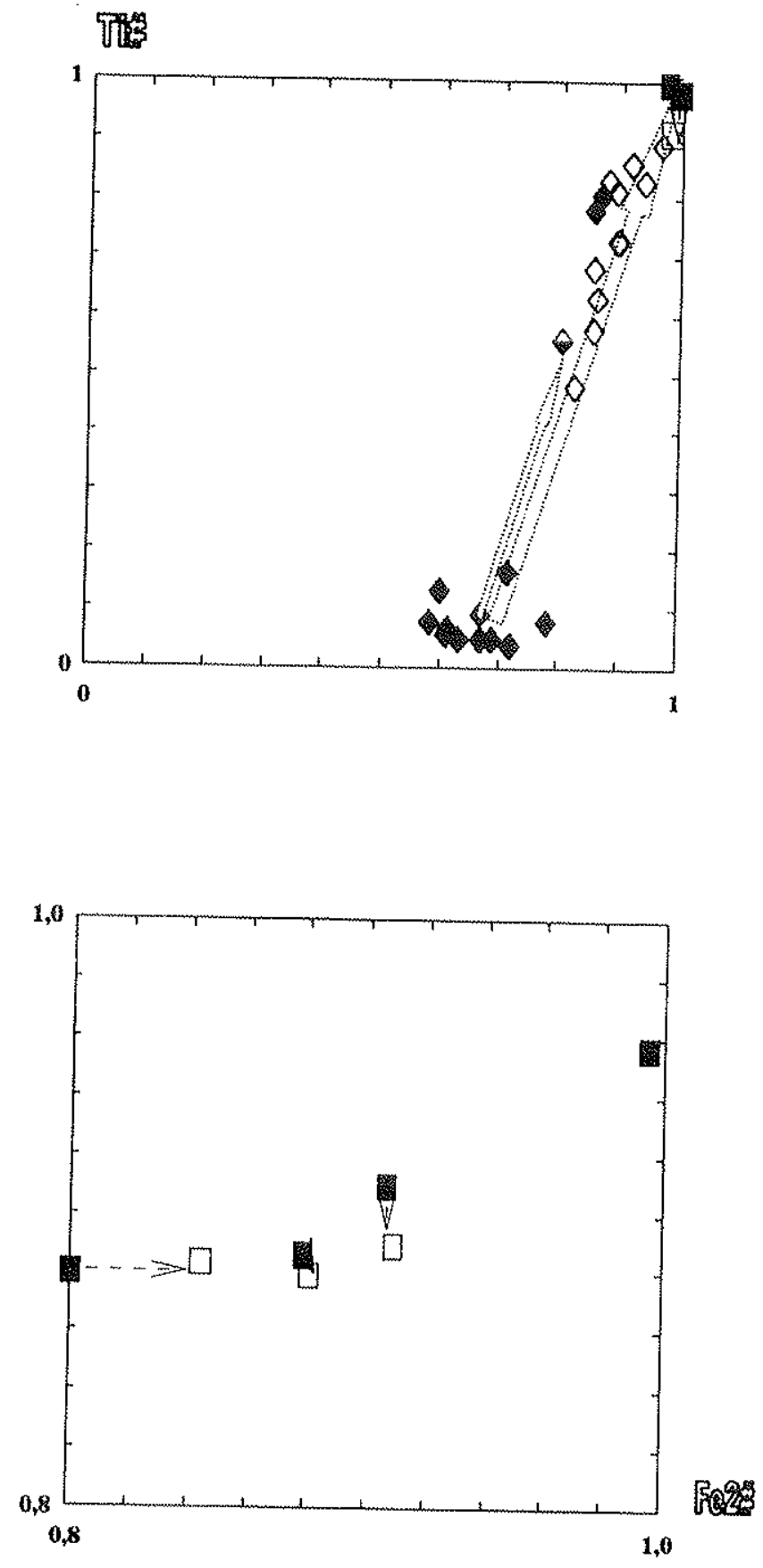

B

Figura 3-8. Zoneamento em espinélios. (a) microfenocristais em Ymi-1, que mostram no centro valores de Tił baixo (cromitas) e uma borda alto a muito alto (magnetitas magnesianas titaniferas) e em Ymi-4, sutis mudanças do centro a borda. Uma inclusão em olivina de Yzu-1 é também representada. (b) espinélios em Ymi5 , com seus centros de magnetita titanifera magnesiana e as bordas de magnetita titanifera. A seta indica centro $\rightarrow$ borda. Simbologia como em 3-2. 
Os fenocristais (única fase analisada desses diques) têm composição (apêndice A2). Foram analizados os centros e bordas dos fenocristais de Ymi-7. As flogopitas possuem alto: mg\# (0.79-0.81 no centro e 0.60-0.67 nas bordas em $Y$ mi-7 e 0.800.87 em $\left.\mathrm{Yzu}_{-1}\right), \mathrm{Cr}_{2} \mathrm{O}_{3}(0.18-1.59 \%$ em $\mathrm{Ymi}-7$ e $0.40-1.22 \%$ em $\mathrm{Yzu}-1)$ e $\mathrm{Al}_{2} \mathrm{O}_{3}$ (14.61-15.80\% em Ymi-7 e 14.61-14.95\% em Yzu-1 aluminosas), e moderado teor em $\mathrm{TiO}_{2} \quad(3.21-3.83 \%$ em $\mathrm{Ymi} 7$ e $2.87-2.97 \%$ em $\mathrm{Yzu}-1$ ittaníferas). Estas carateristicas permitem classificar como flogopita titanífera aluminosa. Essas micas são frequentemente comparáveis aos fenocristais de flogopita encontrados em Ymi-1c; freqüentemente ocorrendo em lamprófiros cálcio alcalinos (cf. Rock, 1991).

\section{Espinélios}

Microfenocristais são raros tanto em Ymi-7 como em Yzu-1. Entretanto, microinclusões similares às descritas em Ymi-1 (nas olivinas e piroxênios apresentam formas euhedrais opacas e microscópicas) ocorrem nas olivinas de Yzu. 1. Espinélios da matriz ocorrem nesses diques como cristais cúbicos a algo irregulares com dimensões $<0.2 \mathrm{~mm}$.

Nas duas intrusões os espinélios estão melhor representados na matriz, com teor (apêndice A4) de $\mathrm{Cr}_{2} \mathrm{O}_{3}<1-5.39 \%$ em $\mathrm{Ymi}-7$ e $<1 \%$ em $\mathrm{Yzu}-1$, de $\mathrm{Al}_{2} \mathrm{O}_{3}$ entre 1.75 e $5.42 \%$ em Ymi-7 e 2.29 e 2.56\% em Yzu-1; de MgO entre 0.62 e $3.25 \%$ em Ymi-7 e 1.42 e 2.50\% em Yzu-1, de $\mathrm{TiO}_{2}$ entre 10.58 e 23.82\% em Ymi-7 e 18.60 e 20.22\% em Yzu-1 e de $\mathrm{MnO}<1 \%$. Estas concentraçöes são comparáveis às composições encontradas nos espinélios da matriz e em alguns microfenocristais de Ymi-1, conforme pode ser constatado nas Figuras 3-7 são magnetita magnesiana titanifera e magnetita titanifera. Os microfenocristais presentes em Ymi-7, diferem dos cristais da matriz por serem algo mais enriquecidos em $\mathrm{Cr}$ e Mg. As inclusões de Yzú-1, como as inclusões nas olivinas de Ymi-1, são de cromita. Nessas rochas são reconhecidas também xenocristais $\left(\mathrm{TiO}_{2}<2 \%\right)$ e cristais magmáticos $\left(\mathrm{TiO}_{2}>2 \%\right.$ )(apêndice $\mathrm{A} 4$ e a Figura 3-7). 

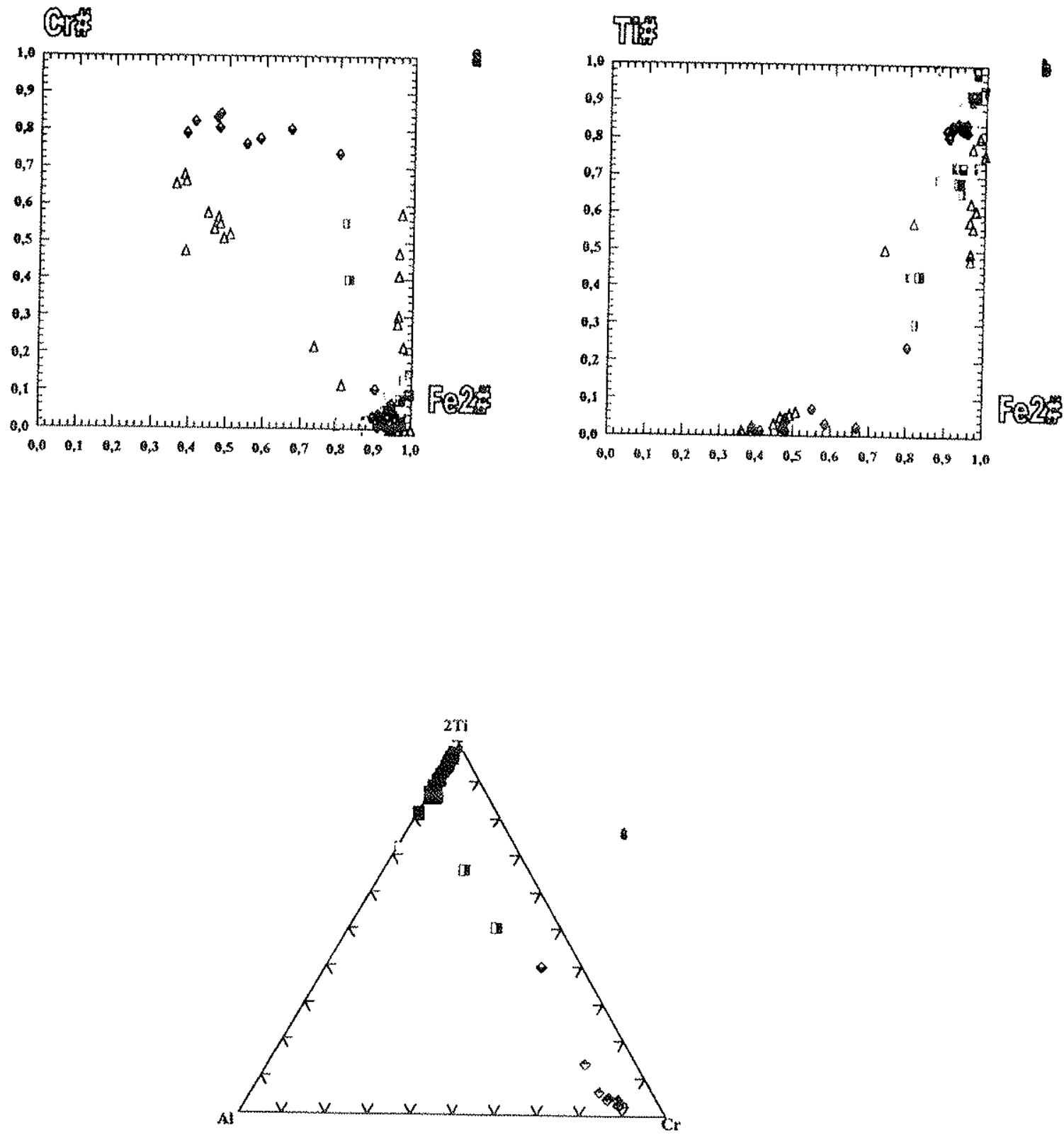

Figura 3-9. Espinélios dos "lamprófiros" Ymi-4, Ymi-7 e Yzu-1. (a) sistema picrocromitamcromita-espinéliohercynita, onde observa-se como os espinélios inclusos nas olivinas de Yzu-1 apresentam elevada concentração da molécula de cromita e espinélios da matriz, elevadas concentraçóes das molécula de hercynita, como é também encontrado nos espinélios de Ymi-4 e Ymi-7; sâo comparados com espinélios dos lamprófiros de São Sebastião e arredores (Garda, 1995). (b) sistema qandilito-magnetita/ulvöespinélio-espinélio-hercynita, aqui também como encontrado nos espinélios de Ymi-1, sobretudo em Yzu-1 evidencia-se um trend paralelo ao mostrado pelos lamproítos. (c) sistema ulvöespinélio-cromita-hercynita, os espinélios de Ymi-4 mostram-se ricos nas moléculas de ulvöespinélion hercynita, Ymi-7 e Yzu-1 mostram o mesmo trend paralelo ao do mostrado pelos lamproítos e também encontrado em Ymi-1. Simbologia como em 3-2. 


\section{Feldspatóides/zeólitas}

Em Yzu-1 feldspatóides/zeólitas (em alto porcentagem modal) isotrópicos estão representados como uma das principais fases minerais presentes na rocha. Trata-se de cristais arredondados em crescimento seriado que vão de $<0.3$ a $>0.5$ milímetros (Fotomicrografia 2), estando interpenetrados (microtextura cumulática) e apresentando-se límpidos a turvos devido a alteração. Já o feldspatóides/zeólitas em Ymi-7 ocorrem como componentes intersticiais da matriz, na forma de cristais isotrópicos.

Quimicamente (apêndice A6) são analcimas $\left(\mathrm{Na}_{2} \mathrm{O}>\mathrm{K}_{2} \mathrm{O}\right)$ de baixo teor em $\mathrm{Fe}_{2} \mathrm{O}_{3}$ $(<1 \%$, excepto um cristal com teor maior que a unidade). Estas feições químicas são muito parecidas às das analcimas de Ymi-1 e aos feldspatóides/zeólitas encontrados em lamprófiros (cf. Rock, 1991).

\section{Feldspatos}

Ocorrem na matriz intergranular de Ymi-7 e intersticialmente em Yzu-1, na forma de ripas a cristais irregulares límpidos, porém em parte alterados (Fotomicrografia 4).

A Figura 3-10 (apêndice A7) mostra que os feldspatos variam de sanidina a sanidina sódicas $\left(\mathrm{Na}_{2} \mathrm{O}\right.$ até $4.2 \%$ em Ymi-7 e 6.18\% em Yzu-1) com teores baixos a altos em $\mathrm{Fe}_{2} \mathrm{O}_{3}$ (0.24-0.98\% em Ymi-7 e 0.17-3.47\% em Yzu-1). Estes feldspatos não são muito diferentes das sanidinas de Ymi-1 e das sanidinas encontradas em lamprófiros (cf. Rock, 1991). No entanto, as sanidinas em Yzu-1 são comparáveis pelo alto teor em $\mathrm{Fe}_{2} \mathrm{O}_{3}$, aos feldspatos alcalinos que ocorrem em lamproitos (cf. p/ex. Mitchell 1985; 1995a; Mitchell \& Bergman, 1991).

\section{Anfibólio}

Anfibólio está presente na matriz de Ymi-7 na forma de cristal euhedral a subedral e cor escuro a amarronzado raramente, ocorre como microfenocristais subheuhedrais. Em Yzu-1 os anfibólios ocorrem na forma de palhas de cor amarronzado claro e 


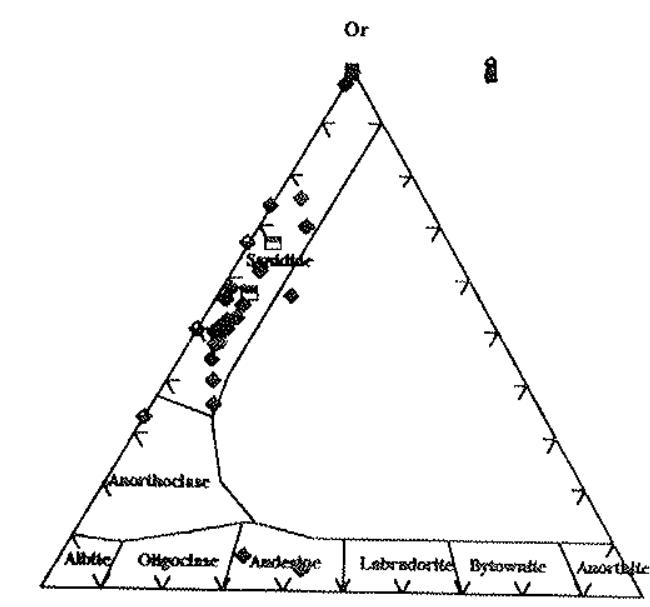

$\mathrm{Ab}$

As
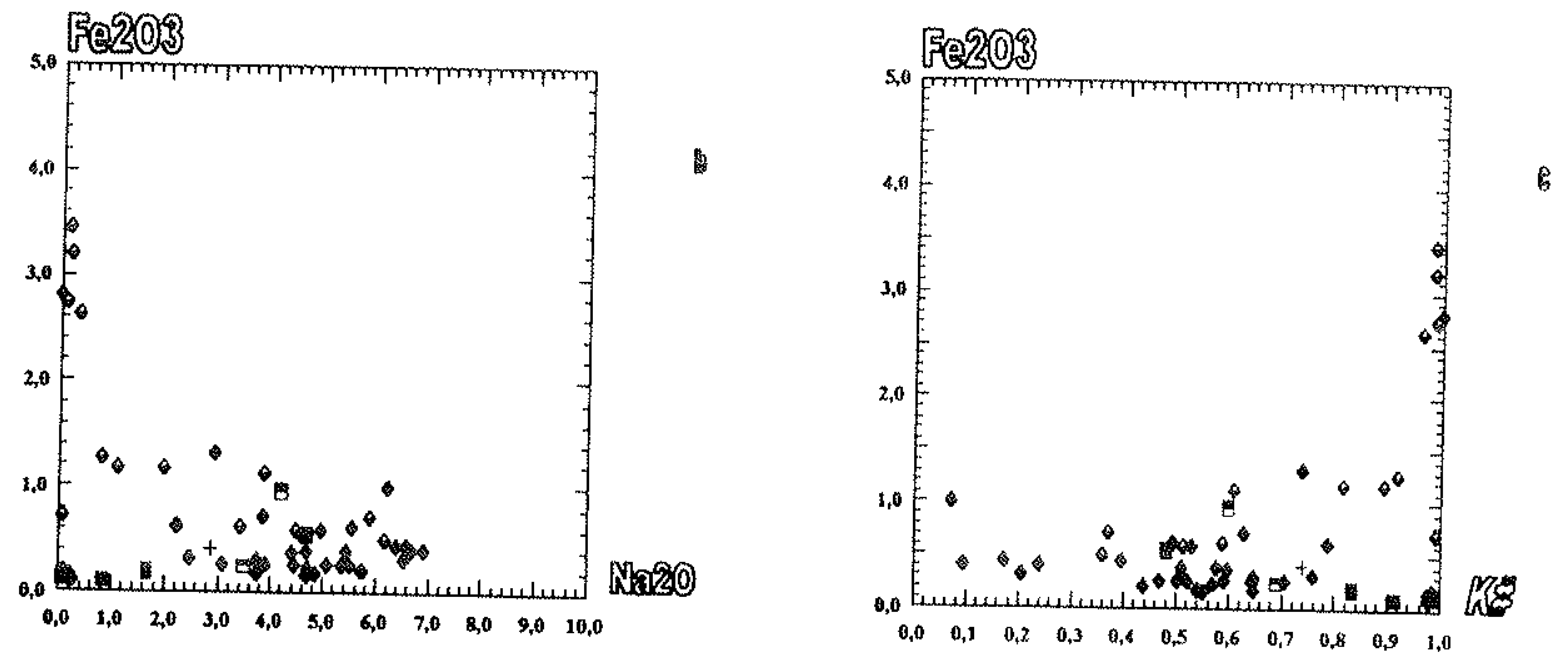

Figura 3-10. Feldspatos dos "lamprófiros". (a), classificação geral no sistema Or-Ab-An. Os feldspatos são sanidina, sendo que em alguns diques (ex. Ymi-1c.) analisaram-se dois plagioclásios, e em Yzu-1 dão-se feldspatos ricos em $\mathrm{Na}$, i.e. sanidina sódica e anortoclásio. Em Ymi- 4 analisaram-se só sanidinas. (b) $\mathrm{Fe}_{2} \mathrm{O}_{3} v s$ $\mathrm{Na}_{2} \mathrm{O}$ nas sanidinas dos "lamprófiros", que permite comparar com sanidinas encontradas em lamproitos (ricas em $\mathrm{Fe}$ e pobres em $\mathrm{Na}$ ). Notar como em Yzu-l ocorrem sanidinas ricas em $\mathrm{Fe}$ e pobres em $\mathrm{Na}$, e assim parecendo-se mais com os lamproítos que com os lamprófiros. (c) sanidinas dos "lamprófiros" no diagrama $\mathrm{Fe}_{2} \mathrm{O}_{3}$ vs $\mathrm{K \#}(\mathrm{K} /(\mathrm{K}+\mathrm{Na})$ ) (Rock et al., 1992). Como em (b) sanidinas de Yzu-1 sugerem forte afinidade com sanidinas de lamproitos (alto $\mathrm{K} \#$ e alto tenor em $\mathrm{Fe}_{2} \mathrm{O}_{3}$ ). Simbologia como em 3-2. 
ocupando intersticialmente as ripas de feldspatos, resultando em difícil a impossivel resolução óptica.

São quimicamente (apêndice A5) hormblenda magnesiana (Figura 3-11) com moderada razão de mg\# (0.6-0.8) e com teores baixos de TiO2 e moderados de $\mathrm{Al}_{2} \mathrm{O}_{3}$. Também se observa na matriz destas rochas, anfibolios secundarios (cumingtonita), em parte similares aos de Ymi-1. Em Yzu-1 analizou-se um cristal de grunerita rica em $\mathrm{K}_{2} \mathrm{O}(>0.50$ de $\mathrm{K})$.

As associações mineralógicas e as feições quimicas de Ymi-7 permitem defunir uma rocha tipo olivinamanalcima-sanidina-diopsidio "lamprófiro", enquanto as de Ymi1 uma variedade do tipo sanidina-olivina-diopsidio-analcima "lamprófiro" picritico. Essas rochas são similares à Ymi-1.

\section{MICA "LAMPRÓFIROS"}

\section{Feições gerais}

Conforme mencionado no capítulo anterior a intrusão Ymi-4 apresenta três formas de ocorrência: lava, brecha intrusiva e diques. A fácies de lava corresponde a uma rocha vulcânica, fortemente vesiculada, algo orientada segundo as formas estiradas das vesículas, que exibe cor amarrom-avermelhado e textura porfirítica com abundantes fenocristais de piroxênio prismáticos de até $5 \mathrm{~mm}$ (algo alterados) e cor verde garrafa; olivina pseudomórfica vermelho escura, submilimétrica a milimétrica; e microfenocristais de mica castanha escura, fresca a algo alterada em formas pseudohexagonais. Os fenocristais achan-se imersos em matriz fina, com estrutura vesiculada. As vesículas são milimétricas a centimétricas e estão em parte preenchidas por zeólitas e carbonato. A brecha intrusiva, de cor algo mais escuro,é formada por fragmentos angulosos milimétricos a centimétricos do mesmo material que as lavas e assim apresentando-se com as mesmas feições macroscópicas; entretanto, em alguns fragmentos observaram-se que as vesículas são muito delgadas e estiradas com larguras milimétricas, sendo também estão preenchidas por zeólitas. Os diques se diferenciam das fácies anteriores pelo aspecio menos 

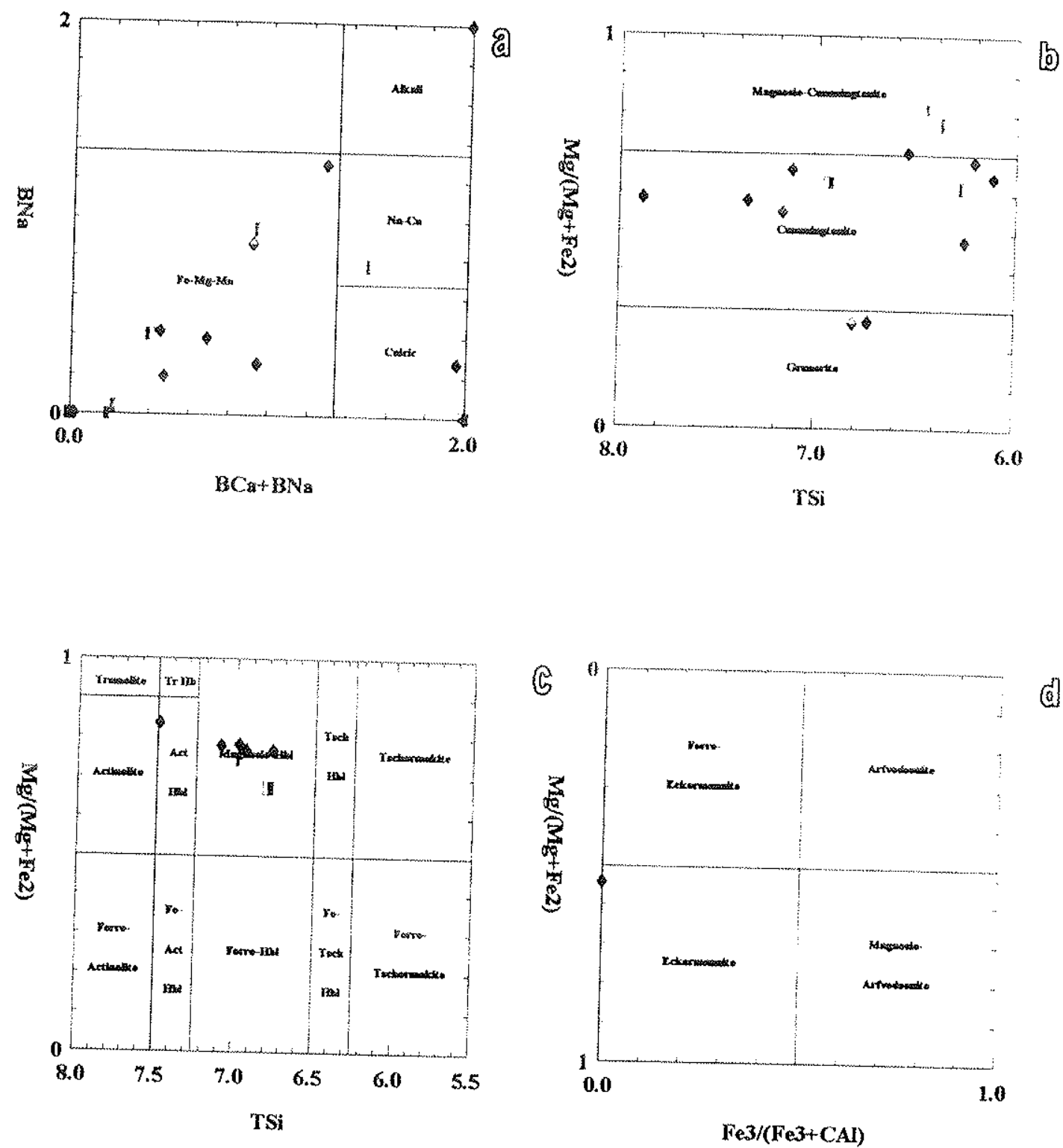

Figura 3-11. Anfibólios nos "lamprófiros". (a) classificaçăo geral dos anfibólios conforme Leake (1977), Yzu-1. Tratan-se de cummigrama Minpet 2.0 (b) anfibólios de Fe-Mg $-\mathrm{Mn}$ dos corpos Ymi-1, Ymi-7, Ymi-4 e o nome magnésio cummingtonita se substitua orientações do IMA (cf. Leake et al., 1997) que recomenda que anfibiólitos cálcicos de Ymi-1 e Ymi-7 =

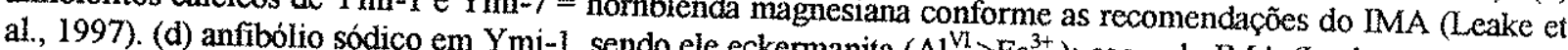
Simbologia como em 3-2. 
vesiculado, porém identificando-se muito com as brechas devido à sua cor marrom avermelhado escuro e as formas estiradas das vesículas. Fenocristais de piroxênio e alguns de mica fresca estão melhor representados nestas rochas. Microscopicamente as diferenças entre as fácies são também bastante sutis Apresentam abundante vesículas e/ou ocelli com zeólita/carbonato segundo o esquema: zeólitas são mais frequentes nas lavas, descendendo nas brechas até os diques o denominador comum, nas três fácies, é dado pela presença de fenocristais milimétricos de mica amarronzada; prismas milimétricos de piroxênio incoloresverdeado; microfenocristais submilimétricos de olivina euhedral totalmente serpentinizada; e microfenocristais de espinélio euhedral (Fotomicrografias 1, 2, e 4). As rochas têm matriz fina $(<0.3$ a $\sim 0.10 \mathrm{~mm}$ ), intergranular a traquitóide, formada por ripas de feldspato, espinélio, raros cristais de piroxênio e vidro alterado intersticial (Fotomicrografias 1 e 2). Os acessorios são anfibólio e apatita. Os dados modais esquematizados na Tabela 3-3, permitem caraterizar as três fácies de rocha. coletivamente de micampiroxênio-feldspato "lamprófiros".

\section{Química mineral}

\section{Micas}

São caraterísticos nesta intrusão os fenocristais milimétricos de mica amarronzada as quais apresentam pleocroismo do marrom ao amarelo mel. "Observam-se formas euhedrais (com visiveis bordas suavizadas pela corrosão e assim substituídas por opacos) a anhedrais (as que acusam profunda corrosão mostrando substituições pelos opacos), como pode-se constatar nas Fotomicrografias 1, 2 e 3. As micas incluem opacos e piroxênios (Fotomicrografia 3), sendo também observadas a presecia de micas como inclusões em alguns cristais de piroxênio.

Composicionalmente (apêndice A2) são micas com variações (Figura 3-5) de flogopita (maioria) a biotita (borda de um cristal). Os fenocristais são zonados e apresentam mg variável de 0.73-0.76 no centro a 0.66-0.79 nas bordas do cristal (Figura 3-6). Nestas micas observa-se teores moderados de $\mathrm{TiO}_{2}(3.39-4.92 \%$ no centro; $2.86-4.82 \%$ nas bordas titaníferas) e altos de $\mathrm{Al}_{2} \mathrm{O}_{3}$ (14.94-16.59\% no centro; 

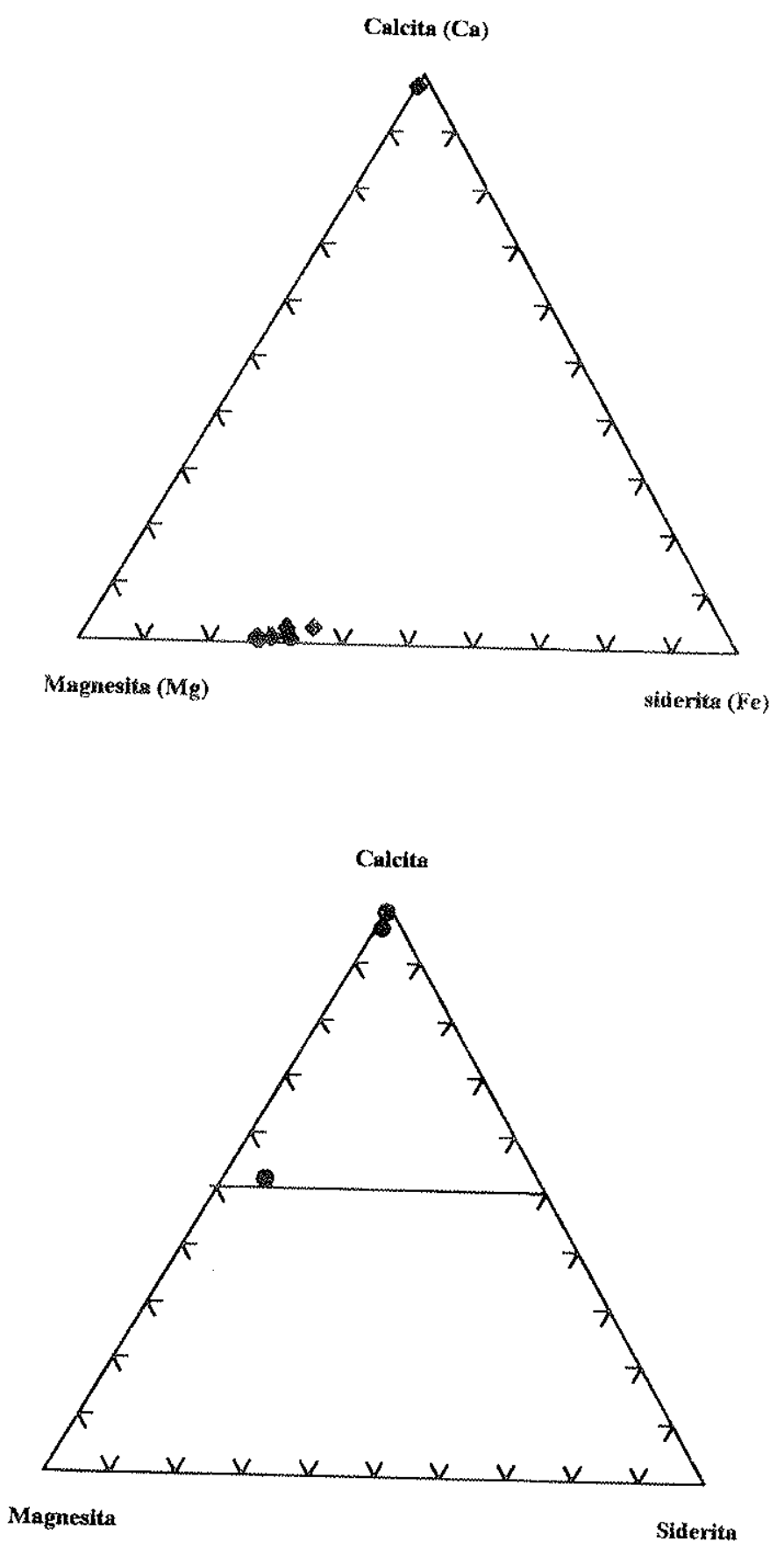

Figura 3-12. Carbonato nas rochas lamprofiricas. Ymi-1 (superior) e Yzu-6 (inferior). Linha horizontal de 50 equivale a dolomita (Rock, 1984). Simbologia como em 3-2. 
$14.52-16.49 \%$ nas bordas aluminosas). Elas possuem teores significativo de $\mathrm{Na}_{2} \mathrm{O}$ (0.37-0.70\% no centro; $0.42-0.72 \%$ nas bordas) junto com teores despreziveis de $\mathrm{Cr}_{2} \mathrm{O}_{3}$. Algumas feições que são freqüentes em micas de alguns minettes (ex. Rock. 1991 ) podem ser evidenciadas por alguns cristais destas rochas, como por exemplo zoneamento normal do centro rumo as bordas em alguns cristais e reverso em outros (teores variando em sentido inverso) (Figura 3-13); assim lambém nelas se observa um enriquecimento em Al e Ti (Figura 3-6) e Al e Fe seguindo um trend freqüente de observar nas micas que ocorrem nos minettes e também nas rochas ultrapotássicas tipo Provincia Romana (Mitchell \& Bergman, 1991; Mitchell, 1995a-b; Rock et al. 1992). Estas feições levam a caraterizá-las como flogopita titanif́era aluminosa $e$ biotita titanifera aluminosa.

\section{Piroxênios}

Piroxênios ocorrem na forma de fenocristais prismáticos, freqüentemente milimétricos, incolores a algo esverdeados, dispostos isoladamente ou agrupados (interpenetrando se). Ocasionalmente, nas rochas onde associam-se a cristais de espinélios e evidenciam, em parte, uma microtextura cumulática (Fotomicrografia 1) Os cristais da matriz são também subheudrais, incolores a esverdeados e eles são pouco freqüentes. Os piroxênios ocorrem nas três fácies de rocha de Ymi-4, porem são levemente mais abundantes no dique.

Composicionalmente (apêndice A3) são piroxênios diopsídicos (Figura 3-3). Estão fortemente zonados (Figura 3-4) conforme evidenciado pelos teores em $\mathrm{TiO}_{2}(0.56$ $1.01 \%$ no centro e $1.00-1.84 \%$ nas bordas e matriz; i.e. titanifero) e $\mathrm{Al}_{2} \mathrm{O}_{3}(3.05$ $6.62 \%$ no centro e $4.80-7.78 \%$ nas bordas/matriz, i.e. aluminosos), que aumenta proporcionalmente do centro em para as bordas (Figura 3-4). Por outro lado eles apresentam teores baixos de $\mathrm{Na}_{2} \mathrm{O}(<0.43 \%)$. Estas feições que o caraterizam à diopsidio titanifero aluminoso. Este tipo de piroxênio é freqüente em minettes e rochas ultrapotássicas tipo Província Romana (Rock, 1991; Mitchell \& Bergman, 1991; Mitchell, 1995a). 

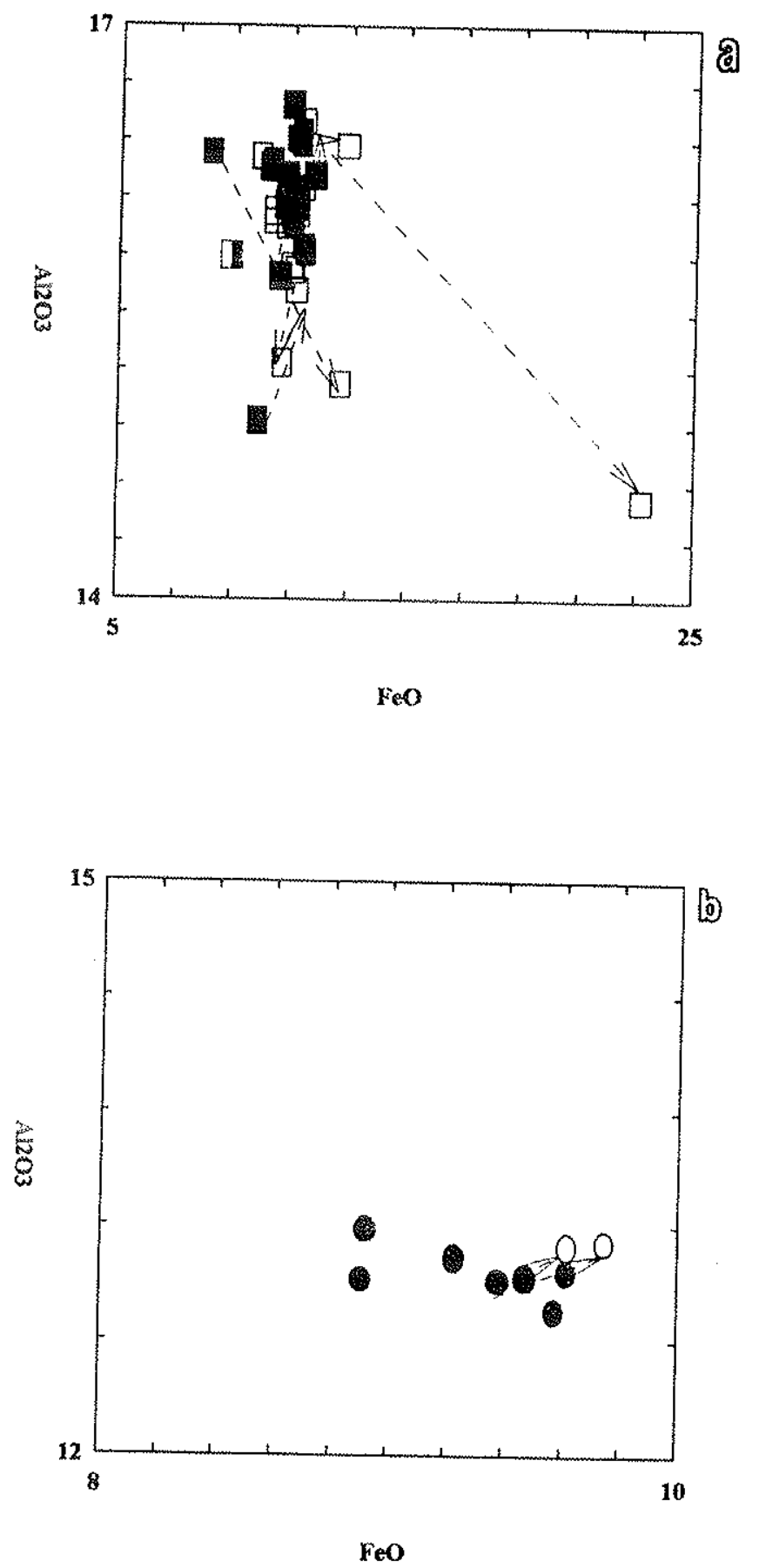

Nigurya 3-13. Zoneamento em fenocristais de mica. (a) Ymi-4, que mostra zoneamento normal e inverso. (b) Yzun 6, que mostra como evoluem do teor da molecula de nogopita para maior concentraf̧áo da molécula de biotita (enriquecimento em Fe) e aumento da concentração de Al. Simbologia como em 3-2. 


\section{Espinélios}

Nestas rochas, os espinélios ocorrem como microfenocristais idiomórficos isolados ou agrupados (Fotomicrografias 1 e 4). Por vezes exibindo microtexturas de exsolução (espinélio com lamelas de ilmenita, cf. apêndice A4). Na matriz aparecem como cristais idiomórficos com seções geralmente retangulares e mais raramente quadraticas (Fotomicrografia 2).

Os espinélios de Ymi-4 ocupam os campos com elevados valores de $\mathrm{Ti \#} \mathrm{e} \mathrm{Fe}^{2+} \#$ Figura 3-9, porquanto que apresentam teores (apêndice A4) baixos em $\mathrm{Cr}_{2} \mathrm{O}_{3}(<1 \%)$, $\mathrm{Al}_{2} \mathrm{O}_{3}(<3 \%)$ e $\mathrm{MgO}(0.1-2.4 \%)$, enquadran-se perfeitamente nas séries do espinélio e magnetitas. Entretanto, como apresentam teores altos de $\mathrm{TiO}_{2}$ (até $26.5 \%$ ) eles se encaixam melhor dentro da série da magnetita, i.e., ulvoespinélio (Figura 3-9). Alguns cristais apresentam teores em MnO de até $4 \%$, assim acusando a presença de moléculas de galaxita (Figura 3-7). As feições observadas nas figuras citadas permitem caraterizar as variedades magnetitas magnesianas tianiferas e magnetitas titaniferas manganesiferas. Essas variedades espinélios são freqüentes em minettes (cf. Rock, 1984; 1991; entre outros). Em dois microfenocristais foram analisadas lamelas exsolvidas de hematita (apêndice A4).

\section{Feldspatos}

Os feldspatos ocorrem na matriz destas rochas como cristais tabulares parcial a totalmente alterados ("argilização") (Fotomicrografias 1 e 2). Composicionalmente (apêndice A7), os poucos análises disponiveis, indicam que os feldspatos são sanidina (natrosanidina em parte, cf. apêndice A7)(Figura 3-10) com baixos teores de $\mathrm{Fe}_{2} \mathrm{O}_{3}(<1 \%)$. Essas caraterísticas são comuns em lamprófiros (ex. minettes), conforme Rock (1991) e rochas ultrapotássicas tipo Província Romana (cf. Mitchell \& Bergman, 1991).

\section{Acessórios}

Foi observado que estas rochas apresentam anfibólios secundários são cummingtonita potássica com $\mathrm{K}>0.50$ (dados no apêndice A5), que ocorrem junto à 
apatita na matriz. Nas amígdalas ocorrem zeólitas ricas em $\mathrm{CaO}$ (até $8 \%$ ), $\mathrm{Na}_{2} \mathrm{O}(4-$ $11 \%$ ) e elas apresentam depreziveis teores de potássio (cf. apêndice A6).

As feições minerais apontadas para as rochas desta intrusão são de sanidinaflogopita-diopsidio "lamprófiro". Este tipo de rocha asemelha-se a muitos micalamprófiros caraterizados como minettes (cf. Rock, 1984; 1991). Diferentemente das rochas basaltóides alcalinas, na matriz das rochas desta intrusão não foi registrada no microscôpio nem através das análises de microssonda eletrônica, a presença de plagioclásio. Por esta razão sugere-se que essas rochas não são basaltóides. Além disso, apresentam baixo teor de máficos, feição que as aproxima mais aos lamprófiros e as afasta das rochas basaltóides alcalinas descritas na região (cf. Comin-Chiaramonti \& Gomes, 1996).

\section{"LAMPROÍTOS"}

Estas rochas podem ser separadas em dois grandes grupos petrográficos, semelhantemente ao procedimento adotado com os "lamprófiros". Um dos grupo reune as rochas com fenocristais de mica e piroxênio e são coletivamente denominados MICA "LAMPROÍTOS". Outro agrupa as rochas com fenocristais de "leucita" piroxênio e/ou mica, sendo denominados LEUCITA "LAMPROÍTOS".

Como tarefa inicial procurou-se estabelecer uma boa fonte de dados da química mineral deste grupo incomum de rochas ultrapotássicas (Foley et al., 1987; Mitchell \& Bergman, 1991) que, juntamente com os kimberlitos e os orangeítos formam um conjunto de rochas de difíceis caraterização, como se constata em Mitchell (1986; 1995a-b) e Mitchell \& Bergman (1991). Minerais como espinélios, titanatos (ilmenita, rutilo, armalcolita, pseudobrookita), anfibólios e feldspato alcalino foram reunidos em arquivos de dados que foram tratados com auxílio do Programa Minpet 2.0. $\mathrm{Na}$ construção dos diagramas, empregaram-se dados minerais de lamproitos de varias localidades do mundo visando a comparação com os dados das rochas estudadas neste trabalho. Nesse sentido, buscou-se uma caraterização precisa dos minerais estudados visando uma definição petrográficas adequada para as rochas estudadas neste trabalho. Os dados da literatura foram extraídos de Mitchell (1985; 1986; 
包
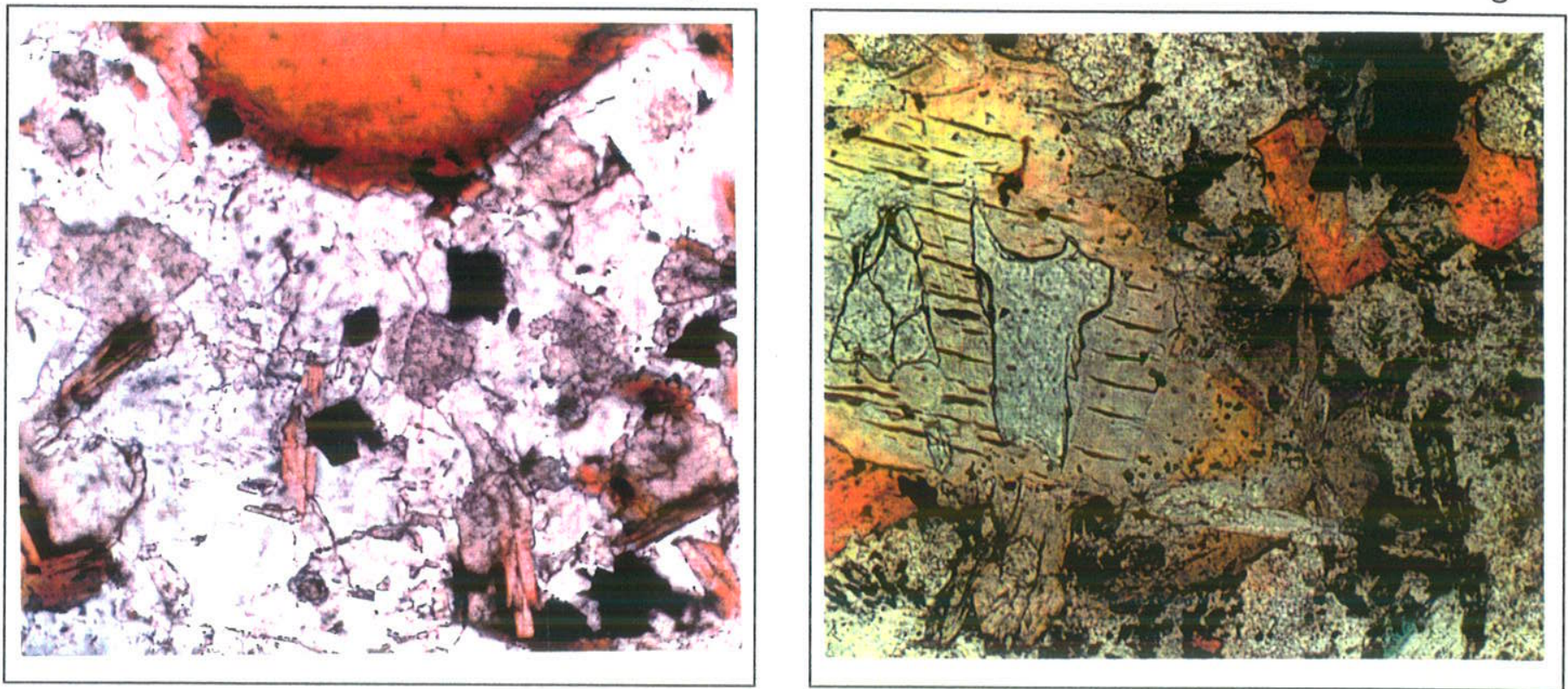

泃
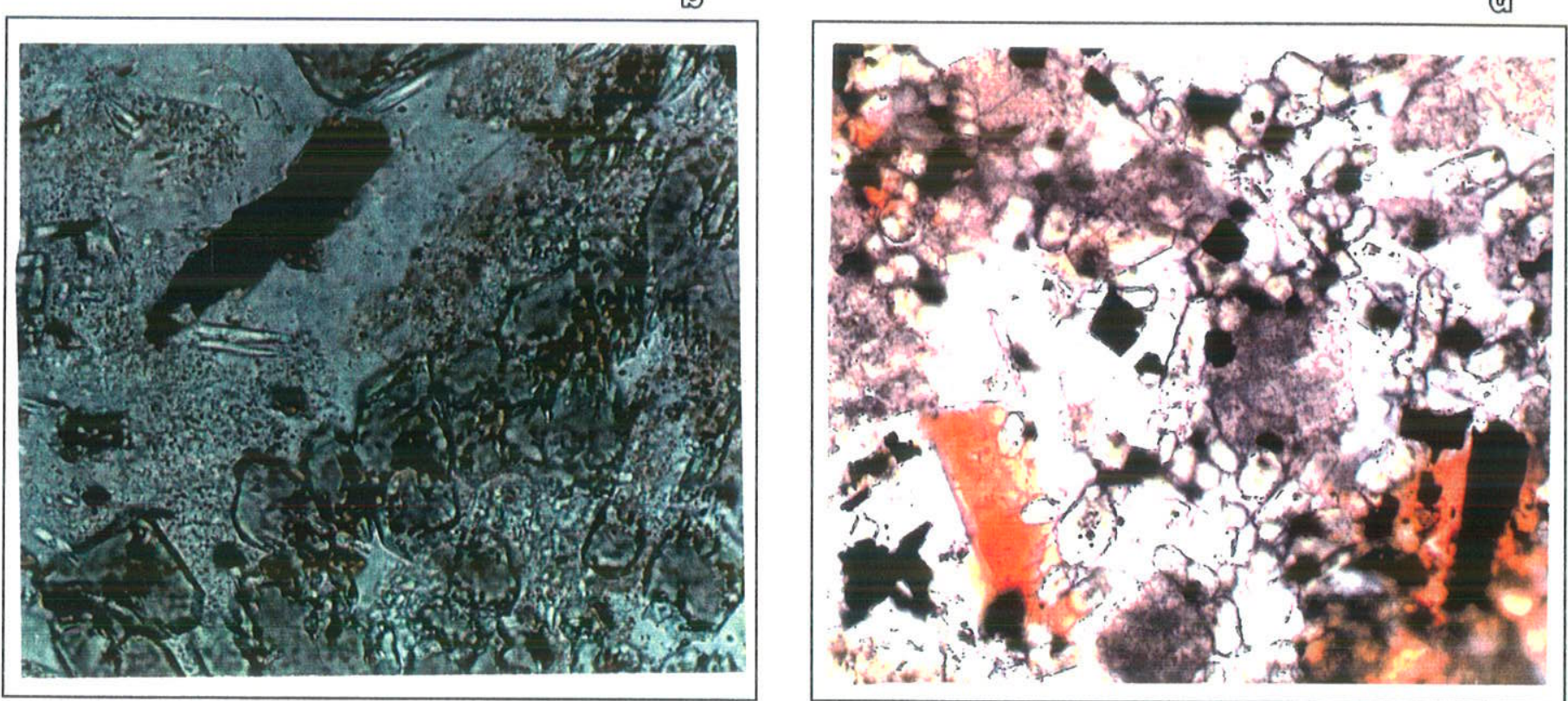

Microfotografia 5. "Lamproítos". (a) Yzu-6, mostra micas marrom avermelhado junto à sanidina (incolor), espinélios $(\sim 0.1 \mathrm{~mm})$ e manchas amarronzadas de anfibólio. (b) Ymi-5, detalhes de piroxênio esverdeado junto a espinélio alongado $(\sim 0.1 \mathrm{~mm})$ e envolvido por biotita; sanidina (incolor, relevo baixo) e apatita (relevo alto). (c) Yzu-2, mostra-se flogopita marrom abóbora, espinélio, "leucita" (incolor arredondada), prismas de sanidina e ferro-heckermanita potássica titanífera (marrom salmão escuro), junto a fenocristal pseudomorfo de olivina. (d) Yzu-3, detalhes dos minerais da matriz; prismas de ilmenita $(\sim 0.1 \mathrm{~mm})$ junto a espinélio, flogopita amarronzada, sanidina (incolor e límpida), leucita/vidro alterado (manchas turvas) e piroxênio; e cristais de apatita relevo alto. Polarizador inferior. 
1995a), Mitchell \& Bergman (1991 e referências), Wagner \& Velde (1986); Middlemost et al. (1988); Sheraton \& Cundari (1980); Gogineni et al. (1978); Waldman et al. (1987); Venturelli et al. $(1984 ; 1991)$; Kuehner et al. (1981); Thy et al. (1987); Contini et al. (1993); Linthout \& Lustenhouwer (1993) e Costa (1996).

\section{MICA "LAMPROÍTOS"}

\section{Sill Yzu-6}

\section{Feições gerais}

Petrográficamente tem características de uma rocha vulcânica porfirítica com marcada textura lamprofírica, contendo fenocristais milimétricos de mica castanha muito escura, piroxênio (de vários milímetros) verde esmeralda (em parte pseudomorfizado pelo carbonato) e ilmenita prismática (sub milimétrica a milimétrica), imersos em matriz microgranular algo alterada, que apresenta amigdalas (ocelli) de carbonato granular (grosso) milimétricos a centimétricos. Estas feições são muito parecidas com os mica lamprófiros (minettes).

Ao microscópio exibe marcada textura porfirítica com fenocristais milimétricos euhedrais de mica amarronzada e piroxênio prismático e assembléia de microfenocristais de espinélio e alguns prismas de ilmenita, acompanhados de amígdalas (milimétricas a centimétricas) preenchidas de carbonato granular grosso. Os fenocristais estão mergulhados em matriz granular euhedral a subhedral fina ( 0.1-0.3 mm) formada por feldspato alcalino, espinélios, mica amarronzada e intersticialmente anfibólio fibroso de cor verde amarelado tcarbonato (Fotomicrografia 5). A apatita prismática, ilmenita e um mineral prismático vermelho sangue escuro muito pequeno ( $<0.10 \mathrm{~mm}$; rutilo?, priderita?) são os acessórios registrados. Fragmentos angulosos irregulares e milimétricos de enclaves sedimentares (de granulação muito fina) são também observados coexistindo com os fenocristais. Os dados modais apresentados na Tabela 3-3 permitem definir esta rocha como piroxênio-mica-feldspato alcalino "lamproito". 

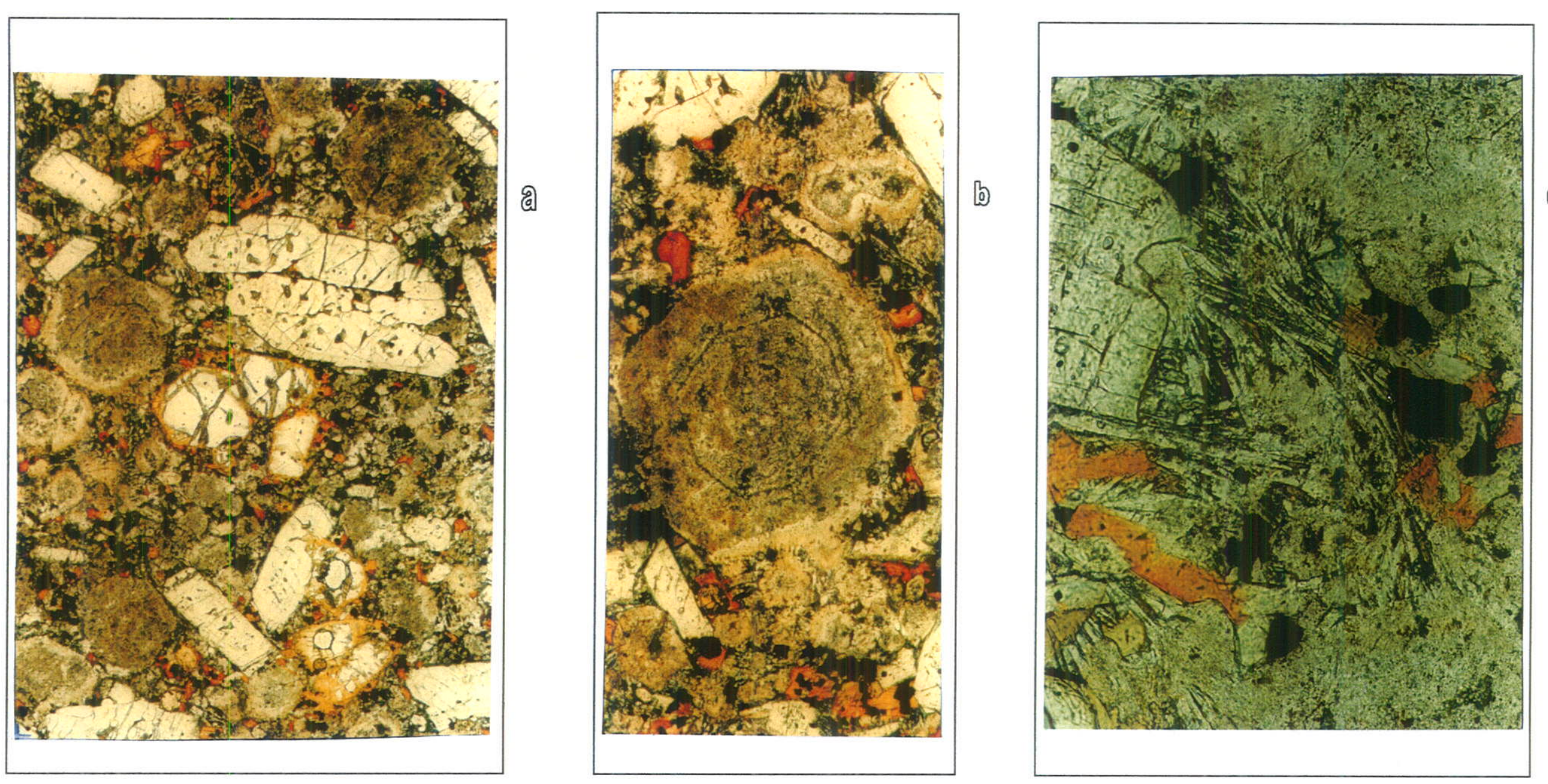

Fotomicrografia 6. "Lamproíto" Yzu-2. (a) fenocristais de olivina (incolor e serpentinizada nas bordas e fraturas), prismas de piroxênio ( 1 mm) e leucita pseudomorfizada (grãos arredondados de marrom turvo). (b) mostra-se um microfenocristal $(\sim 1 \mathrm{~mm})$ poligonal de leucita pseudomorfizada e de crescimento zonado. (c) matriz intersticial entre "leucita" de flogopita lamelar, prismas de sanidina, ferro-heckermanita potássica titanífera de coloração marrom-salmão escuro. Polarizador inferior. 


\section{Química mineral}

\section{Mica}

Fenocristais de mica amarronzada ( $10 \%$ modal) apresentam pleocroísmo de côr marrom âmbar avermelhado a marrom mel. Na matriz, os cristais são apresentam o mesmo pleocroísmo, porém em tons mais escuros. As duas formas de ocorrência apresentam-se como cristais preferencialmente euhedrais a subhedrais. Entretanto, alguns fenocristais apresentam bordas corroídas (engolfamentos), e em outros microtextura kind-band. Os fenocristais apresentam inclusões de apatita.

A composição química destas micas encontram-se listadas no apêndice A2. Composicionalmente são micas com variações de flogopitas a biotitas (com mg\# de 0.77-0.78 nos fenocristais e 0.61-0.73 nas bordas e matriz) (Figura 3-5). Estas micas possuem $\mathrm{TiO}_{2}$ variando de $5.62-5.80 \%$ nos centro dos fenocristais e $5.57-8.16 \%$ nas bordas e matriz (titaniferas) e $\mathrm{Al}_{2} \mathrm{O}_{3}$ de $12.76-13.19 \%$ nos centros dos fenocristais e $11.77-13.11 \%$ nas bordas e na matriz (raramente aluminosas). Os teores medidos de $\mathrm{Cr}_{2} \mathrm{O}_{3}$ e $\mathrm{Na}_{2} \mathrm{O}$ são deprezíveis (apêndice A2). Estas feições químicas permitem caraterizar duas variedades, flogopitas titaniferas e biotitas titaniferas, ambas com baixo teor em alumina. Suas carateristicas químicas são similares às de lamproítos (Mitchell, 1985; Mitchell \& Bergman, 1991) e orangeitos (Mitchell, 1995a-

b). Porém incomum de se encontrar em micas dos minettes (Mitchell, 1995; Rock, 1990).

A Figura 3-6 (c) exibe um trend de diminuição de alumina conforme aumenta o teor de Ti, e na Figura 3-6 (d) evidencia o aumento do teor de Fe conforme diminui o de Al. A Figura 3-13 (b) mostra o zoneamento identificado em dois fenocristais. Este comportamento químico é caraterístico dos lamproitos e de alguns orangeítos e são observados como comportamento inverso ao registrado nas micas de Ymi-4, que se parece mais com as micas dos minettes (cf. Mitchell, 1985; 1995a-b e Mitchell \& Bergman, 1991). 

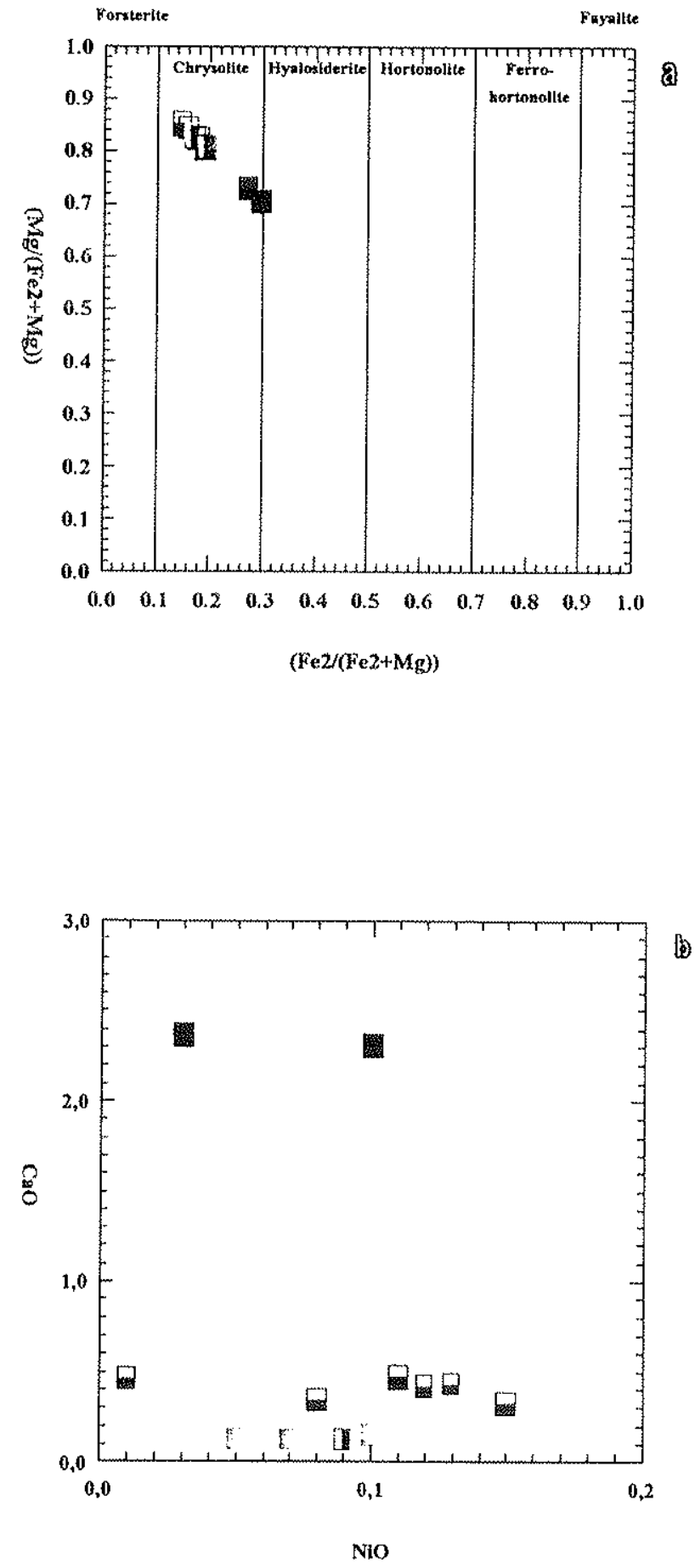

Figura 3-14. Olivinas dos "lamproitos". (a) classificação das olivinas de Ymi-5 (serpentinizadas); Yzu-2 e Yzu3 ; todas elas sendo crysolitas, com sutis variaç̃es do centro para as bordas. (b) comportamento das olivinas em termos de $\mathrm{CaO}$ e $\mathrm{NiO}$. Olivinas de Ymi-5, por estarem serpentinizadas, mostram anormal enriquecimento em $\mathrm{CaO}$. Simbologia como em $3-2$. 


\section{Piroxênios}

Piroxênios só foram observados na forma de escassos fenocristais parcial (fraturas e clivagem) a totalmente pseudomorfizados por carbonato. São milimétricos, em formas prismáticas que ocorrem em geral como cristais individuais incolores a algo esverdeados. Eles não foram observados na matriz.

A sua composição encontra-se no apêndice $\mathrm{A} 3$. Os dados mostram que são diopsídios (Figura 3-15) com baixos teores em $\mathrm{Al}_{2} \mathrm{O}_{3}(0.79-0.94 \%), \mathrm{Cr}_{2} \mathrm{O}_{3}$ (0.39$0.48 \%), \mathrm{TiO}_{2}(0.60-0.65 \%)$ e $\mathrm{Na}_{2} \mathrm{O}(<0.36 \%)$. Asemelham-se aos piroxênios descritos em lamproítos, orangeítos e alguns minettes, porém, se comparados com os piroxênios de Ymi-4, os de Yzu-6 são marcadamente diferentes.

\section{Espinélios}

Espinélios com seições quadradas, retangulares (curtas) a poligonais aparecem em agregados (2 a 3 cristais) ou, mais freqüentemente, como microfenocristais individuais e como cristais da matriz (Fotomicrografia 5).

A composição química dos espinélios estão apresentados no apêndice A4. São espinélios com baixos teores de $\mathrm{MgO}(<1 \%), \mathrm{Cr}_{2} \mathrm{O}_{3}(<0.10 \%)$ e $\mathrm{Al}_{2} \mathrm{O}_{3}(<0.3 \%)$ e altos teores de $\mathrm{TiO}_{2}$ (14-22\%), $\mathrm{FeO}_{\mathrm{t}}(59-72 \%)$ e $\mathrm{MnO}$ (2-4\%; sendo ricos em manganês a manganesiferos). Essas variações químicas caraterizam valores baixos em $\mathrm{Cr}$ e altos a muito altos em Ti\#, $\mathrm{Fe}^{2+} \#$, similar ao observado em espinélios pertencentes às séries da Magnetita e do Espinélio (Figuras 3-17). O alto teor de Ti permite enquadra-los mais apropriadamente dentro da série da magnetita (i.e. ulvoespinélios), e os teores em $\mathrm{Mn}$ evidenciam como encontrado em alguns espinélios de Ymi-4, importantes teores da molécula de galaxita. Com base nos dados químicos e nas Figuras 3-7, os espinélios de Yzu-6 podem ser caraterizados como magnetita titanifera rica em manganês. Estas feições são similares às observadas em espinélios muito diferenciados que ocorrem em alguns lamproítos, orangeitos e em minettes (cf. Mitchell \& Bergman, 1991, e referências). 


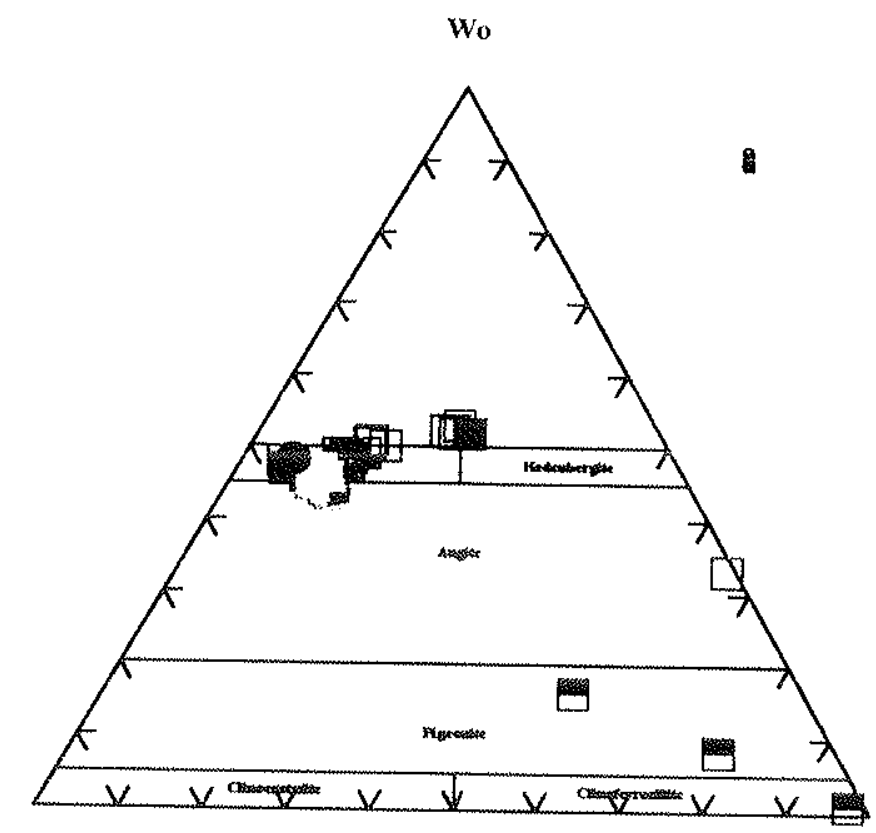

En

Fs

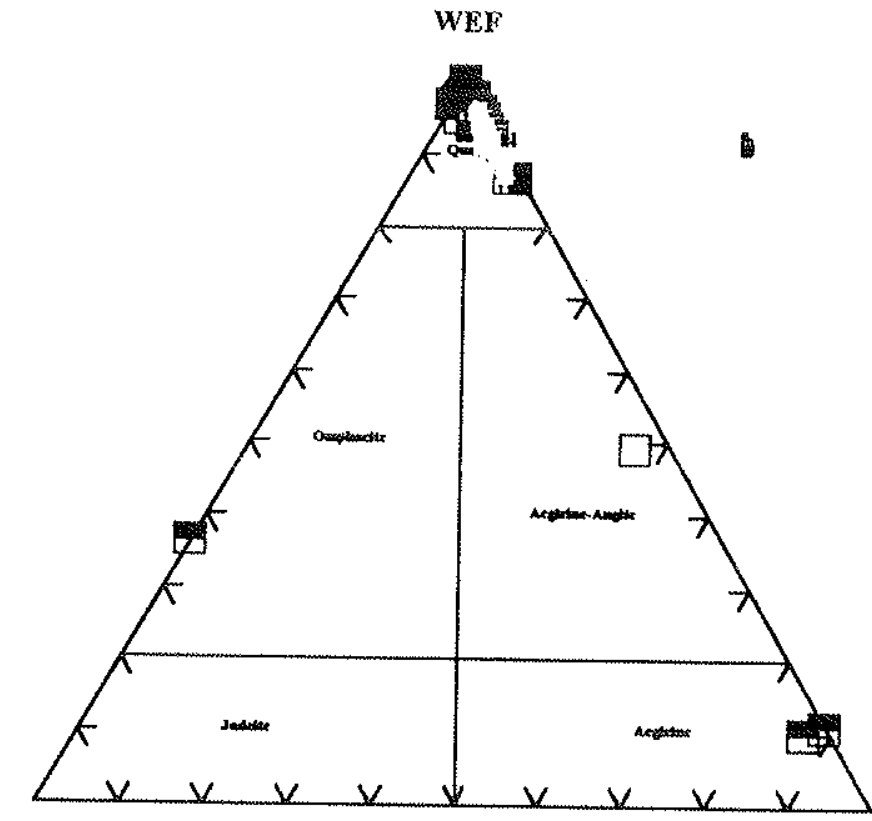

Jd

Figura 3-15. Piroxênio dos "lamproítos". (a) classificação que ressalta o enriquecimento em moléculas de diopsídio nos piroxênios de Yzu-2, Yzu-3 e Yzu-6 estão enriquecidos em moléculas de diopsídio. Ymi-5 apresenta-se com altos teores da molécula de hedembergita. A variação na composição de seus piroxênios finaliza com os cristais quench, sendo eles diopsídio-hedembergiticos ricos na molécula de wollastonita. Cristais esverdeados pleocróicos variam de aeginina-augita (Ymi-5) a aerigina ( $\mathrm{Yzu}-2)(\mathrm{Figura}$ b). Simbologias como em
$3-2$. 
O baixo teor da molécula de hercynita, nos espinélios de Yzú-6 (Figura 3-7) os diferencia dos espinélios de Ymi-4.

\section{limenita}

Microfenocristais prismáticos opacos, alguns deles pseudomorfizados por carbonato e hidróxidos de $\mathrm{Fe}$, possuindo dimensões submilimétricas a milimétricas, foram reconhecidos na assembléia de feno-microfenocristais de Yzu-6. Este mineral também é observado na matriz e ocorre como prismas de seção retangular frescos

O grupo das ilmenitas é composto pela ilmenita $\left(\mathrm{FeTiO}_{3}\right)$, geikielita $\left(\mathrm{MgTiO}_{3}\right)$, pyrofanita $\left(\mathrm{MnTiO}_{3}\right)$, hematita $\left(\mathrm{Fe}_{2} \mathrm{O}_{3}\right)$ e eskolaíta $\left(\mathrm{Cr}_{2} \mathrm{O}_{3}\right)$. Existe uma extensiva série de solução sólida existe entre a ilmenita-geikielita, e entre a ilmenita-hematita nos xenólitos do manto e em óxidos cristalizados de magmas derivados do manto (Haggenty, 1991). Assim freqüentemente, as ilmenitas analisadas quimicamente. quando recalculados $\mathrm{FeO}$ e $\mathrm{Fe}_{2} \mathrm{O}_{3}$, costumam ser representadas em diagramas ternários: Ilmenita-hematita-geikielita e ilmenita-hematita-pyrofanita (Haggerty, 1991; Gaspar \& Wyllie, 1984; Mitchell, 1986; 1985; 1995a) e ilmenita-pyrofanita-geikielita (Haggerty, 1991). É pouco freqüente incluir diagramas ternários onde a eskolaíta esteja presente. Neste trabalho, adotam-se os dois primeiros diagramas ternários (cf. Figura 3-18). Para comparações, empregaram-se os dados de ilmenitas registrados em lamproítos e orangeítos.

As análises de dois cristais (apêndice A8) evidenciam composição de ilmenitas pobres em $\mathrm{Cr}$ (pobres nas moléculas de eskolaíta). Um dos cristais analisados apresenta-se rico em $\mathrm{MnO}$ (4.23\%, representando importantes teores nas moléculas de pyrofanita) e com moderado $\mathrm{MgO}$ ( $1.98 \%$, contendo moderados teores das moléculas de geikielita), assim parecendo-se com as ilmenitas descritas em lamproítos (Thy ef al., 1987; Venturelli et al., 1984 e 1991) e orangeítos (Mitchell, 1995a), conforme pode ser observado na Figura 3-18. 

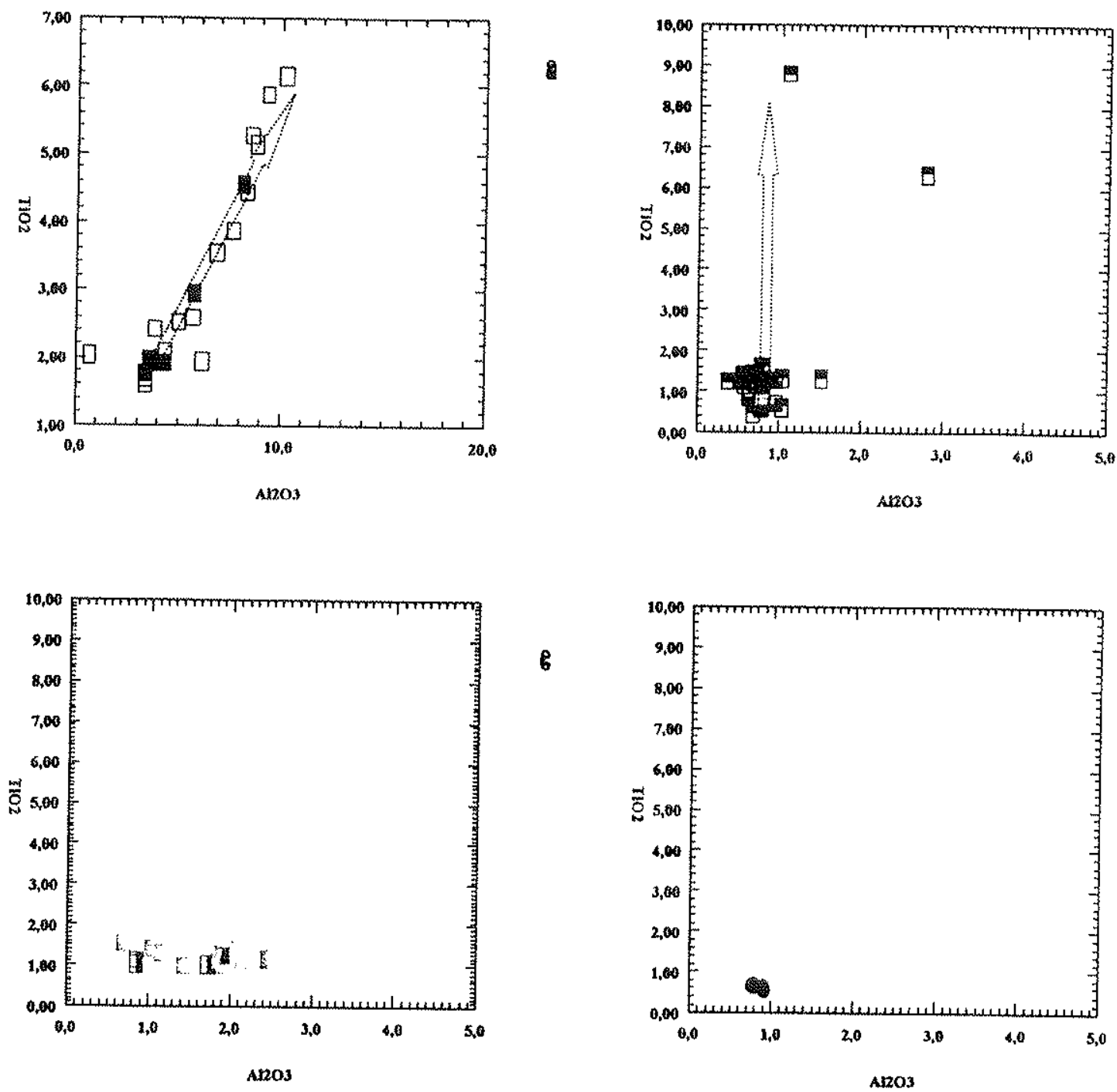

Figura 3-16. Enriquecimento em Ti vs Al em piroxênio dos "lamproitos": (a) Ymi-5 mostra um trend de enriquecimento/zoneamento diretamente proporcional a partir de fenocristais $\rightarrow$ matriz $\rightarrow$ quench, em termos de $\mathrm{Ti}$ UI Al. (b) Yzu-2 e também Yzu-3 (c) e Yzu-6 (d) mostram um enriquecimento/zoneamento segundo um esquema TîAAl, como característico de observar em lamproitos (cf. Mitchell \& Bergman, 1991; Mitchell, 1995a). As setas indicam direção de zoneamento do centro rumo a borda. Simbologia como em 3-2. 


\section{Feldspato alcalino}

Feldspato límpido ocorre na matriz destas rochas na forma predominantemente tabular em parte incluyendo poiquiliticamente as cristais de mica espinélio e anfibólio (Fotomicrografia 5). De acordo com os dados químicos listados no apêndice A7, correspondem a sanidina (Figuras 3-20). De modo similar aos descritos em lamproitos e orangeitos (Mitchell, 1995), são enriquecidos em $\mathrm{Fe}_{2} \mathrm{O}_{3}(0.52-3.21 \%$ ); estes valores acusam importantes teores de moléculas de feldspato de $\mathrm{Fe}$ (rico em Fe). Também são enriquecidos em $\mathrm{Na}_{2} \mathrm{O}(0.20-2.48 \%)$ como registrado em alguns lamproítos, como por exemplo Shiprock dyke, New Mexico e Orciato, Pisa (Wagner \& Velde, 1986; Cancarix, em Venturelli et al. 1984; Jumilla, em Venturelli et al, 1991) e minettes (Rock 1991). Os teores medidos em $\mathrm{BaO}$ nestes feldspatos são depreziveis a moderados (0.00-1.40\%), assim acusando escassa participação das moléculas de hialofana ( $\sim$ rico em $\mathrm{Ba}$ ), indicando uma sanidina rica em Fe e em Ba.

\section{Minerais acessórios}

Quartzo (1\%), apatita, carbonato rico em CaO (Figura 3-12, apêndice A9) e anfibólio (cummingtonita, Figura 3-19 e Fotomicrografia 5) ocorrem na matriz desta rocha. Quartzo é descrito nos anfibólio lamproitos da área de Sisimiut, Groenlândia (Thy et al., 1987) e carbonato nos jumillitos de Espanha (Venturelli et al., 1991), alguns lamproítos da India (Rock et al., 1992) e o lamproíto Argyle (Jaques et al., 1989).

As feições minerais caraterizadas nesta intrusão permitem caraterizam a rocha como um diopsídio-flogopita-sanidina "lamproíto". 

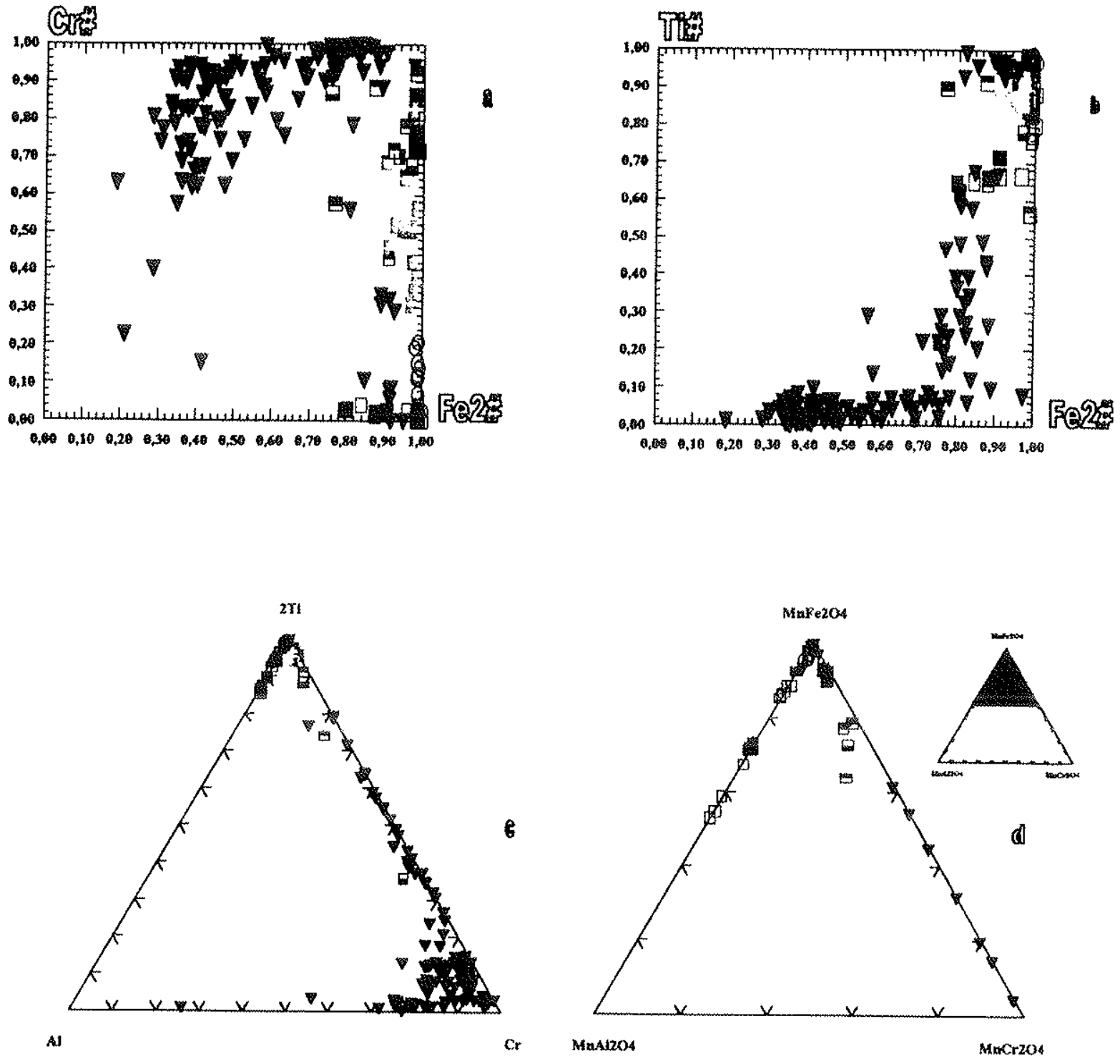

Figura 3-17. Espinélios dos "lamproítos". Nas figuras são comparados com os espinélios que ocorrem em outras localidades do mundo (triângulos invertidos e cheios). (a) base do tetraedro dos espinélios, onde se mostra como os espinélios dos "lamproitos" estudados evidenciam solução sólida entre os end members cromita-hercynita. (b) sistema qandilito-magnetita/ulvobespinélio-espinélio-hercynita, mostrando que os espinélios dos "lamproítos" estudados são membros ricos nas moléculas de magnetita/ulvöespinélio e eles seguem o trend traçado pelos lamproítos como sugerido em Mitchell \&Bergman (1991). (c) Sistema magnetita/ulvöespinélio-cromita-hercynita: aqui como em (b) os espinélios analisados mostram-se ricos nas moléculas de magnetita/ulvöespinélio, notar também como os espinélios de Ymi-5, Yzu-2, Yzu-3 e Yzu-6 seguem o trend traçado pelos lamproítos. (d) sistema jacobsita-manganocromita-galaxita, para espinélios com MnO $1 \%$, mostrando-se como os espinélios estudados são ricos na molécula de jacobsita, sendo que alguns espinélios de Ymi-5 são também ricos em nas moléculas de galaxita. Note-se o trend traçado pelos lamproítos. As fontes sấo citadas no texto. Simbologia como em 3-2. 


\section{LEUCITA "LAMPROÍTOS"}

\section{Intrusões Ymi-5, Yzu-2 e Yzu-3}

\section{Feições gerais}

Três intrusões (Ymi-5, Yzu-2 e Yzu-3) são tratadas em conjunto neste item. Nelas foram registrados como mineral comum, abundantes fenocristais de "leucita" (>30\% modal), diferenciando-se uma da outra pelo grau de desenvolvimento desta face mineral: equidimensionais milimétrico a subcentimétrico em Ymi-5; equidimensionais e milimétrico Yzu-3; e submilimétrico seriado em Yzu-2.

Ymi-5 constituido de rochas vulcânicas marcadamente porfiríticas, maciças, com feno/megacristais, em grande parte glomeroporfiríticos de "leucita" poligonal a arredondada, de cor branca a turquesa pálido, conferindo à rocha aspecto de manchas de liquens brancos. Além disso, possuem feno e microfenocristais de piroxênio esverdeado escuro, em forma prismática milimétrica e olivina serpentinizada milimétrica. Associam-se, também algumas amígdalas de zeólita branca, raramente milimétricas, em formas ovoidais. A matriz possui aspecto basaltóide de granulação fina. Entre alguns glomérulos de leucita ficaram presos restos da matriz, podendo ser identificados fenocristais tabulares finos de piroxênio escuro-amarronzado e alguns microfenocristais de olivina serpentinizada. Esta rocha foi analisada por Gibson et al. (1996) (ver também Comin-Chiaramonti et al., 1993; e Presser, 1994). Os dados são encontrados na Tabela 3-2, onde se observa uma composicão de rocha ultrapotássica $\left(\mathrm{K}_{2} \mathrm{O}=5.55 \%, \mathrm{Na}_{2} \mathrm{O}=1.68 \%\right.$ e $\left.\mathrm{MgO}=4.15 \%\right)$ e que possui altos teores de $\mathrm{TiO}_{2}(2.27 \%)$ e Ba (2078 ppm). Estas feições, se somadas às elevadas razões de $\mathrm{Ba} / \mathrm{Yb}(845)$ e de $\mathrm{La} / \mathrm{Yb}(54)$ e os valores dos isótopos $\mathrm{Sr} / \mathrm{Sr}$ $(0.707205)$ e $\mathrm{Nd} / \mathrm{Nd}(0.511812)$ levam a relacionámlas mais propriamente com magmas lampróiticos que com plagileucitos.

Yzu-2 compöe-se de uma rocha vulcânica cinza com abundantes pontilhados esbranquiçados submilimétricos, de aspecto algo orientado e fortemente porfiritico, com fenocristais de "leucita" arredondada (submilimétrica em maioria, porém com 

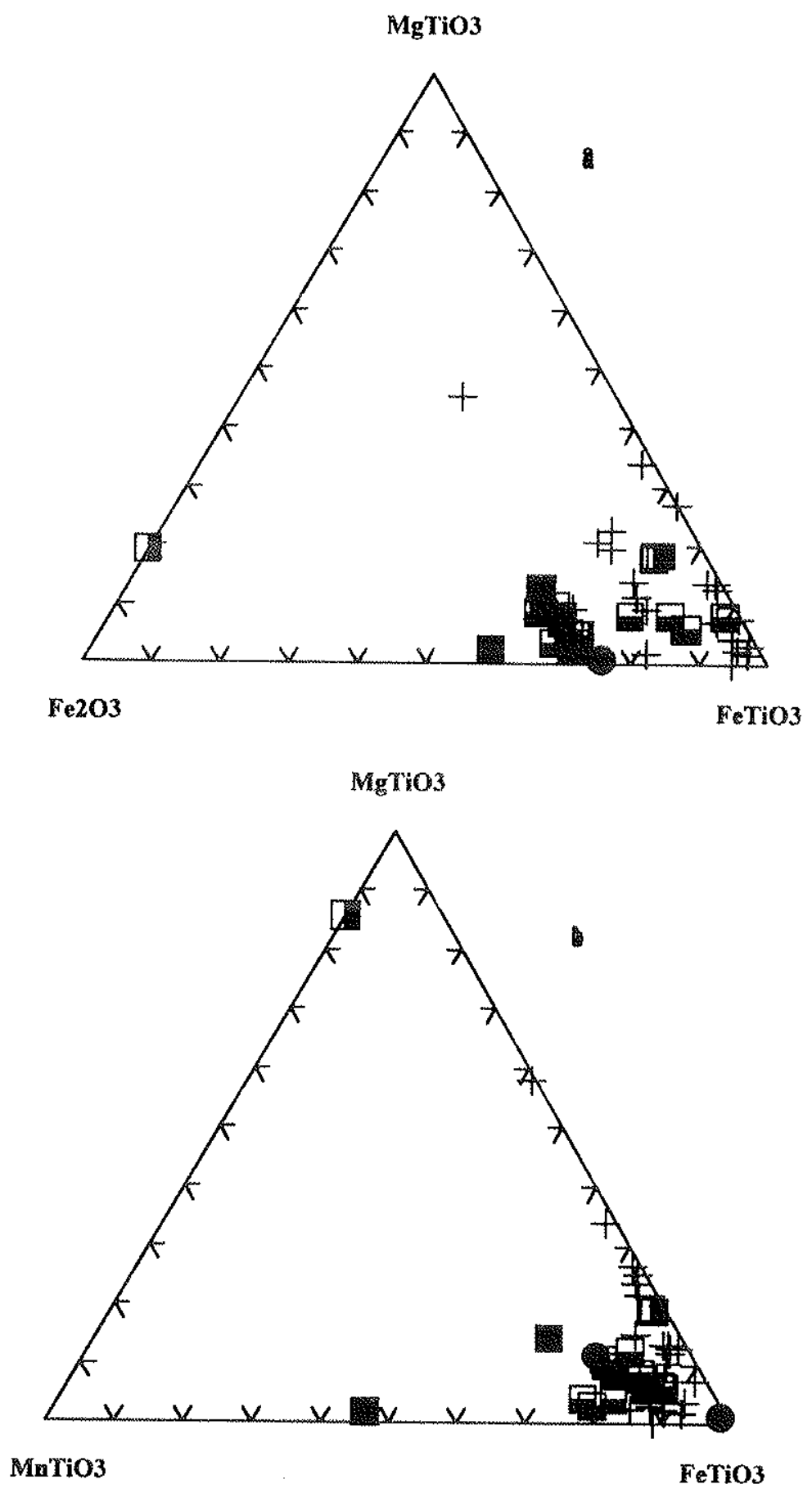

Figura 3-18. limenita dos "lamproitos". Sistemas ternários (a) $\mathrm{MgTiO}_{3}-\mathrm{FeTiO}_{3}-\mathrm{Fe}_{2} \mathrm{O}_{3}$ e (b) $\mathrm{MgTiO}_{3}-\mathrm{FeTiO}_{3}$ " $\mathrm{MnTiO}_{3}$, ilmenitas de $\mathrm{Yzu}-2$, Yzu-3 e Yzu-6 com as ilmenitas que ocorrem nos lamproítos (cruzes) e nos orangeitos (quadro cheio). Ilmeaitas de Ymi-2 e Ymi-3 são comparáveis à dos lamprótos e a de Yzu-6 àquelas dos lamproitos e orangeitos. Para as fontes ver texto. Simbologia como em 3-2. 
caráter seriado) e microfenocristais de piroxênio prismático (submilimétrico até $4 \mathrm{~mm}$ ) verde escuro, olivina incolor submilimétrica e, mais raramente mica marrom escuro. Encontam-se mergulhados em uma matriz fina de aspecto basaltóide. CominChiaramonti \& Gomes (1996) situa a rocha D12/PS515 segundo as coordenadas geográficas Lat.S $25^{\circ} 48,5^{\prime}$ e Long W $56^{\circ} 16,2^{\prime}$. Estas coordenadas são as mesmas elou vizinhas às de Yzu-2, pelo que acredita-se que se trate da mesma localidade. Por esta razão, os dados químicos de D12/PS515 corresponderiam a YZu-2. Contudo, esses dados são tomados temporariamente. Conforme a Tabela 3-2 observa-se que as rochas deste dique apresentam feicões químicas muito similares às observadas em lamproitos, com baixos teores de $\mathrm{Al}_{2} \mathrm{O}_{3}, \mathrm{CaO}$ e $\mathrm{FeO}$, e elevados valores em $\mathrm{TiO}_{2}, \mathrm{MgO}, \mathrm{Cr}, \mathrm{Ni}, \mathrm{Ba}, \mathrm{La}$ e $\mathrm{Nd}$

A amostra de Yzu-3 representa de uma rocha vulcânica cinzenta de aspecto brechóide, que apresenta clastos (angulosos a arredondados) de rochas com aspecto basaltóide (maciça a vesiculada), porfiriticas com fenocristais milimétricos de olivina, piroxênio e abundante "leucita" ("autólitos"?), soldados por uma matriz magmática basaltóide maciça, porfiritica contendo fenocristais de olivina, piroxênio e "leucita". Bitschene (1987), De Min (1993) e Comin-Chiaramonti \& Gomes (1996) fornecem análises das rochas vulcânicas que ocorrem nesta intrusäo (Mbocayaty, ver Figuras do Capitulo anterior). Em Bitschene (1987) faltam os pormenores de uma descrição petrográfica, não dando a certeza de que se trata das rochas porfiriticas ricas em "leucita" amostrada neste trabalho, ou se a análise corresponde a outras litologias que também ocorrem como diques associados. Já em Comin-Chiaramonti \& Gomes (1996) são fornecidas alguns dados petrográficos (dique de rocha basaltóide... plagileucitos?) reunidos a uma análises química (48 PS262, Tabela 3-2) que levam a pensar que se trata da mesma rocha analisada por Bitschene (1987). Feicões petrográficas parecidas ao material amostrado são encontradas na amostra 3152 analisada por De Min (1993) e apresentada na Tabela 3-2. Aqui se observa valores baixos em $\mathrm{Al}_{2} \mathrm{O}_{3}, \mathrm{FeO}_{1}$ e $\mathrm{CaO}$ e elevados de $\mathrm{TiO}_{2}, \mathrm{MgO}, \mathrm{Cr}, \mathrm{Ni}, \mathrm{La}$, Ce e Ba assemelhando-se, assim aos lamproítos. Estes Dados químicos são muito similares ao D12/PS515. 

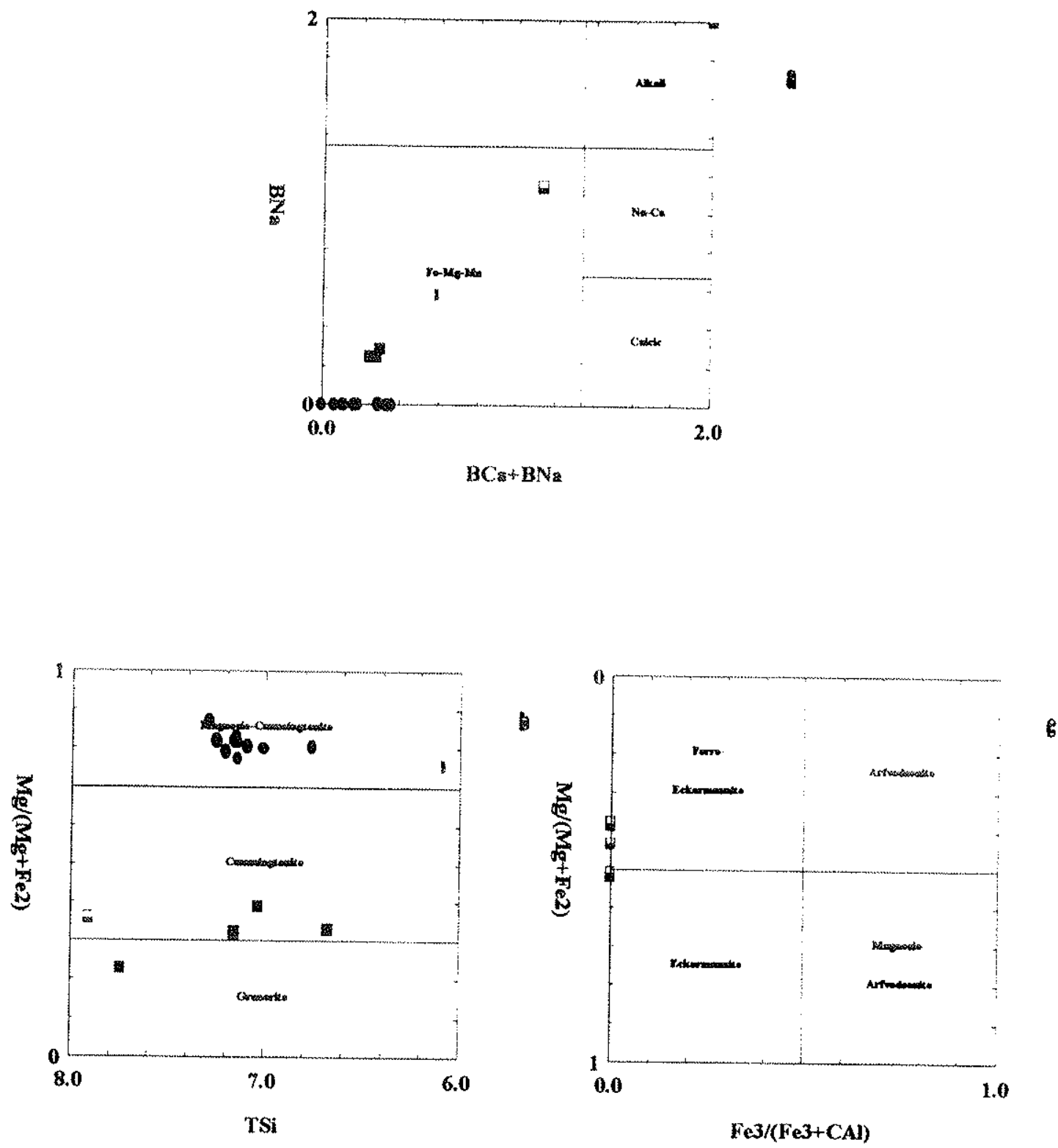

Figura 3-19. Classificação dos anfibólios que ocorrem nos "lamproitos". (a) Esquema de classificação geral dos anfíbólios. (b) anfibólios Fe-Mgg-Mn, cummingtonita em Ymi-5 (potássica e titanada, cf. apêndice A5), Yzu-2, Yzu-3 (idem Ymi-5) e Yzu-6. Em Yzu-2 analisou-se um cristal (22.000) de grunnerita (potássica e titanada) (c) anfibólio sódico, ferro eckermanita $\left(\mathrm{Al}^{\mathrm{V}}>\mathrm{Fe}^{3+}\right)$, conforme Leake et al. (1997) em $\mathrm{Yzu}-2$ (Yzu-22.001, 22.002. 22.004 e 22.005). Os anfibólios de Yzu-2 como mostrado em (a) e (c) corresponderiam também a richterita (potássica e titanada; cf. apêndice A5) se calculadas no esquema 13-CNK ou 15 NK do programa Minpet 2.0 . Ver também fluxograma comentado no Capítulo 1. Simbologia como em 3-2. 
De modo geral, estas rochas são fortemente porfiriticas com caráter seriado, em parte com fenocristais de olivina, piroxênio, "leucita" e mais raramente mica (Yzu-2 e Yzu-3), e microfenocristais de espinélio, ilmenita (Yzu-3) e apatita (Yzu-3) imersos em uma matriz intergranular fina formada por piroxênio, espinélio, mica, feldspato alcalino, ilmenita (Yzu-2 e Yzu-3) e intersticialmente "leucita"/vidro alterado (Fotomicrografias 5 e 6). Como acessórios ocorrem perovsquita (Ymi-5), apatita e anfibólios.

Em Ymi-5, a "leucita" forma agregados cumuláticos de vários cristais que se interpenetram irregularmente. Nos espaços deixados entre os cristais, solidificou o fundido magmático (melt) desenvolvendo-se prismas alongados de piroxênio púrpura (nauve), que Presser (1991) os teria confundido com anfibólio.

Em Yzu-2, nos espaços entre cristais de feldspato alcalino, ilmenita, espinélio, mica. apatita e vidro alterado (?), pode ser observado anfibólio (Fotomicrografias 5 e 6 ) com hábito placóide, de cor salmão e marrom com pleocroísmo variábel de incolor a marrom, marrom rosa ou salmão e verde; que cristalizou com minerais azulesverdeados de alto relevo (faces roedderites?, cf. Wagner \& Velde, 1986).

Em Yzu 3, as estruturas brechadas, apresentam-se ao microscópio como campos granulares finos (matriz) envolvendo "fragmentos" de rocha granular mais fina (fragmentos "fantasmas" de aspecto túrbido). Neste trabalho analisou-se a química mineral de ambos componentes da brecha, tomando-se minerais com melhor resolução petrográfica encontrados como fenocristais e grãos da matriz. "Leucita" pseudomorfizada, olivina fraturada alotriomórfica, piroxênio verde-maçã e microfenocristais de ilmenita, espinélios e apatila estão contidos em matriz fina (intergranular), formada por feldspato alcalino, espinélio e mica marrom, sendo os minerais accessórios apatita prismática e traços de anfibólio. Os fragmentos apresentam os mesmos minerais, porém possuem uma matriz muito fina, algo túrbida (vidro alterado?, Fotomicrografia 5).

Os valores modais estimados destas rochas encontram-se na Tabela 3-3. Numa primeira aproximação classificar as rochas de leucita "lamproítos", conforme 


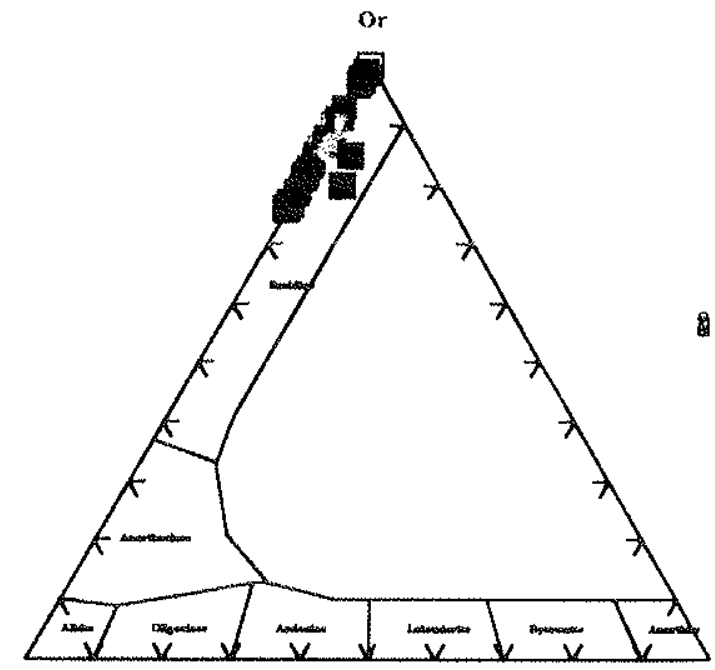

Ab
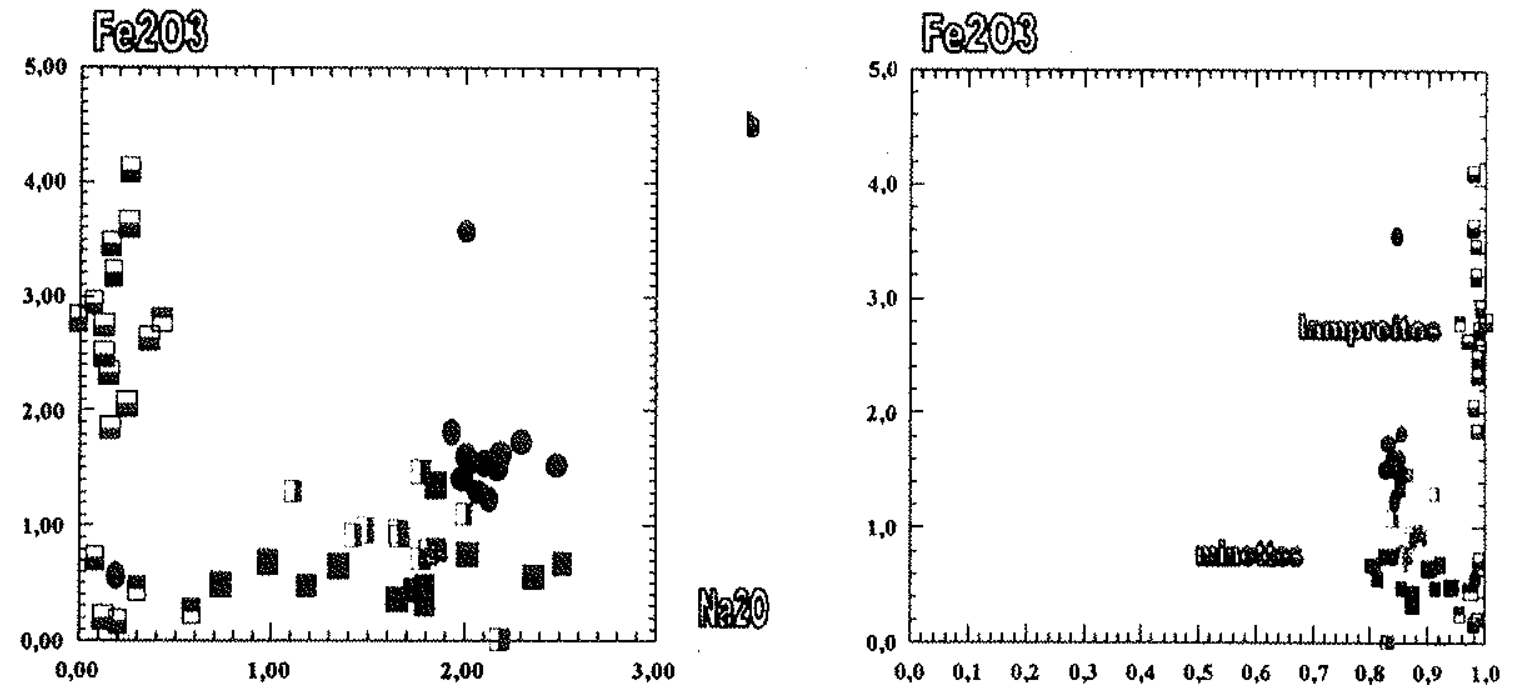

Figura 3-20. Feidsparo dos "lamproitos". (a) ciassificação no sistema Or-Àb-Ȧn mostrando sanidinas em Ymi-5, Yzu-2, Yzu-3 e Yzu-6. (b) $\mathrm{Fe}_{2} \mathrm{O}_{3}$ vs $\mathrm{Na}_{2} \mathrm{O}$ nas sanidinas referidas em (a), que mostram posicionamento, conforme esquematizado por Mitchell \& Bergman (1991), no campo próprio de lamproítos. (c) $\mathrm{Fe}_{2} \mathrm{O}_{3} v s \mathrm{~K} \#$ nas sanidinas de (a), que da mesma forma que em (b) mostram posicionamento conforme esquematizado por Rock et al. (1992), no campo próprio dos lamproltos e em parte também no campo dos minettes (Rock et al., 1992). Simbologia como em 3-2. 
esquema encontrado em Jaques et al. (1984). Em conformidade com as recomendações do IUGS (Woolley et al., 1996), as rochas das ocorrências discutidas são caraterizadas como:

olivina-feldspato alcalino-piroxênio-leucita "lamproito" (Ymi-5),

olivina-feldspato alcalino-mica-piroxênio-leucita "lamproíto" (YZU-2)e,

olivina-mica-feldspato alcalino-piroxênio-leucita "lamproito" (YZU-3).

\section{Química mineral}

De Min (1993) fornece dados químicos de alguns minerais de Yzú-3 que, junto aos analisados neste trabalho, são comentados a seguir

\section{Olivina}

Olivina ( $<10 \%$ modal) ocorre em Yzu-2 e Yzu-3 (Fotomicrografias 5 e 6) como microfenocristais submilimétricos e como fenocristais milímetricos, apresentando bordas finas a amplamente pseudomorfizadas por mica e/ou serpentina (Fotomicrografia 5). Em Yzu-3, as olivinas possuem formas anedrais, sendo que nelas podem ser observadas inclusões microscópicas de espinélio; conta-se com uma análise no apêndice A4. Já os microfenocristais em Ymi-5 estão totaimente serpentinizados, porém conservando, em parte, as formas idiomórficas.

Composicionalmente (apêndice A1) são crysolitas (Figura 3-14) que apresentam variações nosteores de NiO de 0.05-0.18\% (Yzu-2) e de 0.05-0.10\%, centro a $0.09 \%$. borda(Yzu-3); CaO de 0.32 a 0.48 (Yzu-2) e 0.12-0.15\%, centro e 0.12\%, borda (Yzu3). Apesar de algo diferenciadas em termos de mg\# e os teores em Ni, estas olivinas são similares as olivinas encontradas em alguns leucita lamproitos do mundo (cf. Mitchell \& Bergman, 1991). 


\section{Mica}

Microfenocristais amarronzados (pleocroismo amarelo mel a amarronzado), parcial a totalmente substituídos por espinélio e mica de segunda geração (similar às da matriz), são registrados em Yzu-2 (Fotomicrografia 3b). Na matriz das três intrusões, a mica ocorre intersticialmente em formas anhedrais a tabulares, algo idiomórficas (Fotomicrografias 5 e 6), de coloração amarronzado-avermelho (ex YzU-2) ao marrom abóbora (Yzu-3), apresentando pleocroísmo em tons de marrom a amarelo mel. Os cristais em geral incluem poiquiliticamente espinélios e apatita (p/ex. Yzu-2 e Yzu-3). Em Ymi-5, entre os glomérulos de "leucita" foram observados cristais de mica na forma de finos cristais ou lamelares.

Composicionalmente (apêndice A2) o microfenocristal analisado de Yzú-2 apresenta mg\# 0.85 e teores de $\mathrm{Al}_{2} \mathrm{O}_{3} \sim 13 \%, \mathrm{Cr}_{2} \mathrm{O}_{3} \sim 1.6 \%$ (com crômio), $\mathrm{TiO}_{2} \sim 3.5 \%$ (titanifero), $\mathrm{Na}_{2} \mathrm{O} \sim 0.15 \%$ e $\mathrm{BaO} \sim 0.15 \%$, caraterizando assim uma flogopita titanifera com crômio (Figura 3-5). Essa composição é parecida com alguns fenocristais encontrados em Leucite Hills (p/ex. Mitchell \& Bergman, 1991) e os microfenocristais encontrados em Yzu-1. Os cristais que ocorrem na matriz de Yzu-2 e Yzu-3 são flogopitas (Figura 3-5) com mg 0.7 (Yzu-2) a $\sim 0.8$ (Yzu-3) e teores de $\mathrm{Al}_{2} \mathrm{O}_{3}$ entre 8.90-10.09\% (Yzu-2) e 11.38-12.18\% (Yzu-3); $\mathrm{Cr}_{2} \mathrm{O}_{3}<0.1 \%$ em Yzu-2 e $\mathrm{Yzu}-3, \mathrm{TiO}_{2}$ desde $8.08-10.23 \%$ (Yzu-2) a 11.38-12.18\% (Yzu-3) (titaniferas), $\mathrm{Na}_{2} \mathrm{O}$ entre 0.49$0.971 \%$ em Yzu-2 e 0.21-0.42\% em Yzu-3, e BaO de $2.13-3.28 \%$ (Yzu-2) a 0.00$0.20 \%$ (Yzu-3). Estas feições químicas permitem caraterizá-las como a flogopitas titaniferas (Yzu-3) a flogopitas titaniferas pobres em alumínio (YzU-2 e Yzu-3). Trata-se de variedades de micas particulares de lamproitos (cf. Mitchell, 1985; 1995a-b; Bergman, 1987; Mitchell \& Bergman, 1991). Em Ymi-5 reconheceram-se dois grupos distintos de biotitas (Figura 3-5), ambas com $m$ g\# $<0.5$, sendo que os teores em $\mathrm{Al}_{2} \mathrm{O}_{3}$ variam de $10.00-13.78 \%$ (Grupo-I $=\mathrm{G}-1$ ) a $13.66-14.79 \%$ (Grupo-II $=\mathrm{G}-11$ aluminosas, em parte), $\mathrm{Cr}_{2} \mathrm{O}_{3}<0.6 \%$ (ambos os grupos), $\mathrm{TiO}_{2}$ desde $3.22-6.20 \%$ (G-I) a $3.88-9.43 \%$ (G-1I)(titaniferas), $\mathrm{Na}_{2} \mathrm{O}$ de $0.54-0.72 \%$ (G-I) a $0.66-0.73 \%$ (G-II) e; BaO entre $0.14-5.25 \%$ (G-1) e $5.90-7.38 \%$ (G-1l ricas em Ba). Essas feições caraterizam biotitas titaniferas (G-l, quadros vazios nas figuras) e biotitas 
titaníferas aluminosas ricas em Ba (G-ll, quadros cheios nas figuras). Biotitas são pouco freqüentes em lamproítos (Mitchell \& Bergman, 1991).

As micas de Yzu-2 e Yzu-3, como também boa parte das micas de Ymi-5, em termos de $\mathrm{Al}_{2} \mathrm{O}_{3}$ vs $\mathrm{TiO}_{2}$ e $\mathrm{Al}_{2} \mathrm{O}_{3}$ vs $\mathrm{FeO}$ espalham-se segundo um trend característico das micas de lamproitos, com diminuição do teor de Al e aumento do teor de $\mathrm{Ti}$ de $\mathrm{Fe}$ (Figuras 3-6 (a) e (b)). Na rochas de Ymi-5 o grupo caraterizado como sendo aluminoso identifica-se melhor com minettes e com rochas ultrapotássicas tipo Província Romana (cf. Rock, 1990; Rock et al., 1992; Mitchell, 1985; 1995a-b; Mitchell \& Bergman, 1991).

\section{Piroxênios}

Nas três ocorrências aqui estudadas os piroxênios apresentam-se como fenocristais prismáticos submilimétricos a milimétricos incolores a algo esverdeados, estando zonados setorialmente (p/ex. extinção hour glass). Eles são encontrados como cristais isolados (principalmente Yzu-2) a interpenetrados. Em Yzu-3 os cristais são algo mais coloridos de verde-maçã, que torna-se acentuado pelo fato de ter aspecto "sujo" adquirido por encontrarem-se carregados de inclusões microscópicas opacas e em parte também do fundido devitrificado (me/t), mica e espinélio; os cristais estăo zonados segundo um centro claro-esverdeado e esverdeado (algo pleocróico) fino a irregularmente grosso nas bordas, e ocorrem ou isoladamente, ou interpenetrados de forma irregular. Reconheceram-se outros cristais de aparência fraturada em Yzu-3, eles também de cor verde-maçã "sujo" (xenocristais?), que se apresentam também com muitas inclusões da matriz, mica e espinélios. Piroxênios de Ymi-5 evidenciam cores algo amarronzadas, mostram zoneamento (reconhecido sobretudo com ambos polarizadores inseridos no microscópio) e ocorrem como indivíduos isolados ou grupos interpenetrados. Cristais da matriz nas três intrusões são verde fraco a verde maçã sendo que, em YZu-2, foram observados cristais zonados (centro incolor e borda esverdeada e alguns cristais mostram bordas verde-folha, pleocróicos em tons de verde); e em Yzum3 os cristais, como alguns fenocristais, apresentam inclusões de opacos e micas; outros cristais são observados inclusos em alguns espinélios. Prismas alongados ocorrem junto aos glomérulos de "leucita" em Ymi-5, sendo de 
cor púrpura (nauve), alguns dos quais apresentando zoneamento segundo o centro incolor e borda colorida de púrpura, nela desenvolvendo marcado pleocroísmo (tons de marrom a púrpura vivo=nauve). Do mesmo modo que se observou em Yzu-2, alguns cristais desenvolveram bordas verde folha escuro pleocróicos (tons de verde); estas fases cristalinas que parecem terem sido abortadas no crescimento pelas formas compridas e as pontas irregulares, e serăo assim denominadas de cristais quench.

Como apontado acima, os piroxênios em Ymi-5 formam texturalmente três assembléias: fenocristais, matriz (Fotomicrografia 5) e quench; composicionaimente (apêndice A3) variam de diopsídios a diopsidios hedembergiticos (Figura 3-15 (a)) e possuem teores de $\mathrm{Al}_{2} \mathrm{O}_{3}$ entre $3.46-5.84 \%$ (fenocristais, centro) e $0.70-8.32 \%$ (bordas/matriz), 8.21 (centro -quench) a 8.55-10.17\% (borda -quench)(aluminosos); $\mathrm{Cr}_{2} \mathrm{O}_{3}<0.03$ (fenocristais), $<0.06$ (matriz) e $<0.09$ (quench); TiO $\mathrm{T}_{2}$ entre $1.76-2.94 \%$ (fenocristais, centro) a 1.60-4.41 (borda/matriz) e $4.54 \%$ (centro, quench) a 5.16 $6.17 \%$ (borda, quench); i.e. titanífero; e $\mathrm{Na}_{2} \mathrm{O}<0.5$ (fenocristais, centro) a $<0.75$ (borda/matriz) e 0.80-0.85 (quench, centro a borda). Estas feições quimicas permitem caraterizámlos como diopsidio titanífero aluminoso (fenocristais e matriz) e diopsidio hedenbergitico titanado aluminoso (quench). No sistema En-Wo-Fs (Figura 3-15 (a)) alguns dos piroxênios desta intrusão mostram-se com excesso das moléculas de Wo, e para eles o adjetivo de cálcicos seria de certa forma apropriado. Foi também realizada uma análise (apêndice $\mathrm{A} 3$ ) da fase quench que está envolvida de cor verde, encontrando-se $<0.7 \%$ de $\mathrm{Al}_{2} \mathrm{O}_{3}, 0.02 \%$ de $\mathrm{Cr}_{2} \mathrm{O}_{3}, 2.03 \%$ de $\mathrm{TiO}_{2}$ e $6.80 \%$ de $\mathrm{Na}_{2} \mathrm{O}$. Trata-se de uma aegirinamaugita titanifera (Figura 3-15 (b)). Teores elevados em Al são impróprios para rochas lamproíticas (cf. Mitchell, 1985; Bergman, 1987; Mitchell \& Bergman, 1991), sendo mais observado em rochas ultrapotássicas tipo Província Romana e/ou kamafugíticas (ex. Peccerello, 1992) e lamprófiros (ex. Rock, 1991). Como registrado por Garda (1995; 1996), em piroxênios de alnoitos e certos lamprófiros da região de São Sebastião-Ubatuba (SP), o diagrama En-Wo-Fs se apresenta inadequado para as classificações dos piroxênios analisados nessas rochas, devido aos baixos teores de Si que eles apresentam; os piroxênios de Ymi-5, como ilustrado na Figura 3-15, apresentam-se com reições similares; esta feição parece ser comum em piroxênios de algumas rochas alcalinas de Lages (Scheibe, 
1986), associadas a carbonatitos, alguns diques máficos da itha de Búzios (Alves, 1996) e os katungitos de Amorinópolis (Danni \& Gaspar, 1994).

Os piroxênios de Yzu-2 e Yzu-3, são composicionalmente (apêndice A3) mais uniformes e correspondem a diopsídios (Figura 3-15) com baixo teor de $\mathrm{Al}_{2} \mathrm{O}_{3}$ (0.56$0.97 \%$, centro e $0.39-1.53 \%$ em Yzu-2; $0.86-1.91 \%$, centro e $0.69-2.46 \%$, borda/matriz em Yzu-3), $\mathrm{Cr}_{2} \mathrm{O}_{3}(<0.54 \%$ em Yzu-2 e $<0.28 \%$ em Yzu-3), baixo a moderado em $\mathrm{Na}_{2} \mathrm{O}(0.32-0.93 \%$ em $\mathrm{Yzu}-2$ e $0.54-1.87 \%$ em $Y z u-3$ no centro a $0.53-$ $1.95 \%$ em Yzu-2 e $0.45-1.72 \%$ em Yzu-3 nas bordas/matriz), e moderados a altos em $\mathrm{TiO}_{2}(0.61-1.25 \%$ em Yzu-2 e 1.05-1.24\% em Yzu-3 no centro a 1.03-1.20\% em Yzu-2 e 0.98-1.55\% em Yzu-3 nas bordas/matriz, i.e. tiłanifero). Estas composições definem um diopsídio titanífero (pobre em alumina). Este tipo de diopsídio é encontrado em lamproitos, minettes e orangeítos (cf. Mitchell \& Bergman, 1991; Mitchell, 1995a). Apesar de medido piroxênio com $\mathrm{Al}_{2} \mathrm{O}_{3}>2 \%$ em $\mathrm{Yzu}-3$, que é uma feição incomum de observar em lamproitos (cf. Mitchell, 1985), a literatura registra lamproítos com piroxênios contendo teores de alumina de até $2.42 \%$ (cf. Kuehner \& Edgar (1981), para alguns lamproítos de Leucite Hills; Venturelli et al. (1984), para alguns lamproítos de Espanha e Scott-Smith et al. (1989), para alguns lamproitos de Kapamba). Piroxênios esverdeados e pleocróicos que ocorrem em Yzum-2 (apêndice A3 e Figura 3-15 (b)) e os teores em $\mathrm{TiO}_{2}$ (até $8.18 \%$ ) e $\mathrm{Na}_{2} \mathrm{O}$ (4-15\%) tratam-se de aegirina titanifera; contendo uma das análises (22.004b) possui alto teor nas moléculas de jadeíta (i.e. onfacita, Figura 3-15b). Em alguns lamproitos (ex. Venturelli et al., 1984; Conti et al., 1993) e orangeitos (Mitchell, 1995a) säo descritos aegirina e aegirina titanífera.

Yzu-2 e Yzu-3 (Figura 3-16 (b) e (c)) apresentam um trend de enriquecimento em Ti e Al característico de lamproitos e orangeitos. Já Ymi-5, segue um trend particular, i.e. paralelo ao observado em rochas ultrapotássicas tipo Província Romana, que parte do campo lamproítico/minette/orangeíto e extende-se até um pouco a mais do campo kamafugítico (Figura 3-16 (a)). 


\section{Espinélios}

Microfenocristais de seção quadrada a algo anhedrais, isolados a agrupados em mais de um cristal, cristais com seção quadrada, maiormente subhedrais, e cristais euhedrais microscópicos opacos inclusos em olivina formam a suite de espinélios presentes nas três ocorrências. Em Ymi-5, cristais de espinélio isolados a interpenetrados (Fotomicrografia 3) mostram microtextura do tipo cross-arm (cr. Haggerty, 1976).

Ymi-5 quimicamente (apêndice A4) são ricos em $\mathrm{TiO}_{2}$ (18-25\%), $\mathrm{FeO}_{\mathrm{t}}(61-66 \%)$ e $\mathrm{MnO}\left(0.5-3.45 \%\right.$, ricos em manganês) e pobres em $\mathrm{Al}_{2} \mathrm{O}_{3}(1-6 \%)$ e $\mathrm{MgO}(<1-4 \%)$. Essa composição leva a identificá-los, mais apropriadamente, como espinélios da série da magnetita (ulvoespinélio). Observa-se que o centro dos fenocristais apresenta-se, diferentemente dos cristais da matriz e da fase hospedeira dos cristais, com microtexturas de exsolução, mais enriquecidos em $\mathrm{MgO}$ e mais empobrecidos em $\mathrm{TiO}_{2}$ (a-hóspede e b-centro, no apêndice A4 e Figura 3-8). Estas feições químicas e as exibidas nas Figura 3-17 caracterizam magnetitas magnesianas titaníferas e magnetitas titaníferas (ricas em manganês, em parte), conforme 0 esquema indicado por Mitchell \& Bergman (1991).

Em Yzu-2 foi analisada uma inclusão de espinélio em olivina (apêndice A4). Ela possui alto teor de $\mathrm{Cr}_{2} \mathrm{O}_{3}\left(20.90 \%\right.$ ) e $\mathrm{MgO}$ (5.96\%) e baixo de $\mathrm{Al}_{2} \mathrm{O}_{3}$, $\mathrm{TiO}_{2}$ e $\mathrm{MnO}$ (ver apêndice A4), com cr\# 0.9 e mg\# 0.24. Essa composição representa um espinélios da série da cromita e segundo as indicações de Mitchell \& Bergman (1991) seria uma cromita magnesiana aluminosa titanífera (Figura 3-17 (a)). Por sua vez, microfenocristais e cristais da matriz, apresentam altos teores de $\mathrm{FeO}_{\mathrm{t}}(70-83 \%)$ e $\mathrm{TiO}_{2}(11-24 \%)$ e baixos de $\mathrm{Cr}_{2} \mathrm{O}_{3}(0.8-4 \%), \mathrm{Al}_{2} \mathrm{O}_{3}(<1.3 \%), \mathrm{MgO}(<1-3.2 \%)$ e $\mathrm{MnO}$ $(0.8-1.5 \%)$, identificando-se com os espinélios da série da magnetita; adiciona-se ainda valores de cr\# variando de 0.64-0.90 e mg\# <0.10, como mostrado nas Figuras 3-17 (a) e (b). Este conjunto de feições químicas caraterizam uma magnetita magnesiana titanifera e subordinadamente magnetita titanífera, seguindo as recomendaçōes de Mitchell \& Bergman (1991). Se comparados com os cristais da matriz, os fenocristais apresentam-se algo mais enriquecidos em magnésio, crômio e 
alumina e empobrecidos em titânio, ferro e manganês; este comportamento também foi registrado nos espinélios de Ymi-5.

Em Yzu-3, os espinélios possuem (apêndice A4) baixos teores de $\mathrm{Cr}_{2} \mathrm{O}_{3}(0.5-0.80 \%$ ), $\mathrm{Al}_{2} \mathrm{O}_{3}(0.15-0.7 \%), \mathrm{MgO}(0.25-1.70 \%)$ e $\mathrm{MnO}(0.2-1.2 \%)$ e altos teores de $\mathrm{TiO}_{2}(7-$ 13\%) e $\mathrm{FeO}_{\mathrm{t}}(79-85 \%)$. Semelhante aos de Ymi-5 e Yzu-2, são espinélios da série da magnetita (ulvoespinélios). Os valores baixíssimos de mg\# $(<0.08)$ e baixos a altos de cr\# (0.4-0.7), apontam feições químicas similares a uma magnetita magnesiana titanifera e uma magnetita titanifera (Figuras 3-17 (a) -(d)). Contudo, apresentam pequenas diferenças com relação aos espinélios de $Y z u-2$, em termos dos teores de $\mathrm{MigO}, \mathrm{TiO}_{2}$ e os valores de mg\# e cr\$.

\section{IImenita}

Em Yzu-3 ocorrem microfenocristais xenomórficos a euhedrais (matriz) de ilmenita pobres em $\mathrm{Cr}_{2} \mathrm{O}_{3}$ de 0.06 a $0.13 \%$ (porcentagens baixas da molécula de eskolaita) teores em MgO de 5.47 a $5.66 \%$ (porcentagens importantes da molécula de geikelita) e MnO de 1.01 a $1.12 \%$ (porcentagens baixas da molécula de pyrofanita) (apêndice A8). A Figura 3-18, mostra que as ilmenitas desta intrusão são similares às ilmenitas que ocorrem em lamproitos e orangeitos.

Cristais prismaticos longos submilimétricos milimétricos estão presentes na matriz de Yzu-2. São pobres em crômio (porcentagens baixas da molécula de eskolaíta) e possuem teores baixos de $\mathrm{MgO}$, entre 0.59 e $2.24 \%$ (porcentagens baixas da molécula de geikielita) e elevados em $\mathrm{MnO}$, entre 2.25 e $6.60 \%$ (porcentagens importantes da molécula de pyrofanita). A Figura 3-18 evidencia como no caso anterior, que as ilmenitas de Yzu-2 são similares às descritas nos lamproítos (ct. Mitchell \& Bergman, 1991; Venturelli et al., 1984; 1991; Thy et al., 1987; Conti et al., 1993).

\section{"Leucita"}

Em Ymi-5 ocorrem glomérulos de cristais milimétricos reunidos em grande proporção, compõem-se de grãos arredondados incolores a amarronzados nas 
bordas, alguns com centros apresentando fina laminação polissintética em grade. Conforme indicado por Giampaolo et al. (1997), trata-se de uma feição também desenvolvida em analcimas. Conforme os dados da Tabela 6 (apêndice A6) tratamse de analcimas com baixo teor de $\mathrm{Fe}_{2} \mathrm{O}_{3}(<1 \%)$. As feições petrográficas, aliadas ao quimismo desta rocha, (Tabela 3-2) sugerem são leucitas analcimitisadas (i.e. "Leucita").

Já em Yzu-2, cristais arredondados incolores a esbranquiçados, em parte turvos (Fotomicrografias 6), com dimensões variáveis (cristais de matriz a microfenocristais) ocorrem como cristais isotrópicos (pseudomorfizados pela analcima) a birrefringentes segundo agregado microtabular, algo radial, de feldspato alcalino. Aqui, os pseudomorfos de leucita isotrópicos apresentam grandes variações em $\mathrm{K}_{2} \mathrm{O}$, desde $<1 \%$ a $8 \%$ e $\mathrm{Fe}_{2} \mathrm{O}_{3}$ de $<1$ a $3 \%$ (apêndice $\mathrm{A6}$ ), sendo assim similares a "leucitas" descritas nos lamproitos (Mitchell 1985, Mitchell \& Bergman 1991).

Em Yzu-3 os fenocristais apresentam-se totalmente pseudomorfisados pelo agregado de feldspato/zeólitas com formas radiais a escamosas.

\section{Feldspato alcalino}

Na matriz destas rochas o feldspato alcalino ocorre na forma de cristais tabulares a cristais irregulares, em parte poiquilíticos (p/ex. Yzu-3) ou intersticiais, ora limpidos, ora turvos e argilizados (Fotomicrografia 5 e 6 ).

São feldspatos potássicos do tipo sanidina (Figura 3-20) com teores em $\mathrm{Na}_{2} \mathrm{O}$ baixos (0.00-0.59\% em Yzu-2) a altos (1.12-2.19\% em Yzu-3 e 0.74-2.52\% em Ymi-5) e $\mathrm{Fe}_{2} \mathrm{O}_{3}$ moderado a alto $(0.29-1.23 \%$ em $\mathrm{Ymi}-5,0.15-3.69 \%$ em $\mathrm{Yzu}-2$ e $0.01-1.32 \%$ em $\mathrm{Yzu}-3$ ); nos casos em que $\mathrm{Fe}_{2} \mathrm{O}_{3}>1.0 \%$ indicam importante participação da molécula $\mathrm{KFeSi}_{3} \mathrm{O}_{8}$ (ricos em $\mathrm{Fe}$ ), como verificado por Linthout \& Lustenhouwer (1993) nos lamproítos de Cancarix, Espanha). Em alguns casos são ricos em BaO até 4.10\% em Ymi-5, 2.60\% em Yzu-2 e 1.58\% em Yzu-3, sugerindo importantes porcentagens da molécula de hyalofana, igualmente verificado nos lamproítos da Índia (Middlemost et al., 1988)(ricos em Ba) (apêndice A7). Estas feições químicas caraterizam o feldspato como sanidinas, sanidinas ferrosas e sanidinas ricas em 
bário. Tipos similares de feldspatos alcalinos ocorrem (Figura 3-20) ocorrem em lamproítos e orangeítos (Mitchell, 1995a; Mitchell \& Bergman, 1991).

\section{Minerais acessórios}

Em Ymi-5 os minerais acessórios são: apatita, perovskita com baixo SrO $(<1 \%$, apêndice A8) e anfibólio cummingtonítico (Figura 3-19); este último com 1-4\% de $\mathrm{TiO}_{2}$ (em parte titaníferos, como indicado em Leake et al., 1997), <1\% de $\mathrm{Na}_{2} \mathrm{O}$ e de 9-12\% de $\mathrm{K}_{2} \mathrm{O}$ (potássicos, segundo Leake et al., 1997)(apêndice A5); (Figura 3-19).

Em Yzu-2 ocorrem na matriz apatita e anfibólios amarronzados a verdes (Fotomicrografias 5 e 6), que representa as variedades (Figura 3-19): eckermanita ferrosa potássica $\left(\mathrm{Na}_{2} \mathrm{O} / \mathrm{K}_{2} \mathrm{O}\right.$ entre $<1$ e 6.1) titanifera $\left(\mathrm{TiO}_{2}\right.$ entre 2 e $9 \%$ ), similar à composição de alguns anfibólios analisados por Thy et al. (1987) em lamproítos de Sisimiut; e variedades secundárias (?) antofilita (22.003, apêndice A5) potássica $(K>0.25)$ e grunerita $(22.000)$ potássica $(K>0.25)$.

Em Yzu-3 é abundante a apatita, sendo também encontrado anfibólio cummingtonítico rico em titânio (titanífero) e potássio (potássico)(apêndice A5).

As feições químico-mineralogicas caraterizadas para estas intrusões permitem enquadra-los, conforme as recomendações da IUGS (Wooley et al., 1996), como:

olivina-sanidina-diopsídio-leucita "lamproito" (Ymi-5),

olivina-sanidina-flogopita-diopsiodio-leucita "lamproito" (YzU-2) e

olivina-flogopita-sanidina-diopsidio-leucita "lamproíto" (Yzu-3). 

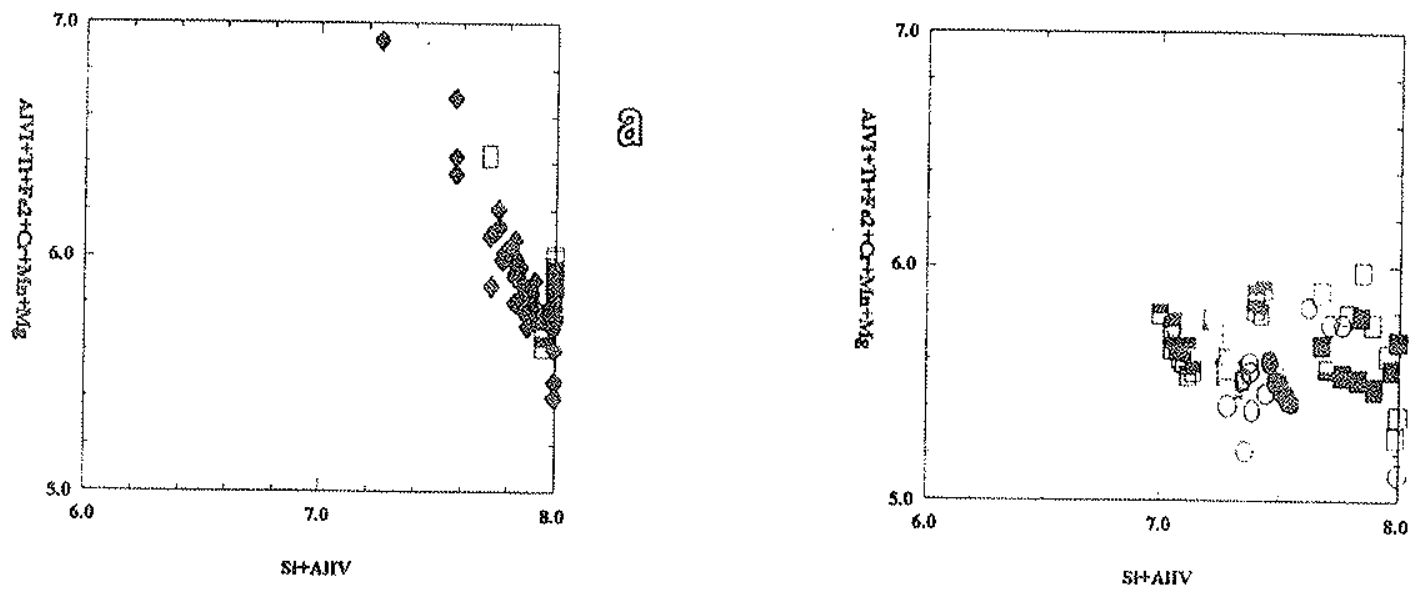

(b)

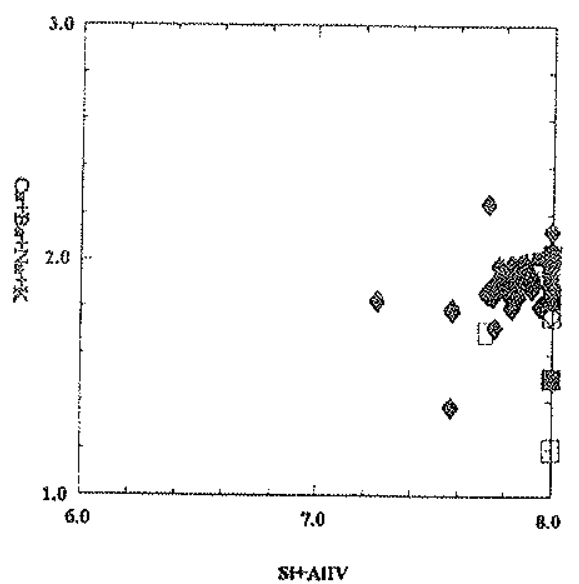

C
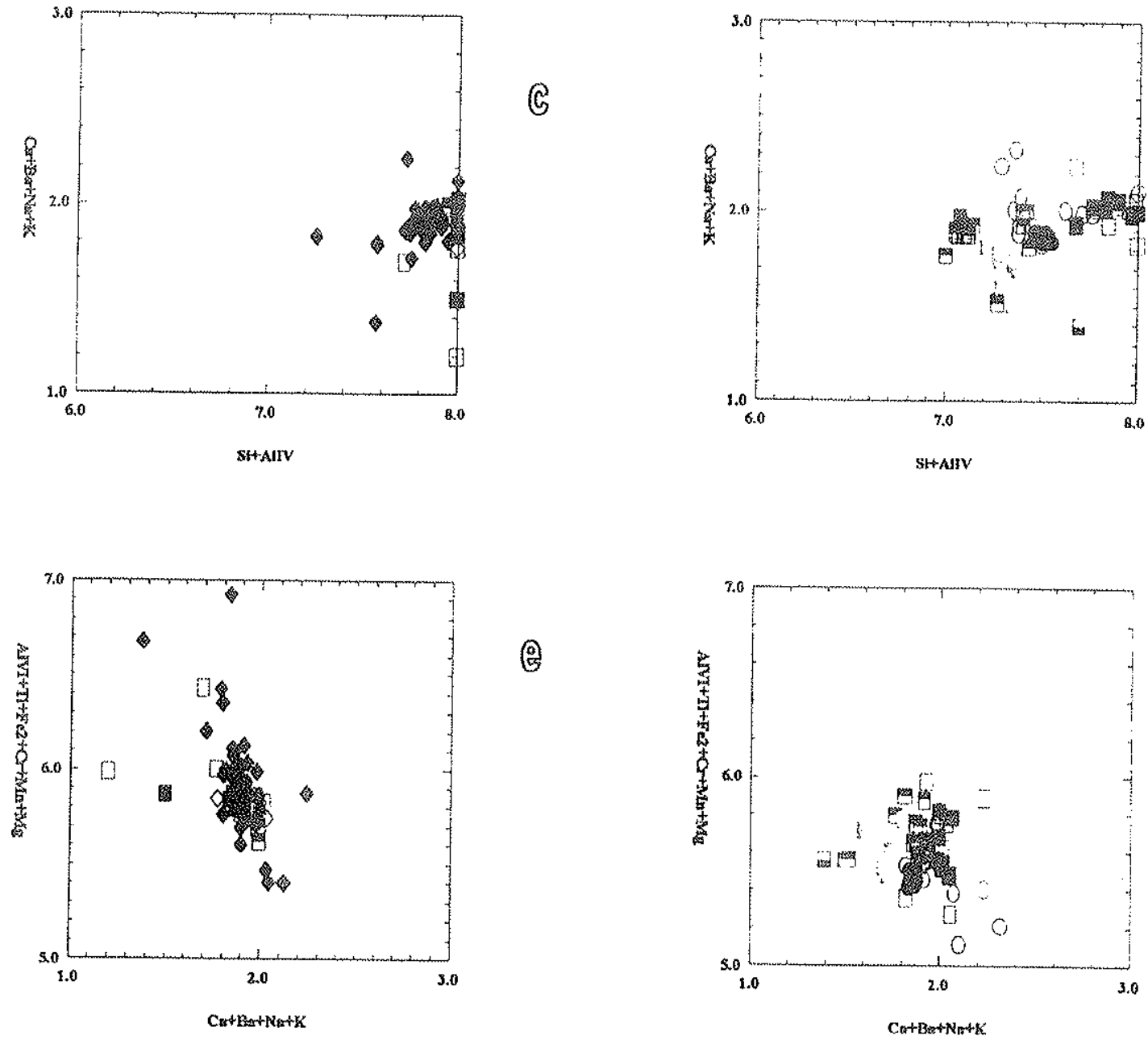

Wiggurara 3-21. Relação entre os sítios catiônicos nas micas dos "lamprófiros" e dos "lamproítos", (a, b) relação do sitio octaédirico vs tetraédrico. $(c, d)$ relação do sitio interlayer vs tetraédrico. (e, f) relaçăo do sitio octaédrico vs interloyer. "Lamprofiros" a direita e "lamproítos" a esquerda. Simbologia como em 3n2. 


\section{SOLUÇÃO SÓLIDA, SUBSTITUIÇÕES EM MICAS, PIROXÊNIOS, ESPINÉLIOS E FELDSPATOS.}

\section{Micas}

Mitchell (1985; 1995a-b), Mitchell \& Bergman (1991), Rock (1991) e Rock et al. (1992) mostram os trends de composição em termos do enriquecimento em Al vs Ti e Al vs Fe caraterísticos para kimberlitos, orangeítos, lamproítos, minettes que poderia estender-se como aplicado aos lamprófiros em geral) e plagileucitos. Esquematiza-se no seguinte esquema de enriquecimento:

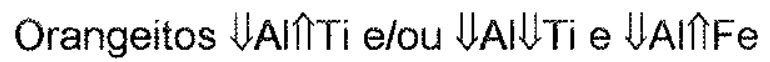

$$
\begin{aligned}
& \text { Lamproitos } \text { AAITTi e } \Downarrow A I T F e
\end{aligned}
$$

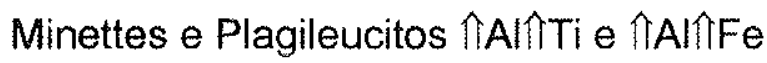

(A)

$O$ trend de enriquecimento nas micas de Yzu-2, Yzu-3, Yzu-6 e as de G-I de Ymi-5 em termos de Al vs Ti segue o esquema (B); enquanto o enriquecimento em $A l$ vs Fe seguem o esquema (B) apenas em micas de Yzu-2, Yzu-3 e as G-1 de Ymi-5 (Figuras 3-6 (c) e (d)) sendo caraterísticamente verificado em lamproítos. Entretanto, Yzu-6 evidencia um trend particularmente observado em orangeítos (cf. Mitchell, 1995a-b). Nas micas de G-ll de Ymi-5 observa-se trend de enriquecimento de Al vs Ti e Al vs Fe (Figuras 3-6c e d) similar ao esquema (C). Esta feição parece indicar que Ymi-5 poderia apresentar assembléias de micas de dois magmas diferentes, um lamproítico (micas G-1) e um outro plagileucítico (micas G-11).

A Figura (3-6a e b) mostra o trend de enriquecimento seguido pelas micas de $\mathrm{Ymi}-1$ e Ymi-7, possuindo um idêntico trend de enriquecimento dos esquemas $B$ e $C$ (também parece que a mesma figura sugere que as duas intrusões poderiam tratarse do mesmo tipo de magma, ou magmas congênitos). Em Ymi-4 observa-se similar enriquecimento ao de Ymi-1 e Ymi-7; contudo nas micas de Ymi-4 é marcado o trend 
de enriquecimento similar ao dos minettes (esquema $\mathrm{C}$ ), conforme Mitchell \& Bergman (1991).

Grande número dos pesquisadores contam com dados de microanálise de micas nas quais faltam os valores de $\mathrm{H}_{2} \mathrm{O}$ e, na maioria das vezes, também os dados dos elementos halógenos; assim sendo, esses resultados são recalculados na base de 22 átomos de oxigênio, assumindo que todo o $\mathrm{Fe}$ é $\mathrm{Fe}^{2+}$. Esta forma de cálculo assume a presença de $4(\mathrm{OH}, \mathrm{F}, \mathrm{Cl})$. Assim a presença do excesso do oxigênio devido a solução sólida de um componente de oxy-mica $\left(\mathrm{O}^{2-} \Leftrightarrow 2 \mathrm{OH}^{-},={ }^{\mathrm{V}} \mathrm{R}^{2+}+2 \mathrm{OH}^{-}\right.$ $\Leftrightarrow \mathrm{VI}^{4 *}+2 \mathrm{O}^{2-}+\mathrm{H}_{2}$, em Dymek 1983) poderia levar o número total de cations demasiadamente baixos. Nestas circunstâncias, a distribuição dos cátions nos sítios estruturais pode produzir aparentes sitios totais, fato que poderia implicar a presença de vacâncias. Em contraposição, a presença de $\mathrm{Fe}^{3+}$ levaria a porcentagens de cations demasiadamente elevadas se o cálculo de fórmula-unitária assume que todo o Fe está presente como Fe $e^{2+}$ (Dymek, 1983), (Henderson \& Foland, 1996).

Flogopitas e biotitas podem ser empregadas para avaliar a atividade magmática em função de $f_{\mathrm{O} 2}$ e $f_{\mathrm{H} 2 \mathrm{O}}$ considerando que estes minerais possuem $\mathrm{Fe}$ nas valências $\mathrm{Fe}^{2+}$ e $\mathrm{Fe}^{3+}$ e proporções variáveis de hidroxila na sua estrutura. A incorporação do $\mathrm{Fe}^{2+} \mathrm{e}$ do $\mathrm{Fe}^{3+}$ na solução sólida flogopita-biotita pode ocorrer como componente oxi-annita $\left(\mathrm{KFe}^{2+} \mathrm{Fe}^{3+}{ }_{2} \mathrm{AlSi}_{3} \mathrm{O}_{12}\right.$ ) ou como outro componente semelhante de composição $\mathrm{KMgFe}_{2}^{3+}{ }_{2} \mathrm{AlSi}_{3} \mathrm{O}_{12}$ (Feldstein et al., 1996). Os métodos de recálculo do $\mathrm{Fe}^{2+}$ e $\mathrm{Fe}^{3+}$ a partir do FeO analisado por microanálises são citados em Brigatti et al. (1996); são métodos de difícil acesso e nem sempre aceitos, por exemplo por Mitchell (1995). No presente trabalho não foram feitos recáiculos das valências de $\mathrm{Fe} e$, assim, no apêndice A2, são apresentados os dados catiônicos com seus cálculos estruturais realizados na base de 22 oxigênios e assumindo todo o $\mathrm{Fe}$ como $\mathrm{Fe}^{2+}$.

Observa-se que as micas de Ymi-1 (matriz), algumas de Ymi-7, e uma de Ymi-4 e sobretudo as micas de Ymi-5, Yzu-2, Yzu-3 e Yzu-6 apresentam deficiências no sítio tetraédrico $\left(\mathrm{Si}^{\mathrm{IV}}+\mathrm{Al}^{\mathrm{IV}}<8.00\right)$, como mostrado na Figura 3-21. Também são observadas deficiências nos sítios octaédricos $\left(\mathrm{Al}^{\mathrm{VI}}+\mathrm{Ti}^{\mathrm{V} / 4+}+\mathrm{Fe}^{2+}+\mathrm{Cr}^{3+}+\mathrm{Mn}^{2+}+\mathrm{Mg}^{\mathrm{VI} 2+}\right.$ $<6.00)$ nas micas dos lamproítos e em algumas micas dos lamprófiros, enquanto 


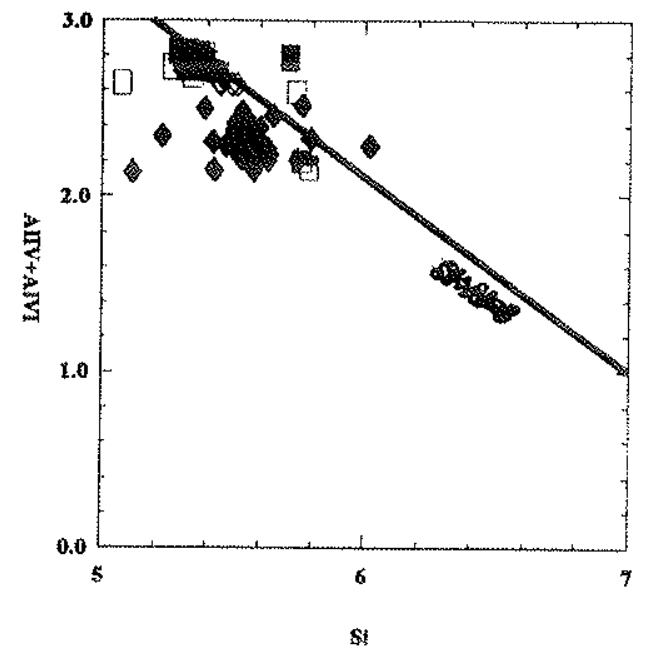

苗
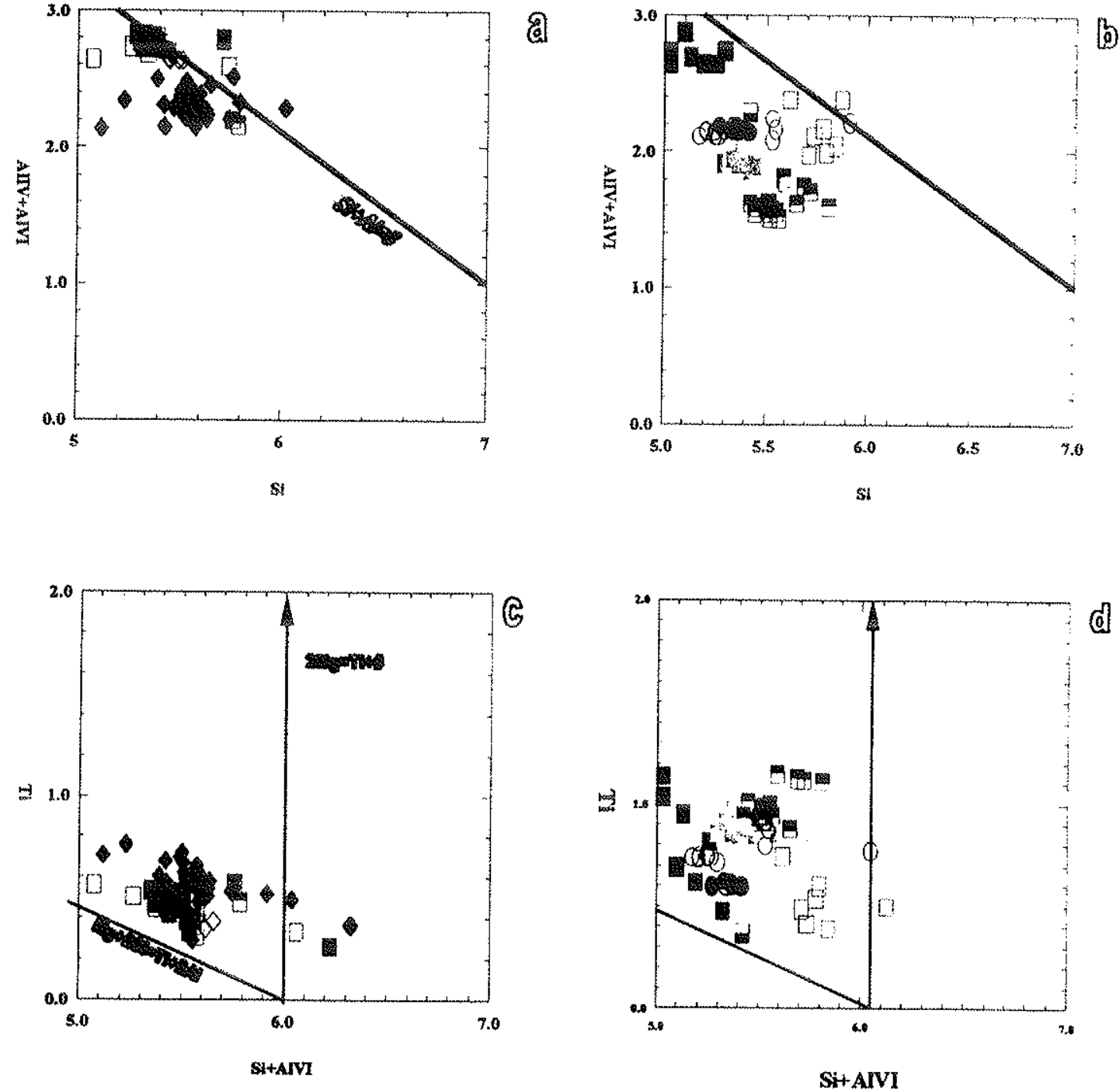

Figura 3-22. Substituiç̃es em micas dos "lamprófiros" e "lamproítos". (a) e (b) micas nos sítios tetraédricos $(\mathrm{Si}+\mathrm{Al}=8$ ) sendo completado em Ymi-1 (fenocristais de Ymi-1c. e alguns da matriz), Ymi-4, Ymi-7 e Yzu-1 (veja-se o apêndice A2). Deficiência de Al é observado em gräos da matriz de Ymi-1 e bordas das micas e matriz. de Ymi-7, assim como também nas micas dos "lamproítos" (b). (c) substituição do tipo Mg+2Si $\Leftrightarrow \mathrm{Ti}+2 \mathrm{Al}$ (cf. Robert 1976) pode ser deduzido nas mesmas micas dos "lamprófiros", enquanto, nos "lamproitos" esta substituição é mais sưul. Simbologia cono em 3-2. 
algumas micas de Ymi-1 (matriz) apresentam excessos neste mesmo sitio (Figuras 3-21).

As micas de Ymi-1 sugerem (Figura 3-21a) uma relação inversamente proporcional do sítio octaédrico com relação ao tetraédrico, pois o Fe foi totalmente alocado no sítio octaédrico devido à determinação do $\mathrm{Fe}_{\mathrm{t}}$ como $\mathrm{Fe}^{2+}$. A mesma observação pode ser feita para o $\mathrm{Ti}$ e o $\mathrm{Mg}$, que podem apresentar-se como $\mathrm{Ti}^{3+}$ e $\mathrm{Ti}^{4+} \mathrm{Mgg}^{4+}$ e $\mathrm{Mg}^{2+}$ respectivamente. A presença de $\mathrm{Fe}^{3+}$ no $\mathrm{Fe}_{\mathrm{t}}, \mathrm{Ti}^{4+}$ no $\mathrm{Ti}_{\mathrm{t}}$ e $\mathrm{Mg}^{2+}$ no $\mathrm{Mg}_{\mathrm{t}}$, não calculados para a distribuição estrutural apresentado no apêndice A2, poderia causar o excesso no sítio octaédrico: $\mathrm{Fe}^{3+}\left(\mathrm{Fe}^{\mathrm{IV3+}}\right)$ como o end member "tetraferriflogopita" (Wendlandt, 1977; Arima \& Edgar, 1981; Mitchell \& Bergman 1991; Mitchell 1995a); $\mathrm{Ti}^{4+}$ e $\mathrm{Mg}^{2+}$ por sua vez, preencheriam a deficiência no sítio tetraédrico (Mitchell, 1995a; Henderson \& Foland, 1996; Brigatti et al., 1996). Desta forma, estas feições poderiam explicar a relação inversamente proporcional mostrada na Figura 3-21.

As deficiências nas posições octaédricas e tetraédricas não seriam devidas aos procedimentos de recálculo cationico realizados, como acima ressaltado, e acredita se que poderiam ocorrer em virtude às condições fisico-químicas no magma do qual estas micas cristalizaram (lamprofírico e lamproítico); neste caso seriam magmas deficientes em Al. Esta deficiência pode ser interpretada como sendo produto da peralcalinidade do magma que se incrementa conforme a diferenciação avança (Mitchell \& Bergman, 1991; Mitchell, 1995a), traduzido pelas micas com falta de $\mathrm{Al}^{\mathrm{VI}}$ e Fe elou falta de cálculo do $\mathrm{Fe}_{t}$ como $\mathrm{Fe}^{2+}$ e $\mathrm{Fe}^{3+}$.

As posições inter-catiônica $(\mathrm{Ca}+\mathrm{Na}+\mathrm{K}=2)$ estão predominantemente preenchidas sendo poucos os grãos com deficiência ou com excesso (Figura 3-21). O cálculo da fórmula estrutural na base de números constantes de cátions nos sítios octaédricos e tetraédricos $(8.00+6.00)$ resulta em excesso de cargas para os cátions, sugerindo indistintamente estados de valência variável ou vacância de cátions (Shaw \& Penczak, 1996).

As Figuras 3-22 (a) e (b) exibem a relação Al vs Si e de certa forma também a deficiência vs preenchimento da posição tetraédrica nas micas estudadas. As micas 

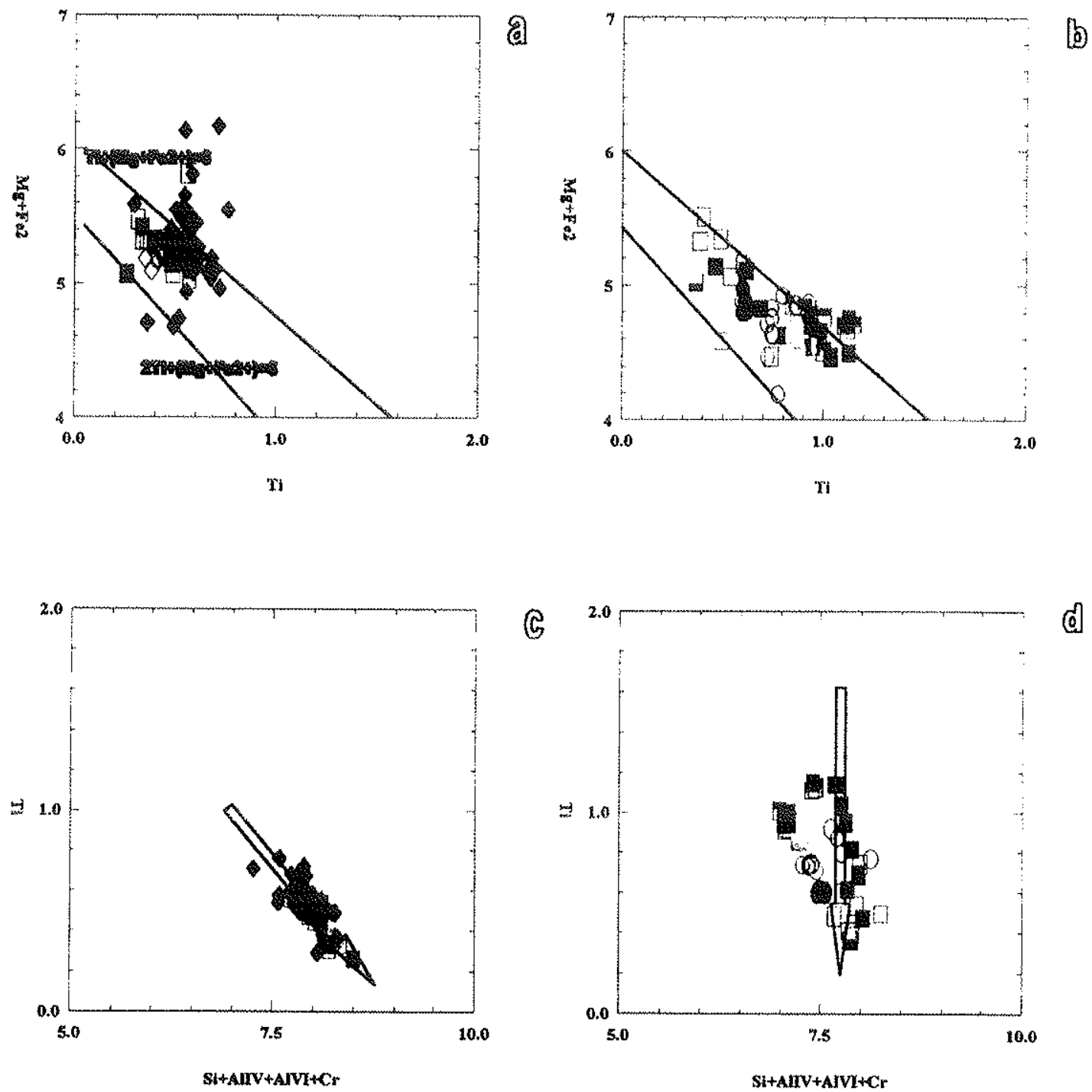

Figura 3-23. Substituiçóes do Ti nas micas. (a) e (b): Correlaça do Ti vs $\mathrm{Mg}+\mathrm{Fe}^{2+}$ (este último elemento nas micas analisadas representa o $\mathrm{Fe}_{\mathrm{q}}$ ) para mostrar a substituição do Ti no sítio tetraédrico (cf. Shaw \& Penczak 1996), que nos "lamprófiros" (a) e nos "lamproítos" (b) parece corresponder à equação Ti $+\left(\mathrm{Mg}+\mathrm{Fe}^{2+}\right)=6$ porém der certa forma tendendo $2 \mathrm{Ti}+\left(\mathrm{Mg}+\mathrm{Fe}^{2+}\right)=6$, pois o valor de $\mathrm{Mg}+\mathrm{Fe}^{2+}$ esta mascarado pelo fato de incluir $\mathrm{Fe}^{3+}$. (c): Correlaça negativa entre Ti vs Si+Al+Cr em micas dos "lamprófiros", feiçao que segundo Wagner \& Velde

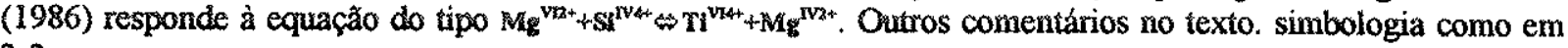
$3-2$. 
ricas em Ti e Ba geralmente apresentam deficiências no sítio octaédrico (Mitchell \& Bergman, 1991; Zhang et al., 1993), sendo propostos numerosos esquemas de substituição:

$2 \mathrm{Mg}^{\mathrm{Vi2}} \Leftrightarrow \mathrm{ri}^{\mathrm{VIA+}}$

Forbes \& Flower (1974)

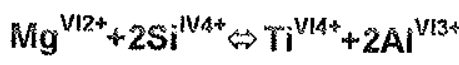

Robert (1976)

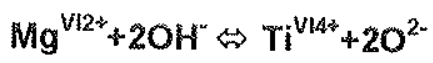

Arima \& Edgar (1981)

$\mathrm{Mg}^{\mathrm{V} 12+}+\mathrm{Si} \mathrm{i}^{\mathrm{IN4+}} \Leftrightarrow \mathrm{Ti}^{\mathrm{V} 14+}+\mathrm{Mg}^{\mathrm{IV2+}}$

Wagner \& Velde (1986)

$\left(\mathrm{Mg}, \mathrm{Fe}^{2+}\right)^{\mathrm{VI}}+2 \mathrm{Si}^{\mathrm{IV}} \Leftrightarrow \mathrm{Ti} \mathrm{V}^{\mathrm{V} / 4+}+2\left(\mathrm{Al}, \mathrm{Fe}^{3+}\right)^{\mathrm{VI}}$

(Zhang et al. 1993)

$\mathrm{R}^{\mathrm{V} / 2 *}+2 \mathrm{OH} \Leftrightarrow \mathrm{Ti}^{\mathrm{V} 14 *}+2 \mathrm{O}^{2-}+\mathrm{H}_{2}$

(Dymek 1983)

(Que eleva o end member "Ti-oxy-biotita" $\quad \mathrm{KMg}_{2} \mathrm{TiSi}_{3} \mathrm{AlO}_{12}$ ).

As Figuras 3-22 (c) e (d) sugerem para as micas dos "lamprófiros" a substituição do tipo representado pela equação (2), substituição menos evidenciada nas micas dos "lamproítos" (Figura 3-22 (d)). Na Figura 3-23 (a) e (b) constata substituição do Ti nas posições deficientes, $\left(\mathrm{Si}+\mathrm{Al}=8\right.$ ) ao empregar Ti vs $\mathrm{Mg}+\mathrm{Fe}^{2+}$ (cf. Shaw \& Penczack, 1993), sendo que as quantidades de $\mathrm{Fe}^{2+}$ nestas figuras estão levemente mais elevadas, pelo fato de não ter-se subtraído delas o $\mathrm{Fe}^{3+}$. Nas últimas figuras citadas a substituição do Ti dar-se-ia segundo a equação $\mathrm{Ti}+(\mathrm{Mg}+\mathrm{Fe})=6$ (Shang et al., 1993). Na Figura 3-27c se observa uma correlação negativa entre $\mathrm{Ti}$ e $(\mathrm{Si}+\mathrm{Al}+\mathrm{Cr})$; segundo Mitchell \& Bergman (1991), responderia ao tipo de substituição do tipo da equação (4) que não se observa nas micas dos lamproítos (Figura 3-23d). A possibilidade de substituições ou não segundo equações dos tipos (3), (5) e (6) torna-se sem resposta em consequência da falta de análises de $\mathrm{OH}$ e do cálculo do $\mathrm{Fe}^{3+}$ nas micas estudadas.

Segundo Mitchell \& Bergman (1991), as complicações surgem quando há substituições nos sítios inter-layer ( $=12$-fold), sendo típico que $(\mathrm{Ca}+\mathrm{K}+\mathrm{Na})$ seja próximo a 2/átomos por fórmula unitária. 

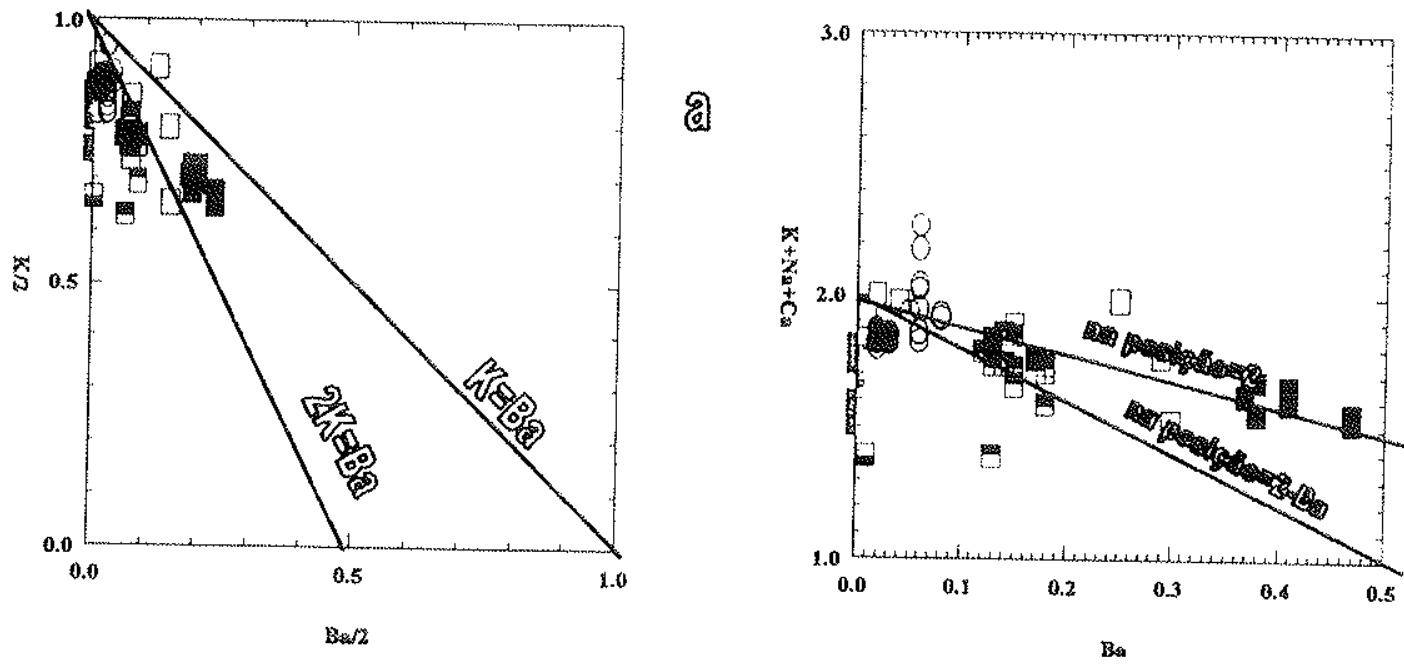

(b)

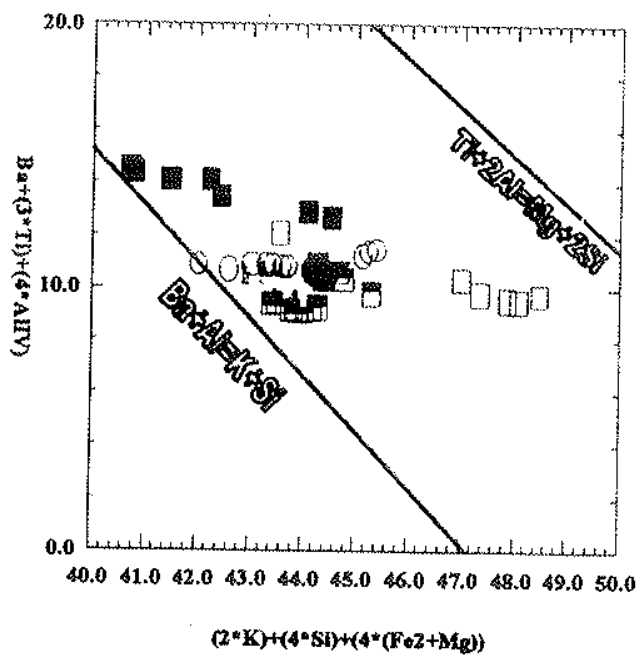

C

Figura 3-24. Incorporaçã̃o do Ba. (a) substituição do $2 \mathrm{~K}$ por $1 \mathrm{Ba}$ (Mitchell \& Bergman, 1991) nas micas de Ymi-5, Yzu-2 e algumas de Yzu-6. (b) substituição do Ba na posição interlayer (Shaw \& Penczak, 1996) das micas como em (a) respondem a "ma posição $=2-\mathbf{B a}$ ", analogamente a (a). (c) partição do Ba vs posição inter comparar também Mitchell \& das micas como em (a) respondem mais adequadamente a $\mathbf{B a}+\mathbf{A l}=\mathbf{K}+\mathrm{Si}$; ver e comparar também Mitchell \& Bergman (1991). Ver também comentáios no texto. Simbologia como em 3-2. 
Micas com teores de $\mathrm{Ba}$ altos a muito altos são encontradas em $Y$ mi-5 e algumas micas de Yzu-2, sendo que as micas de Yzu-3 e Yzu-6 apresentam teores desse elemento bem mais baixos (apêndice A2). As micas de Ymi-5, Yzu-2, Yzu-3 e Yzu-6, conforme Figura 3-24 (a) e (b), seguem a substituição do tipo:

$2 \mathrm{~K} \Leftrightarrow 1 \mathrm{Ba}$. Segundo Mitchell \& Bergman (1991) a substituição do $\mathrm{Ba}^{2+X \|}$ pelo $\mathrm{K}^{+\times \mathrm{XI}}$ envolve compensações de carga que resulta na criação no sítio inter-layer não preenchidas, i.e.,

$2 K^{+X I I} \Leftrightarrow 1 \mathrm{Ba}^{2+X I_{+}} \quad$ (7) (Mitchell, 1981; Wagner \& Velde, 1986),

ou esta substituição envolve complexos acoplamentos entre cations nas posições octaédricas e inter-layer semelhantes a: $\mathrm{Ba}^{\mathrm{XI}}+\mathrm{Al}^{\mathrm{IN}} \Leftrightarrow \mathrm{K}^{\mathrm{X} \|_{+}}+\mathrm{Si}^{\mathrm{in}}$ 1977; Mansker et al., 1979)

(8) (Wendlandt,

Por outro lado, na Figura 3-23 (c) observa-se que as mesmas micas seguem melhor

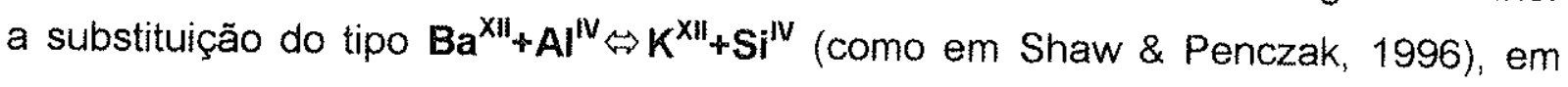
preferência a $\mathrm{Ti}+2 \mathrm{Al} \Leftrightarrow \mathrm{Mg}+\mathbf{2 S i}$ (Shaw \& Penczak, 1996).

Velde (1979) propôs, para as micas com alto teor de BaO, o seguinte esquema de substituição:

$3 M \mathrm{MvI}^{2+} \Leftrightarrow \operatorname{TivI}^{4+}+\mathrm{BaxII}^{2+++}+\square \mathrm{xII}$

Segundo Bol et al. (1989) existe uma repulsão eletrostática entre o $\mathrm{Ba}^{2+}$ e $\circ \mathrm{Ti}^{4+}$ que poderia incrementar a energia da cela do cristal. Este fato leva a crer na impossibilidade de provar a equação (9) nas micas com alto Ba (Robert, 1976 e Forbes \& Flower, 1974).

As informações químicas obtidas sugerem que as micas de Ymi-1, Ymi-4, Ymi-7 e Yzu-1, como observadas nas Figuras 3-5 (a) e (c) pertecem a série de solução sólida entre os end members flogopita-biotita-eastonita-siderofilita. As micas de Ymi-1, conforme constata-se no apêndice A2, são em sua maioria micas deficientes em Allv; isto também pode ser demostrado observando a Figura 3-21 (a); esta feição mostra 


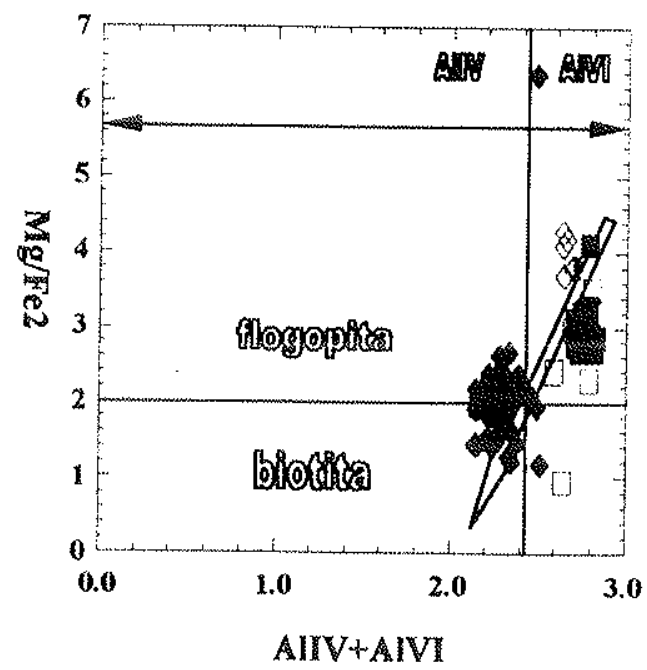

๑

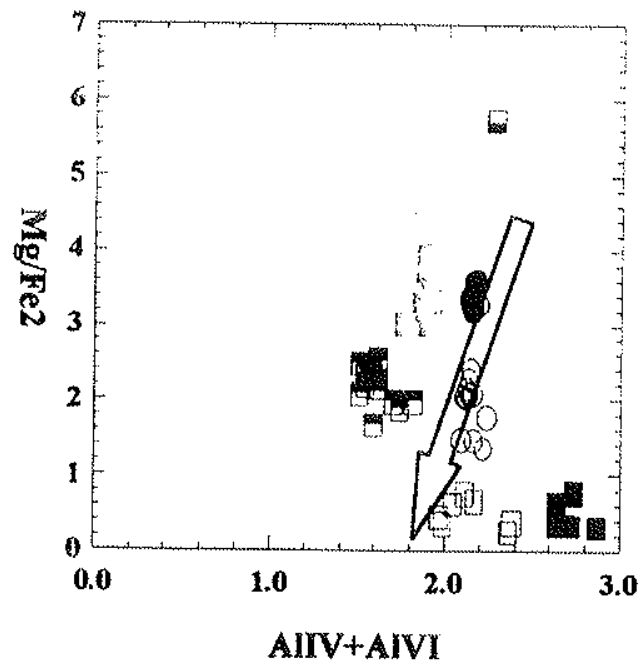

(b)

Figura 3-25. Solução sólida em micas. (a) micas dos corpos Ymi-1 (plug e diques interiores, rombos cheios; dique Ymi-lc, rombo vazio), Ymi-4 e Ymi-7 (simbologia como em 3-2). A seta indica o rumo tomado pelas micas conforme elas se diferenciam, i.e., eastonita $\rightarrow$ biotita (b) micas de Ymi-5, Yzu-2, Yzu-3 e Yzu-6. A seta mostra como as micas de Ymi-5 (GI), Yzu-2, Yzu-3 e Yzu-6 seguem um caminho de diferenciação diferente doque parece responder a flogopita $\rightarrow$ biotita. Na figura superior a seta rumo a direita marca $\sim$ o campo de $\mathrm{Al}^{\mathrm{VI}}$ e o dirigido a esquerda $\sim 0$ campo de $\mathrm{Al}^{\mathrm{IV}}$. Simbologia como em 3-2. 
que elas, mais propriamente, säo produtos da solução sólida entre flogopita-annita (Mitchell \& Bergman, 1991, Mitchell, 1995a).

Os fenocristais de mica nas rochas de Ymi-1c, Ymi-4 e Ymi-7 e em parte também nas de $Y z u-1$, apresentam os sítios tetraédricos perfeitamente preenchidos $(\mathrm{Si}+\mathrm{Al}=8$; Figuras 3-5 (a) e (c), 3-21 e 3-22 (a)) sugerindo uma composicão de solucăo sólida entre as moléculas de eastonita-siderofilita. Na Figura 3-24 (a), observa-se que as micas dos "lamprófiros" com fenocristais de olivina (Ymi-1 e Ymi-7) poderiam guardar consangüinidade com Ymi-4 (rocha com escassos fenocristais de olivina e abundante de mica). A seta parece indicar um trend que se inicia com eastonitas (centro dos fenocristais de Ymi-1c e Ymi-7) e acaba nas biotitas (matriz de Ymi-1 e bordas de Ymi-7), deficientes em Al ${ }^{\vee}$. Grãos da matriz de Ymi-1 e os fenocristais de Ymi-4 situam-se neste trend, com o que parece provável que estas rochas sejam congenéticas. Micas de Yzu-1, situam-se dentro do mesmo trend dos "lamprófiros" (Ymi-1, Ymi-4, Ymi-7 e Yzu-1). A Figura 3-24b segue o mesmo raciocínio feito para as micas anteriores; nelas se observa um trend não muito diferente, pois a curva se inicia com flogopitas eastoníticas (fenocristais) e finaliza em biotitas geralmente deficientes em $\mathrm{Al}^{\mathrm{IV}}$. As micas Gll de Ymi-5 situam-se em um campo diferente e não companham o trend identificado em (a) e o traçado em (b); isto parece evidenciar a impossibilidade de haver consangüinidade entre as micas Gll de Ymi-5 com os "lamprofíros", e parece mais provável uma consangüinidade com rochas basaltóides do tipo plagileucitos (regionalmente associados). As micas de Yzu-2, Yzu-3 e Yzu-6, como mostrado na Figura 3-5 (b) e (d), evidenciam que são micas da solução sólida entre flogopita-annita-eastonita-siderofilita. As micas de $Y z u-2$ e boa parte das micas de Yzu-3 e de Yzu-6 e as G-1 de Ymi-5, são deficientes em Al ${ }^{\mathrm{IV}}$ (apêndice A2, Figuras 3-5 (c) e (d), e figuras 3-21 e 3-22), de forma similar ao encontrado nas micas de Ymi-1 (matriz), tratando-se de micas resultante da solucão sólida entre flogopita-annita.

\section{Piroxênios}

A fórmula estrutural padrão dos piroxênios é $\mathrm{M} 2 \mathrm{M} 1 \mathrm{~T}_{2} \mathrm{O}_{2}$, onde $\mathrm{M} 2$ corresponde aos cátions em coordenação octaédrica distorcida $\left(\mathrm{Mg}^{2+}, \mathrm{Fe}^{2+}, \mathrm{Mn}^{2+}, \mathrm{Li}^{2+}, \mathrm{Ca}^{2+}, \mathrm{Na}^{2+}\right), \mathrm{M} 1$ 

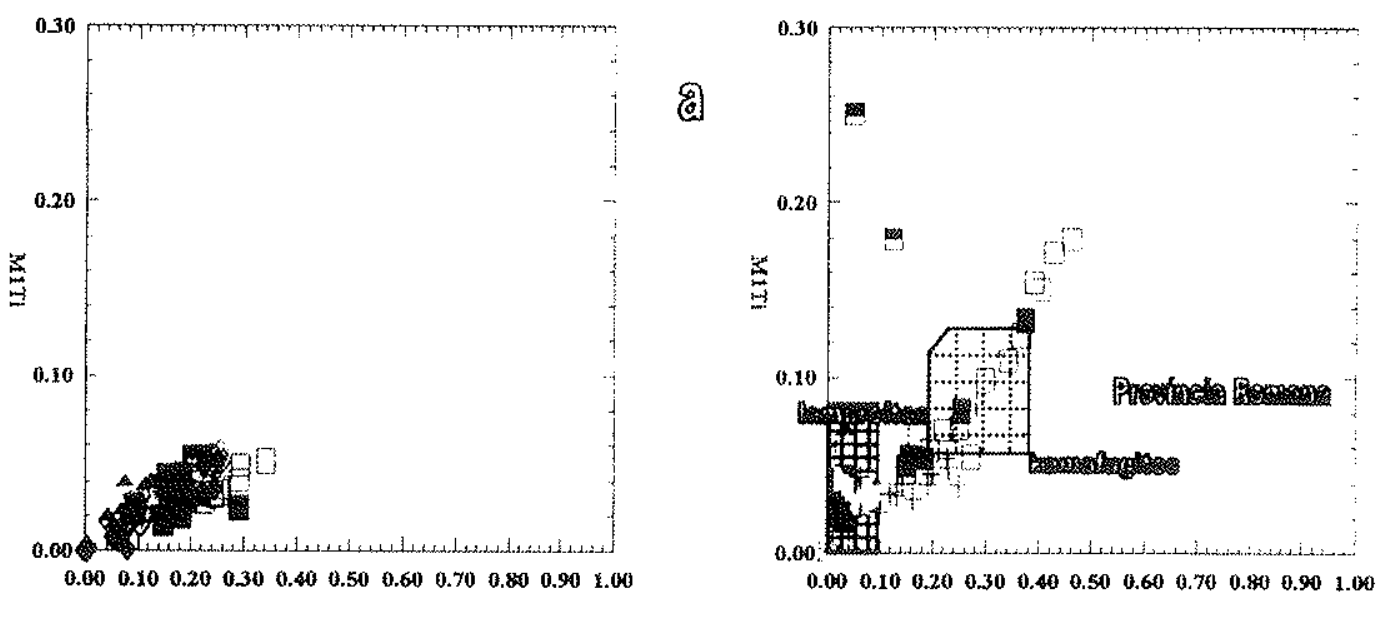

(b)

TAHMLA!

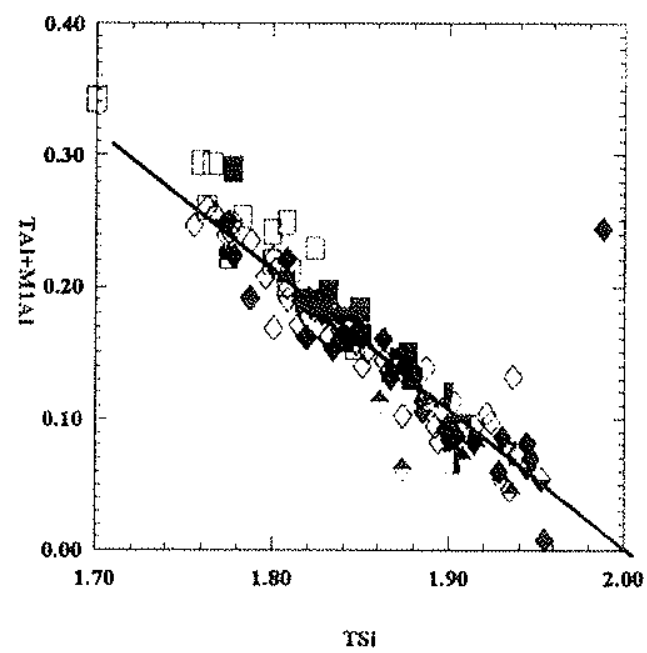

TAIHMAI

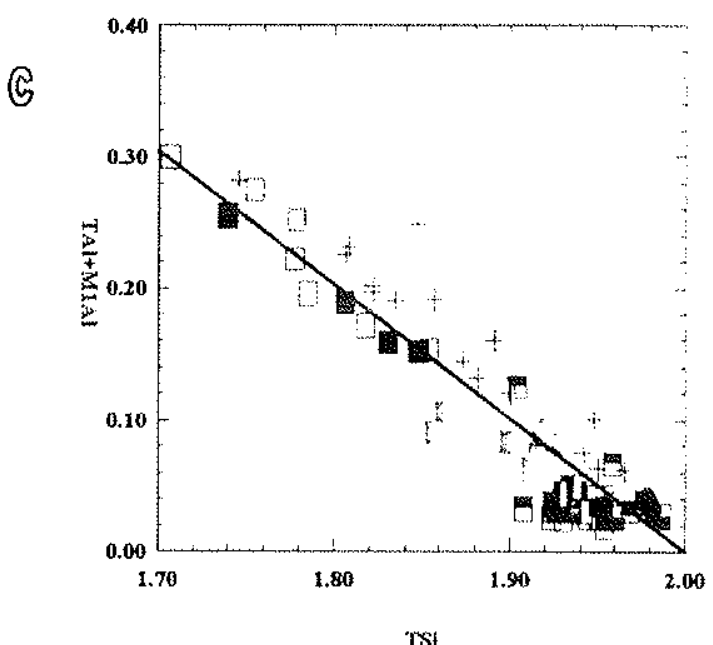

(])

Figura 3-26. Variação da composição catiônica em piroxênios de "lamprófiros" e "lamproítos". (a) e (b) variação Ti/6oxi. vs Al/6oxi. Em (a) mostra-se a relação dos "lamproitos" estudados com o campo lamproitico, kamafugitico e da Província Romana como traçado em Mitchell \& Bergman (1991); observe-se o comportamento particular dos piroxênios de Ymi-5. Em cruzes, piroxênios das rochas potássicas do rift de Asunción (RA) estudadas por De Min (1993). (c) e (d): relação inversamente proporcional em Al vs Si entre ambos tipos de rochas estudados da-se em torno da reta 0.30 (Al)-(Si) muito similar ao determinado por Cundari et al. (1996) em diques potássicos do RA. Em (d) piroxênios de Yzu-2, Yzu-3 e Yzu-6 mostram-se com abundante Si e localmente formam um plano horizontal obliquo à reta da figura. Simbologia como em 3-2. 
aos cátions em coordenação octaédrica regular $\left(\mathrm{Al}^{\mathrm{Vl+3}}, \mathrm{Fe}^{+3}, \mathrm{Ti}^{4+}, \mathrm{Cr}^{+3}, \mathrm{~V}^{+3}, \mathrm{Ti}^{+3}, \mathrm{Zr}^{4+}\right.$, $\mathrm{Sc}^{+3}, \mathrm{Zn}^{2+}, \mathrm{Mg}^{2+}, \mathrm{Fe}^{2+}, \mathrm{Mn}^{2+}$ ) e $\mathrm{T}$ aos cátions em coordenação tetraédrica $\left(\mathrm{Si}^{4+}, \mathrm{Al}^{\mathrm{I}{ }^{+}+}\right.$, $\mathrm{Fe}^{\mathrm{I} \mathrm{V}^{+}}$) (Morimoto, 1989; Garda, 1996). O procedimento para alocar os elementos nessas posições recomendado pela Subcomissão de Piroxênios da International Mineralogical Association (IMA) é empregado pelo programa Minpet 2.0 que neste trabalho foi empregado para os trabalhos de rotina de recálculo mineral (cf. Capítulo 1). Conforme Mitchell \& Bergman (1991) os piroxênios nos minettes são ricos em $\mathrm{Al}$, i.e. suficiente Al para preencher os sítios tetraédricos ( $\mathrm{TAl}^{\mathrm{N} \mathrm{V}^{+}}$) e conseqüentemente apresentam Al em coordenação tetraédrica e octaédrica $\left(\mathrm{M} 1 \mathrm{Al} \mathrm{V}^{\mathrm{V}+3}\right.$ ). O mesmo dá-se com os piroxênios das rochas ultrapotássicas tipo Província Romana (Al/6 oxigênios típicamente $>0.1$ ) e piroxênios que ocorrem em lamprófiros. Os piroxênios dos lamprófiros Ymi-1, Ymi-7 e Ymi-4 são aluminosos e titaníferos, feição (apêndice A3) que indica suficiente Al em posição octaédrica (TAl) e em alguns também na tetraédrica (M1Al). Nestes piroxênios observamse um enriquecimento diretamente proporcional entre o Al e o Ti do centro do fenocristal às bordas (Figura 3-4). Neles observam-se também que definem uma linha média de enriquecimento em Ti/Al (0.18-0.94.), superior à observada em piroxênios que ocorrem em rochas ultrapotássicas tipo Província Romana (Figura 3-4 e 3-25 (a)) e em parte também diferente daquela observada nas rochas vulcânicas potássicas do rift de Asunción (RA)(cf. De Min, 1993). Cundari et al. (1996) observaram que em RA o enriquecimento em $\mathrm{Ti}$ e $\mathrm{Al}$ dos piroxênios espalha-se entre a linha $\mathrm{Ti} / \mathrm{Al}=0.2$ (considerada limite superior das rochas ultrapotássicas tipo Província Romana). Por outro lado, esta feição também sugere que estes piroxênios seriam membros da série de solucão sólida entre CaMaSi206 (diopsídio)-CaAlAISiO6 (piroxênios Ca Tschermak's) e CaTiAl206, em analogia ao apontado por Mitchell (1995a) para os piroxênios de alguns lamprófiros ultramáficos.

Os piroxênios encontrados em Yzu-2, Yzu-3 e Yzu-6, como também aiguns piroxênios de Ymi-5, além dos piroxênios dos "lamproítos", apresentam insuficiente Al e assim provocam deficiências no preenchimento dos sitios octaédricos. Deficiência em Al nos piroxênios reflete diretamente a alcalinidade do magma parental (Mitchell \& Bergman 1991). Na Figura 3-26b, observa-se que estes piroxênios espalham se pelo campo definido para lamproítos, minettes e orangeítos. 


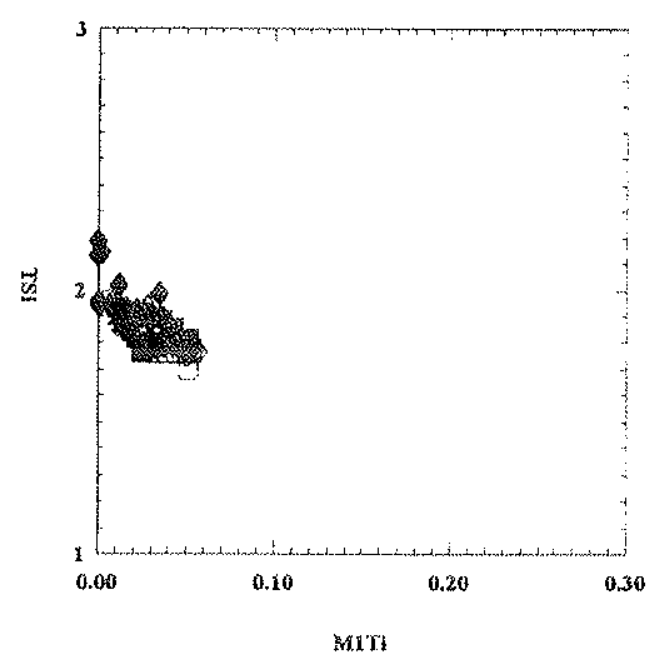

\&

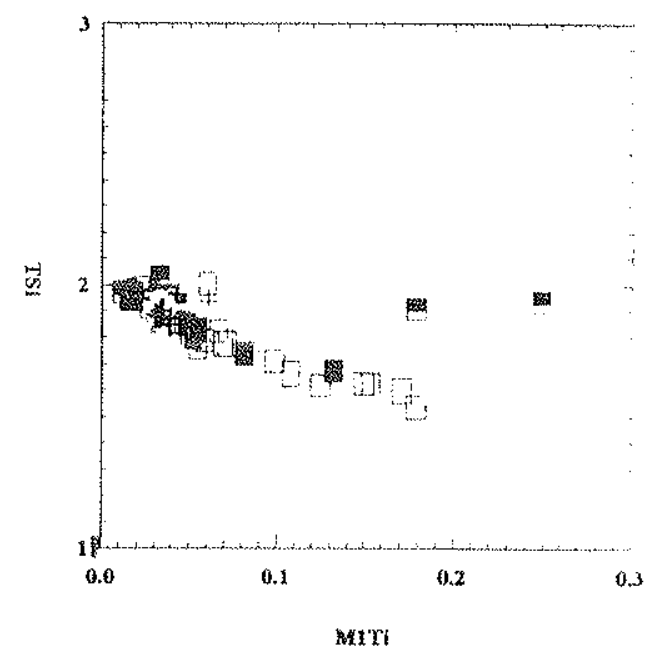

(b)
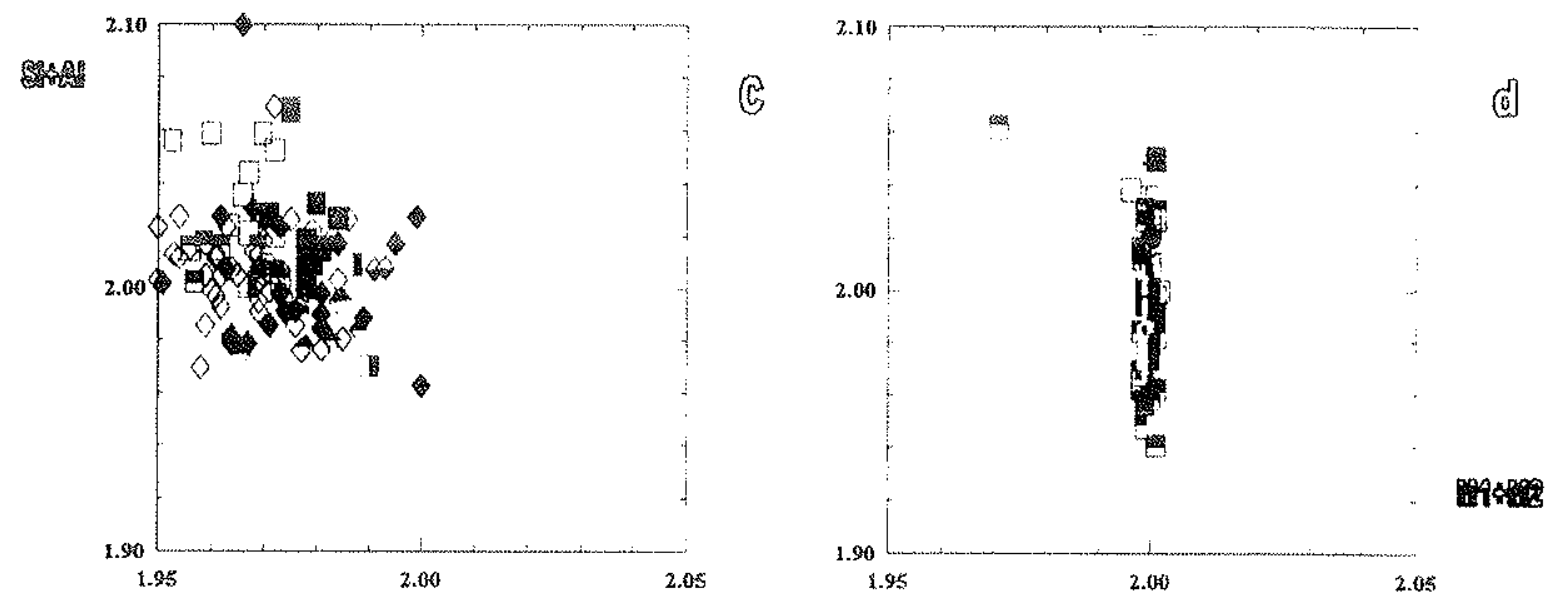

Figura 3-27. Distribuição catiônica em piroxênios dos "lamprófiros" e "lamproítos". (a) e (b) Tsi vs MiTi em "lamprófiros" (a) que mostra suavemente uma relação inversamente proporcional entre Si e Ti, que é acentuada em piroxênios dos "lamproítos" (b). Piroxênios de Ymi-5 como mostrado em (b) e na Figura 3-30b e d apresentam deficiência em $\mathrm{Si}$; esta é preenchida aparentemente pelo $\mathrm{Ti}$, como $\mathrm{Ti}^{4+}$ (cf. Carbonin \& Princivalle 1996); nas mesmas figuras observe-se o comportamento dos piroxênios das rochas potássicas do RA. (c) e (d) relação $\mathrm{Si} \uparrow \mathrm{Al}$ us $\mathrm{M} 1+\mathrm{M} 2$, que mostra como os piroxênios dos "lamprófiros" apresentam a posição octaédrica valores acima e abaixo de 2 e a tetraédrica abaixo de 2; comportamento diferente ao mostrado pelos "lamproitos" (em d) que apresentam posição tetraédrica totalmente preenchida $(M 1+M 2=2)$ e valores inferiores e maiores a 2 no sítio octaédrico $(S i+A l=2)$. Em piroxênios das rochas potássicas do RA apreciam-se valores $>2$ no sítio octaédrico. Simbologia como em 3-2. 
Contudo, os piroxênios de Yzu-2 Yzu-3 e Yzu-6 aparentam-se melhor com os lamproítos $\left(\mathrm{TiO}_{2} / 6\right.$ oxigênios $<0.1$ e $\mathrm{Al}_{2} \mathrm{O}_{3} / 6$ oxigênios $\left.<0.1\right)$. Por outro lado, os piroxênios de Ymi-5 têm uma composição que descreve uma linha de enriquecimento de Ti e Al (Figura 3-26b) particular, que passa pelo campo dos lamprófiros e kamafugitos sendo porém paralela à observada nos plagileucitos (Figura 3-26 (b)).

Em Ymi-2 é esperado alto coeficiente de alcalinidade conforme evidenciado pelo aparecimento de aegirina titanifera intersticial, acompanhada de eckermanita (richterita) potássica titanífera (ver comentários em Capítulo 1). Segundo de Wagner \& Velde (1986), esta paragênese aparece só em condiçöes de peralcalinidade no magma. Assim, também piroxênios quench de Ymi-5 são envolvidos por aegirinaaugita (Figura 3-15 e 3-16).

As Figuras 3-26 (c) e (d) mostram a existência de correlação negativa entre Al vs Si nos piroxênios de Ymi-5, Yzu-2, Yzu-3 e Yzu-6 e de Ymi-1, Ymi-4, Ymi-7 e Yzu-1; na Figura 3-26 (c), os "lamprófiros" traçam uma linha algo similar à encontrada por Cundari et al. (1996). Na Figura 3-26 (d) observa-se que os "lamproítos" possuem alto Si e deficiencias em Al, exceto os de Ymi-5 e alguns de $Y z u-3$. Considera-se que clinopiroxênios que cristalizam em magmas ultrapotássicos peralcalinos, como as fusões de afinidade kamafugítica e lamproítica, são caraterizados pelo alto teor de Si, porém sendo insensível a variação do conteúdo de sílica e a saturação de sílica na fusão; este alto teor de Si é combinado com variações amplas em M1 porém pequena no sítio M2 (Cellai et al., 1994). Alguns dos piroxênios de Ymi-5, por exemplo os quench, embora se apresentem com alto $\mathrm{Al}$, apresentam-se também com deficiências em Si (Figuras 3-26 (d), 3-27 (b) e (d)). Nos piroxênios que possuem alto Si e deficiências em Al no sitio tetraédrico, o $\mathrm{Ti}^{4+}$ passaria a ocupar ora posições octaédricas (Quartieri et al., 1993) ora octaédricas e tetraédricas (Quartieri et al., 1993; Carbonin \& Princivalle, 1996); feição que parece estar indicada em piroxênios de alguns "lamprófiros" (ex. Ymi-' e Ymi-7) e alguns lamproítos (ex. Ymi-5 e Yzu-2), como pode ser interpretado observando-se as Figuras 3-26 e 3-27. 
As Figuras $3-3 ; 3-4 ; 3-15 ; 3-16 ; 3-26$ e 3-27 evidenciam que os piroxênios dos "lamprófiros" são similares considerando os diferentes corpos estudados; os piroxênios dos "lamproítos" se apresentam sem diferenças marcantes, são muito similares, exceto os piroxênios de Ymi-5. Linhas de consangüinidade entre os corpos Ymi-1, Ymi-1c, Ymi-7 e Ymi-4 não são tão evidentes como no caso das micas na Figura 3-25. Entretanto, parece claro que os piroxênios dos "lamprófiros" apresentam consideráveis diferenças químicas e cristaloquímicas (apêndice A2 e A3; Figuras citadas neste parágrafo) em relação aos piroxênios dos "lamproítos". Alguns piroxênios analisados nas rochas do RA e comparadas com as dos lamproítos mostram-se de certa forma não muito diferentes, conforme pode ser constatado nas Figuras 3-26 e 3-27.

\section{Espinélios}

Contorme comentado no início deste capítulo, os espinélios seguem três Séries que se diferenciam uma da outra pelos ânions $\mathrm{Al}^{3+}, \mathrm{Fe}^{3+}$ e $\mathrm{Cr}^{3 *}$, combinando-se com cátions de Mig e Fe para formar soluções sólidas entre os end members. Assim possibilita representá-los em diagramas binários, como ilustrados nas Figuras $3-1 ; 3$ $7 ; 3-9$ e 3-17.

O diagrama binário Cr\#-Fe\# mostra a composição dos espinélios em termos das moléculas de picrocromita-cromita-espinélio-hercynita. O diagrama que é sobretudo útil quando se analisam espinélios cromiferos $\left(\mathrm{Cr}_{2} \mathrm{O}_{3}>10 \%\right)$. Microfenocristais de espinélios em Ymi-1 e inclusões de espinélios em minerais máficos em Ymi-1 e Yzu1 evidenciam solução sólida entre a picrocromita e a cromita (série da cromita) como mostrado na Figura 3-7 e 3-9.

Espinélios com teores de MnO >1\% ocorrem nos espinélios da série do espinélio e da série da magnetita, sendo que a maioria dos diagramas binários ou ternários empregados para representar as composições dos espinélios destas duas séries omitem o teor das moléculas de espinélios manganesíferos. O diagrama ternário galaxita $\left(\mathrm{B}=\mathrm{A} \mathrm{I}^{3+}\right)$-magnetita $\left(\mathrm{B}=\mathrm{F} \mathrm{e}^{3+}\right.$ )-manganocromita $\left(\mathrm{B}=\mathrm{Cr}^{3+}\right)$ (Figuras $3-1$ e 3-9) mostram-se útil para espinélios pobres a muito pobres em crômio; i.e. espinélios da 

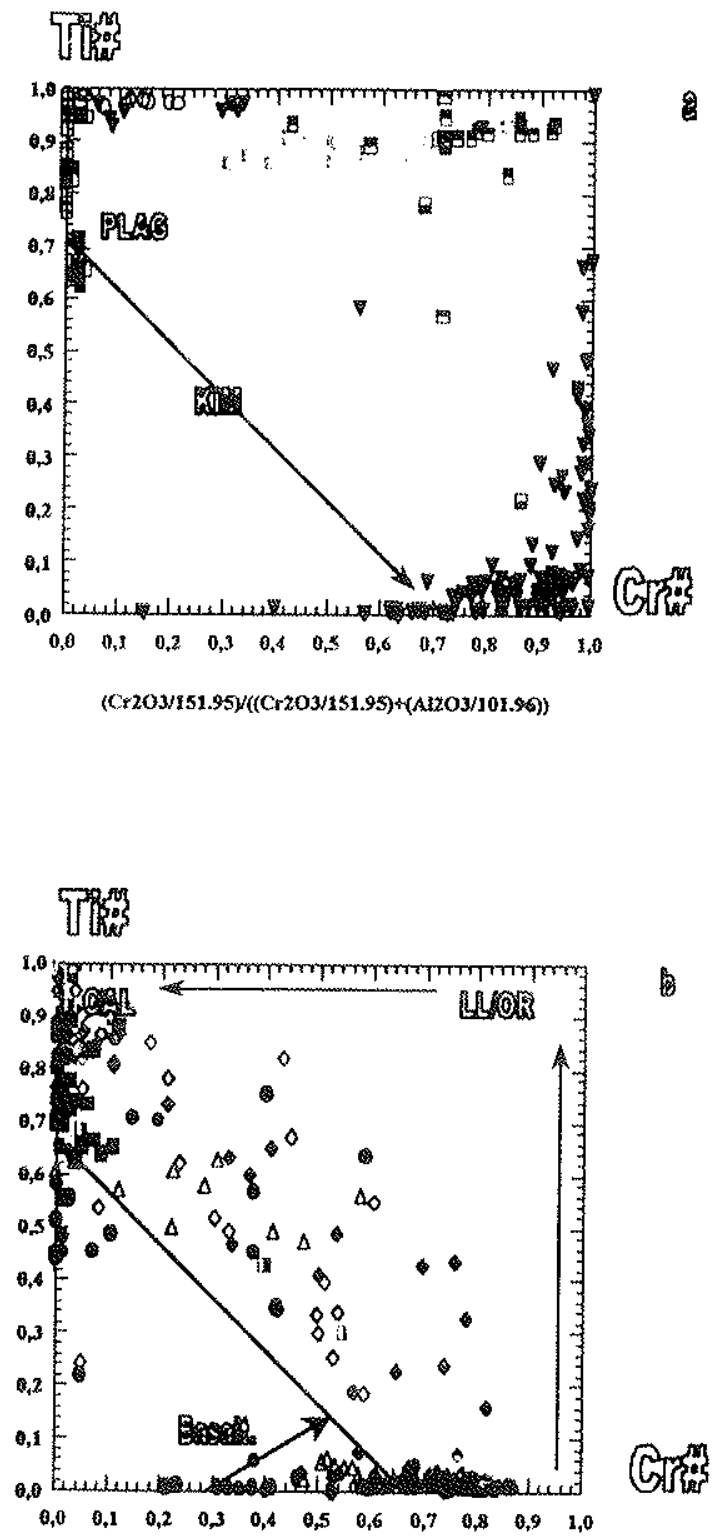

Tigura 3-28. Campo dos espinélios em "lamprófiros" e "lamproítos". (a), Ymi-5, Yzu-2, Yzu-3 e Yzu-6 são comparados com espinélios de lamproítos (tuiângulo cheios). (b), "lamprófiros" Ymi-1, Ymi-4, Ymi-7 e Yzu-1 são comparados com os lamprófiros alcalinos ricos em olivina (circulo cheio) e com fenocristais de mica (uriângulo vazios) de São Sebastiâo e arredores e os de Wandagee (Australia). Campos com base a Mitchell (1995a) e este trabalho. Fontes: Jaques et al. (1989) e Garda (1995). Legenda: KMM-kimberlitos, PLAG plagileucitos, OR-orangeitos, Basalt-basalto, CAL, lamprófiros cálcio alcalinos. Simbologia como em 3-2. 

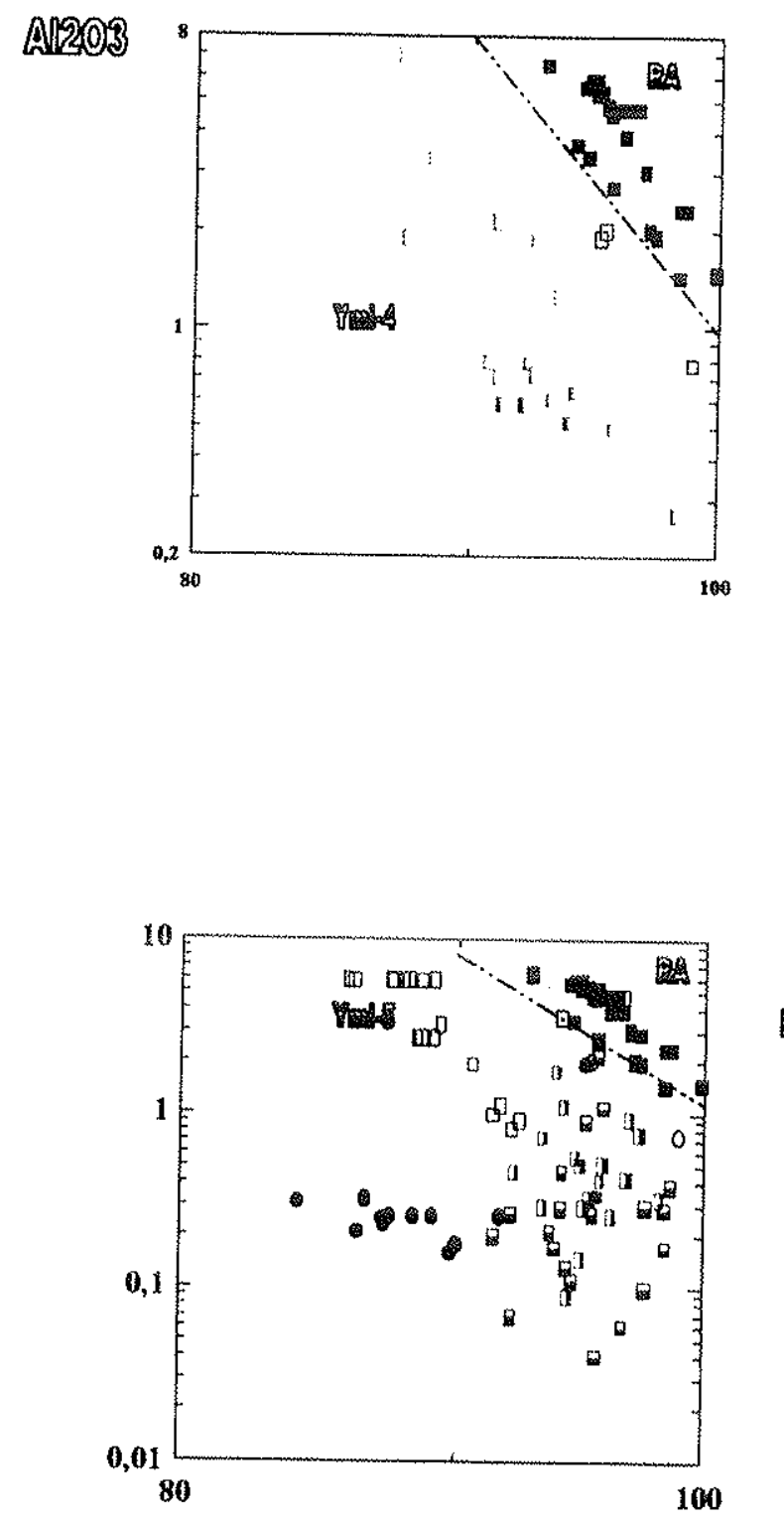

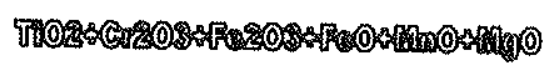

Tigura 3-29. Diferença entre os espinélios em função de log. $\mathrm{Al}_{2} \mathrm{O}_{3}$-demais óxidos nas rochas potássicas do rift de Asunción. (a) espinélios das rochas potássicas basaltóides (quadro cheio, extraido de Comin-Chiaramonti \& Gomes, 1996) sảo confrontados com os espinélios da intrusão Ymi-4 (quadro meio-cheio). Notar o plano de separação entre os espinélios de Ymi-4 e os espinélios das rochas basaltóides. Em quadro vazio, espinélios das lamprófiricas do Campo Ybytymi (D211 em Comin-Chiaramonti \& Gomes, 1996) e do Campo Ybytyruzú (D18, idem D211) junto ao dique D109 (idem D211) este aparentemente de afinidade lamproítica. (b) espinélios das rochas "lamproíticas" Ymi-5, Yzu-2, Yzu-3 e Yzu-6. Compare-se com a Figura (a) os espinélios de Ymi-5 possuem forte afinidade pelos espinélios das rochas lampróticas $Y z u-2$, Yzu-3 e Yzu-6. Círculos cheios e vazios junto aos quadros cheios pertecem as rochas D211, D18 e D109. Simbologia como em 3-2. 
série espinélios $\left(B=A l^{3+}\right)$-magnetita $\left(B=F e^{3+}\right)$ (no gráfico expresso pelo teor das moléculas de galaxito magnetita); assim, este diagrama é útil para os espinélios da matriz dos "lamprófiros" e "lamproítos" analisados neste trabalho, mostrando de forma fácil, o alto teor nas moléculas da série espinélio-magnetita, ambas em solução sólida (Figuras 3-9 e 3-17), sendo que nas rochas de Ymi-5, Yzu-2, Yzum3 e Yzu-6 os espinélios estão enriquecidos na molécula de magnetita e nas de Ymi-1, Ymi-4, Ymi-7, Yzu-1 e em parte também Ymi-5, na molécula de hercynita. De todos eles os espinélios de Ymi-1, Ymi-7 e Yzu-6, Ymi-5 e alguns de Yzu-2 e Yzu-3 estão enriquecidos na molécula de jacobsita ("lamproítos": Ymi-5, Yzu-2, Yzu-3 e Yzu-6) e galaxita ("lamprófiros": Ymi-1, Ymi-4, Ymi-7 e Yzu-1). As Figuras 3-28 e 3-29 mostram semelhanças e diferenças entre espinélios dos "lamprófiros" e dos "lamproítos". Os "lamprófiros" picríticos (Ymi-1 e Yzu-1) seguem um trend que se inicia no extremo enriquecido em $\mathrm{Cr}$ e pobre em $\mathrm{Ti}$ (Cr\# elevado, ex. Figura 3-28b) e acaba no outro extremo empobrecido no primeiro elemento e enriquecido no segundo (alto Tiz, ex. Figura 3-28b), como identificado na matriz (tipo de espinélios comuns para os corpos Ymi-4 e Ymi-7). Espinélios nos "lamproítos" se apresentam muito semelhantes entre si e definem um trend de evolução diferente ao seguido pelos "lamprófiros" (Figura 3-28a) e também diferente ao encontrado nas rochas basaltóides potássicas do RA (Figura 3-29b).

\section{Feldspatos}

Os feldspatos alcalinos em lamproítos, de maneira geral, são enriquecidos em $\mathrm{Fe}_{2} \mathrm{O}_{3}$ (<0.1-5\%; tipicamente $>1 \%$, Mitchell 1995a; Mitchell \& Bergman, 1991), empobrecidos em Na $2 \mathrm{O}(<2.5 \%$; Mitchell 1995; Mitchell \& Bergman, 1991) e são ricos em BaO (0.1-1.7\%; Mitchell 1995a); i.e. sanidinas e sanidinas de Fe $(1.0 \%$ de $\mathrm{Fe}_{2} \mathrm{O}_{3}$ i.e. sanidinas com $>4 \%$ de $\mathrm{KFeSi}_{3} \mathrm{O}_{8}$ ) além de sanidinas com $<0.1 \%$ de $\mathrm{CaO}$ e $\pm 1 \%$ de $\mathrm{Na}_{2} \mathrm{O}$ (Mitchell, 1995a). Desta forma, deve-se reconhecer que os feldspatos alcalinos nos lamproítos formam soluções sólidas entre a sanidina-sanidina de Fehyalofana-anortoclásio, este último em teores bem reduzidos. Na Figura 3-20 (Tabela A7) observa-se que os feldspatos dos "lamproítos" estudados são sanidinas em solução sólida com teores apreciáveis da molécula de sanidina de Fe (Yzu-2 e Yzu- 
6), e variáveis da molécula de anortoclásio (Ymi-5, Yzu-3 e Yzu-6) a moderados (YzU-2) (O programa Minpet 2.0 calcula o teor de $\mathrm{Na}_{2} \mathrm{O}$ como sendo de albita).

Segundo Rock (1991) e Rock et al. (1992), a molécula de albita (altos teores de $\mathrm{Na}_{2} \mathrm{O}$ ) nos lamprófiros é importante levando num diagrama Ab-Or-An a identificar sanidina, anortoclásio e plagioclásio ocorrendo em teores modais traços a valores importantes. Tudo isto pode ser observado nos "lamprófiros" caraterizados neste trabalho (Figura 3-10 e apêndice A7). Além do mais, sanidinas de Yzu-1 apresentamse em solução sólida com teores elevados de sanidina de Fe (Figuras 3-10b e c) e assim, são comparáveis com as sanidinas que ocorrem em lamproítos (cf. Mitchell \& Bergman, 1991; Rock et al., 1992); porém diferentemente dos lamproítos, também em Yzu-1, as sanidinas possuem altos teores da molécula de anortoclásio ( $6 \%$ de $\mathrm{Na}_{2} \mathrm{O}$, Figura 3-10b). 


\section{CAPÍTULO 4}

\section{POTENCIAL ECONÔMICO}

\section{INTRODUÇÃO}

O diamante é producido em 22 paises dos quais os mais importantes em ordem de produção são: Botswana, Africa do Sul; C.I.S., Rússia; Austrália; e Namíbia. Esse mineral é encontrado em rochas igneas derivadas do manto tendo como principais hospedeiros o kimberlito e os lamproítos. Foram reconhecidas cerca de 4.000 ocorrências de kimberlitos e lamproitos no mundo, dos quais provávelmente 500 a 1000 deles sejam diamantiferos; destes menos que 60 são minados, e apenas 15 deles são produtores maiores. Surpreendentemente, os sete maiores corpos mineralizados ( $>3.000$ carats por ano) foram descobertos a partir de 1950: Argyle na Austrália, Orapa e Jwaneng na Botswana, Jubilee, Udachnaya e Mir na C.I.S., e Venetia na Africa do Sul. Estima-se que os campos Lac de Gras (Canadá) e Archangelsk (C.IS.) poderão-se juntar também, no final do século, como maiores produtores. O diamante oscila entre uns dos mais lucrativos negócios minerais produzidos no mundo, colocando-se acima do lucro global do $\mathrm{Ni}, \mathrm{U}, \mathrm{Pt}, \mathrm{Pb}$ e $\mathrm{Ag}$ porém, abaixo do $\mathrm{Fe}, \mathrm{Au}, \mathrm{Cu}$ e $\mathrm{Zn}$. Uma mina individual de diamante apresenta-se como a mais lucrativa perante os outros depósitos minerais com um benefício anual próximo ou acima do bilhão de dolares, e com reservas in-situ arredor de 50 bilhões de dolares, Jennings (1995).

No Capitulo 2 foram descritos vários pipes de rochas potássicas sendo Ymi-1 de natureza lamprófírica e Ymi-8 de natureza petrológica desconhecida. Neles realizaram-se amostragem das fácies epiclástica e de sedimentos de corrente, que 


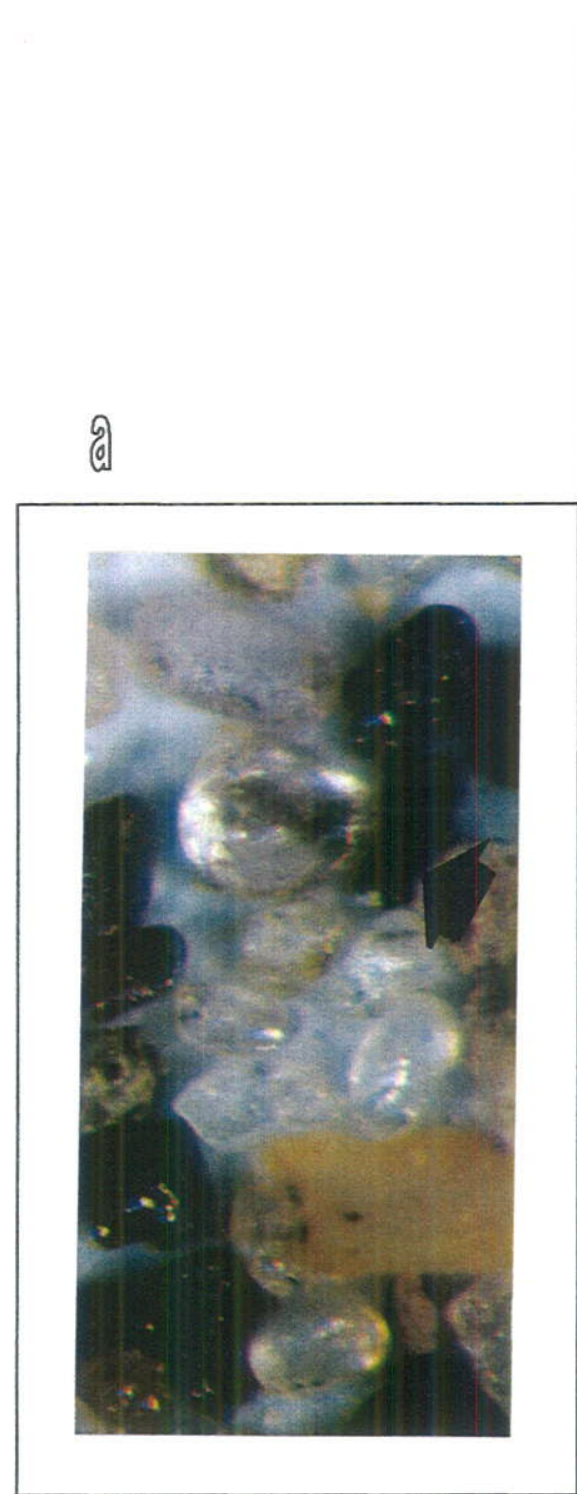

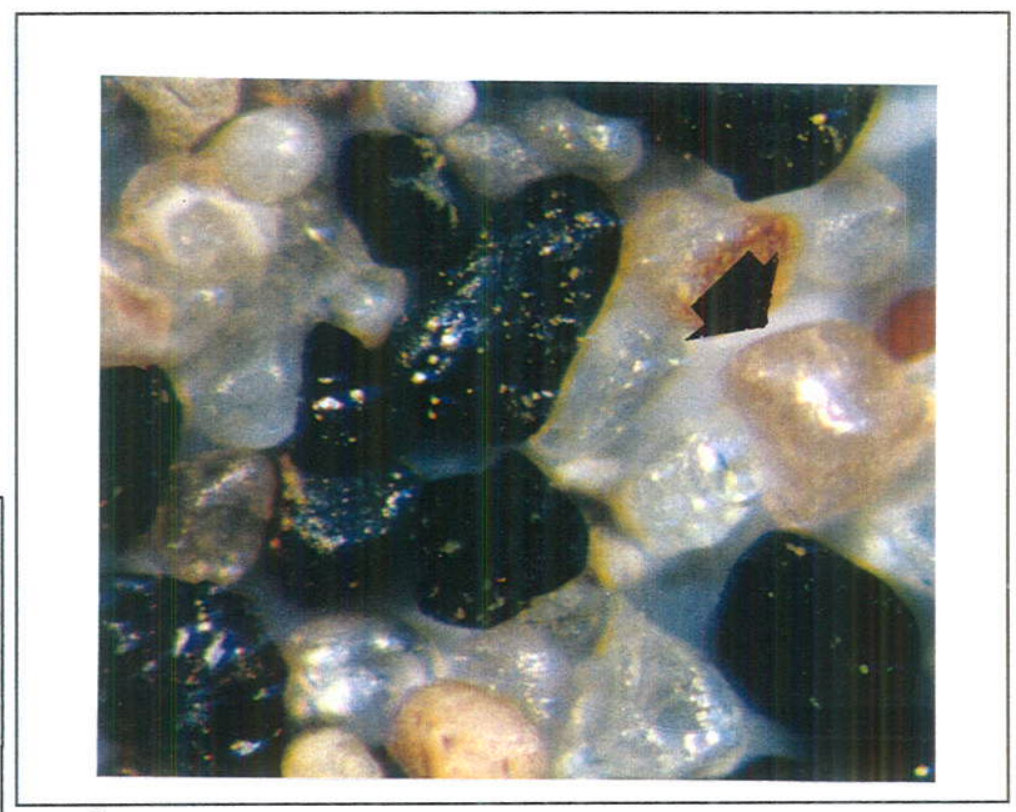

b

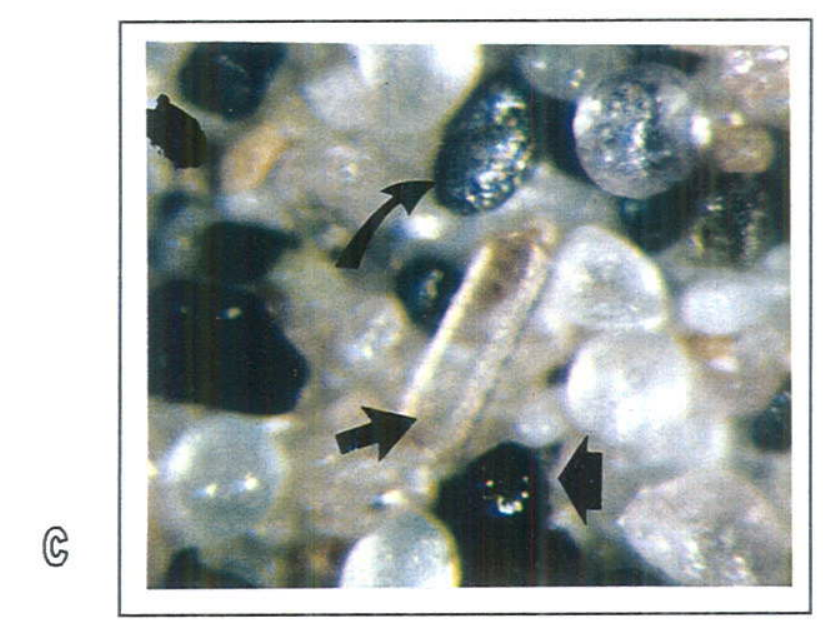

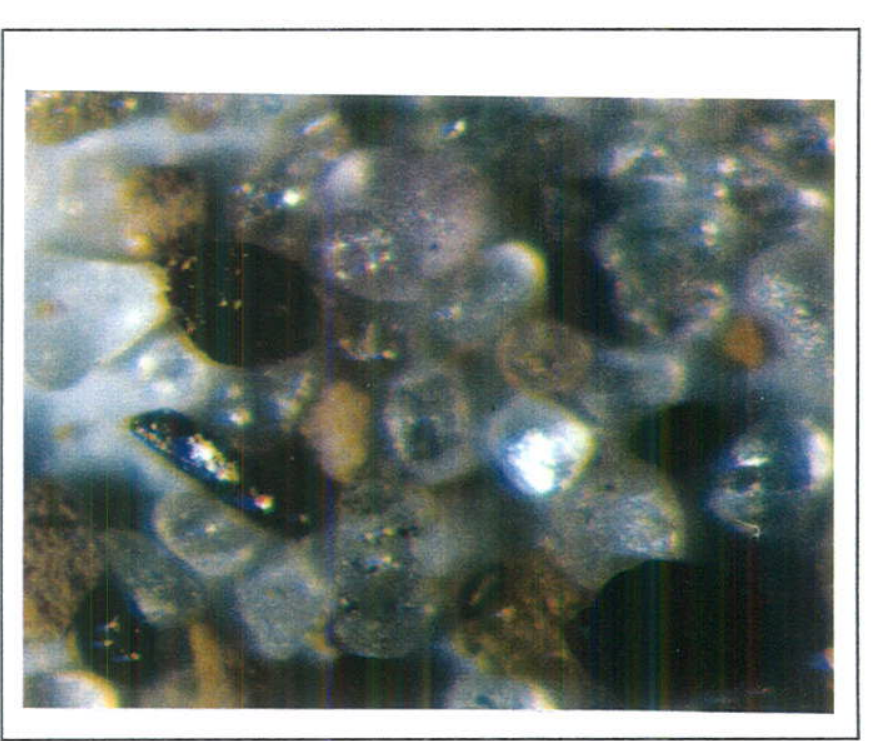

@]

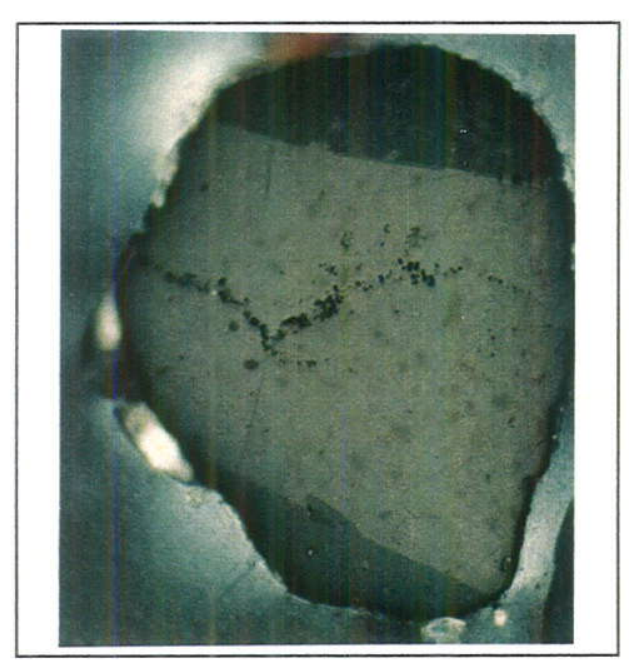

Fotomicrografia 7. Minerais pesados do pipe Ymi-1. (a) microcristal tetrahexaédrico incolor (mostrado pela seta) de "diamante" entre fragmentos do, aparentemente, mesmo

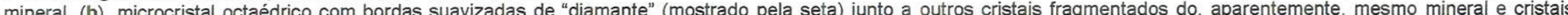
mircol irregula ( julos fragmentos de microcristais de "diamante" incolores. (d) cristal prismático de ilmenita (canto meio-esquerdo) junto a diversos cristais de "diamante" incolor a rosa, junto com grāos de
espinélio (opacos). (e), cristal geminado (?) de rutilo de $\mathrm{Nb}(\sim 0.40 \mathrm{~mm})$ em luz transmitida entre polarizadores; $\mathbf{a}, \mathbf{b}, \mathrm{c}$, e d $\sim 0.10 \mathrm{~mm}=1 \mathrm{~cm}$. 
foram peneirados e lavados (com líquidos densos) as frações entre $0.25-0.50 \mathrm{~mm}$. Uma vez obtido os concentrados de minerais pesados se realizaram neles análises químicas, via microssonda eletrônica apresentadas no apêndice. Em Yzu-4 e no córrego que banha a área de intrusão de Yzu-10 (arroyo Itá, Figura 2-8 e Fotografia 10) realizaram-se amostragem de material epiclástico e concentrado de minerais pesados (em cuia de ouro) para os quais são apontadas algumas feições físicas. Com esse material em mão foram caraterizadas as suites de minerais pesados. Com base nas informações ópticas e químicas pretende-se julgar seu potencial econômico.

\section{Pipe Ymi-1}

Conforme descrição da geologia desta intrusão no Capitulo 2 foram caraterizadas duas facies: epiclástica e vulcânica. A partir de sedimentos de corrente e de furo de sondagem (da facies epiclástica) foram separados a seguinte suíte de minerais pesados: espinélios, minerais de titânio (pseudobrookita, ilmenita, rutilo e rutilo de $\mathrm{Nb}$ ), turmalina, "diamante"/zircão e piroxênios (Fotomicrografia 7). A seguir são pormenorizadamente tratados os principais minerais tratados através de análises por microssonda eletrônica.

\section{Espinélios}

Este mineral ocorre principalmente como cristais isolados anédrais a octaédricos com dimensões de $<0.10$ a $0.5 \mathrm{~mm}$, sendo raros os grãos de maiores tamanhos. Os cristais apresentam caracteristicamente um brilho metálico-vítreo (Fotomicrografia 7) e representam os minerais mais abundante nos concentrados.

Foram analizadas com microssonda eltrônica cerca de 50 grãos, sempre aqueles com dimensões maiores que $0.25 \mathrm{~mm}$ : Os resultados analíticos e os dados referentes a fórmula química, expressa na base de 32 oxigênios e 24 cations, acham-se reunidos no apêndice 44 . Valores inferiores a 24 cátions obtiveram-se devido a falta de análises de $\mathrm{V}_{2} \mathrm{O}_{3}$ e em muitos também pela falta de análises do $\mathrm{ZnO}$. 
Conquanto se tenha em mente que a suite de espinélios analizados poderiam representar tanto xenocristais provenientes de fontes peridotíticas como cristais produto da cristalização do magma "lamprofírico", adouto-se como critério para separálos o teor de $\mathrm{TiO}_{2}$; se $\leq 2 \%$, xenocristais; se $>2 \%$, cristais magmáticos. Este procedimento foi adotado após prévia pesquisa do teor de Ti presente em espinélios de fontes peridotíticas e os que ocorrem como inclusóes nos diamantes (Figura 4-1).

Foram separados 37 cristais com teores de $\mathrm{TiO}_{2}<2.0 \%$ (Figura 4-1) e reunidos a outros cristais presentes na forma de microfenocristais e inclusões (cf. Capitulo 3 ), também com similares valores de $\mathrm{TiO}_{2}$. Estas faces possuem a seguinte composição: $\mathrm{Cr}_{2} \mathrm{O}_{3}, 33-57 \% ; \mathrm{Al}_{2} \mathrm{O}_{3}, 7-33 \% ; \mathrm{MgO}, 5-14 \% ; \mathrm{Ni}, 0.02-0.70 \%$ e $\mathrm{ZnO}$, até $0.30 \%$. As Figuras 4-2 ilustram suas composiçōes em termos das moléculas picrocromita-cromita-espinélio-herynita e também em termos das moléculas de $\mathrm{MgCr}_{2} \mathrm{O}_{4}-\mathrm{MgAl}_{2} \mathrm{O}_{4}-\mathrm{MgFe}_{2} \mathrm{O}_{4}$. Para esta assambléia podem ser apontados algumas feições:

*os espinélios em termos das moléculas de picrocromita-cromita-espinélio-hercynita são espinélios do tipo picrocromita (cromita magnesiana) e cromita; e assim, são similares aos espinélios encontrados em xenólitos peridotíticos (diamantíferos e/ou associados ao diamante) que ocorrem em "kimberlitoides" que se instalam em ambientes cratónicos (cf. por exemplo Jaques et al., 1990).

*os espinélios segundo moléculas de $\mathrm{MgCr}_{2} \mathrm{O}_{4}-\mathrm{MgAl}_{2} \mathrm{O}_{4}-\mathrm{MgFe}_{2} \mathrm{O}_{4}$ ocupam o campo comum de picrocromitas que ocorrem como inclusões no diamante

Quimicamente este grupo de espinélios pertence à série da cromita (Figura 4-2 (a), (b) e (c)); sendo que entre eles os cristais de picrocromita analisados são menos abundantes que os de cromita (Figura 4-2c).

Os critérios segundo Mitchell \& Bergman (1991 e Mitchell (1986; 1995a), para espinélios deste grupo de baixo tenor em $\mathrm{TiO}_{2}(<2 \%$; Grupo-I $=\mathrm{G}-\mathrm{I}$, Figura 4-1) e que apresentam elevadas razões em Cr\# e mg\#, pode ser confiantemente interpretado como xenocristais, que teriam sido incorporados pelo magma ao ser arrancados/desagregados das paredes peridotíticas durante a passagem do magma 


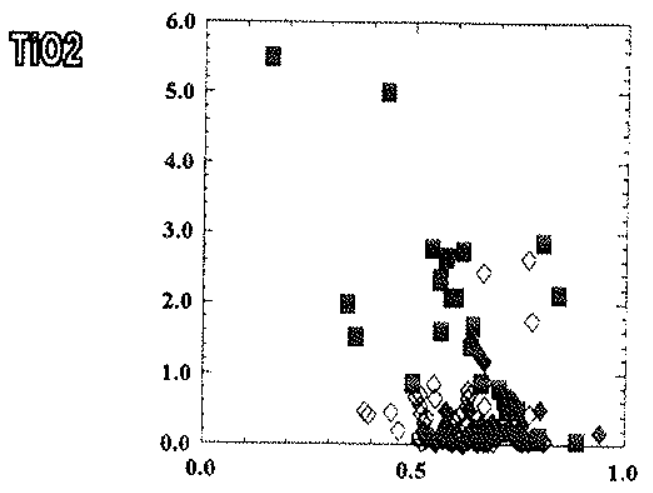

๑

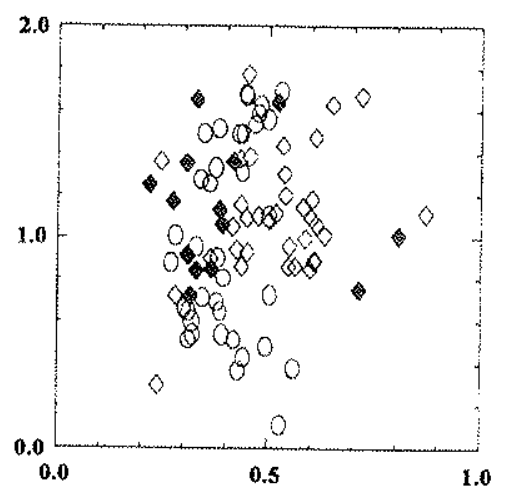

(b)

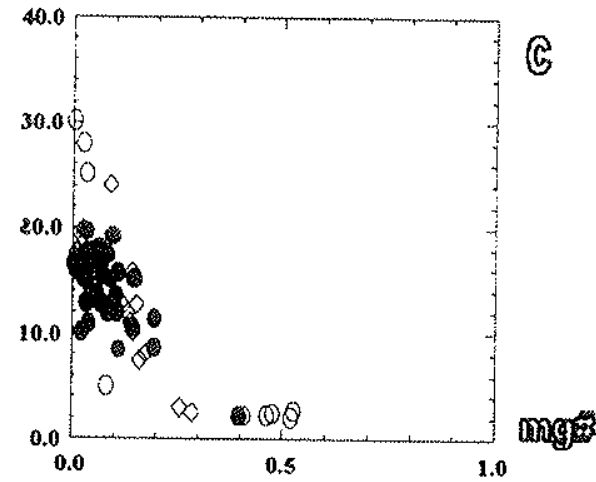

Figura 4-1. Xenocristais e cristais magmáticos de espinélio. (a) cristais de espinélio inclusos em diamante e/ou coexistindo com o diamante (rombos cheios) compara-se com xenocristais de espinélio encontrados em peridotitos da fácies diamantifera e/ou encontrados em concentrados de "kimberlitoides" diamantiferos (rombos vácuos) e xenocristais/megacristais de espinélios que ocorrem em outras rochas alcalinas (quadros cheios). Ooserve-se como os dois primeiros grupos possuem, baixo $\mathrm{Ti}\left(\mathrm{TiO}_{2}<2.0 \%\right)$, feiç̃o que permite separar rapidamente a suite de xenocristais (baixo Ti) da suite de cristais magmáticos ( $\mathrm{TiO}_{2}>2.0 \%$ ) (cf. Mitchell 1986; 1995a e Mitchell \& Bergman, 1991). (b) suite de xenocristais do pipe Ymi-1 (circulo= concentrado; rombo cheio = microfenocristal e; rombo vácuo= inclusăo). (c) suite de cristais magmáticos do pipe Ymi-1 (-microfenocristais, inclušes e matriz). Fontes: Griffin et al. (1992); Haggerty (1991); Fipke
(1994). 
picro-"lamprofírico" rumo à superfície (para discussões e outros comentários ver também Griffin et al. 1992, 1994 (a) e (b)).

Conforme discutido no Capítulo 3 , os grãos de espinélio com $\mathrm{TiO}_{2}>2 \%$ (Grupo 2 =G2) formam em parte assambléia de espinélios cristalizados sob alta pressão e alta temperatura, aqueles com alto teor de $\mathrm{Cr}$; em parte são de baixa pressão e baixa temperatura, como resultado de cristalização do mesmo magma em superficie, aqueles com $\mathrm{Cr}_{2} \mathrm{O}_{3}<5 \%$. Assim o conjunto de grãos com $\mathrm{TiO}_{2}>2 \%$, alto a baixo $\mathrm{Cr}$, alto a muito baixo $\mathrm{Mg}$ e moderado a altíssimo $\mathrm{FeO}_{\mathrm{t}}$, com razões $\mathrm{Cr}$ \# e mg\# variáveis , listados no apêndice A4 são considerados magmáticos. Aproximadamente 11 cristais analisados nos concentrados formam parte deste G2; deles quatro cristais de espinélios (Figura 4-2 (b)) são ricos nas moléculas de hercynita e assim são similares aos analisados na matriz dos plugs e diques deste corpo (=magnetitas) e o restante teriam sido provenientes da decomposição da rocha hóspedeira.

Nos grupo de cristais $\mathrm{G} 2$ observam-se grăos em formas predominantemente subhédrais a octaédricas enquanto aqueles com formas anhédrais a subhédrais são predominantes no G-I (Fotomicrografia 7). Observações petrográficas (microscopia de luz refletida) mostraram que alguns dos cristais G-1 apresentam texturas de recristalização, similares às descritas por Ramsay et at. (1994) em xenocristais de cromita do kimberlito diamantífero Aires (Austrália).

No G-II, espinélios com alto $\mathrm{Cr}(\mathrm{Cr} \#>0.50)$ pertencem à série da cromita; neles também são mais abundantes as cromitas a as cromitas magnesianas (Figura 4-2 (b) e comparar com a Figura 4-1 (c)).

Estes sspinélios, segundo os valores de $\mathrm{Cr}$, mg\#, teor de $\mathrm{Ti}, \mathrm{Al}$ e $\mathrm{Mg}$ (Mitchell \& Bergman, 1991; Mitchell, 1986; 1995a)) correspondem às variedades:

1-cromita magnesiana pobre em Ti (=cromitas magnesias);

2-cromita titanifera magnesiana (=cromitas);

3-cromita magnesiana aluminosa (alguns grãos sobre as linhas $0.5 \mathrm{Cr}$ e mg\# nas Figuras 4-1 (b) e (c)). 

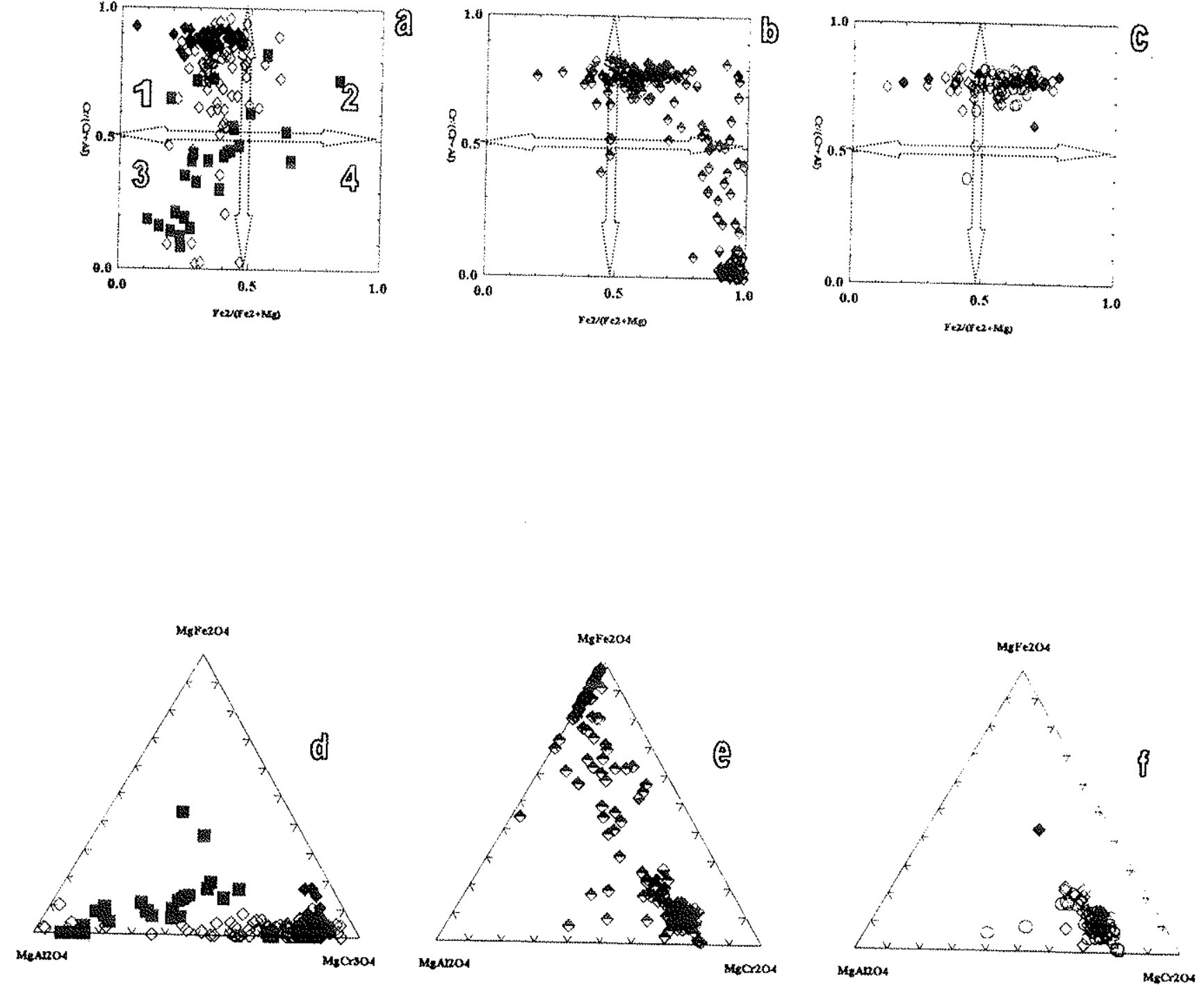

Figura 4-2. Espinélios da fácies do diamante. (a, b e c) sistema cromiła magnesiana (1) -cromila (2) espinélio (3) -hercynita (4). (a) espinélios inclusos em diamantes são comparados com espinélios encontrados em peridotitos de fácies diversas e com espinélios que ocorrem em peridotitos de fácies diamantíferas e/ou corpos "kimberlíticos" diamantíferos. (b) suites de espinélios do pipe Ymi-1, que mostra perian são cromitas magnesianas e cromitas comparável com os espinélios peridotiticos da fácies diamantíferas. (b) xenocristais: concentrados, inclusão e fenocristais de Ymi 1; os que ilustram melhor a provável precedência dos cristais analisados. Dois cristais com $\mathrm{Cr}_{2} \mathrm{O}_{3}<35 \%$ ocupam o campo das cromitas magnesianas aluminosas. ((d), (e), (f)) espinélios como em (a), (b) e (c)) no sistema $\mathrm{MgFe}_{2} \mathrm{O}_{4}-\mathrm{MgCr}_{2} \mathrm{O}_{4}-\mathrm{MgAl}_{2} \mathrm{O}_{4}$. Simbologia como em 4-1. Fontes ver texto. 
Os quatro cristais de espinélio ricos nas moléculas de hercynita pertencem à série da magnetita. Segundo nomenclatura de Mitchell \& Bergman (1991) e Mitchell (1986; 1995a), são:

magnetita titaniffera ( $\mathrm{MgO}<1 \%$ ) e magnetita titanif́era magnesiana ( $\mathrm{MgO} \quad \uparrow-<5 \% \mathrm{e}$ Cr2O3<10\%; são também ricas em MnO (apêndice A4)).

\section{Minerais de titânio}

Pseudobrookita, armalcolita, anasovita $\left(\mathrm{Ti}_{3} \mathrm{O}_{5}\right)$, e kennedyita têm estruturas da pseudobrookita. São minerais titaníferos que junto ao Fe podem conter apreciáveis concentrações de elementos como $\mathrm{Cr}, \mathrm{Al}, \mathrm{V}, \mathrm{Mn}, \mathrm{Ca}, \mathrm{Zr}$, etc. A variação composicional destes minerais nunca foi definida adequadamente, e há certa confusão na literatura que deixa espaço a situações enganosas. Assim uma pesquisa das análises principais de pseudobrookita, armalcolita, änosovita e "kennedyita" conduziu Bowles (1988), a estabelecer uma definição dos campos composicionais. Kennedyita foi suprimido por Bowles (1988) e aprovado pelo IMA.

Pseudobrookita é definido como tendo uma fórmula ideal de $\mathrm{Fe}_{2} \mathrm{TiO}_{5}$ com uma composição limitada por $\mathrm{FeTi}_{2} \mathrm{O}_{5}, \mathrm{Fe}-\mathrm{Mg}_{0.5} \mathrm{Ti}_{1.5} \mathrm{O}_{5}$, e composições intermédias. Armalcolita tem uma fórmula $\mathrm{Fe}_{0.5} \mathrm{MgO}_{0.5} \mathrm{Ti}_{2.5} \mathrm{O}_{5}$ ideal com um alcance de composição limitada pelo $\mathrm{MgTi}_{2} \mathrm{O}_{5}, \mathrm{FeTi}_{2} \mathrm{O}_{5}, \mathrm{FeMgo.5}_{0.5} \mathrm{Ti}_{1.5} \mathrm{O}_{5}$ e $\mathrm{Mg}_{0.5} \mathrm{Ti}_{2.5} \mathrm{O}_{5}$ e inclusive composiçöes intermédias (Bowles, 1988).

As Fotomicrografias 7 mostram que junto aos espinélios ocorrem abundantemente opacos alongados irregulares a euhédrais e de $<0.8-0.3 \mathrm{~mm}$; são de cores prateado escuro com brilho metálico graxo, outros de cor preto e brilho metálico e outros de forma alongada vermelho muito escuro quase opaco com brilho submetálico-graxo. Eles foram analizados na microssonda eletrônica e suas composições encontram-se no apêndice A8. A Figura 4-3 mostra que são grupos minerais diferentes em termos das moléculas de $\mathrm{TiO}_{2}-\mathrm{Fe}_{2} \mathrm{O}_{3}-\mathrm{FeO}$ (Buddington \& Lindsley, 1964); este diagrama ternário permite separar os seguintes grupos de titanatos: 

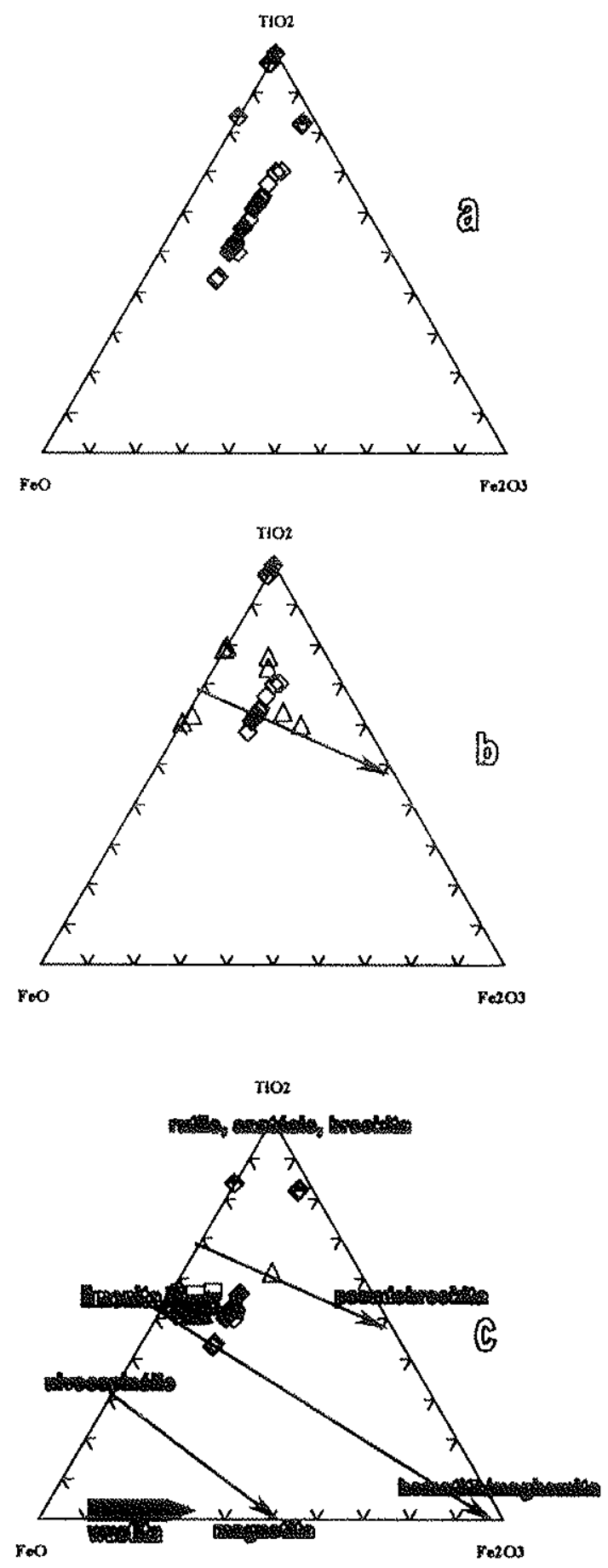

Figura 443. Minerais de titânio. (a) titanatos de Ymi-l (rombos vazios e meio cheio) e Ymi-8 (rombos cheios). (b) titanatos de (a) com $\mathrm{TiO}_{2}>55 \%$ que ocorrem em Ymi-1 e Ymi-8, que são comparados com os que ocorrem em lamproítos de Jumilla e Cancarix =pseudobrookitas. (c) titanatos de (a) $c 0 \mathrm{~m} \mathrm{TiO}_{2}<55 \%$ que também ocorrem em Ymi-1 e Ymi-8 e são comparados com ilmenitas que ocorrem em lamproítos (triângulos; localidades da Espanha, Austrália e USA; limenitas, quadros Yzu-2; Yzu-3 e Yzu-6) =. Em (b) e (c) os triângulos meio cheios representam rutilos (a) e rutilo de $\mathrm{Nb}$ (b). Em (c) os campos composicionais linha $\mathrm{FeTi}_{2} \mathrm{O}_{5}-\mathrm{Fe}_{2} \mathrm{TiO}_{58}$ pseudobrookits; $\mathrm{FeTiO}_{3}-\mathrm{Fe}_{2} \mathrm{O}_{3}$, ilmenita-hematis $\mathrm{e} \quad \mathrm{Fe}_{2} \mathrm{TiO}_{4}-\mathrm{Fe}_{3} \mathrm{O}_{4}$ ulvoespinélio-magnetita segundo Buddington \& Lindsley (1964). Para fontes ver texto. 
Pseudobrooquita (cor preto): possuem altos tenores em $\mathrm{TiO}_{2}(55-64 \%)$, moderados de $\mathrm{MnO}(0.4-7.8 \%), \mathrm{Al}_{2} \mathrm{O}_{3}(0.1-1.2 \%)$ e $\mathrm{Fe}_{\mathrm{t}}(1.8-42 \%)$, e baixos em $\mathrm{Cr}_{2} \mathrm{O}_{3}(0.0-0.15 \%)$ e MgO (0.04-1.54\%), apêndice A8.

IImenita (cor prateado escuro): possui teores elevados de $\mathrm{TiO}_{2}$ (40-54\%), $\mathrm{Fe}_{\mathrm{t}}$ (41$54 \%$ ), moderados de $\mathrm{MgO}$ (0.3-5.7\%) e muito baixos de $\mathrm{Cr}_{2} \mathrm{O}_{3}(<0.05 \%=$ teores baixissimos nas moléculas de eskolaitá) e $\mathrm{Al}_{2} \mathrm{O}_{3}(0.1-0.5 \%)$ a baixos de $\mathrm{MinO}(0.4$ $1.5 \%$ ). A Figura $4-4$ (a) ilustra o comportamento de ilmenitas ricas nas moléculas de ilmenita e hematita e empobrecidas nas moléculas de geykielita; enquanto a Figura 4-4 (b) ilustra o empobrecimento das mesmas ilmenitas nas moléculas de pyrofanita.

Rutilo (cor vermelho sangue escuro): possuem altíssimo a muito alto teor de $\mathrm{TiO}_{2}$ $(92-99 \%)$ e baixos teores de $\mathrm{FeO}(0.1-2.5 \%)$ e $\mathrm{MgO}(<0.17 \%)$. Observa-se um cristal cristal geminado (Fotomicrografia 7); nele mediram-se elevados teores de $\mathrm{Nb}$ (23.35\% de $\mathrm{Nb}_{2} \mathrm{O}_{5}$ ) e em perfil de análises segundo borda-centro-borda obteve-se variaçöes nos teores de $\mathrm{TiO}_{2}$ (48 a $54 \%-54 \%-46$ a $55 \%$ ) e $\mathrm{ZrO}_{2}$ (0.9 a 1.1\%-1.2\%-0.6 a $1.3 \%$ ). No mesmo ponto do cristal onde foi analisado $\mathrm{Nb}$, foram também medidos os teores de $\mathrm{Fe}_{\mathrm{i}}(11 \%), \mathrm{Ce}_{2} \mathrm{O}_{3}(0.60 \%), \mathrm{BaO}(0.25 \%)$ e $\mathrm{PbO}(0.22 \%)$ (apêndice $\mathrm{A} 8$ ). Estas feições químicas permitem caracterizá-lo como rutilo de $\mathrm{Nb}$.

\section{Turmalina}

Este mineral ocorre em grãos prismáticos a arredondados. Os cristais prismáticos possuem cores marrom a verde com marcado pleocroísmo, e dimensões submilimétricas. Cristais arredondados a muito bem arredondados e com tamanhos geralmente inferiores a $0.5 \mathrm{~mm}$ ocorrem abundantemente como cristais amarronzados a esverdeados e escuros, com um característico britho "gelo".

No apêndice A9 são apresentados análises químicas parciais de de turmalinas considerando que eles possuem boro e flúor em concentrações elevadas na sua composição (Deer et al., 1962) e que estes elementos năo foram analisados no processo de análises deste trabalho. Entretanto, nelas se observam teores variáveis de $\mathrm{SiO}_{2}(33-37 \%), \mathrm{TiO}_{2}(0-1 \%), \mathrm{Al}_{2} \mathrm{O}_{3}(20-37 \%)$, FeO $(4-21 \%), \mathrm{MgO}(1-6 \%), \mathrm{Na}_{2} \mathrm{O}(\mathrm{O}-$ $2 \%$ ) e ainda teores inferiores a $1 \%$ de $\mathrm{MnO}, \mathrm{CaO} \in \mathrm{K} 2 \mathrm{O}$. As turmalinas aqui descritas 

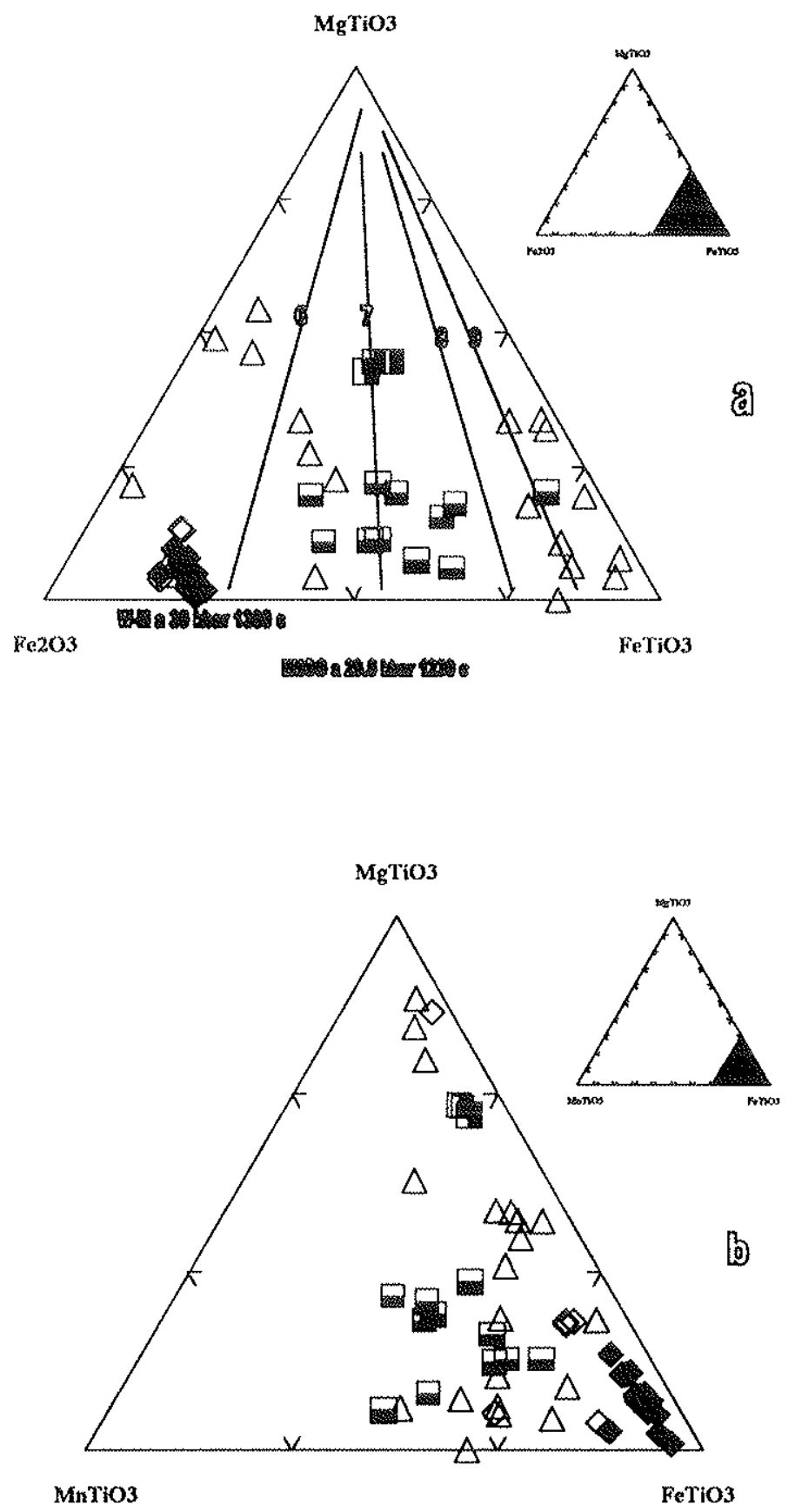

Figura 4.4. Ilmenitas dos pipes. (a) sistema geykielita-ilmenita-hematia, que mostra as ilmenitas de Ymi-1 e Ymi-8 enriquecidas nas moléculas de ilmenita-hematita e pobres nas moléculas de geykielita. As linhas sub verticais correspondem a isolinhas de fugacidade de oxigênio traçadas, aqui parcialmente reproduzidas, por Woermann et al. (1970, in Haggerty, 1990). São também lançados dados das iimenitas dos lamproítos Yzu-2, Yzu-3 e Yzu-6; e todos eles comparados com ilmenitas que ocorrem em alguns lamproitos. (b) sistema geykielita-ilmenita-pyrofanita, que mostra como as ilmenitas de Ymi-1 e Ymi-8 estão enriquecidas nas moléculas de ilmenita e empobrecidas nas moléculas de geykielita e algo de pyrofanita. Fontes como em 4-3. 
se apresentam com algumas feições físicas (cor e arredondamento dos cristais) e químicas (teores de $\mathrm{Ti}$ e $\mathrm{K}$ ) similares aos encontrados em turmalinas de pipes diamantiferos estudados por Fipke (1991, 1994).

\section{Diamante vs zircão}

Foram observados cristais octaédiricos, com as bordas suavizadas a arredondadas, de cristais parecidos com diamante; sendo a grande maioria incolores a rosa suave, amarelo vinho e violeta suave, com marcado brilho adamantino a gelo. Um dos microcristais foi analisado no raios $X$ (método do monocristal em Camera de Gandolfi empregando CuK e filtro de níquel por 24 horas de exposição). O espectro obtido acuso padröes similares aos de diamante $(2 B$ corrigido $=2.10$-médio a forte, 1.29 leve a médio e 0.83 leve). Contudo, foram analisados -20 grãos na microssonda eletrônica muitos cristais de formas alongadas e parecidas ao zircão, após lavado com ácidos e solução levemente alcalina (ver Capitulo 1), estes grãos permaneceram insolúveis e muitas vezes apresentabam seu brilho adamantino acresentado. Alguns dos 20 grãos avaliados na microsonda exibiram florescência azul cobalto radiante; quimicamente apresentaram teores de $\mathrm{SiO}_{2}<1$ a $\sim 10 \%$ e $\mathrm{ZrO}_{2}$ $<3 \%$ (analisado em alguns cristais), feições que não se identificam com zircão e apontam para diamante.

Outros cristais prismáticos euhedrais (Fotomicrografia 7) a arredondados incolores e de tamanhos pequenos $(<0.5 \mathrm{~mm})$, foram observados junto aos cristais de diamante e analisados parcial a total, incluindo $\circ \mathrm{ZrO}_{2}$ e as REE. Entre os cristais, procedentes dos pipes Ymi-1 e Ymi-8, só foram identificados como zirção cerca de cinco grãos; os demais corresponderiam a polimorfos do carbono (ex. diamante).

\section{Pipe Ymi-8}

Como resaltado no Capítulo 2, neste corpo não foi encontado afloramentos de rocha magmática e as análises basejam-se na medida do possível, na suítes de minerais pesados: minerais de titânio (ilmenita, rutilo, pseudobrookita), diamante/zircão e turmalina; foram também reconhecidos piroxênios (verdes e alaranjados) como diminutos cristais angulares a irregulares de $\approx 0.50 \mathrm{~mm}$ e traços de granada. 
Contudo, diferente do pipe anterior, os escassos minerias pesados obtidos foram recuperados de enorme volume de material lavado. Espinélio foi observado apenas em lupa de grande aumento, porém não se conseguiu analizar sequer um cristal.

\section{"Diamante" vs zircão}

Nos concentrados observaram-se (em porcentagens muito menores as de Ymi-1) microcristais $(<0.5-0.2 \mathrm{~mm})$ incolores, quebrados a hexaedroides e prismáticos alongados, com brilho adamantino a gelo. As análises em microssonda eletrônica dos diferentes grãos, como descrito no item anterior, mostraram que eles não apresentam composição de silicatos (ex. zircão). Alguns deles apresentaram florescência azul-cobalto. Essas feições levam a supor que esses cristais seriam polimorfos do carbono como concluído em Ymi-1. Além disso, um monocristal foi submetido ao testador (industrial) eletronico diamond-test e ele mostrou resposta positiva para diamante.

\section{Minerais de titânio}

Nos concentrados são abundam os cristais idiomórficos (retangulares a quadráticos), submilimétricos $(\sim 0.3 \mathrm{~mm})$ a milimétricos, opacos e escuros, junto a outros menores de cor vermelho muito escuro e de britho submetálico graxo. Dentre os cristais analisados obtiveran-se dois (apêndice) de pseudobrookita (Figura 4-2 (a)) com cerca de $55 \%$ de $\mathrm{TiO}_{2}, 35-56 \%$ de $\mathrm{Fe}_{\mathrm{t}}$ e baixos teores de $\mathrm{MnO}$ (<0.52\%) e de $\mathrm{MgO}$ $(<0.48 \%)$. $E$, assim, comparativamente algo evoluídos aos encontrados em $Y \mathrm{mi}-1$. Mais abundantemente ocorrem grãos de ilmenitas (Figura 4-4) ricas em $\mathrm{TiO}_{2}$ (48 $51 \%), \mathrm{Fe}_{\mathrm{t}}(44-49 \%)$ e pobres em MgO (0.08-1.1\%) e MnO (0.39-1.34\%). As Figuras 4-4 (a) e (b) mostram que são ilmenitas enriquecidas nas moléculas de $\mathrm{FeTiO}_{3}$ (ilmenitass) e empobrecidas nas moléculas de $\mathrm{MgTiO}_{3}$ (geykielita) e de $\mathrm{MnTiO}_{2}$ (pyrofanita). Embora existam algumas diferenças entre as ilmenitas de Ymi-1 e de Ymi-8, elas tem em comum que distribuem-se pelo campo das ilmenitas encontradas em carbonatitos (Gaspar \& Wylliie, 1984; Mitchell, 1986) e também em lamproítos (ver as Figuras $3-18$ e 4-4). 
As análises de dois cristais de turmalina arredondada, verde amarronzada $(<0.5$ $\mathrm{mm}$ ) apresentam teores de $\mathrm{SiO}_{2}<30 \%$, considerados como baixo para turmalinas. Provavelmente trata-se de pseudomorfos, e por esta razão foram deixadas de lado.

Embora as análises da suite de minerais pesados (ilmenita, pseudobrookita, rutilo, diamante e zircão) apontem uma origem lamproítica (cf. Fipke, 1994) ou lamprofírica (como p/ex. Ymi-1) a natureza lamprofírica vê-se reforçada se considerado que as rochas apresentam uma suites de minerais pesados parecida com a do pipe lamprofírico Ymi-1 (distante poucos kms a NE) como também reforçado pelo fato das ilmenitas apresentarem feições quimicas (Figura 4-4) similares às ilmenitas encontradas em carbonatitos, o que significa ilmenitas desenvolvidas num ambiente de cristalização rico em $\mathrm{CO}_{2}$ como o é o ambiente de cristalização dos magmas lamprofíricos (Rock, 1991).

\section{Intrusões Yzu-4 e as do arroyo ltá}

Conforme comentado anteriormente, no Campo Ybytyruzú as pesquisas sobre os minerais pesados foram executadas em caráter informativo, conquanto as informações tenham sido obtidas de concentrados obtidos em cuias de ouro no periodo em que o programa deste projeto de trabalho já tinha-se encerrado. A seguir elas serão comentadas brevemente com o intuito de acrescentar mais dados a este trabalho e apontar futuros trabalhos de pesquisa.

Yzu-4: em pequenos volumes de concentrado foram observados abundantemente espinélios, (fundamentalmente) euhedrais, de dimensões pequenas $(<0.5 \mathrm{~mm}$ ); ilmenita prismática sub milimétrica a milimétrica; lamelas de mica escura, preferentemente com formas pseudo-hexagonais e de tamanhos milimétricos; prismas quebrados a cristais irregulares de piroxênio verde a verde-maçã. Aparentam uma assambleia de minerais pesados comum de fontes kimberlitica, orangeítica, lamproíticas e lamprofíricas (cf. Jaques et al., 1989; Fipke, 1991;1994 e também comentários de itens acima). 

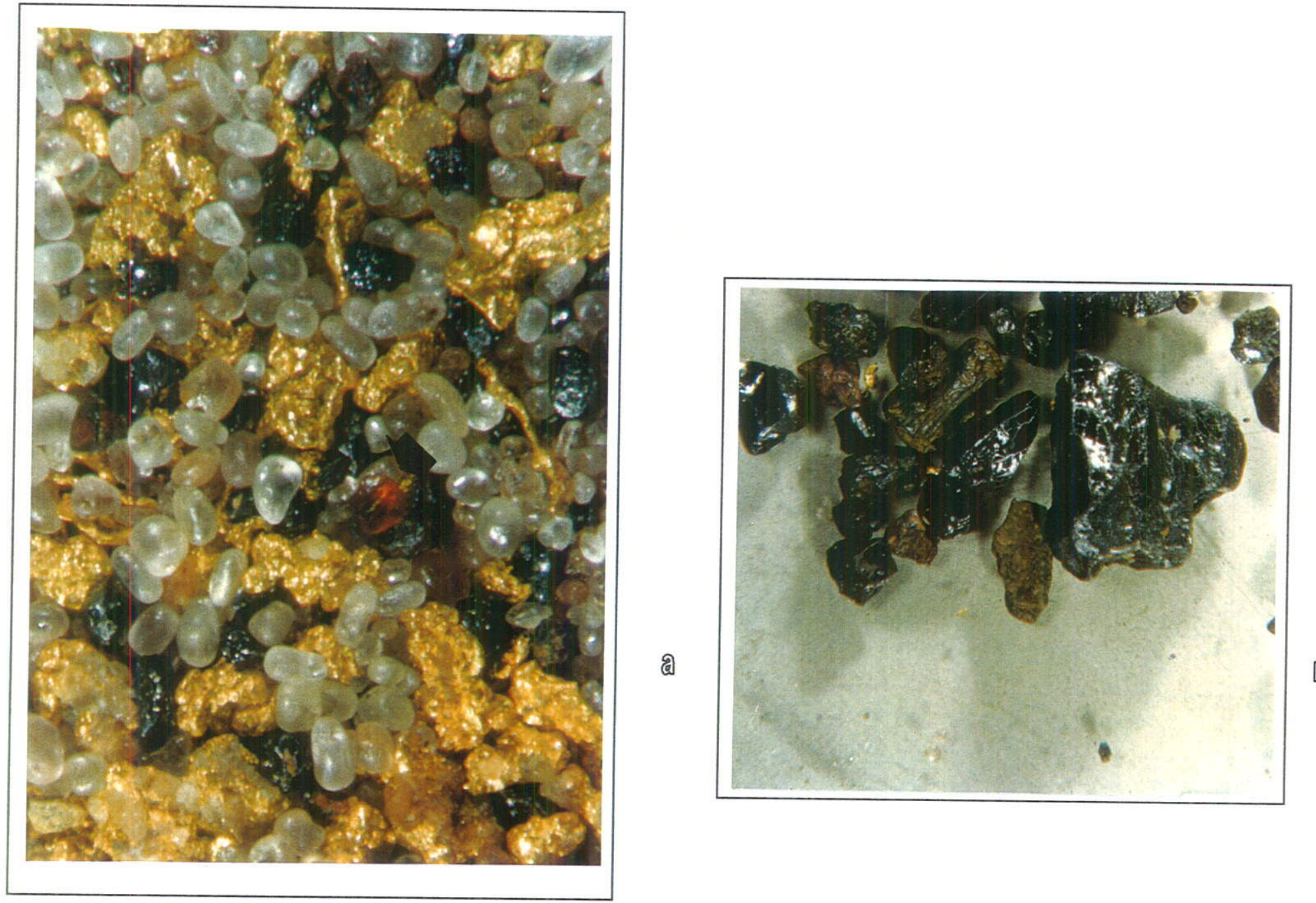

Fotomicrografia 8. Concentrado de minerais pesados do arroyo Itá (Yzu-10).(a) partículas de ouro (1-3 mm) junto a cristais de zircão (incolor), espinélios (preto) e granada (cristal vermelho-roxo indicado pela seta). (b) cristais de ilmenita reunidos evidenciando suas dimensões e formas dos (cristal maior de $\sim 5 \mathrm{~mm}$ =megácristal). Fotografias em lupa binocular, luz natural. 
Arroyo Itá: este córrego alimenta-se dos minerais pesados de várias intrusões lamprofíricas que ocorrem na área de aproximadamente $30 \mathrm{~km}^{2}$ pesquisadas. Através do cascalho do leito de córrego (Itá) foram separados partículas de ouro (Fotomicrografia 8 (a)) sub milimétricas a centimétricas, cristais sub-milimétricos a milimétricos (megacristais de até $5 \mathrm{~mm}$. Fotomicrografia 8 (b)) euhédrais a fragmentos anedrias de ilmenita; cristais octaédricos a irregulares de espinélio (Fotomicrografia 8 (a)), de até submilimétricos; fragmentos irregulares e pequenos $(<0.5 \mathrm{~mm}$ ) de cristais de granada em cores de laranja-vivo, rosa, rosa-brilhante e vermelho sangue-roxo (Fotomicrografia 8 (a)); lamelas pseudo-hexagonais submilimétricas a milimétricas de mica; cristais irregulares de piroxênio escuro, submilimétricos. São assambleia de minerais pesados comuns de zonas com rochas kimberlitóides (cf. Dawson, 1980; Mitchell, 1986; 1995; Mitchell \& Berman, 1991; Atkinson et al., 1984; Fipke, 1991; 1994). 


\section{CAPÍTULO 5}

\section{CONSIDERAÇÕES FÍSICO-QUIMIICAS DOS PIPES}

\section{TERMOBAROMETRIA}

Uma revisão dos diferentes termo-barômetros empregados em xenólitos peridotiticos com granada são encontrados em Finnerty \& Boyd (1987) e também em Finnerty (1989). O problema corrente que apresentam muitos dos métodos consagrados é colocar acertadamente xenólitos diamantíferos na "janela" do diamante e os xenólitos com grafita e/ou anfibólio, e/ou com flogopita colocar no campo de estabilidade da grafita. Como Finnerty (1989), Bertrand et al. (1984) calibraram o barômetro aluminous-enstatite empregando dados de 50-100 kbar obtidos em Yamada \& Takahashi (1983), e assim apresentando as geotermas da Africa do Sul nas que foram exibidas inflexões de baixa temperatura. Dados de alta pressão de solubilidade da alumina (por exemplo em piroxênios) é incorporado por Bertrand et al. (1984) junto aos dados de baixa pressão, porém resultando num barômetro que subestima a pressão: i.e. xenólitos portadores de diamante caem em pelo menos 5.7 kbar no campo de estabilidade da grafita.

Por outro lado Finnerty (1989) revisa o barômetro aluminous enstatite de Nickel \& Gren (1985) modificado por Carswell \& Gibb (1987 a, b) que distribue as moléculas de jadeíta em ortopiroxênio com relativamente alto teor de $\mathrm{Na}$. Como resultado verificou-se que aplicado aos xenólitos do Norte de Lesotho o barômetro näo suporta a inflexão nas geotermas desta localidade. 
Finalmente Finnerty (1989) revisa o barômetro de Adans \& Bishop (1986), que recalibraram o barômetro da olivina de Finnerty \& Boyd (1978), mostrando o arranjo P.T aplicado na Africa do Sul o qual aparece não inferido. Finnerty (1989) encontróu que este barômetro também subestima a pressão entre 10-20 kbar, resultando com que xenólitos de kimberlitos da Africa do Sul são lançados junto ao campo de estabilidade da grafita.

Finnerty (1989) entende que em consequência da inflexão de alta temperatura no Cretáceo ser um fato das geotermas do manto superior da Africa do Sul, conclui que a inflexão é evidente com independentes termômetros e independentes barômetros e eles não deveriam ser pilares, (entende-se) para extrapolações na estimação do P-T. Alguns inconvenientes surgem quando empregados diferentes métodos de cálculo da $T\left({ }^{\circ} \mathrm{C}\right.$ ) e também da pressão (Kbar); assim empregando-se no xenólito UV-198/76 (Udachnaya) Jaques et al. (1990) os termo-barômetros de Brey (1989)-Brey et al. (1989) junto aos de O'Neill \& Wall (1987)-Brey et al. (1989) obtiveram-se temperaturas e pressões de $846^{\circ} \mathrm{C}-3.90 \mathrm{~Kb}$ e $852^{\circ} \mathrm{C}-3.20 \mathrm{~Kb}$; neles, dados prévios de Boy \& Finnety (1980), pelos métodos LD20/M74 e OW79/M74 forneceram os seguintes valores de P-T: $1285^{\circ} \mathrm{C}-66 \mathrm{kbar}$ e $1260^{\circ} \mathrm{Ce} 64 \mathrm{kbar}$ para o mesmo xenólito. Griffint et al. (1993) empregando os termômetro de $\mathrm{Ni}$ em granadas e de $\mathrm{Zn}$ nos espinélios do xenólito Uv-198/76, estimaram temperaturas $1010^{\circ}$ (granada) e $995^{\circ}$ (espinélio) C. Outros exemplos podem ser conferidos nos cálculos de P-T calculadas por Boyd et al. (1993) em 22 xenólitos de granada (de baixo cálcio) harzburgitos da Africa do Sul, como produto da combinação de diferentes pares minerais (diferentes métodos termobarométricos) por eles ensaiados.

Fabríes (1979) e também Ballhaus et al. (1991), com base aos "pares minerais", estabeleceram termômetro levando em consideração o espinélio. Griffin et al. (1992; 1994a-b) observaram que os espinélios que coexistem com granada nas inclusões dos diamante apresentam temperatura de formação, medida nas granadas, inversamente proporcional ao conteúdo de $\mathrm{Zn}$ (ppm.) neles medidos. Com base nesta observação foi estabelecido o Termômetro do Zn (ex. Griffin et al., 1994). Recentemente Presser (1997) observou que espinélios apresentavam teores de MgO diretamente proporcionais a temperatura de formação obtida por Griffin et al. (1993) pelo termômetro do $\mathrm{Zn}$ e assim propôs um novo termômetro, que em analogia ao 
levantado por Griffin et al. (1993) a temperatura de formacão é diretamente obtida num monocristal.

Presser \& Da Silva (1987), aplicando a reta de regressão linear formada pelo teor em $\mathrm{MgO}$ em espinélios cromíferos encontrados em lamproítos e kimberlitos (Sovolev et al., 1989) e as $\mathrm{T}^{\circ} \mathrm{C}$ obtidas (Sobolev et al., 1989) nestes minerais através do método de Fabries (1979), encontraram que a temperatura de formação dos espinélios esta definido pela equação $\mathrm{TMg}=742,48 *\left(26.8^{*} \mathrm{MgO}\right)(=$ Termômetro TMg $)$. Para testar o grau de confiabilidade do termômetro TMg comparou suas medidas com as temperaturas obtidas por outros métodos em cristais de espinélios. Estas comparações são mostradas nas Figura 5-1 (a) e (b); na primeira figura mostra-se excelente correlação entre o termômetro de $\mathrm{Zn}$ e o termômetro TMg aplicado a espinélios que ocorrem como inclusão no diamante e aqueles que ocorrem em peridotitos, i.e., xenocristais. A Figura 5-1 (b), também mostra aproximação entre o termômetro TMg e a temperatura de formação dos espinélios encontrados por Garda (1995) em rochas alcalinas de São Sebastião e arredores. Garda (1995) empregou para os cálculos de temperatura vários métodos e entre eles o termômetro de Balthaus et al. (1991).

Griffin et al. (1993) e Griffin \& Ryan (1995) determinaram com base no termômetro do $\mathrm{Ni}$ (TNi), aplicado em granadas que ocorrem em peridotitos diamantíferos e não diamantíferos, como também em granadas que ocorrem como inclusões em diamantes de kimberlitos, orangeítos e lamproítos instalados em diversos ambientes cratónicos, o tipo de gradiente geotérmico para os crátons onde essas rochas ocorrem. Assim temperaturas de $\approx 850-1100^{\circ} \mathrm{C}$ são próprias de ambientes cratônicos com o gradiente geotérmico da ordem de $35 \mathrm{mw} / \mathrm{m}^{2}$; temperaturas de $\approx 950-1200^{\circ} \mathrm{C}$ são própias de ambientes cratónicos com o gradiente geotérmico da ordem de $40 \mathrm{mw} / \mathrm{m}^{2}$ (Griffin \& Ryan, 1995). Nas Figuras 5-2 são dados os histogramas de temperatura para inclusões de espinélio em diamantes e xenocristais de espinélios coletados nos diferentes corpos portadores de diamantes que ocorrem em regiões cratônicas, estas temperaturas de cristalização foram estimadas com base ao termômetro TMg (Presser \& Da Silva, 1997). Nos espinélios que ocorrem no cráton da Rússia as temperaturas obtidas vão de $1020-1180^{\circ} \mathrm{C} \approx 35 \mathrm{mw} / \mathrm{m}^{2}$ em consonância com o estimado por outros métodos termométricos, como os de Griffin \& Ryan (1995) 

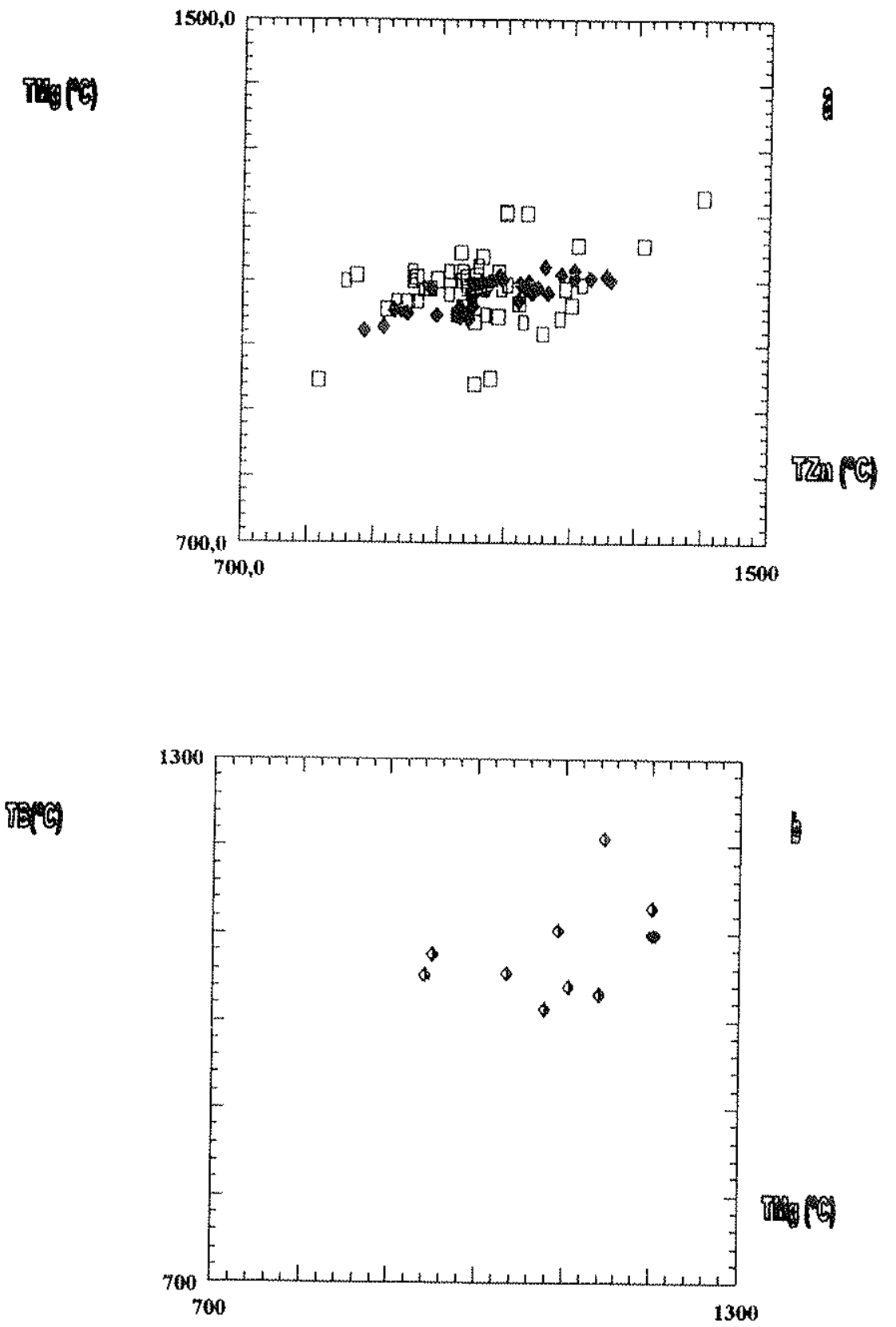

Figura 5-1. Correlação dos métodos de temperatura em espinélios. (a) correlaciona «se as temperaturas obtidas pelo termômetro do $\mathrm{Zn}(\mathrm{TZn})$ (Griffin et al., 1993) e as temperaturas obtidas pelo termômetro TMg $([742.48+(26.8 * \mathrm{MgO})]$, Presser \& Da Silva, 1997). (b) aqui correlaciona-se as temperaturas obtidas por Garda (1995), pelo método de Ballhaus et al (1991)(TB), com as obtidas pelo termômetro TMg. Notar como tanto em (a) como em (b) existe uma boa correlação, com sutis diferenças em (a) (em rombos, inclusões em diamantes e em quadros, xenólitos peridotíticos, cf. Griffin et al., 1993) e algo menos sutil em (b). Fontes são citadas no texto. 
e Griffin et al. (1993). Nos espinélios que ocorrem no cráton Kimberley (Austrália) as temperaturas obtidas vão de $900-1100^{\circ} \mathrm{C}, \approx 35 \mathrm{mw} / \mathrm{m}^{2}$ são coincidentes com o gradiente geotérmico obtidos pelos dados de Jaques et al. (1990; 1994) e, em parte, similares aos estimados por Griffin \& Ryan (1995). Nos espinélios que ocorrem no cráton South Africam (Africa do Sul) as temperaturas obtidas por Griffin \& Ryan (1995), vão de $1030-1100^{\circ} \mathrm{C} \approx 35 \mathrm{mw} / \mathrm{m}^{2}$; gradiente estimado em inclusões de diamantes/xenólitos peridotíticos transportados pelos orangeitos. Nos espinélios que ocorrem no cráton da China (ex. pipe Lianing \#42) as temperaturas obtidas vão de $1055-1112^{\circ} \mathrm{C} \approx 35 \mathrm{mw} / \mathrm{m}^{2}$ a $\approx 40 \mathrm{mw} / \mathrm{m}^{2}$ e assim também muito similar ao determinado por Griffin \& Ryan (1995).

Conquanto que no presente trabalho de tese conta-se com grande número de dados de xenocristais de espinélios cromiferos (cromita magnesiana e cromita), julgou-se conveniente explorar os alcances das informaçöes termodinâmicas acerca dos espinélios.

Acredita que o termômetro TMg fornece temperaturas confiáveis; assim sendo este termômetro será empregado para estimar as temperaturas de formação dos espinélios (xenocristais) que ocorrem nos corpos Ymi-1 (concentrados, inclusão e microfenocristais) e Yzu-1 (inclusão).

A Figura 5-3 fornece os histogramas de temperatura calculados para xenocristais de espinélios de Ymi-1 $\left(\approx 850-1050^{\circ} \mathrm{C}\right)$ e de YZu- $1\left(\approx 900-1050^{\circ} \mathrm{C}\right)$. Essas temperaturas são próprias de espinélios formados em um manto ligados a crátons e que sugerem um gradiente geotérmico da ordem de $35 \mathrm{mw} / \mathrm{m}^{2}$ (cf. Griffin \& Ryan, 1995 e referências). Na mesma Figura 5-3 são também dados Qs histogramas de temperatura calculados para xenocristais de espinélios do meta-vulcanito alcalino Pré-cambriano encontrado na cidade de San Miguel (Alto de Caapucú) $\approx 1145-1300^{\circ}$ $\mathrm{C}$, e para cristais de espinélio que ocorrem no espinélio-peridotito que carrega o nefelinito Terciário de Nemby (cf. Demarchi et al., 1988) $\approx 1200-1300^{\circ} \mathrm{C}$, temperaturas que mostram um alto fluxo térmico e assim prováveimente acusando fluxos termais próprios de regiōes de borda de cráton e/ou faixas móveis nos domínios tectônicos onde ocorrem as rochas que trazem estes xenocristais (p/ex. Rock, 1991; Nixon, 1987). 
$742.48+(26.8 * \mathrm{MgO})$

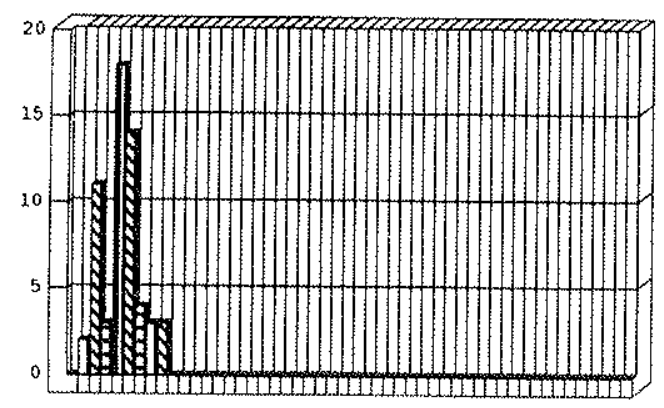

Range $1000-2000$
$742.48+(26.8 * \mathrm{MgO})$

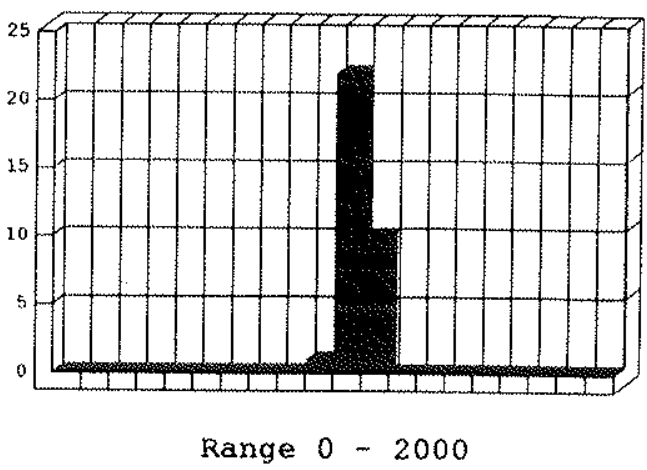

B)
$742.48+(26.8 * \mathrm{MgO})$

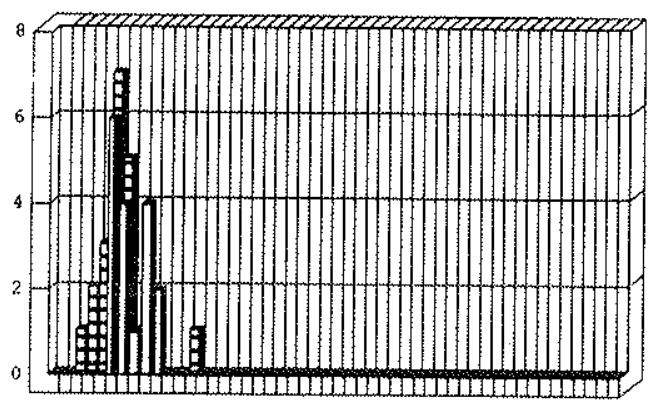

Range $1000-2000$

包

$742.48+(26.8 * \mathrm{MgO})$

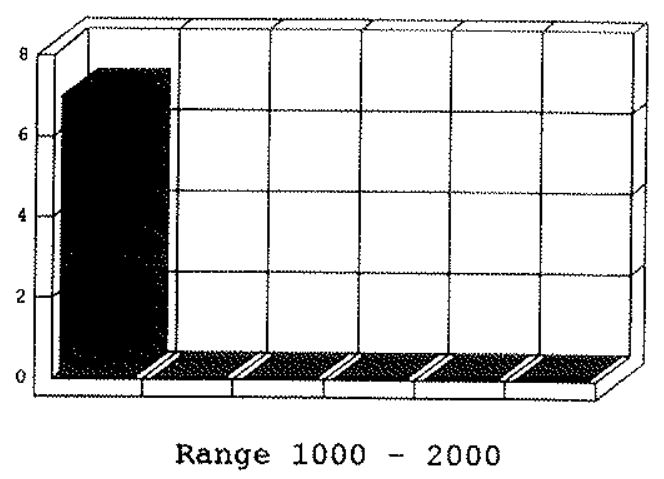

C

Figura 5-2. Histograma do termômetro TMg. (a), temperaturas $\left(\mathrm{T}^{\circ} \mathrm{C}\right.$ ) obtidas nos espinélios inclusos nos diamantes e nos espinélios associados/não associados ao diamante em peridotitos da C.I.S (Rússia) que mostra T: 1020 1180. (b) temperaturas obtidas em inclusíes de espinélios nos diamantes e nos xenocristais de espinélios dos pipes do Crato de Kimberley (Austrália), com T: 900-1100.(c) temperaturas obtidas em inclusóes de espinelios nos diamantes e nos xenocristais de espinélios dos pipes do craton de South African (Sul da Africa), com T: 1030-1100. (d) temperaturas obtidas em inclusóes de espinélios nos diamantes do crato na China (ex pipe Liaoning\#42), com T 1055-1110. As temperaturas da ordem de $850-1100^{\circ} \mathrm{C}$ definem um gradiente geotérmico da ordem de $35 \mathrm{mw} / \mathrm{m}^{2}$ (1) e as de $950-1200^{\circ} \mathrm{C}=40 \mathrm{mw} / \mathrm{m}^{2}$ (2)(Griffin \& Ryan, 1995). $\approx(1)$ em Rússia; Kimberley e South African (em orangeitos) e $\approx(2)$ em South African (em kimberlitos) e China. Dados que mostram como TMg define gradientes geotérmicos similares aos estimados por Griffin \& Ryan (1995) pelo termômetro TNi. Fontes: Griffin et al. (1992); Bulanova (1995); Daniels \& Gurney (1989); Jaques et al. (1984;1994); Atkinson et al. (1984); Fipke (1994); Meyer et al. (1994) o os citados no texto. 
O termômetro TMg poderia ser aplicado a espinélios do trend magmático apesar de que a equação permite temperaturas mínimas de $\sim 770^{\circ} \mathrm{C}$. Entretanto, neste trabalho preferiu-se aplica-lo só aos xenocristais; futuras pesquisas poderão ser conduzidas para testar o alcance deste termômetro.

Observa-se que as inclusões de espinélios da série da cromita nos diamantes possuem pelo geral $>55$ a $\approx 70 \%$ de $\mathrm{Cr}_{2} \mathrm{O}_{3}$ (cf. Nixon 1987); embora que a janela do diamante, segundo Nickel \& Green (1985), oscila entre $40-55 \mathrm{~Kb}$, o teor de crômio medido nos espinélios da Série da Cromita, que ocorrem nos diamantes e/ou em espinélios peridotíticos do manto, com ou sem diamantes, deveria ser um sensor da pressão.

Doroshev \& Turkin (1982) e Turkin et al. (1983) investigaram a composição da granada $e$ do espinélios nos 4 minerais de paragenêse harzburgitica $\left(\mathrm{Gra}_{\mathrm{ss}}+\mathrm{Opx} \mathrm{ps}_{\mathrm{ss}}+\mathrm{Sp}_{\mathrm{ss}}+\mathrm{Fo}\right.$ ), no sistema $\mathrm{MgO}-\mathrm{Al}_{2} \mathrm{O}_{3}-\mathrm{SiO}_{2}-\mathrm{Cr}_{2} \mathrm{O}_{3}$ (MASCr) sob pressão de $30,40,55$ e $70 \mathrm{kbar}$, e temperaturas compativeis mostrando que:

1-o componente knorringita nas granadas aumenta com o incremento da $\mathrm{P}$ e da $\mathrm{T}$ (traço negativo de $\mathrm{dP} / \mathrm{dT}$ das isolinhas de $\mathrm{Cr}$ );

2-o componente picrocromita (=cromita magnesiana) nos espinélios aumenta com a $\mathrm{P}$ e decresce com o aumento da $\mathrm{T}$ (positivo traço $\mathrm{dP} / \mathrm{dT}$ das isolinhas $\mathrm{Cr}$ ).

Brey et al. (1991) com base ao encontrado por Doroshev \& Turkin (1982) e Turkin et al. (1983) investigaram o comportamento da razão $\mathrm{Cr} /(\mathrm{Cr}+\mathrm{Al})$ nos espinélios e nas granadas (ambos cromíferos) e mostraram, que para os espinélios o valor do $\mathrm{Cr} /(\mathrm{Cr}+\mathrm{Al})$ é aproximadamente diretamente proporcional ao aumento da $\mathrm{P}$ e da $\mathrm{T}$. Posteriormente, Doroshev et al. (1997) estudando experimentalmente a assembléia mineral granada+ortopiroxênio+eskolaita granada+ortopiroxênio+espinélio+forsterita a 30-60 kbars e $1200-1500^{\circ} \mathrm{C}$ verificaram que o valor de Cr\# nos espinélios muda num intervalo curto, de 0.76 (40 kbar, $\left.1400^{\circ} \mathrm{C}\right)$ a $0.86\left(60 \mathrm{kbar}, 1500^{\circ} \mathrm{C}\right)$; e assinalando que o efeito da temperatura é negativo a todas as pressões estudadas. O incremento da temperatura de 1200 a $1500^{\circ} \mathrm{C}$ resulta em um decréscimo das moléculas de picrocromita de 0.83 a 0.76 a 40 kbars e de 0.88 a 0.80 a 50 Kbar. 


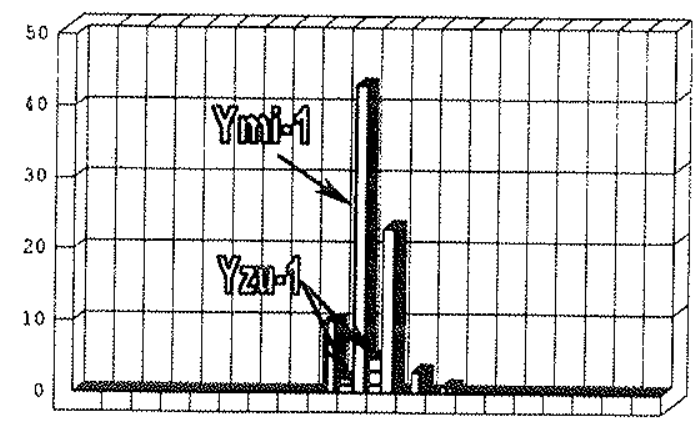

Range $0-2000$

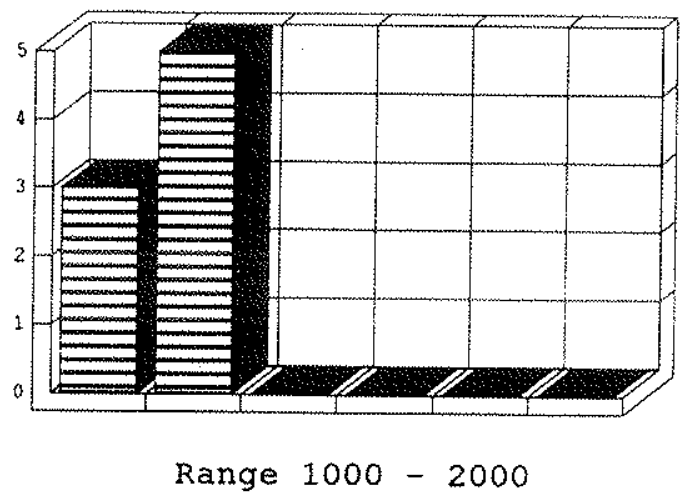

B

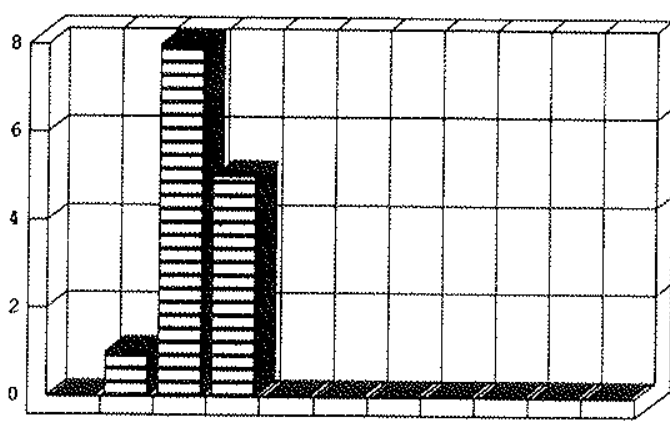

C

$$
\text { Range } 1000-2000
$$

Nigura 5-3. Histograma do termômetro TMg: espinélios do Paraguai. (a) temperaturas de $850-1050^{\circ} \mathrm{C}$ (Ymi-1) e 900-1050 $\mathrm{C}$ (Yzu-1) foram obtidas nos xenocristais de espinélios estudados neste trabalho; eles são comparados com as temperaturas que podem ser registradas em espinélios encontrados no metavulcanito alcalino (b) Pré-cambriano da cidade de San Miguel (Alto de Caapucú, ver Capítulo 2) que ocorre, como indicado no Capítulo 2 , em terrenos de borda cratônica $\approx 1145 \cdot 1300^{\circ} \mathrm{C}$ (Presser dados não publicados) e as temperaturas que podem ser registradas em espinélios dos peridotitos que ocorrem no nefelinito Terciário Nemby (Demarchi et al., 1988), considerado neste trabalho como ocorrendo em ambiente de faixas móveis, em temperaturas entre $1200-1300^{\circ} \mathrm{C}$. 
Como comentado ao início deste item, uma revisão dos diferentes termo-barômetros empregados em xenólitos peridotíticos com granada são encontrados em Finnerty \& Boyd (1987) e também em Finnerty (1989); sendo que aparecem correntemente problemas, quando muitos dos consagrados métodos não colocam acertadamente xenólitos diamantíferos na janela do diamante, e os xenólitos com grafita e/ou anfibólio, e/ou com flogopita no campo de estabilidade da grafita.

$\mathrm{Na}$ Figura 5-4 (a) foram lançados os valores de Cr\# de espinélios que coexistem com o diamante (inclusos em diamante ou junto ao diamante em peridotitos) e aqueles que coexistem com a grafita, flogopita e anfibólio, e na Figura 5-4 (c) os dados dos espinélios inclusos nos diamantes sendo que os valores da $P$ foram determinados com base ao apresentado por Doroshev et al. (1997). Este barômetro de Doroshev et al. (1997) desloca no plano da grafita espinélios que coexistem com o diamante (Figura 5-4 (a)) e espinélios que estão inclusos nos diamantes (Figura 5-4 (c)); mostrando assim que este barômetro estaria subestimado em alguns kbars a pressão real na qual se formaram estas inclusões. Entretanto, porquanto que o teor do $\mathrm{Cr}$ nos espinélios seja um fator dependente da P (Daniels, 1992 em Gurney \& Zweistra, 1995) julgo-se como necessário levar em consideração o teor em $\mathrm{Cr}_{2} \mathrm{O}_{3}$ registrado nos espinélios cromíferos. Assim, se pesquisou se o teor de crômio multiplicado pelo valor do $\mathrm{Cr}$ \# $(\mathrm{Cr} /(\mathrm{Cr}+\mathrm{Al})$-(=barômetro de Doroshev et al., 1997) conseguiria colocar acertadamente xenólitos diamantíferos na janela do diamante e os xenólitos com grafita e/ou anfibólio, e/ou com flogopita no campo de estabilidade da grafita e assim reproduzir adequadamente a pressão de formação destes espinélios. Empregando o termômetro $\mathrm{TMg}$ e o valor de $\mathrm{Cr}_{2} \mathrm{O}_{3}$ multiplicado pelo valor de $\mathrm{Cr}$ a as espinélios pesquisados da fácies do diamante e da fácies da grafita (Figuras 5-4 e 5-4 (c)), nas Figuras 4-8 (b) e (d) testou-se o grau de precisão da pressão de formação i.e., colocando espinélios da fácies do diamante no campo de estabilidade do diamante e colocando espinélios da fácies da grafita no campo de estabilidade da grafita. Esta variação ao barômetro de Doroshev et al. (1997) mostrase efetivo colocando perfeitamente no plano/junto ao plano de estabilidade do diamante, espinélios que coexistem com diamante (Figura 4-8b) e espinélios inclusos nos diamantes (Figura 5-4 (d)). 
g

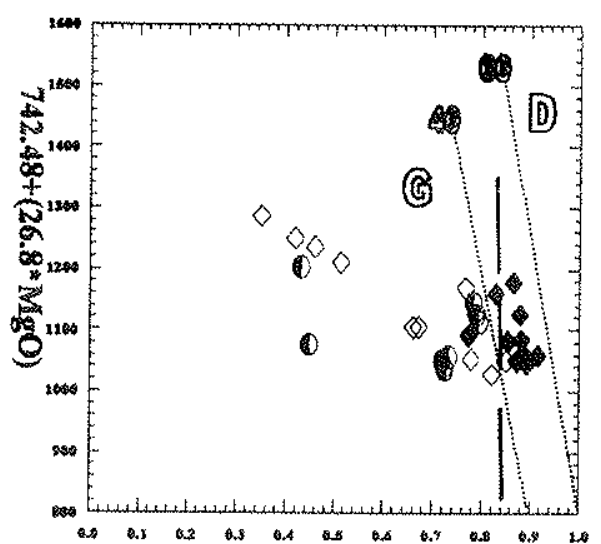

$\mathrm{Cr} /(\mathrm{Cr}+\mathrm{Al})$

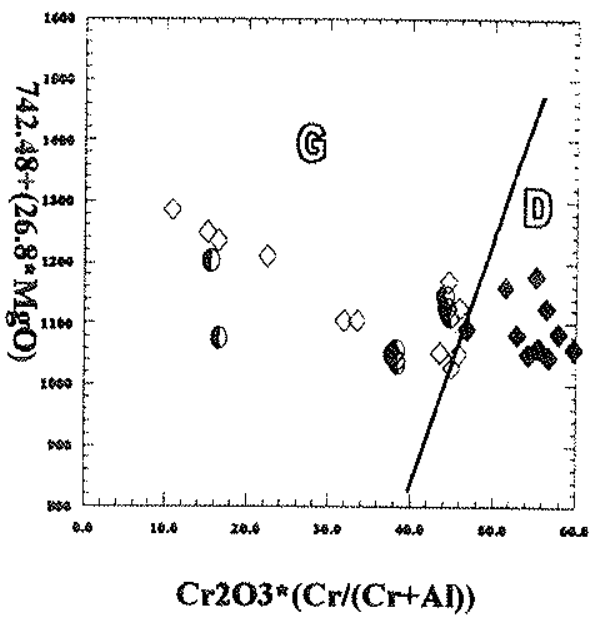

(d]

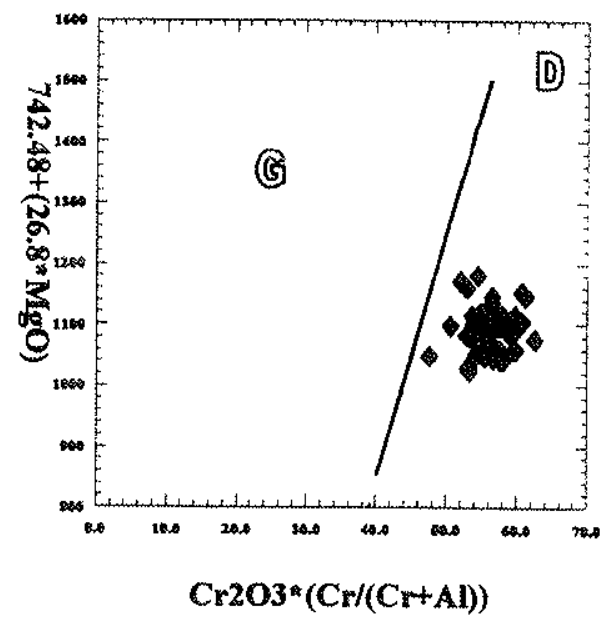

Figura 5-4. P.T em espinélios. (a) diagrama Cr\# vs T (TMg) e (b) PCr\# vs T (TMg) em espinélios que coexistem com grafita/anfibólio/flogopita (em circulo); aqueles espinélios que coexistem com diamante: inclusos neles e/ou encontrados em peridotitos diamamíferos (rombo cheio) e aqueles xenocristais de espinélios que ocorrem como concentrados em fontes ígneas diamantíferas (rombo vácuo). $O$ mesmo procedimento de (a) traçado só para inclusð̌es de espinélio em diamante, é mostrado em (c) e em (d) são mostrados para as mesmas inclusðes como feito em (b). O campo de estabilidade da grafita (G) e o Diamante (D) com base a Kennedy \& Kennedy (1976). As linhas de P em (a) e em (c) foram traçados conforme Doroshev et al. (1997). Em (b) e (d) os cálculos de $P$ e as fontes dos dados ver no texto. 
Desta forma acredita-se que fica levantado como proposição que o valor da razão $\mathrm{Cr}$ nos espinélios multiplicado pelo teor de $\mathrm{Cr}_{2} \mathrm{O}_{3}$ nos mesmos espinélios, pode ser empregado como um barômetro $(=\mathrm{PC} \#)$ e sua aplicação pode ser levada a um monocristal; isto é observado não como um novo barômetro e sim como uma leve modificação do barômetro de Doroshev et al. (1997). Empregar um monocristal para obtenção de dados termométricos (Griffin et al., 1992; 1993; Presser, 1997 e Presser \& Da Silva 1997) barométricos (Brey et al., 1991; Doroshev et al. 1997) constituem portanto não uma novidade.

Os dados colocados nas Figuras 5-4 foram extraidos de Svisero (1975); Popilenko et al. (1972); Sobolev et al. (1972; 1997); Nixon \& Boyd (1973); Smith \& Dawson (1975); Dawson \& Smith (1975); Boyd \& Nixon (1973); Haggerty (1973); Erlank et al. (1987); Witerburm et al. (1990); Griffin et al. (1993); Jaques et al. (1989;1990; 1994); Reid et al. (1975); Danni et al. (1991); Bulanova (1995); Meyer et al. (1994). O plano de separacão da grafita e do diamante pertence a Kennedy \& Kennedy (1976) i.e. $19.4+\mathrm{T}^{\circ} \mathrm{C} / 40=\mathrm{kbar}$.

Quando comentado o termômetro do $\mathrm{Mg}$ observou-se que aparentemente seu emprego poderia ser estendido a espinélios da séries espinélio e magnetitas ( $\mathrm{MgO}$ até $<1 \%$ ). No caso do barômetro PCr\#, como mostrado nas Figuras 5-4 (d), a P parece ser confiável até um máximo de $\sim 65-70 \mathrm{kbar}$. Valores de 70-75 kbar $(\approx 238$ $\mathrm{km}$ ) foram calculados como limites de estabilidade do par granada-espinélio cromíferos (Doroshev et al., 1997) e também são próximos aos estimados como limite da raiz do manto em áreas cratônicas (cf. Nickel \& Green 1985, Griffint \& Ryan 1995). As figuras 5-4 (b) e 5-4 (d) permitem também observar que espinélios inclusos em diamante e os encontrados em peridotitos diamantiferos formaram-se entre pressões de $\approx 50$ a $\approx 60 \mathrm{kbar}$, que são valores similares ao freqüentemente registrado na literatura (ex. Jaques et al., 1990; 1994).

Aplicando o termômetro TMg e o barômetro $\mathrm{PC}$ \# aos xenocristais de espinélios de Ymi-1 (concentrados, microfenocristais e inclusões) colocam-se dentro e fora do campo de estabilidade do diamante (Figura 5-5). Os cristais alocados na janela do diamante apoiam o sugerido pelos mesmos espinélios quando eles lançados nos sistemas Picrocromita-Cromita-Espinélio-Hercynita e $\mathrm{MgFe}_{2} \mathrm{O}_{4}-\mathrm{MgCr}_{2} \mathrm{O}_{4}-\mathrm{MgAl}_{2} \mathrm{O}_{4}$ 

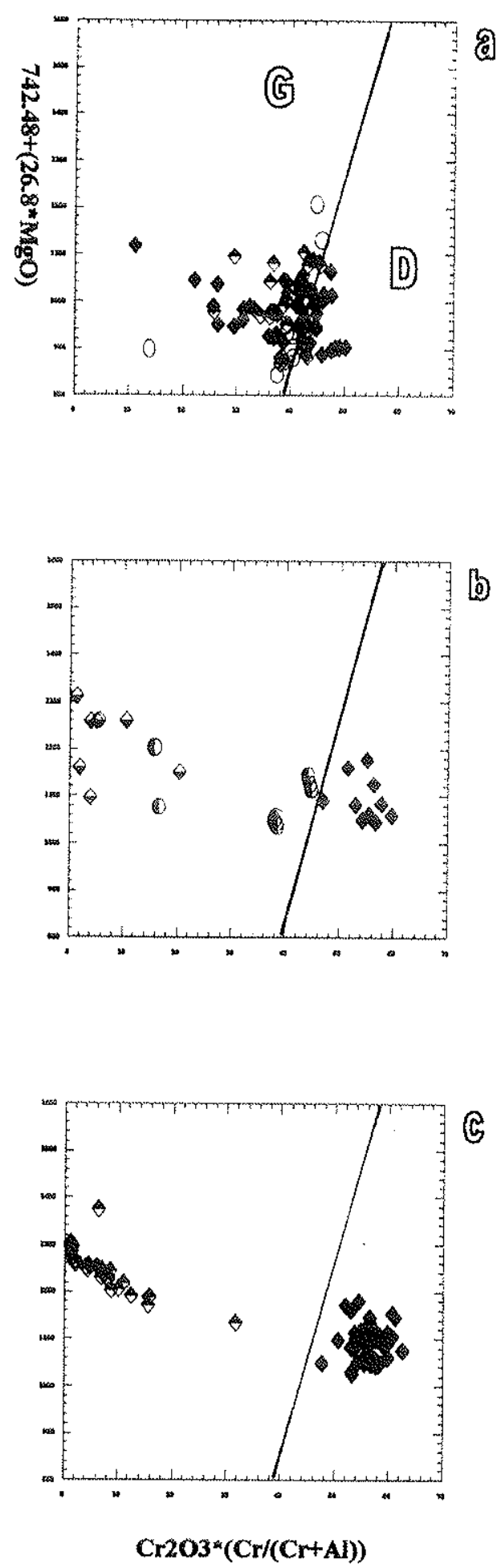

Figura 5-5. P.T em espinélios do Paraguai Centro Oriental (a) espinélios de Ymi-1 (fen-círculos; incltriângulo meio cheio e conc.-rombo cheio) e Yzu-1 (quadros) com relação ao campo de estabilidade do diamante (D) e a da grafita (G); são comparados com xenocristais de espinélios do meta-vulcanito alcalino Pré-cambriano de San Miguel ( $b$, ver texto) e peridotitos com espinélios portados pelo nefelinito Terciário de Nemby ( $c$, triângulo meio cheios). (b) similar a Figura $4-8 b$ e (c) similar a Figura $4 m 8 d$. 
(Figura 4-2) que mostram afinidade dos espinélios de Ymi-1 e Yzu-1 com espinélios da fácies do diamante. Em número maior espinélios das inclusões se espalham pelo campo de estabilidade da grafita -próximos ao campo de estabilidade do diamante, a diferência das inclusões de Yzu-1 que se situam em maior número no campo de estabilidade do diamante e o resto no campo de estabilidade da grafita. Na Figura 55 são também colocados para comparações espinélios do meta-vulcanito alcalino Pré-cambriano da cidade de San Miguel (SM)(5-5 (b)), que sugerem precedência de um manto profundo $(\approx 70-36 \mathrm{~km}$ ) e os do peridotitos com espinélios analisados por Demarchi et al. (1988) que ocorrem no nefelinito Terciário da cidade de Nemby $(\mathrm{PN})(5-5(\mathrm{c}))$ e que sugerem precedência de um manto mais raso $(\approx 50-5 \mathrm{~km})$ com um cristal (24/3282) que parece provir de fontes mais profundas $(\approx 107 \mathrm{~km})$.

Os dados P-T nos corpos Ymi-1 e Yzu-1 sugerem precedência de fontes peridotíticas ligadas a ambientes cratónicos; as do SM e PN sugerem procedência de fontes peridotíticas mais rasas, esta como freqüente das regiöes adelgaçadas, p/ex. borda cratónica no caso de SM, que pode-se seguir pelos dados de T acima comentados e; PM faixa móvel como também sugeridos pelos dados de $T$.

Desta forma, os dados P-T praticados nos xenocristais de espinélio de Ymi-1 e Yzu-1 sugerem que "lamprófiros" picríticos (ver Capítulo 3) amostraram peridotitos de um manto litosférico profundo ( $>150 \mathrm{~km}$ de profundidade) crátonizado, que no Jurássico ( $130 \mathrm{Ma})$ possuía o gradiente geotérmico de $35 \mathrm{~mW} / \mathrm{m}^{2}$, como pode ser deduzido para o cráton Rio de La Plata, onde estäo vinculadas estas intrusões, pelas interpretações geofísicas nele levantadas (ver Capítulo 2).

\section{Ambiente redutor vs oxidante}

Fugacidade de oxigênio inferiores ao tampäo QFM (quartzo-fayalita-magnetita) são indicativos de condições favoráveis para a formação e preservação do diamante (Ramsay \& Tompkins, 1994). Quando investigados os xenocristais de espinélio de Ymi-1 no diagrama $\mathrm{Fe}^{3+} /\left(\mathrm{Fe}^{3+}+\mathrm{Fe}^{2+}\right)$ vs $\mathrm{Cr}$ (Ramsay et al., 1994) indicam condições de formação abaixo do tampão QFM (Figura 5-6), com concentrações elevada das inclusões e alguns espinélios dos concentrados no tampão Q-1 (QFM, menos uma unidade logarítmica). Na mesma figura é evidenciado também que os 


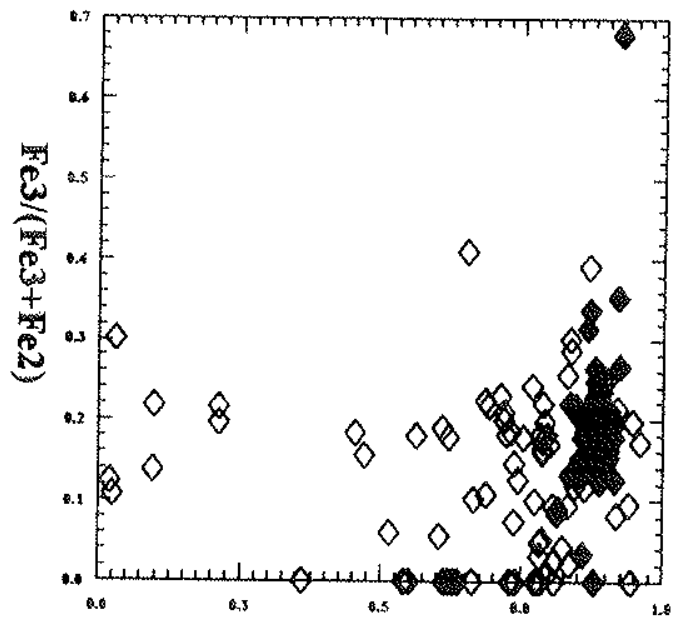

:

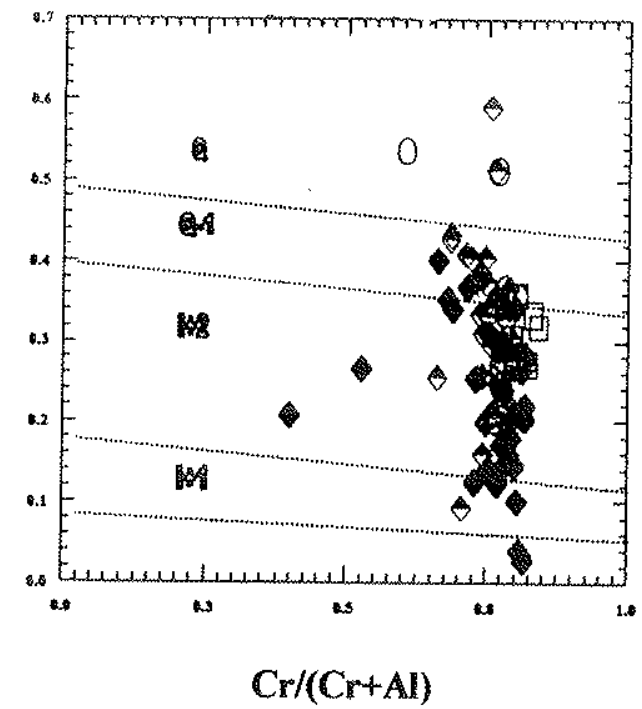

B

Figura 5-6. Condiç̃es de fugacidade de oxigênio nos espinélios. (a) xenocristais e cristais de espinélios associados ao diamante/inclusos no diamante no diagrama $\mathrm{Fe}^{3+} \#$ vs Cr\# (Ramsay \& Tomkins 1994; Ramsay et al., 1994) que evidência condiçães de fugacidade de oxigênio dos espinélios da fácies diamantífera $(\sim 0.4$

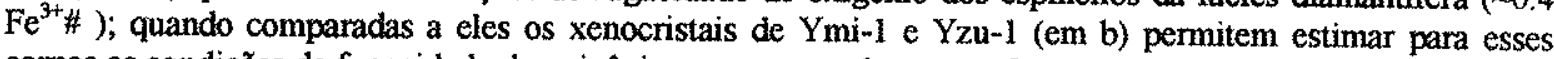
corpos as condiçðes de fugacidade de oxigênio como esperadas para a formação do diamante. Os tampões em (b), colocados aproximadamente: $\mathrm{Q}=$ quartzo-fayalita-magnetita, $\mathrm{Q}-1=$ quartzo-fayalita-magnetita menos uma unidade log. $I+1=$ ferro-wüstita mais uma unidade log., $I+2=$ ferro-wüstita mais dois unidades $\log$. Simbologias em (b) quadros Yzu-1 e rombos Ymi-1. Fontes são citadas no texto. 
microfenocristais, espinélios de concentrados e algumas inclusões apresentam fugacidade ainda menor, i.e., <1+1 (Ferro-Wüstita, mais uma unidade logarítmica), a $1+2$ (Ferro-Wüstita, mais duas unidades logarítmicas). São valores de fugacidade de oxigênio muito favoráveis à formação do diamante nas raizes cratónicas. Assim também as inclusões analisadas em $Y z u-1$ formaram-se num ambiente com tampão Q-1-1+2 (Figura 5-6). Como indicado por Foley (1985; 1989), para os magmas lamproíticos, a fugacidade de oxigênio ao tempo de cristalização dos fenocristais pode ser estimada pela composição dos espinélios cromíferos inclusos nos fenocristais de olivina. Se aplicado a Ymi-1 e Yzu-1, que apresentam abundantes inclusões de espinélios nas olivinas, pode-se esperar condições de transporte com fugacidade de oxigênio favoráveis para a preservação de diamante conquanto estes "lamprofíros". picríticos apresentam fugacidade de oxigênio definida pelos tampões $1+1$ a $Q-1$.

Pesquisado espinélios descritos em pipes diamantíferos, observou-se que os espinélios do trend magmático (Mitchell 1986; 1985; Mitchell \& Bergman, 1991) apresentam concentrações de $\mathrm{Fe}_{2} \mathrm{O}_{3}$ muito baixas (ex Argyle com $<5 \%$, cf. Jaques et al., 1989), moderadas (ex. Prairie Creek com $\sim 45 \%$, cf. Mitchell \& Bergman, $1991 \mathrm{e}$ referências) a altas (ex. Três Ranchos 4 com $\sim 54 \%$, ct. Danni et al. 1991; Costa 1995). Concentrações muito elevadas ( $\sim 60 \%)$ do $\mathrm{Fe}_{2} \mathrm{O}_{3}$ são observadas nos pipes estéreis (p/ex. Peuyuk, cf. Mitchell 1986). Embora ainda não avaliado em Ymi-1, ele possuí espinélios com $\mathrm{Fe}_{2} \mathrm{O}_{3}$ inferiores a $45 \%$ (ver apêndice A4), teores comparáveis com alguns pipes sub econômicos (p/ex. Ellendale 4, com $\sim 15 \mathrm{ct} / 100 t$, Hall \& Smith, 1985) a econômicos (p/ex Dutoitspan com $\sim 20 \mathrm{ct} / 100 t$, Jennings 1995).

Ilmenitas de baixo teor em MgO estão enriquecidas em $\mathrm{Fe}^{2+}$, porém também em $\mathrm{Fe}^{3+}$ e, assim, a série da itmenita serve como index do ambiente de oxidação, este um fator importante na preservação do diamante, tanto na região de origem como no conduto eruptivo (Haggerty, 1994). Ilmenitas analisadas em Ymi-1 e Ymi-8 no sistema $\mathrm{MgTiO}_{3}-\mathrm{FeTiO}_{3}-\mathrm{Fe}_{2} \mathrm{O}_{3}$ (Figura 4m) a $1300^{\circ} \mathrm{C}$ (Woermann ef al., 1970; Haggerty et al., 1979, citados em Haggerty, 1991) observa-se que eles apresentam condições de oxidação/redução em torno do tampão $10^{6}(\sim$ buffers wustita-magnetita a $30 \mathrm{kbar}$ e $1300^{\circ} \mathrm{C}$ ); i.e., um ambiente relativamente redutor o que aponta positivamente para a preservação do diamante. 
Nos últimos anos foi evidenciado que o diamante pode ser trazido a superfície, além dos consagrados kimberlitos e orangeitos e os procurados lamproítos, através de vários outros tipos de rochas alcalinas como lamprófiros ultramáficos (Hamilton \& Rock, 1990) e alcalinos (Jaques et al., 1989) e outras rochas basaltóides alcalinas comentadas em Janse (1994b). Entretanto, os lamprófiros cálcio-alcalinos (ex. as minettas) são referidos ainda modestamente como provável nova classe de rochas diamantíferas (Duggan \& Jaques 1996, ver também Bergman et al., 1988). Destacado em capítulos anteriores o pipe Ymi-1 trataria-se de um lamprófiro picritico cálcio-alcalino (e aparetemente também Ymi-8); fato que pelo menos em relação a Ymi-1 evidenciaria de que lamprófiros cálcio alcalinos são também uma nova fonte dos diamantes.

Na Figura 4-4 foram também lançados as ilmenitas dos lamproitos Yzu-2, Yzu-3 e Yzu-6. Nesta figura observa-se que as ilmenitas colocam-se em volta do tampão 10 7, tampão EMOS a $29.6 \mathrm{kbar}$ e $1230^{\circ} \mathrm{C}$; quando comparadas com a fugacidade de oxigênio das ilmenitas de outros lamproitos (Figura 4-4), o comportamento das ilmenitas neste trabalho estudadas apresenta semelhanças. 


\section{CAPÍTULO 6}

\section{Considerações e conclusões}

\section{Aspectos geodinâmicos sobre o assoalho da Bacia do Paraná: O Paraguai Oriental}

A temperatura é um parâmetro importante que controla todas as propriedades físicas das rochas utilizadas em estudos da litosfera profunda, através dos métodos geofísicos, e assim a litosfera espessa e fria tem uma assinatura potencialmente regional para as técnicas geofísicas ( Morgan, 1995).

Foram propostos dois modelos end member a fim de explicar a estrutura termal da litosfera espessa e fria:

O primeiro modelo faz uma análise dos dados de fluxo de calor global constante que são interpretados indicando que na litosfera continental estável (último evento térmico ou tectônico principal Paleozóico ou anteriores) posssue fluxo de calor debaixo da lâmina da crosta superior, a região onde o enriquecimento da produção de calor é relativamente constante, com um valor $27 \pm 4 \mathrm{mWm}^{-2}$. Esta análise pressupõe que o fluxo de calor de superfície de $35 \mathrm{mWm}^{-2}$ seja o resultado de uma crosta superior que contribuiu com $8 \mathrm{mWm}^{-2}$ de aquecimento radiogenico na produção para o fluxo de calor de superfície.

Um segundo modelo assume que todo aquele calor seria desviado da litosfera espessa de crátons do Archeano pela estabilidade geodinâmica da raiz cratônica litosférica espessa por transmissão na astenosfera (Ballard \& Pollack, 1987). Neste modelo, para determinação das variações de espessura na litosfera foram ajustados parâmetros fixos e os parâmetros de modelos de forma que o gradiente da 
temperatura no manto sub litosférico (astenosférico) era adiabático. Este gradiente adiabático essencialmente controla a temperatura como uma função da base da litosfera. O modelo de referência deste tipo usado por Ballard \& Polack (1987), para um cráton com cerca de $300 \mathrm{~km}$ de espessa litosfera, com um fluxo de calor de superfície de $40 \mathrm{mWm}^{-2}$, e uma crosta de $40 \mathrm{~km}$ de espessa com um calor radiogênico inferior uniforme, aquece a produção de $0.72 \mu \mathrm{Wm}^{-3}$.

A diferença térmica básica entre os dois modelos end member é que o primeiro modelo assume que todas as diferenças no fluxo de calor de superficie em regiões estáveis são causadas através de variações na produção de calor da crosta superior , e as mudanças em espessuras da litosfera é um resultado destas variações. O segundo modelo assume que nas regiões estáveis o espessura da litosfera é um parâmetro independente, e o fluxo de calor superficial é uma resposta das espessuras da litosfera e mudanças laterais na produção de calor crustal (Morgan, 1995).

O modelo petrológico sobre raiz do manto (diamantífero) implica que a litosfera debaixo dos crátons do Archeano é mais fria e mais refratária doque a do manto superior adjacente. Este modelo é apoiado por dados sismológicos e dados geotérmicos que sugerem que as placas em regiões continentais mais antigas são em média de maior espessura estando embaixo recoberta por extensa capa de material de manto anômalo (Helmstaedt \& Gurney, 1995). Se assume-se a variação da espessura da litosférica, ela será controlada geodinamicamente pela intrinseca raiz litosférica estável (Ballard \& Pollack, 1987); nela não há nenhuma largura de superficie mínima de uma anomalia com a raiz litosférica podendo existir independentemente das condições térmicas próximas à superfície. Porém, a análise da raiz litosférica estável foi postulado baseado em baixo fluxo de calor superficial, e as análises assumem variações significantes na produção do aquecimento crustal. Pode-se assumir em prática que se tais raizes existem, elas são expressadas em anomalias de até valores de 40 a $45 \mathrm{mWm}^{-2}$ ou menos. Infelizmente poucas áreas dispõem de dados suficiente sobre a densidade de fluxo de calor superficial para confirmar a associação destas condiçóes e recursos do diamante. $\mathrm{Na}$ determinação das temperaturas de assinaturas geofísicas relacionadas 
para a exploração regional de diamante, é, assim, assumido uma geotherma consistente com cerca de $200 \mathrm{~km}$ de espessura da litosfera. Para a gênese e preservação de diamantes, a base da litosfera deve estar no campo de estabilidade do diamante. Na base da litosfera, geralmente são assumidas temeperaturas como que estão dentro do intervalo de 1200 a $1600^{\circ} \mathrm{C}$ (Morgan, 1995).

De acordo com Ballard \& Pollack (1987), uma raiz cratônica relativamente fria, convectiva e pobremente conductiva, de material empobrecido, estende se a profundidades de $200-400 \mathrm{~km}$ e pode desviar bastante longe o calor do cráton respondendo por 50-100\% do contraste, por exemplo, observado no calor de fiuxo superficial entre o cráton Archeano de Kaapvaal-Limpopo-Zimbábue $\left(\sim 40 \mathrm{mWm}^{-2}\right)$ e a faixa móvel que o rodeia $\left(\sim 65 \mathrm{mWm}^{-2}\right)$. Os dados de fluxo térmico de $\pm 40 \mathrm{mWm}^{-2}$ foram encontrados na Bacia do Paraná (Hamza \& Munoz, 1996; Hamza, 1997).

Duchkov \& Sokolova (1997) estudando a estrutura termal da litosfera da plataforma Siberiana (com $\sim 1600 \times 1800 \mathrm{~km}$ da diämetro) concluiram que ela năo difere em muito de outras plataformas antigas do mundo: seu fluxo de calor comum é 30$40 \mathrm{mWm}^{-2}$, temperatura comum no limite de Moho $\left(-330-350^{\circ} \mathrm{C}\right)$, e a espessura desta litosfera térmica é de aproximadamente $200 \mathrm{~km}$.

Geothermometria e geobarometria de xenólitos podem ser empregados para deduzir as feições geotermais em profundidade. Onde estes dados foram levantados, em regiões associadas com diamantes, eles invariavelmente indicaram espessuras da litosfera ao redor $200 \pm 40 \mathrm{~km}$ (cf. Boyd \& Finnerty, 1980). No Capítulo 5 foram comparados os dados geotérmicos de xenocristais de espinélios dos corpos Ymi-1 e Yzu-1 com os dados geotérmicos obtidos, também em xenocristais de espinélios (de peridotitos e como inclusões de diamantes), dos diferentes corpos da plataforma Siberiana. Os dados térmicos dos corpos estudados assemelham-se em muito aos obtidos para a plataforma Siberiana; i.e., fluxo de calor $\sim 30-40 \mathrm{mWm}^{-2}$; e se comparado com o modelo de referência usado por Ballard \& Polack (1987) sugere, também, um cráton com cerca de $300 \mathrm{~km}$ de espessa litosfera, com um fluxo de calor de superfície de $40 \mathrm{mWm}^{-2}$, e $40 \mathrm{~km}$ de espessa crosta (40-47 km determinado, para o assoalho da Bacia do Paraná, por Assunpção et al., 1997). 
A densidade das rochas é uma função da temperaturas e estes parâmetros estão relacionados pelo coeficiente de volume de expansão térmica da rocha. Regiões com litosfera espessa e fria deveriam ser caracterizadas através da gravidade de Bouguer que são anomalias relativamente positivas com respeito a regiões com litosfera mais quente, e mais delgada. Há regiões nas quais os valores das anomalias de gravidade de Bouguer relativamente positivas concidem com ocorrências do diamante, como os "kimberlitos" diamantiferos de Mengyin (Provincia de Shagdong) na China Norte (Zhang et al., 1994; Morgan, 1995). O Maciço Curitiva e o "cráton" Luis Alves, porção leste do sul do Brasil, registra anomalias positivas de Bouguer (Hallinan et al., 1993; Quintas, 1995) e associados a estas feições ocorrem depósitos de diamante nos leitos dos rios vizinhos à região de Tibagi (Chieragatti, 1996) e rio Itararé (Svisero, 1994). Porém, esta correlação não é comum, e parâmetros diferentes de temperaturas que controlam a densidade da litosfera também devem ser considerados. Assim também, assinaturas mineralógicas distintivas podem ter um controle mais forte em cima da densidade do manto litosférico que os efeitos da temperatura, desta forma se explica a correlação fraca entre a assinatura de gravidade predita de uma raiz litosférica fria, espessa (i.e., manto sub-litosférico) e as ocorrências de diamante (Morgan, 1995). No Capitulo 2 foi levantado o fato que Quintas (1995) com base a dados gravimétricos definiu para o assoalho da bacia do Paraná um mosáico de blocos, sua geometria e localização das principais zonas de falhamento; sendo que, o modelamento isostático permitiu- lhe também, entre outras coisas, definir um bloco que possue caraterísticas de litosfera espessa e resistente (crátonic-like block) ao que denominou de Paranapanema; esto como mostrado na Figura $2-3$ possue uma largura $>1600 \mathrm{~km}$ e espessura variável de $\sim 300$ a $600 \mathrm{~km}$. $\mathrm{O}$ Bloco Paranapanema, constitue, como comentado no capitulo 2, o assoalho do segmento oriental do rift de Asunción, e que hospeda as intrusões de Ymi-1, Yzu-1, entre outras. Bloco cratônico que reune as dimensões de largura e espessura mínimas para constituir-se em uma janela para o diamante.

Morgan (1995) comenta que para que as anomalias térmicas litosféricas sejam significativas para janelas do diamante, elas têm que ter um diâmetro mínimo de cerca de $400 \mathrm{~km}$; este mesmo autor considerando que se pode concluir 
semelhantemente em função das anomalias de gravidade, que estão direta-ouindiretamente relacionados às anomalias térmicas, pode-se esperar anomalias de gravidade de uma largura semelhante.

Com base na tomografia sísmica, Grand (1987) considerou que o escudo e a plataforma estável de América Norte coincidem com uma região de onda shear relativamente rápida e aquelas ondas profundas de velocidade alta da raiz do manto, estando situadas em baixo das províncias Arqueanas Superior e Slave do escudo canadense (uma área de grande interesse atual para exploração de diamante). Estas anomalias parecem debilitar-se a uma profundidade de $200-300 \mathrm{~km}$, porém, sugerindo com clareza que a litosfera é fria e espessa (Morgan, 1995). Como as raízes do manto crátonizado são gravitativamente estáveis, e assim devem estar compostas de material menos denso, as velocidades das shear wave (SW) mais altas dentro das raizes requerem temperaturas mais frias, relativo à astenosfera mais quente adjacente (Heimstaedt \& Gurney, 1995). Dessa forma, segundo Morgan (1995), numa litosfera espessa e fria prevê-se uma velocidade sísmica inferior que numa litosfera mais afinada e mais quente; prevê-se também velocidades locais a qualquer profundidade especifica mais altas na raiz litosférica espessa e fria doque na litosfera mais quente adjacente ou astenosfera à mesma profundidade. Uma diferença de temperatura lateral de $100^{\circ} \mathrm{C}$ que poderia ser muito significante em termos de estar acima ou abaixo da transição do diamante e da grafita, resultaria numa mudança de velocidade de cerca de $0.5 \mathrm{kms}^{-1}$, ou aproximadamente $6 \%$ em 8 $\mathrm{kms}^{-1}$, na velocidade de onda compressional. São previstas mudanças semelhantes em velocidades de onda de shear. Assim, raizes litosféricas espessas e frias estarão associadas com velocidades de onda compressional normal e velocidades de onda shear a profundidade, com anomalias da ordem de poucos por cento (Morgan 1995).

Como as temperaturas aproximam o solidus, há uma diminuição marcada no módulo de rigidez de materiais de rochas e a taxa de diminuição em velocidades sísmicas, como uma função de temperatura crescente, aumenta, especialmente para as ondas shear. Normalmente é chamada esta diminuição de velocidades sísmicas do manto superior como zona de baixa velocidade (LVZ) e é considerado tipicamente para 
marcar o topo do astenosfera. Assim, uma baixa (100 km ou menos) LVZ indica litosfera delgada, morna ou quente; uma profunda $(>150 \mathrm{~km}) \mathrm{LVZ}$, indica litosfera espessa e fria (Morgan, 1995). De fato, LVZ abaixo das regiões cratônicas podem ser muito mal definidas (Jordan, 1975). Medidas de velocidade sísmicas do manto superior podem render valiosa informação relativo ao potencial para as condições favoráveis para gênese do diamante e sua preservação. Qualquer dos dados sísmicos fixos que demostrem informações sobre velocidades sísmicas para uma profundidade de $200 \mathrm{~km}$ ou maior, com uma resoluçäo lateral de $400 \mathrm{~km}$ ou maior, será útil para exploração regional de uma litosfera espessa e fria (Morgan 1995).

Com a exceção de zonas de subduccão, são restringidas como profundidades máximas dos hipocentros dos terremotos, correntemente, do meio à parte superior da crosta; esta correlacionada fracamente inversamente com fluxo de ondas shear de superfície. Assim, hipocentros relativamente fundos indicam baixo fluxo de calor (Morgan, 1995); i.e. litosteras crátonizadas. Nestas zonas também se observam queda da atividade de terremotos associados; estes devem-se concentrar longe da litosfera espessa e fria, caracterizada por escassez de sismicidade. Berrocal \& Fernandes (1996) mostram a distribuição da sismicidade do Paraguai e regiões vizinhas (cordillera dos Andes e a placa Sul-Americana); estes dados sísmicos apontam hipocentros profundos ( $\sim 500$ a $600 \mathrm{~km}$ de profundidade) para o Paraguai e regiöes vizinhas do Brasil evidenciando assim sismicidade típica de zonas de fluxo de calor frio; i.e. litosferas crátonizadas. James et al. (1993) comparam a região cratônica que constitue o assoalho da Bacia do Paraná com a do escudo canadense. As profundidades médias de Moho na Bacia de Paraná oriental é $\sim 42 \mathrm{~km}$ (38-48 de espessura de crosta segundo Assunp̧̧ão et al., 1997); sendo que a velocidade alta da parte do manto-superior tem um máximo shear wave velocity (SWV) de $4.7 \mathrm{k} / \mathrm{s}$, sem razoavel LVZ para menos que os $200 \mathrm{~km}$ de profundidade. Essa sismicidade cratônica indica presença da raiz litosférica embaixo da Bacia do Paraná (Snoke \& James, 1997); i.e., um manto sub-litosférico; o que também pelos estudos de SW e telesísmicos P e SW tomográficos (Van Decar et al., 1995), sugeriumse um manto superior de alta densidade (Assumpção et al., 1997). 
As informações geofísicas integradas e comentadas neste item que apoiadas por alguns dados geocronológicos ( $\sim 3$ a $0.8 \mathrm{Ga})$, e que deram lugar ao esquema da Figura 6 1, são contundentes em assinalar para Bacia do Paraná um assoalho cratônico com raiz litosférica profunda comparável ao escudo canadense e em parte também ao escudo russo (da ordem $>200 \mathrm{~km}$ de profundidade).

Segundo comentado no Capítulo 2, o cráton Rio de la Plata esta bem representado no Uruguai: onde terrenos do Arqueano ( $>2 \mathrm{Ga}$ ) incluem complexos de rochas granitóides com ilhas de diversa litologias de rochas metamóficas e são conhecidos como Terrenos de Piedra Alta ou também como Terreno Tijucas. O Terreno Nico Párez, que engloba áreas de rochas metamórficas que sofreram retrabalhamneto no Brasiliano, estão também considerados como terrenos muito antigos, i.e. Terrenos Arcon. Entre estes terrenos se conhecem três faixas móveis do Proterozóico médio: Faix San Losé, Faixa Montevideo e Faixa Arroyo Grande. Eles compostos por rochas metasedimentares com intercalações de rochas metavulcânicas, i.e. Terrenos Proton. Os terrenos a leste (faixa costeira) estão representados por granitóides Neoproterozóicas ( 0.8-0.55 Ga), i.e. Terrenos Tecton.

A norte do Uruguai e no Brasil observam-se duas janelas do embasamento antigo: Rivera e Acegúa (2272 $\pm 33 \mathrm{Ma}$ ); no Rio Grande do Sul é encontrado o bloco Taquarembo, (1980 a $2370 \mathrm{Ma}$, com idade $\mathrm{Pb} / \mathrm{Pb} 2541 \pm 167$ a $169 \mathrm{Ma}$ ), assim sugerindo um pequeno núcleo Arqueano i.e.Terrenos Arcon. Nos estados de Santa Catarina e Paraná, são encontrados os domínios tectônicos: Luis Alves (2.3-3.1 Ga), Curitiba $(2.3-2.8 \mathrm{Ga})$ e Paranaguá $(\sim 1.97 \mathrm{Ga})$, domínios entre os quais se conhecem terrenos de "faixas móveis" do Proterozóico, como a Faix Ribeira com idades de 1.08-2.2 Ga, que estiveram reativados na orogenia Brasiliana pelas intrusōes granitóide de Cunhaporanga, Três Córregos e o cinturăol Dom Felicinano, que cavalga sobre a margem sul do bloco Luis Alves; i.e., pedaços do embasamento com raizes Arqueanas que estão soldados por "faixas" de terrenos Proterozóicos; no caso do Luis Alves e Curitiba....terrenos Arcon e Paranaguá e o Cinturão Ribeira....terrenos Proton e a faixa costeira Dom Felicinano do Brasiliano que "envolve" os pacotes Arcon e Proton ....terrenos Tecton. 
No Sul, o cráton Rio de la Plata reaparece na Argentina nas Serras de Tandil, embasamento Arqueano do ciclo Transamazônico (2200 Ma) que está exposto acima de $200 \mathrm{~km}$ através de numerosas pequenas ilhas, que raramente excedem os $50 \mathrm{~km}^{2}$ de dimensão; os que foram afetados por séries tectommetamórficas e/ou eventos magmáticos, definidos radiometricamente, oscilando entre 2150 e 1520-1700 Ma, com a última orogenia (?) perto do $900 \mathrm{Ma}$, i.e. terrenos Proton. Este representando a orogenia Transamazônica, que durante o Proterozóico Médio e inicio do Proterozóico superior, foi seguido por granitização, alguns deles associando-se, provávelmente, com eventos orogênicos .....i.e. terrenos Tecton. Nesse caso, os domínios do cráton Rio de la Plata possuem pedaços de blocos Arqueanos "emvolvidos/soldados" por faixas Proterozóicas, registrado em seus limites eventos tecto-termais do Brasiliano.

O fragmento do embasamento exposto a $W$, no Paraguai, conhecido como Alto de Caapucú, corresponderia à porção $W$ do cráton Rio de La Plata. Os dados geocronológicos são escassos $(0.5-0.78 \mathrm{Ga}=$ megaciclo Brasiliano, i.e. terrenos Tecton:; a $2.1 \mathrm{Ga}$; i.e. terrenos Proton) e o seu arcabouço acha-se menlor caraterizado pelos dados geofísicos, com destaque ao Bloco Paranapanema. Este bloco adentra por vários quilômetros no territorio paraguaio (Figuras 2-3 e 6-1) e, conquanto que os sedimentos da Bacia do Paraná emcobrem este bloco, representa uma região de plataforma.

Em síntese pode-se concluir que:

As informações geofísicas (gravimetria, sísmica, aeromagnetometria e termometria) evidenciam que o cráton Rio de La Plata é formado por blocos com raizes arqueanas (Curitiba, Luis Alves, Rivera, Aceguá, Encruzilhada, São Gabriel, Taquarembó, Paranapanema) que estão soldados/bordejados por terrenos de faixas móveis do Proterozóico inferior a médio (Faixa Ribeira, Paranagúa, Cerras de Tandil?) e encobertas por terrenos do megaciclo Brasiliano. Do ponto de vista geofísico, este cráton pode ser comparado com o escudo canadense.

Dentro deste contexto, inclui-se a $W$ os terrenos do Proterozóico inferior ao superior (Alto de Caapucú) no Paraguai que se extende a $N$ no estado de Mato Grosso do 


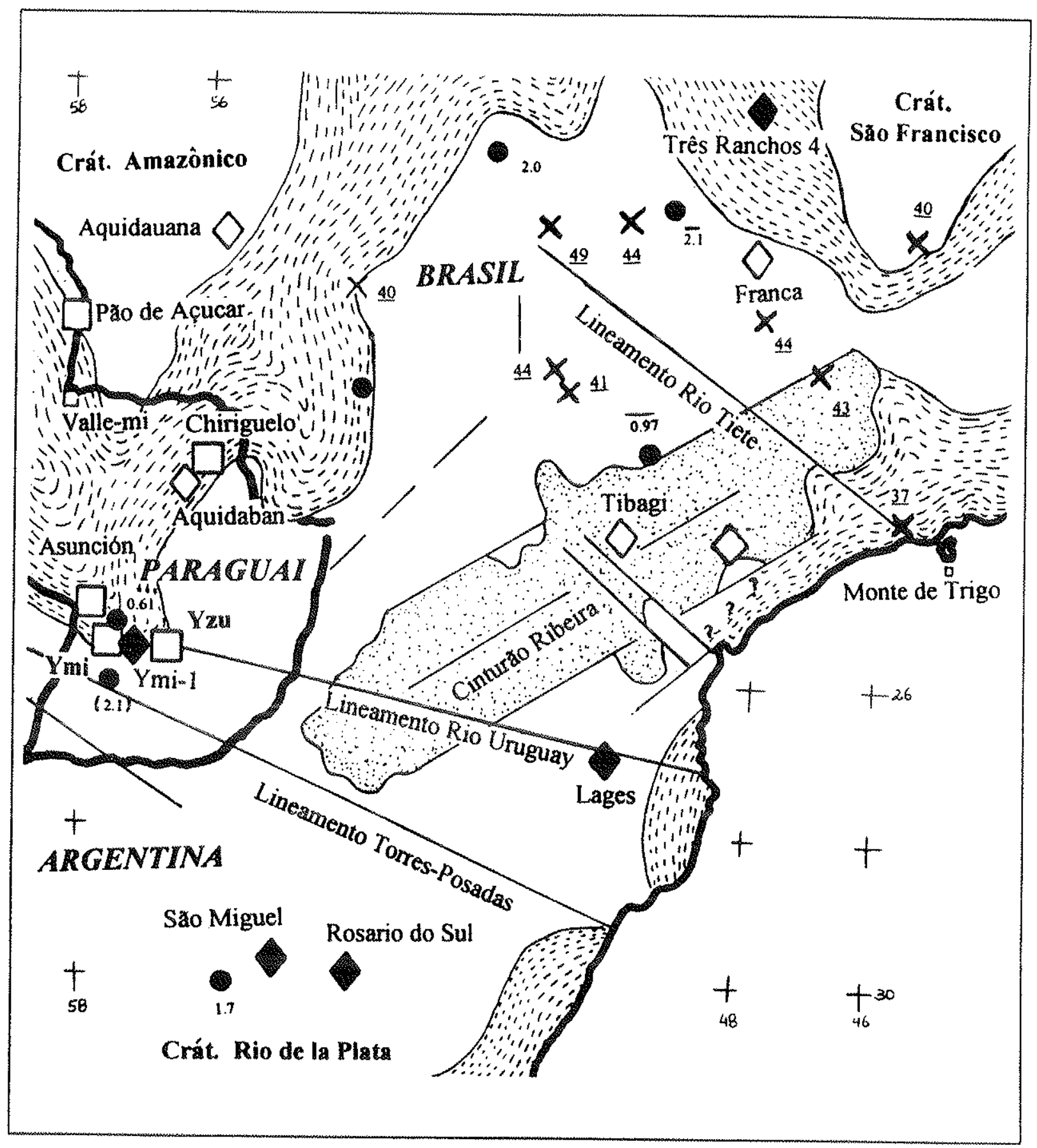

Figura 6-1. O Cráton Rio de La Plata. A figura mostra a porço Centro-Norte do cráton Rio de La Plata, assoalho da Bacia do Paraná, em uma reconstruçăo feita com base a Quintas (1995) modificado. São mostrados: os dados de sísmica, para à porção NNW (= Bloco Paranapanema)(Assumpção et.al., 1997), com X se mostra o ponto de registro de profundidade até onde se estende o embasamento (valores sublinhados); os dados geocronológicos (circulo cheio), com as idades pelo métodos $\mathrm{K} / \mathrm{Ar}$ como números, $\mathrm{Rb} / \mathrm{Sr}$ (rocha total) como números sublinhados acima e U/PO como números em parêntese. Em rombo cheio alguns destacados corpos "kimberlíticos"; em rombo vácuo ocorrências de diamante aluvial e; em quadro algumas ocorrências de rochas alcalinas relacionadas, aparentemente, com alguns dos lineamentos ("fraturas/falhas abissais") assinalados na figura. No Paraguai os quadros mostram campos/provincias de intrusóes alcalinas, com destaque os campos Ymi e Yzu e a intrusáo Ymi-1. Fontes: Cordani et al. (1984), Comte \& Hasui (1971), Bitschene et al. (1986), Bitschene (com. pess. 1993); Chieregatti (1989); Svisero (1994); Proyecto RADANBRASIL (1982); Danni et al. (1991); Rojas (dados näo publicados); Comin Chiaramonti \& Comes (1996). Os dados geocronológicos, do cráton Rio de La Plata, lançados não incluem os da borda leste e o cinturăo que o bordeja 
Sul, em território brasileiro, com alguns dados geocronológicos (Cordani et al., 1984) que mostram a existência de terrenos Tecton bordejando os terrenos Proton. $\mathrm{Na}$ porção NE a Faixa Paraguai o separa do cráton Amazônico; e na porção N a Faixa Brasilia o separa do cráton São Francisco (Figura 6-1).

\section{Relacões geodinámicas com relação as intrusões estudadas}

Junto a regiăo cratônica do Paraguai situa-se o rift de Asunción, que como pode ser observado (Figuras 6-1, 2-8 e 2-9), esta estrutura assenta-se, por um lado, na borda de terrenos Tecton (evidenciado pelos granitoides Brasiliano bem conhecidos no Alto de Caapucú a S, e a cidade de San Bernardino a N), i.e. os segmentos Ocidental e Central; e por outro plado o segmento Ocidental (nas regiões da cordillera del Ybytyruzú), adentramse no bloco Paranapanema, o qual representaria um bloco do arqueano -terrenos Arcon. Este arcabouço geotectônico sugere que o rift de Asunción constitui um rift pericratônico.

Conforme discutido no Capítulo 2, as rochas ígneas alcalinas Mesozóicas (provincia Central; magmatismo em torno de 138-98 Ma; Tabela 2-3) estão amplamente distribuidas nos três segmentos do rift de Asunción, espalhado-se sobretudo em dois maiores campos de intrusões dentro do rift: Campo Ybytymí (segmento Central do rift) e Campo Ybytyruzú (segmento -Oriental do rift, Figura 2-8).

As rochas alcalinas estão densamente distribuídas no Campo Ybytymi, segmento abatido em mais de $1000 \mathrm{~m}$ (Presser \& Ulbrich, 1994), onde destaca-se no seu extremo norte um denso e apertado enxame de diques (Enxame Ybytymi) com rumo médio de $\mathrm{N} 50^{\circ} \mathrm{W}$, que possui uma extensão de aproximadamente $70 \mathrm{~km}$, (Presser 1992 e 1994). No centro-sul deste segmento aparecem pipes, plugs, e alguns diques portadores de xenocristais e/ou microxenólitos do manto; assim como também plugs de rochas fonolitóides com claras assinaturas químicas (por exemplo os valores dos isótopos de Sr/Sr e Nd/Nd, cf. Velázquez, 1992; Comin-Chiaramonti \& Gomes, 1996) de material proveniente de um manto profundo (C. Medina, C. Gimenez, C. Yariguá entre outros)(cf. Velázquez, 1992); aparentemente estão vinculadas com falhas 
abissais E-W e outras NW-SE e NE-SW (Figura 2-8 e Fotografia 1). Estas feições também sugerem um domínio ocupado por falhas profundas (crosta/litosfera?). Este trabalho estudou alguns pipes, plugs e diques de rochas lamprofíricas que ocorrem neste campo.

No segmento Oriental ocorrem centros de efusões e intrusões de diques de composição toleítica que estäo cortados por diques, enxame de diques (Enxame Ybytyruzú com rumo NW-SE Figuras 2-8 e 2-9), plugs, pipes e stoks de rochas alcalinas Mesozóicas ( $130 \mathrm{Ma}$, Tabela $2-3$ ). Neste campo foram estudadas algumas intrusões de rochas "lamprofiricas".

De forma general, como constata-se na Fotografia 7, e também nas figuras 2-8 e 2-9, as intrusões instalaran-se segundo lineações/combinação de lineações E-W e NWSE.

O conjunto das intrusões alcalinas dos segmentos Central e Oriental (Figura 2-8. e 29) permitem ao menos traçar linhas de fratura que locaimente seriam as responsáveis pela colocação dos diferentes corpos magmáticos. Os traços $\mathrm{E}-\mathrm{W}$ em combinação com os traços NE-SW apresentam se como lineações importantes no Campo Ybytymí, enquanto que os traços E-W e NW-SE apresentam-se como estruturas destacadas no Campo Ybytyruzú.

A alta densidade de intrusões no campo Ybytymí que contrasta com uma densidade muito menor no campo Ybyłyruzú pareceria sugerir uma região mais rúptil para o primeiro (domínio de borda de cráton) e menos rúptil para o segundo (domínio intracratônico).

No Campo Ybytymí, dentro da fossa do rift, são encaixantes sedimentos e rochas sedimentares pelíticas (niveis basais) a conglomeráticas (niveis do teto). Para as quais foi atribuida uma idade Permina (Presser, 1992). Estas rochas provavelmente se depositaram isoladamente da sedimentação na Bacia do Paraná. Já no Campo Ybytyruzú as encaixantes sedimentares pertecem a unidades da Bacia do Paraná (Rochas permianas do Grupo Independencia e da Formaçäo Misiones (=Boutucatu)). 
Entre o conjunto de intrusões estudadas nesta província alcalina, os corpos intalaram-se em rochas sedimentares de idades diversas: Siluriano, Ymi-8; Permiano (?) Ymi-1, Ymi-7, entre outros (no Campo Ybytymi) e Yzu-1 e Yzu-10 (no Campo Ybytyruzú); Triássico/Jurássico, Yzu-4 e Yzu-6. E em basaltos toleíticos da Bacia do Paraná, Yzu-2 e basaltóides alcalinos do Mesozoico, Ymi-5 e Ymi-4.

Os aspectos mais relevantes das intrusões estudadas são brevemente destacadas a seguir:

\section{Campo Ybytymi:}

O pipe Ymi-1 possui forma grosseiramente bilobulada a irregular (Figura 2-10) com dimensões que variam de $2050 \mathrm{~m}$ por 1200 e $880 \mathrm{~m}$, onde são destacadas básicamente duas estruturas: uma muito desenvolvida constituida por sedimentos vulcano-epiclásticos (que possuem uma topografia plano-ondulada) e outra menor (de difícil reconhecimento no campo) constituida por rochas sub-vulcânicas (plug) porfiríticas de cor escura formando uma topografia ondulada, algo destacada. Janelas da rocha encaixante sedimentar dentro do pipe (encontradas a NNE) sugere profunda erosão do corpo. Como fase final da atividade do pipe aparecem a ele vinculada diques interiores ao pipe (Ymi-1/d) e exteriores (Ymi-1c).

O pipe Ymi-4 de cerca de $1258 \mathrm{~m}$ de comprimento possue, aindaque pouco evidente nos afloramentos, forma bilobulada. Dentro desta estrutura acham-se expostas fácies de lava roxa, fortemente vesiculada, de aspecto lamprofírico, que estão cortadas por fácies de brecha (autolítica de conducto) de uma rocha vesiculada de aspecto lamprofírico e alguns diques de uma rocha algo vesiculada de aspecto lamprofírico.

O pipe Ymi-8 nas fotografias aéreas apresenta-se como uma estrutura bilobulada com comprimento de 2750 por $1250 \mathrm{~m}$ (lóbulo à $\mathrm{N}$ ) e $1150 \mathrm{~m}$ (lóbulo à $\mathrm{S}$ ). Nessa estrutura ocorrem predominantemente sedimentos vulcano-epiclásticos, formando uma superficie plana no campo, e subordinadamente cortando a fácies vulcanosedimentar, ocorreriam fácies sub-vulcânicas $(p / u g)$ que molda na superficie do terreno uma topografia algo ondulada. A diferença de Ymi-1, este pipe não apresenta 
janela das encaixante e somado ao seu tamanho gigantesco, refletiria um pipe pouco erodido.

O plug Ymi-5 foi definido em fotografia aérea como sendo uma intrusão com diâmetro de $200 \mathrm{~m}$. No campo formam um conjunto de blocos, em parte associados com as encaixantes basaltóides. Compõe-se de uma rocha basaltóide cinza, fortemente porfiritica, com feno-megacristais branco a turquesa esbranquizados de glomérulos de "leucita".

O conjunto de diques decimétrico a métricos paralelos, com rumo E-W de Ymi-7, que ocorrem poucos quilometros a NE de Ymin-1, tratamse de rochas com aspecto basaltóide de cor escuro, portiríticas formadas por fenocristais de minerias máficos e micro-xenólitos peridotíticos. Acham-se intruidos em encaixantes de rochas sedimentares permianas.

\section{Campo Vbytruruz:}

A intrusão Yzu-3, é formada por um conjunto de lavas brechosas (de $\sim 1 \mathrm{~km}^{2}$ de exposição) porfíriticas escuras e de aspecto basaltóide, com uma aparente direção de fluxo de efução a NNE. Intrudem rochas plutônicas máficas e as rochas sedimentares do Grupo Independencia.

O dique Yzu-1 possue dimensão submétrica e compõe-se de uma rocha porfirítica de aspecto basaltóide bastante fresca; encontra-se encaixada em rochas sedimentares do Grupo permiano Independencia.

Na porcão NE, distante alguns quilometros deste corpo (Figura 2-8 e Fotografia 7) foi reconhecida uma intrusão métrica (Yzu-4) em forma de pipe formada por dois facies de rochas: uma lamprofírica e outra basaltóide Essa intrusão achamse também encaixada em rochas sedimentares do Grupo Independencia.

O dique Yzu-2 com espessura aparentemente decimétrica é formado por uma rocha porfirítica escura possuindo abundantes pontilhados de cor branco beje (fenocristais); encontra-se cortando a lavas toleiticas da Bacia do Paraná. 
O sill Yzu-6 tem espessura decimétrica e constituido por rochas cinza esverdeadas de marcado aspecto lamprofírico, encaixado em arenitos da Formaçăo Misiones.

Na porção $W$ da intrusão Yzu-6 ocorre um conjunto de diques decimétricos a métricos (Yzu-10). São rochas de marcado carater lamprofírico e que frequentemente encontram-se alteradas. Encaixam-se em rochas sedimentares do Grupo Independencia. Associados a estes diques, encontra-se Plug de rocha fonolitóide, diabásios toleiticos do Mesozoico e fillöes de quartzo aurifero.

\section{"Lamprófiros" e "lamproítos" vs outras rochas alcalinas: a problemática abordada.}

Como ponto de partida devem ser levadas em consideração as palavras de Rock (1991) em relação às rochas lamprofíricas (lamprófiros cálcio-alcalinos, alcalinos e ultramáficos, kimberlitos* e lamproítos):

"Uma particularidade dos lamprófiros é a coexistência de um ou mais de um mineral normalmente encontrado em rochas máficas-ultramáficas primitivas semelhantes aos peridotitos (ex. olivina magnesiana, piroxênio, flogopita), junto a um ou mais de um mineral típico de rochas altamente evoluidas, semelhantes as rochas félsicas, como granitos peralcalinos (ex. ortoclásio, albita, piroxênios/anfíbólios ricos em $\mathrm{Na}$ )". "Entende-se que kimberlitos e orangeitos säo, neste contexto, colocados coletivamente.

Deve-ser também levado em consideração que a química mineral provê o mais efetivo caminho para se distinguir um tipo de lamprófiro de outro, e os lamprófiros das outras rochas igneas comuns (Rock, 1991). Os dados das Tabelas 1-1 e 1-2, juntamente com os dados petrográficos da Tabela 3-3, permitem, rapidamente, aproximar uma primeira caracterização petrográfica das rochas estudadas no presente trabalho. Como rotina, foi executado ao final da descrição petrográfica de cada intrusão estudada a caracterização química micromanalítica das variedades de minerais presentes nestas rochas; em seguida apresentou-se uma caracterização 
mais aprimorada da variedade petrográfica de rocha estudada, isto sempre feito levando em consideração o apontado por Rock (1991). As rochas de Ymi-1, os diques Ymi-7 e Yzu-1 e as rochas de Ymi-4 são formadas por fenocristais de olivina forsterítica (Ymi-1, Ymi-7 e Yzu-1), diopsídio (todas), flogopita (Ymi-1c, Ymi-7, Ymi-4 e $Y z u-1)$ e microfenocristais de cromita (Ymi-1), minerais caraterísticos de rochas primitivas; em matriz com sanidina e feldspatóides, além de outros minerais como a magnetita titanifera; estes últimos minerais são comuns em rochas alcalinas muito diferenciadas. Assim, também, as rochas de Ymi-5, Yzu-2, Yzu-3 e Yzu-6 são formadas por fenocristais de olivina forsterítica (Yzu-2 eYzu-3), diopsídio (todas), flogopita (Yzu-2 e Yzu-6) e microfenocristais de ilmenita (Yzu-3 e Yzu-6) coexistindo ainda com a "leucita" (Ymi-5, Yzu-2 e Yzu-3); encontram-se em matriz formada por sanidina, analcima e outros minerais como a magnetita titanifera que, são minerias reconhecidos em rochas alcalinas muito evoluidas. Esteas caraterísticas mineralógicas colocaria as rochas estudadas dentro do grupo de rochas lamprofíricas, como sugerido por Rock (1991). Rochas como as de Ymi-1 năo possuem afinidade basaltóide, já que o plagioclásio, quando presente, possui teores modais traços. Ymi-4 apresenta uma matriz alterada onde pôde reconhecer-se tão só a sanidina. Se somado ao fato de observar-se como uma rocha que apresenta fenocristais de flogopita, com índice de coloração baixo, dificultaria uma caraterização como sendo de afinidade basaltóide.

Seguidamente serão transcritas as palavras de Rock (1991) com relação aos minerais tipicamente encontrados nos lamprófiros, elementos de juízo que, se comparados com as descrições e caraterizações minerais das rochas estudadas no Capitulo 3, poderá visualizar com maior eficiência a afinidade petrológica das rochas estudadas:

1. Piroxênios com alto $\mathrm{Al}$ : piroxênios cálcicos com $\mathrm{Al}_{2} \mathrm{O}_{3}>10 \%$ ocorrem só em lamprófiros, metapelitos, basaltos contaminados ou, ocasionalmente, em xenólitos do manto. 
2. Piroxênios $(>5 \%)$, anfibólios $(>5 \%)$ e flogopitas $(>8 \%)$ com elevado $\mathrm{TiO}_{2}$ : observam-se somente em rochas lamprófiricas. Se Al é combinado com alto $\mathrm{Ti}$, resulta uma feição diagnóstica dos lamprófiros.

3. Anfibólios $(>0.5 \%)$, flogopitas e feldspato potássico $(>2 \%)$ com elevado $\mathrm{BaO}$, é feição diagnóstica. Flogopitas com alto $\mathrm{BaO}(>5 \%)$ são também conhecidas em carbonatitos e nefelinitos e muito raramente em mármores, porém é muito comum em lamprófiros ultramáficos, evidenciando a interligação dos lamprófiros ultramáficos com os carbonatitos.

4. Anfibólios e flogopitas com alto $F$ : anfibólios, possuem teores de até $4.1 \%$ e flogopitas, de até $5.7 \%$.

5. Micas enriquecidas em $\mathrm{Fe}^{3+}$ são micas ricas na molécula de tetraferriflogopita $\left(\mathrm{KMg}_{3} \mathrm{Si}_{3} \mathrm{Fe}_{3} \mathrm{O}_{10}(\mathrm{OH})_{2}\right)$, também encontradas em outras rochas peralcalinas, pobres em sílica (p/ex. carbonatitos), sendo particularmente comum nos lamprófiros ultramáficos, kimberlitos e lamproítos; entretanto, entre as rochas ígneas, micas ricas em ferri-annita $\left(\mathrm{KFe}_{23} \mathrm{Si}_{3} \mathrm{Fe}_{3} \mathrm{O}_{10}(\mathrm{OH})_{2}\right)$, restringem-se aos lamprófiros.

6. Carbonatos de $\mathrm{Mg}-\mathrm{Fe}-\mathrm{Sr}-\mathrm{Ba}$ formam um grupo que, dentre as rochas ígneas silicatadas, ocorrem em carbonatitos e restringem-se também aos lamprófiros.

7. Espinélios com alto $\mathrm{Zn}$ : espinélios com $\mathrm{ZnO}>2 \%$ ou $\mathrm{MnO}>2 \%$ é diagnóstico. Ilmenitas de $\mathrm{Mg}-\mathrm{Mn}$ : onde $\mathrm{MgO}>5 \%$ e $\mathrm{MnO}>2 \%$ são diagnósticas.

8. Apatitas ricas em Sr-Ba: apatitas e apatitas de flúor (flúor-apatita) excepcionalmente com alto teor de $\mathrm{BaO}$ e SrO.

9. Sulfetos: sulfetos de Ca-Sr-Ba são abundantes em lamprófiros.

Conforme encontrado correntemente em lamprófiros cálcio alcalinos e em menor proporção em lamprófiros alcalinos e ultramáficos, os piroxênios de Ymi-1, Ymi-4 e Ymi-7 são piroxênios com alto Al e moderado a alto Ti. Em Comin-Chiaramonti \& 
Gomes (1996) são também descritos piroxênios similares ocorrendo nas rochas basaltóides potássicas. Os piroxênios em Yzu-1 Yzu-2, Yzu-3 e Yzu-6, possuem muito baixo a baixo teores de $\mathrm{Al}$; entretanto algumas minettes e alguns orangeítos também apresentam piroxênios similares (cf. Mitchell, 1995a). Em Ymi-5, os piroxênios quench apresentam feições similares aos considerados por Rock (1991) com feições diagnósticas das rochas lamprofíricas (pontos 1 e 2). Em Yzu-2, observam-se nos piroxênios de fase tardia (aegirina) teores muito alto de Ti (ponto 2) feições também diagnósticas das rochas lamprofíricas (Rock, 1991). Contudo, observando-se a Figura 3-6 nota-se que piroxênios de Yzu-2, Yzu-3 e Yzu-6 apresentam um enriquecimento em $\mathrm{TiO}_{2}$ e $\mathrm{Al}_{2} \mathrm{O}_{3}$ similar ao observado em lamproitos; em Ymi-5 é observado um enriquecimento nestes elementos, característico ao dos lamprófiros e dos kamafugitos e diferente do observado em plagileucitos (Mitchell, 1985; 1995a; Mitchell \& Bergman, 1991).

Em Ymi-5, Yzu-2 e Yzu-3 ocorrem anfibólios com $\mathrm{TiO}_{2}>5 \%$ que segundo apontado em (2), é também típico de rochas lamprofíricas. Em Yzu-2 ocorre eckermanita ferrosa (=richterita) potássica titanífera, variedade de anfibólio diagnóstica de lamproítos (Wagner \& Velde, 1986; Rock, 1991).

Em Yzu-1, Ymi-5 e Yzu-2 ocorrem feldspatos potássicos com alto BaO e em Ymi-5 e Yzu-2 micas com alto BaO que, segundo apontado em (3), são feições diagnósticas de rochas lamprofíricas. Ymi-5 e Yzu-2 são rochas com fenocristais de "leucita", dentro das rochas lamprofíricas, que aparentam-se com os lamproitos.

Espinélios com alto MnO (até 4\%) ocorrem em Ymi-1, Ymi-4, Ymi-7, Ymi-5 e Yzu-6 que, segundo item (7), é uma feição diagnóstica das rochas lamprofíricas. Assim, Ymi-1, Ymi-4 e Ymi-7 se tratariam de lamprófiros a Ymi-5 e Yzú-6, de lampróitos.

IImenitas com moderado a alto magnésio (até $5.7 \%$ de MgO) ocorrem em Ymi-1 (amostras de concentrado) e Yzu-3, e com alto MnO (até 7.9\%) ocorrem em Ymi-1, Yzu-2 e Yzu-3. Segundo item (8), quimicamente esses minerais têm feições 
diagnósticas de rochas lamprofíricas; i.e. Ymi-1 lamprófiro e Yzu-2 e Yzu-6 lamproítos.

A Figura 6-2 (a) ilustra a composição dos piroxênios de Yzu-2, Yzu-3 e Yzu-6, segundo as razões log. $\mathrm{SiO}_{2} / \mathrm{TiO}_{2}-\mathrm{MigO} / \mathrm{FeO}$ (Rock, 1991). Observa-se que distribuem-se no campo dos piroxênios dos lamproítos. Os piroxênios de Ymi-5 espalham-se entre o campo dos piroxênios dos lamprófiros ultramáficos e os lamproítos. Já na Figura 6-2 (b) observa-se que os piroxênios de Ymi-1, Ymi-4, Ymi-7 e Yzu-1 caem no campo dos piroxênios dos lamprófiros cálcio-alcalinos e, em menor proporção, no campo dos lamprófiros alcalinos. Piroxênios de outras rochas alcalinas (p/ex. os de algumas rochas basaltóides potássicas de Comin-Chiaramonti \& Gomes, 1996) mostram feições similares aos piroxênios dos lamprófiros alcalinos e ultramáficos.

A Figura 6-3 mostra a composição das micas (fenocristais e matriz) das rochas lamprofíricas Ymi-5, Yzu-2, Yzu-3 e Yzu-6, em função de $\mathrm{Al}_{2} \mathrm{O}_{3} / \mathrm{TiO}_{2}-\mathrm{MgO} / \mathrm{FeO}$ (Rock, 1991). Nota-se que Yzu-2 Yzu-3 e Yzu-6 reúnem-se nas vizinhanças e dentro do campo dos lamproitos. As micas de Ymi-5 ocupam um campo que se espalha entre o de micas dos lamprófiros alcalinos e o de micas dos lamproítos (leve-se em conta que estas micas são biotitas e não flogopitas; se elas possuírem composições de flogopita, certamente adequariam-se melhor com os lamproítos). Em 6-3 (b), as micas de Ymi-1, Ymi-4, Ymi-7 e Yzu-1 ocupam o campo das micas dos lamprófiros cálcio-alcalinos. Evidências maiores podem ser encontradas nas Figuras 3-5 (c) e (b) , 3-6 (c) e (d) com relação às micas que ocorrem em Ymi-5, Yzu-2, Yzu-3 e Yzu-6. Estas feições somadas aos dados do apêndice A2, indicam claramente que:

"ocorrem micas deficientes em Al $\mathrm{Vl}^{\mathrm{V}}$, frequentemente encontrado nos lamproítos, em Ymi-5, Yzu-2, Yzu-3 e Yzu-6.

"micas de Yzu-2, Yzu-3, Yzu-6 e algumas micas de Ymi-5 evidenciam um trend de enriquecimento similar aos de lamproitos, traduzido por um aumento do teor de $\mathrm{TiO}_{2}$ 

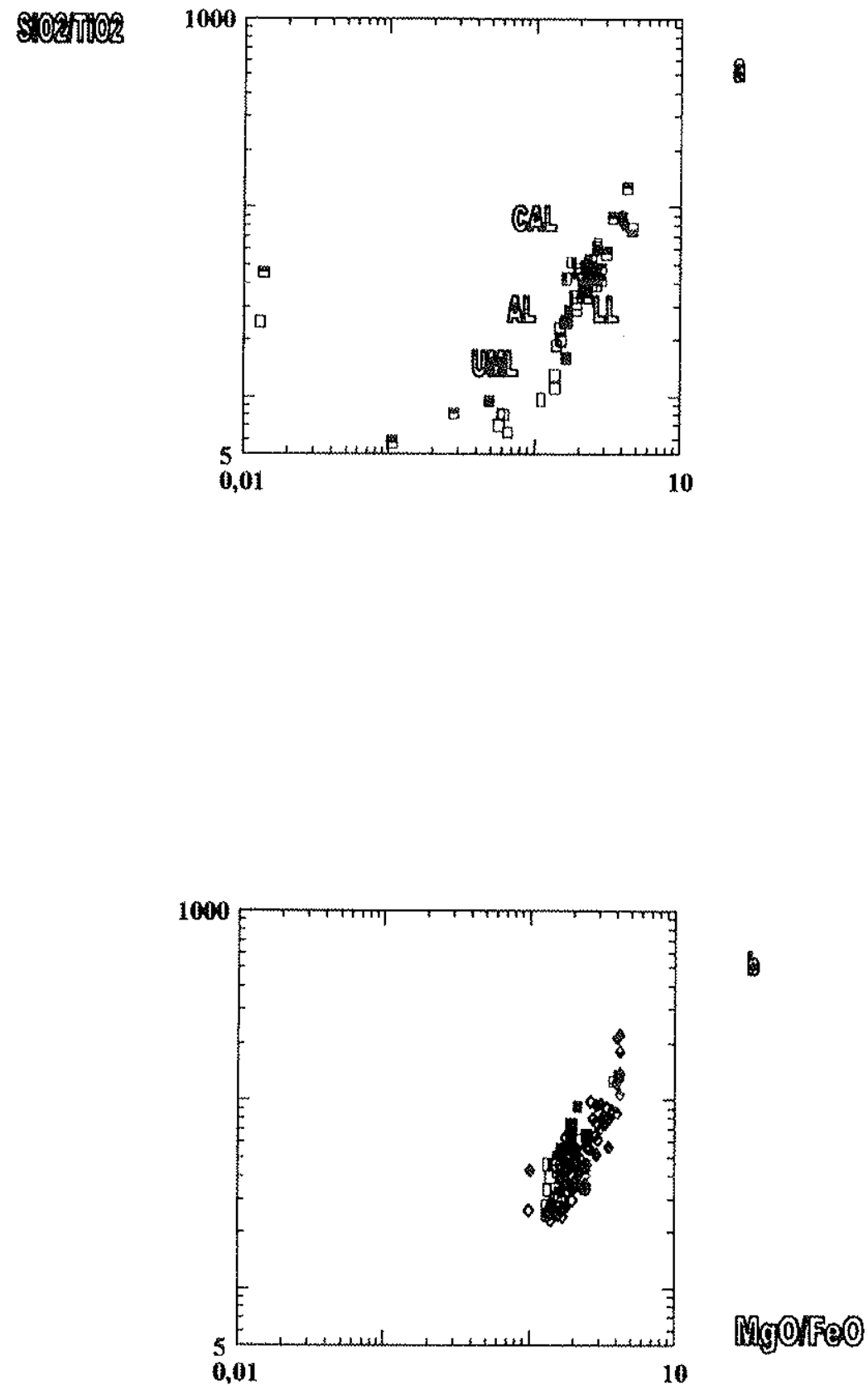

Figura 6-2. Diagrama $\mathrm{SiO}_{2} / \mathrm{TiO}_{2}-\mathrm{MgO} / \mathrm{FeO}$ nos piroxênios dos "lamprófiros" e dos "lamproitos". (a): Ymi5, Yzu-2, Yzu-3 e Yzu-6. (b), Ymi-1, Ymi-4, Ymi-7 e Yzu-1. Campos de composição com base em Rock. (1991).Legenda: lamprófiros CAL-cálcio-alcalinos, AL-alcalinos, UML-ultramáficos, e lamproítos LL e, como em 3-2. 
e FeO com a diminuição do teor de $\mathrm{Al}_{2} \mathrm{O}_{3}$. Entretanto, as micas de $\mathrm{Yzu}-6$ exibem no diagrama $\mathrm{Al}_{2} \mathrm{O}_{3}$ vs $\mathrm{FeO}$, um trend de enriquecimento de orangeitos.

Os espinélios, exibem nas rochas lamprofíricas estudadas trends particulares em termos de Tił vs Cry , segundo o diagrama de Mitchell (1995a). Na Figura 3-28 (a) Ymi-5 (em parte), Yzu-2, Yzu-3 e Yzu-6 se espalham pelo campo dos lamproitos e orangeltos (Mirchell, 1995a). Alguns espinélios de Ymi-5 ocupam o campo comum para minettes e rochas potássicas. Na Figura 3-28 (b) os espinélios de Ymi-1 seguem um trend simitar ao determinado por Mitchell (1995) nos kimbertíticos. Este comportamento pode também ser observado em monchiquitos picríticos de Wandagee (Jaques et al., 1989) e em São Sebastião (Garda, 1995). No extremo com baixo Crł e alto Tił (campo das magnetitas titaniferas magnesianas e magnetitas thaniferas) concentram-se os espinélios de Ymi-4, Ymi-7 e Yzu-1; este é também um campo de minetzes e rochas potássicas (quadro cheio em (b)). Tendo em vista à diflculdade para diferenciar os espinélios de Ymi 4 e Ymi-5 dos espinélios das rochas potássicas do rift de Asunción, eles foram lançados nas Figura 3-29 (a) e (b). A comparação do campo de distribuiçăo dos espinélios dos dois grupamentos de rochas observa-se que as rochas potássicas do rift de Asunción ocupam um campo de valores mais elevados em termos de log. $\mathrm{Al}_{2} \mathrm{O}_{3}$ e demais óxidos $\left(\mathrm{TIO}_{2}+\mathrm{Cr}_{2} \mathrm{O}_{3}+\mathrm{Fe}_{2} \mathrm{O}_{3}+\mathrm{FeO}+\mathrm{MnO}+\mathrm{MgO}\right)$ relativamente ao ocupado pelos espinélios de Ymi-4 (Figura 3-29 (a)) e os de Ymi-5 (Figura 3-29(b)).

Finalmente, deve ser levado em conta que Ymi-5 apresenta em sua paragênese a presença de perovskita; mineral que ocorre, dentre o grupo de rochas ultrapotássicas, semente em lamprofitos e kamafugitos, faltando totalmente nos plagileucitos ou nas rochas potássicas do rift de Asunción.

Desse modo os dados petrográficos, de quimica mineral o discunico nos

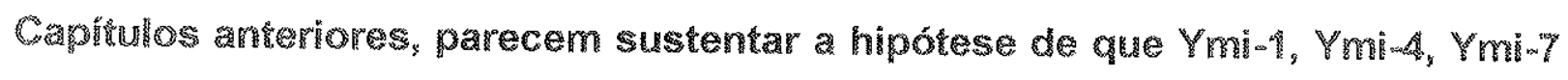

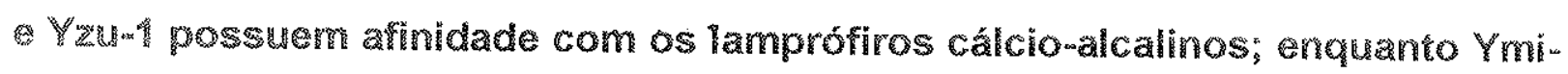

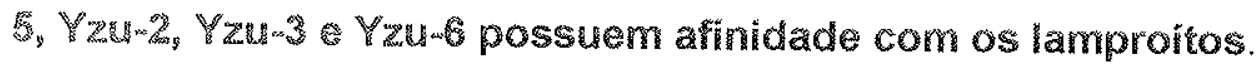




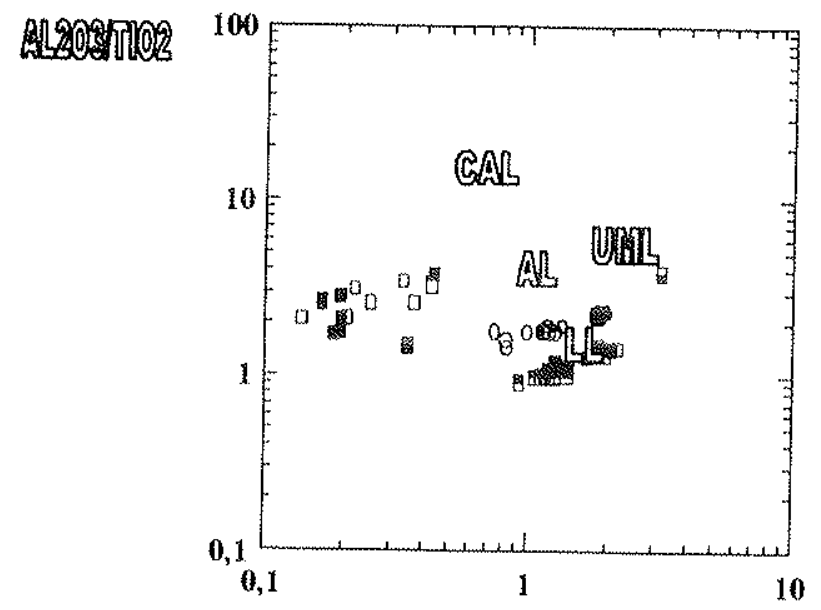

g

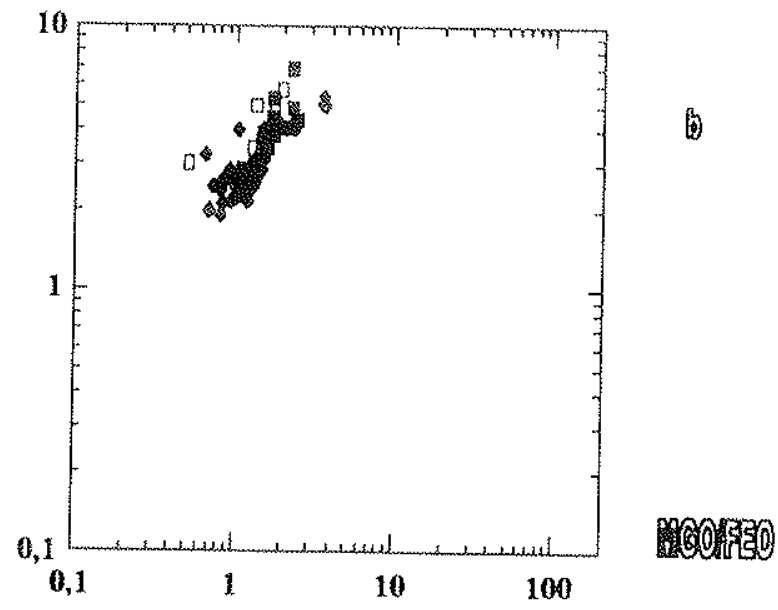

Figura 6-3. Composição das micas em "lamprófiros" e "lamproitos". (a), Yzu-2, Yzu-3 e Yzu-6 situam-se no campo de lamproítos, enquanto Ymi-5 situa-se num campo menos comum para lamproitos e improprio para lamprófiros. (b), "Lamprófiros" (Ymi-1, Ymi-4, Ymi-7 e Yzu-1) espalham-se pelo campo dos lamprófiros cálcio alcalinos. Campos de composição com base a Rock (1990). Legenda como em 3-2. 
Estas considerações e as feições mostradas nas Tabelas 1-1 e 1-2, quando comparadas com o levantado sobre as rochas incomuns no Capítulo 1 permitem concluir:

Ymi-1 representa de uma variedade de lamprófiro picrítico (olivina 10 a 25\%) cálcioalcalino formado por fenocristais/microfenocristais de olivina (Fo92-75), diopsidio (titanífero aluminoso), hornblenda magnesiana e cromita; imersos em uma matriz formada de sanidina (sódica em parte), magnetita titanífera magnesiana, magnetita titanifera, diopsídio (titaniferos aluminosos), flogopitambiotita (titanifera), carbonato e acessórios de apatita, plagioclásio, hornblenda magnesiana, analcima e rutilo. 0 dique Ymi-1c corresponde a uma variedade de lamprófiro cálcio-alcalino formado por fenocristais de olivina ( $\mathrm{FO}_{85-77}$ ), diopsidio (titanifero e aluminoso) e flogopita (titanífera e aluminosa) juntos a uma matriz formada por sanidina, magnetita titanifera, diopsídio (titanifero e aluminoso), homblenda, eckermanita e acessórios de apatita, analcima e plagioclássio.

Ymi-7 compõe-se de uma variedade de lamprófiro cálcio-alcalino formado por fenocristais/microfenocristais de olivina $\left(F_{85-78}\right.$ ), diopsidio (titanífero e aluminoso), hormblenda e flogopita (titanífera aluminosa); que estão imersos em uma matriz formada por sanidina, magnetita titanifera magnesiana, magnetita titanifera, diopsidio (titanífero aluminosos), analcima, hornblenda e acessoriamente apatita, mica e carbonato.

Yzu-1 trata-se de um lamprófiro picritico (olivina 15\%) calcio alcalino formado por fenocristais de olivina (Fo89-75), diopsídio (pobre em Al) e flogopita (titanifera aluminosa); em matriz formada por analcima, sanidina (rica em Fe)-anortoclásio, magnetita titamifera magnesiana, magnetita titanífera e como acessórios, apatita e carbonato. O termo KENTALLEMITO (picrítico Ymi-1 e Yzu-1) se aplica de maneira mais adequada para essa variedade de rocha.

Ymi-4 compõe-se de uma variedade de lamprófiro cálcio-alcalino formado por fenocristais/microfenocristais de olivina serpentinizada, flogopita (titanifera e aluminosa), diopsidio (titanífero e aluminoso) e magnetita titanífera magnesiana imersos em uma matriz formada de sanidina, magnetita titanifera e acessórios de 
diopsidio (titanífero aluminoso), apatita, carbonato e zeólitas. Os lamprófiros desta intrusão são variedades melhor definidas como MINETTE.

As intrusões Ymi-1, Ymi 1c, Ymi-7 e Ymi-4, apresentam caraterísticas petrográficas e de química mineral que guardam entre si fortes evidências de uma mesma filiação magmática. Nesse sentido, num sistema de diferenciação por cristalização fracionada, um magma de composição similar á Ymi-1, pelo fracionamento de olivina-cromita-diopsídio, produziria uma rocha como Ymi-4. Conforme as observações petrográficas, este esquema simples parece evidente que:

$Y$ mi-1 $\Downarrow$ (olivina-cromita-diopsído) $\Rightarrow Y$ mi-1c $\Downarrow$ (olivina-flogopita) $\Rightarrow Y$ mi-7 $\Downarrow \Downarrow Y$ mi-4 (ver também o último item do Capítulo 3).

Ymi-5 constitui de uma variedade de lamproíto formado por fenocristais de "leucita" diopsídio (titanífero a titanado aluminoso), olivina (serpentinizada) e magnetita titanifera magnesiana; encontram-se imersos em uma matriz formada de sanidina (rica em Ba), diopsidio (titanifero aluminoso a pobre em Al), magnetita titanifera. bitotita (titanifera pobre em Al a aluminosa e rica em $\mathrm{Ba}$ ) e acessórios de apatita. perovskita e anfibólio (potássico e titanifero).

Yzu-2 representa uma variedade de lamproíto formado por fenocristais de olivina (Fo85-81), diopsídio (pobre em Al), flogopita (titanifera) e "leucita"; que estão imersos em uma matriz formada por sanidina (rica em Fe), flogopita-biotita (titanifera e pobre em Al), diopsídio (pobre em Al), magnetita titanifera magnesiana, ilmenita e acessórios de (ferro)meckermatita (potássica e titanífera) e apatita.

Yzu-3 é uma variedade de lamproito formado por fenocristais/microfenocristais de olivina (Fo83-81), diopsídio (pobre em Al), "leucita" e ilmenita; imersos em uma matriz formada por sanidina (em parte rica em $\mathrm{Fe}$ ), flogopita (titanifera pobre em Al), diopsídio (pobre em Al), magnetita titanifera magnesiana e acessórios de apatita e anfibólio (tianífero e potássico).

Yzu-6 compõemse de um lamproíto formado por fenocristais/microfenocristais de flogopita (titanifera), diopsidio (pobre em Al) e ilmenita; que estão imersos em uma matriz formada por sanidina (rica em $\mathrm{Fe}, \mathrm{Ba}$ e Na), flogopita-biotita (titanífera), anfibólio e acessórios de ilmenita, apatita, carbonato e rutilo/priderita (?). 
Em verdade, Ymi-5, Yzu-2 e Yzu-3 são "LEUCITA" LAMPROÍrOS, representado pelas variedades:

olivina sanidina diopsidio "leucita" lamproito (Ymi 5),

olivina sanidina flogopita diopsídio "leucita" lamproito (Yzu-2); e

olivina flogopita sanidina diopsídio leucita lamproíto (Yzu-3). Já a intrusão Yzu-6 representa um diopsídio flogopita sanidina lamproito

Quando estudado Ymi-5, observoumse que possuia alguns minerias com feições químicas correspondendo a plagileucítos (diopsídio e micas do GII). Aparentemente, acredita-se que seja devido à contaminação?/mistura? do magma lamproítico com o magma plagileucítico. Assirn, Ymi-5 corresponderia a um lamproíto si $_{\text {(lamproito }}$ transicional); enquanto que $Y z u-2, Y z u-3$ e Yzu-6 correspondem a lamproítoss.

\section{Solução sólida em micas, piroxênios, espinélios e feldspatos}

No Capítulo 3, no item "Solução sólida em micas, piroxênios, espinélios e feldspatos" foram discutidos as relações de solução sólida que caracteriza as micas, os piroxênios, os espinélios e os feldspatos. Foram também considerados os diferentes tipos de enriquecimento e deficiências catiônica que os minerias apresentam. A seguir serão resaltados os detalhes conclusivos mais importantes de cada mineral.

\section{Micas}

*as micas de Ymi-1, Ymi-4, Ymi-7 e Yzu-1 (Figuras 3-5 (a) e (c)), são micas da solução sólida entre os end members flogopita-biotita-eastonita-siderofilita. As micas de Ymi-1 são em maioria micas com deficiência de $\mathrm{Al}^{\mathrm{lV}}$; feição que mostra que elas são micas produto da solução sólida entre flogopita-annita

*os fenocristais das mica de Ymi-1c, Ymi-4 e Ymi-7 e as de Yzu-1, preenchem perfeitamente o sítio tetraédrico $(S i+A l=8)$ (Figuras $3-5$ (a) e (c), 3-21, 3-22(a)) sugerindo solução sólida entre as moléculas de eastonita-siderofilita.

*as micas de Yzu-2, Yzu-3 e Yzu-6 (Figura 3-5 (b) e (d)) evidenciam que são micas da solução sólida entre flogopita-annita-eastonita-siderofilita. As micas de Yzu-2 e boa parte das micas de Yzu-3 e de Yzu-6 e as G-I de Ymi-5, são deficientes em $A l^{\vee V}$ 
(apêndice A2 e as Figuras 3-5 (c) e (d); 3-21 e 3-22) e sugerindo solução sólida entre flogopita-annita

*as micas de Ymi-1 (matriz), algumas de Ymi-7 e uma de Ymi-4 e sobretudo as micas de Ymi-5, Yzum-2, Yzu-3 e Yzu-6 apresentam deficiências no sítio tetraédrico $\left(\mathrm{Si}^{\mathrm{IV}}+\mathrm{Al}^{\mathrm{IV}}<8.00\right.$ ), (Figura 3-21); bem como nos sítios octaédricos $\left(\mathrm{Al}^{\mathrm{V}}+\mathrm{Ti}^{\mathrm{Vi} 4+}+\mathrm{Fe}^{2+}+\mathrm{Cr}^{3+}+\mathrm{Mn}^{2+}+\mathrm{Mg}^{\mathrm{VI}+}<6.00\right)$ como frequente das micas dos lamproitos e em algumas micas dos lamprófiros. Algumas micas de Ymi-1 (matriz) apresentam excessos neste sitio (Figuras 3-21). "nas micas de Ymi-1 observam-se (Figura 3-21 (a)) uma relação inversamente proporcional entre os sítio octaédrico com relação ao tetraédrico, pois o $\mathrm{Fe}$ foi totalmente alocado no sítio octaédrico devido a não determinação do $\mathrm{Fe}^{2+}$ e $\mathrm{Fe}^{3+}$, idem para o Ti e o Mg, que podem apresentar-se como $\mathrm{Ti}^{3+}$ e $\mathrm{Ti}^{4+}$ e $\mathrm{Mg}^{4+}$ e $\mathrm{Mg}^{2+}$, respectivamente. Foi verificado que a presença de $\mathrm{Fe}^{3+}$ no $\mathrm{Fe}, \mathrm{Ti}^{4+}$ no $\mathrm{Ti}$ e $\mathrm{Mg}^{2+}$ no $\mathrm{Mg}$, não calculados para o cálculo estrutural apresentado no apêndice A2, poderia causar o excesso no sitio octaéórico. Fe $\mathrm{F}^{3+}\left(\mathrm{Fe}^{\mathrm{IV} *}\right.$ como o end member "tetraferriflogopita"), $\mathrm{Ti}^{4+}$ e $\mathrm{Mg}^{2+}$ por sua vez, preencheriam a deficiência no sítio tetraédrico. Assim, concluiumse que desta forma, essas feições poderiam explicar a relação inversamente proporcional mostrada na Figura 3-21.

*por outro lado, levantou-se a hipótese de que as deficiências nas posições octaédricas e tetraédricas näo seriam devidas aos procedimentos de recálculo catiônico realizados, supondo-se que seriam devido às condições fisicoquímicas do magma do qual essas micas cristalizaram (lamprofírico e lamproítico). Neste caso, magmas deficientes em Al (deficiência interpretada como sendo produto da peralcalinidade do magma, que se incrementa conforme a diferenciação avança) e/ou falta de cálculo do $\mathrm{Fe}_{\mathrm{t}}$ como $\mathrm{Fe}^{2+}$ e $\mathrm{Fe}^{3+}$.

*as micas dos lamprófiros apresentam (Figuras 3-22 (c)) a substituição do tipo da equação $\mathrm{Mig}^{\mathrm{V} / 2+}+2 \mathrm{Si}^{\mathrm{IV} 4 *} \Leftrightarrow \mathrm{Ti}^{\mathrm{VI} 4 *}+2 \mathrm{Al} \mathrm{V}^{\mathrm{V} 3 *}$, substituiçäo que é menos evidenciada nas micas dos lamproítos (Figura $3-22(d)$ ).

*constatou-se também a substituição do Ti nas posições não preenchidas $(S i+A l=8)$ ao empregar $\mathrm{Ti}$ vs $\mathrm{Mg}_{\mathrm{F}} \mathrm{Fe}^{2 *}$, tanto nas micas dos lamprófiros como dos lamproitos, 
(Figura 3-23 (a) e (b)). A substituição do Ti dar-se-ia segundo a equação $\mathrm{Ti}+(\mathrm{Mg}+\mathrm{Fe})=6$

*assim também, uma correlação negativa entre $\mathrm{Ti}$ e (Si+Al+Cr) (Figura 3-27 (c)), responderia uma substituição do tipo da equação $\mathrm{Mg}^{\mathrm{V} / 2+}+\mathrm{Si}^{\mathrm{V} 4+} \Leftrightarrow \mathrm{Ti}^{\mathrm{V} 14+}+\mathrm{Mg}^{\mathrm{V} 2+}$, não observada nas micas dos lamproitos (Figura 3-23 (d)). Micas com muito alto a aito Ba em Ymi-5 e algumas micas de Yzu-2 (Figura 3-24 (a) e (b)), apresentam substituição de $2 \mathrm{~K} \Leftrightarrow 1 \mathrm{Ba}$; que também se explica segundo a substituição do tipo

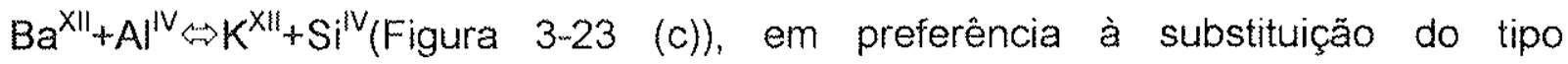
$\mathrm{Ti}+2 \mathrm{Al} \Leftrightarrow \mathrm{Mg}+2 \mathrm{Si}$.

\section{Piroxênios}

*os piroxênios dos lamprófiros Ymi-1, Ymi-7 e Ymi-4 são aluminosos e titaníferos indicando que possuem suficiente $\mathrm{Al}$ na posição octaédrica (TAl) e em alguns também na tetraédrica (MîA). Neles foi observado que o $\mathrm{Al}$ e $\mathrm{Ti}$ apresentam enriquecimento diretamente proporcional (centro do fenocristal em direçäo às bordas Figura 3-4). Esta feição é definida numa linha média de enriquecimento em Ti/Al (0.18-0.94.) superior à observada em piroxênios que ocorrem em rochas ultrapotássicas tipo Província Romana e em parte também diferente daquela observada nas rochas vulcânicas potássicas do rift de Asunción (Figura 3-4 e 3-25 (a)). Essa feições sugerem que eles seriam membros da série de solução sólida entre $\mathrm{CaMgSi}_{2} \mathrm{O}_{6}$ (diopsídio)-CaAlAISi ${ }_{2} \mathrm{O}_{6}$ (piroxênios Camschermak's) e CaTiAl $\mathrm{O}_{6}$

*os piroxênios de Yzu-2 Yzu-3 e Yzu-6, como também alguns piroxênios de Ymi-5, apresentam insuficiência em $\mathrm{Al}$ e assim provocam deficiências no preenchimento dos sítios octaédricos. Os piroxênios de Yzu-2, Yzum3 e Yzu-6 têm caraterísticas que aproximan-se melhor aos lamproítos $\left(\mathrm{TiO}_{2} / 6\right.$ oxigênios $<0.1$ e $\mathrm{Al}_{2} \mathrm{O}_{3} / 6$ oxigênios $<0.1$, Figura 3-26 (b)); já os piroxênios de Ymi-5 descrevem uma línha de enriquecimento de Ti e Al (Figura 3-26 (b)) particular, que passa pelo campo ocupado pelos lamprófiros e kamarugitos e segue paralela à observada nos plagileucitos.

*os piroxênios de Ymi-5, Yzu-2, Yzu-3 e Yzu-6 e de Ymi-1, Ymi-4, Ymi-7 e Yzu-1 exibem correlação negativa entre Al vs Si (Figuras 3-26 (c) e (d)); à exceção de Ymi- 
5 e algumas de Yzu-3, esses piroxênios apresentam alto Si e deficiência em Al. Alguns dos piroxênios de Ymi-5, por exemplo os quench, apresentam-se com alto Al e com deficiências em Si (Figuras 3-26 (d), 3-27(b) e (d)). Já nos piroxênios que possuem alto Si e deficiências em Al no sítio tetraédrico (alguns piroxênios de $Y \mathrm{mi}-1$ e Ymi-7 e em alguns de Ymi-5 e Yzu-2; Figuras 3-26 e 3-27), o Ti ${ }^{4 *}$ passaria a ocupar ora posições octaédricas, ora octaédricamente e tetraédricamente.

\section{Espinélios}

*os microfenocristais de espinélios em Ymi-1 e inclusões de espinélios nos minerais máficos em Ymi-1 e Yzu-1 evidenciam solução sólida entre a picrocromita e a cromita (série da cromita) (Figura 3-7 e 3-9); os espinélios da matriz dos lamprófiros e lamproítos mostram alto teor nas moléculas da série espinélio-magnetita, ambas em solução sólida (Figuras 3-9 e 3-17). Em Ymi-5, Yzu-2, Yzu-3 e Yzu-6 os espinélios estäo enriquecidos na molécula de magnetita e emYmi-1, Ymi-4, Ymi-7. Yzum e em parte também em Ymi-5 foram registrados enriquecimento na molécula de hercynita. Por sua vez, os espinélios de Ymi-1, Ymi-7 e Yzu-6, Ymi-5 e alguns de Yzu-2 e Yzu-3 estão enriquecidos na molécula de jacobsita (lamproítos: Ymi-5, Yzu2, Yzu-3 e Yzu-6) e galaxita (lamprófiros: Ymi-1, Ymi-4, Ymi-7 e Yzu-1).

\section{Feldspatos}

*nos lamprófiros é importante a molécula de albita (altos teores de $\mathrm{Na}_{2} \mathrm{O}$ ) (Figura 310). As sanidinas de Yzu-1 apresentam em solução sólida teores elevados de sanidina de Fe (Figuras 3-10 (b) e (c)) e assim, são comparáveis com as sanidinas que ocorrem em lamproítos. Entretanto, neste corpo, as sanidinas também possuem altos teores da molécula de anortoclásio ( $6 \%$ de $\mathrm{Na}_{2} \mathrm{O}$, Figura 3-10 (b)), caracteristicas que afastam dos lamproitos e aproximam aos lamprófiros.

*os feldspatos dos lamproítos são sanidinas que possuem em solução sólida importantes teores da molécula de sanidina de Fe (Yzu-2 e Yzu-6) e teores da molécula de anortoclásio baixos (Ymi-5, Yzu-3 e Yzu-6) a moderados (Yzu-2). 


\section{Condições termodinámicas acusadas nas rochas estudadas}

A Figura 5-1 (a) e (b); mostrou excelente correlação entre o termômetro de Zn (Griffin et al., 1992) e o termômetro TMig (Presser \& da Silva, 1997), aplicado a espinélios que ocorrem como inclusão no diamante e aqueles que ocorrem em peridotitos, i.e., xenocristais. Além disso mostrou também excelente aproximação entre o termômetro TMg e a temperatura de formação dos espinélios encontrados por Garda (1995) em rochas alcalinas de São Sebastião e arredores, nos quais Garda (1995) empregou para os cálculos de temperatura vários métodos, entre eles o termômetro de Ballhaus et al. (1991). Para testar por outros caminhos a eficácia do método TMg foram calculadas as temperaturas para espinélios: do cráton da Rússia onde foram obtidas temperaturas entre $1020-1180^{\circ} \mathrm{C}$, típicas de regiões cratônicas com gradiente geotérmico da ordem de $\approx 35 \mathrm{~mW} / \mathrm{m}^{2}$; dados similares aos estimados por outros métodos termométricos por Griffin \& Ryan (1995) e Griffin et al. (1993); do cráton Kimberley (Austrália) nos quais foram obtidas temperaturas de entre $900-1100^{\circ} \mathrm{C}$ como próprias de regiões cratónicas com gradiente geotérmico da ordem de $\approx 35 \mathrm{mw} / \mathrm{m}^{2}$, coincidentes também com o gradiente geotérmico que aportam os dados de Jaques et al. $(1990 ; 1994)$ e em parte também, similares aos estimados por Griffin \& Ryan (1995); no cráton South Africam (Africa do Sul) nos quais foram obtidas temperaturas de entre $1030-1100^{\circ} \mathrm{C}$, típicas de regiões cratónicas com gradiente geotérmico da ordem de $\approx 35 \mathrm{~mW} / \mathrm{m}^{2}$ (este gradiente foi estimado por Griffin \& Ryan (1995) em inclusões de diamantes/xenólitos peridotíticos transportados pelos orangeitos); no cráton da China (ex. pipe Lianing \#42) foram obłidas temperaturas de entre $1055-1112^{\circ} \mathrm{C}$ como característica de regiões cratônicas com gradiente geotérmico da ordem de $\approx 35 \mathrm{~mW} / \mathrm{m}^{2}$ a $\approx 40 \mathrm{~mW} / \mathrm{m}^{2}$; este valor também muito similar ao determinado por Griffin \& Ryan (1995).

Tendo comprovado empiricamente a confiabilidade do cálculo da temperatura através do metodo $\mathrm{TMg}$, ele passou a ser empregado para o cálculo de temperatura nos espinélios de Ymi-1 (xenocristais de concentrados, inclusões e microfenocristais) 
e Yzu-1 (inclusões). $Y$ mi-1 $\approx 850-1050^{\circ} \mathrm{C}$ e $Y z u-1 \approx 900-1050^{\circ} \mathrm{C}$, temperaturas que são esperadas encontrar em espinélios formados em um manto soldado a crátons com um gradiente geotérmico da ordem de $\approx 35 \mathrm{~mW} / \mathrm{m}^{2}$. Uma região cratônica com um gradiente geotérmico da ordem de $\approx 35 \mathrm{~mW} / \mathrm{m}^{2}$ possue uma raiz cratônica $>200 \mathrm{Km}$, como foi a estimada para o escudo canadiense. No primeiro item já foi levantado que o cráton Rio de La Plata se compara com o escudo canadiense (p/ex. Assumpção el al. 1997). Desta forma se conclui, que o conjunto das intrusões estudadas, vinculadas ao cráton Rio de La Plata, definem adequadamente, através do cálculo termométrico em xenocristais de espinélios o gradiente geotérmico da ordem de $\approx 35 \mathrm{mw} / \mathrm{m}^{2}$ que também fora deslumbrado através de métodos geofísicos neste cráton.

Foi também discutido no Capítulo 5 que Doroshev et al. (1997) estudando experimentalmente a assembléia mineral granadatortopiroxênioteskolaita e granadatortopiroxênio tespinélio fforsterita a $30-60 \mathrm{kbars}$ e $1200-1500^{\circ} \mathrm{C}$ verificaram que o valor de Cr\# nos espinélios muda com um intervalo curto, de 0.76 (40 kbar, $\left.1400^{\circ} \mathrm{C}\right)$ a $0.86\left(60 \mathrm{kbar}, 1500^{\circ} \mathrm{C}\right)$; assinalando que o efeito da temperatura é negativo a todas as pressões estudadas; i.e., incrementando a temperatura de 1200 a $1500^{\circ} \mathrm{C}$ resulta em um decréscimo das moléculas de picro-cromita de 0.83 a 0.76 a 40 kbars e de 0.88 a 0.80 a 50 Kbar. Este barômetro de Doroshev et al. (1997) ao ser aplicado a algumas inclusões de espinélio em diamante, eles eram deslocados para o plano da grafita em alguns Kbrs. Por esta razão encontrou-se que ao multiplicar o valor de $\mathrm{Cr}$ \# pelo teor de $\mathrm{Cr}_{2} \mathrm{O}_{3}$ a pressão subestimação da já não ocorria quando testado em centenas de inclusões de espinélios em diamantes e espinélios coexistindo com o diamante em xenólitos peridotíticos. Assim a modificação do barômetro de Doroshev et al. (1997), foi aplicado a grãos de espinélio de Ymi-1 e Yzu-1 para cálculo de profundidade de formação/proveniência. Conforme o mostrado na Figura 4-9 as pressöes obtidas oscilam entre 10 e $50 \mathrm{Kbrs}$, sendo compatibel com as pressões da fácies peridotíticas onde o diamante está presente (>40 Kbrs). Os dados termométricoss e baromêtricos praticados nos grãos de xenocristais de espinélio de Ymi-1 e Yzum-1 permitem assim concluir: 
"Os lamprófiros picríticos Ymi-1 e Yzu-1 amostraram peridotitos de um manto lithoesférico profundo ( $50 \mathrm{kbrs})$ crátonizado, que no Jurássico ( $130 \mathrm{Ma})$ possuia o gradiente geotérmico de $35 \mathrm{~mW} / \mathrm{m}^{2 "}$.

\section{Potencial económico que as rochas estudadas sugerem}

\section{O diamante}

A coincidência petrológica e geofísica da raiz do manto é de importância potencial para exploração do diamante, de modo que possibilita predizer o potencial do diamante na base da raiz de um cráton, ela detectabel geofisicamente. Por exemplo, - limite alto shear wave velocity (SWW) debaixo da província Slave (escudo canadense) meridional foi usado para sugerir uma zona de melhor potencial de diamante para esta regiāo (Herimstaedt, 1991). Nesta regiăo a Dia Met exploração anunciou a descoberta, no outono de 1991, de fontes kimberliticas mineralizadas e econômicas (Fipke et al., 1995). Sendo estimado que este campo Lac de Gras junto à Archangelsk (C.I.S.) puderam juntar-se também, no final deste século, como os maiores produtores (Jeggins 1995). Em iten acima foi sublinhado que o asoalho cratônico da Bacia do Paraná era comparável com o escudo canadense; por esta razão, pode-se sugerir que:

-de manerira geral, o cráton Rio de La Plata apresenta-se como um alvo prometedor para a procura de fontes primárias de diamante.

-agora de forma particular, Morgan (1995) salientou sobre o importante papel de megafraturas (paleo-rifts e rifts), que são reconhecidas em e/ou associadas às estruturas cratónicas, como alvos para as fontes primárias do diamante. O segmento Central E-W do rift de Asunción trata-se da continuaçäo, no Paraguai, do lineamneto do Rio Uruguay (ver Figura 6-1). Assim, este ambiente deve ser considerado como de interesse para a procura de fontes magmáticas portadoras de diamante. 
Como os diamantes são geralmente mais velhos que suas rochas ígneas hospedeiras eles não são fenocristais cristalizados do magmas que os transporta, mas xenocristais, derivados da disagregação física de rochas fontes do manto superior. A rocha hospedeira ígnea simplesmente resultando como meio de transporte da fonte de manto superior para a superfície. Julgando a distribuição regional de diamantes em "kimberlitos", os depósitos de diamante verdadeiramente primário (harzburgitos de granada, therzolitos, eclogitos), se concentram nas raizes de crátons Archeanos, onde eles não são diretamente acessiveis. A correlação entre "kimberlitos" diamantíferos e crátons Arqueanos assim como também os dados isotópicos dos diamantes de Africa do Sul mostraram que um monto substancialmente importante de diamantes foram formados durante 0 desenvolvimento da primeira litosfera e que estes diamantes sobreviveram nas raizes de escudos do Pré-cambriano sendo apanhados por kimberlitos e lamproítos que variam em idade do Archeano superior para o Cenozoico (Helmstaedt \& Gurney, 1995). A distribuição de depósitos de diamante aluvial e "kimberlitos" junto e ao redor da Bacia do Paraná, esquematizados na Figura 6-1 sugerem a presênça de raizes fonte onde o diamante foi arrancado por magmas "kimberlíticos" e trazidos em superficie.

Em muitas ocasões os geólogos do diamante apelam a métodos indiretos para o reconhecimento de terrenos cratónicos (p/ex. Arqueanos). Isto realizam-se coletando dos sedimentos de corrente, das regiões pesquisadas, suite de minerais pesados (piropo G10, picro-cromitas e cromitas com alto $\mathrm{Cr}$ e microdiamantes) indicadores indiretos do manto crátonizado frio e profundo (manto sublitosférico). Conquanto que nos pipes estudados foram caraterizados como suite de minerias pesados:

-Ymi-1, pseudobrookita, ilmenita, rutilo, rutilo de Nb, picro-cromita, cromita, magnetita magnesiana titanífera, turmalina, zircão, diamante e traças de piroxênios.

-Ymi-8, pseudobrookita, ilmenita, rutilo, zircão, diamante junto à traças de espinélios, piroxênios e turmalina (todos encontrados junto a escassos a traços cristais de granada), no Capítulo 5 procurou-se potencializar os espinélios encontrados no pipe Ymi-1 (picro-cromitas e cromitas). Como indicado nesse capítulo, nos diagramas Cr\# 
vs $\mathrm{Fe}^{2+} \#$ e $\mathrm{MgCr}_{2} \mathrm{O}_{4}-\mathrm{MgAl}_{2} \mathrm{O}_{4}-\mathrm{MgFe}_{2} \mathrm{O}_{4}$ muitos xenocristais de espinélios de $\mathrm{Ymi}-1$ e algumas inclusões de xenocristais de espinélio (em olivinas) de Yzu-1 ocupam campos comumente também ocupados pelos espinélios que ocorrem em peridotitos da fácies diamantíferas e/ou associadas ao diamante; assim eles teriam sidos arrancados das raizes do manto peridotítico crátonizado da facies do diamante pelo magma que os colocou em superficie (=lamprófiros cálcio-alcalino picrítico), sugerindo, de serta forma que o diamante pode estar presente nessas estruturas. Isto parece confirmado pela coleta de microdiamantes (Fotomicrografia 8) no pipe Ymi-1, e pelo dados termo-barométricos obtidos nesses xenocristais de espinélio.

Estas evidências possibilita encoragar futuras pesquisas de outra fontes primárias do diamante nesta região claramente relacionada com o bloco Paranapanema (pertecente ao cráton Rio de La Plata), esperando-se que elas sejam potencialmente melhores.

\section{Ouro nos magmas "lamprofiricos"?}

Associações entre lamprófiros cálcio-alcalinos e Au de depósitos mesotermais (Arqueanos à Terciário) no qual os lamprófiros são co-genéticos (como também coespaciais) com a mineralização, são crescentemente reconhecidas no mundo (Rock \& Groves, 1988).

Rock \& Groves (1988) sugerem a hipótese que leva a considerar lamprófiros como os agentes transportadores de Au de fontes ricas em Au de um manto profundo, o qual então sofreria interações crustais extensas, gerando magmas félsicos ou lançando o Au em sistemas metamórfico-hydrotermais.

Rock (1991) insiste que existe conexão entre o Au e os lamprófiros, este fato foi examinado e observado por muitos pesquisadores do Au durante muitos anos, em especial Boyle (1979, in Rock 1991) que comenta: "an adage among some gold prospectors that lamprophyres are good indicators of the presence of gold deposits" ("um provérbio entre alguns prospetores de Au que lamprófiros são indicadores bons da presença de depósitos de Au"). 
Em Rock (1991) é encontrado um sumário das principais informações que ligam Au com os lamprófiros (cf. Table 9.2 pag. 152).

Na região associada às intrusões do arroyo ltá (Campo Ybytyruzú) descobriram-se partículas de Au. É uma área muito rica em rochas lamprofíricas (ver comentários nos Capítulos 3 e 4 e outros itens deste Capítulo), assim indicando ser um campo excelente para se pensar numa conexão genética entre as rochas lamprofíricas e as ocorrências de Au.

Observa-se também que minettas e lamproítos apresentam anomalias positivas em $\mathrm{Au}$ e outros elementos preciosos, sendo que o elemento Au parece estar mais concentrado nos lamproitos (cf. Figura 5.6, pag. $92 \mathrm{em}$ Rock, 1991.), fato que viria a apoiar a idéia de conexão genética entre as rochas lamprofíricas (minettas e lamproítos) e as ocorrências de Au do Campo Ybyíyruzú. No lamproíto Yzu-4 foi registrado perto de $1 \%$ de quartzo residual; e como comentado no Capitulo 2 , veios de quartzo aurifero foram encontrados na área aurif́era deste campo.

Associadas ao Au do arroyo ltá (Campo Ybytyruzú) ocorrem grãos de ilmenita, granada, zircão e espinélio. Esta associação é comum de observar em ambientes cratônicos (ex. Cráton de São Francisco). O Campo Ybytyruzú corresponde a um ambiente platform, como já discutido itens acima.

O Arqueano foi o período principal para mineralização de Au sendo que as rochas desta idade compõem $\sim 12 \%$ da crosta exposta mas que se produziu mais da metade do Au do mundo (Cameron, 1988); assim entende-se que os crátons são áreas onde, através de diversos processos tecto-magmáticos no tempo geológico, poderiam concentrar muito Au em superfície. Eventualmente os veios/filões auríferos do Campo Ybytyruzú teriam-se formado pela reconcentração de depósitos auriferos do embasamento cristalino desta região, concentração que teria sido facilitada pelo distúrbio termal a que contribuiu o magmatismo Mesozóico (alcalino) regional. Esta idéia é vista pelo Prof. Dr. Jorge B. (com, pess. Fev./1998) em lugar de esperar uma ligação genética com os magmas lamprofíricos.

Conclui Rock (1991): "a global, intimidade de espaço e tempo da associação dos lamprófiros cálcio-alcalinos-Au faz de alguns lamprófiros calcio-alcalinos indicadores 
do Au no seu próprio direito. Parece provável que aquelas fusões de lamprófiros cálcio-alcalinos contribuem com fluidos e talvez também Au para os sistemas mineralizadores. Em todo caso, a associação tem implicações principais para a colocação tectônica de depósitos de Au de origem mesotermal".

\section{Fugacidade de oxigênio}

Ao ser investigados no Capitulo 5 os xenocristais de espinélio de Ymi-1 no diagrama $\mathrm{Fe}^{3+} /\left(\mathrm{Fe}^{3+}+\mathrm{Fe}^{2+}\right)$ vs Cr\# (Ramsay et al., 1994), eles indicaram condições de formação por baixo do tampão QFM (Figura 5-6), com concentrações elevadas das inclusões e alguns espinélios dos concentrados no tampão Q-1 (QFM, menos uma unidade logarítmica). Foi também evidenciado que espinélios de microfenocristais, dos concentrados e de algumas inclusões apresentam fugacidade ainda menor, i.e., $<1+1$ (Ferro-Wüstita, mais uma unidade logarítmica), a $1+2$ (Ferro-Wüstita, mais duas unidades logarítmicas). Estes valores da fugacidade de oxigênio são muito favoráveis à formação do diamante nas raizes cratônicas. Por sua vez as inclusões de espinélio em olivinas de Yzu-1 formaram-se num ambiente com tampão Q-1 a 1+2 (Figura 5-6). As inclusões de espinélio em Ymi-1 e Yzu-1 possuem valores de fugacidade $1+1$ a $Q-1$ o que indica em favor de condições de transporte com fugacidade de oxigênio favoráveis para a preservaçăo do diamante. Isto permite concluir que a fugacidade de oxigênio que apresentam os xenocristais de espinélio, em geral, e a apresentada pelas inclusões $(<1+1$ a $Q-1)$ em minerias máficos, por exemplo, em Ymi-1, fornecem condições favoráveis para a formação e preservação do diamante.

As ilmenitas de Ymi-1 e Ymi-8, foram também analisadas no sistema $\mathrm{MgTiO}_{3}$ $\mathrm{FeTiO}_{3}-\mathrm{Fe}_{2} \mathrm{O}_{3}$ (Figura $4-4$ (a). Observou-se que elas apresentam condiçōes de oxidação/redução em torno do tampão $10-^{6}(\sim$ buffers wustita-magnetita a $30 \mathrm{kbar}$ e $1300^{\circ} \mathrm{C}$ ). Este dado também apoiando o que já foi concluído com relação aos espinélios, ou seja, um ambiente relativamente redutor indicando positivamente para a preservação do diamante. 


\section{Comentários finais}

É encontrado em Peccerillo (1995) que no Centro-Sul da Itália ocorrem rochas comagmáticas principalmente, vulcânicas cálcio-alcalinas, potássicas (shoshoníticas) a ultrapotássicas: plagileucititos ( $p / e x$. Roma), kamafugitos ( $p / e x$. San Venanzo e Cupaello) e lamproitos (p/ex. Torre Alfina) e rochas transicionais entre rochas potássicas e rochas lamproíticas (p/ex. Toscana, norte de Latium); essas rochas evoluiram de diferente maneira e geraran se a partir de fontes mantélicas também diferentes. Como comentado no Capítulo 1, Barton (1979) e mais tarde Foley et al. (1987) consagram a Provincia Romana como localidade Standard members do grupo. Assim, a Provincia comagmática Romana náo deve ser considerada táo só como Standard members do grupo basaltóide ultrapotássico (plagileucitos) mas também como uma das poucas provincias mundiais onde ocorrem os três grupos de rochas ultrapotássicas; l.e.y plaguileucitos, kamafugitos e

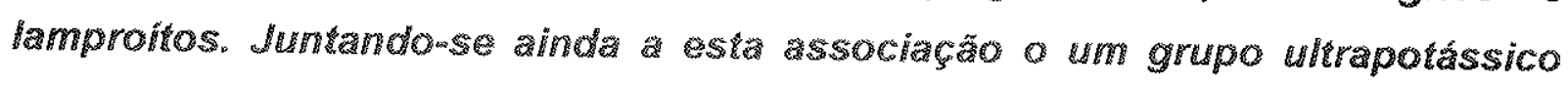
transicional

Uma das conclusões deste trabalho levou a de caraterizar, junto ao rift de Asunción na província potássica a ultrapotássica alcalina Mesozóica do Paraguai Oriental, um grupo de lamproitosss (no Campo Ybytyruzú) e um lamproito transicional (Ymi-5, no Campo Ybytymí). Esses grupos ocorrem juntos a basaltos potássicos a ultrapotássicos (plagileucítos), identificados por Comin-Chiaramonti et al. (1992; 1996; 1997) para o Campo Ybyłymí e em parte também, para o Campo Ybytyruzú, este en número de ocorrência muitissimo reduzido. Assim, embora não reportada ocorrência de kamafugítos associados no rift de Asunción, o tipo de associação de rochas potássicas a ultrapotássicas é comparável a Província co-magmática Romana.

Bitschene (1987) e Comin-Chiaramonti et al. (1992; 1996; 1997) registraram feiçőes geoquímicas, como por exemplo anómalias negativas em Ta-Nb-Ti, assim como também o comportamento nos isótopos de $\mathrm{Sr}$ e Nd, que são identificadas em rochas vulcânicas vinculadas com processos de subdução. As rochas potássicas ultapotássicas do nift de Asunción ocorrem num ambiente continental; i.e., ambiente 
impossivel de vinculámlo com processos de subdução (Comin-Chiaramonti et al. 1992; 1996). Bitchene (1989) indica que estas rochas proviriam da litosfera continetal heterogênea enriquecida possivelmente, através da subdução da cunha crustal subdutada e parcialmente fundida.

É geralmente aceito que uma região do manto existente debaixo de crátons continentais estáveis e antigos poderiam ter registrado o último evento térmico na crosta subjacente (Menzies et al., 1987). Este processo necessariamente leva ao enriquecimento (metassomático) da cunha do manto sobrejacente à placa subduptada. Segundo Haggerty (1990), isto acontece na região por ele denominada de metasome ( $\sim 50-100 \mathrm{kms}$ de profundidade). Posteriormente esta região do manto peridotítico metassomaticamente enriquecida, nas regiões do manto crátonizado que permanece sem pertubações ao longo do tempo, podem sofrer fusão parcial e assim gerar magmas em ambientes atualmente continentais e estáveis, com assinaturas próprias de magmas ligados à subdução (p/ex. Menzies et al., 1987).

O cráton Rio de La Plata esteve até o Proterozóico colado ao cráton Amazônico (Trompete, 1994). No cráton Amazônico tem-se registros que no Proterozóico aconteceram eventos orogênicos a ele vinculados; por exemplo, a orogenia San Ignácio ( $\pm 1.3 \mathrm{Ga}$, Brito-Neves et al., 1996); e veja-se que Gibson et al. (1996) e Castorina et al. (1996) registraram para as rochas potássicas a ultrapotássicas Mesozóicas associadas/vinculadas com o rift de Asunción, idades de enriquecimento para a fonte peridotítica da qual derivaram entre 1.2 e $1.8 \mathrm{Ga}$, que acredita-se, como sugerido por Bitschene (1989), que se deva a enriquecimento através de processos de subdução. Isto inevitavelmente levam os pesquisadores a se perguntar: "este fenômeno estaria explicando o fato de lamprófiros cálcio-alcalinos ocorrem num ambiente tectônico impróprio a eles?". 
PÓS-ESCRITO 



\section{Referências}

ADANS, G.E. \& BISHOP, F.C. 1986. The olivine-clinopyroxene geobarometers: experimental results in the $\mathrm{CaO}-\mathrm{FeO}-\mathrm{MgO}-\mathrm{SiO}_{2}$ system. Cotrib. Mineral. Petrol. 94: 230-237.

ALLAN, J.F. \& CARMICHAEL, 1.S.E., 1984. Lamprophyric lavas in the Colina graben. SW Mexico. Contrib. Mineral. Petrol., 88: 203-216.

ALMEIDA, F.F.M., 1971. Geochronological division of the Precambrian of South America. Rev. Bras. Geoc., 1: 13-21.

ALMEIDA, F.F.M., 1978. Chronotectonic boundaries for Precambrian of South America. An. Acad. Bras. Cienc, 50 (4): 527-535.

ALMEDDA, FE.M., 1983 . Relações Tectônicas das Rochas Alcalinas da Região Meridional da Plataforma Sul-Americana. Rev. Bras. Geoc., 13: 139- 158 :

ALMEIDA, F.F.M.: AMARAL, G. CORDANI, U.G. \& KAWASHITA, K. 1973. The Precambrian evolution of the South America cratonic margin south of the Amazon river. In: NAIR \& STEHLI (eds), The ocean basins and margins Plenum, 1: 411-446.

ALVES, F.R. 1996. Contribuição ao conhecimento geológico e petrológico das rochas alcalinas da ilha Dos Búzios. São Paulo, 274 p. Tese de Doutoramento, IGUSP.

ASSUMPÇÃO, M.; JAMES, D. \& SNOKE, A, 1997. Crustal thicknesses in SE Brazilian shield with receiver function: Isostatic compensation by density variation in the lithospheric mantle. In: Anais do 5, CONGR. INTER. SOC. BRASIL. GEOF., São Paulo. 895-897.

BALLARD, S. \& POLLACK, H.N. 1987. Diversion of heath by Archean cratons: a model for southern Africa. Earth Planet. Sci. Lett., 85: 253-264.

BALLHAUS, C.; BERRY, R.F. GREEN, D.H. 1991. High pressure experimental calibration of the olivine orthopyroxene spinel oxygen geobarometer: implications for the oxidation state of the upper mantle. Contrib. Mineral Petrol. 107: $27-410$. 
BARTON, M., 1979. A comparative study of some minerals occurring in the potassiumrich alkaline rocks of the Leucite Hills, Wyoming, the Vico Volcano, western Italy, and Toro-Ankole region, Uganda. N.J. Miner. Abh., 137: 113-134.

BASEI, M.A.S. 1985. O cinturão Dom Feliciano em Santa Catarina. São Paulo, 195p. Tese de Doutoramento, IGC - USP.

BASEI, M.A.S.; SIGA Jr., O.; REIS NETO, J.M.; HARARA, O.M.; PASSARELLI, C.R. \& MACHIAVELLLI, A. 1997. Geochronological map of the Precambrian terrains of Paraná and Santa Catarina States, southern Brazil: Tectonic implications. In South-Amer. Simp. on Isot. Geol, Extend. Abstr., 44-46. Brazil.

BASEl, M.A.S.; SIGA JUNIOR, O.; MACHIAVELLI, A. \& MANCINI, F. 1992. Evolução tectônica dos terrenos entre os Cinturões Ribeira e Dom Felicinano (PR - SC) Rev. Bras. Geoc., 22 (2): 216-221.

BERGMAN, S.C., 1987. Lamproites and others potassium-rich igneous rocks: a review of thier occurrence, mineralogy and geochemistry. In: FITTON \& UPTON (eds.) Alkaline Igneous Rocks. Geol. Soc. Spec. Publ, 30: 103-190.

BERGMAN, S.C.; DUNN, D.P. \& KROL, L. 1988. Rock and mineral chemistry of Linhaisai minette, Central Kalimantan, Indonesia, and the origin of Borneo diamonds. Canadian Mineralogist, 26:23-43.

BERROCAL, J. \& FERNANDES, C. 1996. Seiismicity in Paraguay and neighbouring regions. In: COMIN-CHIARAMONTI \& GOMES (eds). Alkaline Magmatism In Central Eastern Paraguay. Relationships with coeval magmatism in Brasil. p. 57 66

BITSCHENE, P.R., 1987. Mesozoischer Und Kanozoischer Anorogener Magmatismus in Ostparaguay: Arbeiten zur Geologieund Petrologie zweier Alkaliprovinzen. Heidelberg, 337p., Tese de Doutorado Univ. Hiedelberg.

BITSCHENE, P.R. 1989. Tining and evolution of Late Phanerozoic intraplate alkaline magmatism in Eastern Paraguay. In: $28^{\text {th }}$. INT. GEOL. CONGR., Washington. Ext. Abstr.

BITSCHENE, P.R. \& LIPPOLT, J,H, 1986. Acid magmatites of the Brasiliano cycle in East Paraguay. Zbl. Geol. Palaont, Teil I, 9/10: 1457-1468. 
BITSCHENE, P.R. \& PRESSER, J.L.B., 1989. The Asunción Alkaline Province (Eastern Paraguay): Geologic Setting and Petrogenetic Aspects. Zbl. Geol. Palaont., Teil I5/6: 959-971.

BITSCHENE, P.R.; LIPPOLT, H.d.; STROH, A.; 1986. Junng-mesozoicher, Kbentonter Magmatismus in Ostparaguay (Guairá-Paraguari Provinz) und RiftingProzesse innerhalb der sudamerikanischen Plattform. Fortsch. Miner., 64/1, $p$ 19.

BOL, L.C.G.M.; BOS, A.; SAUTER, P.C.C. \& JANSEN, J..B.H. 1989. Barium-titaniumrich phlogopites in marbles from Rogaland, Southwest Norway. Am. Mineral., 74: 439-447.

BOWLES, J.F.W. 1988. Definition and range of composition of naturally occurring minerals with the pseudobrookite structure. Am. Mineral., 73: 1377- 1383.

BOYD, F.R. \& FINNERTY, A.A. 1980. Conditions of Origin of Natural Diamonds of Peridotite affinity. J. of Geoph.Res., 85, no 12: 6911-6918.

BOYD, F.R. \& NIXON P.H. 1975. Origins of the ultramafic nodules from some kimberlites of the Northern Lesotho and the Monastery Mine, South Africa. Physics and Chem. Of the Earth., 9: 431-454.

BOYD, F.R.; PEARSON, D.G.; NIXON, P.H. \& MERTZMAN, S.A. 1993 LOW-calcium garnet harzburgites from Southern Africa: their relations to craton structure and diamond crystallization. Contrib. Mineral. Petrol., 113: 352-366.

BREY, G.P. 1989. Geothermometry for Iherzolites: experiments from 10 to $60 \mathrm{~kb}$, new geothermometers and apliccation to natural rocks. Hab. Tese. Darm., Min. Inst Univ. Darm.

BREY, G.; DOROSHEV, G. \& KOGARKO, L. 1991. The joint pyrope-knorringite: esxerimental constraint for a new gethermobarometer for coexisting garnet and spinel. In: FITH INTER. KIMB. CONF.. Extend. Abstr. CPRM Spec. Publ. $2 / 91$ Brasilia.

BREY, G.P. ; KOHLER, T. \& NICKEL, K.G. 1989. Geothermobarometry in natural four-phase therzolite: experiments from $10-60 \mathrm{~kb}$, new thermobarometers and aplications. In: $28^{\text {th }}$. INT. GEOL. CONGR., Washington. Ext. Abstr. 
BRIGATTI, M.F.; MEDICI, L.; SACCANI, E. \& VACCARO, C. 1996. Crystal chemistry and petrologic significance of $\mathrm{Fe}^{3+}$-rich phogopite from the Tapira carbonatite complex, Brazil. American Mineral., 81: 913-927.

BRITO-NEVES, B. B. 1995. Crátons e faixas móveis. Bol. IG-USP, Sér. Didát. São Paulo, SP., 7: 1-87

BRITO-NEVES, B. B.; WINGE, M \& CARNEIRO, M.A. 1996. Orogêneses precedendo e tafrogêneses sucedendo Rodimia na América do Sul. Bol. IG-USP, Sér. Cient. 27: $1-40$.

BRITO-NEVES, B.B. \& CORDANI, U., 1991. Tectonic evolution of South America diring the Late Proterozoic. Precam. Research., 53: 23-40.

BUDDINGTON, A.F. \& LINDSLEY, D.H. 1964. Iron-titanium oxide minerals and synthetic equivalents. J. of Petrology, 5: 310-357.

BULANOVA, G.P. 1995. The formation of diamond. J. of Geochemical Exploration, 53: $1-23$.

CAMERON, E.M. 1988. Archean gold: relation to granulite formation and redox oning in the crust. Geology, 16: 109-112.

CARBONIN, S. \& PRINCIVALLE, F. 1996. A crystal-chemical study of pyroxenes with diopsidic structures in alkaline rocks from Central-Eastern Paraguay: some considerations on tetrahedrally coordinated $\mathrm{Ti}^{4+}$. In: COMIN-CHIARAMONTI \& GOMES (eds). Alkaline Magmatism In Central Eastern Paraguay. Relationships with coeval magmatism in Brasil. p. 157-180.

CARMICHAEL, I.S.E; LANGE, R.A. \& LUHR, J.F. 1996. Quaternary minettes and associated volcanic rocks of Mascota, western Mexico: a consequence of plate extension above a subduction modified mantle wedge. Cotrib. Mineral. Petrol., 124: 302-333.

CARSWELL, D. \& GIBB, F.G.F. 1987. Evaluation of mineral thermometers and barometers applicable to garnet iherzolite assamblages. Contrib. Mineral. Petrol., 95: 499-511.

CARSWELL, D. \& GIBB, F.G.F. 1987. Garnet therzolite xenoliths in the kimberlites of northern Lesotho: revised P-T equilibration conditions and upper mantle palaeogeotherm. Contrib. Mineral. Petrol., 97: 473-487. 
CARVALHO, J.B. \& LEONARDOS, O.H. 1997. Garnet peridotites from the Três Ranchos IV kimberlitic pipe, Alto Paranaiba igneous province, Brazil: Geothermobarometric constraints. Russian Geology and Geophsics, 38 (1): 168181

CASTORINA, F.; PETRINI, R.; COMIN-CHIARAMONTI, P.; CAPALDI, G. \& PARDINI, G. 1996. Potassic magmatism from the Asunción-Sapucai graben, Eastern Paraguay: inferences on mantle sources by Sr-Nd isotopic systematics. In: COMIN-CHIARAMONTI \& GOMES (eds). Alkaline Magmatism in Central Eastern Paraguay. Relationships with coeval magmatism in Brasil. p. 195-206.

CELLAI, D.; CONTICELLI, S. \& MENCHETT, \$. 1994. Crystal-chemistry of clinopiroxenes from potassic and ultrapotassic rocks in central ltaly: implications on their genesis. Contrib. Mineral Petrol., 116:301-315.

CHEMALE Jr. F; BABINSKI, M.; VAN SCHMUS, W.R.; WLLNER, W. \& LIMA, E.F. 1997. U-Pb and Sm-Nd isotopic studies of Neoproterozoic to early Paleozoic belts in southern Brazil. In: South-Amer. Simp. on Isot. Geol., Extend. Abstr. Brazil.

CHIEREGATI, L. A. 1989. Aspectos mineralógicos, genéticos e econômicos das ocorrencias diamantíferas da região nordeste do Paraná e sul de São Paulo. 180p. Diss. Mestrado, IGcuUSP.

CINGOLANI, C.; VARELA, R.; DALLA SALDA, L. BOSSI, J.; CAMPAL; N.; FERRANDO, L. PINEYRO, D. ; SCHIPILOV, A. 1997. Rb-Sr geochronology from the Rio de La Plata craton of Uruguay. In: South-Amer. Simp. on Isot. Geol., Extend. Abstr., Brazil.

COMIN-CHIARAMONTI, P. \& GOMES, C.B.s 1996. Alkaline Magmatism In Central Eastern Paraguay. Relationships with coeval magmatism in Brasil. São Paulo: EDUSP/FAPESP, 460p

COMIN-CHIARAMONTI, P.; CENSI, P.; CUNDARI; A.; DE MIN, A.; GOMES, C.B.; MARZOLI, A. \& PICCIRILLO, E.M. 1996. Petrochemistry of early cretaceous potassic rocks from the Asunción-Sapucai graben, Central-Eastern Paraguay. in: COMIN-CHIARAMONTI \& GOMES (eds). Alkaline Magmatism in Central Eastern Paraguay. Relationships with coeval magmatism in Brasil. p. 123-149. 
COMIN-CHIARAMONTI, P.; CUNDARI, A.; De MIN, A.; GOMES, C.B. \& VELÁZQUEZ, V.F. 1996. Magmatism in Eastern Paraguay: occurrence and petrography. In: COMIN-CHIARAMONTI \& GOMES (eds). Alkaline Magmatism In Central Eastern Paraguay. Relationships with coeval magmatism in Brasil. $p$. 103-121.

COMIN-CHIARAMONTI, P.; CUNDARI, A.; GOMES, C.B.; PICCIRILLO, E.M.; CENSI, P.; DE MIN, A.; BELLIENI, G.; VELÁZQUEZ, V.F.; ORUÉ, D. 1992. Potassic dyke swarm in the Sapucai graben, Eastern Paraguay: petrographical, mineral and geochemical outlines. Lithos, 28: 283-301.

COMIN-CHIARAMONTI; P.; CUNDARI; A.; PICCIRLLLO, E.M.; GOMES, C.B.; CASTORINA, F.; CENSI, P.; DE MIN, A.; MARZOLI, A.; SPEZIALE, S. \& VELÁZQUEZ, V.F. 199\%. Potassic and sodic igneous rocks from Eastern Paraguay: their origin from the lithospheric mantle and genetic relationships with the associated Parana flood tholeites. J. of Petrology, 38 (4):495-528.

COMIN-CHIARAMONTI, P; GOMES, C.B.; CENSI, P.; DE MIN, A.; ROTOLO, S.G.; VELÁZQUEZ, V.F., 1993. Geochimica do magmatismo pós-paleozóico no Paraguai Centro-Oriental. Geochim. Brasil., 7(1): 19-34.

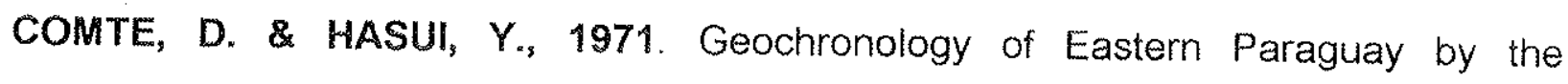
Potassium-Argon Method. Rev. Bras. Geoc., 1:33-43.

CONTICELLI, S. \& PECCERILLO, A. 1990. Petrological significance of highmpressure ultramafic xenoliths from ultrapotassic rocks of Central ltaly. Lithos, 24:305-322.

CONTINI, S.; VENTURELLI, G. \& TOSCANI, L. 1993. Cr-Zr-armalcolite-bearing lamproites of Cancarix, SE Spain. Mineralogical Magazine, 57: 203-216.

CORDANI, U.G.; NEVES, B.B.B.;FUCK, R.A.; PORTO, R.; THOMAZ-FILHO, A. \& DA CUNHA, F.M.B. 1984. Estudo preliminar de integração do Pré-Cambriano com os eventos tectônicos das bacias sedimentares brasileiras. PETROBRAS, Centro de Pesquisas e desenvolvimento, CENPES, DIVEX, 70p.

COSTA V.S. 1996. Estudos mieralógicos e químicos do kimberlito Batobi 6 (MT) em compacação com as intrusões Três Ranchos 4 (GO) e Limeira (MG). Campinas, $112 p$. Diss. de Mestrado, 1.G. Universidade Estadual de Campinas. 
CUADRICULA 41-CORONEL OVIEDO, 1966. Plan de prospección Geológica y Mineral. Direc. Rec. Min. M.O.P.C. Asunción.

CUNDARI, A. COMIN-CHIARAMONTI, P. 1996. Mineral chemistry of alkaline rocks from the Asunción-Sapucai graben (Central-Eastern Paraguay. In: COMINCHIARAMONTI \& GOMES (eds). Alkaline Magmatism In Central Eastern Paraguay. Relationships with coeval magmatism in Brasil. p. 181-193.

DALLA SALDA, Ln; BOSSI, J. \& CINGOLANI, C. 1988. The Rio de La Plata cratonic region of Southwestern Gondwanaland. Episodes, 11 (4): 263-269.

DANIELS, L.R.M. \& GURNEY, J.J. 1989. The chemistry of the garnets, chromites and diamond inclusions from the Dokolwayo kimberlite, Kingdom of Swaziland. Spec.Publ.Geol.Soc.Austr., 14: 1012-1021

DANNI, J.C.M. \& GASPAR, J.C. 1994. Química do katungito de Amorinópolis -Goias contribuição ao estudo do magmatismo kamafugítico. Geochim Brasil., 8 (2): 119-134.

DANNI, J.C.M.; GASPAR, J.C. \& GONZAGA, G.M. 1991. The Fazenda Alagoinha intrution, Três Ranchos, Goias. In: FITH INTER. KIMB. CONF.: Field Guide Book. 31-35.

DAWSON, J.B. \& SNITH, J.V. 1975. Chromita-silicate intergrowths in upper-mantle peridotites. Physics and Chem. Of the Earth, 9: 339-350.

DAWSON, J.B. 1980. Kimberlites and their xenoliths. Springer-Verlag, Berlin, 52pp.

DE MIN, A. 1993. II magmatismo Mesozoico K-alcalino del Paraguai Orientale: aspetti petrogenetici ed implicazioni geodinamiche. Trieste, 242p. Tese de Doutoramento, Univ. egli Studi di Trieste, Fac. di Scie. Mat., Fid. e Nat.

DEER, W.A.; HOWIE, R.A. \& ZUSSMAN, J. 1966. An Introduction to the RockForming Minerals ( $2^{\circ}$ ed., 1992). Logman Scientific \& Technical, 696p.

DEGRAFF \&., 1985. Late mesozoic Crustal Extension and Rifting on the Western Edge of the Paraná basin, Paraguay. Geol. Soc. Amer. Abstr.

DEMARCHI, G.; COMIMHIARAMONTI, P; DE VITO, P.; SINIGOI, S. \& CASTILLO C.A.M. 1988. Lherzolite-dunite xenoliths from Eastern Paraguay: petrological constraints to mantle metasomatism. In: PICCIRILLO \& MELFI (eds) The 
Mesozoic flood volcanism of the Paraná basin, petrogenetic and geophysical aspects., Univ. São Paulo, Inst. Astr. e Geof. 207-227.

DOROSHEV, A.M:; BREY, G.P.; GIRNIS, A.V.; TURKIN, A.I. \& KOGARKO, L.N. 1997. Pyrope-knorringite garnets in the earth's mantle: experiments in the MgO$\mathrm{Al}_{2} \mathrm{O}_{3}-\mathrm{SiO}_{2}-\mathrm{Cr}_{2} \mathrm{O}_{3}$ system. Russian Geology and Geophysics, 38 (2): 559-586.

DRUEKER, M.D. \& GAY, S.P. 1987. Mafic Dyke Swarms Associated with Mesozoic Rifting in Eastern Paraguay, South America. In: HALL \& FAHRIG (eds.), Mafic Dyke Swarms. Geol. Ass. of Can. Spec. Paper, 34: 187-193.

DUCHKOV, A.D. \& SOKOLOVA, L.S. 1997. Thermal structure of the lithosphere of the Siberian platform. Russ. Geol. and Geophysics, 38 (2): 528-537.

DUGGAN, M.B. \& JAQUES, A.L. 1996. Mineralogy and geochemistry of Proterozoic shoshonitic lamprophyres from the Tennant Creek Inlier, Northern Territory. Asutralian J. of E. Sciences, 43: 269-278.

DYMEK, R.F. 1983. Titanium, aluminum and interlayer cation substitions in biotite from high grade gneisses, West Greenland. American Mineralogist, 68: 880899.

EBY, N.G. \& MARIANO, A.N. 1986. Geology and geochronology of carbonatites periferal to the Paraná Basin, Brazil-Paraguay. Carbonatites Symposium, Otawa, 13p.

ECHEVESTE, H.; RIBOT, A.; TEXEIRA, W.; FERNÁNDEZ, R.; GIRARDI, V.A.V.; PICCIRILLO, E.M.; BELLIENI, G. \& JACUMIN, 1997. Preliminary Rb/Sr geochronology of calc-alkaline dykes from the Tandilia system, Buenos Aires Province, Argentina. In: South-Amer. Simp. on Isot. Geol., Extend. Abstr., 107. 109. Brazil.

ECKEL, E.B., 1959. Geology and Mineral Resources of Paraguay. A Reconnaissance. U.S. Geol. Sur. Prof. Pap., 32\%, 110p.

ERLANK, A.J; WATERS, F.G; HAWKESWORTH; C.J; HAGGERTY, S.E; ALLSOPP, H.L.; RICKARD, R.S. \& MENZIES, M. 1987. Evidence for Mantle Metasomatism mi Peridotite Nodules from The Kimberley Pipes, South Africa. In: MENZIES \& HAWKESWORTH (eds.) Mantle Metasomatism. p 221-311. 
FABRIÈS, J. 1979. Spinel-olivine geothermometry in peridotites from ultramafic complexes. Contrib. Mineral. Petrol., 69: 329-336.

FELDSTEIN,SH.N.; LANGE, R.A.; VENNEMANN, T \& O'NEIL, J.R. 1996. Ferricferrous ratios, $\mathrm{H}_{2} \mathrm{O}$ contents and $\mathrm{D} / \mathrm{H}$ ratios of phogopite and biotite from lavas of different tectonic regimes. Contrib. Mineral. Petrol., 126:51-66.

FIELDING, D.C. \& JAQUES, A.L. 1989. Geology, petrology and geochemistry of the Bow Hill lamprophyre dikes, Western Australia. Geol.Soc.Australia Special Publication., 14(1): 206-219.

FINGER, L. W. 1972. The uncertainty of the calculated ferric iron content of a microprobe analysis. Carmeg. Inst. Wash. Year Book, 71: 600-603.

FINNERTY, A.A. \& BOY, F.R. $198 \%$ Thermobarometry for garnet peridotites: basis for the determination of thermal and compositional structure of the upper mantle. In: NIXON (ed.) Mantle Xenoliths, John Wiley \& Sons Ltd., 381-412.

FINNERTY, A.A. 1989. Xenolith-derived mantle geotherms: whiter the inflection. Contrib. Mineral. Petrol, 102: 367-375.

FIPKE, C.E., 1991. Significance of the chromite, G5 Mg-Almandine garnet, Zircon and Tourmaline in heavy mineral Detection of diamond Bearing lamproite. In: FITH INTER. KIMB. CONF. Extend. Abstr. CPRM Spec. Publ., 2/91. Brasilia.

FIPKE, C.E. 1994. Significance of the chromite, ilmenite, G-5 Mg-almandine garnet, zircon and tourmaline in heavy mineral detection of diamond bearing lamproite. In: MEYER \& LEONARDOS (eds.) Diamonds: Characterization, Genesis and Exploration. CPRM Special Publications, I/B Jan/94: 366-381.

FIPKE, C.E:; DUMMETT, H.T.; MOORE, R.O; CARLSON, J.A.; ASHLEY, R.M. \& GURNEY, \. 1995. History of the discovery of diamondiferous kimberlites in the Northwest Territories, Canada.In: SIXTH INTER. KIMB. CONF. Extended Abstracts, Russia. Vol I: $158-160$.

FOLEY, S.F. 1985. The oxidation state of lamproitic magmas. Tschermak Min. Petr. Mitt., 34: $217-238$.

FOLEY, S.F. 1989. The genesis of lamproitic magmas in a reduced fluorine-rich mantle. Geol. Soc. Australia Special Publication, 14(1):616-631. 
FOLEY, S.F. 1992 Petrological characterization of the source components of potassic magmas: geochemical and experimental constraints. Lithos, 28: 187-204.

FOLEY, S.F.; VENTURELLI, G.; GREEN, D.H.; TOSCANINI, L., 1987. The ultrapotassic rocks: Characteristics, classification and constrains for petrogenetic models. Earth Sci. Rev., 24: 81-134.

FORBES, W.C. \& FLOWER, M.J.F. 1974. Phase relations of titan-phlogopite, K2 $\mathrm{Mg}_{4} \mathrm{TiAl}_{2} \mathrm{Si}_{6} \mathrm{O}_{2} \mathrm{O}(\mathrm{OH})_{4}$ : a refractory phase in the upper mantle. Earth. Planet. Sci. Lett., 22: 60-66.

FRAGOSO CESAR, A.R.S. \& MACHADO, R., 1997. Neoproterozoic terranes of the Gaucho shield (Southern Brazil and Uruguay). In: South-Amer. Simp. on Isot. Geol., Extend. Abstr., 65-67. Brazil.

FRAGOSO-CESAR, A.R.S.F. SOLIANI, E. 1984. Compartimentaçăo tectônica do cráton Rio de La Plata. Anais XXXIII Cogr. Brasil. Geol. Rio de Janeiro, Brasil, 5: $2426-2434$.

FÚLFARO, V.J. 1996. Geology of Eastern Paraguay. In: COMIN-CHIARAMONTI \& GOMES (eds). Alkaline Magmatism in Central Eastern Paraguay. Relationships with coeval magmatism in Brasil. p. 17-29.

GANGULY, J. BHATTACHARYA, P.K. 1987 Xenoliths in Proterozoic kimberlites from southern India: petrology and geophysical implications. In: NIXON (ed.) Mantle Xenoliths, p. $431-454$.

GARDA, G.M. 1995 Os diques básicos e ultrabásicos da região costeira entre as cidades de São Sebastião e Ubatuba, estado de São Paulo. São Paulo, 156p. Tese de Doutoramento, IGc-USP.

GARDA, G.M. 1996. Os piroxênios dos diques máficos e ultramáficos do litoral entre São Sebastião e Ubatuba, SP. Geochim. Brasil., 10 (2): 297-323.

GASPAR, J.C. \& WMLLIE, P.J. 1983. IImenite (hing Mg Mn Nb) in the carbonatites from the Jacupiranga complex, Brazil. Am. Mineral., 38: 960-971.

GIAMPAOLO,C; GODANO, R.F. DI SABATINO, B. \& BARRESE, E. 1997. The alteration of leucite-bearing rocks: a possible mechanism. Eur. J. Mineral., 9: $1277-1291$. 
GIBSON, S.A.; THOMPSON, R.N.; LEONARDOS, O.H.; DICKIN, A.P.; MITCHELL, J.G., 1995. The late cretaceous impact of the Trindade mantle plume: Evidence from large-volume, malic potassic magmatism in SE Brasil, J. Petrol., 36: 189229.

GOGINENI, S.V.; MELTON, C.E. \& GIARDINI, A.A. 1978. Some petrological aspects of the prairie Creek diamond-bearing kimberlite diatreme, Arkansas. Contrib. Mineral. Petrol, 66: 251-261.

GOMES, C.B.; COMIN-CHIARAMONTI, P; VELÁZQUEZ, V.F. \& ORUÉ, D. 1996. Akaline magmatism in Paraguay: a review. In: COMIN-CHIARAMONTI \& GOMES (eds). Akaline Magmatism In Central Eastern Paraguay. Relationships with coeval magmatism in Brasil. p. 31-56.

GRAND, S.P. 1987. Tomographic inversion for shear velocity beneath the North American plate. J. Geophys. Res, 92: 14065-14090.

GRIFFI, W.L. : RYAN, C.O. 1995. Trace elements in indicator minerals: area selection and target evaluation in diamond exploration. J. of Geochemical Exploration, 53: $311-337$.

GRIFFIN, W.L.; O'REILLY, S.Y.;RYAN, C.G. \& WALDMAN. M.A. 1994. Indicador minerals from Prairie Creek and Twin Knobs lamproites: relation to diamond grade.In: MEYER \& LEONARDOS (eds.), Diamonds: characterization, genesis and exploration, Spec. Publ., J/B Jan 94 Brasilia: 302-318

GRIFFIN, W.L.; RYAN, C.G.; GURNEY, J.J.; SOBOLEV, N.V. \& WIN, T.T. 1994 Chromite macrocrysts in kimberlites and lamproites: gechemistry and origin. In: MEYER \& LEONARDOS (eds.), Kimberlites, Related Rocks and mantle Xenoliths, Spec Publ., J/B Jan 94 Brasilia: 366-377.

GRIFFIN, W.Ln; RYAN, C.C.; ORELLLY, S.Y. \& GURNEY, J.J. 1995. Lithosphere evolution beneath the Kaapvaal craton: 200-80 Ma. In: SIXTH INTER. KIMB. CONF. Extended Abstracts, Russia, Vol II: 203-204.

GRIFFIN, W.L.; SOBOLEV, N.V.; RYAN, C.G; POKHLENKO, N.P.; WIN, T.T.\& YEFIMOVA, E.S. 1993 . Trace elements in garnets and chromites: Diamond formation in the Siberian lithosphere. Lithos, 29:235-256. 
GUIMARÃES, G.B. 1995. Ocomplexo granitico Cunhaporanga na região de Joaquim Murtinho, Pirai do Sul (Pr): Caraterização Faciológica das rochas granitoides Diss. Mestrado. 1Golusp $144 p$.

GUPTA, A.K. \& YAGl, K. 1980. Petrology and genesis of leucitembearing rocks. Springer-Verlag, Berlin, $252 p$.

GURNEY, J.J. ZWEISTRA, P. 1995. The interpretation of the major element compositions of the mantle minerals in diamond exploration. J. of Geoche. Exploration, 53: 293-309.

HAGGERTY, $S .1973$. Spinels of unique compositions associated with ilmenite reactions in the Liqhobong kimbertite pipe, Lesotho. In: NIXON (ed), Lesotho Kimberlites. Cape \& Transvaal Printers Lid., p. 149-158.

HAGGERTY, S.E. 1975 The chemistry and genesis of the opaque minerals in kimberlites. Physics and Chem. Of the Earth, 9: 295-307.

HAGGERT, S.E. 1976. Opaque mineral oxides in terrestrial igneous rocks. In: RUMBLE (ed.) 1976. Oxide minerals. Mineralogycal Society of America, short Course Notes, $3: 101-300$.

HAGGERTY, S.E. 1990. Redox state of the continental lithosphere. In: MENZIES (ed.) Continental mantle, . Oxf. Mion. on Geol. and Geoph., n' 16: 87-109.

HAGGERTY, S.E. 1991. Oxide mineralogy of the upper mantle. In: LINDSLEY (ed.) 1991. Oxide Minerals: Petrologic and magnetic significance. Mineralogical Society of America, Reviews in Mineralogy, 25: 129-218.

HAGGERTY, S.E. 1994. Upper mantle mineralogy. International Symposium on the physics and chemistry of the Upper Mantle (ISUM). Invited lectures. São Paulo, CPRM/FAPESP. p. 33 82.

HALL, A. 1982. The Pendennis peralkaline minette. Mineral. Magazine., 45: 257-266.

HALL. A.E. SMITH, C.B. 1985. Lamproite diamonds - are they different?.Pubs. Geol. Dep. \& Extension, Univ. West. Aust, 8: 167-212.

HALLINAN, S.E"; MANTOVAN, M.S.M.; SHUKOWSKY, W. \& BRAGGION, I. JT1993. Estrutura do Escudo Sul-Brasileiro: uma revição através de dados gravimétricos e magnetométricos. Rev. Brasil. Geoc., 23 (3): 201-214. 
HAMILTON, R. \& ROCK, N.M.S. 1990. Geochemistry, mineralogy and petrology of a new find of ultramafic lamprophyres from Bulljah Pool, Yilgarn craton, Western Australia. Lithos, 24: 275-290.

HAMZA, V.M. 1997. Were there moving "plumelets" in the South Brazilian Continental lithosphere?. In: Anais do 5, CONGR. INTER. SOC. BRASIL. GEOF., São Paulo. 911-913.

HAMZA, V.M.\& MUÑOS, M. 1996. Heat flow map of South America. Geothermics, 25: $599-646$.

HARARA, O.M.; BASEI, M.A.S. \& SIGA JÚNIOR, O., 1997. Geochronological and geochemical date on the transition zone between Luis Alves and Atuba Complexes, south Brazil. In: South-Amer. Simp. on Isot. Geol., Extend. Abstr., 134-136. Brazil.

HARRIS, J.W.; DUNCAN, D.J.; ZHANG F.; MIA, Q. \& ZHU Y 1994. The physical characteristics and syngenetic inclusion geochemistry of diamonds from pipe 50 , Liaoming Province, People's Republic of China. In: MEYER \& LEONARDOS (eds.) Diamonds: Characterization, Genesis and Exploration. CPRM Special Publications 1/B Jan/94: 106-117.

HELMSTAEDT, H.H \& GURNEY, J.J. 1995. Geotectonic controls of primary diamond deposits: implications for area selection. J. of Geochemical Exploration, 53: 125144.

HENDERSON, C.M. \& FOLAND, K.A. 1996. Ba- and Ti- rich primary biotite from the Brome alkaline igneous complex, Monteregian Hills, Quebec: mechanisms of substitution. Cand. Mineral., 34: 1241-1252.

HERBST, R. 1975. Helechos Pérmicos del Paraguay. In: Actas I Congr. Arg. Paleont. y Bioest., Tucumán, Argentina, 1: 420-438.

HOGARTH, D. 1997. Mineralogy of leucite-bearing dykes from Napoleon Bay, Baffin Island: Multistage Proterozoic lamproites. Can. Mineral., 35: 53-78.

JAMES, D.; ASSUMPÇÃO, M.; SNOKE, A.; RIBOTTA, L.C. \& KUEHNEL, R. 1993. Seismic studies of continental lithosphere beneath Brazil. An. Acad. bras. Ci., 65 (2): $227-250$. 
JAMES, D.E.; ASSUMPÇÃO, M; SNOKE; J.A.; RIBOTTA, L.C. \& KUEHNEL, R. 1993. Seismic studies of continental lithosphere beneath SE Brazil. An. Acad. Bras. Ci., 65 (2): $227-250$.

JANSE, A.J.A. 1985. Kimberlites -where and wen. In: GLOVER \& HARRIS (eds), Kimberlite occurrence and origin: Geol. Dep. and Univ. Ext., University of Western Australia Publication, 8:.19-61

JANSE, A.J.A. 1994 Reviw of supposedly non-kimberlitic and non-lamproitic diamond host rocks. In: MEYER \& LEONARDOS (eds.) Diamonds: Characterization, Genesis and Exploration. CPRM Special Publications 1/B Jan/94: 144m159.

JANSE, A.J.A. 1994. Is Cliffird's Rule still valid? Affirmative examples from around the World. In: Diamonds: Characterization, Genesis and Exploration. MEYER \& LEONARDOS (eds.). CPRM Special Publications, 1/B Jan/94: 215-235.

JAQUES, A.L." HAGGERTY, S.E, LUCAS, H. BOXER, G.L. 1989. Mineralogy and petrology of the Argyle (AK1) lamproite pipe, Western Australia. Spec.Publ.Geol.Soc.Austr., 14: 153-169.

JAQUES, A.L.; HALL, A.E.; SHERATON, J.; SMITH, C.B. \& ROKSANDIC, Z. 1994. Peridotitic planar octahedral diamonds from the Ellendale lamproites pipes, estern Australia. in: Diamonds: MEYER \& LEONARDO (eds.). Characterization, Genesis and Exploration CPRM Special Publications 1/B Jan/94: 69-77.

JAQUES, A.L.; KERR, ID: LUCAS H; SUN, S-S \& CHAPPELL, B.W. 1989. Mineralogy and petrology of picritic monchiquites from Wandagee, Carvon Basin, Western Australia. Spec.Publ.Geol.Soc.Austr., 14:.120-139.

JAQUES, A.L: LEWIS, I.D.; OREGORY, G.P; FERGUSON, J.; SMTH, C.B.; CHAPPELL, B.W: MCCULLOCH, M.T.; 1984. The diamond-bearing ultrpotassic (lamproitic) rocks of the West Kimberley region, Western Australia. In KORNPROBST (ed.) Procedings of the Third International Kimberlite Conference. Vol. 1 Kimberlites I: Kimberlites and Related Rocks, p 225-254.

JAQUES, A. ONE ONLL, H.St.C. SMITH, C.B.; MOON, J. \& CHAPPELL B.W. 1990. Diamondiferous peridotite xenoliths from the Argyle (AK1) lamproite pipe, Western Australia. Contrib. Mineral. Petrol., 104: 255-276. 
JENNINGS, C.M.H. 1995. The exploration contex for diamonds. J. of Geochemical Exploration, 53: 113-124.

JORDAN, T.H. 1975. The continental tectosphere. Rev. Geophys. Space Phy., 13: 1m 12.

KAMINSKY, F.V.; FELDMAN, A.A.; VARLAMOV, V.A.; BOYKO, A.N.; OLOFINSKY, L.N.; SHOFMAN, I.L. \& VAGANOV, V.I. 1995. Prognostication of primary diamond deposits. J. of Geochemical Exploration, 53: 167-182.

KANZLER, A. 1987. The southern Precambrian in Paraguay - Geological inventory and age relations. Zbl.Geol. Palaont., Teil I, 7/8: 753-765.

KAUL, P.F.T. 1980. O cráton de Luiz Alves. An. XXXI Congr. Brasil. Geol, Camboriú, Brasil, 5: 2677-2683.

KENNEDY, C.S. \& KENNEDY G.C. 1976. The Equilibrium Boundary Between graphite and diamond. J. Geophys. Res., 81: 2467-2470.

KUEHNER, S.M."EDGAR, A.D. ARIMA, M. 1981. Petrogenesis of the ultrapotassic rocks from the Leucite Hills, Wyoming. American Mineralogist., 66: 663-677.

LE MAITRE, R.W. 1989. Classification of igneous rocks and glossary of terms. Oxford, Blackwell, 193p.

LEAKE, B.E. 1978. Nomenclature of amphiboles. Can. Mineral., 16: 501-520.

LEAKE, B.E.; WOOLLEY, A.R.; ARPS, C.E.S.; BIRCH, W.D.; GILBERT, M.C. GRICE, J.D; HAWTHORNE, F.C.; KATO, A; KICH, H.J.; KRIVOVICHEV, V.G.; LINTHOUT, K; $K_{*}$ LIRD, $J_{z}$; MANDARINO, J. MARESCH, W.V.; NICKEL, E.H; ROCK, N.M.S.; SHUMACHER, J.C.; SMITH, D.C.; STEPHESON, N.C.N.; UNGARETTI, L.; WHITTAKER, E.J.W. \& YOUZHI, G. 1997. Nomenclature of amphiboles. Report of the Subcommittee on Amphiboles of the International Mineralogical Association Commission on New Minerals and Minerals Names. Eur. J. Mineral, 9:623-651.

LETERRIER, J.; YUWONO, Y.S.; SOERIA-ATMADJA, R. \& MAURY, R.C. 1990. Potassic volcanism in Central Java and South Sulawesi, Indonesia. Journal of $S$. Asian E. Sciences, 4(3): 171-187.

LINTHOUT, K. \&USTENHOUWER, W.J. 1993. Ferrian high sanidine from Cancarix, Spain. Mineralogical Magazine, 57: 289-299. 
LIVIERES, R. A. G. \& QUADE, H.; 1987. Distribuición Regional y asentamiento Tectónico de los Complejos Alcalinos del Paraguay. Zbl. Geol. Palaont., Teil I 7/8: 791-805.

LIVIERES, R. A. G. 1987. Der Karbonatit-Komplex von Chiriguelo, Nordost Paraguay Clausthal, 191 p. Tese de Doutorado, Diss. H28.

LUCAS, H; MUGGERIDGE, M.T. \& MCCONCHIE, D.M. 1989. Iron in kimberitic ilmenites and chromian spinels: a survey of analytical techniques. Spec.Publ.Geol.Soc.Austr., 14(1): 312-320.

MANSKER, W.L.; EWING, R.C. \& KEIL, K. 1979. Barian-fitanian biotites in nephelinites from Oahu, Hawaii. Am. Mineral., 64: 156-159.

MANTOVANI, M.S.M.; HAWKESWORTH, C.J. \& BASEI M.A.S., 1987. Nd and Pb isotope studies bearing on the crustal evolution of southeastern Brazil. Rev. Brasil. Geociênc., 17: 263-268.

MANTOVANI, M.S.M.; VASCONCELLOS, A.C.B.C.; SHUKOWSKY, W. 1991. Global Geoscience Transect 4: Brusque Transect from Atlantic Coast to Bolivian Border, Southern Brazil. Washington, AGU, p. 1-20. (Spec. Publ.).

MARIANO, A.N. 1978. Report on alkaline rocks. Exploration in sputhern Paraguay and Supplement on exploration in the area of Pedro Juan Caballero. T.A.C. (relatorio interno), Asunción, 134p.

MARQUES, A.; ZAOTTO, O.A.; FRANĢA, A.B.; ASTOLFI, M.A.M. \& PAULA, O.B. 1993. Compartimentação tectônica da Bacia do Paraná. Curitiba: PETROBRAS/NEXPAR, $87 \mathrm{p}$.

MENZIES, M.; ROGERS, N.; TINDLE, A. \& MAWKESWORTH, CH. 1987. Metasomatic and enrichment processes in lithospheric peridotites, an effect of asthenosphere-lithosphere interaction. In MENZIES \& HAWKESWORTH (eds.) Mantle Metasomatism. p. 313-361.

MEYER, O.H.O.A.; ZHANG ANDI; MLLEDGE; H.J. MENDELSSOHN, M.J. 1994. Diamonds and mineral inclusions in diamonds from Shandong and Liaoning Provinces, China. In: MEYER \& LEONARDOS (eds.) Diamonds: Characterization, Genesis and Exploration. CPRM Special Publications 1/B Jan/94: 98-107. 
MIDDLEMOST, E.A.K.; DALIM K.P. \& FLETCHER, I.R. 1988. Geochemistry and mineralogy of minette-lamproite association from the Indian Gondwanas. Lithos, 22: $31-42$.

MILANI, E.D.s 1997. Evolução tecto-estratigráfica da Bacia do Paraná e seu elacionamento com a geodinámica Fanerozóica do Gondwana Sul-Ocidental. Porto Alegre, Vol l: 255 p. (Texto) e II (llustrações).Tese de Doutoramento UFRGS.

MITCHELL, R.N.; 1985. A review of mineralogy of Lamproites. Trans. Geol. Soc. S. Africa, 88: 411-437.

MITCHELL, R.N. 1986. Kimberlites: Mineralogy, geochemistry and petrology. Plenum Press, 442p.

MITCHELL, R.N. 1995. Kimberlites, orangeites, and related rocks. Plenum Press, $410 p$.

MITCHELL, R.N. 1995. The role of petrography and lithogeochemistry in exploration for diamondiferous rocks. Journal of Geoch. Explor., 53: 339-350.

MITCHEL, R.N.; PLATT, R.G. \& DOWNEY, M. 1987. Petrology of lamproites from Smoky Butte, Montana. J. Petrol., 28: 645-677.

MITCHEL, R.N. \& BERGMAN, S.C. 1991. Petrology of lamproites. Plenum press, New York. 447p.

MORGAN, P. 1995. Diamond exploration from the bottom up: regional geophysical signatures of lithosphere conditions favorable for diamond exploration. J. of Geochemical Exploration, 53: 145-165.

MORIMOTO, N. 1988. Nomenclature of pyroxenes. Amer. Mineral., 73: 1123-1133.

MORRISON, G.W. 1980. Characteristics and tectonic setting of the shoshonite rocks association. Lithos, 13: 97-108.

MULLER, D., MORRIS, B.J. \& FARRAND, M.G. 1993. Potassic alkaline lamprophyres with affinities to lamproites from the karinya syncline, Sourh Australia. Lithos, 30: 123-137.

NICKEL, K.G. GREEN, D.H. 1985 Empirical geothermobarometry for garnet peridotites and implicationas for the nature os the lithosphere, kimberlites and diamonds. Earth and Planet. Scien. Letters, 73:158-170. 
NIXON, P.H. 1973. Lesotho Kimberlites.Cape \& Transvaal Printers Ltd.350 p.

NIXON, P.H. 1987. Mantle xenoliths. Wiley, New York, 844pp.

NIXON, $P$ BOYD, R. 1975. Origins of ultramafic nodules from some kimberlites of Northern Lesoto and the Monastery Mine, South Africa. Phy. and Chem. of the Earth, 9: 431-454.

NIXON, P. BOYD, F.R. 1973. Petrogenesis of the granular and sheared ultrabasis nodules suite in kimberlite. In: NIXON (ed), Lesotho Kimberlites.Cape \& Transvaal Printers Ltd., 48-56.

O'NEILL, H.St. \& WALL, V.J. 1987. The olivine-orthopiroxenempinel oxygen barometers, the nickel precipitation in curve, and the oxygen fugacity of the Eanth's upper mantle. J. of Petrology, 28: 1169-1191.

ORUÉ, D. 1996. Síntese da geologia do Paraguai Oriental, com ênfase para o magmatismo alcalino associado. São Paulo, 163p. Diss. de Mestrado. 1Gc, USP.

PALMIER J.H. ARRIBAS, A 1975 . El Complejo Alkalino Potásico de Sapukai (ParaguaimOriental). In: Cogr. Lat. Amer. de Geol. Econ., 5to., Buenos Aires, Vol NV: $267-300$.

PECCERILLO, A. 1992. Potassic and ultrapotassic rocks: compositional characteristics, petrogenesis, and geologic significance. Episodes, 15 (4): 243250.

PECCERILLO, A. 1995. Mafic calcalkatine to ultrapotassic magmas in CentralSouthern ltaly: Constrains on evolutionary processes and inplications for source compositions and conditions of magma generation. An. Acad. bras. Ci., 67 (2): $171-189$.

PECCERILLO, A. \& MANETTI, P. 1985. The potassic alkaline volcanism of central southern ltaly; a review of the data relevant to petrogenesis and geodynamic significance. Trans. Geol. Soc. S. Africa, 88: 379-394.

POKHLENKO, N.P.; SOBOLEV, N.V. LAVRENTEV, Y.G. 1977. Xenoliths of diamondiferous uttramafic rocks from Yakutian kimberlites. In: SEC. INTERN. KIMB.CONF. Ext. Abst. Santa Fe, New Mexico. 
PRESSER, J.L.B., 1991. Characterization of lamproites from Paraguay (South America). In: FITH INTER. KIMB. CONF. Extend. Abstr. CPRM Spec. Publ. 2/91. Brasilia.

PRESSER, J.L.B.; 1992. Geologia da Folha 5569-III La Colmena, Paraguai Oriental. São Paulo, 205p. Diss. de Mestrado, IG-USP.

PRESSER, J.L.B.; 199A. Leucita e Olivina-Lamproitos do Vale de Acahay (Rift de Asunción)(Paraguai-Oriental): Dados Gerais. Anais da Acad. brasil. de Ciências, 66/2.

PRESSER, J.L.B., 1994. Characterization of lamproites from Paraguay (South America). In: MEYER \& LEONARDOS (eds.), Kimberlites, Related Rocks and mantle Xenoliths, Spec. Publ. J/B Jan 94 (1): 211-217.

PRESSER, J.L.B. s 1996. Feições Minerais Nos Lamproitos Mesozóicos do Rift Valley de Acahay (Paraguai): Inclusōes de Cromita em Olivinas. In: $2^{\circ}$ Simp. da Pósgraduação, São Paulo, Instituto de Geociências, USP. Boletim de Resumos.

PRESSER, J.L.B. 1996. Magnésio em cromitas: novo geotremômetro. Anais da Acad. brasil de Ciências (no prelo).

PRESSER, J.L.B. \& BITSCHENE, P.R., 1990. The Guairá-Paraguari Alkaline Province (GPAP Eastern Paraguay): Geochemical Constrains on Mesozoic Krich Intracontinental Rocks. In: $1^{\circ}$ Coloquio de Rocas Magmáticas de Paraguay, San Lorenso, Dep. Geol. Fac. Ciencias Nat. \& Exactas. Resumos.

PRESSER, J.L.B. \& DA SILVA, A.J.C. 1997. Termômetro do Mg em espinélios cromíferos. II SIMP. BRASIL. GEOL. DIAM. Programa, resumos, palestras e roteiro de excursão. UFMT - Publ. Especial 03/97. Cuiabá-Brasil.

PRESSER, J.L.B. \& ULBRICH, H.G.J.H., 1994. Porção central do "rift" de Asunción, Paraguai Oriental: dados estruturais e estratigráficos. Anais da Acad. brasil. de Ciências, 66/2.

PROYECTO PAR 83/005, 1986. Mapa Geológico del Paraguay (1 mapa 1: e texto explicativo). Realização por Palmieri \& Fúlfaro, Asunción Paraguay. Gov. Rep. del Paraguay/ONU. 
PROYECTO RADAMBRASIL, 1982. Folha SF.21 Campo Grande. Levantamento de Recursos Naturais, Min. das Minas e Energia Scret. Gral., Rio de Janeiro, vol. $28,412 p$

PUTZER, $H_{s}$, 1962. Geologie von paraguay. Beitr. Reg. Geol. Erde, Bd. 2, 183p., Berlin.

QUARTIERI, S.; ANTONIOLI, G.; ARTIOLI, G. \& LOTTICI, P.P. 1993. Xames study of titanium coordination in natural diopsidic pyroxenes. Eur. J. Mineral. 5: 11011109.

QUINTAS, M.C.L. 1995. O embasamento da Bacia do Paraná: reconstrução geofísica de seu arcabouço. São Paulo, 213p Tese de Doutoramento, IAG-USP.

RAMOS, V.A. 1988. Late Proterozoic-Early Paleozoic of the South America -a collisional history. Episodes, 11 (3): 168-174.

RAMSAY, R.P. \& TOMPKINS, L.A. 1994. The geology, heavy mineral concentrate mineralogy, and diamond prospectivity of the Boa Esperança and Cana Verde pipes, corrego D'Anta, Minas Gerais, Brasil. In: MEYER \& LEONARDOS (eds.), Diamonds: Characterization, Genesis and Exploration.. CPRM Special Publications 1/B Jan/94: 329-345.

RAMSAY, R.R.; EDWARDS, D.; TAYLOR, W.R.; ROCK, N.M.S. \& GRIFFIN B.J. 1994. Compositions of garnet and espinels from the Airieas diamondiferous kimberlite pipe, central Kimberley Block, Western Australia -implications for exploration. J. of Geoch. Explor., 51: 59-78.

REID, A.M.; DONALDSON C.H.; BROWN, R.W.; RIDLEY, W.I. \& DAWSON J.B. 1975. Mineral Chemistry of Peridotite Xenoliths from the Lashaine Volcano, Tanzania. Physics and Chem. Of the Earth., 9:525-544.

ROBERT, J.L. 1976. Titanium solubility in synthetic phlogopite solid solutions. Chem Geol., 17: 213-227.

ROCK, N.M.S. 1977 The nature and origin of lamprophyres: some definitions, distinctions, and derivations. Earth Science Reviews, 13: 123-169.

ROCK, N.M.S. 1986. The nature and origin of ultramafic lamprophyres: alnöites and allied rocks. J.Petrol, 27: 155-196. 
ROCK, N.M.S. 1987. The nature and origin of lamprophyres: an overview. In: FITTON \& UPTON (eds.). Alkaline igneous rocks. Spec.Publ.Geol.Soc.Lond., 30: 191. 226.

ROCK, N.M.S. 1991. Lamprophyres. Blakie, 258p.

ROCK, N.M.S.\& GROVES, D.1. 1988. Can lamprophyres resolve the genetic controversy over mesothermal gold deposits?. Geology, 16: 538-541.

ROCK, N.M.S.; GASKARTH, J.W.; HENNEY, P.J. \& SHAND, P. 1988. Late Caledonian dyke-swarms of the Northern Britain: some preliminary petrogenetic and tectonic implications of their province-wide distribution and chemical variation. Can. Mineral., 26: 3-22.

ROCK, N.M.S.; GRIFFIN, B.J.; EDGAR, A.E.; PAUL, D.K. \& HERGT, J.M. 1992. A spectrum of potentially diamondiferous lamproites and minettes from the Jharia coalfield, eastern india. J. of Volc, and Geoth. research, 50: 55-83.

RODEN, M.F. 1981. Origin of coexisting minette and ultramafic breccia, Navajo Volcanic Field. Contrib. Mineral. Petrol., 77: 195-206.

SAHAMA, Th.G., 1974. Potassium-rich alkaline rocks. In SORENSEN (ed.), The Alkaline Rocks. Wiley, New York, p. 96-109.

SALVIOLIMARIANI,E. \& VENTURELLI, G. 1996. Temperature of crystallization and evolution of the Jumilla and Cancarix lamproites (SE Spain) as suggested by melt and solid inclusions in minerals. Eur. J. Mineral., 8: 1027-1039.

SCHOBBENHAUS, C.; CAMPOS, D.A.; DERZE, G.R. \& ASMUS, H.E. 1984. Geologia do Brasil. Texto explicativo do mapa geológico do Brasil e da area oceânica adjacente incluindo depósitos minerais. Dep. Nac. Prodç. Mineral (DNPM), Brasilia, $501 p$.

SCOTT-SMITH, B.H. \& SKINNER, E.M.W. 1984. Diamondiferous Lamproites. J Geol, 92: $433-438$

SCOTT-SMITH, B.H: SKINNER, E.MW. \& LONEY, P.E. 1989. The Kapamba lamproites of the Luangwa valley, eastern Zambia. Spec.Publ.Geol.Soc.Austr. $14(1): 189-205$. 
SHAW, C.S.J. \& PENCZAK, R.S. 1996. Barium- and Titanium-rich biotite and phlogopite from the western and eastern gabbro, Coldwell alkaline complex, Northwestern Ontario. Canadian Mineral., 34: 967-975.

SHEE, S.R*; GURNEY, J.J. \& ROBINSON, D.N. 1982. Two diamond-bearing peridotie xenoliths from the Finsch kimberlite, South Africa. Contrib. Mineral. Petrol, 81: $79-87$.

SHEIBE, L.F. 1986. Geologia e petrologia do distrito alcalino de Lages, SC. São Paulo, 244p., Tese de doutoramento, IGc - USP.

SHERATON, J.W. \& CUNDARI, A. 1980. Leucitites from Geussberg, Antarctica Contrib. Mineral. Petrol., $71: 417-427$

SIGA Jr., O.; BASEI, M.A.S.; REIS NETO, J.M.; HARARA, O.M.; PASSARELLI, C.R.; PRAZERES, H. WEBER, W. \& MACHIAVELLI, A. 1997. Ages and tectonic setting of alkaline -.peralkaline granitoids of Paraná and Santa Cataria States, southern Brazil. In: South-Amer. Simp. on Isot. Geol., Extend. Abstr., 301-303. Brazil.

SMITH, J.V. \& DAWSON, J.B. 1975. Chemistry of Ti-poor spinels, ilmenites and rutiles from peridotite and eclogite. Physics and Chem. Of the Earth., 9: 309322.

SNOKE, J.A. \& JAMES, D.E. 1997. Lithospheric structure of the Chaco and Paraná Basins of Soith America from surface-wave inversion. J. of Geophy. Research. 102 (B2): $2939-2951$

SOBOLEV, N.V; KAMINSKY, F.V.; GRIFFIN, W.L.; YEMINOVA, E.S.; WIN, T.T.; RYAN, C.G. \& BOTKUNOV, A.I. 199\%. Mineral inclusions in diamonds from the Sputnik kimberlite pipe, Yakutia. Lithos, 39: 135-157.

SOBOLEV, N.V.; POKHILENKO, N.P.; LAVRENTEV, Y.G. \& YEFIMOVA E.S. 1977. Deep-seated xenoliths, xenocrysts in kimberlites and crystalline inclusions in diamonds from "udachnaya" kimberlite pipe, Yakutia. In: In: SEC. INT. KIMB.CONF. Ext. Abst. Santa Fe, New Mexico.

SOLIANI Jr, E. 1986. Os dados geocronológicos do escudo Sul-Rio-Grandense e suas implicações de ordem geotectônica. São Paulo 396 p. Tese de Doutoramento. IGC - USP. 
SONOKI, I.K. \& GARDA, G.M. 1988. Idade K-Ar de rochas alcalinas do Brasil Meridional e Paraguai Oriental: compilação e adaptação às novas constantes de decaimento. Boletim IG-USP, Série Científica, 19: 63-85.

SOVOLEV, A.V.; SOBOLEV, N.V.; SMITH, C.B. \& DUBESSY, J. 1989. Fluid and melt compositions in lamproites and kimberlites based on the study of inclusions in olivine. Spec. Publ.Geol.Soc.Austr, $14(1): 220$-240.

STOLZ, A.J.; VARNE, R.; WHELLER, G.E;; FODEN, J.D. \& ABBOTT, M.J. 1988. The geochemistry and petrogenesis of K-rich alkaline volcanics from the Batu Tara Volcano, eastern Sunda arc. Contrib. Mineral. Petrol., 98: 374-389.

SVISERO, D.P. 1978. Composiçăo química, origem e significado geológico de inclusões minerais de diamantes do Brasil. São Paulo, 165p. Tese de LivreDocência. IG USP.

SVICERO, D.P. 1994. Distribution and origin of diamond in Brazil: an overview. In: International Symposium on the physics and chemistry of the Upper Mantle (ISUM). São Paulo, CPRM/FAPESP. p. 257-287.

T.A.C., 1981. Geologic Map of Eastern Paraguay, 1:500.000 (compilação por F. Wiens) 1 mapa (inédito), Asunción.

TASSINARI, C.C.G. 1996. O mapa geocronológico do cráton Amazônico no Brazil: Revisão dos dados isotópicos. São Paulo, 248p. Tese de Livre-Docente, 1Gc. USP.

TEXEIRA, W. 1992. Contribuição ao conhecimento geocronolígico do cráton do São Francisco: Avaliação de dados isotópicos em rochas ígneas e metamórficasImplicações na evolução crustal Pré-Cambriana. São Paulo, 172p. Tese de Livre-Docente, IGC-USP.

THY, P: STECHER, O. \& KORSTGARD, J.A. 1987. Mineral chemistry and crystallization sequences in kimberlite and lamproite dikes from the Sisimiut area, central West Greenland. Lithos, 20:391-417.

TROMPETTE, R. 1994. Geology of Western Gondwana 2.000 500 Ma. The PanAfrican Brasiliano Amalgamation of South America and Adjacent Africa. Rotterdan, Balkema. 366p. 
ULBRICH, H.H.G.J. \& PRESSER, J.L.B., 1992. The Asunción Rift, Eastern Paraguay A Preliminary Interpretation. Bol. IG-USP, Publ. Esp., 3 1-82.

VANDECAR, J.C.; JAMES, D. \& ASSUMPÇÃO, M. 1995. Seismic evidence for fossil mantle plume beneath South America and implications for plate driving forces. Nature, 378: 25-31.

VELÁZQUEZ, V.F., 1992. Província Alcalina Central, Paraguai Centro-Oriental: Aspectos Tectônicos, Petrogáficos e Geocronológicos. Säo Paulo, 189p. Diss. Mestrado IG-USP,

VELÁZQUEZ, V.F.; GOMES, C.B.; COMIN-CHIARAMONTI, P.; ERNESTO, M.; KAWASHITA, K. PETRINI, R. \& PICCIRLLLO, E.M. 1992. Magmatismo alcalino Mesozóico na porção centromoriental do Paraguai: aspectos geocronológicos. Geochim. Brasil., $6(1): 23-35$.

VELÁZQUEZ, V.F. 1996. Província alcalina Alto Paraguai: caraterísticas petrográficas, geoquímicas e geocronológicas. São Paulo, 101p. Tese de Doutoramento, IGc - USP.

VELDE, D. 1979. Trioctahedral mica in melilite-bearing eruptive rocks. Carmagie. Int. Washington Yearbk., 78: 468-475.

VENTURELLI, G.; CAPEDRI, S.; BARBIERI, M.; TOSCANI, L.; SALVIOLI MARIANI, E.\& ZERBI, W. 1991. The Jumilla lamproite revised: a petrological oddity. Eur. Journal of Mineral., 3: 123-145.

VENTURELLI, G.; CAPEDRI, S.; DI BATTISTINI, G. CRAWFORD A.; KOGARKO, L.N. CELESTINI, S. 1984. The ultrapotássic rocks from southeastern Spain. Lithos, 17: 37-54.

WADE, A. \& PRIDER, R.T., 1940. The leucite-bearing rocks of the West Kimberley area, Western Australia. Q.J.Geol. Soc. London, 96: 39-98.

WAGNER, C. \& VELEE, D. 1986. The mineralogy of k-richterite-bearing lamproites American Mineralogist, $71: 17, \cdots 37$.

WALDMAN, M.A.; MICCANDLESS, T.E. DUMMETT, H.T. 1987. Geology and petrography of the Twin Knobs 1 lamproite, Pike County, Arkansas. In MORRIS \& PASTERIS (eds) Mantle Metasomatism and Alkaline Magmatism. Geol. Soc. of America Spec. Paper, $215: 205-216$. 
WENLANDT, R.F. 1977. Barium phlogopites from Haystacks Butte, Highwood Mountains, Montana. Carmegie Inst. Washington, Year Book, 76: 534-539.

WHITE, S.H.; de BOORDER, H.\& SMITH, C.B. 1995. Structural controls of kimberlite and lamproite emplacement. J. of Geochemical Exploration, 53: 245-264.

WIENS, F. 1984. El Precámbrico Paraguayo. In: $1^{\circ} \mathrm{Simp}$. Nac de Geol. Resumen. Asunción.

WIENS, F., 1986. Zur lithostratigraphischen, petrographischen und strukturellen Entwicklung des Rio Apa-Hochlandes, Nordost Paraguay. Claustal, 280p., Tese de Doutorado Diss $\mathrm{H} 19$.

WILDING, MC.; HARTE, B; FALLICK, A.E. \& HARRIS, J.W. 1994. Inclusion chemistry, carbon isotopes and nitrogen distribution in diamonds from the Bultfontein mine, South Africa. In: MEYER \& LEONARDOS (eds.), Kimberlites, Related Rocks and mantle Xenoliths, Spec. Publ. J/B Jan 94 (2): 116-126

WINTERBURN, P.A. MARTE, B. \& GURNEY, J. 1990. Peridotite xenolith from the Jagerstontein kimberlite pipe: 1. Primary and primary-metasomatic mineralogy. Geochim. El Cosmochim. Acta, 54: 329-341.

WOOLEY, A.R.; BERGMAN, S.C.; EDGAR, A.D.; LE BAS, M.J.; MITCHELL, R.H.; ROCK, N.M.S. \& SCOTT-SMITH, B.H. 1996. Classification of the lamprophyres, lamproites, kimberlites and kalsilite-melilite- and leucite-bearing rocks. Can. Mineral., 34: 175-186.

ZHANG, A.; DEHUAM, X.; XILING, X. LIHE, G.; JIANZONG, Z. \& WUYI, W. 1994. The status and future of diamond exploration in China. In: MEYER \& LEONARDOS (eds), Diamonds: Characterization, Genesis and Exploration. CPRM Spec. Publ. 1B/93: 285-301.

ZHANG, M.; SUDDABY, P.; THOMPSON, R.N. \& DUNGAN, M.A. 1993. Bariantitanian phlogopite from potassic lavas in northeast China: chemistry, substitutions and paragenesis. Am. Mineral., 78: 1056-1065. 


\section{Apêndice \\ Análises quúmicas dos minerais}

FEICÕES MINERALÓGICAS DE ROCHAS LAMPROFÍRICAS MESOZÓICAS

DA PROVÍNCIA ALCALINA CENTRAL, PARAGUAI ORIENTAL

Jaime Leonardo Báez Presser

(TESE DE DOUTORAMENTO)

1998 


\section{A1}

Composição química, em porcentagem em peso, de olivinas de rochas "lamprofíricas" do Paraguai.

\section{"Lamprófiros"}

Ymi 1 (pipe) $(10.000-10.040,10 \mathrm{c} .001-10 \mathrm{c} .006)$, sendo que $1-\mathrm{p} 1=$ plug $1 ; 1 \mathrm{p} 2=$ plug 2; $\mathrm{d}=$ dique, Kirito $=$ dique $10 \mathrm{c} .000$,

Ymi-"7 (dique) (17.001-17.006),

Yzu-1 (dique) $(20.000,21.001-21.008 \mathrm{a} / \mathrm{b})$.

\section{"Lamproítos"}

Ymi-5 (p/ug) (45.000 e 15.001),

Yzu-2 (dique) (22.000-22.006),

Yzu-3 (intrusão) (23.000-23.002a/b). 


\begin{tabular}{|c|c|c|c|c|c|c|c|c|c|}
\hline $\begin{array}{l}\text { Sampopic } \\
\text { Analysis }\end{array}$ & $10.006 a$ & 10.0060 & 10.0098 & $10,009 \mathrm{~s}$ & $10.010 \mathrm{a}$ & 10.0106 & 10.0112 & $10.011 \mathrm{~b}$ & $10,012 a$ \\
\hline Location & $\mathrm{YMa}-1 \cdot \mathrm{pl}$ & YMII-k-pl & $\mathrm{YML}[-1-\mathrm{pl}$ & YMI-1-p? & YMit-pl & $\mathrm{YM} / \mathrm{A}-\mathrm{pl}$ & $Y \mathrm{MA}-1-\mathrm{pl}$ & YMal-1-p1 & YMA-1-pl \\
\hline Mineral & Olv & Olv & Olr & Olv & Olv & Olv & Ofv & $\mathrm{OH}$ & Oly \\
\hline $\mathrm{SiO} 2$ & 41.42 & 41.09 & 38.39 & 38.96 & 41.39 & 41.29 & 41.34 & & 41.20 \\
\hline $\mathrm{TOO} 2$ & 0.00 & 0.00 & 0.02 & 0.08 & 0,0 & 0.05 & 0.03 & 0.09 & 0.03 \\
\hline $\mathrm{Al} 2 \mathrm{O}_{3}$ & 0.04 & 0.06 & 0.06 & 0.09 & 0.00 & 0.14 & 0.14 & $0.1 !$ & $\begin{array}{l}0.03 \\
0.08\end{array}$ \\
\hline $\mathrm{Fe} 203$ & 0.00 & 0.00 & 0.00 & 0.00 & 0.00 & 0.00 & 0.00 & $\begin{array}{l}0.1 ! \\
0.00\end{array}$ & $\begin{array}{l}.08 \\
0.00\end{array}$ \\
\hline Feo & 9.14 & 13.56 & 22.12 & 21.38 & 8.25 & 8.80 & 8.76 & 11.09 & 8.60 \\
\hline MnO & 0.08 & 0.13 & 0.44 & 0.48 & 0.18 & 0.15 & 0.09 & 0.09 & 0.18 \\
\hline $\mathrm{MgO}$ & 51.07 & 47.00 & 40.07 & 40.36 & 49.59 & 48.97 & 49.10 & 47.97 & 49.28 \\
\hline $\mathrm{CaO}$ & 0.16 & 0.26 & 0.33 & 0.28 & 0.11 & 0.14 & 0.16 & 0.19 & 0.14 \\
\hline $\mathrm{N}_{2} 2 \mathrm{O}$ & 0.00 & 0.00 & 0.00 & 0.00 & 0.00 & 0.00 & 0.00 & 0.00 & 0.00 \\
\hline $\mathrm{k} 20$ & 0.00 & 0.00 & 0.00 & 0.00 & 0.00 & 0.00 & 0.00 & 0.00 & 0.00 \\
\hline $\mathrm{NiO}$ & 0.35 & 0.24 & 0.01 & 0.04 & 0.32 & 0.37 & 0.26 & 0.18 & 0.41 \\
\hline Total & 102.26 & 102.34 & 101.44 & 101.67 & 99.93 & 99.91 & 99.88 & 100.82 & 99.92 \\
\hline $\mathrm{Si}$ & 0.991 & 1.001 & 0.985 & 0.993 & 1.008 & 1.008 & 1.009 & 1.006 & 1.006 \\
\hline Al & 0.001 & 0.002 & 0.002 & 0.003 & 0.003 & 0.004 & 0.004 & 0.003 & 0.002 \\
\hline Ti & 0.000 & 0.000 & 0.000 & 0.002 & 0.000 & 0.001 & 0.001 & 0.000 & 0.001 \\
\hline $\mathrm{Fe} 3$ & 0.000 & 0.000 & 0.000 & 0.000 & 0.000 & 0.000 & 0.000 & 0.000 & 0.000 \\
\hline $\mathrm{F} \in \hat{2}$ & 0.183 & 0.276 & 0.475 & 0.456 & 0.168 & 0.180 & 0.179 & 0.227 & 0.176 \\
\hline $\mathrm{Mn}$ & 0.002 & 0.003 & 0.010 & 0.010 & 0.004 & 0.003 & 0.002 & 0.002 & 0.004 \\
\hline$M_{B}$ & $1.82 t$ & 1.706 & $\hat{1} .533$ & 1.533 & 1.800 & 1.782 & 1.786 & 1.746 & 1.793 \\
\hline $\mathrm{Ca}$ & 0.004 & 0.007 & 0.009 & 0.008 & 0.003 & 0.004 & 0.004 & 0.005 & 0.004 \\
\hline $\mathrm{Nz}$ & 0.000 & 0.000 & 0.000 & 0.000 & 0.000 & 0.000 & 0.000 & 0.000 & 0.000 \\
\hline $\mathrm{x}$ & 0.000 & 0.000 & 0.000 & 0.000 & 0.000 & 0.000 & 0.000 & 0.000 & 0.000 \\
\hline $\mathrm{Ni}$ & 0.007 & 0.005 & 0.000 & 0.001 & 0.006 & 0.003 & 0.005 & 0.004 & 0.008 \\
\hline Cations & 3.009 & 3.000 & 3.014 & 3.006 & 2.992 & 2.989 & 2.990 & 2.993 & 2.994 \\
\hline $\mathrm{Fe}$ Eelig & 0.09 & 0.14 & 0.24 & 0.23 & 0.09 & 0.09 & 0.09 & 0.12 & 0.09 \\
\hline $\mathrm{Mg} \mathrm{FeMg}_{2}$ & 0.91 & 0.86 & 0.76 & 0.77 & 0.91 & 0.91 & 0.91 & 0.88 & 0.91 \\
\hline
\end{tabular}




\begin{tabular}{|c|c|c|c|c|c|c|c|c|c|}
\hline $\begin{array}{l}\text { Sampie } \\
\text { Analysis }\end{array}$ & 10.0128 & $10.013 \mathrm{a}$ & $10.013 b$ & 100172 & 100176 & $10.018 \mathrm{a}$ & $10.018 b$ & $10.022 \mathrm{a}$ & $10.022 \mathrm{~b}$ \\
\hline Location & YMa-1-pl & YMI-1-d & YMI-I-d & $\mathrm{YM}-1-\mathrm{p} 2$ & YMA-1-p2 & $Y M 1-1-p 2$ & YMI-1-p2 & $Y M(1-p)$ & YMI-1-pl \\
\hline Mineral & Olv & Olw & Olv & Olv & Ofy & Olv & Ofy & Ofv & Olv \\
\hline $\mathrm{SiO} 2$ & 40.78 & 39.93 & 42.51 & 39.60 & 39.41 & 40.29 & 37.97 & 41.11 & 39.89 \\
\hline $\mathrm{T}: 02$ & 0.01 & 0.00 & 0.00 & 0.03 & 0.00 & 0.00 & 0.00 & 0.00 & 0.00 \\
\hline $\mathrm{A} 12 \mathrm{O} 3$ & 0.07 & 0.07 & 0.09 & 0.06 & 0.06 & 0.06 & 0.04 & 0.09 & 0.07 \\
\hline $\mathrm{Fe} 203$ & 0.00 & 0.00 & 0.00 & 0.00 & $0 . \infty$ & 0,00 & 0.00 & 0.00 & 0.00 \\
\hline $\mathrm{F} \oplus \mathrm{O}$ & 10.34 & 9.15 & 8.66 & 12.15 & 18.23 & 12.12 & 22.48 & 8.47 & 13.82 \\
\hline $\mathrm{N} n \mathrm{O}$ & 0.11 & 0.15 & 0.12 & 0.19 & 0.36 & 0.21 & $0.5 \mathrm{~s}$ & 0.10 & 0.25 \\
\hline $\mathrm{MgO}$ & 47.75 & 50.07 & 47.97 & 47.44 & 41.50 & 47.71 & 38.43 & 49.56 & 45.34 \\
\hline $\mathrm{C} 20$ & 0.20 & 0.17 & 0.15 & 0.20 & 0.25 & 0.17 & 0.28 & 0.14 & 0.25 \\
\hline $\mathrm{N} 22 \mathrm{O}$ & 0.00 & 0.00 & 0.00 & 0.00 & $0 \infty$ & 0.00 & 0.00 & $0 . \infty$ & 0.00 \\
\hline $\mathrm{K} 20$ & 0.00 & 0.00 & 0.00 & 0.00 & 0.00 & 0.00 & 0.00 & 0.00 & 0.00 \\
\hline $\mathrm{NiO}$ & 0.39 & 0.44 & 0.39 & 0.25 & 0.09 & 0.20 & 0.13 & 0.49 & 0.23 \\
\hline Total & 99.65 & 99.98 & 99.89 & 99.92 & 99.90 & 100.76 & 99.88 & 99.96 & 99.85 \\
\hline $\mathrm{Si}$ & 1.006 & 0.980 & 1.034 & 0.985 & 1.005 & 0.992 & 0.993 & 1.003 & 0.990 \\
\hline $\mathrm{Ai}$ & 0.002 & 0.002 & 0.003 & 0.002 & 0.002 & 0.002 & 0.001 & 0.003 & 0.002 \\
\hline $\mathrm{Ti}$ & 0.000 & 0.000 & 0.000 & 0.001 & 0.000 & 0.000 & 0.000 & 0.000 & 0.000 \\
\hline $\bar{F} \subset 3$ & 0.000 & 0.000 & 0.000 & 0.000 & 0.000 & 0.000 & 0.000 & 0.000 & 0.000 \\
\hline $\mathrm{F} \subset 2$ & 0.213 & 0.188 & 0.176 & 0.253 & 0.389 & 0.250 & 0.492 & 0.173 & 0.289 \\
\hline $\mathrm{Mnn}$ & 0.002 & 0.003 & 0.002 & 0.004 & 0.008 & 0.004 & 0.012 & 0.002 & 0.005 \\
\hline $\mathrm{Mg}$ & 1.756 & 1.832 & 1.739 & 1.759 & 1.579 & 1.751 & 1.498 & 1.802 & 1.693 \\
\hline $\mathrm{Ca}$ & 0.005 & 0.004 & 0.004 & 0.005 & 0.007 & 0.004 & 0.008 & 0.004 & 0.007 \\
\hline$N_{a}$ & 0.000 & 0.000 & 0.000 & 0.000 & 0.090 & 0.000 & 0.000 & 0.000 & 0.000 \\
\hline $\mathrm{x}$ & 0.000 & 0.000 & 0.000 & 0.000 & 0.000 & 0.000 & 0.000 & 0.000 & 0.000 \\
\hline$N_{\bar{z}}$ & 0.008 & 0.009 & 0.008 & 0.005 & 0.002 & 0.004 & 0.003 & 0.010 & 0.005 \\
\hline Cations & 2.992 & 3.018 & 2.966 & 3.014 & 2.993 & 3.007 & 3.007 & 2.997 & 3.000 \\
\hline Fe FoMg & 0.11 & 0.09 & 0.09 & 0.13 & 0.20 & 0.12 & 0.25 & 0.09 & 0.15 \\
\hline $\mathrm{ME}_{B_{-}} \mathrm{F} \in \mathrm{M}_{\mathrm{g}}$ & 0.89 & 0.91 & 0.91 & 0.87 & 0.80 & 0.88 & 0.75 & 0.91 & 0.85 \\
\hline
\end{tabular}




\begin{tabular}{|c|c|c|c|c|c|c|c|c|c|}
\hline $\begin{array}{l}\text { Seanple } \\
\text { Analysis }\end{array}$ & $10.023 a$ & $10.023 b$ & $10.025 a$ & $10.025 \mathrm{~b}$ & $10.026 \mathrm{a}$ & 10.0266 & $10.031 a$ & $10.031 \mathrm{~b}$ & $10.039_{3}$ \\
\hline Location & YMI-1-pl & $\mathrm{YM}-1-\mathrm{pl}$ & YMARi-d & YM-I & YMI-1-d & $Y M a-1-d$ & YMI-i-d & YMAI- Id & YMA-1-d \\
\hline Minteral & Oly & Olv & Olv & Olv & OAv & Olv & Oiv & Olv & Olv \\
\hline $\mathrm{SiO} 2$ & 40.92 & 39.75 & 41.30 & 40.95 & 41.18 & 40.96 & 40.48 & 40.70 & 40.71 \\
\hline $\mathrm{Ti} \mathrm{IO}_{2}$ & 0.05 & 0.05 & 0.06 & 0.00 & 0.00 & 0.05 & $0 . \infty$ & 0.00 & 0.05 \\
\hline A1203 & 0.04 & 0.07 & 0.05 & 0.08 & 0.09 & 0.09 & 0.11 & 0.06 & 0.08 \\
\hline $\mathrm{Fe} 203$ & $0 . \infty$ & 0.00 & 0.00 & 0.00 & 0.09 & 0.00 & 0.00 & 0.00 & 0.00 \\
\hline$E=0$ & 10.67 & 12.98 & 8.52 & 9.94 & 8.65 & 8.85 & 8.37 & 8.07 & 10.73 \\
\hline $\mathrm{MnO}$ & 0.14 & 0.21 & 0.09 & 0.11 & 0.13 & 0.00 & 0.17 & 0.07 & 0.15 \\
\hline $\mathrm{MgO}$ & 47.55 & 46.43 & 49.43 & 48.23 & 49.37 & 43.37 & 50.31 & 51.11 & 49.53 \\
\hline $\mathrm{C} \infty$ & 0.16 & 0.21 & 0.17 & 0.21 & 0.18 & 0.19 & 0.15 & 0.19 & 0.14 \\
\hline $\mathrm{N} 22 \mathrm{O}$ & 0.00 & 0.00 & 0.00 & 0.00 & 0.00 & 0.00 & 0.00 & 0.00 & 0.01 \\
\hline $\mathrm{K} 20$ & 0.00 & 0.00 & 0.00 & 0.00 & 0.00 & $0 . \infty$ & 0.00 & 0.00 & 0.00 \\
\hline $\mathrm{NiO}$ & 0.27 & 0.23 & 0.22 & 0.38 & 0.33 & 0.34 & 0.38 & 0.40 & 0.31 \\
\hline Toral & 99.80 & 99.93 & 99.84 & 99.90 & 99.94 & 93.85 & 99.97 & 100.60 & 101.69 \\
\hline $\mathrm{Si}$ & 3.008 & 0.992 & 1.007 & 1.006 & 1.005 & 1.059 & 0.989 & 0.986 & 0.987 \\
\hline A] & 0.001 & 0.002 & 0.001 & 0.002 & 0.003 & 0.003 & 0.003 & 0.002 & 0.002 \\
\hline $\mathrm{Ti}$ & 0.001 & 0.001 & 0.001 & 0.000 & 0.000 & 0.001 & 0.000 & 0.000 & 0.001 \\
\hline Fes & 0.000 & 0.000 & 0.000 & 0.000 & 0.000 & 0.000 & 0.000 & 0.000 & 0.000 \\
\hline $\mathrm{F} \in 2$ & 0.220 & 0.271 & 0.174 & 0.204 & 0.177 & 0.191 & 0.171 & 0.164 & 0.218 \\
\hline $\mathrm{Mn}$ & 0.003 & 0.004 & 0.002 & 0.002 & 0.003 & 0.000 & 0.008 & 0.001 & 0.003 \\
\hline Ms & 1.747 & 1.727 & 1.797 & 1.766 & 1.796 & 1.672 & 1.832 & 1.847 & 1.790 \\
\hline $\mathrm{Cz}$ & 0.004 & 0.006 & 0.004 & 0.006 & 0.005 & 0.005 & 0.004 & 0.005 & 0.004 \\
\hline $\mathrm{Nz}$ & 0.000 & 0.000 & 0.000 & 0.000 & 0.000 & 0.000 & 0.000 & 0.000 & 0.000 \\
\hline $\mathrm{K}$ & 0.000 & 0.000 & 0.000 & 0.000 & 0.000 & 0.000 & 0.000 & 0.000 & 0.000 \\
\hline $\mathrm{Ni}$ & 0.005 & 0.005 & 0.004 & 0.008 & 0.006 & 0.007 & 0.007 & 0.008 & 0.006 \\
\hline Cxions & 2.989 & 3.008 & 2.990 & 2.994 & 2.995 & 2.938 & 3.010 & 3.013 & 3.011 \\
\hline Fe_Ferkg & 0.11 & 0.14 & 0.09 & 0.10 & 0.09 & 0.10 & 0.09 & 0.08 & 0.11 \\
\hline ME FeM & 0.89 & 0.86 & 0.91 & 0.90 & $0.9\}$ & 0.90 & 0.91 & 0.92 & 0.89 \\
\hline
\end{tabular}




\begin{tabular}{|c|c|c|c|c|c|c|c|c|c|c|}
\hline $\begin{array}{l}\text { Sample } \\
\text { Arazysis }\end{array}$ & 30.0396 & $\begin{array}{l}10.000 \\
\mathrm{mf}\end{array}$ & 10.001 & 10.002 & 10.003 & 10.004 & 10.005 & $\begin{array}{l}10.007 \\
\mathrm{mI}\end{array}$ & $\begin{array}{l}10.008 \\
\mathrm{mf}\end{array}$ & 10.014 \\
\hline Lacation & YMI-1-d & $Y M-1-p 2$ & YMA-1-pl & $\mathrm{YM}-1-\mathrm{pl}$ & 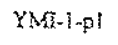 & $\langle M I-1-p|$ & $\mathrm{YMI}+\mathrm{I}-\mathrm{d}$ & YM-1-p! & YNA-1-p! & $Y M 1-i-p 2$ \\
\hline Mineral & Olv & Olv & Olv & Olv & Olp & Olv & Olv & ON & Ofv & Olv \\
\hline $\mathrm{SiO} 2$ & 38.92 & 38.34 & 39.78 & 40.81 & 39.74 & $40.5\}$ & 39.08 & 39.81 & 40.13 & 39.27 \\
\hline $\mathrm{TiO} 2$ & 0.08 & 0.09 & 0.00 & 0.00 & 0.04 & 0.05 & 0.06 & 0.05 & 0.00 & 0.03 \\
\hline $\mathrm{A}_{2} 2 \mathrm{O}_{3}$ & 0.07 & 0.05 & 0.03 & 0.04 & 0.04 & 0.10 & 0.03 & 0.02 & 0.03 & 0.05 \\
\hline $\mathrm{Fe} 203$ & 0.00 & 0.00 & 0.00 & 0.00 & 0.00 & 0.00 & 0.00 & 0.00 & 0.00 & 0.00 \\
\hline FeO & 17.33 & 22.49 & 15.29 & 13.68 & 15.03 & 11.53 & 22.83 & 11.44 & 12.84 & 8.97 \\
\hline $\mathrm{M} \cap \mathrm{O}$ & 0.35 & 0.57 & 0.21 & 0.31 & 0.21 & 0.04 & 0.51 & 0.20 & 0.29 & 0.22 \\
\hline$M \otimes O$ & 42.70 & 39.80 & 45.69 & 47.00 & 45.93 & 48.50 & 39.64 & 49.13 & 47.44 & 50.81 \\
\hline $\mathrm{CsO}$ & 0.32 & 0.26 & 0.21 & 0.24 & 0.16 & 0.16 & 0.32 & 0.20 & 0.22 & 0.17 \\
\hline $\mathrm{Na} 2 \mathrm{O}$ & 0.00 & 0.01 & 0.00 & 0.00 & $0 \infty$ & 0.00 & 0.00 & 0.00 & 0.00 & 0.00 \\
\hline $\mathrm{K} 2 \mathrm{O}$ & $0 . \infty$ & 0.00 & 0.00 & 0.00 & $0 . \infty$ & 0.00 & 0.00 & 0.00 & 0.00 & 0.00 \\
\hline $\mathrm{NO}$ & 0.14 & 0.04 & 0.19 & 0.22 & 0.17 & 0.23 & 0.14 & 0.37 & 0.30 & 0.34 \\
\hline Total & 99.91 & 101.65 & 101.40 & 102.30 & 101.32 & 01.12 & $102.6 \mathrm{i}$ & 101.22 & 101.25 & 99.86 \\
\hline Si & 0.992 & 0.984 & 0.988 & 0.996 & 0.986 & 0.990 & 0.993 & 0.976 & 0.988 & 0.966 \\
\hline $\mathrm{A}$ & 0.002 & 0.002 & 0.001 & 0.001 & 0.001 & 0.003 & 0.001 & 0.001 & 0.001 & 0.001 \\
\hline Ti & 0.002 & 0.002 & 0.000 & 0.000 & 0.001 & 0.001 & 0.003 & 0.001 & 0.000 & 0.001 \\
\hline $\mathrm{F} e 3$ & 0.000 & 0.000 & 0.000 & 0.000 & 0.000 & 0.000 & 0.000 & 0.000 & 0.000 & 0.000 \\
\hline Fe2 & 0.369 & 0.483 & 0.318 & 0.279 & 0.312 & 0.236 & 0.485 & 0.234 & 0.264 & 0.185 \\
\hline Mar & 0.008 & 0.012 & 0.004 & 0.006 & 0.024 & $0.00 \mathrm{I}$ & 0.011 & 0.034 & 0.006 & 0.005 \\
\hline $\mathrm{Mg}$ & 1.622 & 1.523 & 1.692 & 1.710 & 1.700 & 1.768 & 1.502 & 1.795 & 1.741 & 1.864 \\
\hline $\mathrm{Ca}$ & 0.009 & 0.007 & 0.006 & 0.006 & 0.008 & 0.004 & 0.009 & 0.005 & 0.006 & 0.004 \\
\hline NE & 0.000 & 0.000 & 0.000 & 0.000 & 0.000 & 0.000 & 0.000 & 0.090 & 0.000 & 0.000 \\
\hline K & 0.000 & 0.000 & 0.000 & 0.000 & 0.000 & 0.000 & 0.000 & 0.000 & 0.000 & 0.000 \\
\hline $\mathrm{Ni}$ & 0.003 & 0.001 & 0.004 & 0.004 & 0.003 & 0.005 & 0.003 & 0.007 & 0.006 & 0.007 \\
\hline Cations & 3.007 & 3.014 & 3.013 & 3.002 & 3.011 & 3.008 & 3.005 & 3.023 & 3.012 & 3.033 \\
\hline FeF FeNs & 0.19 & 0.24 & 0.16 & 0.14 & 0.16 & 0.12 & 0.24 & 0.12 & 0.13 & 0.09 \\
\hline ME_FeNg & 0.81 & 0.76 & 0.84 & 0.86 & 0.84 & 0.88 & 0.76 & 0.88 & 0.87 & 0.91 \\
\hline
\end{tabular}




\begin{tabular}{|c|c|c|c|c|c|c|c|c|c|}
\hline Sample & 10.015 & 10.016 & 10.019 & 10.020 & 10.023 & 10.024 & 10.027 & 10.028 & 10.029 \\
\hline Andysis & & $\mathrm{mI}$ & & I -opx & $\log x$ & & & & \\
\hline Location & $Y M A-1-p 2$ & YM-1-p2 & $Y M-1-p 2$ & YMa-1-pl & MII-1-pl & $Y M B-1-p l$ & YM-1-d & YMI-1 $1-\mathrm{d}$ & YMB-1-d \\
\hline Mineral & Olv & Olv & Oiv & Olv & $\mathrm{Olr}$ & olv & Olv & Olv & Olv \\
\hline $\mathrm{SiO} 2$ & 40.59 & 39.72 & 39.85 & 40.74 & 41.21 & 40.83 & 40.42 & 40.43 & 40.00 \\
\hline $\mathrm{THO}_{2}$ & 0.00 & 0.00 & 0.00 & 0.00 & 0.00 & 0.00 & 0.00 & 0.00 & 0.00 \\
\hline$A 1203$ & 0.02 & 0.00 & 0.05 & 0.05 & 0.07 & 0.36 & 0.00 & 0.12 & 0.12 \\
\hline $\mathrm{Fe} 203$ & 0.00 & 0.00 & 0.00 & 0.00 & 0.00 & 0.00 & 0.00 & 0.00 & 0.00 \\
\hline $\mathrm{FeO}$ & 8.74 & 17.01 & 16.36 & 8.96 & 9.28 & 9.23 & 8.89 & 8.30 & 8.59 \\
\hline $\mathrm{MnO}$ & 0.18 & 0.35 & 0.31 & 0.07 & 0.18 & 0.09 & 0.10 & 0.16 & 0.12 \\
\hline$M_{B O}$ & 49.72 & 42.47 & 43.01 & 49.61 & 48.62 & 49.03 & 50.75 & 50.58 & 50.53 \\
\hline $\mathrm{C} 30$ & 0.17 & 0.22 & 0.21 & 0.14 & 0.16 & 0.38 & 0.14 & 0.17 & 0.15 \\
\hline $\mathrm{N} 22 \mathrm{O}$ & 0.00 & 0.00 & 0.00 & 0.00 & 0.00 & 0.00 & 0.00 & 0.00 & 0.00 \\
\hline $\mathrm{k} 20$ & 0.00 & 0.00 & 0.00 & 0.00 & 0.00 & 0.00 & 0.00 & 0.00 & 0.00 \\
\hline $\mathrm{NiO}$ & 0.42 & 0.17 & 0.13 & 0.32 & 0.37 & 0.34 & 0.30 & 0.40 & 0.34 \\
\hline Total & 99.84 & 99.94 & 99.92 & 99.89 & 99.80 & 99.86 & 100.60 & 100.56 & 99.85 \\
\hline $\mathrm{Si}$ & 0.994 & 1.008 & 1.008 & 0.997 & 1.000 & 1.000 & 0.983 & 0.984 & 0.980 \\
\hline A I & 0.001 & 0.000 & 0.001 & 0.001 & 0.002 & 0.005 & 0.000 & 0.003 & 0.003 \\
\hline $\mathrm{Ti}$ & 0.000 & 0.000 & 0.000 & 0.000 & 0.000 & 0.000 & 0.000 & 0.000 & 0.000 \\
\hline Fe3 & 0.000 & 0.000 & 0.000 & 0.000 & 0.000 & 0.000 & 0.000 & 0.000 & 0.000 \\
\hline $\mathrm{Fe} 2$ & 0.179 & $0.36 ?$ & 0.346 & 0.183 & 0.190 & 0.189 & 0.181 & 0.177 & 0.176 \\
\hline Mn & 0.004 & 0.008 & 0.007 & 0.001 & 0.004 & 0.002 & 0.002 & 0.003 & 0.002 \\
\hline $\mathrm{Mg}$ & 1.815 & 1.606 & 1.621 & 1.810 & 1.774 & 1.790 & 1.841 & 1.835 & 1.846 \\
\hline $\mathrm{Ca}$ & 0.004 & 0.006 & 0.006 & 0.004 & 0.004 & 0.005 & 0.004 & 0.004 & 0.004 \\
\hline $\mathrm{Nz}$ & 0.000 & 0.000 & 0.000 & 0.000 & 0.000 & 0.000 & 0.000 & 0.000 & 0.000 \\
\hline $\mathrm{k}$ & 0.000 & 0.000 & 0.000 & 0.000 & 0.020 & 0.000 & 0.000 & 0.000 & 0.000 \\
\hline $\mathrm{Ni}$ & 0.008 & 0.003 & 0.003 & 0.006 & 0.007 & 0.007 & 0.006 & 0.008 & 0.007 \\
\hline Caxions & 3.005 & 2.992 & 2.992 & 3.002 & 2.990 & 2.998 & 3.017 & 3.014 & 3.018 \\
\hline $\mathrm{Fe} F \mathrm{~F}$ e & 0.09 & 0.18 & 0.18 & 0.09 & 0.10 & 0.10 & 0.09 & $0 . \infty$ & 0.09 \\
\hline $\mathrm{Mg}_{\mathrm{g}} \mathrm{FeMg}$ & 0.91 & 0.82 & 0.82 & 0.91 & 0.90 & 0.90 & 0.91 & 0.91 & 0.91 \\
\hline
\end{tabular}




\begin{tabular}{|c|c|c|c|c|c|c|c|c|c|}
\hline Sampic & 10.030 & 10.032 & 10.033 & 10.034 & 10.035 & 10.036 & 10.037 & 10.038 & 10.040 \\
\hline Laration & & & & & & & & & \\
\hline Minetal & $\mathrm{MNI}-\mathrm{I}-\mathrm{d}$ & YMA-1-d & YMA-1-d & YMI-1-d & YMI- $-1-d$ & YMI-1 $\propto$ & YMI-1-d & YM-1-d & $\mathrm{YM} M-1-\mathrm{p} 2$ \\
\hline & & Oly & Olv & Olv & Olv & Olv & Olv & Olv & Olv \\
\hline $\mathrm{SiO} 2$ & 39.21 & 40.37 & 40.69 & 40.80 & 40.33 & 38.28 & 38.15 & & 41.30 \\
\hline $\mathrm{THO} 2$ & 0.08 & 0.00 & 0.02 & 0.09 & 0.02 & 0.03 & 000 & 0.00 & $\begin{array}{l}41.30 \\
0.70\end{array}$ \\
\hline $\mathrm{A} 2 \mathrm{O}_{3}$ & 0.13 & 0.03 & 0.09 & 0.08 & 0.10 & & & 0.03 & 0.07 \\
\hline $\mathrm{Fe} 2 \mathrm{O}_{3}$ & 0.00 & 0.00 & 0.00 & & & & 0.11 & 0.07 & 0.07 \\
\hline $\mathrm{F} \in \mathrm{O}$ & 9.01 & 12.81 & & 000 & & 0.00 & 0.00 & 0.03 & 0.00 \\
\hline Mro & 0.11 & 0.19 & 9.50 & 10.25 & 10.25 & 21.66 & 21.66 & 8.31 & 12.38 \\
\hline $\mathrm{M} 8 \mathrm{O}$ & 50.45 & $\begin{array}{l}0.19 \\
46.19\end{array}$ & 0.07 & 0.17 & 0.18 & 0.54 & 0.49 & 0.13 & 0.24 \\
\hline $\mathrm{C} \approx \mathrm{O}$ & 0.17 & $\begin{array}{l}46.19 \\
0.18\end{array}$ & 49.62 & 47.91 & 49.11 & 38.96 & 39.15 & 49.75 & 47.14 \\
\hline $\mathrm{N}_{2} 2 \mathrm{O}$ & 0.00 & & 0.15 & 0.17 & 0.17 & 0.31 & 0.29 & 0.16 & 0.22 \\
\hline $\mathrm{K} 20$ & $0 . \infty$ & & 0.00 & 0.00 & 0.00 & 0.00 & 0.00 & 0.00 & 0.03 \\
\hline $\mathrm{NiO}$ & 0.36 & & 0.00 & 0.00 & 0.00 & 0.00 & 0.00 & $0 . \infty$ & 0.02 \\
\hline Total & 99.52 & $\begin{array}{l}0.21 \\
99.98\end{array}$ & 0.28 & 0.38 & 0.37 & 0.08 & 0.00 & 0.39 & 0.23 \\
\hline Si & 0.968 & $\begin{array}{l}99.98 \\
1.004\end{array}$ & 100.42 & 99.85 & 100.53 & 99.92 & 99.91 & 99.89 & 101.70 \\
\hline $\mathrm{Al}$ & 0.004 & $\begin{array}{l}1.004 \\
0.001\end{array}$ & 0.993 & 1.004 & 0.988 & 0.996 & 0.992 & 1.002 & 1.007 \\
\hline $\mathrm{Ti}$ & 0.001 & 0.001 & 0.003 & 0.002 & 0.003 & 0.092 & 0.003 & 0.002 & 0.002 \\
\hline $\mathrm{F} \in 3$ & 0.000 & 0.000 & 0.000 & 0.002 & 0.000 & 0.001 & 0.001 & 0.000 & 0.001 \\
\hline $\mathrm{Fe} 2$ & 0.186 & 0.000 & 0.000 & 0.000 & 0.000 & 0.000 & 0.000 & 0.000 & 0.000 \\
\hline $\mathrm{Mn}$ & 0.002 & 0.266 & 0.194 & 0.211 & 0.210 & 0.471 & 0.471 & 0.170 & 0.252 \\
\hline$M g$ & 1.856 & 0.004 & 0.001 & 0.004 & 0.004 & 0.012 & 0.011 & 0.003 & 0.005 \\
\hline $\mathrm{Ca}$ & 0.004 & 1.712 & 1.805 & 1.758 & 1.793 & 1.511 & 1.518 & 1.809 & 1.713 \\
\hline $\mathrm{Na}$ & 0.000 & 0.005 & 0.004 & 0.004 & 0.004 & 0.009 & 0.008 & 0.004 & 0.006 \\
\hline $\mathrm{K}$ & 0.000 & 0.000 & 0.000 & 0.000 & 0.000 & 0.000 & 0.000 & 0.000 & 0.001 \\
\hline $\mathrm{Ni}$ & 0.007 & 0.000 & 0.000 & 0.000 & 0.000 & 0.000 & 0.000 & 0.000 & 0.001 \\
\hline Crtions & 3.028 & $\begin{array}{l}0.004 \\
2006\end{array}$ & 0.005 & 0.008 & 0.007 & 0.002 & 0.000 & 0.008 & 0.005 \\
\hline Fe_Felig & 0.09 & $\begin{array}{l}2.996 \\
0.13\end{array}$ & 3.005 & 2.993 & 3.009 & 3.004 & 3.004 & 2.998 & 2.993 \\
\hline $\mathrm{MB}$ Fe & 0.91 & $\begin{array}{l}0.13 \\
0.87\end{array}$ & 0.10 & 0.11 & 0.10 & 0.24 & 0.24 & 0.09 & 0.13 \\
\hline & & & 0.90 & 0.89 & 0.90 & 0.76 & 0.76 & 0.91 & 0.87 \\
\hline
\end{tabular}




\begin{tabular}{|c|c|c|c|c|c|c|c|c|c|}
\hline $\begin{array}{l}\text { Samp!c } \\
\text { Arralysis }\end{array}$ & 100.001 & $10 c .002$ & $10 \mathrm{c} .003$ & $10 \mathrm{c} .004$ & $10 c .005$ & $10 c .006$ & $10 c .006$ & 17.001 & 17.002 \\
\hline Location & kirito & kinto & kirito & kirito & kirito & kinto & & & \\
\hline Mineral & Olv & Olv & Olv & Oly & Olv & & & & \\
\hline & & & & & & & Olv & Oly & Oly \\
\hline $\mathrm{SiO} 2$ & 39.82 & 39.95 & 40.24 & 39.53 & 39.30 & 39.05 & & & \\
\hline $\mathrm{TiO}_{2}$ & 0.00 & 0.01 & 0.06 & 0.03 & 000 & & & & \\
\hline $\mathrm{AN} 2 \mathrm{O} 3$ & 0.02 & 0.03 & 0.06 & 0.04 & & & & & \\
\hline$F \in 203$ & 0.00 & $0 . \infty$ & 0.00 & & 0.11 & 0.07 & 0.07 & 0.01 & 0.03 \\
\hline 700 & 18.79 & 16.01 & 13.72 & 0.00 & 0.00 & 0.00 & 0.00 & 0.00 & 0.00 \\
\hline $\mathrm{MnO}$ & 0.38 & 0.32 & & 15.08 & 17.16 & 20.94 & 20.94 & 19.90 & 14.14 \\
\hline $\operatorname{lig}_{80}$ & 41.16 & & 0.23 & 0.19 & 0.34 & 0.46 & 0.46 & 0.33 & 0.24 \\
\hline $\mathrm{COO}$ & 0.22 & 43.32 & 44.67 & 42.98 & 41.43 & 38.79 & 38.79 & 39.64 & 44.97 \\
\hline $\mathrm{Na} 2 \mathrm{O}$ & $0 \infty$ & 0.20 & 0.23 & 0.17 & 0.23 & 0.26 & 0.26 & 0.30 & 0.24 \\
\hline $\mathrm{K} 20$ & 000 & 0.00 & 0.00 & 0.00 & 0.4 & 0.00 & 0.00 & 0.00 & $0 . \infty$ \\
\hline $\mathrm{NiO}$ & & 0.00 & 0.00 & 0.00 & 0.00 & 0.00 & 0.00 & 0.00 & 0.00 \\
\hline Total & 0.10 & 0.25 & 0.18 & 0.13 & 0.19 & 0.17 & 0.17 & 0.00 & 0.15 \\
\hline $\mathrm{Si}$ & 100.49 & 100.09 & 99.39 & 98.15 & 98.89 & 99.74 & 99.74 & 99.91 & 100.51 \\
\hline 要 & 1.012 & 1.007 & 1.010 & 1.012 & 1.009 & 1.012 & 1.012 & 1.018 & 1.012 \\
\hline Rs & 0.001 & 0.001 & 0.002 & 0.001 & 0.003 & 0.002 & 0.002 & 0.000 & 0.091 \\
\hline $\mathrm{Ti}$ & 0.000 & 0.000 & 0.001 & 0.001 & 0.0032 & 0.000 & 0.000 & 0.002 & 0.000 \\
\hline$E \in 3$ & 0.000 & 0.000 & 0.000 & 0.000 & 0.000 & 0.000 & 0.000 & 0.000 & 0.000 \\
\hline $\mathrm{Fe2}$ & 0.399 & 0.338 & 0.288 & 0.323 & 0.369 & 0.454 & 0.454 & 0.427 & 0.294 \\
\hline Mn & 0.008 & 0.007 & 0.005 & 0.004 & 0.097 & 0.010 & 0.010 & 0.007 & 0.005 \\
\hline $\mathrm{Ng}_{\mathrm{g}}$ & 1.559 & 1.629 & 1.672 & 1.640 & 1.586 & 1.498 & 1.498 & 1.517 & 1.666 \\
\hline $\mathrm{Ca}$ & 0.006 & 0.005 & 0.006 & 0.005 & 0.006 & 0.007 & 0.007 & 0.008 & 0.006 \\
\hline $\mathrm{Na}$ & 0.000 & 0.000 & 0.000 & 0.000 & 0.002 & 0.000 & 0.000 & 0.000 & 0.000 \\
\hline $\mathrm{K}$ & 0.000 & 0.000 & 0.000 & 0.000 & 0,000 & 0.000 & 0.000 & 0.000 & 0.000 \\
\hline $\mathrm{N} i$ & 0.002 & 0.005 & 0.004 & 0.003 & 0.034 & 0.004 & 0.004 & 0.000 & 0.003 \\
\hline Crations & 2.987 & 2.992 & 2.988 & 2.989 & 2.988 & 2.987 & 2.987 & 2.979 & 2.987 \\
\hline$F \in F \in N_{g}$ & 0.20 & 0.17 & 0.15 & 0.16 & 0.19 & 0.23 & 0.23 & 0.22 & 0.15 \\
\hline 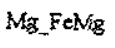 & 0.80 & 0.83 & 0.85 & 0.84 & 0.81 & 0.77 & 0.77 & 0.78 & 0.85 \\
\hline
\end{tabular}




\begin{tabular}{|c|c|c|c|c|c|c|c|c|c|}
\hline $\begin{array}{l}\text { Sampie } \\
\text { Aralysis }\end{array}$ & 17.003 & 17.004 & 17.005 & 17.006 & $\begin{array}{l}20.030 \\
\mathrm{C} / \mathrm{spg} \times \mathrm{Xt}\end{array}$ & 23001 & 21.0012 & $21.0 \times 3$ & 21.004 \\
\hline Lacedion & MM-7 & YME-7 & YMQ-7 & $\mathrm{YMH}-7$ & YZE: & YZU.1 & YZU-1 & YZU. & YZU-1 \\
\hline Mineral & Oly & Olv & Olv & Olv & OLY & Olv & Olv & Or & Olv \\
\hline $\mathrm{SiO} 2$ & 40.11 & 40.57 & 39.25 & 38.16 & 39.26 & 39.16 & 39.62 & 40.19 & 40.39 \\
\hline $\mathrm{TiO}_{2}$ & 0.06 & 0.08 & 0.00 & 0.03 & 0.27 & 0.03 & 0.00 & 0.00 & 0.00 \\
\hline $\mathrm{Al} 2 \mathrm{O}_{3}$ & 0.00 & 0.03 & 0.02 & 0.03 & 2.64 & 0.09 & 0.07 & 0.07 & 0.07 \\
\hline $\mathrm{Fe} 203$ & 0.00 & 0.00 & 0.00 & 0.00 & 0.00 & 0,00 & 0.00 & 0.09 & 0.00 \\
\hline $\mathrm{FeO}$ & 15.93 & 15.32 & 19.50 & 19.35 & 12.85 & 18.44 & 14.54 & 17.99 & 16.95 \\
\hline Mino & 0.13 & 0.21 & 0.33 & 0.29 & 0.03 & 0.11 & 0.29 & 0.40 & 0.45 \\
\hline $\mathrm{MgO}$ & 44.22 & 44.07 & 40.53 & 43.21 & 21.86 & 46.42 & 47.34 & $42.8 \mathrm{I}$ & 43.68 \\
\hline $\mathrm{C} 20$ & 0.27 & 0.26 & 0.23 & 0.32 & 0.00 & 0.21 & 0.32 & 0.35 & 0.44 \\
\hline $\mathrm{Na} 2 \mathrm{O}$ & 0.00 & 0.00 & 0.00 & 0.00 & 0.00 & 0.00 & 0.00 & 0.00 & 0.00 \\
\hline $\mathrm{K} 2 \mathrm{O}$ & 0.00 & 0.00 & 0.00 & 0.00 & 0.00 & 0.00 & 0.00 & 0.00 & 0.00 \\
\hline $\mathrm{NiO}$ & 0.11 & 0.13 & 0.15 & 0.08 & 0.34 & 0.26 & 0.15 & 0.08 & 0.14 \\
\hline Tots & 100.83 & 100.57 & 100.01 & 101.47 & 77.25 & 100.72 & 102.33 & 101.89 & 102.12 \\
\hline $\mathrm{Si}$ & 1.002 & 1.014 & 1.007 & 0.968 & 1.234 & 0.977 & 0.973 & 1.004 & 1.002 \\
\hline AI & 0.000 & 0.001 & 0.001 & 0.001 & 0.098 & 0.003 & 0.002 & 0.002 & 0.002 \\
\hline ח & 0.001 & 0.002 & 0.000 & 0.001 & 0.006 & 0.001 & 0.000 & 0.000 & 0.000 \\
\hline $\mathrm{Fe} 3$ & 0.000 & 0.000 & 0.000 & 0.000 & 0.000 & 0.000 & 0.000 & 0.000 & 0.000 \\
\hline$F \subset 2$ & 0.333 & 0.315 & 0.418 & 0.411 & 0.338 & 0.301 & 0.299 & 0.376 & 0.352 \\
\hline Mn & 0.003 & 0.034 & 0.007 & 0.006 & 0.001 & 0.002 & 0.005 & 0.008 & 0.009 \\
\hline $\mathrm{Ng}_{\mathrm{B}}$ & 1.648 & 1.638 & 1.550 & 1.634 & 1.025 & 1.726 & 1.734 & 1.594 & 1.616 \\
\hline $\mathrm{Ca}$ & 0.007 & 0.007 & 0.006 & 0.009 & 0.000 & 0.005 & 0.008 & 0.008 & 0.012 \\
\hline $\mathrm{Na}$ & 0.000 & 0.000 & 0.000 & 0.000 & 0.000 & 0.000 & 0.000 & 0.000 & 0.000 \\
\hline $\mathrm{K}$ & 0.000 & 0.000 & 0.000 & 0.000 & 0.000 & 0.000 & 0.000 & 0.000 & 0.000 \\
\hline $\mathrm{Ni}$ & 0.002 & 0.003 & 0.003 & 0.002 & 0.0009 & 0.005 & 0.003 & 0.002 & 0.003 \\
\hline Caxions & 2.996 & 2.984 & 2.992 & 3.032 & 2.731 & 3.021 & 3.025 & 2.995 & 2.996 \\
\hline $\mathrm{Fe}_{-} \mathrm{FeN} / 8$ & 0.17 & 0.16 & $0.2 !$ & 0.20 & 0.25 & 0.15 & 0.15 & 0.19 & 0.18 \\
\hline $\mathrm{NGB}_{\mathrm{F}} \mathrm{FeNG}$ & 0.83 & 0.84 & 0.79 & 0.80 & 0.75 & 0.85 & 0.85 & 0.81 & 0.82 \\
\hline
\end{tabular}




\begin{tabular}{|c|c|c|c|c|c|c|c|}
\hline Szample & 21.005 & $21.006 \mathrm{a}$ & 21.0068 & $21.007 a$ & $21.007 b$ & 21.0083 & $21.008 b$ \\
\hline \multicolumn{8}{|l|}{ Analysis } \\
\hline Lacation & YZU-1 & YZU.i & YZU-1 & YZU-1 & YZU-1 & YZU-1 & YZU-1 \\
\hline Mineral & Olv & Olv & Olv & Olv & Olr & Olv & \\
\hline $\mathrm{SiO} 2$ & 40.19 & 40.71 & 39.71 & 40.79 & 41.38 & 40.67 & 39.97 \\
\hline $\mathrm{TiO2}$ & 0.15 & 0.05 & 0.08 & 0.08 & 0.00 & 0.00 & 0.05 \\
\hline $\mathrm{Al} 2 \mathrm{O} 3$ & 0.00 & 0.08 & 0.07 & 0.06 & 0.05 & 0.06 & 0.05 \\
\hline $\mathrm{Fe} 203$ & $0 . \infty 0$ & 0.00 & 0.00 & 0.00 & 0.00 & 0.00 & 0.00 \\
\hline FeO & 15.91 & 10.73 & 17.68 & 12.14 & 12.29 & 13.10 & 14.70 \\
\hline $\mathrm{MnO}$ & 0.30 & 0.15 & 0.36 & 0.30 & 009 & 0.15 & 0.37 \\
\hline $\mathrm{M} \times 0$ & 44.01 & 49.51 & 43.56 & 47.81 & 45.95 & 47.27 & 45.59 \\
\hline $\mathrm{C} 20$ & 0.46 & 0.14 & 0.32 & 0.27 & 0.23 & 0.17 & 0.23 \\
\hline $\mathrm{N} 22 \mathrm{O}$ & $0 . \infty$ & 0.00 & 0.00 & 0.00 & 0.00 & 0.00 & 0.00 \\
\hline $\mathrm{K} 20$ & 0.00 & 0.00 & 0.00 & 0.00 & 0.00 & 0.00 & 0.00 \\
\hline $\mathrm{NiO}$ & 0.01 & 0.31 & 0.15 & 0.15 & 0.20 & 0.36 & 0.17 \\
\hline Total & 101.03 & 101.68 & 101.93 & 301.40 & 100.19 & 101.58 & 10113 \\
\hline $\mathrm{Si}$ & 1.003 & 0.987 & 0.992 & 0.997 & 1.021 & 0.996 & 0.993 \\
\hline A & 0.000 & 0.002 & 0.002 & 0.002 & 0.001 & 0.002 & 0.001 \\
\hline $\mathrm{Ti}$ & 0.003 & 0.001 & 0.002 & 0.001 & 0.000 & 0.000 & 0.001 \\
\hline $\mathrm{Fe} 3$ & 0.000 & 0.000 & 0.000 & 0.000 & 0.000 & 0.000 & 0.000 \\
\hline $\mathrm{Fe2}$ & 0.332 & 0.218 & 0.369 & 0.248 & 0.254 & 0.268 & 0.305 \\
\hline Mn & 0.006 & 0.003 & 0.008 & 0.002 & 0.002 & 0.003 & 0.008 \\
\hline $\mathrm{M}_{3 \mathrm{~B}}$ & 1.637 & 1.790 & 1.622 & 1.741 & 1.690 & 1.726 & 1.688 \\
\hline $\mathrm{Ca}$ & 0.012 & 0.004 & 0.009 & 0.007 & 0.006 & 0.004 & 0.006 \\
\hline $\mathrm{Na}$ & 0.000 & 0.000 & 0.000 & 0.000 & 0.000 & 0.000 & 0.000 \\
\hline $\mathrm{K}$ & 0.000 & 0.000 & 0.000 & 0.000 & 0.000 & 0.000 & 0.000 \\
\hline $\mathrm{N}_{\hat{z}}$ & 0.000 & 0.006 & 0.003 & 0.003 & 0.004 & 0.003 & 0.003 \\
\hline Cations & 2.993 & 3.011 & 3.007 & 3.001 & 2.978 & 3.002 & 3.005 \\
\hline $\mathrm{Fe} \_\mathrm{Fe} \mathrm{MB}$ & 0.17 & 0.11 & 0.19 & 0.12 & 0.13 & 0.13 & 0.15 \\
\hline $\mathrm{Mg}_{8} \mathrm{FeN} \hat{q}_{8}$ & 0.83 & 0.89 & 0.81 & 0.88 & 0.37 & 0.87 & 0.85 \\
\hline
\end{tabular}




\begin{tabular}{|c|c|c|c|c|c|c|c|c|}
\hline Sample & 150000 & $15(x) 1$ & $220 \times 0$ & $22 \omega n$ & $22(x) 2$ & 22003 & 22.004 & $22(x)$ \\
\hline Analysis & mf & $m f$ & & & & & & $C / n-C R$ \\
\hline Location & YM-5 & YMI-5 & YZU-2 & YZU:-2 & YZU.2 & $Y Z Z \mid-2$ & $Y Z U_{-2}$ & $\mathrm{YZU}-2$ \\
\hline Mineral & olv & OLV & OLV & OEV & OLV & OLV & o.v & ov \\
\hline $\mathrm{SiO} 2$ & $47 \% 2$ & 43.67 & 37.24 & 4078 & 40.19 & 39.62 & 40.19 & 39.53 \\
\hline $\mathrm{TiO} 2$ & 0.00 & 0.04 & 0.10 & 0.08 & 0.15 & 000 & 0.00 & 0.00 \\
\hline $\mathrm{A} 2 \mathrm{O} 3$ & 14.36 & 13.10 & 0.04 & 0.09 & 0.00 & 0.07 & 0.07 & 0.07 \\
\hline $\mathrm{Fe} 2 \mathrm{O} 3$ & 0.00 & 0.00 & 0.03 & 0.00 & 0.00 & 0.00 & $0 . \infty$ & 0.00 \\
\hline FeO & 11.22 & 13.40 & 15.55 & 16.36 & 15.91 & 14.54 & 17.99 & 16.59 \\
\hline $\mathrm{MnO}$ & 0.04 & 0.00 & 0.36 & 0.20 & 0.30 & 0.29 & 0.40 & 0.44 \\
\hline $\mathrm{MgO}$ & 16.77 & 17.85 & 46.18 & 43.15 & 44.01 & 47.34 & 42.81 & 42.75 \\
\hline $\mathrm{CaO}$ & 2.31 & 2.37 & 0.42 & 0.48 & 0.46 & 0.32 & 0.35 & 0.43 \\
\hline $\mathrm{N}_{22} \mathrm{O}$ & 0.02 & 0.02 & 0.00 & 0.00 & 0.00 & 0.08 & 0.07 & 0.00 \\
\hline$\times 20$ & 0.24 & 0.20 & 0.00 & 0.00 & 0.03 & 0.00 & 0.01 & 0.00 \\
\hline $\mathrm{NiO}$ & 0.10 & 0.03 & 0.12 & 0.11 & 0.01 & 0.15 & 0.08 & 0.13 \\
\hline Total & 92.08 & 90,68 & 100.01 & 101.25 & 101.06 & 102.41 & 101.97 & 99.94 \\
\hline Si & 1.201 & 1.156 & 0.946 & 1.016 & 1.003 & 0.973 & 1.003 & 1.002 \\
\hline $\mathrm{Al}$ & 0.432 & 0.408 & 0.001 & 0.003 & 0.000 & 0.002 & 0.002 & 0.002 \\
\hline $\mathrm{Ti}$ & 0.000 & 0.001 & 0.002 & 0.001 & 0.003 & 0.000 & 0.000 & 0.000 \\
\hline Fe.3 & 0.000 & 0.000 & 0.000 & 0.000 & 0.000 & 0.000 & 0,000 & 0.000 \\
\hline Fet & 0.240 & 0.297 & 0.330 & 0.341 & 0.332 & 0.259 & 0.376 & 0.352 \\
\hline $\mathrm{Mn}$ & 0.001 & 0.000 & 0.008 & 0.004 & 0.006 & 0.006 & 0.008 & 0.009 \\
\hline $\mathrm{Mg}$ & 0.639 & 0.704 & 1.750 & 1.602 & 1.637 & 1.733 & 1.593 & 1.616 \\
\hline $\mathrm{Cz}$ & 0.063 & 0.067 & 0.011 & 0.013 & 0.012 & 0.008 & 0.009 & 0.012 \\
\hline $\mathrm{N}_{2}$ & 0.001 & 0.001 & 0.000 & 0.000 & 0.000 & 0.004 & 0.003 & 0.000 \\
\hline $\mathrm{k}$ & 0.008 & 0.003 & 0.000 & 0.000 & 0.001 & 0.000 & 0.000 & 0.000 \\
\hline $\mathrm{Ni}$ & 0.002 & 0.001 & 0.002 & 0.002 & 0.000 & 0.003 & 0.002 & 0.003 \\
\hline Cartions & 2.587 & 2,642 & 3.050 & 2.982 & 2.994 & 3.028 & 2.996 & 2.996 \\
\hline Fe_FeNg & 0.27 & 0,30 & 0.16 & 0.18 & 0.17 & 0.15 & 0.19 & 0.18 \\
\hline $\mathrm{M}_{8} \mathrm{~F} \in \mathrm{N} / \mathrm{g}$ & 0.73 & 0,70 & 0.84 & 0.82 & 0.83 & 0.85 & 0.81 & 0.82 \\
\hline
\end{tabular}




\begin{tabular}{|c|c|c|c|c|}
\hline Sample & $23000)$ & $23 \mathrm{col}$ & $230 \times 2 a$ & $23 \mathrm{na926}$ \\
\hline \multicolumn{5}{|l|}{ Analysis } \\
\hline Location & $Y Z U 1-3$ & $\mathrm{YZU} \cdot 3$ & YZU-3 & $\times 2013$ \\
\hline Mineral & orv & OLV & oLV & OLV \\
\hline $\mathrm{SiO} 2$ & 39.28 & 39.82 & 40.66 & 39.84 \\
\hline $\mathrm{IiO} 2$ & 0.08 & 0.02 & 0.00 & 0.11 \\
\hline $\mathrm{A}_{2} \mathrm{O} 3$ & 0.02 & 0.00 & 0.00 & $0.0 !$ \\
\hline $\mathrm{Fe} 203$ & 0.00 & $\theta(x)$ & 0.00 & 0.00 \\
\hline Feo & 17.78 & 17.77 & 15.77 & 17.74 \\
\hline Mno & 0.62 & 0.60 & 0.48 & 0.65 \\
\hline $\mathrm{MgO}$ & 42.51 & 42.69 & 43.49 & 41.92 \\
\hline $\mathrm{COO}$ & 0.12 & 0.15 & 0.12 & 0.12 \\
\hline $\mathrm{Na} 2 \mathrm{O}$ & $0, \infty$ & 0.00 & 0.00 & 0.00 \\
\hline $\mathrm{k} 2 \mathrm{O}$ & 0.00 & 0.00 & 0.00 & 0.00 \\
\hline NiO & 0.07 & 0.30 & 0.05 & 0.09 \\
\hline Total & 100.48 & 101.15 & 100.57 & 100.48 \\
\hline $\mathrm{Si}$ & 0.997 & 1.002 & 1.017 & 1.009 \\
\hline A & 0.001 & 0.000 & 0.000 & 0.000 \\
\hline $\mathrm{Ti}$ & 0.002 & 0.000 & 0.000 & 0.002 \\
\hline $\mathrm{Fe} 3$ & 0.000 & 0.000 & 0.000 & 0.000 \\
\hline $\mathrm{Fe} 2$ & 0.377 & 0.374 & 0.330 & 0.376 \\
\hline $\mathrm{Mn}$ & 0.013 & 0.013 & 0.010 & 0.014 \\
\hline $\mathrm{Mg}$ & 1.608 & 1.602 & 1.622 & 1.583 \\
\hline $\mathrm{Cs}$ & 0.003 & 0.004 & 0.003 & 0.003 \\
\hline $\mathrm{Na}$ & 0.000 & 0.000 & 0.000 & 0.000 \\
\hline $\mathrm{K}$ & 0.000 & 0.000 & 0.000 & 0.000 \\
\hline $\mathrm{Ni}$ & 0.001 & 0.002 & 0.001 & 0.092 \\
\hline Crations & 3.002 & 2.997 & 2.983 & 2.989 \\
\hline $\mathrm{Fe}_{-} \mathrm{FeM}_{8}$ & 0.19 & 0.19 & 0.17 & 0.19 \\
\hline $\mathrm{Mg}_{\mathrm{B}} \mathrm{FeMg}$ & 0.81 & 0.81 & 0.83 & 0.81 \\
\hline
\end{tabular}


Composiçăo química, em porcentagem em peso, de micas de rochas "lamprofíricas" do Paraguai.

Flogopita (Flo) Mg:Fe 2:1 $=$ Mg/Fe $>2(\mathrm{mg}>/=0.67)$

Biotita (Bio) Mg:Fe 1:2 = Mg/Fe <2 (mg</ $=0.67)^{*}$

cf. Deer et al. (1962)

\author{
"lamprófiros" \\ $Y$ mi-1 $(10.000-10.050,10 \mathrm{c} .000-10 \mathrm{c} .004)$, \\ Ymi-4: 14.000 (14.000a/b-14.019a/b): br (brecha), I (lava), d (dique), \\ Ymi-7(17.000a-17.000b, 17.001).
}

\author{
"lamproitos" \\ Ymi-5 (15.000-15.013), \\ Yzu-2 (22.000-22.016), Yzu-3 (23.000-23.011), \\ Yzu-6 (sill): 26.000 (26.000a/b-26.048). \\ Titaníferas: todas as micas; \\ Aluminosas: $10.013,10.043,10 \mathrm{c} .000-10 \mathrm{c} .004,10.000-10.002,10.021$, Ymi-4 \\ (todas), 17.000 e Yzu-1 (todas), 15.009, 15.010, 26.010. \\ Com crômio: $21.000,21.001,22.000,10.043,10 \mathrm{c} .000-10 \mathrm{c} .002$ e 17.000
}




\begin{tabular}{|c|c|c|c|c|c|c|c|c|c|}
\hline Sample & 10.000 & 10.001 & 10.002 & 10.003 & 10.004 & 10.005 & 10.006 & 10.007 & 10.008 \\
\hline Anakysis & $g \pi$ & $g m$ & ध्या & $\mathrm{gm}$ & m & क्षा & हाग & gाt & (अ) \\
\hline Locations & XM[-1-p\} & $Y M-1-d$ & $Y M A-1-p l$ & YMQ-1-d & YMA-1-p! & MMI- & YM-1-pl & YMI- $\{-d$ & YMI-1-d \\
\hline Mineral & 810 & Bro & $\mathrm{BIO}$ & FLO & FLO & FLO & $\mathrm{BHO}$ & FLO & Bto \\
\hline $\mathrm{SiO} 2$ & 41.47 & 41.40 & 38.41 & 37.49 & 36.70 & 37.74 & 36.74 & 36.47 & 37.20 \\
\hline $\mathrm{THO}_{2}$ & 3.34 & 3.34 & 4.36 & 4.30 & 5.29 & $5.6 ?$ & 5.28 & 4.87 & 5.08 \\
\hline Al2O3 & 13.37 & 13.37 & 14.26 & 13.32 & 13.35 & 13.70 & 13.03 & 12.24 & 13.42 \\
\hline $\mathrm{Cz} 2 \mathrm{O} 3$ & 0.00 & 0.00 & 0.02 & 0.00 & $0 . \infty$ & 0.02 & 0.05 & 0.00 & 0.01 \\
\hline $\mathrm{FeO}$ & 13.50 & 13.50 & 17.13 & 11.86 & 13.42 & 14.02 & 17.56 & 15.48 & 34.78 \\
\hline $\mathrm{MnO}$ & 0.19 & 0.19 & 0.13 & 0.03 & 0.12 & 0.14 & 0.16 & 0.00 & 0.11 \\
\hline MEO & 14.18 & 14.18 & 11.33 & 17.75 & 15.76 & 16.02 & 12.77 & 18.97 & 16.03 \\
\hline $\mathrm{C} 20$ & 0.00 & 0.00 & 0.00 & 0.00 & 0.07 & 0.00 & 0.00 & 0.00 & 0.00 \\
\hline $\mathrm{B} 2 \mathrm{O}$ & 0.00 & 0.00 & 0.00 & 0.38 & 0.00 & 0.00 & 0.04 & 0.18 & 0.14 \\
\hline $\mathrm{N} 220$ & 0.67 & 0.67 & 0.95 & 0.71 & 0.38 & 0.87 & 0.28 & 0.59 & 0.64 \\
\hline $\mathrm{K} 20$ & 10.46 & 10.46 & 9.18 & 8.74 & 9.56 & $\$ .16$ & 9.39 & $6.3 ?$ & 8.75 \\
\hline Total & 97.18 & 97.11 & 95.77 & 94.58 & 94.65 & 97.34 & 95.30 & 95.11 & 96.16 \\
\hline $\mathrm{Si}$ & 6.021 & 6.017 & 5.759 & 5.580 & 5.518 & 5.511 & 5.588 & 5.428 & 5.515 \\
\hline AINV & 1.979 & 1.983 & 2.241 & 2.335 & 2.364 & 2.356 & 2.334 & 2.146 & 2.343 \\
\hline AlVI & 0.307 & 0.305 & 0.277 & 0.000 & 0.000 & 0.000 & 0.000 & 0.000 & 0.000 \\
\hline $\mathrm{Ti}$ & 0.365 & 0.365 & 0.492 & 0.481 & 0.598 & 0.623 & 0.604 & 0.545 & 0.567 \\
\hline$F \subset 2$ & 1.639 & 1.641 & 2.148 & 1.476 & 1.687 & 1.312 & 2.233 & 1.927 & 1.833 \\
\hline $\mathrm{Cr}$ & 0.000 & 0.000 & 0.002 & 0.000 & 0.000 & 0.002 & 0.006 & 0.000 & 0.001 \\
\hline $\mathrm{Mn}$ & 0.023 & 0.023 & 0.017 & 0.004 & 0.015 & 0.017 & 0.021 & 0.000 & 0.014 \\
\hline $\mathrm{Mg}$ & 3.069 & 3.072 & 2.533 & 3.938 & 3.532 & 3.487 & 2.895 & 4.209 & 3.543 \\
\hline $\mathrm{Ca}$ & 0.000 & 0.000 & 0.000 & 0.000 & 0.011 & 0.000 & 0.000 & 0.000 & 0.000 \\
\hline $\mathrm{Ba}$ & 0.00 & 0.00 & 0.00 & 0.02 & 0.00 & 0.00 & $0 . \infty$ & 0.01 & 0.01 \\
\hline $\mathrm{Na}$ & 0.189 & 0.189 & 0.276 & 0.205 & 0.111 & 0.246 & 0.083 & 0.170 & 0.184 \\
\hline $\mathrm{k}$ & 1.938 & 1.939 & 1.756 & 1.659 & 1.834 & 1.706 & 1.822 & 1.198 & 1.655 \\
\hline Caions & 15.530 & 15.534 & 15.501 & 15.698 & 15.570 & 15.660 & 15.586 & 15.633 & 15.665 \\
\hline 0 & 22.000 & 22.000 & 22.000 & 22.000 & 22.000 & 22.000 & 22.000 & 22.000 & 22.000 \\
\hline $\mathrm{Fe}_{-} \mathrm{FeN} \mathrm{M}_{\mathrm{B}}$ & 0.35 & 0.35 & 0.46 & 0.27 & 0.32 & 0.33 & 0.44 & $0.3 i$ & 0.34 \\
\hline $\mathrm{Mg}_{8} \mathrm{FeM}$ & 0.65 & 0.65 & 0.54 & 0.73 & 0.68 & 0.67 & 0.56 & 0.69 & 0.66 \\
\hline
\end{tabular}




\begin{tabular}{|c|c|c|c|c|c|c|c|c|c|}
\hline Sampic & 10.009 & 10.010 & 10.011 & 10.012 & 10013 & 10.014 & 10.015 & 10.016 & 10.017 \\
\hline Analysis & $\mathrm{g}$ & $g$ & $\mathrm{gm}$ & $g m$ & $g n:$ & $g^{n}$ & $\mathrm{gmb}$ & $g m$ & $g \pi$ \\
\hline Lacation & YME-1-d & YMI-1-d & $\mathrm{MM}-1 \cdot \mathrm{pl}$ & YMA-1-pl & $Y M N+1, p l$ & YMa-1.d & YMII-1-d & YMl-1-d & YML-1-p] \\
\hline Mineral & FLO & FLO & FLO & FLO & FLO & BiO & $\mathrm{BIO}$ & $B 10$ & $\mathrm{BlO}$ \\
\hline $\mathrm{S}: \mathrm{O} 2$ & 36.89 & 36.52 & 37.51 & 38.14 & 39.10 & 37.19 & 36.63 & 34.92 & 36.74 \\
\hline $\mathrm{TiO2}$ & 4.46 & 4.76 & 6.11 & 5.36 & 5.10 & 5.36 & 4.81 & 6.75 & 6.21 \\
\hline $\mathrm{A} 12 \mathrm{O} 3$ & 13.16 & 12.99 & 13.95 & 14.27 & 14.85 & 12.15 & 32.67 & $\{3.32$ & 13.28 \\
\hline $\mathrm{Cr} 2 \mathrm{O} 3$ & 0.02 & 0.00 & 0.00 & 0.00 & 0.01 & 0.02 & 0.00 & 0.03 & 0.04 \\
\hline $\mathrm{F}=\mathrm{O}$ & 13.81 & 12.87 & 13.05 & 13.45 & 13.14 & 14.88 & 37.88 & 19.38 & 15.14 \\
\hline MnO & 0.17 & 0.13 & 0.14 & 0.19 & 0.07 & 0.22 & 0.00 & 0.32 & 0.01 \\
\hline Mgo & 37.14 & 17.75 & 15.72 & 15.89 & 15.54 & 16.04 & 15.18 & 13.59 & 14.41 \\
\hline $\mathrm{C} O$ & 0.00 & 0.00 & 0.00 & 0.00 & 0.00 & 0.00 & 0.00 & 0.00 & 0.00 \\
\hline $\mathrm{B} 2 \mathrm{O}$ & 0.00 & 0.00 & 0.00 & 0.00 & $0, \infty$ & 0.00 & 0.00 & 0.00 & 0.00 \\
\hline $\mathrm{Na} 3 \mathrm{O}$ & 0.51 & 0.84 & 0.71 & 0.66 & 0.65 & 0.72 & 0.53 & 0.97 & 0.60 \\
\hline $\mathrm{K} 20$ & 8.96 & 8.73 & 9.23 & 9.24 & 9.31 & 8.66 & 8.12 & 7.92 & 9.51 \\
\hline Total & 95.12 & 94.59 & 96.42 & 97.20 & 97.37 & 95.24 & 95.82 & 97.80 & 95.94 \\
\hline $\mathrm{Si}$ & 5.512 & 5.470 & 5.504 & 5.549 & 5.651 & 5.577 & 5.513 & 5.230 & 5.493 \\
\hline AIrV & 2.316 & 2.291 & 2.411 & 2.445 & 2.349 & 2.146 & 2.246 & 2.350 & 2.338 \\
\hline Alvi & 0.000 & 0.000 & 0.000 & 0.000 & 0.110 & 0.000 & 0.000 & 0.000 & 0.000 \\
\hline $\mathrm{ri}$ & 0.501 & 0.536 & 0.674 & 0.587 & 0.559 & 0.605 & 0.545 & 0.750 & 0.698 \\
\hline $\mathrm{Fez}$ & 1.726 & 1.612 & 1.602 & 1.637 & 1.588 & 1.866 & 2.250 & 2.490 & 1.893 \\
\hline $\mathrm{Cr}$ & 0.002 & 0.000 & 0.000 & 0.000 & 0.001 & 0.002 & 0.000 & 0.004 & 0.005 \\
\hline Mn & 0.022 & 0.016 & 0.017 & 0.023 & 0.009 & 0.028 & 0.000 & 0.041 & 0.001 \\
\hline $\mathrm{Mg}$ & 3.818 & 3.963 & 3.439 & 3.447 & 3.348 & 3.586 & 3.406 & 3.057 & 3.212 \\
\hline $\mathrm{Ca}$ & 0.000 & 0.000 & 0.000 & 0.000 & 0.000 & 0.000 & 0.000 & 0.000 & 0.000 \\
\hline $\mathrm{Bz}$ & 0.00 & 0.00 & 0.00 & 0.00 & 0.00 & $0 . \infty$ & 0.00 & 0.00 & 0.00 \\
\hline $\mathrm{Na}$ & 0.148 & 0.244 & 0.202 & 0.186 & 0.382 & 0.209 & 0.155 & 0.282 & 0.174 \\
\hline $\mathrm{x}$ & 1.708 & 1.668 & 1.728 & 1.715 & 1.717 & 1.657 & 1.559 & $1.5: 3$ & 1.814 \\
\hline Cations & 15.753 & 15.800 & 15.577 & 15.589 & 15.509 & 15.676 & 15.674 & 15.727 & 15.628 \\
\hline 0 & 22.000 & 22.000 & 22.000 & 22.000 & 22.000 & 22,000 & 22.000 & 22.000 & 22.000 \\
\hline Fe_FeNig & 0.31 & 0.29 & 0.32 & 0.32 & 0.32 & 0.34 & 0.40 & 0.45 & 0.37 \\
\hline $\mathrm{Mg} F \mathrm{FeME}$ & 0.69 & 0.71 & 0.68 & 0.68 & 0.68 & 0.66 & 0.60 & 0.55 & 0.63 \\
\hline
\end{tabular}




\begin{tabular}{|c|c|c|c|c|c|c|c|c|c|}
\hline Sampic & 10.018 & 10.019 & 10.020 & 10.021 & 10.022 & 10.023 & 10.024 & 10.025 & 10.026 \\
\hline Analysis & $g m$ & grar & $g^{m}$ & gin & $g$ & $g n$ & $\mathrm{~g}^{2 x}$ & $g \pi$ & $m$ \\
\hline Iocation & $Y M-l-d$ & YMd-1-p2 & $\mathrm{MM}-1-\mathrm{p} 2$ & YNB-1-p2 & Yhat $1-d$ & YMI-1-p2 & YML1-1-p2 & YMI-1-p2 & YMI-1-p2 \\
\hline Mśnerai & $\mathrm{BHO}$ & Bro & BTO & BIO & FlO & BIO & BFO & FLO & $\mathrm{BlO}$ \\
\hline $\mathrm{SiO} 2$ & 38.14 & 37.34 & 36.81 & 38.86 & 37.47 & 37.18 & 37.87 & 37.49 & 39.25 \\
\hline $\mathrm{TiO2}$ & 5.28 & 5.05 & 5.53 & 4.65 & 5.26 & 5.19 & 5.94 & 5.42 & 4.82 \\
\hline Ai2O3 & 12.88 & 12.58 & 14.48 & 13.29 & 13.46 & 13.15 & 13.20 & 13.37 & 12.80 \\
\hline $\mathrm{Cr} 2 \mathrm{O}_{3}$ & 0.07 & 0.00 & 0.02 & 0.07 & 0.00 & 0.00 & 0.09 & 0.06 & 0.00 \\
\hline $\mathrm{FeO}$ & 17.26 & 15.19 & 14.48 & 14.29 & $\{3.5\}$ & 15.22 & 14.80 & 12.88 & 14.24 \\
\hline $\mathrm{M}$ ino & 0.24 & 0.17 & 0.20 & 0.13 & 0.08 & 0.20 & 0.15 & 0.02 & 0.04 \\
\hline $\mathrm{M} 8 \mathrm{O}$ & 13.88 & 15.53 & 15.83 & 13.30 & 16.03 & 15.00 & 14.90 & 16.86 & 15.94 \\
\hline $\mathrm{C} 2 \mathrm{O}$ & 0.00 & 0.00 & 0.00 & 0.95 & 0.64 & 0.00 & 0.00 & 0.00 & 0.00 \\
\hline$B a O$ & 0.00 & 0.00 & 0.00 & 0.00 & 0.00 & 0.04 & 0.00 & 0.00 & 0.00 \\
\hline $\mathrm{Na} 2 \mathrm{O}$ & 0.46 & 0.56 & 1.26 & 0.61 & 0.65 & 0.73 & 0.77 & 0.72 & 0.50 \\
\hline $\mathrm{K} 20$ & 9.42 & 8.57 & 8.73 & 9.05 & 9.06 & 9.16 & 9.25 & 9.04 & $8.9\}$ \\
\hline Tot:a & 97.63 & 94.99 & 97.34 & 95.20 & 96.22 & 95.87 & 96.97 & 95.86 & 96.45 \\
\hline $\mathrm{Si}$ & 5.636 & 5.606 & 5.390 & 5.793 & 5.530 & 5.555 & 5.573 & 5.527 & 5.744 \\
\hline AIIV & 2.242 & 2.224 & 2.497 & 2.207 & 2.339 & 2.314 & 2.288 & 2.321 & 2.208 \\
\hline$A_{i} v_{1}$ & 0.000 & 0.000 & 0.000 & 0.126 & 0.000 & 0.000 & 0.000 & 0.000 & 0.000 \\
\hline $\mathrm{Ti}$ & 0.587 & 0.570 & 0.609 & 0.521 & $0.58 d$ & 0.583 & 0.658 & 0.601 & 0.531 \\
\hline $\mathrm{Fe}^{2}$ & 2.133 & 1.907 & 1.773 & 1.782 & 1.675 & 1.902 & 1.822 & 1.588 & 1.745 \\
\hline $\mathrm{Cr}$ & 0.008 & 0.000 & 0.002 & 0.008 & 0.000 & 0.000 & 0.010 & 0.007 & 0.000 \\
\hline Mr & 0.030 & 0.023 & 0.025 & 0.016 & 0.010 & 0.025 & 0.019 & 0.002 & 0.005 \\
\hline $\mathrm{Mg}$ & 3.058 & 3.476 & 3.456 & 2.956 & 3.527 & 3.341 & 3.269 & 3.705 & 3.481 \\
\hline $\mathrm{Cr}$ & 0.000 & 0.000 & 0.000 & 0.152 & 0.101 & 0.000 & 0.000 & 0.000 & 0.000 \\
\hline $\mathrm{Ba}$ & 0.00 & 0.00 & 0.00 & $0 . \infty$ & 0.00 & 0.00 & 0.00 & 0.00 & 0.00 \\
\hline $\mathrm{Ng}$ & 0.132 & 0.163 & 0.358 & 0.176 & 0.186 & 0.211 & 0.220 & 0.206 & 0.142 \\
\hline $\mathrm{K}$ & 1.776 & 1.641 & 1.631 & 1.721 & 1.706 & 1.746 & 1.737 & 1.700 & 1.665 \\
\hline Cxaions & 15.602 & 15.609 & 15.741 & 15.458 & 15.658 & 15.677 & 15.596 & 15.657 & 15.521 \\
\hline 0 & 22.000 & 22.000 & 22.000 & 22.000 & 22.000 & 22.000 & 22.000 & 22.000 & 22.000 \\
\hline Fe $F$ FeMg & 0.41 & 0.35 & 0.34 & 0.38 & 0.32 & 0.36 & 0.36 & 0.30 & 0.33 \\
\hline Mg_Ferds & 0.59 & 0.65 & 0.66 & 0.62 & 0.68 & 0.68 & 0.64 & 0.70 & 0.67 \\
\hline
\end{tabular}




\begin{tabular}{|c|c|c|c|c|c|c|c|c|c|}
\hline Sampic & 10.027 & 10.028 & 10.029 & 10.030 & 10.031 & 10.032 & 10.033 & 10.034 & 10.035 \\
\hline Aralysis & $g m$ & $g$ & $g m$ & $g n$ & $\mathrm{gm}$ & $8 \pi$ & $g n$ & $g m$ & $\mathrm{gm}$ \\
\hline Laction & YMI-1-p2 & YMa-1-p2 & YM[-1-p] & YMI-1-pl & YM-I-pl & YMa-i-pi & YMA-I-pl & YMI-1-pl & YMI-1-pl \\
\hline Mineral & FLO & FLO & FLO & BIO & BIO & FLO & FLO & $\mathrm{BIO}$ & FLO \\
\hline $\mathrm{SiO} 2$ & 36.74 & 37.34 & 37.39 & 36.76 & 37.30 & 37.44 & 37.90 & 35.72 & 38.32 \\
\hline $\mathrm{THO} 2$ & 4.88 & 5.20 & 5.11 & 4.67 & 6.49 & 5.15 & 5.57 & 5.08 & 4.47 \\
\hline $\mathrm{A} 1203$ & 12.45 & 13.22 & 12.72 & 12.94 & 13.72 & 12.88 & 13.29 & 12.05 & 13.86 \\
\hline $\mathrm{Cr} 203$ & 0.00 & 0.00 & 0.05 & 0.00 & 0.00 & 0.04 & 0.02 & 0.00 & 0.02 \\
\hline $\mathrm{FeO}$ & 12.72 & 14.03 & 13.61 & 16.01 & 16.24 & 16.08 & 14.22 & 28.68 & 12.75 \\
\hline $\mathrm{MnO}$ & 0.12 & 0.12 & 0.09 & 0.22 & 0.18 & 0.14 & 0.19 & 0.24 & 0.14 \\
\hline $\mathrm{MgO}$ & 16.99 & 16.60 & 17.41 & 15.53 & 13.45 & 16.59 & 16.24 & 15.21 & 16.93 \\
\hline $\mathrm{C} \times$ & 0.09 & 0.00 & 0.00 & 0.00 & 0.00 & 0.08 & 0.08 & 0.16 & 0.07 \\
\hline $\mathrm{B} 20$ & 0.00 & 0.00 & 0.00 & 0.00 & 0.18 & 0.00 & 0.00 & 0.00 & 0.18 \\
\hline Na2O & $0.4 !$ & 0.48 & 0.62 & 0.53 & 0.44 & 0.81 & 0.64 & 0.50 & 0.46 \\
\hline $\mathrm{K} 2 \mathrm{O}$ & 9.14 & 8.88 & 8.86 & 9.28 & 9.77 & 9.19 & 9.13 & 8.33 & 9.38 \\
\hline Total & 93.54 & 95.87 & 95.86 & 95.94 & 97.37 & 96.40 & 97.28 & 95.97 & 96.58 \\
\hline $\mathrm{Si}$ & 5.566 & 5.528 & 5.532 & 5.517 & 5.502 & 5.535 & 5.540 & 5.425 & 5.602 \\
\hline AIN & 2.221 & 2.305 & 2.216 & 2.287 & 2.383 & 2.242 & 2.288 & 2.155 & 2.386 \\
\hline AlVT & 0.000 & 0.000 & 0.000 & 0.000 & 0.000 & 0.000 & 0.000 & 0.000 & 0.000 \\
\hline $\mathrm{Ti}$ & 0.556 & 0.579 & 0.569 & 0.527 & 0.720 & 0.573 & 0.612 & 0.580 & 0.492 \\
\hline $\mathrm{Fe} 2$ & 1.611 & 1.737 & 1.684 & 2.009 & 2.003 & 1.741 & 1.738 & 2.373 & 1.559 \\
\hline $\mathrm{Ct}$ & 0.000 & 0.000 & 0.006 & 0.000 & 0.000 & 0.005 & 0.002 & 0.000 & 0.002 \\
\hline $\mathrm{Nan}$ & 0.015 & 0.015 & 0.011 & 0.028 & 0.022 & 0.018 & 0.024 & 0.031 & 0.017 \\
\hline $\mathrm{Mg}$ & 3.837 & 3.664 & 3.840 & 3.475 & 2.958 & 3.656 & 3.539 & 3.444 & 3.690 \\
\hline $\mathrm{Cs}$ & 0.015 & 0.000 & 0.000 & 0.000 & 0.000 & 0.013 & 0.013 & 0.026 & 0.011 \\
\hline $\mathrm{Be}$ & 0.00 & 0.00 & 0.00 & 0.00 & 0.01 & 0.00 & 0.00 & 0.00 & 0.01 \\
\hline $\mathrm{Na}$ & 0.120 & 0.138 & 0.178 & 0.154 & 0.126 & 0.232 & 0.181 & 0.147 & 0.130 \\
\hline $\mathrm{x}$ & 1.766 & 1.677 & 1.672 & 1.777 & 1.839 & 1.733 & 1.703 & 1.614 & 1.749 \\
\hline Cations & 15.707 & 15.643 & 15.708 & 15.774 & 15.563 & 15.748 & 15.640 & 15.795 & 15.648 \\
\hline 0 & 22.000 & 22.000 & 22.000 & 22.000 & 22.000 & 22.000 & 22.000 & 22.000 & 22.000 \\
\hline $\mathrm{Fe} F$ FeMG & 0.30 & 0.32 & 0.30 & 0.37 & 0.40 & 0.32 & 0.33 & 0.41 & 0.30 \\
\hline Mg_Felig & 0.70 & 0.68 & 0.70 & 0.63 & 0.60 & 0.68 & 0.67 & 0.59 & 0.70 \\
\hline
\end{tabular}




\begin{tabular}{|c|c|c|c|c|c|c|c|c|c|}
\hline Sample & 10.036 & 10.037 & 10.038 & 10.039 & 10040 & $10.04\}$ & 10.042 & 10.043 & 10.045 \\
\hline Analysis & हत्र & $g m$ & $8 \pi$ & $g \pi$ & \&m & $\operatorname{gxt}$ & gn & $\mathrm{gm}$ & $g m$ \\
\hline Eocation & $\mathrm{YMa}-1-\mathrm{pl}$ & YMI-1-pi & YM-1-pi & $Y M-i-p l$ & 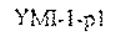 & YMa-1-p! & $Y M 1-1-p^{2}$ & $X M(-1-1-\delta$ & YMM-1.d \\
\hline Mineral & FLO & FLO & Bro & Bio & FLO & BHO & BIO & FLO & BlO \\
\hline $\mathrm{SiO}_{2}$ & 36.25 & 38.25 & 37.75 & 36.74 & 3752 & 37.98 & 37.48 & 38.67 & 32.49 \\
\hline riO2 & 6.06 & 4.92 & 5.42 & 5.28 & 5.03 & 4.93 & 5.29 & 2.74 & 6.01 \\
\hline $\mathrm{Al} 2 \mathrm{O} 3$ & 13.12 & 13.34 & 13.08 & 13.03 & 13.10 & 12.67 & 13.15 & 14.75 & 11.54 \\
\hline $\mathrm{Cr} 2 \mathrm{O} 3$ & 0.00 & 0.00 & 0.00 & 0.05 & 0.04 & 0.00 & 0.07 & 0.28 & 0.00 \\
\hline $\mathrm{F} \in \mathrm{O}$ & 13.17 & 12.61 & 14.80 & 17.56 & 13.26 & 16.91 & 14.41 & 6.34 & 19.10 \\
\hline MrO & 0.11 & 0.12 & 0.23 & 0.16 & 0.21 & 0.19 & 0.17 & 0.01 & 0.30 \\
\hline $\mathrm{MgO}$ & 15.86 & 16.99 & 14.88 & 12.77 & 17.29 & 15.72 & 16.04 & 22.66 & 35.58 \\
\hline $\mathrm{CWO}$ & 0.05 & 0.00 & 0.06 & 0.00 & 0.00 & 0.00 & 0.00 & 0.15 & 0.00 \\
\hline $\mathrm{BaO}$ & $0 . \infty$ & 0.04 & 0.25 & 0.04 & $0 . \infty$ & 0.00 & 0.00 & 0.00 & 0.00 \\
\hline $\mathrm{Na} 2 \mathrm{O}$ & 1.71 & 0.80 & 0.80 & 0.28 & 0.60 & 0.43 & 0.78 & 0.59 & 0.75 \\
\hline $\mathrm{K} 20$ & 9.11 & 9.23 & 9.07 & 9.39 & 9.05 & 9.36 & 9.02 & $9.4 \hat{z}$ & 7.99 \\
\hline Total & 95.44 & 96.30 & 96.34 & 95.30 & 96.10 & 97.19 & 96.41 & 95.62 & 93.76 \\
\hline $\mathrm{Si}$ & 5.422 & 5.605 & 5.602 & 5.588 & 5.532 & 5.630 & 5.539 & 5.535 & 5.116 \\
\hline AIIV & 2.311 & 2.302 & 2.286 & 2.334 & 2.275 & 2.212 & 2.289 & 2.465 & 2.140 \\
\hline AIVI & 0.000 & 0.000 & 0.000 & 0.000 & 0.000 & 0,000 & 0.000 & 0.021 & 0.000 \\
\hline $\mathrm{Ti}$ & 0.682 & 0.542 & 0.605 & 0.604 & 0.558 & 0.550 & 0.588 & 0.295 & 0.712 \\
\hline $\mathrm{Fe} 2$ & 1.647 & 1.545 & 1.837 & 2.233 & 1.635 & 2.096 & 1.781 & 0.759 & 2.515 \\
\hline $\mathrm{Cs}$ & 0.000 & 0.000 & 0.000 & 0.006 & 0.005 & 0.000 & 0.008 & 0.032 & 0.000 \\
\hline Mn & 0.014 & 0.015 & 0.029 & 0.021 & 0.026 & 0.024 & 0.021 & 0.001 & 0.040 \\
\hline$M_{B}$ & 3.536 & 3.711 & 3.292 & 2.895 & 3.800 & 3.253 & 3.534 & 4.835 & 3.658 \\
\hline $\mathrm{Ca}$ & 0.008 & 0.000 & 0.010 & 0.000 & 0.000 & 0.000 & 0.000 & 0.023 & 0.000 \\
\hline $\mathrm{Bz}$ & 0.00 & 0.00 & 0.01 & 0.00 & 0.00 & 0.00 & 0.00 & 0.00 & 0.00 \\
\hline $\mathrm{Na}$ & 0.496 & 0.227 & 0.230 & 0.083 & 0.172 & 0.124 & 0.224 & 0.164 & 0.229 \\
\hline $\mathrm{x}$ & 1.738 & 1.725 & 1.717 & 1.822 & 1.702 & 1.770 & 1.701 & 1.722 & 1.605 \\
\hline Cations & 15.854 & 15.672 & 15.618 & 15.586 & 15.705 & 15.659 & 15.685 & 15.852 & 16.015 \\
\hline 0 & 22.000 & 22.000 & 22.000 & 22.000 & 22.000 & 22.000 & 22.000 & 22.090 & 22.000 \\
\hline $\mathrm{Fe}$-Felgg & 0.32 & 0.29 & 0.36 & 0.44 & 0.30 & 0.39 & 0.34 & 0.14 & 0.41 \\
\hline $\mathrm{MB}_{B_{z}} \mathrm{~F} \in \mathrm{MB}_{8}$ & 0.68 & 0.71 & 0.64 & 0.56 & 0.70 & 0.61 & 0.65 & 0.86 & 0.59 \\
\hline
\end{tabular}




\begin{tabular}{|c|c|c|c|c|c|c|c|c|c|}
\hline Sample & 10050 & $10 c .000$ & $10 c .00\}$ & $10 c .0022$ & $10 \mathrm{c} 003$ & $10 \mathrm{cos} 4$ & $14000 \mathrm{a}$ & $14.0000 \mathrm{~b}$ & $\{4.00) 1 \mathrm{a}$ \\
\hline Analysis & $\mathrm{gm}$ & fen & fen & $\{e n$ & Eetro & fen & fers & fen & fen \\
\hline Locedion & $\mathrm{YMI}-1-\mathrm{p} 2$ & YMI-1. & YM-1.c & $\mathrm{YM} A \mathrm{l}, \mathrm{c}$ & $\gamma_{\mathrm{MAF}} \cdot \mathrm{c}$ & YM-1, & $\gamma M a-4 d$ & $Y M-4-d$ & YM-4-d \\
\hline Mineral & FLO & FLO & FLO & FLO & Flo & FLO & FLO & FLO & FL.O \\
\hline $\mathrm{SiO} 2$ & 38.55 & 37.58 & 37.56 & 37.75 & 35.46 & 37.91 & 36.50 & 3616 & 37.31 \\
\hline $\mathrm{TiO} 2$ & 4.66 & 3.81 & 3.83 & 3.49 & 3.55 & 3.21 & 4.01 & 4.30 & 4.59 \\
\hline $\mathrm{A} 2 \mathrm{O} 3$ & 13.26 & 15.59 & 15.80 & 15.36 & $14.6\}$ & 15.45 & 16.14 & 15.61 & 16.15 \\
\hline $\mathrm{Cr} 203$ & 0.06 & $0.4 !$ & 0.29 & 0.88 & 0.18 & 1.59 & 0.02 & 0.02 & 0.00 \\
\hline $\mathrm{F} \infty$ & 12.01 & 8.25 & 8.88 & 7.02 & 8.82 & 8.42 & 13.10 & 11.17 & 11.25 \\
\hline $\mathrm{AnO}$ & 0.13 & 0.11 & 0.10 & 0.05 & 0.00 & 0.00 & 0.01 & 0.12 & 0.09 \\
\hline $\mathrm{M} \$ \mathrm{O}$ & 17.69 & 19.32 & 18.99 & 18.96 & 18.22 & $99.3\}$ & 17.80 & 17.83 & 17.7 \\
\hline $\mathrm{CaO}$ & 0.00 & 0.00 & 0.00 & 0.00 & 0.03 & 0.00 & 0.00 & 0.00 & 0.00 \\
\hline BaO & 0.0 & 0.46 & 0.19 & 0.28 & 0.44 & 0.34 & 0.38 & 0.54 & 0.47 \\
\hline $\mathrm{N}_{2} 2 \mathrm{O}$ & 0.50 & 0.56 & 0.46 & 0.5 & 0.45 & 0.49 & 0.57 & 0.53 & 0.47 \\
\hline $\mathrm{K} 2 \mathrm{O}$ & 9.62 & 9.91 & 9.75 & 9.82 & 9.03 & 8.75 & 9.18 & 9.29 & 9.28 \\
\hline Total & 96.48 & 96.09 & 95.85 & 95.01 & 90.79 & 95.47 & 95.71 & 95.57 & 97.32 \\
\hline Si & 5.625 & 5.443 & 5.446 & 5.509 & 5.446 & 5.492 & 5.354 & 5.336 & 5.381 \\
\hline AltV & 2.279 & 2.557 & 2554 & $2.49\}$ & 2.554 & 2.508 & 2.646 & 2.654 & 2.619 \\
\hline AIVI & 0.000 & 0.102 & 0.144 & 0.149 & 0.088 & 0.128 & 0.142 & 0.049 & 0.124 \\
\hline $\mathrm{Ti}$ & 0.511 & 0.415 & 0.418 & 0.383 & 0.410 & 0.350 & 0.442 & 0.477 & 0.498 \\
\hline $\mathrm{Fe}_{2}$ & i.466 & 0.999 & 1.077 & 0.967 & 1.133 & 1.020 & 1.362 & 1.378 & 1.357 \\
\hline $\mathrm{Cr}$ & 0.007 & 0.047 & 0.033 & 0.101 & 0.022 & 0.182 & 0.002 & 0.032 & 0.000 \\
\hline Mn & 0.016 & 0.013 & 0.012 & 0.006 & 0.000 & 0.000 & 0.001 & 0.015 & 0.011 \\
\hline M8 & 3.848 & 4.172 & 4.105 & 4.125 & 4.172 & 4.170 & 3.892 & 3.922 & 3.808 \\
\hline $\mathrm{Ca}$ & 0.000 & 0.014 & 0.000 & 0.000 & 0.005 & 0.000 & 0.000 & 0.000 & 0.000 \\
\hline $\mathrm{Ba}$ & 0.00 & 0.03 & 0.01 & 0.02 & 0.03 & 0.02 & 0.02 & 0.03 & 0.03 \\
\hline $\mathrm{Na}$ & 0.141 & 0.157 & 0.129 & $0.14 i$ & 0.134 & 0.138 & 0.162 & 0.152 & 0.131 \\
\hline $\mathrm{K}$ & 1.391 & 1.831 & 1.804 & 1.828 & 1.769 & 1.617 & 1.718 & 1.749 & 1.708 \\
\hline Cations & 15.684 & 15.780 & 15.732 & 15.720 & 15.763 & 15.625 & 15.741 & 15.774 & 15.667 \\
\hline 0 & 22.000 & 22.000 & 22.000 & 22.000 & 22.000 & 22.000 & 22.000 & 22.000 & 22.000 \\
\hline $\mathrm{Fe}_{-} \mathrm{FeNg}$ & 0.28 & 0.19 & 0.21 & 0.19 & 0.21 & 0.20 & 0.26 & 0.26 & 0.26 \\
\hline $\mathrm{MB}_{\mathrm{B}} \mathrm{FeNB}$ & 0.72 & 0.81 & 0.79 & 0.81 & 0.79 & 0.80 & 0.74 & 0.76 & 0.74 \\
\hline
\end{tabular}




\begin{tabular}{|c|c|c|c|c|c|c|c|c|c|}
\hline Sample & 14.0016 & $14.002 \mathrm{a}$ & $14,002 b$ & 14.0038 & $\{4 \ldots\} b$ & $14 \cdot(x)+4 a$ & $14.004 \mathrm{~b}$ & $14.005 a$ & $14.005 b$ \\
\hline Analysis & fen & fer & fen & fen & fen & fen & fen & fen & fen \\
\hline Location & XMi $-4-d$ & YMisd & YMI-4-d & YM-4-d & YM- $-4-d$ & XMI-4 & $Y M G-4$ & YMI-4 & YM-4 \\
\hline Mineral & FLO & FLO & FLO & FLO & FLO & FLO & FLO & Fi.O & FLO \\
\hline $\mathrm{SiO} 2$ & 37.08 & 34.51 & 37.44 & 36.60 & 35.62 & 370 & & & \\
\hline $\mathrm{FiO} 2$ & 4.48 & 3.83 & 4.78 & 4.15 & 4.0 & & & 36.38 & 3668 \\
\hline $\mathrm{A} 2203$ & 16.49 & 14.94 & 16.15 & 15.84 & 15.24 & 3.66 & 4.34 & 4.89 & 4.78 \\
\hline $\mathrm{Cr} 203$ & 0.01 & 0.11 & 0.08 & 0.04 & & 15.69 & 16.02 & 16.44 & 16.36 \\
\hline $\bar{F} \times O$ & 11.44 & 9.91 & 11.36 & 11.41 & 0.01 & 0.09 & 0.00 & 0.02 & 0.02 \\
\hline $\mathrm{MnO}$ & 0.15 & 0.00 & 0.07 & $\begin{array}{l}11.41 \\
0.08\end{array}$ & 10.74 & 10.58 & 11.16 & 11.33 & 12.87 \\
\hline $\mathrm{MgO}$ & 17.07 & 17.32 & 17.70 & & 0.0 & 0.07 & 0.06 & 0.04 & 0.09 \\
\hline $\mathrm{C} \approx$ & 0.00 & 0.00 & 0.00 & 17.36 & 17.84 & 18.40 & 17.69 & 17.37 & 16.67 \\
\hline $\mathrm{BaO}$ & 0.29 & 0.22 & 0.36 & 0.00 & 0.0 & 0,00 & 0.00 & 0.00 & $0 . \infty$ \\
\hline $\mathrm{N} 22 \mathrm{O}$ & 0.58 & 0.61 & 0.66 & 0.16 & 0.67 & 0.29 & 0.70 & 0.90 & 0.79 \\
\hline $\mathrm{k} 20$ & 9.28 & 8.77 & 9.13 & 0.65 & 0.55 & 0.56 & 0.60 & 0.57 & 0.72 \\
\hline Toial & 96.87 & 90.22 & $\begin{array}{l}9.13 \\
97.73\end{array}$ & 9.48 & 9.54 & 8.96 & 9.42 & 9.22 & 9.04 \\
\hline Si & $5.37 \%$ & 5.358 & $\begin{array}{l}97.73 \\
5.374\end{array}$ & 95.77 & 94.22 & 95.31 & 96.39 & 97.16 & 98.02 \\
\hline AIIV & 2.626 & 2.642 & $\begin{array}{l}5.374 \\
2.626\end{array}$ & 5.378 & 5.342 & 5.425 & 5.329 & 5.286 & 5.310 \\
\hline Alv & 0.188 & 0.089 & $\begin{array}{l}2.626 \\
0.104\end{array}$ & 2.622 & 2.658 & 2.575 & 2.671 & 2.714 & 2.690 \\
\hline $\mathrm{Ti}$ & 0.488 & 0.447 & & 0.119 & 0.034 & 0.133 & 0.091 & 0.099 & 0.099 \\
\hline$F \subset 2$ & 1.386 & 1.287 & $\begin{array}{l}0.516 \\
1.364\end{array}$ & 0.459 & 0.451 & 0.404 & 0.478 & 0.534 & 0.521 \\
\hline$C r$ & 0.001 & 0.013 & $\begin{array}{l}1.364 \\
0.009\end{array}$ & 1.402 & 1.347 & 1297 & 1.366 & 1.377 & 1.558 \\
\hline $\mathrm{Mn}$ & 0.018 & 0.000 & 0.009 & 0.005 & 0.001 & 0.010 & 0.000 & 0.002 & 0.002 \\
\hline Mg & 3.688 & 4008 & 0.009 & 0.010 & 0.001 & 0.009 & 0.007 & 0.095 & 0.011 \\
\hline $\mathrm{Ca}$ & 0.000 & 0.000 & 3.787 & 3.803 & 3.989 & 4.021 & 3.861 & 3.753 & 3.598 \\
\hline$B a$ & 0.02 & 0.01 & 0.000 & 0.000 & 0.000 & 0.000 & 0.000 & 0.000 & 0.000 \\
\hline $\mathrm{Na}$ & 0.163 & 0.184 & 0.02 & 0.01 & 0.04 & 0.02 & 0.04 & 0.05 & 0.04 \\
\hline $\mathrm{K}$ & 1.716 & 1.737 & 0.184 & 0.185 & 0.160 & 0.159 & 0.170 & 0.161 & 0.202 \\
\hline Cations & 15.668 & 15.775 & 1.672 & 1.777 & 1.825 & 1.676 & 1.759 & 1.709 & 1.670 \\
\hline o & 22.000 & 22.000 & 15.665 & 15.770 & 15.848 & 15.729 & 15.772 & 15.700 & 15.701 \\
\hline $\mathrm{Fe} F \mathrm{Fe}$ & 0.27 & 0.24 & 22.000 & 22.000 & 22.000 & 22.000 & 22.000 & 22.000 & 22.000 \\
\hline $\mathrm{Ag} F e M_{8}$ & 0.73 & 0.76 & 0.26 & 0.27 & 0.25 & 0.24 & 0.26 & 0.27 & 0.30 \\
\hline & & & 0.74 & 0.73 & 0.75 & 0.76 & 0.74 & 0.73 & 0.70 \\
\hline
\end{tabular}




\begin{tabular}{|c|c|c|c|c|c|c|c|c|c|}
\hline Sample & $14.006 a$ & $\$ 4.006 b$ & $14.007 \mathrm{a}$ & $14.007 \mathrm{~b}$ & $34.008 \mathrm{a}$ & $14.0088 b$ & 14.009 & 14.0108 & $14.010 \mathrm{~b}$ \\
\hline Analysis & fert & fen & fen & fen & fen & fen & fen & $\mathrm{fen}$ & fent \\
\hline Location & YML-4 & YM-4 & YM-4 & YMI-4 & $\mathrm{MM}-4$ & $\mathrm{YM}-4$ & $Y M(j-4-b r$ & YME-4-I & $Y M M-4-4$ \\
\hline Minerai & FLO & BIO & FLO & FLO & FLO & FLO & FLO & FLLO & FLO \\
\hline $\mathrm{SiO} 2$ & 37.05 & 32.82 & 36.17 & 37.03 & 36.48 & 35.55 & 37.08 & 36.92 & 36.94 \\
\hline $\mathrm{TOO}$ & 4.82 & 4.82 & 4.20 & 3.26 & 3.87 & 4.53 & 4.18 & 3.70 & 3.60 \\
\hline $\mathrm{A}: 2 \mathrm{O}$ & 16.38 & 14.52 & 15.96 & 16.03 & 16.26 & 15.72 & 16.22 & 16.29 & 15.97 \\
\hline $\mathrm{Cr} 2 \mathrm{O}$ & 0.01 & 0.07 & 0.05 & 0.04 & 0.07 & 0.00 & 0.03 & 0.16 & 0.10 \\
\hline $\mathrm{FoO}$ & 11.30 & 23.21 & 11.41 & 10.37 & 10.22 & 11.15 & 11.77 & 10.31 & 10.39 \\
\hline $\mathrm{N}$ no & 0.04 & 0.30 & 0.12 & 0.10 & 0.08 & 0.05 & 0.01 & 0.02 & 0.01 \\
\hline $\mathrm{MgO}$ & 17.79 & 12.22 & 3790 & 18.66 & 18.72 & 17.96 & 17.72 & 18.60 & 18.62 \\
\hline$\infty$ & 0.00 & 0.11 & 0.05 & 0.00 & 0.00 & 0.00 & 0.00 & 0.00 & 0.00 \\
\hline $\mathrm{B} \infty \mathrm{O}$ & 0.54 & 0.75 & 0.79 & 0.36 & 0.13 & 0.54 & 0.00 & 0.00 & 0.00 \\
\hline $\mathrm{N} 22 \mathrm{O}$ & $0.6 \hat{3}$ & 0.55 & 0.62 & 0.58 & 0.68 & 0.58 & 0.62 & 0.44 & 0.46 \\
\hline $\mathrm{K} 2 \mathrm{O}$ & 9.68 & 7.41 & 9.35 & 9.55 & 9.24 & 9.39 & 9.21 & 9.51 & 9.49 \\
\hline Total & 98.24 & 96.78 & 96.32 & 95.98 & 95.75 & 95.47 & 96.84 & 95.95 & 95.58 \\
\hline $\mathrm{Si}$ & 5.316 & 5.078 & 5.307 & 5.405 & 5.324 & 5.263 & 5.370 & 5.370 & 5.396 \\
\hline AlrV & 2.684 & 2.645 & 2.693 & 2.595 & 2.676 & 2.737 & 2.630 & 2.630 & 2.604 \\
\hline AlvI & 0.084 & 0.000 & 0.065 & 0.160 & 0.119 & 0.003 & 0.136 & 0.160 & 0.143 \\
\hline $\mathrm{Ti}$ & 0.520 & $0.56 \mathrm{I}$ & 0.464 & 0.358 & 0.425 & 0.504 & 0.455 & 0.405 & 0.396 \\
\hline Fez & 1.356 & 3.003 & 1.363 & 1.266 & 1.247 & 1.380 & 1.426 & 1.254 & 1.269 \\
\hline $\mathrm{Ct}$ & 0.001 & 0.009 & 0.006 & 0.005 & 0.008 & 0.000 & 0.003 & 0.018 & 0.012 \\
\hline Mn & 0.005 & 0.039 & 0.015 & 0.012 & 0010 & 0.006 & 0.001 & 0.002 & 0.001 \\
\hline $\mathrm{Mq}$ & 3.805 & 2.818 & 3.915 & 4.060 & 4.073 & 3.963 & 3.826 & 4.033 & 4.055 \\
\hline $\mathrm{Ca}$ & 0.000 & 0.018 & 0.008 & 0.000 & 0.000 & 0.000 & 0.000 & 0.000 & 0.000 \\
\hline $\mathrm{Ba}$ & 0.03 & 0.05 & 0.05 & 0.02 & 0.01 & 0.03 & 0.00 & 0.00 & 0.00 \\
\hline $\mathrm{Na}$ & 0.175 & 0.165 & 0.176 & 0.164 & 0.192 & 0.166 & 0.174 & 0.124 & 0.130 \\
\hline $\mathrm{K}$ & 1.772 & 1.463 & 1.750 & 1.778 & 3.720 & 1.773 & 1.702 & 1.765 & 1.768 \\
\hline Cations & 15.748 & 15.849 & 15.812 & 15.823 & 15.804 & 35.825 & 15.723 & 15.761 & 15.774 \\
\hline 0 & 22.000 & 22.000 & 22.000 & 22.000 & 22.000 & 22.000 & 22.000 & 22.000 & 22.000 \\
\hline $\mathrm{Fe}$ _ FeNg & 0.26 & 0.52 & 0.26 & 0.24 & 0.23 & 0.26 & 0.27 & 0.24 & 0.24 \\
\hline$M_{B_{Z}} F \in M_{8}$ & 0.74 & 0.48 & 0.74 & 0.76 & 0.77 & 0.74 & 0.73 & 0.76 & 0.76 \\
\hline
\end{tabular}




\begin{tabular}{|c|c|c|c|c|c|c|c|c|c|}
\hline Sample & $14011 a$ & $14011 \mathrm{~b}$ & $14.012 a$ & 140120 & 10013 & 14.014 & $14.015 a$ & $18.015 b$ & 14016 \\
\hline Andysis & fen & fen & fen & fen & fen & fen & fen & fent & fen \\
\hline Location & YML-4.1 & $\mathrm{YM}-4-1$ & YMI-4! & YMI-4-1 & YMa-4-1 & YM:-4. & YM-4- & $\mathrm{XM}-4-1$ & $Y M-4-1$ \\
\hline Mineral & FLO & FLO & FLOO & FLO & FLO & FLO & FLO & FLO & FLO \\
\hline $\mathrm{SiO} 2$ & 37.17 & 36.89 & 39.40 & & & & & & \\
\hline TiO2 & 3.63 & 2.86 & 2.39 & & 4.65 & $\begin{array}{l}36.81 \\
4.42\end{array}$ & 3671 & 36.70 & 36.47 \\
\hline $\mathrm{Al} 2 \mathrm{O} 3$ & 16.22 & 16.31 & 16.33 & & $\begin{array}{l}4.45 \\
16.41\end{array}$ & 4.42 & 3.05 & 3.43 & 4.92 \\
\hline $\mathrm{Cr}_{2} 2 \mathrm{O}$ & 0.07 & 0.16 & 0.09 & $\begin{array}{l}15.13 \\
0.02\end{array}$ & $\begin{array}{l}16.41 \\
0.00\end{array}$ & 16.59 & 16.06 & 16.27 & 15.81 \\
\hline $\mathrm{FeO}$ & 10.77 & 9.93 & 8.22 & $\begin{array}{l}0.02 \\
12.73\end{array}$ & & 0.06 & 0.15 & 0.19 & 0.03 \\
\hline $\mathrm{M}=\mathrm{O}$ & 0.01 & 0.00 & 0.09 & $\begin{array}{l}12.73 \\
0.36\end{array}$ & 1115 & 10.94 & 10.71 & 10.29 & 11.47 \\
\hline $\mathrm{MgO}$ & 8.64 & 19.59 & 18.87 & 0.16 & 0.02 & 0.14 & 0.10 & 0.06 & 0.07 \\
\hline $\mathrm{CaO}$ & 0.00 & $0 . \infty$ & 0.00 & 17.34 & 17.83 & 17.65 & 18.77 & 18.63 & 17.71 \\
\hline $\mathrm{BaO}$ & 0.00 & & & 0.49 & 0.00 & 0.00 & 0.00 & 0.00 & 0.00 \\
\hline $\mathrm{Na} 2 \mathrm{O}$ & 0.53 & & $\begin{array}{l}0.00 \\
0.37\end{array}$ & 0.00 & 0.00 & 0.00 & 0.00 & 0.00 & 0.63 \\
\hline $\mathrm{K} 20$ & 9.50 & & $\begin{array}{l}0.37 \\
7.54\end{array}$ & 0.43 & $0.5 \%$ & 0.70 & 0.43 & 0.57 & 0.57 \\
\hline Total & 95.54 & 8.84 & 7.54 & 5.43 & 9.37 & 9.30 & 9.39 & 9.28 & 8.82 \\
\hline Si & 5.382 & $\begin{array}{l}95.00 \\
5387\end{array}$ & 93.30 & 94.26 & 95.95 & 95.61 & 95.37 & 95.62 & 96.50 \\
\hline Alry & 2.618 & 5.387 & 5.717 & 5.737 & 5.286 & 5.332 & 5.384 & 5.366 & 5.320 \\
\hline AIVI & 0.148 & 2.613 & 2.283 & 2.263 & 2.714 & 2.668 & 2.616 & 2.634 & 2.680 \\
\hline $\mathrm{Ti}$ & 0.395 & 0.192 & 0.507 & 0.327 & 0.112 & 0.162 & 0.158 & 0.168 & 0.036 \\
\hline $\mathrm{F} \subset 2$ & 1.304 & 0.314 & 0.261 & 0.335 & 0.489 & 0.482 & 0.336 & 0.377 & 0.540 \\
\hline$C_{t}$ & 0.008 & 1.213 & 0.997 & 1.547 & 1.363 & 1.325 & 1.314 & 1.258 & 1.399 \\
\hline $\mathrm{Mn}$ & 0.001 & 0.018 & 0.010 & 0.002 & 0.000 & 0.007 & 0.017 & 0.022 & 0.003 \\
\hline $\mathrm{Mg}$ & 4.023 & 0.000 & 0.011 & 0.020 & 0.002 & 0.017 & 0.012 & 0.007 & 0.009 \\
\hline $\mathrm{Ca}$ & 0.000 & 4.264 & 4.082 & 3.757 & 3.886 & 3.812 & 4.104 & 4.061 & 3.851 \\
\hline $\mathrm{Ba}$ & 0.00 & $\begin{array}{l}0.000 \\
0.00\end{array}$ & 0.000 & 0.076 & 0.000 & 0.000 & 0.000 & 0.000 & 0.000 \\
\hline Na & 0.149 & $\begin{array}{l}0.00 \\
0.119\end{array}$ & 0.00 & 0.00 & 0.00 & $0 . \infty$ & 0.00 & 0.00 & 0.04 \\
\hline $\mathrm{x}$ & 1.755 & $\begin{array}{l}0.119 \\
1.647\end{array}$ & 0.104 & 0.121 & 0.162 & 0.197 & 0.122 & 0.162 & 0.161 \\
\hline Cations & 15.783 & $\begin{array}{l}1.647 \\
15.767\end{array}$ & 1.396 & 1.007 & 1.748 & 1.719 & 1.757 & $1.73 !$ & 1.641 \\
\hline 0 & 22.000 & $\begin{array}{l}15.767 \\
22.000\end{array}$ & 15.368 & 15.192 & 15.762 & 15.721 & 15.820 & 15.386 & 15.680 \\
\hline $\mathrm{Fe} F \mathrm{~F}$ Mg & 0.24 & $\begin{array}{l}22.000 \\
0.22\end{array}$ & 22.000 & 22.000 & 22.000 & 22.000 & 22.000 & 22.000 & 22.000 \\
\hline $\mathrm{Mg}_{2} \mathrm{~F} \in \mathrm{Mg}$ & 0.76 & $\begin{array}{l}0.22 \\
0.78\end{array}$ & 0.20 & 0.29 & 0.26 & 0.26 & 0.24 & 0.24 & 0.27 \\
\hline & & & 0.80 & 0.71 & 0.74 & 0.74 & 0.76 & 0.76 & 0.73 \\
\hline
\end{tabular}




\begin{tabular}{|c|c|c|c|c|c|c|c|c|c|}
\hline Sample & $14.017 \mathrm{a}$ & $14017 \mathrm{~h}$ & $14018 \mathrm{a}$ & $14018 \mathrm{~b}$ & 14019 & $14019 \mathrm{~b}$ & $17.000 \mathrm{a}$ & 17.6006 & $170 n$ \\
\hline Arailysis & fen & fen & fen & En & fen & fen & fen & fer: & Sen \\
\hline Location & $\mathrm{YM}-4.3$ & Ma-4-1 & YMI-4-C & $x \mathrm{M}-4 \cdot d$ & $m_{1}-4$ & YMI-4-d & YMI-7 & YML-7 & YMI.7 \\
\hline Mineral & FLO & FLO & FLO & FLO & FLO & HOO & FLO & BIO & $\mathrm{BHO}$ \\
\hline $\mathrm{SiO} 2$ & 3638 & 36.68 & 36.22 & 36.3 .3 & 3635 & 36.33 & 37.56 & 38.03 & 3935 \\
\hline $\mathrm{TO} 2$ & 4.89 & 4.78 & 4.17 & 4.42 & 4.18 & 4.33 & 3.83 & 5.01 & 4.36 \\
\hline $\mathrm{A} 2203$ & 16.44 & 16.36 & 16.05 & 15.74 & 15.94 & 15.96 & 1580 & 12.28 & 12.49 \\
\hline $\mathrm{C} 203$ & 0.02 & 0.02 & 0.05 & 0.03 & 000 & 0.07 & 0.29 & 0.10 & 0.00 \\
\hline $\mathrm{FeO}$ & 11.33 & 12.87 & 11.20 & 10.99 & 110 & 10.81 & 8.88 & 13.59 & $\$ 4.11$ \\
\hline $\mathrm{MnO}$ & 0.04 & 0.09 & 0.09 & 0.12 & 0.10 & 0.06 & 0.10 & 0.09 & 0.19 \\
\hline $\mathrm{MgO}$ & 17.37 & 16.67 & 17.70 & 17.39 & 17.79 & 17.80 & 18.99 & 14.64 & 15.77 \\
\hline $\mathrm{CaO}$ & 0.00 & 0.00 & 0.00 & 0.00 & 000 & 0.00 & 0.00 & 0.00 & 0.00 \\
\hline $\mathrm{BaO}_{2}$ & 0.90 & 0.79 & 0.67 & 0.74 & 0.60 & 0.69 & 0.19 & 0.00 & 0.06 \\
\hline $\mathrm{Ni2O}$ & 0.57 & 0.72 & 0.45 & 0.59 & 0.57 & 0.70 & 0.46 & 0.73 & 0.96 \\
\hline $\mathrm{K} 2 \mathrm{O}$ & 9.22 & 9.04 & 9.35 & 9.45 & 9.14 & 9.37 & 9.75 & 9.22 & 9.13 \\
\hline Totai & 93.16 & 98.02 & 9595 & 95.80 & 95.85 & 96.12 & 95.85 & 93.69 & 96.42 \\
\hline $\mathrm{Si}$ & 5.286 & 5.310 & 5.325 & 5.354 & 5.342 & 5.327 & 5.446 & 5.759 & 5.787 \\
\hline AlYV & 2.714 & 2.690 & 2.675 & 2.646 & 2.658 & 2.673 & 2.554 & 2.190 & 2.163 \\
\hline AVII & 0.099 & 0.099 & 0.104 & 0.086 & 0.101 & 0.083 & 0.144 & 0.000 & 0.000 \\
\hline $\mathrm{Ti}$ & 0.534 & 0.521 & 0.461 & 0.490 & 0.462 & 0.478 & 0.418 & 0.571 & 0.482 \\
\hline $\mathrm{Fe} 2$ & 1.377 & 1.558 & 1.377 & 1.354 & 1.363 & 1.326 & 1.077 & 1.721 & 1.735 \\
\hline $\mathrm{Cr}$ & 0.002 & 0.002 & 0.006 & 0.003 & 0.000 & 0.008 & 0.033 & 0.012 & 0.000 \\
\hline $\mathrm{Mn}$ & 0.005 & 0.011 & 0.011 & 0.015 & 0.012 & 0.007 & 0.012 & 0.012 & 0.024 \\
\hline $\mathrm{Mg}$ & 3.763 & 3.598 & 3.879 & 3.820 & 3.897 & 3.891 & 4.105 & 3.305 & 3.457 \\
\hline $\mathrm{Ca}$ & 0.000 & 0.000 & 0.000 & 0.000 & 0.000 & 0.000 & 0.000 & 0.000 & 0.000 \\
\hline $\mathrm{Ba}$ & 0.05 & 0.04 & 0.04 & 0.04 & 0.04 & 0.04 & 0.01 & 0.00 & 0.00 \\
\hline $\mathrm{Na}$ & 0.161 & 0.202 & 0.128 & 0.169 & 0.162 & 0.199 & 0.129 & 0.214 & 0.274 \\
\hline $\mathrm{K}$ & 1.700 & 1.670 & 1.754 & 1.777 & 1.714 & 1.753 & 1.804 & 1.781 & 1.713 \\
\hline Cations & 15.700 & 15.701 & 15.760 & 15.754 & 15.751 & 15.785 & 15.732 & 15.565 & 15.635 \\
\hline 0 & 22.000 & 22.000 & 22.000 & 22.000 & 22.000 & 22.000 & 22.000 & 22.000 & 22.000 \\
\hline $\mathrm{Fe}_{-} \mathrm{FeMg}_{\mathrm{g}}$ & 0.27 & 0.30 & 0.26 & 0.26 & 0.26 & 0.25 & $0.2 \mathrm{I}$ & 0.34 & 0.33 \\
\hline $\mathrm{Mg}_{\mathrm{g}} \mathrm{FeMg}$ & 0.73 & 0.70 & 0.74 & 0.74 & 0.74 & 0.75 & 0.79 & 0.66 & 0.67 \\
\hline
\end{tabular}




\begin{tabular}{|c|c|c|c|}
\hline Sample & $210 \times$ & 21.001 & 21.001 \\
\hline Analysis & $\mathrm{fen}$ & fen & $\operatorname{ten}$ \\
\hline I.ocation & YZU:-1 & YZU-1 & YZU-1 \\
\hline Mineral & Fo & FLO & FLO \\
\hline $\mathrm{SiO} 2$ & 38.69 & 38.84 & 38.84 \\
\hline $\mathrm{roz}$ & 2.97 & 2.87 & 2.87 \\
\hline $\mathrm{A}: 2023$ & 14.95 & 14.61 & $\{4.61$ \\
\hline $\mathrm{C} 2 \mathrm{O}_{3}$ & 0.40 & 1.22 & 1.22 \\
\hline $\mathrm{FeO}$ & 5.99 & 6.15 & 6.15 \\
\hline MnO & 0.04 & 0.10 & 0.10 \\
\hline $\mathrm{MgO}$ & 22.22 & 21.81 & 21.81 \\
\hline $\mathrm{C} 2 \mathrm{O}$ & 0.00 & 0.00 & 0.00 \\
\hline $\mathrm{BaO}$ & 0.04 & 0.22 & 0.22 \\
\hline $\mathrm{N} 220$ & 0.54 & 0.41 & 0.41 \\
\hline $\mathrm{k} 20$ & 9.86 & 9.04 & 9.04 \\
\hline Toial & 95.70 & 95.27 & 95.27 \\
\hline Si & 5.536 & 5.575 & 5.575 \\
\hline AIV & 2.464 & 2.425 & 2.425 \\
\hline AIVI & 0.055 & 0.045 & 0.045 \\
\hline $\mathrm{Ti}$ & 0.320 & 0.310 & 0.310 \\
\hline $\mathrm{Fe} 2$ & 0.717 & 0.738 & 0.738 \\
\hline $\mathrm{Cr}$ & 0.045 & 0.138 & 0.138 \\
\hline $\mathrm{Mn}$ & 0.005 & 0.012 & 0.012 \\
\hline$M_{E}$ & 4.740 & 4.667 & 4.667 \\
\hline $\mathrm{C}_{3}$ & 0,000 & 0.000 & 0.000 \\
\hline $\mathrm{Ba}$ & 0.00 & 0.01 & 0.01 \\
\hline $\mathrm{NB}$ & 0.150 & 0.114 & 0.114 \\
\hline $\mathrm{K}$ & 1.800 & 1.655 & 1.655 \\
\hline Cztions & 15.832 & 15.689 & 15.689 \\
\hline o & 22.000 & 22.000 & 22.000 \\
\hline Fe_FcMig & 0.13 & 0.14 & 0.14 \\
\hline $\mathrm{Mg} F \mathrm{ME}$ & 0.87 & 0.86 & 0.86 \\
\hline
\end{tabular}




\begin{tabular}{|c|c|c|c|c|c|c|c|c|c|}
\hline Szmple & 15000 & 15.001 & 15002 & 15003 & 15.004 & 150005 & 15.006 & 15.003 & $1500 \%$ \\
\hline Analysis & $\mathrm{gm}$ & gm & घूm & gem & छात & שका & gm & $g n$ & $g m$ \\
\hline Location & YMM-S & YM-S & YMOS & YM-5 & $Y M A S$ & YM-5 & YM:-5 & YMI-5 & YMT-5 \\
\hline Mineral & $\mathrm{BiO}$ & $\mathrm{BIO}$ & B1O & BIO & BiO & Blo & BIO & BYO & $\mathrm{BIO}$ \\
\hline $\mathrm{SiO}_{2}$ & 31.63 & 35.97 & 35.84 & 36.82 & 36.04 & 36.68 & 30.89 & 35.28 & 31.57 \\
\hline TiO2 & 7.78 & 4.10 & 4.43 & 3.49 & 4.96 & 3.22 & 5.57 & 6.20 & 4.97 \\
\hline $\mathrm{Al} 2 \mathrm{O} 3$ & 14.09 & 10.51 & 11.44 & 11.53 & 10.51 & 10.90 & 14.79 & 12.65 & 13.66 \\
\hline $\mathrm{C}_{2} 2 \mathrm{O}_{3}$ & 0.01 & 0.00 & 0.05 & 0.03 & 0.00 & 0.02 & 0.01 & 0.03 & 0.00 \\
\hline $\mathrm{FeO}$ & 24.75 & 27.74 & 2260 & 23.93 & 28.04 & 24.88 & 26.93 & 26.94 & 27.59 \\
\hline Mno & 0.15 & 0.34 & 0.14 & 0.37 & 0.22 & 0.29 & 0.29 & 0.37 & 0.40 \\
\hline $\mathrm{MgO}$ & 4.88 & 7.05 & 8.34 & 10.33 & 5.80 & 8.46 & 4.49 & 3.75 & 5.36 \\
\hline $\mathrm{CaO}$ & 0.00 & 0.00 & 0.00 & 0.06 & 0.01 & 0.00 & 0.05 & 0.04 & 0.01 \\
\hline $\mathrm{BaO}$ & 6.42 & 4.08 & 0.28 & 0.14 & 0.58 & 2.43 & 7.34 & 4.72 & 6.36 \\
\hline $\mathrm{N} 22 \mathrm{O}$ & 0.73 & 0.54 & 0.55 & 0.55 & 0.67 & 0.58 & 0.70 & 0.54 & 0.68 \\
\hline $\mathrm{K} 20$ & 6.64 & 8.99 & 8.87 & 8.78 & 8.58 & 8.41 & 6.11 & 7.85 & 6.87 \\
\hline Total & 97.08 & 99.32 & 92.54 & 96.01 & 95.41 & 95.87 & 97.17 & 98.37 & 97.47 \\
\hline Si & 5.137 & 5.712 & 5.781 & 5.735 & 5.797 & 5.846 & 5.098 & 5.618 & 5.194 \\
\hline AINV & 2.695 & 1.965 & 2.173 & 2.111 & 1.991 & 2.046 & 2.875 & 2.372 & 2.647 \\
\hline AVI & 0.000 & 0.000 & 0.000 & 0.000 & 0.000 & 0.000 & 0.000 & 0.050 & 0.000 \\
\hline Ti & 0.951 & 0.490 & 0.538 & 0.409 & 0.600 & 0.386 & 0.692 & 0.743 & 0.615 \\
\hline $\mathrm{Fe} 2$ & 3.362 & 3.684 & 3.049 & 3.117 & 3.772 & 3.316 & 3.717 & 3.588 & 3.796 \\
\hline $\mathrm{Cr}$ & 0.001 & 0.000 & 0.006 & 0.004 & 0.000 & 0.003 & 0.001 & 0.004 & 0.000 \\
\hline Mn & 0.021 & 0.046 & 0.019 & 0.049 & 0.030 & 0.039 & 0.041 & 0.050 & 0.056 \\
\hline $\mathrm{Mg}$ & 1.182 & 1.669 & 2.006 & 2.398 & 1.391 & 2.010 & 1.05 & 0.890 & 1.315 \\
\hline $\mathrm{Ca}$ & 0.000 & 0.000 & 0.000 & 0.010 & 0.002 & 0.000 & 0.009 & 0.007 & 0.002 \\
\hline $8 a$ & $0.4]$ & 0.25 & 0.02 & 0.01 & 0.04 & 0.15 & 0.47 & 0.20 & $0.4 !$ \\
\hline $\mathrm{Zn}$ & 0.00 & 0.00 & 0.00 & 0.00 & 0.08 & 0.00 & 0.00 & 0.00 & 0.00 \\
\hline $\mathrm{Nz}$ & 0.230 & 0.166 & 0.172 & 0.106 & 0.208 & 0.179 & 0.224 & 0.167 & 0.217 \\
\hline $\mathrm{K}$ & 1.376 & 1.821 & 1.825 & 1.745 & 1.761 & 1.710 & 1.287 & 1.505 & 1.442 \\
\hline Cations & 15.365 & 15.803 & 15.589 & 15.754 & 15.593 & 15.685 & 15.519 & 15.324 & 15.694 \\
\hline 0 & 22.000 & 22.000 & 22.000 & 22.000 & 22.000 & 22.000 & 22.000 & 22.000 & 22.000 \\
\hline $\mathrm{Fe}$ FelMg & 0.74 & 0.69 & 0.60 & 0.57 & 0.73 & 0.62 & 0.77 & 0.80 & 0.74 \\
\hline MEFeNg & 0.26 & 0.31 & 0.40 & 0.43 & $0.2 \%$ & 0.38 & 0.23 & 0.20 & 0.26 \\
\hline
\end{tabular}




\begin{tabular}{|c|c|c|c|c|c|c|c|c|c|}
\hline Simpie & 1500 & 1500 & $15 \mathrm{~m} 1$ & $15: 12$ & 15013 & $22 . n(x)$ & $220 \mathrm{mi}$ & $22(A) 2$ & $22 \times 1013$ \\
\hline Anatyis & En: & Eni & $E *$ & 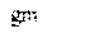 & : & Sen & $g m$ & gn & $\mathrm{gm}$ \\
\hline Weation & YMA-5 & MMls & Yat-5 & $Y M 15$ & M1.s & YZ:2 & $Y / 1-2$ & $z u_{-2}$ & $Y Z U 2$ \\
\hline Nincral & mo & $\mathrm{BHO}$ & $\mathrm{Bi}(1$ & mo & \%o: & $\mathrm{FlO}$ & tho & Bto & $B O$ \\
\hline $50 \%$ & 330 & 39.95 & 3071 & $3 ! \varsigma$ & $3: 30$ & 3905 & 38.10 & 38.72 & 3827 \\
\hline THO2 & 388 & 449 & 8.40 & 0.43 & 6.68 & 353 & 8.43 & 10.23 & 9.67 \\
\hline $\mathrm{A}: 2 O 3$ & 14.49 & 13.78 & 14.15 & $14 n 8$ & 1382 & 1395 & 946 & 1000 & 8.90 \\
\hline 9203 & $0.0 ?$ & 000 & 0.03 & 000 & 60 & 156 & $\theta \infty$ & $0 \%$ & 600 \\
\hline $\mathrm{FeO}$ & 21,42 & 26.69 & 24.51 & 20,71 & 2522 & 643 & 12.14 & 13.28 & 1385 \\
\hline MOO & 028 & 028 & 0.18 & 026 & 021 & $00 \%$ & $0 ! !$ & 0.11 & 0.10 \\
\hline $\mathrm{Mg} !$ & 9.46 & 590 & 4.56 & 7.25 & 49 & $20.6 !$ & 1582 & 14.23 & 130 \\
\hline$c 0$ & 0.00 & 008 & 0.00 & 000 & 0.3 & 0.13 & 000 & 0.00 & 0.67 \\
\hline 3 & 5.05 & 528 & 7.38 & 615 & $5 . \infty$ & 0.27 & 2.61 & 254 & 2.47 \\
\hline $\mathrm{Na2O}$ & 0.71 & 0.72 & 0.66 & 0.68 & 072 & 015 & 0.62 & 0.65 & 0.67 \\
\hline $\mathrm{k} 0$ & 6.87 & 6.96 & 544 & 659 & 698 & 748 & 8.51 & 700 & 8.45 \\
\hline mas & 96.07 & 104.13 & 97.02. & 96.60 & 0658 & 9316 & 95.80 & 9775 & 9546 \\
\hline Si & 5.296 & 5872 & 5.034 & 5038 & 5258 & 5424 & 5.462 & 5.688 & 5.808 \\
\hline Aiv & 2.704 & 2128 & 2.732 & 2646 & 2642 & 2.282 & 3.597 & 1.746 & 1.591 \\
\hline $\mathrm{A} \cup \mathrm{I}$ & 6034 & 0.257 & 0.000 & 0.009 & $0 \times 101$ & 000 & 0.000 & 0000 & 0.000 \\
\hline$\pi i$ & (1). 468 & 0.496 & 1.036 & 1.133 & 0.816 & 0.369 & $0.0 \times 18$ & 1.130 & 1.104 \\
\hline $\mathrm{Fe}^{2}$ & 2.874 & 3.281 & 3.360 & 2.765 & 3.424 & 0747 & 1.455 & 1632 & 1.758 \\
\hline $\mathrm{Cr}$ & 0,600 & 0.000 & 0.004 & 0000 & 6075 & 0171 & 0.000 & 0.000 & 0.000 \\
\hline Mn & 0.038 & 0.035 & 0.025 & 0035 & 0029 & 0,100 & 0013 & 0.014 & 0.013 \\
\hline $\mathrm{Mg}_{\mathrm{E}}$ & 2.262 & 1.293 & 1.114 & 1.726 & 1.208 & $\Leftrightarrow 268$ & 3.381 & 3.117 & 2.941 \\
\hline $\mathrm{Ca}$ & 000 & 0.013 & 0.000 & 0000 & 0005 & 0.019 & 0.000 & 0.000 & 0.011 \\
\hline $\mathrm{Ba}$ & 0.37 & 0.30 & 0.47 & 0.38 & 0.38 & 001 & 0.15 & 0.15 & 0.15 \\
\hline in & 000 & 0.00 & 000 & 0.00 & 0.60 & 0.00 & 0.00 & 0.00 & 0.00 \\
\hline $\mathrm{Na}$ & 0.221 & 0.205 & 0.210 & 0.211 & 0.227 & 0,040 & 0.172 & 0.185 & 0.197 \\
\hline k & $1.4 \%$ & 1.305 & 1.347 & 1.342 & 1.446 & 1.325 & 1.556 & 1.481 & 1638 \\
\hline Cantons & 15.673 & 15.185 & 15.332 & 15.276 & 15.440 & 14.655 & 14.695 & 15.143 & 15.211 \\
\hline 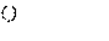 & 22.000 & 22.000 & 22.000 & 22.000 & 22000 & 22000 & 22.000 & 22.000 & 22.000 \\
\hline Fe ferg & 0.56 & 0.72 & 0.75 & 0.62 & 0.74 & 0.15 & 0.30 & 0.34 & 0.37 \\
\hline$M g F C M g$ & 0.44 & 0.28 & 0.25 & 038 & 0.26 & 085 & 0.70 & 0.66 & 0.63 \\
\hline
\end{tabular}




\begin{tabular}{|c|c|c|c|c|c|c|c|c|c|}
\hline Sample & $22 \omega_{4}$ & $220 \times 15$ & 2306 & $22 \cdot 4: 7$ & 2018 & $22180 \%$ & 22010 & $22 \cdots 1$ & 22012 \\
\hline Aralysis & $2 \pi$ & $g r:$ & $\mathrm{z}^{\mathrm{m}}$ & gent & ent & Wn: & gnin & Ex & gen \\
\hline A nation & $Y Z A=$ & YZIS: & Y>L: & $m: 2$ & $\because 21 \%$ & $Y \pi t: 2$ & $Y Z 12$ & MU:-2 & $Y M j-2$ \\
\hline Mineral & FIO & 130 & $\mathrm{ni}$ & 56 & $\mathrm{H}$ & 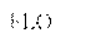 & FLO & 130 & FLO \\
\hline $\sin 2$ & 3760 & $386 !$ & $3 k 43$ & . & 928 & $3: 26$ & $3 \times 74$ & 36.48 & 3896 \\
\hline $\mathrm{FiO2}$ & 8.66 & 1005 & 890 & 936 & $8: i$ & 808 & 8.63 & 9.06 & 9.23 \\
\hline $\mathrm{N} 2 \mathrm{O} 3$ & 952 & 9.77 & 963 & 917 & 907 & 955 & 919 & 1007 & 917 \\
\hline $\mathrm{C} 203$ & $f(x)$ & 006 & $0 \omega$ & $n$ & nan & $n(x)$ & $a n$ & 608 & $f(x)$ \\
\hline Fo & 1113 & 1257 & 1215 & 1247 & 1127 & 11.89 & 1137 & 12.24 & 12.72 \\
\hline $\mathrm{MnO}$ & 0.17 & $\operatorname{los}$ & 910 & 011 & 010 & 005 & 0.15 & 0.14 & 0.13 \\
\hline $\mathrm{Mo}_{0}$ & 150 & $14 \infty$ & 1458 & 1538 & 560 & 1514 & 15.70 & 13.72 & 1486 \\
\hline$\infty$ & $0(0)$ & 002 & 0.00 & 004 & 002 & 000 & 0.00 & 005 & 0.02 \\
\hline 836 & 311 & $24 ?$ & 225 & 328 & 200 & 229 & 227 & 3.88 & 311 \\
\hline $\mathrm{N} 22 \mathrm{O}$ & 069 & 083 & 080 & 069 & 99 & 049 & 0.97 & 060 & 068 \\
\hline $\mathrm{K}>\mathrm{O}$ & 828 & 856 & 857 & 751 & 837 & 683 & 861 & 7.95 & 8.32 \\
\hline Total & 9512 & 9705 & 9541 & 9625 & 9640 & 9358 & 95.68 & 9438 & 9723 \\
\hline Si & 5428 & $5 ? 2 ?$ & 5513 & 5453 & 5688 & 5653 & $\leq 529$ & 5500 & 5.526 \\
\hline AllV & 3618 & 1705 & 1627 & 1.544 & 1514 & 1619 & 1.545 & 1817 & 1.520 \\
\hline $\mathrm{AvI}$ & $600 \%$ & now & 0.009 & $a n g$ & $0 \mathrm{mg}$ & f: $: 0$ & tho & 90 & 0.000 \\
\hline $\mathrm{ri}$ & 0.40 & 1.120 & 0050 & 1007 & 0939 & 0875 & 0926 & 1.148 & 0.985 \\
\hline Fed & 1.34 & 1.558 & 1.488 & 1491 & 13.36 & 1432 & 1357 & 1569 & 1.509 \\
\hline $\mathrm{Cr}$ & 0.000 & $0,0,7$ & 0000 & 0000 & 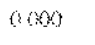 & 6009 & 00.6 & 0.010 & $\theta(6)$ \\
\hline $\mathrm{Mrn}$ & $(1,02\}$ & 0.008 & 0012 & 0013 & $\operatorname{son} 2$ & $\sin 6$ & 0018 & 0018 & 0.016 \\
\hline$M_{\varepsilon}$ & 3.435 & 3106 & 3.118 & 3.278 & 3314 & 3250 & 3341 & 3134 & 3.142 \\
\hline $\mathrm{Ca}$ & 000 & $0,0 / 3$ & $\operatorname{lin} \theta$ & $\operatorname{sen} 6$ & $\sin 3$ & 3000 & $n(x)$ & 0.098 & 0.003 \\
\hline 32 & 0.18 & 0.14 & 0.13 & 018 & 017 & 013 & 013 & 0.18 & 0.17 \\
\hline $2 n$ & 0.00 & $0 \infty$ & $o w$ & 909 & $\theta(x)$ & $\theta \infty$ & 0.00 & 0.00 & 0.00 \\
\hline$\therefore$ & 0.193 & 0.238 & 0.223 & 0191 & 6247 & 137 & (1) 268 & 0178 & 0.187 \\
\hline K & 1525 & 1.618 & 1568 & 1.388 & 154 & 1255 & 3568 & 1556 & 1.523 \\
\hline Crstions & 14684 & 35.224 & 14.649 & 14.551 & 14617 & 14.357 & 14.688 & 15.208 & 14.581 \\
\hline 0 & 22000 & 22.000 & 22.000 & 22.000 & 22000 & 22000 & 22.000 & $22.5 x$ & 220000 \\
\hline Fe FeMg & 0.28 & 0.33 & 0.32 & 0.31 & 0.29 & 0.31 & 0.29 & 0.33 & 0.32 \\
\hline ME FeM & 0.72 & 0.67 & 0.68 & 0.69 & 071 & 069 & 071 & 067 & 0.68 \\
\hline
\end{tabular}




\begin{tabular}{|c|c|c|c|c|c|c|c|c|c|}
\hline Sunple & 22013 & 2201.2 & 2200.6 & $22: 16$ & $2 x, x$ & 2300 & 230012 & 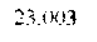 & $23(4,14$ \\
\hline Amalysis & $2 \pi$ & $8 m$ & झ्याi & $g n$ & 2 & gn: & $m^{n}$ & Fin & $g m$ \\
\hline i.sertion & $Y Z 12$ & YYU2 & YZU:2 & $Y Z 1: 2$ & YZT & 1203 & $Y Z X X .3$ & YZU-3 & YZL:3 \\
\hline Mineral & mo & FElO & $\ddot{F} \mathrm{LO}$ & Flo & Ylo? & $F(1)$ & FLO & $\mathrm{F}: \mathrm{O}$ & FEO \\
\hline Sis? & 3088 & 3915 & 3859 & 388 & $3 \%$ & 3055 & 3719 & 39.15 & 3965 \\
\hline $\mathrm{HO} 2$ & $8.8 n$ & 883 & 9.18 & 9.30 & 827 & 8.53 & 7.97 & 8.47 & 8.66 \\
\hline $\mathrm{Al} 203$ & .65 & 958 & 9.41 & 929 & 1218 & 01.55 & 11.41 & 1138 & 11.77 \\
\hline $\mathrm{Cr} 203$ & $\{: 13$ & 005 & $0: 8$ & 000 & 102 & 000 & 0.01 & 0.02 & 0.02 \\
\hline $\mathrm{FeO}$ & 1180 & 1156 & 1168 & if 59 & 923 & 934 & 9.20 & 9.48 & 9.40 \\
\hline 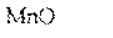 & 009 & 0.13 & 0.00 & 013 & 0.15 & $1 \infty$ & 0.09 & 0.08 & 0.10 \\
\hline MaO & 1620 & 1500 & 1502 & 149 & 1725 & 1596 & 1795 & 17.49 & 17.05 \\
\hline$\{0\rangle$ & 000 & 0.04 & $g(x)$ & $0(0)$ & 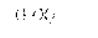 & 100 & 0.00 & 0.00 & 0.01 \\
\hline $\mathrm{BaO}$ & 237 & 2.78 & 2.54 & 21.3 & 0.18 & 04 & 003 & $0(x)$ & 0.10 \\
\hline $\mathrm{Na2O}$ & 0.60 & 0.76 & 0.39 & 080 & 9.1 & 040 & 0.31 & 0.40 & 0.21 \\
\hline$k 20$ & 888 & 85.3 & 8.38 & 8.58 & $9: 8$ & 923 & 9.47 & 9.26 & 9.46 \\
\hline Total & 9830 & 97.21 & 0567 & 9539 & 0536 & 95.69 & 93.63 & 95.73 & 96.43 \\
\hline $\mathrm{Si}$ & 5533 & $5.5 \%$ & 5.513 & $5 \$ 56$ & 5.387 & $\$ 471$ & 5.297 & 5.425 & 5.449 \\
\hline AIN & $\$ .577$ & 1587 & 1.583 & 1563 & 1092 & 881 & 1.914 & 1.857 & 1.905 \\
\hline AlvT & 000 & 0000 & 0100 & 000 & $\tan \theta$ & 0000 & 0,000 & 0000 & 0.000 \\
\hline$T i$ & 0918 & 0.334 & 0987 & $i(n)$ & 0.864 & 0.888 & 0.854 & 0.883 & 0.895 \\
\hline $\mathrm{Fez}$ & 1369 & 1360 & 1.396 & 138.5 & 1072 & 1080 & 1.096 & 1.099 & 1.080 \\
\hline $\mathrm{Cr}$ & $0.6 \times 3$ & 11006 & 0009 & 0.000 & 000 & $0.0 \times 0$ & 0.001 & 0.002 & 0.002 \\
\hline Mn & mil & 0.015 & 0.000 & 0.016 & $\cos x$ & 0013 & 0.011 & 0.009 & 0.012 \\
\hline M & 3.351 & 3.334 & 3.199 & 3129 & 3.57 & 3497 & 3.811 & 3.613 & 3.493 \\
\hline $\mathrm{Ca}$ & $0 \times 0$ & 0.606 & 0.000 & $0<0$ & 0000 & 0.000 & 0.000 & 0.000 & 0.001 \\
\hline Ba & 0.13 & 0.15 & 0.14 & 0.12 & 001 & 000 & 0.00 & 0.93 & 0.01 \\
\hline$Z_{\pi}$ & $0 \infty 0$ & 000 & 000 & 0.00 & $0 \mathrm{~m}$ & $\infty \infty$ & $0(\infty)$ & 0.00 & 0.00 \\
\hline$\therefore 3$ & 0161 & 0.277 & 0239 & 0222 & 0083 & 6197 & 0.086 & 0.107 & 0.056 \\
\hline K & 1572 & 1.513 & 1.527 & 1564 & 160 & 1.629 & 1.721 & 1.637 & 1.658 \\
\hline Cations & 34.625 & 14.618 & 34.573 & 14.555 & 34.596 & 14.564 & 14.791 & 14.632 & 14.561 \\
\hline 0 & 22.000 & 22.000 & 22.000 & 220000 & 22000 & 22.0063 & 22.000 & 22.000 & 22.000 \\
\hline $\mathrm{Fe} F \mathrm{FeM}$ & 0.29 & 0.29 & 0.30 & 031 & 0.23 & 0.24 & 0.22 & 0.23 & 0.24 \\
\hline $\mathrm{Mg}_{\mathrm{B}} \mathrm{FCM}$ & 0.71 & 0.71 & 0.70 & 0.69 & 0.77 & 0.76 & 0.78 & 0.77 & 0.76 \\
\hline
\end{tabular}




\begin{tabular}{|c|c|c|c|c|c|c|c|c|c|}
\hline Sumple & 23015 & 230106 & $23(x)$ & $2 x \div 49$ & 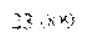 & 23010 & 23.041 & $269(x) a$ & $260 \mathrm{moth}$ \\
\hline Analysis & $g$ & $\underline{g} \pi$ & $g m$ & Eii & $g n$ & 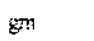 & Delsin & fent & fen \\
\hline 1.eration & $Y 20.3$ & $\mathrm{YZE}-3$ & YZU. 3 & $Y Z 1-3$ & $7 n+3$ & $Y Z U-3$ & YZU-3 & YZU.6 & YZI: 6 \\
\hline Mineral & $\mathrm{HOO}$ & Flo & FLO & $\mathrm{Fi} . \mathrm{O}$ & $\mathrm{FiO}$ & Ho & FLO & FLO & FLO \\
\hline $\mathrm{SiO} 2$ & 3873 & 3882 & 39,93 & 8805 & 3975 & 3871 & 41.18 & 38.19 & 3770 \\
\hline T:O2 & 9.30 & 856 & 8.82 & 807 & 811. & 827 & 8.45 & 5.79 & 5.57 \\
\hline $\mathrm{A2} 203$ & 11.58 & 11.71 & 1202 & 13.55 & 1157 & 1185 & 10.98 & 12.94 & 13.10 \\
\hline $\mathrm{CrO} 3$ & 0.08 & 0.02 & 00 & 003 & $a m$ & 002 & 000 & 0.16 & 0.00 \\
\hline $\mathrm{FeO}$ & 9.71 & 885 & 909 & 850 & 857 & 826 & 10.23 & 9.47 & 9.62 \\
\hline Mno & 0.09 & 607 & 0.10 & 014 & $6 n$ & 609 & 0.08 & 0.09 & 0.00 \\
\hline $\mathrm{MgO}$ & 1653 & 1791 & 17.75 & 1872 & 1776 & 1829 & 1739 & 17.92 & 17.70 \\
\hline 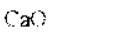 & $\{03$ & $0(0)$ & 0.02 & 0.01 & 002 & 060 & $0 \infty$ & 0.08 & 0.05 \\
\hline 320 & 60 & 020 & $n 07$ & 100 & $0 \mathrm{os}$ & 011 & 000 & 0.50 & 0.61 \\
\hline $\mathrm{NaOO}$ & 0.42 & 0.37 & 0.32 & 0.31 & 0.34 & 035 & 000 & 0.27 & 0.26 \\
\hline$\times 20$ & 9.32 & 9.44 & 9.58 & 896 & 941 & 936 & 8.65 & 9.65 & 9.74 \\
\hline Total & 0579 & 95.95 & 96.80 & 9484 & 0967 & 2931 & 96.96 & 9506 & 94.35 \\
\hline Si & 5.378 & 5.368 & 5.341 & 5.402 & 5483 & 5368 & 5.595 & 5.362 & 5.345 \\
\hline AII & 1894 & $1.90 \%$ & 1.942 & 1887 & 1878 & 1.935 & 1.757 & 2.140 & 2.187 \\
\hline $\mathrm{AWt}$ & $6 k 0$ & 0.000 & 000 & 0000 & ment & 0.60 & 0.000 & 0.000 & 8000 \\
\hline $\mathrm{Ti}$ & 997 & 0.890 & 0.910 & (1) 842 & 88,43 & () 863 & 0.864 & 0.611 & 0.594 \\
\hline $\mathrm{f} e \hat{2}$ & 1.128 & 1.023 & 1043 & 0985 & 040 & 0.958 & 1.162 & 1.112 & 1.141 \\
\hline$c$ & 0,009 & 0,092 & 0.000 & 0.003 & 060 & 0602 & 0.000 & 0.018 & 0.000 \\
\hline$M n$ & 8011 & 0038 & 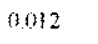 & 0016 & $a \cos$ & 0011 & 0.009 & 0.011 & 0.0100 \\
\hline Mg & 3.422 & 3602 & 3.630 & 3871 & 362 & 3781 & 3.523 & 3.751 & 3.741 \\
\hline $\mathrm{Ca}$ & 6004 & oes & 0003 & 6001 & 0,003 & 0000 & $0 \times 00$ & 0.012 & 0.008 \\
\hline $\mathrm{Pa}$ & $\theta 00$ & 0.01 & 0.00 & $\theta 0$ & $0 w$ & 001 & 0.00 & 0.03 & 0.03 \\
\hline $7 n$ & $0 \times \infty$ & 0.00 & 000 & 0.09 & $00 \%$ & $0 \mathrm{~m}$ & $n \infty$ & 0.00 & 0.00 \\
\hline $\mathrm{Na}$ & 0113 & 0.099 & 0.085 & 0083 & $\log 1$ & 0004 & $0 . m x_{i}$ & 0.074 & $0.07 !$ \\
\hline K & 1.651 & 1.665 & 1.694 & 1.515 & 1.556 & 1655 & 1.499 & 1.728 & 1.762 \\
\hline Cations & 14.581 & 14.664 & 14.660 & 14.666 & $14 \sin \theta$ & 14.678 & 14.409 & 14.849 & 14.879 \\
\hline 0 & $22 f(x)$ & 22.000 & 22.000 & 22.000 & $22 x \%$ & $22 n \times 0$ & 22.000 & 22.000 & 22.0000 \\
\hline Fo FeVg & 0.25 & 0.22 & 0.22 & 0.20 & 0.21 & 020 & 0.25 & 0.23 & 0.23 \\
\hline Mg FrMg & 075 & 0.78 & 0.78 & 080 & 0.79 & 0.80 & 0.75 & 0.77 & 0.77 \\
\hline
\end{tabular}




\begin{tabular}{|c|c|c|c|c|c|c|c|c|c|}
\hline Sample & $20 \mathrm{kla}$ & 260110 & $26 \mathrm{~m} / 3$ & 364 & 260 & $26.2 \times 16$ & $26 \mathrm{~kg} 7$ & $26 \times 18$ & 260009 \\
\hline Analysis & fer & fen & fen & $\mathrm{fen}$ & $\mathrm{ien}$ & fer: & \{en & $g n$ & $g m$ \\
\hline Location & YZU.6 & $y 2 t-6$ & YZU-6 & Y7L, & 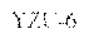 & YZu & $37:-6$ & Y.zi. 6 & $Y Z \mathrm{YU} \cdot 6$ \\
\hline Mfineral & FLo & FEO & FLO & Ho & $\mathrm{FLO}$ & $F 1,0$ & Fio & FLO & FLO \\
\hline $\mathrm{stc} 32$ & 3855 & 38.19 & $3 \times 11$ & 370 & 378 & 37.20 & 3771 & 37.19 & 3527 \\
\hline $\mathrm{TiO2}$ & 5.68 & 5.80 & 580 & 5.70 & 562 & 5.73 & 5.76 & 6.71 & 6.54 \\
\hline $\mathrm{Al}_{203}$ & 1291 & 13.11 & 1319 & 1296 & 1204 & 1276 & 3292 & 12.80 & 12.37 \\
\hline $\mathrm{Cr} 203$ & 0199 & 020 & 0.14 & 008 & 013 & 102 & 0.08 & $0(12$ & 0.60 \\
\hline FeO & 9.38 & 975 & 8.92 & 962 & 923 & 958 & 891 & $\| 61$ & 11.67 \\
\hline $\mathrm{MnO}$ & 003 & $O(n)$ & 0.02 & 009 & 010 & 015 & 0.00 & 0.10 & 0.05 \\
\hline $\mathrm{MEO}$ & 1766 & 1802 & 1798 & 1736 & {$[8.31$} & 37.40 & 1781 & 15.73 & 13.79 \\
\hline $\mathrm{C2O}$ & 006 & 00 & 004 & 911 & 005 & 001 & 000 & 0.24 & 2.85 \\
\hline $\mathrm{BaO}$ & 0.40 & (1) $\$ 4$ & 044 & 047 & 0.39 & 062 & 0.56 & 0.99 & 1.01 \\
\hline $\mathrm{Na} 20$ & 0.15 & 27 & 0.26 & 033 & 0.39 & 024 & 0.25 & $0 \leq \leq 4$ & 0.58 \\
\hline $\mathrm{k} 20$ & 985 & 969 & 9.76 & 960 & 968 & 0.77 & 986 & 9.23 & 8.73 \\
\hline Towal & 9476 & 0548 & 0466 & 0.425 & 9.12 & 9348 & 9386 & 95.16 & $928 \%$ \\
\hline$\$ i$ & 5418 & 5.341 & $\leq 357$ & 5375 & $52 \%$ & 5336 & 5359 & 5.297 & 5.209 \\
\hline NIV & 2137 & 2.150 & 2.183 & 2.163 & $2 i 8 i$ & 2.155 & 2.162 & 2.147 & 2.151 \\
\hline $\mathrm{Ant}$ & 0000 & 0000 & 0000 & 0000 & 0,0 & 000 & 0.000 & 0000 & $0.0(x)$ \\
\hline $\mathrm{Ti}$ & $060 \%$ & 0.610 & 0.613 & 0608 & $\sin \theta$ & $05: 8$ & 0616 & 0.719 & 0.727 \\
\hline $\mathrm{Fe} 2$ & 1.162 & 1.140 & 1049 & 1140 & 3100 & 1149 & 1059 & 1.383 & $1.44 \xi$ \\
\hline $\mathrm{Cr}$ & 0010 & 01022 & 0.016 & 0.0009 & 0195 & 0,42 & 0.009 & 0.002 & 0.000 \\
\hline $\mathrm{Mn}$ & 0004 & $n(x)$ & 0.002 & $0+11$ & 0012 & 0018 & oflus & 0012 & $0.1 \times 6$ \\
\hline $\mathrm{Mg}$ & 3.700 & 3.757 & 3.767 & 3667 & 3475 & 3721 & 3.773 & 3.340 & 3.036 \\
\hline $\mathrm{Ca}$ & nik & 0.001 & 0.006 & 0017 & 6048 & $(n)]_{2}$ & $\theta(x)$ & 0037 & 0.451 \\
\hline $\mathrm{Ba}$ & 0.02 & 002 & 002 & 063 & 00 & $n 03$ & 0013 & 000 & 0.06 \\
\hline $7 \pi$ & 000 & 0.00 & $0 n$ & 0.00 & 00 & $\infty$ & 0.00 & 0.00 & 0.00 \\
\hline $\mathrm{Na}$ & $0.04 i$ & 0.073 & 0071 & 0.091 & 0.317 & 0067 & 0.069 & 0149 & 0.166 \\
\hline K & 1.766 & 1.729 & 1.750 & 1736 & 1.754 & 1.788 & 1.788 & 1.677 & 1.645 \\
\hline Cusions & 14.807 & 14.852 & 14.834 & 14.847 & 14.848 & 14.886 & 14.865 & 14.823 & 14.892 \\
\hline 0 & 22.000 & $22 .(150)$ & 22.000 & 22000 & $220 \mathrm{wo}$ & 22.000 & 22000 & 22.000 & 22.000 \\
\hline Fe FeM & 0.23 & 0.23 & 0.22 & 024 & 022 & 024 & 0.22 & 0.29 & 0.32 \\
\hline$M_{E} F A M g$ & 0.77 & 0.77 & 078 & 0.76 & 078 & ก 76 & 0.78 & 0.71 & 0.68 \\
\hline
\end{tabular}




\begin{tabular}{|c|c|c|c|c|c|c|c|c|c|}
\hline Stuph & 20000 & 26011 & 3612 & $x+4$ & $2 \sin 4$ & 26015 & 26016 & 26017 & 26018 \\
\hline Asialysis & स्राT & $g m$ & wn & g्ञ⿰氵丶 & 8 & $\mathrm{gm}$ & $g \mathfrak{m}$ & gri: & $\mathrm{gm}$ \\
\hline 1.ceation & YZI: & $x 70-6$ & YR1:6 & $Y 71: 6$ & 3706 & $Y \%, 6$ & $Y Z U-6$ & YZU-6 & $\gamma Z, 0$ \\
\hline Mineral & $3 \%$ & FLO & fro & Fus & $\mathrm{BO}$ & 130 & FLO & FLO & $\mathrm{BLO}$ \\
\hline $\mathrm{SiO}_{2}$ & 3925 & 36,8 & 3561 & $36: 4$ & 3630 & 3636 & 36.28 & 36.89 & 36.72 \\
\hline$T \% 2$ & 685 & 693 & 6.79 & 585 & 697 & 757 & 6.92 & 6.92 & 8.16 \\
\hline $\mathrm{A} 203$ & 12.51 & 1253 & 1230 & 1247 & 1244 & 120 & 1265 & 12.63 & 11.77 \\
\hline 0203 & $0 \times$ & 011 & 000 & 000 & 06 & $O m$ & 0.02 & 0.06 & 0.00 \\
\hline FeO & 24.15 & 1313 & 1255 & 11.61 & 1384 & 15.43 & 12.83 & 12.89 & 15.54 \\
\hline $\mathrm{MmO}$ & 6.23 & 014 & 017 & $0(\infty)$ & 119 & 019 & 0.15 & 0.13 & 0.20 \\
\hline $\mathrm{MgO}$ & 1067 & 1493 & $1+38$ & 1482 & 138 & 1269 & 1500 & $15.4 ?$ & 12.96 \\
\hline 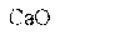 & $n 0$ & 0.01 & 2.42 & 101 & 010 & 000 & 0.64 & 0.0 & 0.00 \\
\hline FaO & 6.99 & 106 & 110 & 100 & 1092 & 1.27 & 1.11 & 1.01 & $\{.4\}$ \\
\hline $\mathrm{Na} 2 \mathrm{O}$ & 050 & $04 !$ & 050 & 044 & (1), & 039 & 0.47 & $0.4 \mathrm{i}$ & 0.60 \\
\hline $\mathrm{K} 20$ & 9.88 & 9.53 & 8.94 & 935 & 920 & 923 & 938 & 9.43 & 9.11 \\
\hline Iotal & 9503 & 9545 & 2476 & 93.59 & 9435 & 9.16 & 95.45 & 95.84 & 96.47 \\
\hline $\mathrm{S}:$ & 5913 & 5.264 & 5.176 & 5.252 & 5532 & 5.550 & 5.213 & 5.257 & 5.535 \\
\hline ANN & 2.087 & 2.118 & 2.196 & 2140 & 2233 & 2.163 & 2.141 & 2.120 & 2.089 \\
\hline AlVI & 0132 & 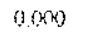 & $0(x)$ & 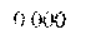 & 0000 & $0(x)$ & $0.0\left(x^{\circ}\right)$ & 0.000 & 0.000 \\
\hline $\mathrm{Ti}$ & 0.776 & 0748 & 0742 & 0351 & 0.799 & 0869 & 0.748 & 0.742 & 0.925 \\
\hline $\mathrm{Fez}$ & 1.783 & 1576 & 1526 & $: 415$ & 1.754 & 1970 & 1.542 & 1.536 & 1.959 \\
\hline $\mathrm{Cr}$ & $n 000$ & 0.012 & $0,0 \times s$ & $\theta \sin$ & 0.007 & 0000 & 0.002 & 0.007 & 0.000 \\
\hline Mn & 0.029 & 0,017 & 0.021 & $a 000$ & 0025 & 0025 & 0.018 & 0.016 & 0.026 \\
\hline $\mathrm{Mg}$ & 2.396 & 3.194 & 3116 & 3.220 & 3156 & 2888 & 3.213 & 3.287 & 2.912 \\
\hline $\mathrm{Ca}$ & vom? & $\mathrm{OM}_{2}$ & 0.377 & f.158 & 0016 & i) & 0.099 & 0.000 & 0.000 \\
\hline $\mathrm{Ba}$ & 0.06 & 066 & 0,0 & 006 & 0.05 & 0.08 & 0.06 & 0.06 & 0.08 \\
\hline $2 n$ & $n 00$ & 000 & 000 & 000 & 000 & 000 & 0.00 & 0.00 & 0.00 \\
\hline $\mathrm{Na}$ & 0146 & 0114 & $0: 41$ & 0.124 & 0130 & 0115 & $0.13 i$ & 0.113 & 0.175 \\
\hline$\ddot{k}$ & 1809 & 1.745 & 1.658 & 1738 & 1.789 & 1.797 & 1.720 & 1.714 & 1.752 \\
\hline Caxions & 15.221 & 14850 & 14.923 & j4.858 & 15501 & 15.457 & 14.887 & 14.852 & 15.453 \\
\hline 0 & 22.1000 & 22.000 & 22.0003 & 22000 & $22.00 \%$ & 22.000 & 22.0000 & 22.000 & 22.0000 \\
\hline $\mathrm{Fe}_{\mathrm{e}} \mathrm{Fe}$ & 0.43 & 0.33 & 033 & 0.31 & 0.36 & 0.41 & 0.32 & 0.32 & 0.40 \\
\hline$M_{g} F C M g$ & 057 & 0.67 & 0.67 & 069 & 1164 & 0.59 & 0.68 & 0.68 & 0.60 \\
\hline
\end{tabular}




\section{A3}

Composiçăo química, em porcentagem em peso, de piroxénios de rochas "lamprofíricas" do Paraguai.

(cpx e opx)

\section{"Lamprófiros"}

Ymi-1 (10.000a/b-10.050; 10c.005-10c.009), Ymi-4 (14.000a/b-14.017), Ymi-7 (17.001a/b-17.015), Yzu-1 (21.001-21.009).

"Lamproitos"

Ymi-5 (15.000a/b-15.023), Yzu-2 (22.000a/b-22.028), Ymi-3 (23.000a/b-23.026), Yzu-6 (26.000-26.001).

\section{"Plagileucititos"}

30.000-30.017 (Tirado de De Min, 1993).

Titaniferos: todos e em Ymi-5 15.00a-b, 15.002, 15.003a, 15.004, 15.040

Titanados: 10c.009,15.001a-b, 15.003a-b, 15.005a-b, 15.006 a 15.009, 15.013, $15.021-15.023,22.004,22.025$ e 30.009 .

Não aluminosos: $10.000 \mathrm{~b}, 10.005 \mathrm{a}, 10.040 \mathrm{~b}, 10.046$, centro dos fenocristais de Ymi-1c, 10.031, 10.032, 10.034, 17.002a, 17.003a, 21.001, 21.003, 21.005a, 21.008b, 15.013, Yzu-2 e Yzu-3 (com 22.004, 23.004b, 23.010 e 23.024 aluminosos). 


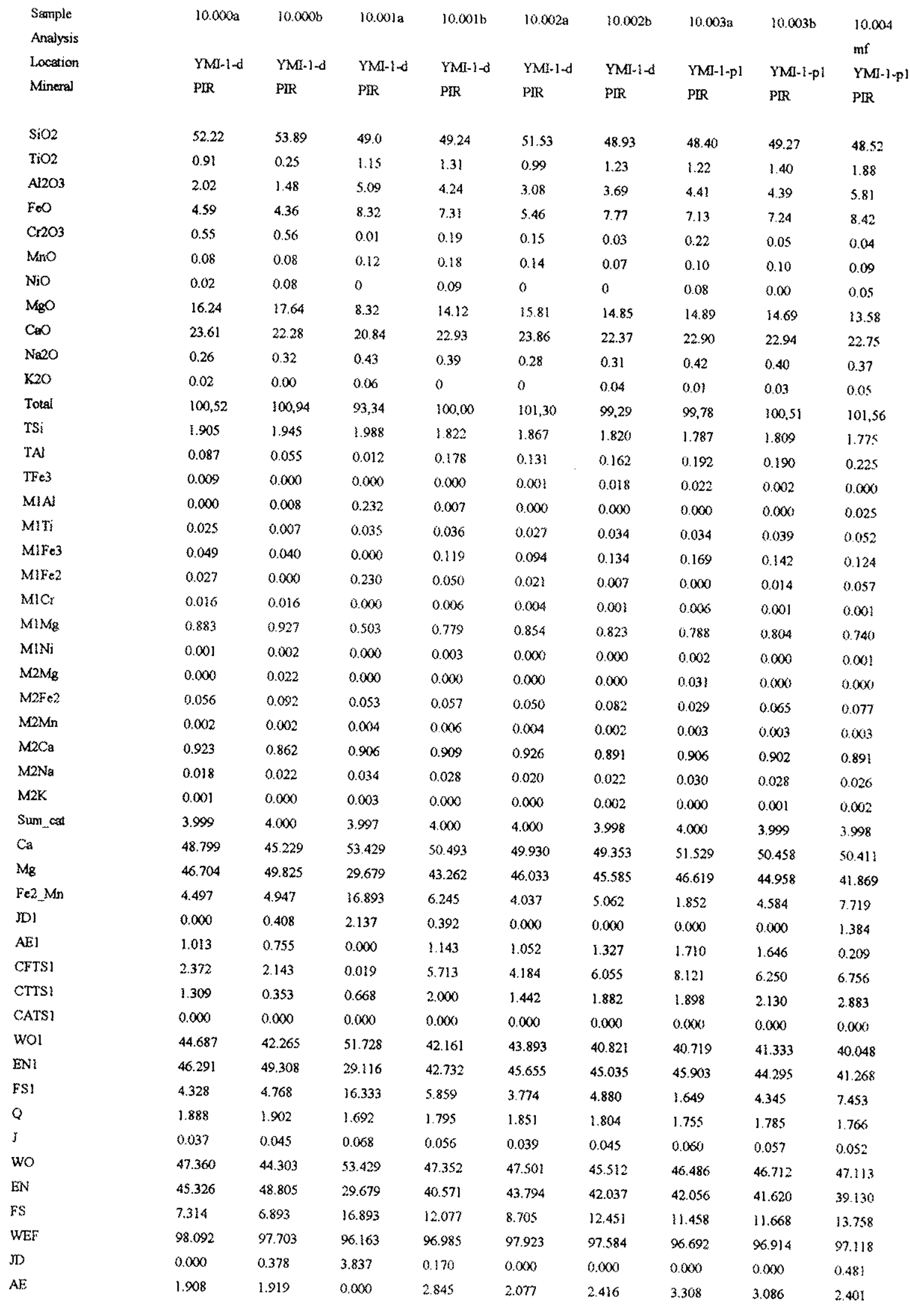




\begin{tabular}{|c|c|c|c|c|c|c|c|c|c|}
\hline Sample & $10.005 \mathrm{a}$ & $10.005 b$ & 10.010 & $10.014 \mathrm{~B}$ & $10.014 b$ & $10.015 \mathrm{a}$ & $10.015 b$ & $10.016 \mathrm{a}$ & $10.016 \mathrm{~b}$ \\
\hline \multicolumn{10}{|l|}{ Ansalysis } \\
\hline Location & YML-1-pl & YMI-1-p] & YMI-1-p2 & $Y M 1-1-p 2$ & $Y M I+1-p^{2}$ & YM1-1-p2 & YMI-1-p2 & $Y M-1-d$ & YMI-1-d \\
\hline Mineral & PIR & PIR & PIR & PIR & PIR & PIR & PIR & PIR & PIR \\
\hline $\mathrm{SiO} 2$ & 51.92 & 49.55 & 51.01 & 47.78 & 49.54 & 50.97 & 49.72 & 47.87 & 48.09 \\
\hline $\mathrm{TiO} 2$ & 0.65 & 1.46 & 0.93 & 1.14 & 1.36 & 0.95 & 1.67 & 1.75 & 1.97 \\
\hline $\mathrm{Al} 2 \mathrm{O} 3$ & 1.95 & 3.96 & 2.43 & 4.34 & 4.38 & 3.72 & 4.39 & 5.1 & 5.54 \\
\hline $\mathrm{F} \infty \mathrm{O}$ & 5.19 & 7.57 & 8.22 & 7.00 & 7.18 & 7.54 & 7.22 & $8 . \infty 0$ & 7.99 \\
\hline $\mathrm{Cr} 2 \mathrm{O}_{3}$ & 0.2 & 0.02 & 0.05 & 0 & 0.1 & 0.11 & 0.08 & 0.08 & 0.09 \\
\hline $\mathrm{MnO}$ & 0.08 & 0.16 & 0.31 & 0.16 & 0.17 & 0.11 & 0.12 & 0.20 & 0.18 \\
\hline $\mathrm{NiO}$ & 0 & 0 & 0.09 & 0.01 & 0 & 0.08 & 0.05 & 0 & 0.06 \\
\hline $\mathrm{MgO}$ & 16.47 & 14.86 & 14.48 & 14.72 & 14.86 & 14.87 & 14.28 & 13.91 & 13.64 \\
\hline $\mathrm{C} \otimes \mathrm{O}$ & 23.33 & 22.74 & 22.21 & 22.86 & 23.32 & 22.05 & 23.04 & 22.44 & 22.5 \\
\hline $\mathrm{N} 22 \mathrm{O}$ & 0.21 & 0.43 & 0.48 & 0.37 & 0.31 & 0.52 & 0.39 & 0.4 & 0.41 \\
\hline $\mathrm{K} 2 \mathrm{O}$ & 0 & 0.05 & 0.07 & 0 & 0.02 & 0.01 & 0 & 0 & 0.01 \\
\hline Total & 100,00 & 100,80 & 100,28 & 98,38 & 100,84 & 100.93 & 100,96 & 99,75 & 100.48 \\
\hline TS: & 1.901 & 1.815 & 1.885 & 1.788 & 1.816 & 1.863 & 1.823 & 1.778 & 1.776 \\
\hline TAl & 0.084 & 0.17 & 0.106 & 0.191 & 0.184 & 0.137 & 0.177 & 0.222 & 0.224 \\
\hline TFe3 & 0.015 & 0.014 & 0.009 & 0.021 & 0.000 & 0.000 & 0.000 & 0.000 & 0.000 \\
\hline MIAl & 0.000 & 0.000 & 0.000 & 0.000 & 0.005 & 0.023 & 0.012 & 0.002 & 0.017 \\
\hline $\mathrm{M} 1 \mathrm{Ti}$ & 0.018 & 0.040 & 0.026 & 0.032 & 0.038 & 0.026 & 0.046 & 0.049 & 0.055 \\
\hline MlFe3 & 0.072 & 0.136 & 0.098 & 0.174 & 0.123 & 0.095 & 0.098 & 0.148 & 0.124 \\
\hline $\mathrm{M} 1 \mathrm{Fe} 2$ & 0.005 & 0.011 & 0.073 & 0.000 & 0.041 & 0.040 & 0.060 & 0.029 & 0.049 \\
\hline $\mathrm{MlCr}$ & 0.006 & 0.001 & 0.001 & 0.000 & 0.003 & 0.003 & 0.002 & 0.092 & 0.003 \\
\hline MIMg & 0.899 & 0.811 & 0.798 & 0.793 & 0.790 & 0.810 & 0.780 & 0.770 & 0.751 \\
\hline $\mathrm{M} 1 \mathrm{Ni}$ & 0.000 & 0.000 & 0.003 & 0.000 & 0.000 & 0.002 & 0.001 & 0.000 & 0.002 \\
\hline $\mathrm{M} 2 \mathrm{Mg}$ & 0.000 & 0.000 & 0.000 & 0.028 & 0.000 & 0.000 & 0.000 & 0.000 & $0.0 \times 0$ \\
\hline $\mathrm{M} 2 \mathrm{~F} \in 2$ & 0.067 & 0.070 & 0.073 & 0.024 & 0.056 & 0.096 & 0.064 & 0.072 & 0.074 \\
\hline $\mathrm{M} 2 \mathrm{Mn}$ & 0.002 & 0.005 & 0.010 & 0.005 & 0.005 & 0.003 & $0.0 \times 14$ & 0.006 & 0.006 \\
\hline $\mathrm{M} 2 \mathrm{Ca}$ & 0.915 & 0.892 & 0.880 & 0.916 & 0.916 & 0.864 & 0.905 & 0.893 & 0.890 \\
\hline $\mathrm{M} 2 \mathrm{Na}$ & 0.015 & 0.031 & 0.034 & 0.027 & 0.022 & 0.037 & 0.028 & 0.029 & 0.029 \\
\hline M2K & 0.000 & 0.002 & 0.003 & 0.000 & 0.001 & 0,000 & 0.000 & 0.000 & 0.000 \\
\hline Sum_ca & 4,000 & 3.998 & 3.997 & 4.000 & 3.999 & 4.000 & 4.000 & 4.000 & 4,0003 \\
\hline $\mathrm{Ca}$ & 48.441 & 49.858 & 47.971 & 51.881 & 50.655 & 47.639 & 49.931 & 50.453 & 50.290 \\
\hline $\mathrm{Mg}$ & 47.582 & 45.3 .33 & 43.516 & 46.482 & 43.703 & 44.701 & 43.059 & 43.516 & 42.426 \\
\hline $\mathrm{Fe} 2 \mathrm{Mn}$ & 3.978 & 4.809 & 8.513 & 1.637 & 5.643 & 7.660 & 7.009 & 6.031 & 7.275 \\
\hline DI & 0.000 & 0.000 & 0.000 & 0.000 & 0.280 & 1.259 & 0.659 & 0.085 & 0.957 \\
\hline AE1 & 0.784 & 1.809 & 2.025 & 1.501 & 0.978 & 0.762 & 0.850 & 1.522 & 0.706 \\
\hline CFTS1 & 3.290 & 5.730 & 3.363 & 8.244 & 5.937 & 4.557 & 4.614 & 6.868 & 6.331 \\
\hline CrTs! & $0.94 !$ & 2.213 & 1.389 & 1.794 & 2.054 & 1.414 & 2.508 & 2.728 & 3.050 \\
\hline CATSI & 0.000 & 0.000 & 0.000 & $0.0(x)$ & $0.000)$ & 0.000 & 0.000 & 0.000 & 0.000 \\
\hline wol & 43.893 & 41.150 & 42.498 & 41.211 & 42.173 & 40.793 & 42.157 & 40.224 & 40.239 \\
\hline EN1 & 47.271 & 44.637 & 42.861 & 45.916 & 43.279 & 43.880 & 42.497 & 42.969 & 41.854 \\
\hline FSI & 3.821 & 4.462 & 7.864 & 1.334 & 5.299 & 7.335 & 6.715 & 5.604 & 6.863 \\
\hline$Q$ & 1.887 & 1,785 & 1.824 & 1.761 & 1.803 & 1.809 & 1.809 & 1.764 & 1.765 \\
\hline $\mathrm{J}$ & 0.030 & 0.061 & 0.069 & 0.054 & 0.044 & 0.074 & 0.055 & 0.058 & 0.059 \\
\hline wo & 46.326 & 45.985 & 45.309 & 46.718 & 47.419 & 45.266 & 47.369 & 46.559 & 47.015 \\
\hline EN & 45.504 & 41.811 & 41.101 & 41.857 & 40.911 & 42.474 & 40.850 & 40.157 & 39.656 \\
\hline FS & 8.170 & 12.204 & 13.589 & 11.425 & 11.669 & 12.260 & 11.781 & 13.284 & 13.329 \\
\hline WEF & 98.446 & 96.700 & 96.383 & 97.050 & 97.621 & 96.093 & 97.032 & 96.847 & 96.789 \\
\hline JD & 0.000 & 0.000 & 0.000 & 0.000 & 0.095 & 0.768 & 0.326 & 0.032 & 0.391 \\
\hline $\mathrm{AE}$ & 1.554 & 3.300 & 3.617 & 2.950 & 2.285 & 3.139 & 2.642 & 3.121 & 2.819 \\
\hline
\end{tabular}




\begin{tabular}{|c|c|c|c|c|c|c|c|c|c|}
\hline Sample & $10.017 \mathrm{a}$ & $10.017 \mathrm{~b}$ & 10.0188 & $10.018 b$ & 10.019 & $10.019 b$ & 10.027 & 10.037 & $10.040 \mathrm{a}$ \\
\hline Analysis & & & & & & & $\mathrm{mif}$ & $\mathrm{mf}$ & \\
\hline Location & YMI-I-d & YMI-1-d & YMI-J-d & YMI- $1-d$ & YMI-1-d & YMI-1-d & YMl-1-d & l'Ml-1-pl & $\mathrm{YM}=1+\mathrm{l}-\mathrm{d}$ \\
\hline Mineral & PIR & PIR & PIR & PlR & PIR & PIR & PIR & PIR & PIR \\
\hline $\mathrm{SiO} 2$ & 49.63 & 48.61 & 50.47 & 50.89 & 49.33 & 50.2 & 51.65 & 49.81 & 52.90 \\
\hline $\mathrm{TiO} 2$ & 1.12 & 1.35 & 1.35 & 0.92 & $1 . \infty$ & 1.46 & 0.64 & 1.17 & 0.38 \\
\hline $\mathrm{A} 12 \mathrm{O} 3$ & 4.14 & 5.09 & 4.14 & 3.34 & 3.46 & 422 & 2.12 & 5.18 & 1.40 \\
\hline $\mathrm{FoO}$ & 7.61 & 7.65 & 7.49 & 6.04 & 7.15 & 6.12 & 4.66 & 8.45 & 4.21 \\
\hline $\mathrm{Cr} 2 \mathrm{O} 3$ & 0 & 0.02 & 0.09 & 0.15 & 0.03 & 0.36 & 0.6 & 0.01 & 0.34 \\
\hline $\mathrm{MnO}$ & 0.17 & 0.15 & 0.14 & 0.17 & 0.15 & 0.07 & 0.13 & 0.12 & 0.04 \\
\hline $\mathrm{NiO}$ & 0.04 & 0.03 & 0.07 & 0 & 0.05 & 0.08 & 0 & 0.00 & 0.07 \\
\hline $\mathrm{MBO}$ & 15.00 & 15.34 & 14.29 & 15.52 & 14.88 & 14.99 & 16.32 & 15.14 & 17.67 \\
\hline $\mathrm{CaO}$ & 21.77 & 20.69 & 22.64 & 22.79 & 22.70 & 22.95 & 23.19 & 21.18 & 22.33 \\
\hline $\mathrm{Na} 2 \mathrm{O}$ & 0.53 & 0.35 & 0.4 & 0.41 & 0.38 & 0.35 & 0.29 & 0.43 & 0.34 \\
\hline $\mathrm{K} 2 \mathrm{O}$ & 0 & 0.04 & 0 & 0.07 & 0 & 0 & 0 & 0.07 & 0.05 \\
\hline Total & 100,01 & 99,32 & 101,08 & 100,30 & 99,13 & 100,80 & $9 x, 60$ & 101,50 & 99,73 \\
\hline $\mathrm{TSi}$ & 1.828 & 1.801 & 1.849 & 1.863 & 1.834 & 1.835 & 1.898 & 1.809 & 1.920 \\
\hline TAl & 0.172 & 0.199 & 0.151 & 0.337 & 0.152 & 0.165 & 0.092 & 0.191 & 0.060 \\
\hline TFe3 & 0.000 & 0.000 & 0.000 & 0.000 & 0.014 & 0.000 & 0.010 & 0.000 & 0.011 \\
\hline$M[A]$ & 0.008 & 0.023 & 0.027 & 0.007 & 0.000 & 0.017 & 0.000 & 0.030 & 0.000 \\
\hline MITi & 0.031 & 0.038 & 0.037 & 0.025 & 0.028 & 0.040 & 0.018 & 0.032 & 0.010 \\
\hline Mife3 & 0.140 & 0.126 & 0.075 & 0.107 & 0.136 & 0.081 & 0.069 & 0.130 & 0.067 \\
\hline MIFe? & 0.000 & 0.000 & 0.076 & 0.009 & 0.009 & 0.032 & 0.001 & 0.000 & $0.0 x x$ \\
\hline $\mathrm{MlCr}$ & 0.000 & 0.001 & 0.003 & 0.004 & 0.001 & 0.030 & 0.017 & 0.000 & 0.010 \\
\hline MIMg & 0.820 & 0.812 & 0.780 & 0.847 & 0.825 & 0.817 & 0.894 & 0.808 & 0.911 \\
\hline MIN: & $0 .(0) 1$ & 0.001 & 0.002 & 0,000 & 0.001 & 0.002 & 0.000 & 0.000 & 0002 \\
\hline$M 2 M g$ & 0.003 & 0.036 & 0.000 & 0.000 & 0.000 & 0.000 & 0.000 & 0.012 & 0.049 \\
\hline $\mathrm{M} 2 \mathrm{Fe} 2$ & 0.095 & 0.111 & 0.079 & 0.068 & 0.063 & 0.074 & 0.062 & 0.127 & 0.051 \\
\hline $\mathrm{M} 2 \mathrm{Mn}$ & 0.005 & 0.005 & 0.004 & 0.005 & 0.005 & 0.002 & 0.004 & $0.0 \times 34$ & 0.001 \\
\hline $\mathrm{M} 2 \mathrm{Ca}$ & 0.859 & 0.821 & 0.888 & 0.894 & 0.904 & 0.899 & 0.913 & 0.824 & 0.872 \\
\hline $\mathrm{M} 2 \mathrm{~N}_{3}$ & 0.038 & 0.025 & 0.028 & 0.029 & 0.027 & 0.025 & 0.021 & 0.030 & 0.024 \\
\hline $\mathrm{M} 2 \mathrm{2} \mathrm{K}$ & 0.000 & 0.002 & 0.000 & 0.003 & 0.000 & 0.000 & 0.000 & 0.003 & 0.002 \\
\hline Sum & 4.000 & 3.998 & 4.000 & 3.997 & 4.000 & 4.000 & $4.000)$ & 3.997 & 3.998 \\
\hline $\mathrm{Ca}$ & 48.192 & 46.029 & 48.618 & 49.006 & 50.064 & 49.285 & 48.703 & 46.442 & 46.286 \\
\hline $\mathrm{Mg}$ & 46.202 & 47.484 & 42.698 & 46.435 & 45.662 & 44.790 & 47.690 & 46.192 & 50.962 \\
\hline $\mathrm{Fe} 2 \mathrm{Mnn}$ & 5.606 & 6.486 & 8.684 & 4.558 & 4.275 & 5.926 & 3.607 & 7.366 & 2.752 \\
\hline JDI & 0.414 & 1.290 & 1.468 & 0.375 & 0.000 & 0.922 & 0.000 & 1.678 & 0.000 \\
\hline AEI & 1.671 & 0.206 & 0.056 & 1.374 & 1.498 & 0.422 & 1.093 & 0.179 & 1.380 \\
\hline CFTSI & 6.030 & 6.801 & 4.130 & 4.643 & 5.972 & 4.538 & 3.501 & 7.020 & 2.624 \\
\hline CTrS1 & 1.709 & 2.082 & 2.009 & 1.369 & 1.529 & 2.174 & 0.935 & 1.771 & 0.546 \\
\hline CATSI & 0.000 & 0.000 & 0,000 & 0.000 & 0.000 & 0.000 & 0.000 & 0.000 & 0.000 \\
\hline WO1 & 39.589 & 36.577 & 41.848 & 42.277 & 41.943 & 41.968 & 43.839 & 36.883 & 42.507 \\
\hline EN1 & 45.374 & 46.897 & 42.143 & 45.756 & 45.096 & 44.241. & 47.271 & 45.428 & $\$ 0.292$ \\
\hline FSI & 5.213 & 6.146 & 8.336 & 4.207 & 3.963 & 5.736 & 3.361 & 7,040 & 2.651 \\
\hline$Q$ & 1.777 & 1.780 & 1.823 & 1.819 & 1.802 & 1.822 & 1.871 & 1.771 & 1.883 \\
\hline j & 0.076 & 0.050 & 0.057 & 0.058 & 0.055 & 0.050 & 0.041 & 0.061 & 0.048 \\
\hline wo & 44.688 & 42.993 & 46.700 & 46.290 & 46.229 & 47.184 & 46.719 & 43.281 & 44.452 \\
\hline EN & 42.843 & 44.352 & 41.013 & 43.861 & 42.164 & 42.881 & 45.747 & 43.047 & 48.943 \\
\hline FS & 12.469 & 12.654 & 12.288 & 9.849 & 11.607 & 9.935 & 7.535 & 13.672 & 6.605 \\
\hline WEF & 95.926 & 97.259 & 96.985 & 96.908 & 97.056 & 97.352 & 97.843 & 96.700 & 97.513 \\
\hline YD & 0.208 & 0.428 & 0.802 & 0.188 & 0.000 & 0.459 & $0.0 \times 0$ & 0.625 & $0.0 \times 0$ \\
\hline $\mathrm{AE}$ & 3.866 & 2.313 & 2.214 & 3.904 & 2.944 & 2.190 & 2.157 & 2.675 & 2.487 \\
\hline
\end{tabular}




\begin{tabular}{|c|c|c|c|c|c|c|c|c|c|}
\hline Sampie & $10.040 \mathrm{~b}$ & $10,041 \mathrm{a}$ & $10.041 \mathrm{~b}$ & $10.042 a$ & $10.042 b$ & 10.046 & $10.100 \mathrm{a}$ & $10.100 \mathrm{~b}$ & 10.101 \\
\hline Analysis & & & & $\mathrm{mf}$ & $\mathrm{m} f$ & $\mathrm{mf}$ & $m f$ & $\mathrm{mi}$ & $\mathrm{mf}$ \\
\hline Lacation & $\mathrm{YMI}-1-\mathrm{d}$ & YMII-I-pl & YMI-l-pl & YMI-1-pl & YMI- - $-\mathrm{pl}$ & YMl-1-pl & YMI-1-pl & $Y M I-1-p \mid$ & YMI-1-pl \\
\hline Mineral & PIR & PIR & PIR & PIR & PIR & $\mathrm{PlK}$ & $o p x$ & opx & $o p x$ \\
\hline $\mathrm{SiO} 2$ & 54.31 & 49.98 & 51.53 & 48.93 & 48.40 & 53.20 & 53.84 & 53,44 & 48.90 \\
\hline $\mathrm{TiO} 2$ & 0,30 & 1.33 & 0.99 & 1.23 & 1.22 & 0.72 & 0.08 & 0.00 & 0.03 \\
\hline $\mathrm{Al} 203$ & 1.27 & 4.31 & 3.08 & 3.69 & 4.41 & 1.96 & 0.08 & 0.02 & 0.18 \\
\hline $\mathrm{FOO}$ & 4.22 & 7.42 & 5.46 & 7.77 & 7.13 & 5.10 & 12.72 & 14.39 & 14.43 \\
\hline $\mathrm{Cr} 2 \mathrm{O} 3$ & 0.53 & 0.19 & 0.15 & 0.08 & 0.22 & 0.19 & 0.10 & 0.12 & 0.01 \\
\hline Mno & 0.14 & 0.18 & 0.14 & 0.07 & 0.10 & 0.05 & 0.06 & 0.03 & 0.06 \\
\hline NiO & 0.04 & 0.09 & 0.00 & 0.00 & 0.08 & 0.02 & 0.45 & 0.25 & 0.44 \\
\hline $\mathrm{MgO}$ & 17.82 & 14.33 & 15.81 & 14.85 & 14.89 & 16.59 & 23.37 & 22.67 & 25.55 \\
\hline $\mathrm{CeO}$ & 22.24 & 23.28 & 23.86 & 22.37 & 22.90 & 23.72 & 0.10 & 0.13 & 0.11 \\
\hline $\mathrm{Na} 2 \mathrm{O}$ & 0.35 & 0.40 & 0.28 & 0.31 & 0.42 & 0.23 & 0.05 & 0.09 & 0.04 \\
\hline $\mathrm{K} 2 \mathrm{O}$ & 0.03 & 0.00 & 0.00 & 0.09 & 0.01 & 0.00 & 0.08 & 0.10 & 0.13 \\
\hline Totas & 101,25 & 101,51 & 101,30 & 99,34 & $\$ 9,78$ & 101,78 & 90,93 & 91,24 & 89,88 \\
\hline $\mathrm{TSi}$ & 1.953 & 1.822 & 1.867 & 1.819 & 1.787 & 1.915 & 2.148 & 2.136 & 1.955 \\
\hline TAl & 0.047 & 0.178 & 0.131 & 0.162 & 0.192 & 0.083 & 0.000 & 0.000 & 0.008 \\
\hline TFe3 & 0.000 & 0.000 & 0.001 & 0.019 & 0.022 & 0.002 & 0.000 & 0.000 & 0.037 \\
\hline $\mathrm{MIAl}$ & 0.007 & 0.007 & 0.000 & 0.000 & 0,000 & 0.000 & 0.004 & 0.001 & 0.000 \\
\hline MITi & 0.008 & 0.036 & 0.027 & 0.034 & 0.034 & 0.019 & 0.002 & 0.000 & 0.001 \\
\hline MiFe3 & 0.035 & 0.120 & 0.094 & 0.133 & 0.169 & 0.056 & 0.000 & 0.000 & 0.053 \\
\hline $\mathrm{M} F \mathrm{Fe} 2$ & 0.000 & 0.049 & 0.021 & 0.007 & 0.000 & 0.028 & 0.000 & 0.000 & 0.000 \\
\hline $\mathrm{M} / \mathrm{Cr}$ & 0.015 & 0.005 & 0,004 & 0.002 & 0.006 & $0.00 \mathrm{~S}$ & 0.003 & 0.006 & $0 .(x)$ \\
\hline $\mathrm{M} I \mathrm{Mg}$ & 0.934 & 0.779 & 0.854 & 0.823 & 0.788 & 0.890 & 0.976 & 0.987 & 0.932 \\
\hline $\mathrm{MINi}$ & 0.001 & 0.003 & 0.000 & 0.000 & 0.002 & 0.001 & 0.014 & 0.008 & 0.014 \\
\hline $\mathrm{M} 2 \mathrm{Mg}$ & 0.021 & 0.000 & 0.000 & 0.000 & 0.031 & 0.000 & 0.414 & 0.364 & 0.591 \\
\hline M2Fe2 & 0.092 & 0.057 & 0.050 & 0.082 & 0.029 & 0.068 & 0.424 & 0.481 & 0.393 \\
\hline $\mathrm{M} 2 \mathrm{Mnn}$ & 0.004 & 0.006 & 0.004 & 0.002 & 0.003 & 0.002 & 0.002 & 0.001 & 0.002 \\
\hline $\mathrm{M} 2 \mathrm{Ca}$ & 0.857 & 0.909 & 0.926 & 0.891 & 0.906 & 0.915 & 0.004 & 0.006 & 0.005 \\
\hline $\mathrm{M} 2 \mathrm{Na}$ & 0.024 & 0.028 & 0.020 & 0.022 & 0.030 & 0.016 & 0.004 & 0.007 & 0.003 \\
\hline$M 2 K$ & 0.001 & 0.000 & 0.000 & 0.002 & 0.000 & 0.000 & 0.004 & 0.005 & 0.007 \\
\hline Sum_er & 3.999 & 4.000 & 4.000 & 3.998 & 4.000 & 4.000 & 3.996 & 3.995 & 3.993 \\
\hline $\mathrm{Ca}$ & 44.896 & 50.520 & 49.930 & 49.353 & 51.529 & 48.096 & 0.235 & 0.303 & 0.245 \\
\hline $\mathrm{Mg}$ & 50.052 & 43.268 & 46.033 & 45.585 & 46.619 & 46,804 & 76.343 & 73.477 & 79.216 \\
\hline $\mathrm{Fe} 2 \mathrm{Mn}$ & 5.052 & 6.212 & 4.037 & 5.062 & 1.852 & 5.100 & 23.422 & 26.220 & 20.539 \\
\hline $\mathrm{DI}$ & 0.345 & 0.394 & 0.000 & 0.000 & 0.000 & 0.000 & 0.206 & 0.051 & 0.000 \\
\hline $\mathrm{AE} 1$ & 0.991 & 1.157 & 1.052 & 1.327 & 1.710 & 0.838 & 0.229 & 0.602 & 0.494 \\
\hline CFTS! & 1.590 & 5.725 & 4.184 & 6.095 & 8.121 & 2.380 & 0.000 & 0.000 & 2.206 \\
\hline CTTSI & 0.420 & 2.001 & 1.442 & 1.882 & 1.898 & 1.017 & 0.000 & 0.000 & 0.046 \\
\hline CATSI & 0.000 & 0.000 & 0.000 & 0.000 & 0.000 & 0.000 & 0.000 & 0.000 & 0.000 \\
\hline WOI & 42.385 & 42.164 & 43.893 & 40.781 & 40.719 & 44.334 & 0.234 & 0.301 & 0.000 \\
\hline ENI & 49.494 & 42.729 & 45.655 & 45.035 & 45.903 & 46.450 & 76.096 & 73.038 & 77.312 \\
\hline FS1 & 4.775 & 5.830 & 3.774 & 4.887 & 1.649 & 4.982 & 23.235 & 26.008 & 19.942 \\
\hline$Q$ & 1.904 & 1.794 & 1.851 & 1.804 & 1.755 & 1.901 & 1.818 & 1.838 & 1.920 \\
\hline$y$ & 0.049 & 0.057 & 0.039 & 0.045 & 0.060 & 0.032 & 0.008 & 0.014 & 0.006 \\
\hline wo & 44.093 & 47.363 & 47.501 & 45.512 & 46.486 & 46.671 & 0.235 & 0.303 & 0.234 \\
\hline EN & 49.157 & 40.565 & 43.794 & 42.037 & 42.056 & 45.418 & 76.343 & 73.477 & 75.685 \\
\hline FS & 6.750 & 12.073 & 8.705 & 12.451 & 11.458 & 7.910 & 23.422 & 26.220 & 24.080 \\
\hline WEF & 97.506 & 96.954 & 97.923 & 97.584 & 96.692 & 98.340 & 99.577 & 99.247 & 99.678 \\
\hline $\mathrm{j}$ & 0.401 & 0.172 & 0.000 & 0.000 & 0.000 & 0.000 & 0.423 & 0.753 & 0.000 \\
\hline $\mathrm{AE}$ & 2.092 & 2.874 & 2.077 & 2.416 & 3.308 & 1.660 & 0.000 & 0.000 & 0.322 \\
\hline
\end{tabular}




\begin{tabular}{|c|c|c|c|c|c|c|c|c|c|}
\hline Sumpic & 10.102 & $100.001 \mathrm{~B}$ & $10 \mathrm{c} .001 \mathrm{~b}$ & $100.002 \mathrm{~s}$ & $10 \mathrm{c} .002 \mathrm{~b}$ & $10 \mathrm{c} .003 \mathrm{a}$ & $10 c .003 b$ & $10 \mathrm{c} .004 \mathrm{a}$ & $10 \mathrm{c} .004 \mathrm{~b}$ \\
\hline Arailysis & $\mathrm{mf}$ & & & & & & & & \\
\hline Locstion & YMI-1-d & YMI-1 & $\mathrm{YMI}-1$ & YMI-1C & YMA-IC & YMalC & YMI-1C & YMI-1C & YMJ-IC \\
\hline Mineral & opx & PIR & PIR & PIR & PIR & PIR & PRR & PIR & PIR \\
\hline $\mathrm{SiO}_{2}$ & 55.83 & 57.74 & 51.79 & 52.23 & 52.67 & 53.15 & 51.96 & 53.07 & 51.66 \\
\hline $\mathrm{TiO}_{2}$ & 0.00 & 0.47 & 0.78 & 0.55 & 0.53 & .046 & 0.65 & 0.24 & 0.56 \\
\hline $\mathrm{Al} 2 \mathrm{O}_{3}$ & 0.10 & 1.88 & 2.23 & 1.97 & 2.41 & 1.91 & 2.66 & 1.62 & 2.49 \\
\hline$F_{0} \mathrm{O}$ & 9.09 & 4.10 & 5.35 & 5.40 & 5.95 & 4.01 & 564 & 3.98 & 4.65 \\
\hline $\mathrm{Cr} 2 \mathrm{O} 3$ & 0.11 & 0.71 & 0.38 & 0.15 & 0.14 & 0.51 & 0.40 & 0.77 & 0.66 \\
\hline $\mathrm{MnO}$ & 0.05 & 0.08 & 0.13 & 0.11 & 0.15 & 0.06 & 0.12 & 0.14 & 0.10 \\
\hline $\mathrm{NiO}$ & 0.44 & 0.03 & 0 & 0.05 & 0.03 & 0 & 0.01 & 0.02 & 0.08 \\
\hline $\mathrm{MgO}$ & 25.47 & 16.21 & 15.36 & 15.66 & 15.67 & 16.81 & 15.62 & 16.78 & 15.79 \\
\hline $\mathrm{CaO}$ & 0.12 & 23.39 & 22.88 & 22.94 & 22.83 & 22.76 & 22.95 & 22.51 & 23.55 \\
\hline $\mathrm{Ne}_{2} \mathrm{O}$ & 0.03 & 0.31 & 0.19 & 0.28 & 0.33 & 0.32 & 0.33 & 0.35 & 0.34 \\
\hline $\mathrm{K} 2 \mathrm{O}$ & 0.06 & 0 & 0 & 0 & 0 & 0 & 0 & 0 & 0.01 \\
\hline Total & 91,30 & 104,92 & 99,09 & 99.34 & 100,71 & 99,58 & 100,34 & 99.48 & 99,89 \\
\hline TSi & 2.184 & 2.022 & 1.924 & 1.931 & 1.922 & 1.945 & 1.503 & 1.947 & 1.846 \\
\hline TAl & 0.000 & 0.000 & 0.076 & 0.069 & 0.078 & 0.055 & 0.097 & 0.053 & 0.104 \\
\hline Tre 3 & 0.000 & 0.000 & 0.000 & 0.000 & 0.000 & 0.000 & 0.000 & 0.000 & 0.000 \\
\hline MIAJ & 0.005 & 0.078 & 0.022 & 0.017 & 0.026 & 0.027 & 0.017 & 0.017 & 0.003 \\
\hline MlTi & 0.000 & 0.012 & 0.022 & 0.015 & 0.015 & $0 .(x)$ & 0.018 & 0.007 & 0.015 \\
\hline $\mathrm{M}$ Fe3 & 0.000 & 0.000 & 0.013 & 0.037 & 0.042 & 0.033 & 0.056 & 0.026 & 0.076 \\
\hline MlFe2 & 0.000 & 0.043 & 0.082 & 0.062 & 0.060 & 0.007 & 0.045 & 0.011 & o.(32) \\
\hline $\mathrm{M} / \mathrm{Cr}$ & 0.003 & 0.020 & 0.011 & 0.004 & 0.004 & 0.015 & 0.012 & 0.022 & 0.019 \\
\hline MIMg & 0.978 & 0.846 & 0.851 & 0.863 & 0.853 & 0.917 & 0.853 & 0.918 & 0.864 \\
\hline $\mathrm{M} 1 \mathrm{Ni}$ & 0.014 & 0.001 & 0.000 & 0.001 & 0.001 & 0.000 & 0.000 & 0.001 & 0.002 \\
\hline $\mathrm{M} 2 \mathrm{MB}$ & 0.507 & 0.000 & 0.000 & $0.0 \times 0)$ & 0.000 & $0.0 \times 0$ & 0.000 & $0.0(x)$ & 0.000 \\
\hline $\mathrm{M} 2 \mathrm{Fe} \mathrm{e}$ & 0.297 & 0.077 & 0.071 & 0.068 & 0.079 & 0.083 & 0.072 & 0.086 & 0.046 \\
\hline $\mathrm{M} 2 \mathrm{Mn}$ & 0.002 & 0.002 & 0.004 & 0.003 & 0.005 & 0.002 & 0.004 & 0.0044 & 0.003 \\
\hline $\mathrm{M} 2 \mathrm{Ca}$ & 0,005 & 0.878 & 0.911 & 0.909 & 0.893 & 0.892 & 0.900 & 0.885 & 0.926 \\
\hline $\mathrm{M} 2 \mathrm{Na}$ & 0.002 & 0.021 & 0.014 & 0.020 & 0.023 & 0.023 & 0.023 & 0.025 & 0.024 \\
\hline $\mathrm{M} 2 \mathrm{~K}$ & 0.003 & 0.000 & 0.000 & 0.000 & 0.000 & 0.000 & 0.000 & 0.000 & 0.000 \\
\hline Sum_cat & 3.997 & 4.000 & 4.000 & 4.000 & 4.000 & 4.000 & 4.000 & 4.000 & 4.000 \\
\hline $\mathrm{Ca}$ & 0.281 & 47.533 & 47.463 & 47.702 & 47.245 & 46.939 & 48.053 & 46.483 & 49.784 \\
\hline Mg & 83.007 & 45.835 & 44.335 & 45.309 & 45.120 & 48.237 & 45.505 & 48.213 & 46.444 \\
\hline $\mathrm{Fe} 2 \mathrm{Mn}$ & 16.711 & 6.632 & 8.202 & 6.989 & 7.634 & 4.824 & 6.442 & 5.304 & 3.772 \\
\hline $\mathrm{DDl}$ & 0.257 & 1.129 & 0.710 & 0.867 & 1.224 & 1.181 & 0.915 & 0.872 & 0.16 .5 \\
\hline $\mathrm{AE} !$ & 0.037 & 0.000 & 0.000 & 0.177 & 0.000 & 0.000 & 0.322 & 0.422 & 1.146 \\
\hline CFISI & 0.153 & 1.053 & 1.249 & 1.990 & 2.412 & $2.47 \gamma$ & 3.232 & 2.063 & 3.891 \\
\hline CTTSI & 0.000 & 0.000 & 1.130 & 0.796 & 0.762 & 0.066 & 0.946 & 0.344 & 0.822 \\
\hline CATS1 & 0.000 & 0.000 & 0.412 & 0.00 & 0.125 & 0.239 & 0.000 & 0.000 & 0.000 \\
\hline wol & 0.128 & 46.004 & 44,436 & 44,503 & 43.482 & 43.648 & 43.375 & 43.580 & 44.501 \\
\hline ENI & 82.840 & 45.376 & 44.114 & 44.917 & 44.678 & 47.714 & 45.032 & 47.698 & 45.912 \\
\hline FS! & 16.585 & 6.438 & 7.949 & 6.749 & 7.317 & 4.675 & 6.178 & 5.021 & 3.564 \\
\hline$Q$ & 1.788 & 1.844 & 1.915 & 1.901 & 1.885 & 1.899 & 1.870 & 1.899 & 1.857 \\
\hline$J$ & 0.005 & 0.042 & 0.027 & 0.040 & 0.047 & 0.045 & 0.047 & 0.050 & 0.048 \\
\hline wo & 0.281 & 47.533 & 47.146 & 46.787 & 46.218 & 46.141 & 46.665 & 45.869 & 47.838 \\
\hline EN & 83.007 & 45.835 & 44.038 & 44.440 & 44.139 & 47.417 & 44.191 & 47.575 & 44.629 \\
\hline FS & 16.711 & 6.632 & 8.817 & 8.774 & 9.642 & 6.442 & 9.144 & 6.556 & 7.533 \\
\hline WEF & 99.746 & 97.771 & 98.593 & 97.936 & 97.588 & 97.667 & 97.560 & 97.451 & 97.464 \\
\hline $\mathrm{JD}$ & 0.254 & 2.229 & 0.880 & 0.638 & 0.917 & 1.058 & 0.579 & 1.011 & 0.100 \\
\hline $\mathrm{AE}$ & 0.000 & 0.000 & $0 . \$ 26$ & 1.426 & 1.495 & 1.275 & 1.861 & 1.538 & 2.436 \\
\hline
\end{tabular}




\begin{tabular}{|c|c|c|c|c|c|c|c|c|c|}
\hline Sample & 10.006 & 10.007 & 10.008 & 10.009 & 10.011 & 10.012 & 10.013 & 10.020 & 10.021 \\
\hline Analysis & $\mathrm{gm}$ & $g m$ & $g m$ & $g m$ & gn & $\mathrm{gm}$ & gm & gn: & gm \\
\hline Location & YMI-1-pl & $Y M I+1-p l$ & $Y M 1-i-p l$ & YM(n) $\mathrm{d}$ & $\mathrm{YM} / 1+\mathrm{p} 2$ & $Y M 1-1-p_{2}^{2}$ & $Y M-1-p^{2}$ & YMl-1-d & $Y M(-)-d$ \\
\hline Mineral & PIR & PIR & PIR & PIR & PIR & $P R R$ & PIR & PIR & PIR \\
\hline $\mathrm{SiO} 2$ & 51.86 & 49.85 & 48.29 & 49.23 & 51.49 & 51.00 & 50.30 & 51.64 & 49.58 \\
\hline $\mathrm{THO}_{2}$ & 0.82 & 1.13 & 1.77 & 1.42 & 1.04 & 1.11 & 1.10 & 0.82 & 1.42 \\
\hline $\mathrm{A} 12 \mathrm{O} 3$ & 2.01 & 3.77 & 5.39 & 4.40 & 2.64 & 3.29 & 3.23 & 2.18 & 4.09 \\
\hline $\mathrm{FeO}$ & 8.17 & 8.06 & 7.79 & 7.26 & 6.93 & 7.39 & 8.01 & 5.48 & 6.42 \\
\hline $\mathrm{Cr} 2 \mathrm{O} 3$ & 0.02 & 0.06 & 0.11 & 0.23 & 0 & 0.04 & 0.04 & 0.38 & 0.49 \\
\hline $\mathrm{MnO}$ & 0.31 & 0.18 & 0.18 & 0.08 & 0.1 & 0.07 & 0.24 & 0.09 & 0.08 \\
\hline NiO & 0 & 0 & 0 & 0 & 0.08 & 0 & 0.03 & 0 & 0.03 \\
\hline $\mathrm{MgO}$ & 14.28 & 14.91 & 13.66 & 14.08 & 15.52 & 14.54 & 14.79 & 16.19 & 14.67 \\
\hline $\mathrm{CaO}$ & 22.42 & 22.25 & 22.58 & 23.11 & 22.67 & .22 .78 & 22.42 & 23.07 & 23.4 \\
\hline $\mathrm{Na} 2 \mathrm{O}$ & 0.53 & 0.32 & 0.34 & 0.26 & 0.24 & 0.36 & 0.37 & 0.26 & 0.37 \\
\hline $\mathrm{K} 2 \mathrm{O}$ & 0.15 & 0.05 & 0.07 & 0.05 & 0.02 & 0 & - & 0.04 & 0.02 \\
\hline Total & 100,57 & 100,58 & 100,18 & 100,12 & 100,73 & 100,58 & - & 100,15 & 100,57 \\
\hline $\mathrm{TSi}$ & 1.912 & 1.832 & 1.788 & 1.821 & 1.885 & 1.876 & 1.851 & 1.892 & 1.820 \\
\hline TAl & 0.087 & 0.163 & 0.212 & 0.179 & 0.114 & 0.124 & 0.140 & 0.094 & 0.177 \\
\hline TFe 3 & 0.001 & 0.005 & 0.000 & $0.0 \times 3$ & 0.001 & 0.000 & 0.009 & 0.014 & $0 .(x) 4$ \\
\hline $\mathrm{M} \mid \mathrm{Al}$ & 0.000 & 0.000 & 0.023 & 0.013 & 0.000 & 0.018 & 0,000 & 0.000 & 0,000 \\
\hline MITi & 0.023 & 0.031 & 0.049 & 0.040 & 0.029 & 0.031 & 0.030 & 0.023 & 0.039 \\
\hline Mife? & 0.086 & 0.128 & 0.114 & 0.160 & 0.075 & 0.069 & 0.113 & 0.072 & 0.115 \\
\hline M]Fe? & 0.105 & 0.022 & 0.056 & 0.064 & 0.047 & 0.084 & 0.043 & 0.010 & 0.029 \\
\hline $\mathrm{MlCr}$ & 0.001 & 0.002 & 0,003 & 0.007 & $0,(x)$ & 0.001 & 0,001 & 0.011 & 0.014 \\
\hline MIMg & 0.785 & 0.817 & 0.754 & 0.777 & 0.847 & 0.797 & 0.812 & 0.884 & 0.80 .3 \\
\hline$M I N i$ & 0.000 & 0.000 & 0.000 & 0.000 & 0.002 & 0.000 & 0,001 & 0.000 & 0.001 \\
\hline $\mathrm{M} 2 \mathrm{Mg}$ & 0.000 & 0.000 & 0.000 & 0.000 & 0.000 & 0.000 & 0.000 & 0.000 & 0.000 \\
\hline $\mathrm{M} 2 \mathrm{Fe} 2$ & 0.060 & 0.093 & 0.071 & 0.060 & 0.090 & 0.075 & 0.082 & 0.071 & 0.050 \\
\hline $\mathrm{M} 2 \mathrm{Mn}$ & 0.080 & 0.006 & 0.006 & $0 .(x) 3$ & 0.003 & 0.002 & 0.007 & 0.003 & 0.001 \\
\hline $\mathrm{M} 2 \mathrm{Ca}$ & 0.886 & 0.876 & 0.896 & 0.916 & 0.889 & 0.898 & 0.884 & 0.905 & 0.920 \\
\hline $\mathrm{M} 2 \mathrm{Na}$ & 0.038 & 0.023 & 0.024 & 0.019 & 0.017 & 0.026 & 0.026 & 0.018 & 0.026 \\
\hline $\mathrm{M} 2 \mathrm{~K}$ & 0.007 & 0.002 & 0.003 & 0.002 & 0.001 & 0.000 & 0.000 & 0.002 & 0.001 \\
\hline Sum_cat & 3.093 & 3.998 & 3.997 & 3.998 & 3.999 & 4.000 & 4.000 & 3.998 & 3.999 \\
\hline $\mathrm{Ca}$ & 47.999 & 48.311 & 50.251 & 50.349 & 47.407 & 48.378 & 48.352 & 48.319 & 51.000 \\
\hline $\mathrm{Mg}$ & 42.537 & 45.045 & 42.298 & 42.681 & 45.158 & 42.964 & 44.381 & 47.181 & 44.492 \\
\hline $\mathrm{Fe} 2 \mathrm{Mn}$ & 9.464 & 6.644 & 7.450 & 6.970 & 7.435 & 8.657 & 7.267 & 4.500 & 4.502 \\
\hline JDI & 0.000 & 0.000 & 1.279 & 0.709 & 0.000 & 0.966 & 0.000 & 0.000 & 0.000 \\
\hline $\mathrm{AEl}$ & 2.390 & 1.372 & 0.257 & 0.435 & $0.9 \$ 1$ & 0.400 & 1.429 & 1.075 & 1.491 \\
\hline CFTSI & 2.237 & 5.718 & 6.241 & 5.389 & 3.016 & 3.326 & 4.725 & 3.319 & $\$ .552$ \\
\hline CTrS1 & 1.209 & 1.704 & 2.732 & 2.150 & 1.515 & 1.634 & 1.648 & 1.195 & 2.144 \\
\hline CATSI & 0.000 & $0.0(x)$ & 0.000 & 0.000 & 0.000 & $0.0(x)$ & 0.000 & 0.000 & 0.000 \\
\hline wol & 43.652 & 40.374 & 40.664 & 42.302 & 42.503 & 42.813 & 41.483 & 43.358 & 42.619 \\
\hline ENI & 41.740 & 44.565 & 41.781 & 42.252 & 44.802 & 42.427 & 43.926 & 46.744 & 43.889 \\
\hline FS & 8.772 & 6.267 & 7.046 & 6.763 & 7.213 & 8.433 & 6.787 & 4.310 & $4.30 \mathrm{~s}$ \\
\hline$Q$ & 1.836 & 1.808 & 1.777 & 1.817 & 1.873 & 1.853 & 1.821 & 1.871 & 1.801 \\
\hline 3 & 0.076 & 0.046 & 0.049 & 0.037 & 0.034 & 0.051 & 0.053 & 0.037 & 0.053 \\
\hline wo & 45.838 & 45.014 & 47.229 & 47.718 & 45.565 & 46.647 & 45.347 & 46.191 & 47.866 \\
\hline $\mathrm{EN}$ & 40.623 & 41.970 & 39.755 & 40.451 & 43.403 & 41.427 & 41.623 & 45.103 & 41.754 \\
\hline FS & 13.539 & 13.016 & 13.016 & 11.831 & 11.031 & 11.925 & 13.030 & 8.707 & 10.380 \\
\hline WEF & 96.055 & 97.547 & 97.334 & 97.991 & 98.216 & 97.307 & 97.193 & 98.067 & 97.164 \\
\hline m & 0.000 & 0.000 & 0.449 & 0.231 & 0.000 & 0.562 & 0.000 & 0.000 & 0.000 \\
\hline$A E$ & 3.945 & 2.453 & 2.217 & 1.778 & 1.784 & 2.131 & 2.807 & 1.933 & 2.836 \\
\hline
\end{tabular}




\begin{tabular}{|c|c|c|c|c|c|c|c|c|c|}
\hline Sampic & 10.022 & 10.023 & 10.024 & 10.025 & 10.026 & 10.028 & 10.029 & 10030 & 10031 \\
\hline Analysis & $\mathrm{gm}$ & $g m$ & $\mathrm{gm}$ & gm & $\mathrm{gm}$ & $g m$ & $\mathrm{gm}$ & grn & gn: \\
\hline Location & $Y M l+1-d$ & YMI-1-d & YMi-I-d & YMl-1-d & YMA-1-d & YMln $1-d$ & XMA-1-d & IMI-l-d & $\mathrm{YMl}+1+\mathrm{d}$ \\
\hline Mineral & PIR & PIR & $P L R$ & PIR & $\mathrm{PJR}$ & PRR & PIR & PIR & PIR \\
\hline $\mathrm{SiO}_{2}$ & 50.09 & 51.23 & $\$ 0.87$ & 51.27 & 50.50 & 50.94 & $5\} .72$ & 48.33 & $5 \geq 12$ \\
\hline $\mathrm{TiO} 2$ & 1.39 & 0.90 & 0.96 & 0.91 & 1.09 & 0.83 & 0.98 & 1.47 & 0.68 \\
\hline $\mathrm{A}: 2 \mathrm{O} 3$ & 4.20 & 2.49 & 2.94 & 3.22 & 3.5 & 2.36 & 2.16 & 3.84 & 195 \\
\hline $\mathrm{F} \infty \mathrm{O}$ & 7.21 & 6.28 & 7.39 & 7.08 & 6.10 & 6.47 & 8.17 & 7.90 & 5.71 \\
\hline $\mathrm{Cr} 2 \mathrm{O} 3$ & 0.08 & 0.10 & 0 & 0 & 0.34 & 0.07 & 0.01 & 0.03 & 0.12 \\
\hline $\mathrm{MnO}$ & 0.16 & 0.19 & 0.25 & 0.13 & 0.17 & 0.16 & 0.26 & 0.21 & 0.18 \\
\hline $\mathrm{NiO}$ & 0.11 & 0.04 & 0.05 & 0.04 & 0 & 0 & 0.15 & 0.07 & 0.09 \\
\hline $\mathrm{MgO}$ & 14.79 & 15.71 & 12.57 & 14.82 & 1500 & 16.2 & 13.97 & 14.55 & 16.31 \\
\hline $\mathrm{CaO}$ & 22.77 & 22.63 & 22.68 & 22.48 & 23.15 & 22.60 & 22.22 & 22.45 & 23.51 \\
\hline $\mathrm{Na2O}$ & 0.33 & 0.24 & 0.26 & 0.36 & 0.36 & 0.23 & 0.61 & 0.32 & 0.28 \\
\hline $\mathrm{K} 2 \mathrm{O}$ & 0 & 0.00 & 0 & 0 & 0 & 0 & 0.03 & 0.11 & 0.01 \\
\hline Total & 101,13 & 99,81 & 97,97 & 300,31 & 100,30 & 99,86 & 100,28 & 99,28 & 100,96 \\
\hline $\mathrm{TS} \mathrm{i}$ & 1.830 & 1.889 & 1.937 & 1.887 & 1.854 & 1.874 & 1.915 & 1.801 & 1894 \\
\hline $\mathrm{TAl}$ & 0.170 & 0.108 & 0.063 & 0.113 & 0.146 & 0.102 & 0.085 & 0.169 & 0.083 \\
\hline Tfes & 0.000 & 0.003 & 0.000 & 0.000 & 0.000 & 0.024 & 0.000 & 0.030 & 0.023 \\
\hline MlAl & $0.01\}$ & 0.000 & 0.069 & 0.026 & 0.005 & $0.0 \times 0$ & 0.009 & 0.000 & 0.000 \\
\hline MITi & 0.038 & 0.025 & 0.028 & 0.025 & 0.030 & 0.023 & 0.027 & 0.041 & 0.019 \\
\hline MIFe3 & 0.103 & 0.075 & 0.000 & 0.062 & 0.096 & 0.095 & 0.066 & 0.143 & 0.085 \\
\hline$M] F \in 2$ & 0.037 & 0.032 & 0.188 & 0.073 & 0.033 & 0.000 & 0.122 & 0.004 & 0.006 \\
\hline $\mathrm{M}: \mathrm{Cr}$ & 0.002 & 0.003 & 0.000 & 0.000 & 0.010 & 0.002 & $0(0 x)$ & $0(x) 1$ & $(j(k) 3$ \\
\hline MlM\& & 0.806 & 0.86 .3 & 0.714 & 0.813 & 0.826 & 0.880 & 0.771 & 0.808 & 0.884 \\
\hline $\mathrm{M} 1 \mathrm{Ni}$ & $0.0 \times 3$ & 0.001 & 0.002 & 0.001 & 0.000 & 0.000 & 0,004 & 0.002 & 0,003 \\
\hline $\mathrm{M}_{2} \mathrm{M}_{\mathrm{B}}$ & 0.000 & 0.000 & 0.000 & 0.000 & 0.000 & 0.008 & 0.000 & 0.000 & 0.000 \\
\hline $\mathrm{M} 2 \mathrm{Fe} 2$ & 0.080 & 0.083 & 0.047 & 0.084 & 0.058 & 0.080 & 0.065 & 0.069 & 0.059 \\
\hline $\mathrm{M} 2 \mathrm{Mn}$ & 0.005 & $0 .(x) 6$ & 0.0018 & $0 .(x) 4$ & 0.005 & 0.005 & 0,008 & $0 .(x) 7$ & $0(x) 6$ \\
\hline $\mathrm{M} 2 \mathrm{Ca}$ & 0.891 & 0.894 & 0.925 & 0.886 & 0.911 & 0.891 & 0.881 & 0.896 & 0.915 \\
\hline $\mathrm{M} 2 \mathrm{Na}$ & 0.023 & 0.017 & 0.019 & 0.026 & 0.026 & 0.016 & 0.644 & 0.023 & 0.020 \\
\hline $\mathrm{M} 2 \mathrm{X}$ & 0.000 & 0.000 & 0.000 & 0.000 & 0.000 & 0.000 & 0.001 & 0.005 & $0.0(x)$ \\
\hline Sum_at & 4.000 & 4.000 & 4.000 & 4.000 & 4.000 & 4.000 & 3.999 & 3.995 & 4000 \\
\hline $\mathrm{Ca}$ & 49.006 & 47.586 & 49.159 & 47.659 & 49.670 & 47.778 & 47708 & 50.246 & 48.954 \\
\hline Ms & 44.290 & 45.964 & 37.909 & 43.716 & 45.048 & 47.652 & 41.734 & 45.310 & 47.254 \\
\hline $\mathrm{Fe} 2 . \mathrm{Mn}$ & 6.704 & 6.451 & 12.931 & 8.625 & 5.282 & 4.570 & 10.558 & 4.444 & 3.792 \\
\hline Dl & 0.586 & 0.000 & 1.014 & 1.365 & 0.288 & 0.000 & 0.482 & 0.000 & 0.000 \\
\hline$A E I$ & 0.687 & 0.908 & 0.000 & 0.000 & 1.095 & 0.875 & 1.916 & 1.570 & 1.072 \\
\hline CFrSI & 5.062 & 3.228 & 0.000 & 3.271 & 4.602 & 4.277 & 1.604 & 6416 & 3.646 \\
\hline CTTS! & 2.079 & 1.321 & 1.452 & 1.339 & 1.624 & 1.224 & 1.448 & 2.282 & 0.986 \\
\hline CATS1 & 0.000 & 0.000 & 1.856 & 0.040 & 0.000 & 0.000 & 0.000 & 0.000 & 0.000 \\
\hline WOI & 41.373 & 42.754 & 45.562 & 42.460 & 42.899 & 41.986 & 43.718 & 40.944 & 43.941 \\
\hline EN1 & 43.846 & 45.691 & 37.687 & 43.214 & 44.554 & 47.362 & 40.913 & 44.765 & 46.886 \\
\hline $\mathrm{FS1}$ & 6.368 & 6.098 & 12.429 & 8.310 & 4.939 & 4.277 & 9.918 & 4.023 & 3.469 \\
\hline$Q$ & 1.814 & 1.873 & 1.874 & 1.856 & 1.828 & 1.859 & 1.839 & 1.777 & 1.864 \\
\hline$j$ & 0.047 & 0.034 & 0.038 & 0.051 & 0.051 & 0.033 & 0.088 & 0.046 & 0.039 \\
\hline wo & 46.372 & 45.680 & 49.159 & 46.132 & 47.205 & 44.915 & 46.061 & 45.791 & 46.277 \\
\hline EN & 41.909 & 44.123 & 37.909 & 42.316 & 42.813 & 44.797 & 40.294 & 41.293 & 44.670 \\
\hline FS & 11.719 & 10.198 & 12.931 & 11.552 & 9.983 & 10.288 & 13.645 & 12.916 & 9.053 \\
\hline WEF & 97.494 & 98.206 & 98.001 & 97.312 & 97.280 & 98.271 & 95.474 & 97.473 & 97.933 \\
\hline DD & 0.236 & 0.000 & 1.999 & 0.808 & 0.144 & 0.000 & 0.548 & 0.000 & 0.000 \\
\hline $\mathrm{AE}$ & 2.270 & 1.794 & 0,000 & 1.880 & 2.576 & 1.729 & 3.978 & 2.527 & 2.067 \\
\hline
\end{tabular}




\begin{tabular}{|c|c|c|c|c|c|c|c|c|c|}
\hline Sample & 10.032 & 10.033 & 10.034 & 10.035 & 10.036 & 10.038 & 10.039 & 10.044 & 10.045 \\
\hline Analysis & gm & $g m$ & $\mathrm{gn}$ & $\mathrm{gn}$ & $\mathrm{gm}$ & gn & $\mathrm{gm}$ & $\mathrm{gm}$ & $\mathrm{gm}$ \\
\hline Lowation & YMI-1-d & YMI-l-d & $Y M 1-d-d$ & YMI-1-d & YMl- $-d$ & YMI-1-pl & YMI-l-pl & $Y M(-1-p)$ & $Y M l-l-p l$ \\
\hline Mineral & $P \mathbb{R}$ & PIR & PIR & PIR & PIR & PIR & $\mathrm{PIR}$ & PIR & PlR \\
\hline $\mathrm{SiO}_{2}$ & 52.92 & 50.64 & 53.11 & $\$ 7.78$ & 50.08 & 49.84 & 50.83 & 50.38 & 48.41 \\
\hline $\mathrm{TiO}_{2}$ & 0.49 & 1.26 & 0.61 & 1.92 & 1.38 & 1.10 & 1.43 & 1.28 & 1.76 \\
\hline $\mathrm{A} 1203$ & 1.25 & 2.63 & 1.08 & 5.61 & 3.81 & 4.06 & 3.68 & 3.78 & 5.56 \\
\hline $\mathrm{z} e \mathrm{O}$ & 4.16 & 6.25 & 4.21 & 8.43 & 6.01 & 6.43 & 6.29 & 8.67 & 8.54 \\
\hline $\mathrm{Cr} 2 \mathrm{O} 3$ & 0.60 & 0.00 & 0.27 & 0.01 & 0.40 & 0.50 & 0.43 & 0.00 & 0.03 \\
\hline $\mathrm{MnO}$ & 0.09 & 0.05 & 0.13 & 0.13 & 0.14 & 0.13 & 0.17 & 0.20 & 0.21 \\
\hline $\mathrm{NiO}$ & 0.00 & 0.09 & 0.00 & $0 . \infty$ & 0.00 & 0.00 & $0 . \infty$ & 0.00 & 0.01 \\
\hline $\mathrm{MgO}$ & 17.33 & 15.35 & 17.06 & 13.13 & 14.72 & 14.84 & 15.08 & 14.38 & 13.38 \\
\hline $\mathrm{COO}$ & 22.86 & 23.73 & 23.56 & 22.71 & 23.13 & 22.69 & 23.16 & 22.46 & 22.91 \\
\hline $\mathrm{Na} 2 \mathrm{O}$ & 0.23 & 0.21 & 0.22 & 0.33 & 0.33 & 0.35 & 0.38 & 0.34 & 0.52 \\
\hline $\mathrm{K} 2 \mathrm{O}$ & 0.10 & 0.05 & $0 .(x)$ & 0.00 & 0.02 & 0.06 & 0.01 & 0.02 & 0.06 \\
\hline Total & 100,03 & 100,27 & 100,25 & 100,05 & 100,02 & $100,(0)$ & 101,46 & 101,51 & 101.39 \\
\hline $\mathrm{TSi}$ & 1.930 & 1.861 & 1.935 & 1.777 & 1.847 & 1.837 & 1.848 & 1.842 & 1.773 \\
\hline TAJ & 0.054 & 0.114 & 0.046 & 0.223 & 0.153 & 0.163 & 0.152 & 0.158 & 0.227 \\
\hline TFe 3 & 0.017 & 0.025 & 0.019 & 0.000 & 0.000 & 0.000 & 0.000 & 0.000 & 0.000 \\
\hline $\mathrm{M} I \mathrm{Al}$ & 0.000 & 0,000 & 0.000 & 0.023 & 0.012 & 0.013 & 0.005 & 0.005 & 0.013 \\
\hline $\mathrm{MlTi}$ & 0.013 & 0.035 & 0.017 & 0.054 & 0.038 & 0.030 & 0.039 & 0.035 & 0.048 \\
\hline MlFe3 & 0.047 & 0.086 & 0.039 & 0.115 & 0.076 & 0.101 & 0.083 & 0.107 & 0.155 \\
\hline $\mathrm{M}) \mathrm{Fe} 2$ & 0.000 & 0.035 & 0.010 & 0.080 & 0.052 & 0.025 & 0.043 & 0.069 & 0.052 \\
\hline $\mathrm{MlCr}$ & 0.017 & 0.000 & 0.008 & 0.000 & 0.012 & 0.015 & 0.012 & 0.000 & 0.001 \\
\hline MlMg & 0.923 & 0.841 & 0.927 & 0.728 & 0.809 & 0.815 & 0.817 & 0.784 & 0.731 \\
\hline $\mathrm{MINi}$ & 0.000 & 0.003 & 0.000 & 0.000 & 0.000 & 0.000 & 0.000 & 0.000 & 0.000 \\
\hline $\mathrm{M} 2 \mathrm{Mg}$ & 0.020 & 0.000 & 0.000 & 0.000 & 0.000 & 0.000 & $0.0 \times 6$ & 0.0000 & 0.000 \\
\hline $\mathrm{M} 2 \mathrm{Fe} 2$ & 0.064 & 0.046 & 0.061 & 0.067 & 0.057 & 0.072 & 0.065 & 0.089 & 0.055 \\
\hline M2Mir: & 0.003 & 0.002 & 0.064 & 0.004 & 0.004 & 0.004 & 0.005 & $0.0 \times 6$ & 0.007 \\
\hline $\mathrm{M} 2 \mathrm{Ca}$ & 0.893 & 0.935 & 0.920 & 0.905 & 0.914 & 0.896 & 0.902 & 0.880 & 0.899 \\
\hline $\mathrm{M} 2 \mathrm{Na}$ & 0.016 & 0.015 & 0.016 & 0.024 & 0.024 & 0.025 & 0.027 & 0.024 & 0.037 \\
\hline $\mathrm{M} 2 \mathrm{~K}$ & 0.005 & 0.003 & 0.000 & 0.000 & 0.001 & 0.003 & 0.000 & $0(x) 1$ & 0.003 \\
\hline Sum $_{\ldots} c a t$ & 3.995 & 3.997 & 4.000 & 4.000 & 3.999 & 3.997 & 4.000 & 3.999 & 3.997 \\
\hline $\mathrm{Ca}$ & 46.968 & 50.289 & 47.881 & 50.729 & 49.761 & 49.439 & 49.214 & $48 .\{4]$ & 51.594 \\
\hline $\mathrm{Mg}$ & 49.542 & 45.262 & 48.241 & 40.809 & 44.063 & 44.991 & 44.587 & 42.886 & 41.926 \\
\hline $\mathrm{Fe} 2 \mathrm{Mn}$ & 3.489 & 4.448 & 3.879 & 8.461 & 6.175 & 5.570 & 6.199 & 8.973 & 6.480 \\
\hline $\mathrm{ID}\}$ & $0.0 \times 0$ & 0.000 & 0.000 & 1.267 & 0.672 & 0.725 & 0.294 & 0.260 & 0.727 \\
\hline $\mathrm{AE} !$ & 1.089 & 0.949 & 0.804 & 0.053 & 0.650 & 0.791 & 1.175 & 1.096 & 1.511 \\
\hline CFTS1 & 2.246 & 3.656 & 1.624 & 6.360 & 4.088 & 5.519 & 3.956 & 4.715 & 7.277 \\
\hline CTTSI & 0.700 & 1.858 & 0.865 & 2.978 & 2.062 & $1,66]$ & 2.108 & 1.906 & 2.731 \\
\hline CATSI & 0.000 & 0.000 & $0.0 \times 1$ & 0.000 & 0.000 & 0.000 & 0.0010 & 0.000 & 0.000 \\
\hline wo! & 43.578 & 44.340 & 45.106 & 40.838 & 43.072 & 41.619 & 42.566 & 41.028 & 40.622 \\
\hline ENI & 49.074 & 44.871 & 47.953 & 40). 363 & 43.585 & 44.408 & 44.057 & 42.448 & 41.341 \\
\hline FS1 & 3.311 & 4.327 & 3.648 & 8.142 & 5.873 & 5.277 & 5.843 & 8.546 & $\$ .992$ \\
\hline$Q$ & 1.899 & 1.857 & 1.917 & 1.780 & 1.832 & 1.808 & 1.828 & 1.821 & 1.736 \\
\hline J & 0.033 & 0.030 & 0.031 & 0.048 & 0.047 & 0.050 & 0.054 & 0.048 & 0.074 \\
\hline wo & 45.455 & 47.454 & 46.482 & 47.648 & 47.776 & 46.822 & 47.086 & 45.471 & 47.375 \\
\hline $\mathrm{EN}$ & 47.947 & $42.71 !$ & 46.832 & 38.330 & 42.305 & 42.609 & 42.659 & 40.508 & 38.497 \\
\hline FS & 6.598 & 9.835 & 6.686 & 14.021 & 9.918 & 10.569 & 10.255 & 14.021 & 14.128 \\
\hline WEF & 98.318 & 98.415 & 98.407 & 97.401 & 97.495 & 97.314 & 97.160 & 97.430 & 95.934 \\
\hline $\mathrm{JD}$ & 0.000 & 0.000 & 0.000 & 0.430 & 0.352 & 0.312 & 0.175 & 0.110 & 0.312 \\
\hline$A E$ & 1.682 & 1.585 & 1.593 & 2.169 & 2.153 & 2.374 & 2665 & 2460 & 3.754 \\
\hline
\end{tabular}




\begin{tabular}{|c|c|c|c|c|c|c|c|c|c|}
\hline Sample & 10.047 & 10.048 & 10.049 & 10.050 & $10 \mathrm{c} .00 \mathrm{~s}$ & $10 c .000$ & $10 c .007$ & $10 \mathrm{c} .008$ & 100.009 \\
\hline Analysis & $g m$ & $\mathrm{gm}$ & $g n$ & $\mathrm{gm}$ & gm & gm & $\mathrm{gm}$ & $\mathrm{gm}$ & $g n$ \\
\hline Location & $\mathrm{YMI}-1-\mathrm{p} 2$ & $Y M[-] \cdot p 2$ & YMI-1-p2 & YMI-1-p2 & $Y M-1 C$ & YMI-1C & $\mathrm{YMA}-1 \mathrm{C}$ & YMI-1C & YMa-1C \\
\hline Minerad & PIR & PIR & PIR & PIR & PIR & PIR & PIR & PIR & PIR \\
\hline $\mathrm{SiO} 2$ & $\$ 1.54$ & 49.76 & 49.97 & 49.94 & 47.69 & 46.97 & 46.99 & 47.38 & 47.30 \\
\hline $\mathrm{TiO}_{2}$ & 1.17 & 1.18 & 1.12 & 1.34 & 1.68 & 1.84 & 1.81 & 1.81 & 2.02 \\
\hline $\mathrm{Al} 2 \mathrm{O}^{3}$ & 3.18 & 4.65 & 4.10 & 3.76 & $5.6 x$ & 5.89 & 5.77 & 5.65 & 5.78 \\
\hline $\mathrm{F} \infty \mathrm{O}$ & 7.76 & 7.15 & 6.16 & 8.54 & 8.90 & 9.42 & 8.94 & 9.07 & 8.97 \\
\hline $\mathrm{Cr} 2 \mathrm{O} 3$ & 0.06 & 0.62 & 0.28 & 0.05 & 0.03 & 0 & 0.20 & 0.08 & 0.13 \\
\hline $\mathrm{MnO}$ & 0.07 & 0.18 & 0.12 & 0.21 & 0.15 & 0.14 & 0.14 & 0.21 & $0.2 !$ \\
\hline $\mathrm{NiO}$ & 0.00 & 0.06 & 0.02 & 0,00 & 0.12 & 0.01 & 0.10 & 0.15 & 0 \\
\hline $\mathrm{MgO}$ & 14.93 & 14.70 & 14.71 & 14.42 & 12.61 & 12.43 & 12.51 & 12.24 & 12.55 \\
\hline $\mathrm{CaO}$ & 23.10 & 23.00 & 23.47 & 22.51 & 22.67 & 22.29 & 22.27 & 22.88 & 22.32 \\
\hline $\mathrm{Na} 2 \mathrm{O}$ & 0.35 & 0.35 & 0.31 & 0.33 & 0.45 & 0.43 & 0.42 & 0.51 & 0.49 \\
\hline $\mathrm{K} 2 \mathrm{O}$ & 0.03 & 0.01 & 0.01 & 0.07 & 0 & 0.04 & 0.04 & 0.65 & 0.02 \\
\hline Total & 102,19 & 101,66 & 100,27 & 101,17 & 99,96 & 99,46 & 99.39 & 100,63 & 99,79 \\
\hline TSi & 1.866 & 1.809 & 1.837 & 1.831 & 1.778 & 1.763 & 1.767 & 1.756 & 1.768 \\
\hline TAl & 0.134 & 0.191 & 0.163 & 0.162 & 0.222 & 0.237 & 0.233 & 0.244 & 0.232 \\
\hline TFe3 & 0.000 & 0.000 & 0.000 & $0.0 \times 6$ & 0.000 & 0.000 & 0.000 & 0.000 & $0(x)$ \\
\hline $\mathrm{MlAl}$ & 0.002 & 0.008 & 0.014 & 0.000 & 0.027 & 0.023 & 0.023 & 0.003 & 0.023 \\
\hline MlTi & 0.032 & 0.032 & 0.031 & 0.037 & 0.047 & 0.052 & 0.051 & 0.050 & 0.057 \\
\hline $\mathrm{M}\{\mathrm{Fe}\}$ & 0.093 & 0.126 & 0.101 & 0.120 & 0.131 & 0).143 & 0.133 & 0.205 & 0.128 \\
\hline $\mathrm{MIFe} 2$ & 0.066 & 0.018 & 0.039 & 0.054 & 0.089 & 0.086 & 0.082 & 0.059 & 0.090 \\
\hline $\mathrm{M} / \mathrm{Cr}$ & 0.002 & 0.018 & 0.008 & 0.001 & 0.001 & 0.000 & 0.000 & 0.002 & 0.004 \\
\hline$M I M B$ & 0.806 & 0.797 & 0.806 & 0.788 & 0.701 & 0.695 & 0.701 & 0.676 & 0.699 \\
\hline $\mathrm{MINi}$ & 0.000 & 0.002 & $0.00 \mathrm{i}$ & 0.000 & 0.004 & 0.000 & 0.003 & 0.004 & 0.000 \\
\hline $\mathrm{M} 2 \mathrm{Mg}$ & 0.000 & $0.0 \times 00$ & $0.0 \times 0$ & $0.0 \times 0$ & 0.000 & 0.000 & 0.000 & 0.000 & 0.000 \\
\hline $\mathrm{M} 2 \mathrm{~F} e 2$ & 0.076 & 0.074 & 0.049 & 0.082 & 0.057 & 0.066 & 0.066 & 0.017 & 0.063 \\
\hline $\mathrm{M} 2 \mathrm{Mn}$ & 0.002 & 0.006 & 0.004 & $0 .(x) 7$ & 0.005 & 0004 & 0.0014 & 0.0017 & 0.007 \\
\hline $\mathrm{M} 2 \mathrm{Ca}$ & 0.896 & 0.896 & 0.924 & 0.884 & 0.906 & 0.896 & 0.897 & 0.909 & 0.894 \\
\hline $\mathrm{M} 2 \mathrm{Na}$ & 0.025 & 0.025 & 0.022 & 0.023 & 0.033 & 0.031 & 0.031 & 0.037 & 0.036 \\
\hline $\mathrm{M} 2 \mathrm{~K}$ & 0.001 & 0.000 & 0.000 & 0.003 & 0.000 & 0.002 & 0.002 & 0.031 & 0.001 \\
\hline Sum_cat & 3.999 & 4.000 & 4.000 & 3.997 & 4000 & 3.998 & 3.998 & 3.969 & 3999 \\
\hline $\mathrm{Ca}$ & 48.532 & 50.052 & 50.715 & 48.720 & 51.534 & 51.252 & 51.246 & 54.470 & 51.002 \\
\hline $\mathrm{Mg}$ & 43.644 & 44.510 & 44.227 & 43.425 & 39.88 .5 & 39.767 & 40.054 & 40.545 & 39.901 \\
\hline $\mathrm{Fe} 2 \mathrm{Mn}$ & 7.825 & 5.438 & 5.059 & 7.855 & 8.581 & 8.981 & 8.700 & 4.985 & 9.097 \\
\hline $\mathrm{JDl}$ & 0.082 & 0.432 & 0.775 & 0.000 & 1.505 & 1.289 & 1.284 & 0.157 & 1.265 \\
\hline AE 1 & 1.306 & 0.957 & 0.451 & 1.457 & 0.317 & 0.579 & 0.546 & 3.741 & $0.78 t$ \\
\hline CFTSI & 3.739 & 6.967 & 5.470 & 5.135 & 7.096 & 7.468 & 7.280 & 8.227 & 6.593 \\
\hline CTrsl & 1.704 & 1.783 & 1.682 & 2.014 & 2.639 & 2.922 & 2.878 & 2.919 & 3.186 \\
\hline CATSI & 0.000 & 0.000 & 0.000 & 0.0000 & 0.000 & 0.000 & 0.000 & $0.0 \times 10$ & $0.0 \times 0$ \\
\hline wol & 42.471 & 40.759 & 43.045 & 41.035 & 40.996 & 40.033 & 40.279 & 41.409 & 40.369 \\
\hline EN1 & 43.088 & 44.028 & 43.774 & 42.947 & 39.264 & 39.124 & 39.422 & 39.119 & 39.234 \\
\hline FS1 & 7.610 & 5.073 & 4.804 & 7.413 & 8.182 & 8.585 & 8.312 & 4.428 & 8.572 \\
\hline$Q$ & 1.844 & 1.784 & 1.819 & 1.809 & 1.753 & 1.744 & 1.747 & 1.661 & 1.746 \\
\hline J & 0.049 & 0.049 & 0.044 & 0.047 & 0.065 & 0.063 & 0.051 & 0.073 & 0.071 \\
\hline wo & 46.213 & 46.770 & 48.054 & 45.562 & 47.947 & 47.377 & 47.621 & 48.520 & +7.540 \\
\hline EN & 41.559 & 41.592 & 41.907 & 40.610 & 37.109 & 36.760 & 37.221 & 36.115 & 37.193 \\
\hline FS & 12.228 & 11.638 & 10.039 & 13.828 & 14.944 & 15.863 & 15.158 & 15.365 & 15.266 \\
\hline WEF & 97.407 & 97.317 & 97.633 & 97.480 & 96.430 & 96.545 & 96.620 & 95.790 & 96.105 \\
\hline J & 0.042 & 0.157 & 0.293 & 0.000 & 0.606 & 0.477 & 0.494 & 0.055 & 0.585 \\
\hline$A E$ & 2.550 & 2.526 & 2.074 & 2.520 & 2.965 & 2.978 & $2.88 \mathrm{~S}$ & 4.155 & 3.310 \\
\hline
\end{tabular}




\begin{tabular}{|c|c|c|c|c|c|c|c|c|c|}
\hline Sample & $10 c .010$ & 100.011 & $14.000 \mathrm{a}$ & $14.000 \mathrm{~b}$ & 14.0023 & $14.002 \mathrm{~b}$ & 14.010 & 14.011 & 14012 \\
\hline Analysis & gm & gm & & & & & $\mathrm{mf}$ & $m !$ & $\mathrm{mf}$ \\
\hline Location & YMI-1C & YM-1 & YMl-4-1 & $Y M I-4+1$ & YMI-4-1 & YMB-4-I & YMl-4-br & I'Ml-4-br & YMII-And \\
\hline Mineral & PIR & $P \mathbb{R}$ & PIR & PIR & PIR & PIR & PIR & PIR & PIR \\
\hline $\mathrm{SiO} 2$ & 47.67 & 47.44 & 51.39 & 48.28 & 50.15 & 48.21 & 51.64 & 49.98 & 47.78 \\
\hline $\mathrm{TOO} 2$ & 1.54 & 1.83 & 0.56 & 1.19 & 0.67 & 1.04 & 0.79 & 1.01 & 0.88 \\
\hline $\mathrm{Al} 2 \mathrm{O} 3$ & 4.78 & 4.67 & 3.46 & 5.50 & 4.19 & 4.98 & 3.05 & 4.55 & 6.62 \\
\hline $\mathrm{FeO}$ & 8.78 & 12.12 & 6.84 & 7.84 & 7.20 & 767 & 6.33 & 8.32 & 8.10 \\
\hline $\mathrm{Cr} 2 \mathrm{O} 3$ & 0.15 & 0 & 0.03 & 0.00 & 0.05 & $0 .(x)$ & 0.05 & 0.00 & $0 .(x)$ \\
\hline $\mathrm{MnO}$ & 0.15 & 0.16 & 0.17 & 0.15 & 0.21 & 0.15 & 0.10 & 0.27 & 0.23 \\
\hline $\mathrm{NiO}$ & 0 & 0 & 0.03 & 0.06 & 0.00 & 0.00 & 0.00 & $0(x)$ & 0.001 \\
\hline $\mathrm{MgO}$ & 12.99 & 12.03 & 14.90 & 13.34 & 14.19 & 14.08 & 15.34 & 19.37 & 13.51 \\
\hline $\mathrm{CaO}$ & 22.09 & 20.47 & 23.21 & 22.60 & 23.15 & 22.47 & 23.72 & 22.22 & 21.91 \\
\hline $\mathrm{Na} 2 \mathrm{O}$ & 0.37 & 0.58 & 0.33 & 0.36 & 0.31 & 0.35 & 0.20 & 0.32 & 0.32 \\
\hline $\mathrm{K} 2 \mathrm{O}$ & 0.02 & 0.08 & 0.00 & 0.02 & 0.03 & 0.00 & 0.02 & 000 & 0.04 \\
\hline Total & 98,54 & 99,38 & 100,92 & 99,34 & 100,15 & 98,95 & 101.24 & 101,04 & 99,39 \\
\hline $\mathrm{TSi}$ & 1.802 & 1.796 & 1.877 & 1.801 & 1.850 & 1.8001 & 1.879 & 1.832 & 1.778 \\
\hline TAS & 0.198 & 0.204 & 0.123 & 0.199 & 0.150 & 0.200 & 0.121 & 0.168 & 0.222 \\
\hline TFe3 & 0.000 & 0.000 & 0.000 & 0.000 & 0.000 & 0.000 & 0.000 & $0.0 \times 0$ & 0.0001 \\
\hline $\mathrm{M} I \mathrm{Al}$ & 0.015 & 0.004 & 0.026 & 0.043 & 0.032 & 0.019 & 0.010 & 0.028 & 0068 \\
\hline $\mathrm{MITi}$ & 0.044 & 0.052 & 0.015 & 0.033 & 0.019 & 0.029 & 0.022 & 0.028 & 0.025 \\
\hline $\mathrm{M}] \mathrm{Fe} 3$ & 0.119 & 0.142 & 0.089 & 0.115 & 0.102 & 0.148 & 0.082 & 0.106 & 0.129 \\
\hline $\mathrm{MlFe}_{2}$ & 0.086 & 0.123 & 0.057 & 0.065 & 0.065 & 0.021 & 0.054 & 0.052 & 0.029 \\
\hline $\mathrm{M} / \mathrm{Cr}$ & 0.004 & 0.000 & 0.001 & 0.000 & 0.001 & 0.000 & 0.001 & 0.000 & 0000 \\
\hline MIMg & 0.732 & 0.679 & 0.811 & 0.742 & 0.780 & 0.784 & 0.832 & 0.785 & 0.749 \\
\hline $\mathrm{MlNi}$ & 0,000 & 0.000 & 0.001 & 0.002 & 0.000 & 0.000 & 0.000 & 0.000 & 0.000 \\
\hline $\mathrm{M} 2 \mathrm{Mg}$ & 0.000 & 0.000 & 0.000 & 0.000 & 0.000 & 0.000 & 0.000 & 0.000 & 0000 \\
\hline $\mathrm{M} 2 \mathrm{Fe}^{2}$ & 0.072 & 0.118 & 0.063 & 0.065 & 0.055 & 0.07 & 0.057 & 0.096 & 0.094 \\
\hline $\mathrm{M} 2 \mathrm{Mn}$ & 0.005 & 0.005 & 0.005 & 0.005 & 0.007 & 0.005 & 0.003 & 0.008 & 0.007 \\
\hline $\mathrm{M} 2 \mathrm{Ca}$ & 0.895 & 0.830 & 0.908 & 0.903 & 0.915 & 0.899 & 0.925 & 0.873 & 0.874 \\
\hline $\mathrm{M} 2 \mathrm{Na}$ & 0.027 & 0.043 & 0.023 & 0.026 & 0.022 & 0.025 & 0.014 & 0.023 & 0.023 \\
\hline $\mathrm{M} 2 \mathrm{~K}$ & 0.001 & 0.004 & 0.000 & 0.001 & 0.001 & 0.000 & 0.001 & 0.000 & 0.002 \\
\hline Sum_cat & 3.999 & 3.996 & 4.000 & 3.999 & 3.999 & 4.000 & 3.999 & 4.000 & 3998 \\
\hline $\mathrm{Ca}$ & 49.974 & 47.288 & 49.224 & 50.764 & 50.219 & 50.522 & 49.426 & $48.08 \mathrm{I}$ & 49.817 \\
\hline $\mathrm{Mg}$ & 40.889 & 38.668 & 43.968 & 41.692 & 42.830 & 44.048 & 44.475 & 43.265 & 42.740 \\
\hline $\mathrm{Fe} 2, \mathrm{Mn}$ & 9.136 & 14.044 & 6.808 & 7.543 & 6.950 & 5.430 & 6.099 & 8.655 & 7443 \\
\hline $\mathrm{DI}$ & 0.810 & 0.210 & 1.254 & 1.498 & 1.283 & 1.045 & 0.506 & 1.243 & 1.411 \\
\hline $\mathrm{AEl}$ & 0.739 & 2.374 & 0.000 & 0.000 & 0.000 & 0.363 & 0.293 & 0.000 & 0.000 \\
\hline CFTSI & 6.059 & 5.542 & 4.800 & 6.389 & 5.629 & 7.839 & 4.117 & 5.813 & 7.273 \\
\hline CTISI & 2.415 & 2.900 & 0.826 & 1.853 & 1.011 & 1.623 & 1.148 & 1.522 & 1391 \\
\hline CATSI & 0.000 & 0.000 & 0.129 & 0.889 & 0.468 & 0.000 & 0.000 & 0.302 & 2.432 \\
\hline WOI & 40.859 & 37.760 & 42.991 & 41.007 & 42.647 & 40.481 & 43.847 & 40.066 & 38.222 \\
\hline ENI & 40.364 & 37.779 & 43.541 & 41.177 & 42.434 & 43.544 & 44.193 & 42.925 & 42.312 \\
\hline FSI & 8.754 & 13.436 & 6.460 & 7.187 & 6.529 & 5.104 & 5.896 & 8.129 & 6.959 \\
\hline$Q$ & 1.785 & 1.750 & 1.840 & 1.775 & 1.816 & 1.774 & 1.868 & 1.806 & 1.746 \\
\hline J & 0.054 & 0.085 & 0.047 & 0.052 & 0.044 & 0.051 & 0.028 & 0.045 & 0.046 \\
\hline wo & 46.864 & 43.744 & 46.969 & 47.680 & 47.556 & 46.651 & 47.361 & 45.419 & 46.408 \\
\hline EN & 38.345 & 35.770 & 41.954 & 39.159 & 40.559 & 40.673 & 42.616 & 40.870 & 39.816 \\
\hline FS & 14.791 & 20.487 & 11.076 & $13.16 \mathrm{\}}$ & 11.886 & 12.676 & 10.023 & 13.711 & 13.777 \\
\hline WEF & 97.059 & 95.375 & 97.529 & 97.156 & 97.624 & 97.231 & 98.514 & 97.555 & 97.434 \\
\hline$m$ & 0.323 & 0.119 & 0.557 & 0.773 & 0.570 & 0.31 .3 & 0.155 & 0.513 & 0.887 \\
\hline $\mathrm{AE}$ & 2.617 & 4.506 & 1.914 & 2.070 & 1.807 & 2.457 & 1.331 & 1.932 & $1.6 \%$ \\
\hline
\end{tabular}




\begin{tabular}{|c|c|c|c|c|c|c|c|c|c|}
\hline Sample & 14.004 & 14.005 & 14066 & 14.007 & $14(6) 8$ & 14.0009 & 14.013 & 14014 & $1401 S_{11}$ \\
\hline Analysis & $\mathrm{gm}$ & gan & grn & gा & gm & $\operatorname{mf}$ & $\mathrm{mf}$ & $\mathrm{mf}$ & \\
\hline Location & $Y M I-4+]$ & YMI-4-1 & YMl-4-br & YMa-4-br & YMl-4-br & $Y M I-4-b r$ & YMI-Ad & YMl-4-d & $Y M 1-4-d$ \\
\hline Minesal & PIR & PIR & PIR & PIR & PIR & PIR & PIR & PIR & PIR \\
\hline $\mathrm{SiO} 2$ & 47.30 & 49.09 & 45.40 & 48.32 & 47.94 & 49.63 & 50.19 & 50.19 & 49.33 \\
\hline $\mathrm{TiO} 2$ & 1.70 & 1.08 & 1.84 & 1.21 & 1.43 & $0.8 !$ & 0.77 & 0.67 & 084 \\
\hline $\mathrm{Al} 2 \mathrm{O} 3$ & 6.73 & 5.75 & 7.78 & 5.80 & 6.73 & 4.35 & 3.71 & 3.75 & 4.34 \\
\hline $\mathrm{FeO}$ & 9.36 & 8.12 & 9.43 & 9.54 & 9.53 & 7.61 & 7.63 & 7.55 & 7.62 \\
\hline $\mathrm{Cr} 2 \mathrm{O} 3$ & 0.04 & 0.00 & 0.00 & 0.00 & $0 . \infty)$ & 0.04 & 0.07 & 0.00 & $0 . \infty$ \\
\hline $\mathrm{MnO}$ & 0.31 & 0.16 & 0.27 & 0.28 & 0.29 & 0.13 & 0.18 & 0.22 & 0.18 \\
\hline $\mathrm{NiO}$ & $0 . \infty$ & 0.00 & 0.06 & 0.05 & 0.00 & 0.03 & 0.00 & 0.01 & 0.06 \\
\hline $\mathrm{MgO}$ & 12.33 & 13.50 & 12.50 & 13.45 & 12.90 & 14.63 & 15.00 & 14.72 & 14.66 \\
\hline $\mathrm{CaO}$ & 22.15 & 22.57 & 21.67 & 21.52 & 21.74 & 22.59 & 22.81 & 22.56 & 2269 \\
\hline $\mathrm{Na} 2 \mathrm{O}$ & 0.36 & 0.34 & 0.32 & 0.42 & 0.40 & 0.32 & 0.27 & 0.33 & 0.33 \\
\hline $\mathrm{K} 2 \mathrm{O}$ & 0.06 & 0.00 & 0.21 & 0.12 & 0.08 & $0.0 x)$ & 0.00 & 0.01 & 0.00 \\
\hline Total & 100,34 & 100,61 & 99,48 & 100,71 & 101,04 & $1(x), 14$ & 100,63 & 100,01 & 100,05 \\
\hline $\mathrm{TSi}$ & 1.760 & 1.809 & 1.700 & 1.783 & 1.766 & 1.829 & 1.841 & 1.852 & 1.819 \\
\hline TAl & 0.240 & 0.191 & 0.300 & 0.217 & 0.234 & 0.171 & 0.159 & 0.148 & 0.181 \\
\hline $\mathrm{TF} e 3$ & 0.000 & 0.000 & 0.000 & 0.000 & 0.000 & 0.000 & 0.000 & 0.000 & 0.000 \\
\hline MIAl & 0.055 & 0.058 & 0.043 & 0.035 & 0.058 & 0.018 & 0.001 & 0.015 & 0.008 \\
\hline Miri & 0.048 & 0.030 & 0.052 & 0.034 & $0 .(140)$ & 0.022 & 0.021 & 0.019 & 0.023 \\
\hline $\mathrm{M} 1 \mathrm{Fe} 3$ & 0.117 & 0.097 & 0.186 & 0.149 & 0.127 & 0.129 & 0.132 & 0.119 & 0.149 \\
\hline MlFe2 & 0.096 & 0.074 & 0.020 & 0.040 & $0.0(x)$ & 0.025 & 0.023 & 0.037 & 0.012 \\
\hline $\mathrm{M} / \mathrm{Cr}$ & 0.001 & 0.000 & 0.000 & 0.000 & 0.000 & 0.001 & 0.002 & 0.000 & 0.000 \\
\hline MlMg & 0.684 & 0.741 & 0.698 & 0.740 & 0.709 & 0.804 & 0.820 & 0.810 & 0.806 \\
\hline $\mathrm{MINi}$ & 0.000 & 0.000 & 0.002 & 0.001 & 0.000 & 0.001 & 0.000 & 0.000 & 0.002 \\
\hline M2Mg & 0.000 & 0.000 & 0.000 & 0.000 & 0.000 & 0.000 & 0.000 & 0.000 & 0.0000 \\
\hline $\mathrm{M} 2 \mathbf{F}_{\mathrm{F}} \mathrm{e}$ & 0.078 & 0.080 & 0.089 & 0.105 & 0.100 & 0.081 & 0.079 & 0.077 & 0.074 \\
\hline $\mathrm{M} 2 \mathrm{Mn}$ & 0.010 & 0.005 & 0.009 & 0.009 & 0.009 & 0.004 & 0.006 & 0.007 & 0.006 \\
\hline $\mathrm{M} 2 \mathrm{Ca}$ & 0.883 & 0.891 & 0.869 & 0.851 & 0.858 & 0.892 & 0.896 & 0.892 & 0.897 \\
\hline $\mathrm{M} 2 \mathrm{Na}$ & 0.026 & 0.024 & 0.023 & 0.030 & 0.029 & 0.023 & 0.019 & 0.024 & 0.024 \\
\hline $\mathrm{M} 2 \mathrm{~K}$ & 0.003 & 0.000 & 0.010 & 0.006 & 0.004 & 0.000 & 0.000 & 0.000 & 0.000 \\
\hline Sum_at & 3.997 & 4.000 & 3.990 & 3.994 & 3.996 & 4000 & 4.000 & 4.000 & 4.000 \\
\hline $\mathrm{Ca}$ & 50.436 & 49.753 & 51.611 & 48.772 & 49.261 & 49.405 & 49.138 & 48.936 & 49.971 \\
\hline $\mathrm{Mg}$ & 39.065 & 4). 407 & 41.423 & 42.413 & 40.671 & 44.520 & 44,961 & 44.427 & 44.923 \\
\hline$F e 2, M n$ & 10.499 & 8.840 & 6.967 & 8.816 & 10.068 & 6.075 & 5.901 & 6.637 & 5.106 \\
\hline $\mathrm{JD} 1$ & 1.628 & 1.342 & 1.946 & 1.989 & 1.832 & 0.989 & 0.067 & 0.828 & 0.438 \\
\hline AE I & 0.000 & 0.000 & 0.000 & 0.027 & 0.000 & 0.264 & 0.978 & 0.481 & 0.864 \\
\hline CFrs1 & 6.689 & 5.352 & 10.912 & 8.405 & 7.211 & 6.867 & 6.315 & 5.981 & 7.360 \\
\hline cTrs1 & 2.688 & 1.654 & 3.032 & 1.896 & 2.245 & 1.231 & 1.156 & 1.011 & 1.286 \\
\hline CATS! & 1.459 & 1.870 & 0.545 & 0.000 & 1.479 & 0.000 & 0.000 & 0.000 & 0.000 \\
\hline Wol & 39.057 & 40.346 & 36.376 & 37.729 & 37.676 & 40.798 & 41.304 & 41.486 & 40.829 \\
\hline ENI & 38.644 & 40.965 & 40.824 & 41.768 & 40.135 & 44.061 & 44.628 & 44.011 & 44.477 \\
\hline FS1 & 9.834 & 8.470 & 6.365 & 8.187 & 9.422 & 5.790 & 5.553 & 6.202 & 4.745 \\
\hline$Q$ & 1.741 & 1.786 & 1.676 & 1.736 & 1.733 & 1.802 & 1.819 & 1.816 & 1.789 \\
\hline J & 0.052 & 0.049 & 0.046 & 0.060 & 0.057 & 0.046 & 0.038 & 0.047 & 0.047 \\
\hline wo & 47.272 & 47.199 & 46.466 & 44.925 & 45.907 & 46.113 & 45.823 & 45.939 & 46.139 \\
\hline $\mathrm{EN}$ & 36.613 & 39.282 & 37.294 & 39.068 & 37.901 & 41.552 & 41.927 & 41.706 & 41.478 \\
\hline FS & 16.115 & 13.519 & $16.24 !$ & 16.007 & 16.192 & 12.335 & 12.250 & 12.354 & 12.384 \\
\hline WEF & 97.118 & 97.359 & 97.316 & 96.669 & 96.824 & 97.529 & 97.938 & 97.475 & 97.437 \\
\hline $\mathrm{JD}$ & 0.916 & 0.991 & 0.499 & 0.636 & 1.000 & 0.303 & 0.019 & 0.287 & 0.130 \\
\hline$A E$ & 1.965 & 1.651 & 2.186 & 2.695 & 2.177 & 2.167 & 2.043 & 2.239 & 2.433 \\
\hline
\end{tabular}




\begin{tabular}{|c|c|c|c|c|c|c|c|c|c|}
\hline Sample & $14.015 b$ & 14016 & 14017 & $17.001 \mathrm{a}$ & $17.001 b$ & 17.0023 & $17.002 \mathrm{~b}$ & $17.003 \mathrm{a}$ & 170030 \\
\hline Analysis & & $\mathrm{gm}$ & gan & & & & & & \\
\hline Location & YMI-4-d & XMl-4-d & $Y M 1-4 d$ & YMl-7 & YMI-7 & $\mathrm{YM}=7$ & YMl-7 & YMA-7 & $\mathrm{YAl}-7$ \\
\hline Mineral & PIR & PIR & PIR & PIR & PIR & PIR & PIR & PIR & PIR \\
\hline $\mathrm{SiO}_{2}$ & 49.09 & 47.80 & 48.57 & 50.93 & 47.86 & 52.33 & 49.73 & $\$ 3.07$ & 4946 \\
\hline $\mathrm{TiO}_{2}$ & 1.00 & 1.25 & 1.16 & 1.18 & 1.95 & 39 & 1.61 & 0.43 & 1.00 \\
\hline $\mathrm{Al} 2 \mathrm{O} 3$ & 5.20 & 5.99 & 4.80 & 3.18 & 5.06 & 1.56 & 4.37 & 1.74 & 360 \\
\hline $\mathrm{FeO}$ & 7.31 & 8.27 & 9.03 & 711 & 8.35 & 4.30 & 8.23 & 4.28 & 8.69 \\
\hline $\mathrm{Cr} 2 \mathrm{O} 3$ & 0.03 & 0.00 & 0.08 & 0.05 & 0 & .023 & 0.01 & 0.48 & 0.04 \\
\hline $\mathrm{MnO}$ & 0.19 & 0.24 & 0.33 & 0.12 & 0.16 & 0.11 & 0.22 & 0,03 & 0.28 \\
\hline $\mathrm{NiO}$ & 0.01 & 0.01 & 0.00 & 0 & 0.02 & 0.02 & 0.02 & 0.11 & 0.03 \\
\hline $\mathrm{MgO}$ & 13.64 & 13.71 & 14.09 & 15.02 & 13.67 & 17.69 & 13.8 .3 & 16.35 & 12.62 \\
\hline $\mathrm{CaO}$ & 22.85 & 22.81 & 21.39 & .22 .84 & 22.56 & 23.27 & 22.81 & 23.45 & 24.05 \\
\hline $\mathrm{Na}_{2} \mathrm{O}$ & 0.28 & 0.33 & 0.22 & 0.39 & 0.44 & 0.25 & 0.35 & 0.36 & 0.54 \\
\hline $\mathrm{K} 2 \mathrm{O}$ & 0.01 & 0.00 & 0.00 & 0.01 & 0 & 0 & 0 & 0.02 & 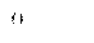 \\
\hline Total & 99,61 & 100,41 & 99,67 & 100,83 & 100,07 & 9,94 & 101,18 & 100,32 & 99,77 \\
\hline$T S \mathbf{j}$ & 1.824 & 1.763 & 1.810 & 1.864 & 1.775 & 1.903 & 1.826 & 1.934 & 1.845 \\
\hline TAl & 0.176 & 0.237 & 0.190 & 0.136 & 0.221 & 0.067 & 0.174 & 0.066 & 0.155 \\
\hline $\mathrm{TFe} 3$ & 0.000 & 0.000 & 0.000 & 0.000 & 0.003 & 0.030 & 0.000 & $0.00 \times$ & 0.000 \\
\hline$M|A|$ & 0.052 & 0.023 & 0.021 & 0.001 & 0.000 & 0.000 & 0.015 & 0.009 & 0,000 \\
\hline $\mathrm{M}$ (Ti & 0.028 & 0.035 & 0.033 & 0.032 & 0.054 & 0.011 & 0.044 & 0.012 & 0.028 \\
\hline MlFe3 & 0.087 & 0.167 & 0.117 & 0.096 & 0.147 & 0.092 & 0.093 & 0.045 & 0.130 \\
\hline MlFe2 & 0.076 & 0.021 & 0.044 & 0.049 & 0.042 & 0.000 & 0.089 & 0.028 & 0.123 \\
\hline $\mathrm{MICr}$ & 0.001 & 0.000 & 0.002 & $0.00 !$ & 0.000 & 0.001 & 0.000 & 0.014 & 0.001 \\
\hline MIME & 0.756 & 0.754 & 0.783 & 0.820 & 0.756 & 0.896 & 0.757 & 0.888 & 0.702 \\
\hline $\mathrm{M} I \mathrm{Ni}$ & 0.000 & 0.000 & 0.000 & 0.000 & 0.001 & 0.001 & 0.001 & 0.003 & $0(x) 1$ \\
\hline $\mathrm{M} 2 \mathrm{Mg}$ & 0.000 & 0.000 & 0.000 & 0.000 & 0.000 & 0.063 & 0.000 & 0.000 & $0.0(x)$ \\
\hline Malic2 & 0.064 & 0.067 & 0.120 & 0.072 & 0.067 & 0.009 & 0.071 & $0.05 \%$ & 0000 \\
\hline $\mathrm{M} 2 \mathrm{Mn}$ & 0.006 & 0.007 & 0.010 & 0.004 & 0.005 & 0.003 & 0.007 & 0.001 & 0,000 \\
\hline $\mathrm{M} 2 \mathrm{Ca}$ & 0.910 & 0.901 & 0.854 & 0.896 & 0.897 & 0.907 & 0.898 & 0.916 & 0.961 \\
\hline $\mathrm{M} 2 \mathrm{Na}$ & 0.020 & 0.024 & 0.016 & 0.028 & 0.032 & 0.018 & 0.025 & 0.025 & 0.039 \\
\hline $\mathrm{M} 2 \mathrm{~K}$ & 0.000 & 0.000 & 0.000 & 0.000 & 0.000 & $0.0 \times 0$ & 0.000 & 0.001 & 0.000 \\
\hline Sum $\operatorname{cad}$ & 4.000 & $4.0(x)$ & 4000 & 4.000 & 4.000 & 4.000 & 4.000 & 3.999 & 4.000 \\
\hline $\mathrm{Ca}$ & 50.229 & 51.480 & 47.150 & 48.659 & 50.756 & 48.277 & 49.289 & 48.443 & 53.563 \\
\hline Mg & 41.718 & 43.052 & 43.214 & 44.524 & 42.793 & 51.065 & 41.581 & 46.995 & 39.108 \\
\hline $\mathrm{Fe} 2 \mathrm{Mn}$ & 8.053 & 5.468 & 9.636 & 6.817 & 6.451 & 0.657 & 9.129 & 4.562 & 7.329 \\
\hline SDI & 1.131 & 1.324 & 0.875 & 0.067 & 0.000 & 0.000 & 0,836 & 0.476 & 0.338 \\
\hline AE 1 & 0.000 & 0.011 & 0.000 & 1.442 & 1.765 & 0.932 & 0.519 & 0.900 & 1.802 \\
\hline CFTS & 4.829 & 9.430 & 6.585 & 3.776 & 6.414 & 3.967 & 4.574 & 2.177 & 5.371 \\
\hline CTTSI & 1.531 & 1.963 & 1.790 & 1.742 & 3.034 & 0.564 & 2.418 & 0.615 & 1.538 \\
\hline CATS! & 1.702 & 0.000 & 0.260 & 0.000 & $0.0 \times 10$ & 0.000 & 0.000 & 0.000 & 0.000 \\
\hline WOI & 41.763 & 39.618 & 38.372 & 42.504 & 40.555 & 43.384 & 41.813 & 45,007 & 45.768 \\
\hline EN1 & 41.383 & $42.660)$ & 43.084 & 43.941 & 42.157 & $\$ 0.6 \$ 1$ & 41.173 & 46.371 & 38.460 \\
\hline $\mathrm{FSI}$ & 7.661 & 4.994 & 9.034 & 6.528 & 6.075 & 0.473 & 8.667 & 4.453 & 6.723 \\
\hline$Q$ & 1.805 & 1.744 & 1.801 & 1.837 & 1.762 & 1.875 & 1.814 & 1.890 & 1.786 \\
\hline J & 0.040 & 0.047 & 0.032 & 0.055 & 0.063 & 0.035 & 0.050 & 0.051 & 0.078 \\
\hline wo & 47.919 & 47.001 & 44.282 & 46.251 & 46.781 & 45.337 & 46.885 & 47.313 & 49.953 \\
\hline EN & 39.800 & 39.307 & 40.586 & 42.319 & 39.441 & 47.955 & 39.553 & 45.899 & 36.472 \\
\hline FS & 12.281 & 13.692 & 15,132 & 11.430 & 13.77 & 6.709 & 1.3 .562 & 6.788 & 13.576 \\
\hline WEF & 97.821 & 97.375 & 98.275 & 97.080 & 96.541 & 98.157 & 97.335 & 97.379 & 95.829 \\
\hline JD & 0.811 & 0.323 & 0.258 & 0.038 & 0.000 & 0.000 & 0.377 & 0.441 & 0.190 \\
\hline $\mathrm{AE}$ & 1.368 & 2.302 & 1.467 & 2.882 & 3.459 & 1.843 & 2.288 & 2.180 & 3982 \\
\hline
\end{tabular}




\begin{tabular}{|c|c|c|c|c|c|c|c|c|c|}
\hline Sample & $17.004 a$ & $17.004 \mathrm{~b}$ & 17005 & 17.006 & 17.007 & 17.008 & 17.009 & 17.010 & $17.015 a$ \\
\hline Analysis & & & gns & $g m$ & $\mathrm{gn}$ & $g m$ & $\mathrm{gm}$ & $\mathrm{gm}$ & \\
\hline Location & YMI-7 & YMI-7 & YMI-7 & YMi-7 & YMl-7 & YMI-7 & YML-7 & YMI.7 & $\mathrm{YM}-7$ \\
\hline Mineral & PIR & PIR & PIR & PIR & PIR & PIR & PIR & PIR & PIR \\
\hline $\mathrm{SiO} 2$ & 51.10 & 50.37 & 50.68 & 48.77 & 50.38 & 52.03 & 49.41 & 49.43 & 51.80 \\
\hline $\mathrm{TiO} 2$ & 0.84 & 1.11 & 1.09 & 190 & 1.33 & 0.96 & 1.48 & 1.53 & 1.15 \\
\hline $\mathrm{Al} 2 \mathrm{O} 3$ & 2.55 & 3.29 & 270 & 4.64 & 3.16 & 2.21 & 4.03 & 3.52 & 2.83 \\
\hline Fo & 6.49 & 6.65 & 9.65 & 8.43 & 7.98 & 7.21 & 7.27 & 8.50 & 6.34 \\
\hline $\mathrm{Cr} 203$ & 0.09 & 0.10 & 0 & 0 & 0 & 0 & 0.17 & 0 & 0.25 \\
\hline $\mathrm{MnO}$ & 0.19 & 0.16 & 0.28 & 0.13 & 0.05 & 0.00 & 0.12 & 0.14 & 0.08 \\
\hline $\mathrm{NiO}$ & 0.08 & 0 & 0 & 0 & 0.01 & 0.07 & 0 & 0.04 & 0 \\
\hline $\mathrm{MgO}$ & 14.74 & 14.05 & 12.95 & 12.96 & 13.87 & 14.88 & 13.59 & 13.50 & 15.39 \\
\hline $\mathrm{C} 2 \mathrm{O}$ & 23.68 & 23.35 & 22.18 & 23.39 & 22.55 & 23.13 & 23.14 & 22.53 & 23.37 \\
\hline $\mathrm{Na} 2 \mathrm{O}$ & 0.33 & 0.40 & 0.39 & 0.31 & 0.32 & 0.31 & 0.36 & 0.40 & 0.31 \\
\hline $\mathrm{K} 2 \mathrm{O}$ & 0.03 & 0.03 & 0.02 & 0.07 & 0.04 & 0 & 0.03 & 0.03 & 0.01 \\
\hline Total & 100,12 & 99,51 & 99,94 & 100,60 & 99,69 & 100,89 & 99,60 & 99,62 & 101,53 \\
\hline TSi & 1.884 & 1.872 & 1.897 & 1.808 & 1.877 & 1.908 & 1.841 & 1.847 & 1.881 \\
\hline TAl & 0.111 & 0.128 & 0.103 & 0.192 & 0.123 & 0.092 & 0.159 & 0.153 & 0.119 \\
\hline TFe3 & 0.005 & 0.000 & 0.000 & 0.000 & 0.000 & 0.000 & 0.000 & 0.000 & 0.000 \\
\hline MIA & 0.000 & 0.016 & 0.016 & 0.011 & 0.016 & 0.003 & 0.017 & 0.002 & 0.002 \\
\hline MITi & 0.023 & 0.031 & 0.031 & 0.053 & 0.037 & 0.026 & 0.041 & 0.043 & 0.031 \\
\hline MlFe3 & 0.091 & 0.077 & 0.054 & 0.100 & 0.056 & 0.058 & 0.081 & 0.096 & 0.069 \\
\hline $\mathrm{MlFe} 2$ & 0.070 & 0.095 & 0.176 & 0.120 & 0.119 & 0.097 & 0.101 & 0.107 & 0.057 \\
\hline $\mathrm{MICr}$ & 0.003 & 0.003 & 0.000 & 0.000 & 0.000 & 0.000 & 0.005 & 0.000 & 0.007 \\
\hline M)Mg & 0.810 & 0.778 & 0.723 & 0.716 & 0.771 & 0.813 & 0.755 & 0.752 & 0.833 \\
\hline MINi & 0.002 & 0.000 & 0,000 & 0.000 & 0.000 & 0.002 & 0.000 & 0.001 & $0.000)$ \\
\hline $\mathrm{M} 2 \mathrm{Mg}$ & 0.000 & 0.000 & 0.000 & 0.000 & 0.000 & 0.000 & 0.000 & 0.000 & 0.000 \\
\hline $\mathrm{M} 2 \mathrm{Fe} 2$ & 0.034 & 0.035 & 0.072 & 0.041 & 0.073 & 0.066 & 0.045 & 0.063 & 0.066 \\
\hline $\mathrm{M} 2 \mathrm{Mn}$ & 0.0016 & 0.005 & 0.009 & $0.0 \times 44$ & 0.002 & 0.003 & 0.004 & 0.004 & 0.002 \\
\hline $\mathrm{M} 2 \mathrm{Ca}$ & 0.936 & 0.930 & 0.890 & 0.929 & 0.900 & 0.909 & 0.924 & 0.902 & 0.909 \\
\hline $\mathrm{M} 2 \mathrm{Na}$ & 0.024 & 0.029 & 0.028 & 0.022 & 0.023 & 0.022 & 0.026 & 0.029 & 0.022 \\
\hline $\mathrm{M} 2 \mathrm{~K}$ & 0.001 & 0.001 & 0.001 & 0.003 & 0.002 & 0.000 & 0.001 & 0.001 & 0.000 \\
\hline Sum_cat & 3.999 & 3.999 & 3.999 & 3.997 & 3.998 & 4.000 & 3.999 & 3.999 & $4.0 \times(x)$ \\
\hline $\mathrm{Ca}$ & 50.420 & 50.450 & 47.580 & 51.317 & 48.282 & 48.119 & 50.530 & 49.331 & 48.660 \\
\hline $\mathrm{Mg}$ & 43.668 & 42.238 & 38.653 & 39.563 & 41.320 & 43.072 & 41.291 & 41.128 & 44.595 \\
\hline $\mathrm{Fe} 2$ Mn & 5.912 & 7.312 & 13.767 & 9.120 & 10.397 & 8.809 & 8.179 & 9.541 & 6.736 \\
\hline JD1 & 0.000 & 0.852 & 0.872 & 0.580 & 0.856 & 0.175 & 0.944 & 0.087 & 0.100 \\
\hline $\mathrm{AE}]$ & 1.334 & 0.767 & 0.676 & 0.817 & 0.469 & 0.980 & 0.538 & 1.553 & 1.080 \\
\hline CFrSI & 3.675 & 3.510 & 2.159 & 4.660 & 2.517 & 2.036 & 4.096 & 3.602 & 2.962 \\
\hline CTTSI & 1.243 & 1.661 & 1.624 & 2.892 & 1.974 & 1.388 & 2.240 & 2.319 & 1.664 \\
\hline CATSI & 0.000 & 0.000 & 0.000 & 0.000 & 0.000 & 0.000 & 0.000 & 0.000 & 0.000 \\
\hline WOl & 44.989 & 44.598 & 43.284 & 43.162 & 43.191 & 44.210 & 43.549 & 42.718 & 43.532 \\
\hline EN! & 43.224 & 41.668 & 38.236 & 39.098 & 40.807 & 42.637 & 40.764 & 40.552 & 44.126 \\
\hline FS1 & $5 . \$ 36$ & 6.944 & 13.149 & 8.790 & 10.185 & 8.574 & 7.870 & 9.168 & 6.535 \\
\hline Q & 1.850 & 1.838 & 1.861 & 1.806 & 1.863 & 1.886 & 1.824 & 1.824 & 1.866 \\
\hline$j$ & 0.047 & 0.058 & 0.057 & 0.045 & 0.046 & 0.044 & 0.052 & 0.058 & 0.044 \\
\hline wo & 47.930 & 48.428 & 46.254 & 48.623 & 46.865 & 46.696 & 48.391 & 46.880 & 46.932 \\
\hline EN & 41.512 & 40.545 & 37.576 & 37.485 & 40.108 & 41.798 & 39.543 & 39.085 & 43.003 \\
\hline FS & 10.558 & 11.028 & 16.170 & 13.892 & 13.027 & 11.505 & 12.065 & 14.035 & 10.065 \\
\hline WEF & 97.520 & 96.967 & 97.061 & 97.597 & 97.580 & 97.719 & 97.233 & 96.927 & 97.717 \\
\hline $\mathrm{ND}$ & 0.000 & 0.520 & 0.692 & 0.230 & 0.539 & 0.125 & 0.492 & 0.051 & 0.061 \\
\hline$A E$ & 2.480 & 2.513 & 2.247 & 2.172 & 1.881 & 2.156 & 2.275 & 3.021 & $2.22 ?$ \\
\hline
\end{tabular}




\begin{tabular}{|c|c|c|c|c|c|c|c|c|c|}
\hline Sample & $21 .(x) 1$ & 21.002 & 21.003 & $21.0 \times 4$ & 21005 & $23.0 \times 6$ & $21.007 a$ & $21007 \mathrm{~b}$ & $21.008 \mathrm{a}$ \\
\hline Analysis & $2 m$ & $g m$ & gni & $\mathrm{gm}$ & $g m$ & gm & & & \\
\hline Location & YZU-1 & $\mathrm{YZU}-1$ & YZU-1 & $\mathrm{YZU}+1$ & YZU-1 & $Y Z U-1$ & YZU. & YZL-1 & YZU-! \\
\hline Mineral & PlR & PIR & PIR & PIR & PlR & PER & PIR & PIR & PlR \\
\hline $\mathrm{SiO}_{2}$ & 52.37 & 52.36 & 53.11 & 50.64 & $\$ 2.92$ & 51.75 & 54.31 & 5000 & 53.89 \\
\hline $\mathrm{TiO} 2$ & 0.75 & 0.54 & 0.61 & 1.26 & 0.49 & 1.33 & 0.3 & 0.38 & 0.25 \\
\hline $\mathrm{A} / 2 \mathrm{O} 3$ & 1.63 & 2.24 & 1.03 & 2.63 & 1.25 & 1.79 & 1.27 & 1.4 & 1.48 \\
\hline $\mathrm{FaO}$ & 5.51 & 5.32 & 4.21 & 6.25 & 4.16 & 7.21 & 4.22 & 4.21 & 4.36 \\
\hline $\mathrm{Cr} 2 \mathrm{O} 3$ & 0.05 & 0.18 & 0.27 & 0 & 0.6 & 0 & 0.53 & 0.34 & 0.56 \\
\hline $\mathrm{MnO}$ & 0.14 & 0.12 & 0.13 & 0.05 & 0.09 & 0.18 & 0.14 & 0.04 & 0.08 \\
\hline $\mathrm{NiO}$ & 0 & 0 & 0 & 0.09 & 0 & 0 & 0.04 & 0.07 & 0.08 \\
\hline $\mathrm{MgO}$ & 16.52 & $16(x)$ & 17.06 & 15.35 & 17.33 & 14.67 & 17.82 & 17.67 & 17.64 \\
\hline $\mathrm{CaO}$ & 23.5 & 22.8 & 23.56 & 23.73 & 22.86 & 23.28 & 22.24 & 22.33 & 22.28 \\
\hline $\mathrm{Na} 20$ & 0.2 & 0.43 & 0.22 & 0.21 & 0.23 & 0.5 & 0.35 & 0.34 & 0.32 \\
\hline $\mathrm{K} 20$ & 0 & 0.01 & 0 & 0.06 & 0.1 & 0 & 0.03 & 0.05 & 0 \\
\hline Total & 100,67 & 100,66 & 100,20 & 100,27 & 100,03 & 100,71 & 101,25 & 96,92 & 100,94 \\
\hline TSi & 1.908 & $1.9 \times 0$ & 1.936 & 1.861 & 1.930 & 1.902 & 1.953 & 1.874 & 1.945 \\
\hline TAI & $0.0 \%$ & 0.096 & 0.044 & 0.114 & 0.054 & 0.077 & 0.047 & 0.062 & 0.055 \\
\hline$T F E 3$ & 0.022 & 0.004 & 0.020 & 0.025 & 0.017 & 0.020 & 0.000 & 0.000 & 0.000 \\
\hline$M \backslash A]$ & 0.000 & 0.000 & 0.000 & 0.000 & 0.000 & 0.000 & 0.007 & 0.000 & 0.008 \\
\hline $\mathrm{M}] \mathrm{Ti}$ & 0.021 & 0.015 & 0.017 & 0.035 & 0.013 & 0.037 & 0.008 & 0.011 & 0.007 \\
\hline $\mathrm{M} 1 \mathrm{Fe} 3$ & 0.064 & 0.095 & 0.038 & 0.086 & 0.047 & 0.060 & 0.035 & 0000 & 0.040 \\
\hline MlFe2 & 0.017 & 0.000 & 0.010 & 0.035 & 0.000 & 0.100 & 0.000 & 0,000 & $0.0 \times 0$ \\
\hline $\mathrm{MICr}$ & 0.001 & 0005 & 0.008 & 0.000 & 0.017 & 0.000 & 0.015 & 0.010 & 0016 \\
\hline $\mathrm{M} 1 \mathrm{Mg}$ & 0.897 & 0.885 & 0.927 & 0.841 & 0.923 & 0.804 & 0.934 & 0.977 & 0.927 \\
\hline MINi & 0.000 & 0.000 & 0.000 & 0.003 & 0.000 & 0.000 & 0.001 & $0.0 \times 12$ & 0.002 \\
\hline $\mathrm{M} 2 \mathrm{Mg}$ & 0.000 & 0.017 & 0.000 & 0.000 & 0.020 & 0.000 & 0.021 & 0000 & 0.022 \\
\hline $\mathrm{M} 2 \mathrm{~F}_{2}{ }_{2}$ & 0.064 & 0.062 & 0.060 & 0.046 & 0.064 & 0.042 & 0.092 & 0.132 & 0.092 \\
\hline $\mathrm{M} 2 \mathrm{Mn}$ & 0.0044 & 0.004 & 0.004 & 0.002 & $0.0 \times 3$ & 0.006 & $0(0) 4$ & $0(0) 1$ & $0.60_{2}$ \\
\hline $\mathrm{M} 2 \mathrm{Ca}$ & 0.917 & 0.887 & 0.920 & 0.935 & 0.893 & 0.917 & 0.857 & 0.895 & 0.862 \\
\hline $\mathrm{M} 2 \mathrm{Na}$ & 0.014 & 0.030 & 0.016 & 0.015 & 0.016 & 0.036 & 0.024 & 0.025 & 0,022 \\
\hline $\mathrm{M} 2 \mathrm{~K}$ & 0.600 & 0.000 & 0.000 & 0.003 & 0.005 & 0,5000 & 0.001 & 0.002 & 0.000 \\
\hline Sum cot & $4.0(x)$ & 4000 & 4.000 & 3.997 & 3.995 & 4.000 & $3 . \operatorname{sx} 90$ & 3.998 & $4(x \times)$ \\
\hline $\mathrm{Ca}$ & 48.268 & 47.823 & 47.881 & 50.289 & 46.968 & 49.083 & 44.896 & 44.452 & 45.229 \\
\hline $\mathrm{Mg}$ & 47.211 & 48.621 & 48.241 & 45.262 & 49.542 & 43.035 & 50.052 & 48.943 & 49.825 \\
\hline $\mathrm{Fe} 2 \mathrm{Mn}$ & 4.521 & 3.557 & 3.878 & 4.448 & 3.489 & 7.882 & 5052 & 6.605 & 4.947 \\
\hline JD! & 0.000 & 0.000 & 0.000 & 0.000 & 0.000 & 0.000 & 0.345 & 0.000 & 0.408 \\
\hline$A E]$ & 0.740 & 1.633 & 0.804 & 0.949 & 1.089 & 1.878 & 0.991 & 1.326 & 0.755 \\
\hline CFISI & 2.675 & 3.711 & 1.569 & 3.656 & 2.246 & 1.267 & 1.590 & 0.000 & 2.143 \\
\hline CTTS I & 1.076 & 0.784 & 0.865 & 1.858 & 0.700 & 1.937 & 0.420 & 0.524 & 0.353 \\
\hline CAISI & 0.000 & $0.6 \times 0$ & 0.0000 & 0.000 & 0.000 & 0.000 & 0.000 & $0.0 \times 0$ & $0.0 \times 1$ \\
\hline WOI & 44.269 & 42.640 & 45.161 & 44.340 & 43.578 & 45.102 & 42.385 & 43.366 & 42.265 \\
\hline ENI & 46.969 & 47.922 & 47.953 & 44.871 & 49.074 & 42.354 & 49.494 & 48.324 & 49,308 \\
\hline FS1 & 4.272 & 3.309 & 3.648 & 4.327 & 3.311 & 7.462 & 4.775 & 6.459 & 4.768 \\
\hline$Q$ & 1.896 & 1.850 & 1.918 & 1.857 & 1.899 & 1.862 & 1.904 & 2.013 & 1.902 \\
\hline J & 0.028 & 0.061 & 0.031 & 0.030 & 0.033 & 0.071 & 0.049 & 0.049 & 0.045 \\
\hline wo & 46.171 & 45.393 & 46.482 & 47.454 & 45.455 & 47.067 & 44.093 & 44.452 & 44.303 \\
\hline EN & 45.161 & 46.151 & 46.832 & 42.711 & 47.947 & 41.268 & 49.157 & 48.943 & 48.805 \\
\hline FS & 8.667 & 8.456 & 6.686 & 9.835 & 6.598 & 11.666 & 6.750 & 6.6015 & 6.893 \\
\hline WEI: & 98.535 & 96.839 & 98.407 & 98.415 & 98.318 & $\$ 6.325$ & 97.506 & 97.609 & 97.703 \\
\hline $\mathbb{D}$ & $0.000)$ & 0.000 & 0.000 & 0.000 & 0.000 & 0.000 & 0.401 & 0.000 & 0.378 \\
\hline $\mathrm{AE}$ & 1.465 & 3.161 & 1.593 & 1.585 & 1.682 & 3.675 & 2.092 & 0.027 & 1.919 \\
\hline
\end{tabular}




\begin{tabular}{|c|c|c|}
\hline Sarnplc & $21.008 \mathrm{~b}$ & 21.009 \\
\hline Analysis & & $\mathrm{mf}$ \\
\hline Location & YZU.1 & YZU. \\
\hline Mineral & PIR & PIR \\
\hline $\mathrm{SiO} 2$ & 53.12 & 52.22 \\
\hline $\mathrm{TiO}_{2}$ & 0.59 & 0.91 \\
\hline $\mathrm{A} 22 \mathrm{O} 3$ & 1.87 & 2.02 \\
\hline FeO & 4.64 & 4.59 \\
\hline $\mathrm{Cr} 2 \mathrm{O} 3$ & 0.67 & 0.55 \\
\hline MnO & 0.06 & 0.08 \\
\hline $\mathrm{NiO}$ & 0.06 & 0.02 \\
\hline $\mathrm{MgO}$ & 17.27 & 16.24 \\
\hline $\mathrm{C} \otimes \mathrm{O}$ & 22.61 & 23.61 \\
\hline $\mathrm{Na} 2 \mathrm{O}$ & 0.32 & 0.26 \\
\hline $\mathrm{K} 2 \mathrm{O}$ & 0.04 & 0.02 \\
\hline Total & 101,25 & 100,52 \\
\hline TSi & 1.916 & 1.9015 \\
\hline TAl & 0.079 & 0.087 \\
\hline TFe 3 & 0.005 & 0.009 \\
\hline$M|A|$ & 0.000 & 0.000 \\
\hline Miti & 0.016 & 0.025 \\
\hline MlFe 3 & 0.057 & 0.049 \\
\hline Mife2 & 0.000 & 0.027 \\
\hline $\mathrm{M} J \mathrm{Cr}$ & 0.019 & 0.016 \\
\hline MIMg & 0.906 & 0.883 \\
\hline $\mathrm{M} 1 \mathrm{Ni}$ & 0.002 & 0.001 \\
\hline $\mathrm{M}_{2} \mathrm{M}_{8}$ & 0.022 & 0.000 \\
\hline$M 2 F \odot 2$ & 0.078 & 0.056 \\
\hline $\mathrm{M} 2 \mathrm{Mn}$ & 0.002 & 0.002 \\
\hline $\mathrm{M} 2 \mathrm{Ca}$ & 0.874 & 0.923 \\
\hline $\mathrm{M} 2 \mathrm{Na}$ & 0.022 & 0.018 \\
\hline $\mathrm{M} 2 \mathrm{~K}$ & 0.002 & 0.001 \\
\hline Sum_cat & 3.998 & 3.999 \\
\hline $\mathrm{Ca}$ & 46.425 & 48.799 \\
\hline M8 & 49.339 & 46.704 \\
\hline $\mathrm{Fe} 2_{-} \mathrm{Mn}$ & 4.236 & 4.497 \\
\hline NDI & 0.000 & 0.000 \\
\hline AE! & 1.272 & 1.013 \\
\hline CFTS1 & 2.732 & 2.372 \\
\hline CTTS1 & 0.841 & 1.309 \\
\hline CATSI & 0.000 & 0.000 \\
\hline wo1 & 42.307 & 44.687 \\
\hline EN! & 48.759 & 46.291 \\
\hline FS1 & 4.090 & 4.328 \\
\hline$Q$ & 1.880 & 1.888 \\
\hline$y$ & 0.045 & 0.037 \\
\hline wo & 44.943 & 47.360 \\
\hline EN & 47.764 & 45.326 \\
\hline FS & 7.293 & 7.314 \\
\hline WEF & 97.677 & 98.092 \\
\hline $\mathrm{D}$ & 0.000 & 0.000 \\
\hline $\mathrm{AE}$ & 2.323 & 1.908 \\
\hline
\end{tabular}




\begin{tabular}{|c|c|c|c|c|c|c|c|c|c|}
\hline Sample & $15 .(x \times) a$ & $15.000 \mathrm{~b}$ & $15001 a$ & $15001 \mathrm{~b}$ & 15002 & $15.003 a$ & $15003 b$ & $150005 a$ & $150,0,5 b$ \\
\hline Analysis & & & & & $\mathrm{mf}$ & & & q & 4 \\
\hline Location & YMI-5 & YMI-5 & YMl-s & $Y M 1+5$ & YMI-S & $Y M 1-5$ & YMJ-5 & YM! 5 & YMI-5 \\
\hline Mineral & PIR & PIR & PIR & PIR & PIR & PIR & PIR & PIR & PIR \\
\hline $\mathrm{SiO} 2$ & 49.67 & 46.87 & 46.75 & 42.97 & 49.73 & 48.59 & 44.31 & 42.98 & 41.90 \\
\hline $\mathrm{TiO} 2$ & 1.76 & 1.95 & 2.94 & 4.41 & 1.97 & 1.90 & 3.87 & 4.54 & 5.16 \\
\hline $\mathrm{A} 2 \mathrm{O} 3$ & 3.46 & 6.21 & 5.84 & 8.32 & 3.65 & 4.31 & 7.71 & 8.21 & 885 \\
\hline $\mathrm{FeO}$ & 7.82 & 7.95 & 7.86 & 9.63 & 8.25 & 7.78 & 8.41 & 13.64 & 12.73 \\
\hline $\mathrm{Cr} 2 \mathrm{O} 3$ & 0 & 0 & 0 & 0 & 0.04 & 0.00 & 0.03 & 0.07 & 0.03 \\
\hline $\mathrm{MnO}$ & 0.21 & 0.22 & 0.14 & 0.27 & 0.25 & 0.15 & 0.12 & 0.3 & 0.21 \\
\hline $\mathrm{NiO}$ & 0.08 & 0.05 & 0.05 & 0.01 & 0 & 0.00 & 0.1 & 0.03 & 0.05 \\
\hline $\mathrm{MgO}$ & 13.55 & 12.61 & 12.95 & 10.86 & 13.45 & 13.48 & 11.42 & 6.66 & 7.55 \\
\hline $\mathrm{CrO}$ & 23.03 & 22.89 & 23.02 & 22.68 & 23.45 & 23.18 & 23.12 & 21.81 & 21.75 \\
\hline $\mathrm{NB} 2 \mathrm{O}$ & 0.39 & 0.49 & 0.47 & 0.78 & 0.42 & 0.44 & 0.49 & 0.85 & 0.85 \\
\hline $\mathrm{K} 2 \mathrm{O}$ & 0 & 0.01 & 0.01 & 0.02 & 0.02 & 0.05 & 0.07 & 0 & 0 \\
\hline Tolal & 99,97 & 99,25 & 100,03 & 99,95 & 101,23 & 99,88 & 99,65 & 99,09 & 99,17 \\
\hline $\mathrm{TSi}$ & 3.849 & 1.755 & 1.740 & 1.615 & 1.831 & 1.807 & 1.666 & 1.673 & 1.625 \\
\hline TAl & $0.15\}$ & 0.245 & 0.256 & 0.368 & 0.158 & 0.189 & 0.334 & 0.327 & 0.375 \\
\hline IFe3 & 0.000 & 0.000 & 0.004 & 0.016 & 0.011 & $0 .(x) 5$ & 0.000 & 0.000 & 0.000 \\
\hline $\mathrm{M} \mid \mathrm{Al}$ & 0.000 & 0.029 & 0.000 & 0.000 & 0000 & 0.000 & 0.008 & 0.050 & 0.028 \\
\hline MlTi & 0.049 & 0.055 & 0.082 & 0.125 & $0.0 \$ 5$ & 0.053 & 0.109 & 0.13 .3 & 0.150 \\
\hline MIFe3 & 0.081 & 0.141 & 0.129 & 0.192 & 0.090 & 0.121 & 0.144 & 0.072 & 0.100 \\
\hline $\mathrm{M} J \mathrm{Fe} 2$ & 0.116 & 0.069 & 0.069 & 0.074 & 0.117 & 0.079 & 0.094 & 0.356 & 0.275 \\
\hline $\mathrm{MHCr}$ & 0.000 & 0.000 & 0.000 & $0.0 \times x)$ & 0.001 & 0.000 & 0.001 & 0.002 & 0.001 \\
\hline $\mathrm{MlMg}$ & 0.752 & 0.704 & 0.719 & 0.609 & 0.738 & 0.747 & 0.640 & 0.387 & $(1,435$ \\
\hline $\mathrm{M} 1 \mathrm{Ni}$ & 0.002 & 0.002 & 0.001 & $0 .(x \times)$ & 0.000 & 0.000 & 0.003 & 0.001 & 0.002 \\
\hline $\mathrm{M} 2 \mathrm{Mg}$ & 0.000 & 0.000 & 0.000 & 0.000 & 0.000 & $0.00 \times 1$ & 0.000 & $0.0 \times 0$ & $0 .(x)$ \\
\hline M2Fe2 & 0.047 & 0.039 & 0.043 & 0.020 & 0.036 & 0.038 & 0.026 & 0.016 & 0.028 \\
\hline $\mathrm{M} 2 \mathrm{Mn}$ & 0.007 & 0.007 & 0.004 & 0.009 & 0.008 & 0.005 & 0.004 & 0.010 & 0.007 \\
\hline $\mathrm{M} 2 \mathrm{Ca}$ & 0.918 & 0.918 & 0.918 & 0.914 & 0.925 & 0.923 & 0.931 & 0.910 & 0.902 \\
\hline $\mathrm{M} 2 \mathrm{Ng}$ & 0.028 & 0.036 & 0.034 & 0.057 & 0.030 & 0.032 & 0.036 & 0.004 & 1).(K64 \\
\hline M2K & 0.000 & 0.000 & 0.000 & 0.001 & 0.001 & 0.002 & 0.003 & 0.000 & 0.000 \\
\hline Sum_cot & 4,000 & 4.000 & 4.000 & 3.999 & 3.999 & 3.998 & 3.997 & 4.000 & 4.000 \\
\hline $\mathrm{Ca}$ & 49.920 & 52.864 & 52.373 & 56.207 & $50.7 ! 1$ & 51.526 & $\$ 4.939$ & 54.213 & 54.747 \\
\hline $\mathrm{Mg}$ & 40.866 & 40.521 & 40.994 & 37.448 & 40.470 & 41.692 & 37.758 & 23.034 & 26.442 \\
\hline $\mathrm{Fe} 2 \mathrm{Mn}$ & 9.214 & 6.616 & 6.634 & 6.345 & 8.819 & 6.783 & 7.304 & 22.753 & 18.812 \\
\hline IDI & 0.008 & 1.648 & 0.000 & 0.000 & 0.000 & 0.000 & 0.439 & 2.864 & 1.631 \\
\hline AE1 & 1.504 & 0.393 & 1.929 & 3.453 & 1.674 & 1.872 & 1.819 & 0.840 & 2.112 \\
\hline CFISI & 2.821 & 7.590 & 5.300 & 8.010 & 3.244 & 4.745 & 6.579 & 3.450 & 4.338 \\
\hline CITS1 & 2.647 & 3.110 & 4.617 & 7.447 & 2.953 & 2.917 & 6.325 & 7.674 & 8.814 \\
\hline CATS1 & 0.000 & 0.000 & 0.000 & 0.000 & $0 .(x)$ & 0.000 & 0.000 & 0.000 & $0.0 \times 1$ \\
\hline wot & 43.874 & 41.294 & 41.575 & 39.098 & 43.879 & 43.032 & 40.915 & 41.390 & 39.767 \\
\hline ENI & 40.394 & 39.853 & 40.304 & 36.347 & 39.963 & 41.019 & 36.988 & 22.312 & 25.559 \\
\hline FS1 & 8.752 & 6.112 & 6.275 & 5.645 & 8.286 & 6.414 & 6.934 & 21.469 & 17.780 \\
\hline$Q$ & 1.833 & 1.730 & 1.748 & 1.617 & 1.816 & 1.788 & 1.692 & 1.668 & 1.640 \\
\hline Ј & 0.056 & 0.071 & 0.068 & 0.114 & 0.060 & 0.063 & 0.071 & 0.128 & 0.128 \\
\hline wo & 47.826 & 48.895 & 48.684 & 49.824 & 48.052 & 48.164 & 50.625 & 51.977 & $\$ 1.349$ \\
\hline ENN & 39.153 & 37.478 & 38.107 & 33.195 & 38.348 & 38.972 & 34.793 & 22.084 & 24.801 \\
\hline FS & 13.021 & 13.627 & 13.209 & 16.982 & 13.600 & 12.864 & 14.582 & 25.938 & 23,850 \\
\hline WEF & 97.031 & 96.065 & 96.274 & 93.461 & 96.817 & 96.581 & 95.956 & 92.896 & 92.813 \\
\hline ID & 0.005 & 0.673 & 0.000 & 0.000 & 0,000 & 0.000 & 0.202 & 2.894 & 1.460 \\
\hline$A E$ & 2.964 & 3.261 & 3.726 & 6.539 & 3.183 & 3.419 & 3.842 & 4.210 & 5.727 \\
\hline
\end{tabular}




\begin{tabular}{|c|c|c|c|c|c|c|c|c|c|}
\hline Sample & 15.006 & 15.007 & 15.008 & 15009 & 15010 & 15.011 & 15012 & 15.013 & 15021 \\
\hline Analysıs & gn: & gn & $\mathrm{gm}$ & $\mathrm{gm}$ & gn & $g n t$ & $g m$ & $g n$ & 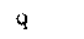 \\
\hline Location & YMi-5 & YMI-5 & YMI-S & YMl-5 & Y'Ml-5 & YMI-S & YMI-S & YMl-5 & YMI.5 \\
\hline Mineral & PIR & PIR & PIR & PIR & PIR & PIR & PIR & PIR & PIR \\
\hline $\mathrm{SiO}_{2}$ & 47.28 & 48.14 & 47.92 & 45.83 & 49.69 & 49.65 & 48.77 & 50.30 & 41.36 \\
\hline $\mathrm{THO} 2$ & 2.07 & 2.51 & 2.58 & 3.53 & 1.60 & 1.68 & 2.39 & 2.03 & 5.87 \\
\hline $\mathrm{Al} 2 \mathrm{O} 3$ & 4.42 & 5.08 & 5.75 & 6.84 & 3.45 & 3.44 & 3.91 & 0.7 & 9.37 \\
\hline$F_{0 O}$ & 8.56 & 8.24 & 8.62 & 8.49 & 7.28 & 7.22 & 8.62 & 26.12 & 12.5 \\
\hline $\mathrm{Cr} 2 \mathrm{O} 3$ & 0.04 & 0.02 & 0 & 0.03 & 0 & 0.05 & 0.08 & 0.02 & 0.03 \\
\hline $\mathrm{MnO}$ & 0.2 & 0.21 & 0.1 & 0.17 & .014 & 0.2 & 0.31 & 0.86 & 0.27 \\
\hline $\mathrm{NiO}$ & 0.02 & 0.07 & 0 & 0 & 0.00 & 0 & 0.04 & 0 & 0 \\
\hline $\mathrm{MgO}$ & 12.58 & 13.03 & 12.23 & 11.75 & 13.91 & 13.84 & 12.89 & 0.34 & 706 \\
\hline $\mathrm{CaO}$ & 23.3 & 23.09 & 22.86 & 23.40 & 22.9 & 23.3 & 22.85 & 10.64 & 22.23 \\
\hline $\mathrm{Na} 2 \mathrm{O}$ & 0.42 & 0.49 & 0.52 & 0.51 & 0.37 & 0.33 & 0.40 & 6.80 & 08 \\
\hline $\mathrm{K} 2 \mathrm{O}$ & 0.01 & 0.02 & 0.07 & 0.03 & 0.03 & 0.03 & 0.05 & 0.03 & 0 \\
\hline Total & 98,90 & 100,90 & 100,65 & 100,58 & 99,33 & 99,74 & 100,31 & 97,84 & $\$ 9,49$ \\
\hline $\mathrm{TSi}$ & 1.785 & 1.778 & 1.779 & 1.707 & 1.855 & 1.848 & 1.818 & 2.005 & $1.60 \times$ \\
\hline TAl & 0.196 & 0.221 & 0.221 & 0.293 & 0.145 & 0.151 & 0.172 & 0.000 & 0.400 \\
\hline IFe3 & 0.019 & 0.001 & 0.000 & 0.000 & 0.600 & 0.002 & 0.010 & 0.000 & $0, \times(1)$ \\
\hline $\mathrm{M} 1 \mathrm{Al}$ & 0.000 & 0.000 & 0.030 & 0.006 & 0.007 & 0.000 & 0.000 & 0.033 & 0.027 \\
\hline MIT & 0.059 & 0.070 & 0.072 & 0.099 & 0.045 & $0 .(147$ & 0.067 & $0.0 \times 1$ & 0.171 \\
\hline MIFe3 & 0.127 & 0.117 & 0.087 & 0.126 & 0.077 & 0.082 & 0.076 & 0.363 & i) $(x) 0$ \\
\hline MlFe2 & 0.104 & 0.093 & 0.134 & 0.116 & 0.095 & 0.102 & 0.137 & 0.508 & 0.305 \\
\hline $\mathrm{MlCr}$ & 0.001 & 0.001 & 0.000 & 0.001 & 0.000 & 0.001 & 0.002 & 0.001 & 0.001 \\
\hline MIMg & 0.708 & 0.718 & 0.677 & 0.652 & 0.774 & 0.768 & 0.717 & 0.020 & 0.407 \\
\hline MINi & 0.001 & 0.002 & 0.000 & 0.000 & 0.003 & 0.000 & 0.001 & 0,000 & $0.0(x)$ \\
\hline $\mathrm{M} 2 \mathrm{Mg}$ & 0.000 & 0.000 & 0.000 & $0.0 \times 0$ & 0.000 & 0.000 & 0.000 & 0.600 & $0.6 x)$ \\
\hline$M 2 F e 2$ & 0.020 & 0.044 & 0.047 & 0.023 & 0.055 & 0.039 & 0.046 & 0.000 & 0.010 \\
\hline $\mathrm{M} 2 \mathrm{Mn}$ & 0.0016 & 0.007 & 0.003 & 0.005 & 0,000 & 0.006 & 0.010 & 0.029 & 000 \\
\hline $\mathrm{M} 2 \mathrm{Ca}$ & 0.942 & 0.914 & 0.909 & 0.934 & 0.916 & 0.929 & 0.913 & 0.454 & 0.921 \\
\hline $\mathrm{M} 2 \mathrm{Na}$ & 0.031 & 0.035 & 0.037 & 0.037 & 0.027 & 0.024 & 0.029 & 0.525 & 0.660 \\
\hline $\mathrm{M} 2 \mathrm{~K}$ & 0.000 & 0.001 & 0.003 & 0.001 & 0.001 & 0.001 & 0.002 & 0.002 & 0.000 \\
\hline Sum $\operatorname{car}$ & 4.000 & 3.999 & 3.997 & 3.999 & 3.999 & 3.999 & 3.998 & 3.998 & 4.000 \\
\hline $\mathrm{Ca}$ & 52.910 & 51.499 & 51.363 & $\$ 3.969$ & 49.746 & $50.36 \%$ & 50.095 & 44.913 & 55.771 \\
\hline $\mathrm{Mg}$ & 39.748 & 40.436 & 38.234 & 37.706 & 42.043 & 41.623 & 39.320 & 1.997 & 24.645 \\
\hline $\mathrm{Fen} M n$ & 7.342 & 8.065 & 10.403 & 8.325 & 8.211 & 8.015 & 10.584 & 53.000 & 19.584 \\
\hline JD1 & 0.000 & 0.000 & 1.679 & 0.367 & 0.349 & 0.000 & 0.000 & 2.176 & 1.566 \\
\hline AE1 & 1.729 & 1.998 & $0 . \$ 75$ & 1.803 & 1.161 & 1.354 & 1.698 & 32.735 & 1.957 \\
\hline CFTSI & 5.376 & 4.528 & 4.215 & 5.380 & 2.935 & 3.102 & 2.546 & 0.000 & 3.364 \\
\hline CTrSl & 3.255 & 3.866 & 3.985 & 5.609 & 2.404 & 2.523 & 3.636 & 0.000 & 10.028 \\
\hline CATSI & 0.000 & 0.000 & 0.000 & 0.000 & 0.000 & 0.000 & 0.000 & $0.0 \times 0$ & $0.00(x)$ \\
\hline Wol & 43.552 & 42.263 & 42.095 & 41.973 & 43.668 & 44.225 & 43.330 & 30.097 & 40.704 \\
\hline ENI & 39.201 & 39.775 & 37.439 & 37.003 & 41.419 & 41.200 & 38.861 & 1.338 & 23.904 \\
\hline FS1 & 6.887 & 7.569 & 10.013 & 7.865 & 8.065 & 7.596 & 9.930 & 33.654 & 18.476 \\
\hline$Q$ & 1.775 & 1.768 & 1.767 & 1.724 & 3.841 & 1.838 & 1.812 & 0.983 & 1.643 \\
\hline J & 0.061 & 0.070 & 0.075 & 0.074 & 0.054 & 0.048 & 0.058 & 1.051 & 0.120 \\
\hline wo & 48.905 & 48.288 & 48.967 & 50.312 & 47.760 & 48.190 & 47.845 & 33.063 & 52.899 \\
\hline EN & 36.739 & 37.915 & 36.451 & 35.151 & 40.365 & 39.828 & 37.554 & 1.470 & 23.376 \\
\hline FS & 14.356 & 13.798 & 14.582 & 14.537 & 11.874 & 11.983 & 14.601 & 65.467 & 23.726 \\
\hline WEF & 96.663 & 96.195 & 95.943 & 95.916 & 97.173 & 97.483 & 96.924 & 49.045 & 93.227 \\
\hline ID & 0.000 & 0.000 & 1.053 & 0.200 & 0.222 & 0.000 & $0.0 \times 0$ & 4.234 & 1.553 \\
\hline $\mathrm{AE}$ & 3.337 & 3.805 & 3.004 & 3.884 & 2.605 & 2.517 & 3.076 & 46.721 & 5.220 \\
\hline
\end{tabular}




\begin{tabular}{|c|c|c|}
\hline Sample & 15.022 & 15.023 \\
\hline Analysis & $q$ & 9 \\
\hline Eocation & YMI-5 & YMI-5 \\
\hline Mineral & PIR & $\mathrm{P} 3 \mathrm{R}$ \\
\hline $\mathrm{SiO} 2$ & 39.82 & 41.58 \\
\hline $\mathrm{TiO} 2$ & 6.17 & 5.26 \\
\hline $\mathrm{Al} 203$ & 10.17 & 8.55 \\
\hline $\mathrm{FeO}$ & 11.89 & 12.37 \\
\hline $\mathrm{Cr}_{2} \mathrm{O}_{3}$ & 0.09 & 0.07 \\
\hline MnO & 0.21 & 0.33 \\
\hline $\mathrm{NiO}$ & 0.01 & \\
\hline $\mathrm{M}_{8} \mathrm{O}$ & 7.87 & 7.49 \\
\hline $\mathrm{CaO}$ & 22.25 & 22.09 \\
\hline $\mathrm{N} 20$ & 0.81 & 0.85 \\
\hline $\mathrm{K} 2 \mathrm{O}$ & 0 & 0.03 \\
\hline Total & 99,29 & 98,62 \\
\hline $\mathrm{TSi}$ & 1.535 & 1.618 \\
\hline TAI & 0.462 & 0.382 \\
\hline TFe? & 0.004 & 0.000 \\
\hline $\mathrm{M} \mid \mathrm{Al}$ & 0.000 & 0.010 \\
\hline $\mathrm{MITi}$ & 0.179 & 0.154 \\
\hline MiFe3 & 0.164 & 0.127 \\
\hline MIFe2 & 0.202 & 0.273 \\
\hline $\mathrm{M} 1 \mathrm{Cr}$ & 0.003 & 0.002 \\
\hline MIMg & 0.452 & 0.434 \\
\hline MiNi & 0.000 & 0.000 \\
\hline $\mathrm{M}_{2} \mathrm{M} \mathrm{Mg}$ & 0.000 & 0.000 \\
\hline $\mathrm{M} 2 \mathrm{Fe} 2$ & 0.014 & 0.003 \\
\hline $\mathrm{M} 2 \mathrm{Mn}$ & 0.007 & 0.011 \\
\hline $\mathrm{M} 2 \mathrm{Ca}$ & 0.919 & 0.921 \\
\hline $\mathrm{M} 2 \mathrm{Na}$ & 0.061 & 0.064 \\
\hline $\mathrm{M} 2 \mathrm{~K}$ & 0.000 & 0.001 \\
\hline Stun_an & 4.000 & 3.999 \\
\hline $\mathrm{Ca}$ & 57.655 & 56.093 \\
\hline Mg & 28.375 & 26.463 \\
\hline $\mathrm{Fe} 2 \_\mathrm{Mn}$ & 13.970 & 17.444 \\
\hline JD1 & 0.000 & 0.565 \\
\hline $\mathrm{AEl}$ & 3.675 & 3.303 \\
\hline CFTS1 & 6.439 & 4.310 \\
\hline crTs1 & 10.859 & 9.074 \\
\hline CATSI & 0.000 & 0.000 \\
\hline wol & 38.479 & 40.898 \\
\hline ENI & 27.450 & 25.609 \\
\hline FSI & 13.099 & 16.240 \\
\hline$Q$ & 1.587 & 1.631 \\
\hline $\mathrm{J}$ & 0.121 & 0.128 \\
\hline wo & 52.173 & 52.065 \\
\hline EN & 25.676 & 24.563 \\
\hline $\mathrm{FS}$ & 22.151 & 23.372 \\
\hline WEF & 92.939 & 92.754 \\
\hline $\mathfrak{D}$ & 0.000 & 0.508 \\
\hline$A E$ & 7.061 & 6.738 \\
\hline
\end{tabular}




\begin{tabular}{|c|c|c|c|c|c|c|c|c|c|}
\hline Sample & $22.000 \mathrm{a}$ & $22.000 \mathrm{~b}$ & $22.001 \mathrm{a}$ & $22.001 \mathrm{~b}$ & $22.002 \mathrm{a}$ & $22.002 \mathrm{~b}$ & $22003 \mathrm{a}$ & 22.0036 & 22.0044 \\
\hline Analysis & & & & & & & & & \\
\hline Lacadion & $Y Z U_{-2}$ & $Y Z U: 2$ & Y2U:2 & YZU-2 & $\mathrm{YZU}-2$ & $Y Z U-2$ & YZU-2 & $Y Z U-2$ & YZU-2 \\
\hline Mineral & PIR & PIR & PIR & PIR & PIR & PIR & PIR & PLR & PIR \\
\hline $\mathrm{SiO} 2$ & 52.69 & 52.69 & 54.15 & 52.35 & 53.63 & 52.63 & 53.62 & 51.18 & $\$ 1.99$ \\
\hline $\mathrm{TiO}_{2}$ & 1.25 & 1.33 & 0.88 & 1.24 & 0.84 & 1.61 & 1.23 & 1.35 & 1.13 \\
\hline $\mathrm{Al} 2 \mathrm{O} 3$ & 0.97 & 1.04 & 0.64 & 0.53 & 0.65 & 0.8 & 0.56 & 0.75 & 0.78 \\
\hline $\mathrm{FeO}$ & 6.98 & 6.13 & 5.88 & 6.48 & 5.43 & 6.51 & 5.78 & 5.79 & 5.85 \\
\hline $\mathrm{Cr} 2 \mathrm{O} 3$ & 0.04 & 0.07 & 0.03 & 0.05 & 0.15 & 0 & 0 & 0.11 & 0.07 \\
\hline $\mathrm{MnO}$ & 0.21 & 0.11 & 0.11 & 0.2 & 0.14 & 0 & 0.1 & 0.2 & 0.23 \\
\hline $\mathrm{NiO}$ & 0 & 0 & 0.11 & 0.09 & 0.04 & 0.02 & 0.02 & 0.01 & 0.05 \\
\hline $\mathrm{MgO}$ & 14.89 & 15.38 & 15.91 & 15.46 & 14.9 & 15.31 & 15.75 & 15.63 & 15.71 \\
\hline $\mathrm{CaO}$ & 21.52 & 23.19 & 23.16 & 22.72 & 23.1 & $23.0 !$ & 23.1 & 22.83 & 22.54 \\
\hline $\mathrm{Na} 2 \mathrm{O}$ & 0.93 & 0.62 & 0.62 & 0.71 & 0.55 & 0.84 & 0.67 & 0.63 & 0.67 \\
\hline $\mathrm{K} 2 \mathrm{O}$ & 0 & 0 & 0.01 & 0.04 & 0.04 & 0.01 & 0.02 & 0.12 & 0.06 \\
\hline Total & 99,48 & 100,56 & 101.50 & 99,87 & 99,47 & 100,74 & 100,85 & 98,60 & 99,08 \\
\hline TSi & 1.954 & 1.931 & 1.961 & 1.931 & 1.988 & 1.925 & $1.95 \mathrm{~S}$ & 1.908 & 1.928 \\
\hline TAl & 0.042 & 0.045 & 0.027 & 0.023 & 0.012 & 0.034 & 0.024 & 0.033 & 0.034 \\
\hline TFe.3 & 0.004 & 0.024 & 0.011 & 0.046 & 0.000 & 0.041 & 0.021 & 0.060 & 0.038 \\
\hline MlAl & 0.000 & 0.000 & 0.000 & 0.000 & 0.016 & 0.000 & 0.000 & 0.000 & 0.000 \\
\hline MlTi & 0.035 & 0.037 & 0.024 & 0.034 & 0.023 & 0.044 & 0.034 & 0.038 & 0.032 \\
\hline $\mathrm{M} 1 \mathrm{Fe} 3$ & 0.042 & 0.038 & 0.034 & 0.051 & 0.000 & 0.046 & 0.025 & 0.065 & 0.058 \\
\hline $\mathrm{M} \mid \mathrm{Fe} 2$ & 0.099 & 0.083 & 0.079 & 0.060 & 0.131 & 0.074 & 0.084 & 0.026 & 0.038 \\
\hline $\mathrm{M} I \mathrm{Cr}$ & 0.001 & 0.002 & 0.001 & 0.001 & 0.004 & 0.000 & 0.000 & 0.003 & 0.002 \\
\hline $\mathrm{MLMg}_{\mathrm{g}}$ & 0.823 & 0.840 & 0.859 & 0.850 & 0.823 & 0.835 & 0.856 & 0.868 & 0.868 \\
\hline $\mathrm{M} 1 \mathrm{Ni}$ & 0.000 & 0.000 & 0.003 & 0.003 & 0.001 & 0.001 & 0.001 & 0.000 & 0.001 \\
\hline M2Mg & 0.000 & 0.000 & 0.000 & 0.000 & 0.000 & 0.000 & 0.000 & 0.000 & $0.00 \times 1$ \\
\hline $\mathrm{M} 2 \mathrm{Fe} 2$ & 0.072 & 0.042 & 0.054 & 0.043 & 0.037 & 0.038 & 0.046 & 0.031 & 0.046 \\
\hline $\mathrm{M} 2 \mathrm{Mn}$ & 0.007 & 0.003 & 0.003 & 0.006 & 0.004 & 0.000 & 0.003 & 0.006 & 0.007 \\
\hline $\mathrm{M} 2 \mathrm{Ca}$ & 0.855 & 0.910 & 0.899 & 0.898 & 0.917 & 0.902 & 0.903 & 0.912 & 0.895 \\
\hline $\mathrm{M} 2 \mathrm{Na}$ & 0.067 & 0.044 & 0.044 & 0.051 & 0.040 & 0.050 & 0.047 & 0.046 & 0.048 \\
\hline MaK & 0.000 & 0.000 & 0.000 & 0.002 & 0.002 & 0.000 & 0.001 & 0.006 & 0.003 \\
\hline Sun_cas & $4.0 \times 0$ & 4.000 & 4.000 & 3.998 & 3.998 & 4.000 & 3.999 & 3.994 & 3.997 \\
\hline $\mathrm{Ca}$ & 46.089 & 48.443 & 47.450 & $48.34]$ & 47.944 & 48.776 & 47.704 & 49.474 & 48.250 \\
\hline $\mathrm{Mg}$ & 44.371 & 44.703 & 45.354 & 45.768 & 43.029 & 45.155 & 45.256 & 47.128 & 46.792 \\
\hline $\mathrm{Fe} 2 \mathrm{Mn}$ & 9.540 & 6.854 & 7.197 & 5.892 & 9.027 & 6.069 & 7.040 & 3.397 & 4.958 \\
\hline JDI & 0.000 & 0.000 & 0.000 & 0.000 & 0.830 & 0.000 & 0.000 & 0.000 & 0.000 \\
\hline$A E\}$ & 3.491 & 2.294 & 2.274 & 2.766 & 1.294 & 3.146 & 2.494 & 2.714 & 2.685 \\
\hline CFrS! & 0.000 & 0.000 & 0.000 & 0.000 & 0.000 & 0.000 & 0.000 & 0.882 & 0.489 \\
\hline CTISI & 1.820 & 1.909 & 1.239 & 1.209 & 0.625 & 1.805 & 1.241 & 1.744 & 1.659 \\
\hline CATSl & 0.000 & 0.000 & 0.000 & 0.000 & 0.000 & 0.000 & 0.000 & 0.000 & 0.000 \\
\hline wOl & 42.818 & 45.508 & 45.214 & 45.953 & 46.410 & 45.436 & 45.349 & 45.671 & 44.990 \\
\hline ENI & 42.975 & 43.757 & 44.401 & 44.652 & 42.212 & 43.735 & 44.200 & 46.007 & 45.713 \\
\hline FS1 & 8.895 & 6.531 & 6.871 & $\$ .420$ & 8.630 & 5.878 & 6.716 & 2.982 & 4.463 \\
\hline$Q$ & 1.848 & 1.876 & 1.891 & 1.852 & 1.909 & 1.849 & 1.889 & 1.836 & 1.848 \\
\hline$I$ & 0.134 & 0.088 & 0.087 & 0.102 & 0.079 & 0.119 & 0.005 & 0.091 & 0.096 \\
\hline wo & 44.972 & 46.885 & 46.344 & 45.948 & 47.944 & 46.585 & 46.568 & 46.351 & 45.863 \\
\hline EN & 43.296 & 43.265 & 44.297 & 43.503 & 43.029 & 43.127 & 44.178 & 44.153 & 44.476 \\
\hline FS & 11.732 & 9.850 & 9.358 & 10.549 & 9.027 & 10.288 & 9.254 & 9.496 & 9.661 \\
\hline WEF & 93.276 & 95.522 & 95.604 & 94.816 & 96.032 & 93.945 & 95.231 & 95.291 & 95.065 \\
\hline JD & 0.000 & 0,000 & 0.000 & 0.000 & 3.968 & 0.000 & 0.000 & 0.000 & $0.0 \times 0$ \\
\hline $\mathrm{AE}$ & 6.724 & 4.478 & 4.396 & 5.184 & 0.000 & 6.055 & 4.769 & 4.709 & 4.935 \\
\hline
\end{tabular}




\begin{tabular}{|c|c|c|c|c|c|c|c|c|c|}
\hline Sample & 22.004 & 22.0058 & $22.005 \mathrm{~b}$ & $22.006 a$ & $22.006 \mathrm{~b}$ & 22.007 & $22.007 \mathrm{~b}$ & & 22.009 \\
\hline Analysis & fen-s/b. & & & & & $\mathrm{mf}$ & $\mathrm{gm}$ & gn & $g m$ \\
\hline Laction & YZU-2 & YZU-2 & YZU-2 & YZU-2 & YZU-2 & YZU-2 & $Y Z U-2$ & YZU-2 & $Y Z U_{2} 2$ \\
\hline Mineral & PIR & PIR & PIR & PIR & PIR & PIR & PIR & PIR & PIR \\
\hline $\mathrm{SiO} 2$ & 50.78 & 53.82 & 52.49 & 51.93 & 53.21 & 53.09 & $\$ 2.89$ & 52.17 & 52.24 \\
\hline $\mathrm{TiO} 2$ & 6.34 & 0.61 & 1.39 & 1.20 & 0.60 & 0.69 & 1.34 & 1.29 & 1.27 \\
\hline $\mathrm{Al} 2 \mathrm{O} 3$ & 2.81 & 0.80 & 0.72 & 0.78 & 1.04 & 0.97 & 1.53 & 0.84 & 0.66 \\
\hline $\mathrm{F} \infty$ & 16.53 & 4.07 & 6.62 & 5.92 & 4.67 & 3.59 & 5.68 & 5.37 & 5.92 \\
\hline $\mathrm{Cr} 2 \mathrm{O} 3$ & 0 & 0.18 & 0.06 & 0.05 & 0.07 & 0.53 & 0.16 & 0.11 & 0.11 \\
\hline $\mathrm{MnO}$ & 0.16 & 0.10 & 0.13 & 0.14 & 0.17 & 0.10 & 0.12 & 0.03 & 0.14 \\
\hline $\mathrm{NiO}$ & 0.06 & 0.13 & 0.15 & 0.05 & 0.01 & 0.07 & 0 & 0.07 & 0.12 \\
\hline $\mathrm{MgO}$ & 4.67 & 16.73 & 14.59 & 14.24 & 16.27 & 16.47 & 14.37 & 15.54 & 15.34 \\
\hline $\mathrm{CaO}$ & 3.74 & 23.52 & 22.20 & 22.81 & 23.69 & 23.68 & 22.00 & 23.29 & 22.86 \\
\hline $\mathrm{Na2O}$ & 11.28 & 0.55 & 1.06 & 0.80 & 0.55 & 0.32 & 0.86 & 0.75 & 0.55 \\
\hline $\mathrm{K} 2 \mathrm{O}$ & 0.70 & 0 & 0 & 0.01 & 0.03 & 0.02 & 0.51 & 0.02 & 0.01 \\
\hline Total & 97,07 & 100,51 & 99,41 & 98,63 & 100,31 & 99,53 & 99,46 & 99,48 & 99,22 \\
\hline TSi & 1.905 & 1.954 & 1.948 & 1.938 & 1.939 & 1.950 & 1.959 & 1.925 & 1.941 \\
\hline TAl & 0.095 & 0.034 & 0.031 & 0.034 & 0.045 & 0.042 & 0.041 & 0.037 & 0.029 \\
\hline $\mathrm{TF}+3$ & 0.000 & 0.012 & 0.021 & 0.028 & 0.016 & 0.008 & 0,000 & 0.038 & 0.030 \\
\hline $\mathrm{M} \mid \mathrm{Al}$ & 0.030 & 0.000 & 0.000 & 0.000 & 0.000 & 0.000 & 0.026 & 0.000 & 0.000 \\
\hline MlTi & 0.179 & 0.017 & 0.039 & 0.034 & 0.016 & 0.019 & 0.037 & 0.036 & 0.035 \\
\hline MlFe3 & 0.000 & 0.046 & 0.049 & 0.051 & 0.066 & 0.020 & 0.021 & 0.054 & 0.025 \\
\hline MIFe2 & 0.519 & 0.023 & 0.099 & 0.081 & 0.031 & 0.042 & 0.117 & 0.050 & 0.083 \\
\hline $\mathrm{M} / \mathrm{ICr}$ & 0.000 & 0.005 & 0.002 & 0.001 & 0.002 & 0.015 & 0.005 & 0.003 & 0.003 \\
\hline MlMg & 0.261 & 0.906 & 0.807 & 0.831 & 0.884 & 0.902 & 0.793 & 0.855 & 0.850 \\
\hline $\mathrm{M} 1 \mathrm{Ni}$ & 0.002 & 0.004 & 0.004 & 0.002 & 0.000 & 0.002 & 0.000 & 0.002 & 0.004 \\
\hline $\mathrm{M} 2 \mathrm{MB}$ & 0.000 & 0.000 & 0.000 & 0.000 & $0.0(0)$ & $0.0 \times 0$ & 0.000 & 0.000 & 0.000 \\
\hline $\mathrm{M} 2 \mathrm{~F} \in 2$ & 0.000 & 0.043 & 0.037 & 0.025 & 0.029 & 0.041 & 0.037 & 0.024 & 0.046 \\
\hline $\mathrm{M} 2 \mathrm{Mn}$ & 0.005 & 0.003 & 0.004 & $0.0 \times 14$ & 0.005 & 0.003 & 0.004 & 0.001 & 0.004 \\
\hline $\mathrm{M} 2 \mathrm{Ca}$ & 0.150 & 0.915 & 0.883 & 0.912 & 0.925 & 0.932 & 0.873 & 0.921 & 0.910 \\
\hline $\mathrm{M} 2 \mathrm{Na}$ & 0.821 & 0.039 & 0.076 & 0.058 & 0.039 & 0.023 & 0.062 & 0.054 & 0.040 \\
\hline MaK & 0.034 & 0.000 & 0.000 & 0.000 & 0.001 & 0.001 & 0.024 & 0.001 & 0.000 \\
\hline Sum_an & 3.966 & 4.000 & 4.000 & 4.000 & 3.999 & 3.999 & 3.976 & 3.999 & 4.000 \\
\hline $\mathrm{Ca}$ & 16.074 & 48.420 & 48.240 & 49.206 & 49.336 & 48.543 & 47.844 & 49.780 & 48.079 \\
\hline $\mathrm{Mg}$ & 27.927 & 47.922 & 44.112 & 44.843 & 47.14 .5 & 46.978 & 43.482 & 46.215 & 44.890 \\
\hline $\mathrm{Fe} 2 \mathrm{Mn}$ & 55.998 & 3.659 & 7.648 & 5.952 & 3.520 & 4.479 & 8.674 & 4.005 & 7.031 \\
\hline IDI & 1.659 & 0.000 & 0.000 & 0.000 & 0.000 & 0.000 & 1.354 & 0.000 & 0.000 \\
\hline $\mathrm{AE} 1$ & 46.208 & 2.011 & 4.010 & 3.060 & 2.108 & 1.223 & 3.149 & 2.869 & 2.079 \\
\hline CFTSI & 0.000 & 0.642 & 0.000 & 0.000 & 1.438 & 0.585 & 0.000 & 0.156 & 0.000 \\
\hline Crrsi & 5.299 & 0.865 & 1.654 & 1.766 & 0.861 & 0.982 & 1.958 & 1.881 & 1.498 \\
\hline CATS1 & 0.000 & 0.000 & 0,000 & 0.000 & 0.000 & 0.000 & 0.000 & 0,000 & 0.000 \\
\hline wol & 3.127 & 46.016 & 44.755 & 46.048 & 46.132 & 46.460 & 43.826 & 46.339 & $45.69 !$ \\
\hline ENI & 14.639 & 47.034 & 42.438 & 43.574 & 46.280 & 46.478 & 41.610 & 44,912 & 44.059 \\
\hline FS1 & 29.058 & 3.433 & 7.143 & 5.551 & 3.180 & 4.271 & 8.104 & 3.843 & 6.672 \\
\hline$Q$ & 0.930 & 1.887 & 1.826 & 1.849 & 1.870 & 1917 & 1.821 & 1.849 & 1.888 \\
\hline J & 1.641 & 0.077 & 0.153 & 0.116 & 0.078 & 0.046 & 0.124 & 0.107 & 0.079 \\
\hline wo & 16.074 & 46.989 & 46.472 & 47.197 & 47.278 & 47.860 & 47.289 & 47.407 & 46.715 \\
\hline EN & 27.927 & 46.506 & 42.496 & 43.012 & 45.179 & 46.316 & 42.978 & 44.012 & 43.617 \\
\hline FS & 55.998 & 6.505 & 11.032 & 9.790 & 7.543 & 5.823 & 9.734 & 8.580 & 9.669 \\
\hline WEF & 36.301 & 96.063 & 92.305 & 94.121 & 96.019 & 97.681 & 93.660 & 94.516 & 95.981 \\
\hline $\mathrm{J}$ & 63.699 & 0.000 & 0.000 & 0.000 & 0.000 & 0.000 & 3.465 & 0.000 & 0.000 \\
\hline$A E$ & 0.000 & 3.937 & 7.695 & 5.879 & 3.981 & 2.319 & 2.875 & 5.484 & 4.019 \\
\hline
\end{tabular}




\begin{tabular}{|c|c|c|c|c|c|c|c|c|c|}
\hline Sernple & 22.015 & 22.017 & 22.019 & 22020 & 22.021 & 22023 & 22.024 & 22.025 & 22020 \\
\hline Analysis & $g m$ & 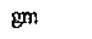 & $g n$ & gाn & $g m$ & gin & $g n$ & $\mathrm{gm}$ & $\mathrm{gm}$ \\
\hline Loxation & YZU-2 & 120.2 & YZU.2 & $Y Z U^{\prime} 2$ & $Y Z U .2$ & $\mathrm{YZU}+2$ & YZU:= & YZU.2 & $\mathrm{YZU}-2$ \\
\hline Mineral & PIR & PIR & PIR & PIR & PIR & PIR & PIR & PIR & PIR \\
\hline $\mathrm{SiO} 2$ & 51.44 & 52.48 & 53.19 & 54.75 & 52.59 & 53.09 & 52.28 & 51.15 & 52.72 \\
\hline $\mathrm{TiO} 2$ & 1.27 & 1.18 & 1.15 & 0.43 & 1.21 & 0.91 & 1.27 & 8.78 & 1.12 \\
\hline $\mathrm{Al} 203$ & 0.56 & 0.75 & 0.59 & 0.7 & 0.39 & 0.84 & 0.90 & 1.10 & 0.58 \\
\hline FoO & 6.66 & 28.95 & 5.64 & 3.97 & 6.51 & 5.19 & 5.58 & 19.30 & $\$ .33$ \\
\hline $\mathrm{Cr} 2 \mathrm{O} 3$ & 0 & 0 & 0 & 0.2 & 0 & 0.02 & 0.03 & 0 & 0.02 \\
\hline $\mathrm{MnO}$ & 0.11 & 0.16 & 0.17 & 0.07 & 0.24 & 0.16 & 0.10 & 0.18 & 0.11 \\
\hline $\mathrm{NiO}$ & 0 & 0.02 & 0 & 0.15 & 0.15 & 0.13 & 0 & 0.05 & 0 \\
\hline $\mathrm{MBO}$ & 15.81 & 0.39 & 15.47 & 17.13 & 14.88 & 15.95 & 15.78 & 202 & 15.67 \\
\hline $\mathrm{CaO}$ & 22.97 & 0.35 & 23.35 & 23.77 & 21.61 & 23.72 & 22.46 & 1.62 & 23.14 \\
\hline $\mathrm{Na} 2 \mathrm{O}$ & 0.03 & 12.29 & 0.69 & 0.32 & 1.31 & 0.50 & 0.88 & 13.09 & 0.74 \\
\hline $\mathrm{K} 2 \mathrm{O}$ & 0 & 0.08 & 0 & 0.03 & 0.04 & 0.01 & 0.01 & 0.18 & 0.02 \\
\hline Total & 98,85 & 96,65 & 100,25 & 101,52 & 98,93 & 100,52 & 99,29 & 97,47 & 99,45 \\
\hline $\mathrm{TSi}$ & 1.924 & 2.028 & 1.951 & 1.969 & 1.954 & 1.939 & 1.930 & 1.935 & 1.945 \\
\hline TAl & 0.025 & 0.000 & 0.025 & 0.030 & 0.017 & 0.036 & 0.039 & 0.049 & 0.025 \\
\hline TFe 3 & 0.052 & 0.000 & 0.023 & 0.001 & 0.029 & 0.025 & 0.031 & 0.016 & 0.030 \\
\hline $\mathrm{M} I \mathrm{Al}$ & 0.000 & 0.034 & 0.000 & 0.000 & 0.000 & 0.000 & 0.000 & 0.000 & 0.000 \\
\hline MiTi & 0.036 & 0.034 & 0.032 & 0.012 & 0.034 & 0.025 & 0.035 & 0.250 & 0.031 \\
\hline MlFe3 & 0.007 & 0.766 & 0.034 & 0.026 & 0.075 & 0.046 & 0.062 & 0.534 & 0.046 \\
\hline $\mathrm{M} 1 \mathrm{Fe} 2$ & 0.076 & 0.143 & 0.088 & 0.034 & 0.063 & $0,0.56$ & 0.033 & 0.060 & 0.060 \\
\hline $\mathrm{M} 1 \mathrm{Cr}$ & 0.000 & 0.000 & 0.000 & 0.006 & 0.000 & 0.001 & 0.001 & 0.000 & 0.001 \\
\hline M1MB & 0.881 & 0.022 & 0.846 & 0.918 & 0.824 & 0.868 & 0.868 & 0.114 & 0.862 \\
\hline $\mathrm{MINi}$ & 0.000 & 0.001 & 0.000 & 0.004 & 0.004 & 0.004 & 0.000 & 0.002 & 0.000 \\
\hline $\mathrm{M} 2 \mathrm{Mg}$ & 0.000 & 0.000 & 0.000 & 0.000 & 0.000 & 0.000 & 0.000 & 0.000 & $0 .(0 \times 0)$ \\
\hline $\mathrm{M} 2 \mathrm{~F} \mathrm{e} 2$ & 0.074 & 0.027 & 0.028 & 0.058 & 0.036 & 0.031 & 0.045 & 0.000 & 0.028 \\
\hline $\mathrm{M} 2 \mathrm{Mn}$ & 0.003 & 0.005 & 0.005 & 0.002 & 0.008 & 0.005 & 0.003 & 0.006 & $0.0 \times 3$ \\
\hline $\mathrm{M} 2 \mathrm{Ca}$ & 0.920 & 0.014 & 0.918 & 0.916 & 0.860 & 0.928 & 0.888 & 0.066 & 0.915 \\
\hline $\mathrm{M} 2 \mathrm{Na}$ & 0.002 & 0.921 & 0.049 & 0.022 & 0.094 & 0.035 & 0.063 & 0.960 & 0.053 \\
\hline $\mathrm{M} 2 \mathrm{~K}$ & 0.000 & 0.004 & 0.000 & 0.001 & 0.002 & 0.000 & 0.000 & 0.009 & 0.001 \\
\hline Sum $c a t$ & 4.000 & 3.996 & $4.000)$ & 3.999 & 3.998 & 4.000 & 4.000 & 3.991 & 3.999 \\
\hline $\mathrm{Ca}$ & 47.074 & 6.832 & 48.690 & 47.481 & 48.038 & 49.149 & 48.321 & 26.722 & 48.955 \\
\hline $\mathrm{Mg}$ & 45.082 & 10.592 & 44.884 & 47.610 & 46.023 & 45.984 & 47.237 & 46.362 & 46.127 \\
\hline $\mathrm{Fe} 2 \mathrm{Mn}$ & 7.845 & 82.577 & 6.425 & 4.910 & 5.939 & 4.867 & $4.44 I$ & 26.916 & 4.918 \\
\hline $\mathbb{D} 1$ & 0.000 & 3.016 & 0.000 & 0.000 & 0.000 & 0.000 & 0.000 & 0.000 & 0.000 \\
\hline AE] & 0.111 & 78.704 & 2.545 & 1.215 & 5.122 & 1.869 & 3.342 & 80.150 & 2.808 \\
\hline CFTSI & 0.240 & 0.000 & 0.000 & 0.387 & 0.000 & $0.58 !$ & 0.000 & 0.000 & $0.0(x)$ \\
\hline CTrS1 & 1.262 & 0.000 & 1.322 & 0.596 & 0.908 & 1.302 & 1.857 & 4.054 & 1.313 \\
\hline CATS1 & 0.000 & 0.000 & 0.000 & 0.000 & 0.000 & $0 .(\infty)$ & 0.000 & 0.000 & 0.000 \\
\hline WOl & 45.603 & 1.280 & 46.263 & 45.973 & 44.862 & 46.474 & 44.929 & 1.378 & 46.355 \\
\hline ENI & 45.112 & 1.985 & 43.865 & 47.083 & 43.851 & 45.243 & 45.736 & 9.424 & 44.914 \\
\hline FS 1 & 7.672 & 15.015 & 6.005 & 4.746 & 5.257 & 4.530 & 4.136 & 4.994 & 4.610 \\
\hline$Q$ & 1.952 & 0.207 & 1.880 & 1.927 & 1.783 & 1.88 .3 & 1.835 & 0.240 & 1.865 \\
\hline J & 0.004 & 1.842 & 0.098 & 0.045 & 0.189 & 0.071 & 0.126 & 1.920 & 0.106 \\
\hline wo & 45.708 & 1.482 & 47.256 & 46.829 & 45.413 & 47.355 & 45.977 & 8.250 & 47.042 \\
\hline EN & 43.774 & 2.298 & 43.562 & 46.957 & 43.509 & 44.305 & 44.945 & 14.312 & 44.324 \\
\hline FS & 10.518 & 96.220 & 9.181 & 6.214 & 31.077 & 8.340 & 9.078 & 77.438 & 8.634 \\
\hline WEF & 99.778 & 10.328 & 95.050 & 97.739 & 90.465 & 96.386 & 93.587 & 11.344 & 94.637 \\
\hline ID & 0.000 & 3.827 & 0.000 & 0.000 & 0.000 & $0,(0 \times)$ & 0.000 & 0,000 & 0.000 \\
\hline $\mathrm{AE}$ & 0.222 & 85.846 & 4.950 & 2.261 & 9.535 & 3.614 & 6.413 & 88.656 & 5.363 \\
\hline
\end{tabular}




\begin{tabular}{|c|c|c|c|c|c|c|c|c|c|}
\hline Srample & 22.027 & 22.028 & $23.000 \mathrm{a}$ & $23.000 b$ & $23.002 a$ & $23.002 \mathrm{~b}$ & $23.004 \mathrm{a}$ & $23.004 \mathrm{~b}$ & 23.005 \\
\hline Analysis & $g m$ & $\mathrm{gm}$ & & & & & & & $\mathrm{gm}$ \\
\hline Lacation & YZU-2 & YZU-2 & $Y Z U_{-3}$ & YZU.3 & $Y Z U_{.3}$ & $Y Z U_{-3}$ & $\mathrm{YZU}_{3} 3$ & YZU-3 & YZU-3 \\
\hline Mineral & PIR & PlR & PIR & PIR & PLR & PIR & PIR & PIR & PIR \\
\hline $\mathrm{SiO} 2$ & 52.06 & 52.90 & 52.05 & 52.31 & 53.10 & 51.96 & 51.25 & 49.98 & 52.34 \\
\hline $\mathrm{TiO} 2$ & 1.44 & 1.41 & 1.11 & 1.06 & 1.05 & 0.99 & 1.24 & 1.41 & 1.07 \\
\hline $\mathrm{Al} 2 \mathrm{O} 3$ & 0.70 & 0.57 & 0.87 & 1.73 & 0.86 & 1.91 & 1.91 & 2.09 & 1.86 \\
\hline $\mathrm{F} 0 \mathrm{O}$ & 6.77 & 6.58 & 7.15 & 5.98 & 7.75 & 6.40 & 6.60 & 7.07 & 6.44 \\
\hline $\mathrm{Cr} 2 \mathrm{O} 3$ & 0.09 & 0 & 0.01 & 0.27 & 0.04 & 0.66 & 0.17 & 0.18 & 0.05 \\
\hline $\mathrm{MnO}$ & 0.16 & 0.26 & 0.21 & 0.13 & 0.17 & 0.16 & 0.14 & 0.09 & 0.14 \\
\hline $\mathrm{NiO}$ & 0 & 0 & 0.03 & 0.02 & 0.01 & 0.02 & 0.02 & 0.02 & 0.02 \\
\hline $\mathrm{MgO}$ & 15.35 & 15.05 & 14.74 & 15.26 & 13.88 & 15.07 & 15.34 & 15.06 & 14.43 \\
\hline $\mathrm{CaO}$ & 22.65 & 22.17 & 20.49 & 22.95 & 20.35 & 22.83 & 22.39 & 22.40 & 22.40 \\
\hline $\mathrm{Na} 2 \mathrm{O}$ & 0.55 & 0.94 & 1.83 & 0.72 & 1.87 & 0.45 & 0.54 & 0.73 & 1.04 \\
\hline $\mathrm{K} 2 \mathrm{O}$ & 0 & 0.03 & 0.02 & 0 & 0 & 0.01 & 0 & 0.10 & 0.03 \\
\hline Total & 99,77 & 99,91 & 98,51 & 100,43 & 99,08 & 99,86 & 99,60 & 99,13 & 99,82 \\
\hline TSi & 1.927 & 1.952 & 1.935 & 1.916 & 1.972 & 1.919 & 1.896 & 1.857 & 1.930 \\
\hline TAl & 0.031 & 0.025 & 0.038 & 0.075 & 0.028 & 0.081 & 0.083 & 0.091 & 0.070 \\
\hline TFe3 & 0.042 & 0.023 & 0.027 & 0.010 & 0.000 & 0.000 & 0.021 & 0.051 & 0.000 \\
\hline MIA] & 0.000 & 0.000 & 0.000 & 0.000 & 0.010 & 0.002 & 0.000 & 0.000 & 0.011 \\
\hline $\mathrm{MlTi}$ & 0.040 & 0.039 & 0.031 & 0.029 & 0.029 & 0.027 & 0.035 & 0.039 & 0.030 \\
\hline $\mathrm{MHF} 3$ & 0.029 & 0.038 & 0.135 & 0.069 & 0.092 & 0.055 & 0.069 & 0.116 & 0.073 \\
\hline $\mathrm{M}] \mathrm{Fe} 2$ & 0.081 & 0.095 & 0.015 & 0.060 & 0.098 & 0.084 & 0.845 & 0.005 & 0.090 \\
\hline $\mathrm{MiCr}$ & 0.003 & 0.000 & 0.000 & 0.008 & 0.001 & 0.002 & 0.005 & 0.005 & 0.001 \\
\hline MlMg & 0.847 & 0.828 & 0.817 & 0.833 & 0.769 & 0.830 & 0.846 & 0.834 & 0.793 \\
\hline $\mathrm{M} I \mathrm{Ni}$ & 0.000 & 0.000 & 0.001 & 0.001 & 0.000 & 0.001 & 0.001 & $0.00 \mathrm{I}$ & 0.001 \\
\hline $\mathrm{M} 2 \mathrm{Mg}$ & 0.000 & 0.000 & 0.000 & 0.000 & 0.000 & 0.000 & 0.000 & 0.000 & 0.000 \\
\hline $\mathrm{M} 2 \mathrm{Fe} 2$ & 0.057 & 0.047 & 0.044 & 0.044 & 0.050 & 0.059 & 0.069 & 0.048 & 0.035 \\
\hline $\mathrm{M} 2 \mathrm{Mn}$ & 0.005 & 0.008 & 0.007 & 0.004 & 0.005 & 0.005 & 0.004 & 0.003 & 0,004 \\
\hline $\mathrm{M} 2 \mathrm{Ca}$ & 0.898 & 0.876 & 0.816 & 0.901 & 0.810 & 0.903 & 0.887 & 0.892 & 0.885 \\
\hline $\mathrm{M} 2 \mathrm{Na}$ & 0.039 & 0.067 & 0.132 & 0.051 & 0.135 & 0.032 & 0.039 & 0.053 & 0.074 \\
\hline $\mathrm{M} 2 \mathrm{~K}$ & 0.000 & 0.001 & 0.001 & 0.000 & 0.000 & 0.000 & 0.000 & 0.005 & 0.001 \\
\hline Sum_cat & 4.000 & 3.999 & 3.999 & 4.000 & 4.000 & 4.000 & 4.000 & 3.995 & 3.999 \\
\hline $\mathrm{Ca}$ & 47.572 & 47.279 & 48.021 & 48.879 & 46.756 & 48.033 & 47.902 & 50.056 & 48.954 \\
\hline $\mathrm{Mg}$ & 44.858 & 44.657 & 48.066 & 45.222 & 44.372 & 44.116 & 45.6634 & 46.825 & 43.879 \\
\hline $\mathrm{Fe} 2 . \mathrm{Mn}$ & 7.570 & 8.063 & 3.913 & 5.899 & 8.873 & 7.851 & 6.434 & 3.119 & 7.168 \\
\hline $\mathfrak{D} 1$ & 0.000 & 0.000 & 0.000 & 0.000 & 0.535 & 0.098 & 0.000 & 0.000 & 0.588 \\
\hline AEI & 2.053 & 3.587 & 7.277 & 2.706 & 6.700 & 1.615 & 2.053 & 3.123 & 3.444 \\
\hline CFTS1 & 0.000 & 0.000 & 0.157 & 1.354 & 0.000 & 1.359 & 1.843 & 3.466 & 0.539 \\
\hline CTrS1 & 1.587 & 1.294 & 1.700 & 1.545 & 1.485 & 3.441 & 1.829 & 2.146 & 1.579 \\
\hline CATS! & 0.000 & 0.000 & 0.000 & 0.000 & 0.000 & 0.000 & 0.000 & $0.0 \times X)$ & 0.000 \\
\hline wol & 45.132 & 44.490 & 42.844 & 44.762 & 42.022 & 44.536 & 43.359 & 42.958 & 44.976 \\
\hline ENI & 44.054 & 43.245 & 44.742 & 44.095 & 41.289 & 43.476 & 44.833 & 45.435 & 42.211 \\
\hline FSI & 7.174 & 7.384 & 3.280 & 5.538 & 7.969 & 7.475 & 6.084 & 2.872 & 6.663 \\
\hline$Q$ & 1.883 & 1.846 & 1.693 & 1.838 & 1.727 & 1.876 & 1.848 & 1.779 & 1.804 \\
\hline J & 0.079 & 0.135 & 0.264 & 0.102 & 0.269 & 0.064 & 0.077 & 0.105 & 0.149 \\
\hline wo & 45.833 & 45.757 & 43.833 & 46.882 & 44.388 & 46.668 & 45.697 & 45.767 & 47.044 \\
\hline EN & 43.218 & 43.219 & 43.873 & 43.373 & 42.125 & 42.862 & 43.562 & 42.813 & 42.167 \\
\hline FS & 10.949 & 11.024 & 12.294 & 9.745 & 13.488 & 10.470 & 10.740 & 11.420 & 10.789 \\
\hline WEF & 95.987 & 93.235 & 86.562 & 94.741 & 86.542 & 96.687 & 95.986 & 94.425 & 92.399 \\
\hline $\mathfrak{D}$ & $0.000)$ & 0.000 & $0.0 \times 0$ & 0.000 & 1.310 & 0.109 & $0.0 \times 0$ & 0.000 & 0.994 \\
\hline AE & 4.013 & 6.765 & 13.438 & 5.259 & 12.148 & 3.204 & 4.014 & 5.575 & 6.607 \\
\hline
\end{tabular}




\begin{tabular}{|c|c|c|c|c|c|c|c|c|c|}
\hline Srample & 23.006 & 23.007 & 23.008 & 23,009 & 23.010 & 23.011 & 23.020 & 23.024 & 23.025 \\
\hline Analysis & $g m$ & gm & $\mathrm{gn}$ & gn: & $\mathrm{gm}$ & $g m$ & $\mathrm{gm}$ & $\mathrm{gm}$ & DeMin93 \\
\hline Location & YZU-3 & YZU-3 & YZU-3 & YZU-3 & $Y Z Y-3$ & $Y Z Z j-3$ & $Y Z U-3$ & YZU-3 & $Y z u-3$ \\
\hline Mineral & PIR & PIR & PIR & PIR & PIR & PIR & PIR & PIR & PIR \\
\hline $\mathrm{SiO} 2$ & 51.48 & 52.97 & 52.18 & 52.11 & $\$ 1.90$ & $\$ 1.57$ & 51.74 & 50.73 & $\$ 2.68$ \\
\hline $\mathrm{TiO}_{2}$ & 0.98 & 1.55 & 1.29 & 1.40 & 1.16 & 1.09 & 1.31 & 1.20 & 1.23 \\
\hline $\mathrm{Al} 2 \mathrm{O} 3$ & 1.44 & 0.69 & 1.16 & 1.04 & 2.14 & 1.91 & 1.90 & 2.46 & 1.73 \\
\hline $\mathrm{FeO}$ & 5.92 & 7.90 & 6.37 & 6.74 & 7.04 & 6.55 & 6.51 & 8.47 & 5.70 \\
\hline $\mathrm{Cr} 2 \mathrm{O} 3$ & 0.11 & 0.03 & 0.01 & 0.04 & 0.11 & 0.22 & 0.17 & 0.07 & 0.55 \\
\hline $\mathrm{MnO}$ & 0.16 & 0.19 & 0.22 & 0.26 & 0.16 & 0.16 & 0.15 & 0.19 & 0.16 \\
\hline $\mathrm{NiO}$ & 0.01 & 0.01 & 0 & 0.01 & 0.02 & 0 & 0.03 & 0 & 0.00 \\
\hline $\mathrm{MgO}$ & 15.01 & 14.74 & 14.95 & 34.80 & 13.94 & 14.70 & 14.91 & 13.99 & 16.36 \\
\hline $\mathrm{C} N$ & 22.53 & 20.34 & 21.01 & 20.79 & 21.68 & 22.93 & 22.39 & 22.33 & 21.85 \\
\hline $\mathrm{Na} 2 \mathrm{O}$ & 1.07 & 1.72 & 1.33 & 1.60 & 1.25 & 0.83 & 0.98 & 1.18 & 0.30 \\
\hline $\mathrm{K} 2 \mathrm{O}$ & $0.0 ?$ & 0.01 & 0.06 & 0.06 & 0.14 & 0.02 & 0 & 0.04 & 0.00 \\
\hline Total & 98,72 & 100,15 & 98,58 & 98,85 & 99,54 & 99,98 & 100,09 & 100,60 & 100,56 \\
\hline TSi & 1.912 & 1.946 & 1.942 & 1.934 & 1.922 & 1.900 & 1.902 & 1.863 & 1,927 \\
\hline TAI & 0.063 & 0.030 & 0.051 & 0.045 & 0.078 & 0.083 & 0.082 & 0.106 & 0,073 \\
\hline TFe3 & 0.025 & 0.024 & 0.007 & 0.021 & 0.000 & 0.017 & 0.016 & 0.031 & 0,000 \\
\hline MIAI & 0.000 & 0.000 & 0.000 & 0.000 & 0.015 & 0.000 & 0.000 & 0.000 & 0,001 \\
\hline $\mathrm{MlTi}$ & 0.027 & 0.043 & 0.036 & 0.039 & 0.032 & 0.030 & 0.036 & 0.033 & 0.034 \\
\hline MlFe3 & 0.107 & 0.090 & 0.084 & 0.105 & 0.092 & 0.093 & $0.0 \times 0$ & 0.155 & 0,000 \\
\hline $\mathrm{M}\} \mathrm{Fe} 2$ & 0.031 & 0.059 & 0.050 & 0.0 .36 & 0.088 & 0.063 & 0.051 & 0.044 & 0.057 \\
\hline $\mathrm{MICr}$ & 0.003 & 0.001 & 0.000 & 0.001 & 0.003 & 0.006 & 0.005 & 0.002 & 0,016 \\
\hline MlMg & 0.831 & 0.807 & 0.829 & 0.819 & 0.769 & 0.808 & 0.817 & 0.766 & 0.892 \\
\hline MlNi & 0.000 & 0.000 & 0.000 & 0.000 & 0.001 & 0.0000 & 0.001 & 0,000 & 0,000 \\
\hline $\mathrm{M} 2 \mathrm{Mg}$ & 0.000 & 0.000 & 0.000 & 0.000 & 0.000 & 0.000 & 0.000 & $0.0 \times 0$ & 0,000 \\
\hline $\mathrm{M} 2 \mathrm{Fe} 2$ & 0.021 & 0.070 & 0.057 & 0.047 & 0.039 & 0.029 & 0.044 & 0.030 & 0,117 \\
\hline $\mathrm{M} 2 \mathrm{Mn}$ & 0.005 & 0.006 & 0.007 & 0.008 & 0.005 & 0.005 & 0.005 & 0.006 & 0,005 \\
\hline $\mathrm{M} 2 \mathrm{Ca}$ & 0.897 & 0.801 & 0.838 & 0.827 & 0.860 & 0.905 & 0.882 & 0.878 & 0,856 \\
\hline $\mathrm{M} 2 \mathrm{Na}$ & 0.077 & 0.123 & 0.096 & 0.115 & 0.090 & 0.059 & 0.070 & 0.084 & 0,021 \\
\hline $\mathrm{M} 2 \mathrm{~K}$ & 0.000 & 0.000 & 0.003 & 0.003 & 0.007 & 0.001 & 0.000 & 0.002 & 0,000 \\
\hline Sum_cat & 4,000 & 4.000 & 3.997 & 3.997 & 3.993 & 3.999 & 4.000 & 3.998 & $4,0(X)$ \\
\hline $\mathrm{Ca}$ & 50.249 & 45.943 & 47.050 & 47.595 & 48.841 & 50.008 & 49.050 & 50.944 & 44,421 \\
\hline $\mathrm{Mg}$ & 46.579 & 46.325 & 46.583 & 47.143 & 43.695 & 44.607 & 45.447 & 44.409 & 46,277 \\
\hline $\mathrm{Fe} 2 \mathrm{Mn}$ & 3.172 & 7.733 & 6.366 & 5.262 & 7.464 & 5.385 & 5.503 & 4.647 & 9,302 \\
\hline $\mathrm{SDI}$ & 0.000 & 0.000 & 0.000 & 0.000 & 0.809 & 0.000 & 0.000 & 0.000 & 0,070 \\
\hline$A E 1$ & 4.176 & 6.613 & 5.278 & 6.389 & 4.393 & 3.229 & 3.749 & 4.760 & 1,025 \\
\hline CFTS1 & $\{.778$ & 0.000 & 0.000 & 0.000 & 0.725 & 2.083 & 1.355 & 3.928 & 0,000 \\
\hline CTISI & 1.475 & 1.605 & 1.929 & 2.116 & 1.744 & 1.619 & 1.944 & 1.837 & 1,741 \\
\hline CATS! & 0.000 & 0.000 & 0.000 & 0.000 & 0.000 & 0.000 & 0.000 & 0.000 & 0,000 \\
\hline WOI & 45.034 & 41.445 & 42.813 & 42.649 & 43.964 & 44.825 & 44.034 & 42.921 & 42,307 \\
\hline EN] & 44.761 & 43.408 & 44.297 & 44.340 & $41.54 !$ & 43.286 & 43.857 & 42.440 & 45,889 \\
\hline FSI & 2.777 & 6.928 & 5.684 & 4.506 & 6.825 & 4.957 & 5.060 & 4.114 & 8,969 \\
\hline$Q$ & 1.779 & 1.737 & 1.773 & 1.728 & 1.756 & 1.805 & 1.793 & 1.718 & 1.923 \\
\hline J & 0.154 & 0.245 & 0.192 & 0.230 & 0.179 & 0.119 & 0.140 & 0.168 & 0,043 \\
\hline wo & 46.780 & 43.125 & 44.743 & 44.377 & 46.426 & 47.159 & 46.322 & 45.987 & 44,421 \\
\hline $\mathrm{EN}$ & 43.364 & 43.483 & 44.298 & 43.955 & 41.535 & 42.066 & 42.920 & 40.088 & 46,277 \\
\hline FS & 9.857 & 13.392 & 10.959 & 11.668 & 12.038 & 10.775 & 10.758 & 13.925 & 9,302 \\
\hline WEF & 92.049 & 87.672 & 90.269 & 88.294 & 90.750 & 93.851 & 92.790 & 91.121 & 97,840 \\
\hline $\mathrm{DD}$ & 0.000 & 0.000 & 0.000 & 0.000 & 1.301 & 0.000 & 0.000 & 0.000 & 2,160 \\
\hline $\mathrm{AE}$ & 7.951 & 12.328 & 9.731 & 11.706 & 7.949 & 6.149 & 7.210 & 8.879 & 0,000 \\
\hline
\end{tabular}




\begin{tabular}{|c|c|c|c|c|c|c|c|c|c|}
\hline Sample & 23.026 & 26000 & 26.001 & 30.000 & 30.001 & 30.002 & 30.003 & 30.004 & 30.005 \\
\hline Analysis & DeMin93 & & & DeMin 93 & Dethin93 & DeMing3 & DeMin93 & DeMin93 & DeMnej \\
\hline Lacation & $Y z a-3$ & $Y Z U$ & $Y Z U-6$ & plaglc & plagle & plaglc & plaglc & plagic & plagic \\
\hline Mineral & PIR & PRR & PIR & PIR & PIR & Plk & PJR & PIR & PIR \\
\hline $\mathrm{SiO}_{2}$ & 53.70 & 53.64 & 54.04 & 50.85 & 52.41 & 48.44 & 49.78 & $\$ 3.18$ & 53.69 \\
\hline $\mathrm{TiO} 2$ & 1.47 & 0.65 & 0.60 & 1.10 & 0.82 & 1.74 & 1.43 & 0.79 & 1.60 \\
\hline $\mathrm{Al} 2 \mathrm{O} 3$ & 0.86 & 0.79 & 0.94 & 3.66 & 2.30 & 5.25 & 4.35 & 1.48 & 1.44 \\
\hline $\mathrm{F} \infty \mathrm{O}$ & 7.01 & 3.79 & 4.02 & 8.288 & 7.46 & 6.61 & 7.62 & 4.69 & 6.13 \\
\hline $\mathrm{Cr} 2 \mathrm{O} 3$ & 0.00 & 0.39 & 0.48 & 0.00 & 1.14 & 2.48 & 1.64 & 1.03 & 0.69 \\
\hline $\mathrm{MnO}$ & 0.28 & 0.04 & 0.11 & 0.24 & 0.36 & 0.39 & 0.19 & 0.16 & 0.33 \\
\hline $\mathrm{NiO}$ & 0.00 & 0.11 & 0.14 & $0 .(x)$ & 0.00 & $0 .(x)$ & 0.00 & 0.00 & 0.00 \\
\hline $\mathrm{MBO}$ & 16.35 & 15.97 & 15.89 & 14.43 & 13.14 & 13.51 & $13.6)$ & 16.77 & 14.73 \\
\hline $\mathrm{CaO}$ & 21.57 & 23.60 & 23.59 & 21.38 & 21.36 & 21.44 & 20.79 & 21.29 & 21.49 \\
\hline $\mathrm{Na} 2 \mathrm{O}$ & $0 . \infty 0$ & 0.24 & 0.35 & 0.00 & 1.01 & 0.17 & 0.40 & 0.47 & 0.89 \\
\hline $\mathrm{K} 2 \mathrm{O}$ & 0.00 & 0.03 & 0 & 0.0 & $*$ & 0.00 & 0.00 & $0 . \alpha$ & 0.00 \\
\hline Total & 101.24 & 99,25 & 100,16 & 99.95 & . & 99.93 & 99.86 & 99.86 & 100.99 \\
\hline TSi & 1,963 & 1.982 & 1.980 & 1.891 & 1.948 & 1.809 & 1.857 & 1.950 & 1.966 \\
\hline TAl & 0,037 & 0.018 & 0.020 & 0.109 & 0.052 & 0.191 & 0.143 & 0.050 & 0.034 \\
\hline $\mathrm{TFe} 3$ & 0,000 & 0.000 & 0.000 & 0.000 & 0.000 & 0.000 & 0.000 & 0.000 & 0.000 \\
\hline $\mathrm{M} \mid \mathrm{Al}$ & 0,000 & 0.016 & 0.020 & 0.052 & 0.049 & 0.040 & 0.048 & 0.013 & 0.028 \\
\hline Ml'Ti & 0,040 & 0.018 & 0.017 & 0.031 & 0.023 & 0.049 & 0.040 & 0.022 & 0.044 \\
\hline Mife3 & 0,000 & 0.000 & 0.000 & 0.000 & 0.000 & 0.000 & $0(0 \times 0)$ & $0,00 x$ & $0.0 \times 0$ \\
\hline $\mathrm{M}] \mathrm{Fe} 2$ & 0,068 & 0.071 & 0.077 & 0.117 & 0.167 & 0.086 & 0.104 & 0.018 & 0.104 \\
\hline $\mathrm{MiCr}$ & $0,00 x)$ & 0.011 & 0.014 & 0.000 & 0.033 & 0.073 & 0048 & 0.030 & 0.020 \\
\hline MilMg & 0,891 & 0.880 & 0.868 & 0.800 & 0.728 & 0.752 & 0.760 & 0.917 & 0.804 \\
\hline $\mathrm{M} I \mathrm{Ni}$ & 0,000 & 0.003 & 0.004 & 0.000 & $0,0 \times 0$ & 0.000 & $0.0 \times 0$ & 0.000 & 0.000 \\
\hline $\mathrm{M} 2 \mathrm{Mg}$ & 0,000 & 0.000 & 0.000 & 0.000 & 0.000 & 0.000 & 0.000 & 0.000 & 0.000 \\
\hline $\mathrm{M} 2 \mathrm{~F} 2$ & 0,146 & 0.046 & 0.046 & 0.140 & 0.065 & 0.121 & 0.134 & 0.125 & 0.084 \\
\hline $\mathrm{M} 2 \mathrm{Mn}$ & 0,009 & 0.001 & 0.003 & 0.008 & 0.011 & 0.009 & 0.006 & 0.005 & 0.010 \\
\hline $\mathrm{M} 2 \mathrm{Ca}$ & 0,845 & 0.934 & 0.926 & 0.852 & 0.851 & 0.858 & 0.831 & 0.836 & 0.843 \\
\hline $\mathrm{M} 2 \mathrm{Na}$ & $0,0 \times 0$ & 0.017 & 0.025 & 0.000 & 0.073 & 0.012 & 0.029 & 0.033 & 0.063 \\
\hline $\mathrm{M} 2 \mathrm{~K}$ & 0,000 & 0.001 & 0.000 & 0.000 & 0.000 & 0.000 & $0.00 \times 0$ & 0.000 & 0.000 \\
\hline Sum cat & 4.000 & 3.999 & 4.000 & $4,(x)$ & 4,000 & 4.000 & 4.000 & $4(x)$ & 4.000 \\
\hline $\mathrm{Ca}$ & 43,129 & 48.350 & 48.218 & 44.434 & 46.688 & 46.900 & 45.300 & 43.978 & 45.693 \\
\hline $\mathrm{Mg}$ & 45,487 & 45.524 & 45.191 & 41.727 & 39.962 & 41.199 & 41.413 & 48.199 & 4.3 .578 \\
\hline $\mathrm{Fe}^{2} \mathrm{Mnn}_{-}$ & 11,383 & 6.126 & 6.591 & 13.839 & 13.350 & 11.810 & 13.287 & 7.823 & 10.728 \\
\hline JDI & 0,000 & 0.838 & 1.044 & 0.000 & 2.590 & 0.673 & 1.558 & 0.698 & 1.468 \\
\hline $\mathrm{AE} !$ & 0,000 & 0.116 & 0.236 & 0.000 & 1.275 & 0.000 & 0.000 & 1.033 & 1.861 \\
\hline CFTSI & 0,000 & 0.467 & 0.479 & 0.000 & 0.502 & 3.999 & 2601 & 0.512 & 0.000 \\
\hline CITS! & 1,877 & 0.925 & 0.851 & 1.611 & 1.217 & 2.673 & 2.160 & 1.129 & 1.804 \\
\hline CATSI & 0,000 & 0.000 & 0.000 & 2.706 & 0.000 & 1.513 & 1.037 & 0.000 & 0.000 \\
\hline wol & 41,444 & 46.528 & 46.355 & 40.292 & 43.445 & 38.725 & 38.941 & 41.688 & 42.615 \\
\hline EN1 & 45,690 & 45.119 & 44.692 & 41.892 & 38.658 & 41.129 & 40.902 & 47.489 & 42.362 \\
\hline FS! & 10,989 & 6.007 & 6.343 & 13.498 & 12.312 & 11.289 & 12.800 & 7.450 & 9.890 \\
\hline$Q$ & 1,950 & 1.931 & 1.917 & 1.910 & 1.811 & 1.817 & 1.828 & 1.897 & $1.83 \mathrm{~S}$ \\
\hline$J$ & 0,000 & 0.034 & 0.050 & 0.000 & 0.146 & 0.025 & 0.058 & 0.067 & 0.126 \\
\hline wo & 43,129 & 48.350 & 48.218 & 44.434 & 46.688 & $46.99 \times 1$ & 45.3001 & 43.978 & 45.693 \\
\hline EN & 45,487 & 45.524 & 45.191 & 41.727 & 39.962 & 41.199 & 41.413 & 48.199 & 43.578 \\
\hline FS & 11,383 & 6.126 & 6.591 & 13.839 & 13.350 & 11.810 & 13.287 & 7.823 & 10.728 \\
\hline WEF & 100,000 & 98.251 & 97.476 & 100.000 & 92.601 & 98.669 & 96.942 & 96.605 & 93.590 \\
\hline JD & 0,000 & 1.749 & 2.524 & $0.000)$ & 7.399 & $1.33\}$ & 3.058 & 3.395 & 6.410 \\
\hline AE & 0,000 & 0.000 & 0,000 & 0.000 & $0.0 \times 0 \mathrm{j}$ & 0.000 & 0.000 & 0.000 & 0.000 \\
\hline
\end{tabular}




\begin{tabular}{|c|c|c|c|c|c|c|c|c|c|}
\hline Sample & 30.006 & 30.007 & 30.008 & 30.000 & 30.010 & 30.011 & 30.012 & 30.013 & 30014 \\
\hline Analysis & DeMing3 & DeMin93 & DeMnn93 & DeMins3 & DelMin93 & DeMins3 & DeMin93 & DeMin93 & DeMin93 \\
\hline Location & plaglc & plaglc & plagle & plaglc & plaglc & ploglc & plaple & plagklc & plaglc \\
\hline Mineral & PIR & PIR & PIR & PWR & PIR & PLR & PIR & PIR & PLR \\
\hline $\mathrm{SiO} 2$ & 49.42 & 48.67 & 49.36 & 46.33 & 48.68 & 49.51 & 50.47 & 50.24 & 51.68 \\
\hline $\mathrm{TiO} 2$ & 1.62 & 1.95 & 1.75 & 3.00 & 1.62 & 1.40 & 2.10 & 1.43 & 1.22 \\
\hline $\mathrm{A} / 2 \mathrm{O} 3$ & 4.55 & 5.16 & 4.33 & 6.35 & 4.59 & 5.65 & 1.68 & 3.29 & 2.77 \\
\hline $\mathrm{FeO}$ & 7.61 & 7.94 & 7.47 & 9.53 & 8.07 & 14.92 & 24.21 & 7.59 & 6.58 \\
\hline $\mathrm{Cs} 2 \mathrm{O} 3$ & 0.08 & 0.02 & 0.00 & 0.02 & 0.06 & 0.08 & 0.01 & 0.07 & 0.09 \\
\hline $\mathrm{MnO}$ & 0.61 & 0.23 & 0.17 & 0.26 & 0.24 & 0.91 & 1.59 & 0.33 & 0.26 \\
\hline $\mathrm{NiO}$ & 0.00 & 0.00 & 0.00 & 0.00 & 0.00 & 0.00 & 0.00 & 0.00 & 000 \\
\hline MgO & 13.93 & 13.27 & 13.73 & 11.48 & 13.04 & 7.52 & 1.50 & 15.24 & 15.62 \\
\hline $\mathrm{CaO}$ & 22.26 & 22.08 & 22.28 & 22.14 & 22.38 & 21.10 & 10.93 & 20.28 & 21.20 \\
\hline $\mathrm{Na} 2 \mathrm{O}$ & 0.49 & 0.63 & 0.55 & 0.54 & 0.59 & 1.44 & 7.41 & 0.51 & 0.57 \\
\hline $\mathrm{K} 2 \mathrm{O}$ & 0.00 & $0 . \infty$ & 0.00 & 0.00 & $0.0 \times$ & $0 .(x)$ & 0.00 & 0.00 & 0.00 \\
\hline Total & 100.57 & 99.95 & 99.64 & 99.65 & 99.27 & 102.53 & 99.90 & 98.98 & 99.99 \\
\hline $\mathrm{TSi}$ & 1.822 & 1.807 & 1.835 & 1.746 & 1.822 & 1.848 & 1.942 & 1.873 & 1.901 \\
\hline $\mathrm{TAl}$ & 0.178 & 0.193 & 0.165 & 0.254 & 0.178 & 0.152 & 0.058 & 0.127 & 0009 \\
\hline TFe 3 & 0.000 & 0.000 & 0.000 & $0.0 \times 0$ & 0.000 & 0.600 & 0.000 & 0.000 & 0.000 \\
\hline M1Al & 0.019 & 0.033 & 0.025 & 0.028 & 0.024 & 0.097 & 0.018 & 0.017 & 0.021 \\
\hline Miri & 0.045 & 0.054 & 0.040 & 0.085 & 0.046 & 0.039 & 0.061 & 0.040 & 0.034 \\
\hline $\mathrm{M} 1 \mathrm{Fe} 3$ & 0.101 & 0.005 & 0.081 & 0.095 & 0.103 & 0.077 & 0.470 & 0.064 & 0.049 \\
\hline $\mathrm{MIFe} 2$ & 0.067 & 0.082 & 0.084 & 0.147 & 0.098 & 0.366 & 0.309 & 0.030 & 0.038 \\
\hline $\mathrm{MlCr}$ & 0.002 & $0 .(x) 1$ & 0.000 & 0.001 & 0.002 & 0.002 & 0.000 & $0 .(6) 2$ & 0.003 \\
\hline $\mathrm{M} M \mathrm{Me}$ & 0.766 & 0.735 & 0.761 & 0.645 & 0.728 & 0.419 & 0.086 & 0.847 & 0.856 \\
\hline MINi & 0.000 & $0.0(x)$ & 0.000 & 0.000 & 0.000 & 0.000 & 0.000 & 0.000 & 0.000 \\
\hline $\mathrm{M} 2 \mathrm{Mg}$ & 0.000 & 0,000 & 0.000 & 0.000 & 0.000 & 0.000 & 0.000 & $0.0 \times x)$ & 0.000 \\
\hline $\mathrm{M} 2 \mathrm{Fe} 2$ & 0.067 & 0.069 & 0.067 & 0.058 & 0.052 & 0.023 & 0.000 & 0.343 & 0.116 \\
\hline $\mathrm{M} 2 \mathrm{Mn}$ & 0.019 & 0.0007 & 0.005 & 0.008 & 0.008 & 0.029 & 0.052 & 0.010 & 0.0018 \\
\hline $\mathrm{M} 2 \mathrm{Ca}$ & 0.879 & 0.878 & 0.888 & 0.894 & 0.898 & 0.844 & 0.451 & 0.810 & 0.835 \\
\hline $\mathrm{M} 2 \mathrm{Na}$ & 0.035 & 0.045 & 0.040 & 0.039 & 0.043 & 0.104 & 0.553 & 0.037 & $0\{4\}$ \\
\hline $\mathrm{M} 2 \mathrm{~K}$ & 0.000 & 0.000 & 0.000 & 0.000 & 0.000 & 0.000 & 0.000 & 0.000 & 0.000 \\
\hline Sum_cat & 4.000 & 4.000 & 4.000 & $4 .(X \times)$ & 4.000 & $4.0 \times 0)$ & 4000 & $4.0 \times 0$ & $4(x)$ \\
\hline $\mathrm{Ca}$ & 48.918 & 49.583 & 49.160 & 50.997 & 50.347 & 50.239 & 50.219 & 44.030 & 45.070 \\
\hline $\mathrm{Mg}$ & 42.594 & 41.462 & 42.152 & 36.793 & 40.817 & 24.913 & 9.589 & 46.037 & 46.205 \\
\hline Fez_Mn & 8.488 & 8.954 & 8.689 & 12.210 & 8.837 & 24.848 & 40.192 & 9.933 & 8.725 \\
\hline JDI & 1.067 & 1.814 & 1.360 & 1.545 & 1.344 & 5.518 & 1.311 & 0.919 & 1.097 \\
\hline $\mathrm{AEl}$ & 0.865 & 0.693 & 0.795 & 0.666 & 1.012 & 0.420 & 38.227 & 1.057 & 1.058 \\
\hline CFTSI & 4.839 & 4.598 & 3.594 & 4.670 & 4.734 & 4.111 & 0.000 & $2.5(x)$ & 1.666 \\
\hline CTTS1 & 2.477 & 3.009 & 26660 & 4.767 & 2.509 & 2.240 & 4.134 & 2.149 & 1.789 \\
\hline CATS1 & 0.000 & 0.000 & 0,000 & 0.000 & 0.000 & $0.6 \times 0$ & 0.000 & 0.000 & 0.000 \\
\hline WOI & 41.171 & 40.931 & 41.989 & 40.670 & 42.128 & 41.729 & 28.091 & 38.757 & 40.837 \\
\hline ENI & 42.218 & 40.589 & 41.366 & 36.150 & 40.026 & 23.842 & 6.153 & 45.38 .5 & 45.407 \\
\hline FS: & 7.363 & 8.366 & 8.236 & 11.532 & 8.247 & 22.140 & 22.085 & 9.234 & 8.145 \\
\hline$Q$ & 1.778 & 1.764 & 1.800 & 1.744 & 1.775 & 1.651 & 0.846 & 1.829 & 1.845 \\
\hline 3 & 0.070 & 0.091 & 0.079 & 0.079 & 0.086 & 0.208 & 1.106 & 0.074 & 0.081 \\
\hline wo & 46.313 & 47.056 & 47.055 & 48.386 & 47.604 & 48.033 & 32.950 & 42.542 & 43.915 \\
\hline EN & 40.325 & 39.349 & 40.347 & 34.908 & 38.593 & 23.819 & 6.292 & 44.482 & 45.020 \\
\hline FS & 13.362 & 13.595 & 12.598 & 16.706 & 13.802 & 28.148 & 60.758 & 12.975 & 11.065 \\
\hline WEF & 96.249 & 95.129 & 95.792 & 95.692 & 95.416 & 88.960 & 44.797 & 96.147 & 95.798 \\
\hline m & 0.602 & 1.249 & 0.995 & 0.972 & 0.881 & 6.145 & 2.071 & 0.811 & 1.252 \\
\hline$A E$ & 3.149 & 3.622 & 3.212 & 3.336 & 3.703 & 4.895 & 53.132 & 3.042 & 2.950 \\
\hline
\end{tabular}




\begin{tabular}{|c|c|c|c|}
\hline Sample & 30.015 & 30.016 & 30.017 \\
\hline Analysis & DeMin93 & DeMin93 & DeMin93 \\
\hline Location & plaglc & piaglc & plaglc \\
\hline Mineral & PIR & PIRR & PIR \\
\hline $\mathrm{SSO} 2$ & 51.35 & 50.52 & 48.68 \\
\hline $\mathrm{TiO} 2$ & 1.25 & 1.19 & 1.62 \\
\hline $\mathrm{Al} 2 \mathrm{O} 3$ & 3.02 & 3.00 & 4.59 \\
\hline $\mathrm{F} \infty \mathrm{O}$ & 7.72 & 8.11 & 8.07 \\
\hline $\mathrm{Cr} 203$ & 0.15 & 0.06 & 0.06 \\
\hline $\mathrm{MnO}$ & 0.39 & 0.30 & 0.24 \\
\hline $\mathrm{NiO}$ & 0.00 & 0.00 & 0.00 \\
\hline $\mathrm{MgO}$ & 14.26 & 13.81 & 13.04 \\
\hline $\mathrm{CrO}$ & 21.64 & 21.47 & 22.38 \\
\hline $\mathrm{Na} 2 \mathrm{O}$ & 0.37 & 0.90 & 0.59 \\
\hline $\mathrm{K} 2 \mathrm{O}$ & 0.00 & 0.00 & 0.00 \\
\hline Total & 100.15 & 99.36 & 99.27 \\
\hline TSi & 1.903 & 1.882 & 1.822 \\
\hline TAl & 0.097 & 0.118 & 0.178 \\
\hline TFe 3 & 0.600 & 0.000 & 0.000 \\
\hline $\mathrm{M} \mid \mathrm{Al}$ & 0.035 & 0.014 & 0.024 \\
\hline$M 1 T_{j}$ & 0.035 & 0.033 & 0.046 \\
\hline $\mathrm{M} 1 \mathrm{Fe} 3$ & 0.013 & 0.100 & 0.103 \\
\hline $\mathrm{M} 1 \mathrm{Fe} 2$ & 0.124 & 0.084 & 0.098 \\
\hline $\mathrm{MlCr}$ & 0.004 & 0.002 & 0.002 \\
\hline MiMg & 0.788 & 0.767 & 0.728 \\
\hline $\mathrm{M} I \mathrm{Ni}$ & 0.000 & 0.000 & 0.000 \\
\hline $\mathrm{M} 2 \mathrm{Mg}$ & 0.000 & 0.000 & 0.000 \\
\hline $\mathrm{M} 2 \mathrm{Fe} 2$ & 0.102 & 0.069 & 0.052 \\
\hline $\mathrm{M} 2 \mathrm{Mn}$ & 0.012 & 0.009 & 0.008 \\
\hline $\mathrm{M} 2 \mathrm{Ca}$ & 0.859 & 0.857 & 0.898 \\
\hline $\mathrm{M} 2 \mathrm{Na}$ & 0.027 & 0.065 & 0.043 \\
\hline$M 2 \mathrm{~K}$ & 0.000 & 0.000 & 0.000 \\
\hline Sum_en & 4.000 & 4.000 & 4.000 \\
\hline $\mathrm{Ca}$ & 45.581 & 47.988 & 50.347 \\
\hline $\mathrm{Mg}$ & 41.793 & 42.948 & 40.817 \\
\hline $\mathrm{Fe} 2 \mathrm{Mn}$ & 12.626 & 9.063 & 8.837 \\
\hline JD1 & 1.400 & 0.746 & 1.344 \\
\hline AEl & 0.000 & 2.784 & 1.012 \\
\hline CFTS1 & 0.942 & 2.758 & 4.734 \\
\hline CTISI & 1.835 & 1.811 & 2.509 \\
\hline CATSI & 0.454 & 0.000 & 0.000 \\
\hline wol & 42.007 & 41.972 & 42.128 \\
\hline $\mathrm{EN}$ & 41.477 & 41.653 & 40.026 \\
\hline FS1 & 11.886 & 8.276 & 8.247 \\
\hline$Q$ & 1.873 & 1.776 & 1.775 \\
\hline$J$ & 0.053 & 0.130 & 0.086 \\
\hline wo & 45.257 & 45,437 & 47.604 \\
\hline EN & 41.496 & 40.665 & 38.593 \\
\hline $\mathrm{FS}$ & 13.247 & 13.899 & 13.802 \\
\hline WEF & 97.257 & 93.213 & 95.416 \\
\hline $\mathfrak{D}$ & 1.983 & 0.818 & 0.881 \\
\hline $\mathrm{AE}$ & 0.760 & 5.969 & 3.703 \\
\hline
\end{tabular}




\section{A4}

Composição química, em porcentagem em peso, de espinélios de rochas "lamprofíricas" do Paraguai.

(sp)

\section{"Lamprófiros"}

Ymi-1 $\quad(010.007-010.138 \mathrm{a} / \mathrm{b}-$ fenocristais/microfenocristais; $\quad 100.049-100.088-$ inclusão; 1.102-1.145-matriz; 10.00-10.69-concentrado e; 10c.001-10c.002);

Ymi-4 (14.010-14.159);

Ymi-7 (17.001-17.008);

Yzu-1 (21.001-21.019).

\section{"Lamproítos"}

Ymi-5 (15.000-15.120);

Yzu-2 (22.000-22.164);

Yzu-3 (23.012-23.167);

Yzu-6 (26.000-26.011).

Rico em Mn: $10.068,1.117,1.130,1.131,1.136,1.139,1.140,1.110,1.113$, $1.115,1.120,1.130,1.136,1.139,1.140,100.002,14.159,22.001,22.154$, $22.156,22.162,23.018,23.152,23.158$.

Manganesifero: $100.062,1.137,14.102 \mathrm{~b}, 15.000,15.030,15.104,15.110$, $26.000,26.010$.

$\mathrm{mf} / \mathrm{f}$ e em branco (ex. em Yini-7) $=$ fenocristal; ix, ix-opx, xi-olv=xenocristal, $x$ em opx e $x$

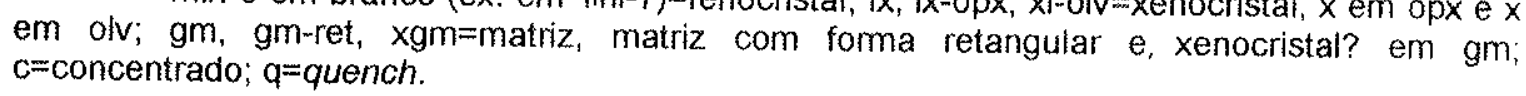




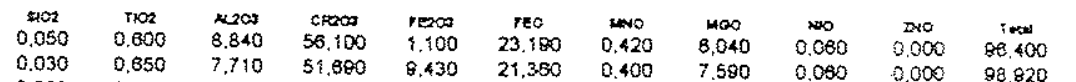

$\begin{array}{lllllllllll}0.020 & 0.680 & 8.040 & 52.150 & 8.720 & 21.840 & 0.380 & 7.450 & 0.0050 & 0.000 & 98.820 \\ 0.320 & 0.000 & 88.320\end{array}$

$\begin{array}{lllllllllll}0.060 & 0.710 & 8.880 & 53,410 & 10,680 & 18,450 & 0.330 & 5.430 & 0.060 & 0.000 & 87.870 \\ 0.040 & 0.860 & 8.780 & 54.300 & 3.000 & 23,840 & 0.300 & 5.770 & 0.050 & 0.000 & 89.720\end{array}$

$\begin{array}{llllllllllll}0.070 & 0.880 & 10.140 & 50.800 & 3.870 & 25.020 & 0.370 & 5.180 & 0.700 & 0.000 & 87.730 \\ 0.180 & 0.510 & 8.810 & 57.250 & 0.980 & 23.850 & 0.300 & .340 & 0.140 & 0.00 & 97.070\end{array}$

$\begin{array}{lllllllllllll}0.180 & 0.900 & 8,320 & 52,080 & 5.480 & 21.850 & 0.230 & 7.580 & 0.140 & 0.000 & 88,070\end{array}$

$\begin{array}{lllllllllll}0.050 & 0.430 & 8,520 & 52,180 & 8.710 & 19.800 & 0.2300 & 8.570 & 0.020 & 0.000 & 98.580 \\ 0.110 & 0.540 & 11,290 & 51.400 & 8.010 & 11,850 & 0.530 & 8.410 & 0.070 & 0.000 & 07.310\end{array}$

$\begin{array}{lllllllllll}0.220 & 1.530 & 8 ., 530 & 51,400 & 8.010 & 17,850 & 0.530 & 8.410 & 0.070 & 0.000 & 97.310 \\ 0 & 51.710 & 18,140 & 0.220 & 8.410 & 0.090 & 0.009 & 96,390\end{array}$

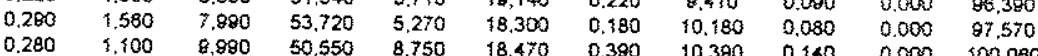

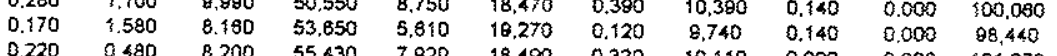

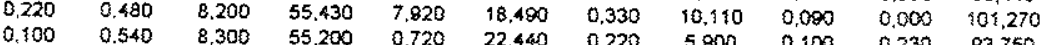

$\begin{array}{llllllllllll}0.110 & 0.540 & 8.300 & 55.200 & 0.720 & 22.440 & 0.220 & 5.800 & 0.100 & 0,230 & 89.750 \\ 0.110 & 0.850 & 8.780 & 50,840 & 4.330 & 23.120 & 0.340 & 8.350 & 0.050 & 0.000 & 85,850\end{array}$

$\begin{array}{lllllllllll}0.140 & 1,270 & 12.220 & 48.070 & 3.810 & 23.680 & 0.250 & 8,780 & 0.100 & 0,000 & 87.340 \\ 0.020 & 1.010 & 8.800 & 48.830 & 5.780 & 24,850 & 0.280 & 5,380 & 0,090 & 0.000 & 98.980\end{array}$

$\begin{array}{llllllllllll}0,130 & 1,870 & 10,040 & 48.870 & 5.7510 & 24,850 & 0.280 & 5,380 & 0.090 & 0.000 & 96.880 \\ 0 ., 220 & 0,590 & 8,210 & 0.160 & 0.000 & 88.500\end{array}$

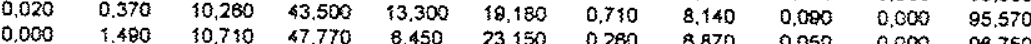

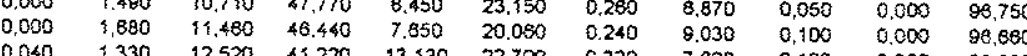

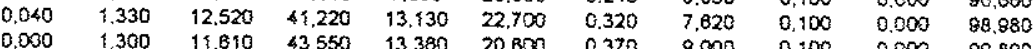

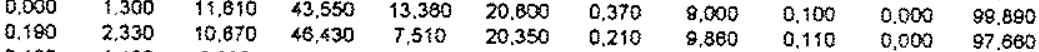

$\begin{array}{llllllllllll}0.100 & 1,480 & 8.800 & 4.530 & 4,480 & 18,320 & 0.140 & 8.180 & 0.140 & 0.450 & 91.840\end{array}$

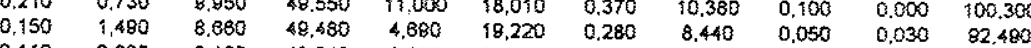

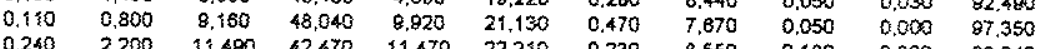

$\begin{array}{lllllllllll}0.240 & 2.200 & 11,480 & 42,470 & 11.470 & 22,210 & 0,230 & 8,550 & 0.180 & 0.000 & 89.040 \\ 0.210 & 1,820 & 8,980 & 47,670 & 8.310 & 17.250 & 0,140 & 8.320 & 0.180 & 0.300 & 82.670\end{array}$

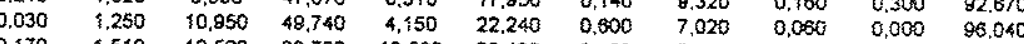

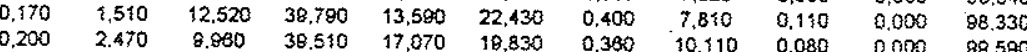

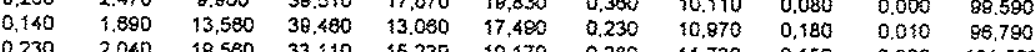

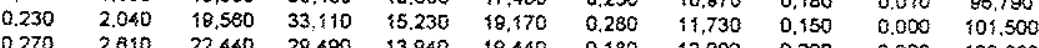

$\begin{array}{llllllllllll}0.270 & 2,810 & 22.440 & 28.480 & 13,840 & 18,440 & 0.180 & 12,090 & 0.200 & 0.000 & 100,680 \\ 0.270 & 0,380 & 33,330 & 33,250 & 0,500 & 14,590 & 0.220 & 14,080 & 0.210 & 0,000 & 86,330\end{array}$

$\begin{array}{llllllllllll}0.180 & 0.110 & 23,280 & 38,840 & 7,300 & 14,580 & 0,220 & 14,080 & 0,210 & 0.000 & 86.830 \\ 0 & 0.1700 & 0.280 & 11,310 & 0,180 & 0.000 & 98.210\end{array}$

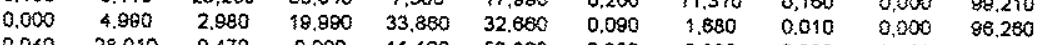

$\begin{array}{lllllllllll}0.040 & 28.010 & 0.470 & 0.000 & 13.100 & 53.800 & 0.330 & 0,880 & 0.090 & 0.000 & 84.720\end{array}$

$\begin{array}{lllllllllll}0,150 & 18,880 & 0.880 & 0,040 & 32,720 & 44,480 & 0.380 & 0.820 & 0,010 & 0.000 & 88.570 \\ 0.200 & 14,180 & 2.450 & 0,040 & 37220 & 41,830 & 0.480 & 1.220 & 0,000 & 0.000 & 87,300\end{array}$

$\begin{array}{lllllllllll}0.260 & 14,180 & 2.450 & 0,040 & 37,220 & 41,830 & 0,480 & 1,220 & 0,000 & 0,000 & 87,800 \\ 0.150 & 25,110 & 0.270 & 0,000 & 18,720 & 50,830 & 0,350 & 1,010 & 0,100 & 0,000 & 84,380\end{array}$

$\begin{array}{ccccccccccc}0.180 & 0.510 & 8,230 & 54,880 & 3,840 & 20,460 & 0,320 & 8,300 & 0.050 & 0.000 & 87,830 \\ 0.510 & 30,400 & 1,780 & 0,080 & 1,960 & 54,720 & 2500 & 0,120 & 0.070 & 0.000 & 8150\end{array}$

$\begin{array}{lllllllllll}0,250 & 0,850 & 8,740 & 53,000 & 8,230 & 15,020 & 0.2500 & 0.120 & 0,070 & 0.000 & 81,850 \\ 0 & 12,520 & 0.250 & 0.000 & 100,320\end{array}$

$\begin{array}{lllllllllll}0.170 & 1,890 & 9.380 & 51,810 & 9,470 & 14,900 & 0,300 & 12.520 & 0.100 & 0.000 & 89.520\end{array}$

$\begin{array}{lllllllllll}0.230 & 1.180 & 11,860 & 51,210 & 5.810 & 14.820 & 0.130 & 12,600 & 0.190 & 0.000 & 88.220\end{array}$

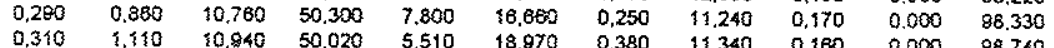

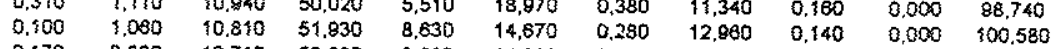

$\begin{array}{llllllllllll}0,170 & 0.880 & 10,710 & 52,880 & 8.690 & 14,880 & 0,330 & 12,860 & 0.140 & 0,000 & 100.580 \\ 0 & 0.830 & 0,200 & 0,000 & 101,7090\end{array}$

$\begin{array}{llllllllllll}0.180 & 0,800 & 8,850 & 50,140 & 8,380 & 22,880 & 0,530 & 7,250 & 0,140 & 0,000 & 100.170\end{array}$

$\begin{array}{lllllllllll}0.310 & 1,010 & 12,120 & 50.820 & 7,850 & 14,183 & 0,270 & 13,540 & 0,140 & 0,000 & 100,320 \\ 0,150 & 0,830 & 9,710 & 52,330 & 7,540 & 20,060 & 0,340 & 9,200 & 0.210 & 0,000 & 103470\end{array}$

$\begin{array}{lllllllllll}0,330 & 0.380 & 10,110 & 50,490 & 9.280 & 18.280 & 0,170 & 11.740 & 0,270 & 0,000 & 89.570\end{array}$

$\begin{array}{lllllllllll}0.280 & 0,920 & 10.180 & 50,310 & 7.780 & 24,890 & 0,830 & 8,210 & 0.050 & 0.000 & 101,350 \\ 0.080 & 0.300 & 11.880 & 50,770 & 5.580 & 28,370 & 0.180 & 4,830 & 0.110 & 0.00 & 98,720\end{array}$

$\begin{array}{lllllllllll}0,250 & 1,380 & 8,050 & 45,830 & 8,020 & 18,810 & 1,130 & 7,830 & 0,110 & 0,000 & 98.720 \\ 0 ., 830 & 0,030 & 0,000 & 03,210\end{array}$

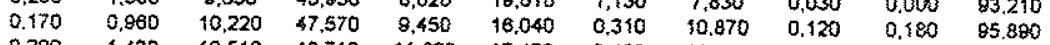

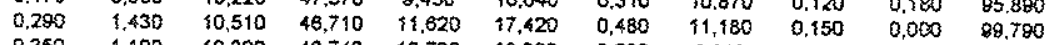

$\begin{array}{lllllllllll}0.350 & 1.100 & 10,390 & 48,740 & 10,730 & 18,300 & 0,230 & 8,810 & 0.040 & 0.000 & 88.680\end{array}$

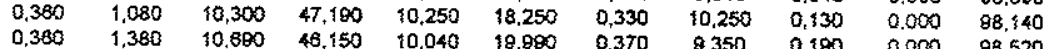

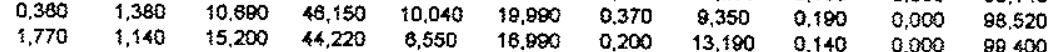

$\begin{array}{llllllllllll}1,410 & 1,200 & 15,200 & 44,220 & 8,550 & 18.980 & 0,200 & 13,480 & 0,140 & 0,000 & 98,400 \\ 0.48,080 & 1,890 & 17,200 & 0,880 & 11,250 & 0,130 & 0,000 & 93,810\end{array}$

$\begin{array}{llllllllllll}0.070 & 1,150 & 10,280 & 43,880 & 14,450 & 20,530 & 0,340 & 8,820 & 0.0,30 & 0.000 & 98,340 \\ 0,180 & 1,050 & 30,570 & 43,150 & 14,300 & 21,190 & 0,280 & 8,390 & 0.120 & 0.000 & 88,220\end{array}$

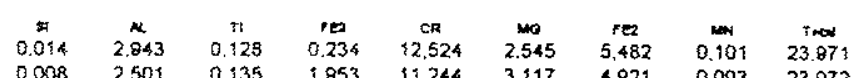
$\begin{array}{lllllllll}0.005 & 2.587 & 0.1342 & 1.853 & 11.244 & 3.317 & 4.821 & 0.093 & 23.872\end{array}$ $\begin{array}{lllllllll}0,000 & 2,887 & 0.147 & 2.218 & 11.632 & 2.232 & 4.255 & 0.077 & 23,448 \\ 0.014 & 2.917 & 0.440 & 0.638 & 12.125 & 2.432 & 5.338 & 0.072 & 23,973\end{array}$ $\begin{array}{llllllllll}0.014 & 2.817 & 0.140 & 0.838 & 12.125 & 2.432 & 5.838 & 0.072 & 23.873 \\ 0.020 & 3.383 & 0.188 & 0.840 & 11.297 & 2.175 & 5.392 & 0.088 & 23.381\end{array}$ $\begin{array}{lllllllll}0.020 & 3,383 & 0.188 & 0.840 & 11.287 & 2.175 & 5.882 & 0.088 & 23.881 \\ 0.050 & 2.388 & 0.107 & 0.207 & 12.578 & 2.505 & 5.548 & 0.071 & 23.853\end{array}$

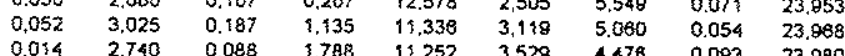

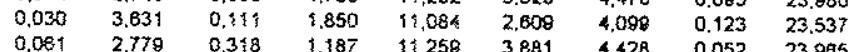

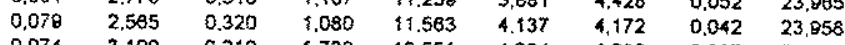

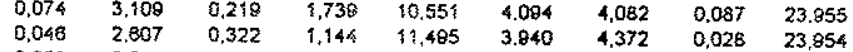

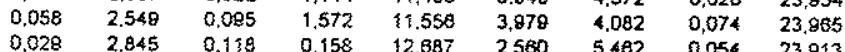
$\begin{array}{llllllllll}0.034 & 3.248 & 0,202 & 0,820 & 11,348 & 2.676 & 5.465 & 0.081 & 23,973 \\ 0.038 & 3.853 & 0,282 & 0.787 & 10.843 & 2.780 & 5.441 & 0.058 & 23.082\end{array}$

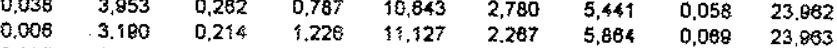

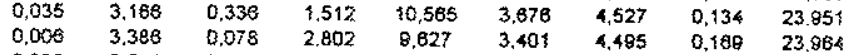
$\begin{array}{llllllllll} & 0.000 & 3.511 & 0.312 & 1.350 & 10.500 & 2.851 & 5.388 & 0.061 & 23.974\end{array}$

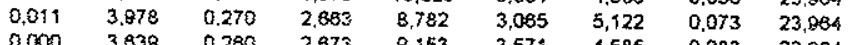
$\begin{array}{lllllllll}0.051 & 3,838 & 0.286 & 2.873 & 8.153 & 3.574 & 4,585 & 0,083 & 23,984 \\ 0.050 & 3.400 & 0,474 & 1.528 & 8.821 & 3,977 & 4,605 & 0,048 & 24,004\end{array}$ $\begin{array}{llllllllll}0.028 & 3.014 & 0.328 & 0.884 & 11.374 & 3.946 & 4.898 & 0.036 & 23.915 \\ 0.055 & 3.093 & 0.145 & 2.883 & 10.330 & 4.085 & 3.878 & 0.083 & 23.950\end{array}$

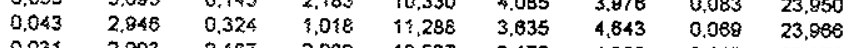
$\begin{array}{lllllllll}0 ., 831 & 2.893 & 0.187 & 2.088 & 10,527 & 3.173 & 4.803 & 0.110 & 23.873 \\ 0.004 & 3.836 & 0.445 & 2.317 & 8.013 & 3.425 & 4.902 & 0.052 & 23.844\end{array}$ $\begin{array}{lllllllll}0.080 & 3.031 & 0.348 & 1.358 & 10.777 & 3.878 & 4.298 & 0.034 & 23.885\end{array}$ $\begin{array}{lllllllll}0.046 & 3.801 & 0.283 & 0.879 & 10,838 & 2,823 & 5.194 & 0.142 & 23.871 \\ & 0.308 & 2,768 & 8.514 & 3.155 & 5.083 & 0.082 & 23.961\end{array}$ $\begin{array}{llllllllll}0.053 & 3.131 & 0.498 & 3,425 & 8,329 & 4.024 & 5,427 & 0,083 & 23,861 \\ 23,267\end{array}$

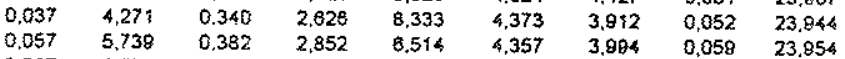
$\begin{array}{lllllllll}0.087 & 8.533 & 0.485 & 2.581 & 5.757 & 4,458 & 4.019 & 0.038 & 23.846\end{array}$ $\begin{array}{lllllllll}0.060 & 8.720 & 0.086 & 0.978 & 5.834 & 4,883 & 3,888 & 0.041 & 24,048 \\ 0,045 & 8,850 & 0.024 & 1,372 & 7.831 & 4,216 & 3,782 & 0.055 & 23.852\end{array}$ $\begin{array}{llllllllll}0.0013 & 0.173 & 1.148 & 7,787 & 4.828 & 0.786 & 8.358 & 0.023 & 23.883 \\ 0.585 & 2.612 & 0.000 & 0.411 & 14.083 & 0.087 & 23.874\end{array}$ $\begin{array}{lllllllll}0.048 & 0,361 & 3,856 & 7,818 & 0.010 & 0.378 & 13,520 & 0.100 & 23,880\end{array}$ $\begin{array}{llllllllll}0,084 & 0,877 & 3,241 & 8.502 & 0,010 & 0,553 & 10.629 & 0.118 & 23.881 \\ 0,047 & 0,100 & 5.828 & 3.848 & 0,000 & 0,473 & 13383 & 0.083 & 23.071\end{array}$

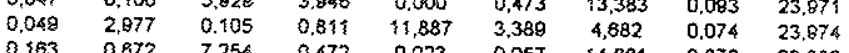
$\begin{array}{lllllllll}0.085 & 2.888 & 0.167 & 0.412 & 0.023 & 0.057 & 14.881 & 0.678 & 23,880 \\ 0 & 1.0819 & 4.864 & 3.273 & 0.044 & 23.833\end{array}$ $\begin{array}{lllllllll}0.080 & 3.858 & 0.233 & 1.144 & 10.585 & 4,858 & 3.272 & 0.067 & 23.864\end{array}$ $\begin{array}{lllllllll}0.077 & 3.368 & 0.172 & 1,559 & 10.558 & 4,454 & 3,704 & 0.058 & 23,849 \\ 0.082 & 3,425 & 0.222 & 1.101 & 1,500 & 4.494 & 4,217 & 0.008 & 24,127\end{array}$

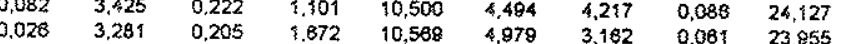

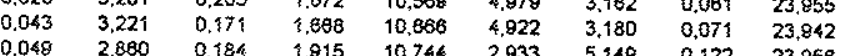

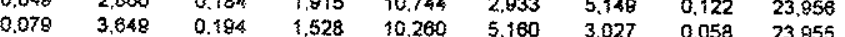
$\begin{array}{lllllllll}0.040 & 3.040 & 0.188 & 1.507 & 10.885 & 3.848 & 4.480 & 0.077 & 23.041\end{array}$ $\begin{array}{lllllllll}0.103 & 3.128 & 0.170 & 1.830 & 10.480 & \$ .800 & 3.578 & 0.038 & 23.928\end{array}$ $\begin{array}{llllllllll}0.070 & 3.224 & 0.188 & 1,573 & 10,875 & 2,487 & 5,615 & 0.143 & 23.873\end{array}$ $\begin{array}{llllllllll}0.072 & 3.789 & 0.082 & 0.1489 & 10,887 & 1.868 & 8,032 & 0.042 & 23,827\end{array}$ $\begin{array}{llllllllll}0.046 & 3,291 & 0.197 & 1,842 & 10.471 & 3,362 & 4,723 & 0.276 & 23,878\end{array}$

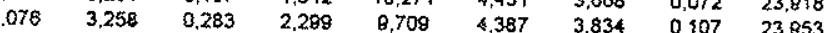

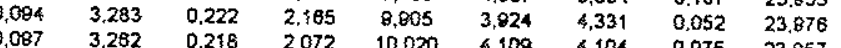
$\begin{array}{lllllllll}0.087 & 3,399 & 0,278 & 2,032 & 9,811 & 3,752 & 4,500 & 0,084 & 23,044\end{array}$ $\begin{array}{lllllllll}0.448 & 4,542 & 0,218 & 1,248 & 8,861 & 4.849 & 3,605 & 0.043 & 23.859\end{array}$ $\begin{array}{lllllllll}0.172 & 4.317 & 0.247 & 0.407 & 10.388 & 4.588 & 3.235 & 0.042 & 24.036 \\ 0.018 & 3.285 & 0.233 & 2.827 & 8.288 & 3.542 & 4.826 & 0.078 & 23.079\end{array}$ $\begin{array}{lllllllll}0,043 & 3,362 & 0.233 & 2,827 & 8.288 & 3,542 & 4,826 & 0,078 & 23,878 \\ & & 0,213 & 2,804 & 8,204 & 3.378 & 4,787 & 0,068 & 23.858\end{array}$ 


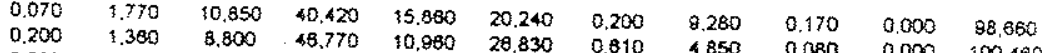
$\begin{array}{llllllllllll}0.090 & 0.880 & 8.860 & 44.110 & 10,480 & 28.830 & 0.810 & 4.850 & 0.380 & 0.000 & 100.460 \\ 0.150 & 0.940 & 10.550 & 41.100 & 15.450 & 2.40 & 0.270 & 9.830 & 0.170 & 0.000 & 100.150\end{array}$

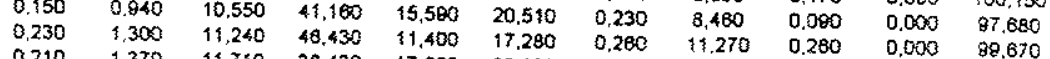

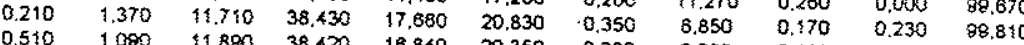
$\begin{array}{lllllllllll}0.510 & 1.090 & 11.880 & 38,420 & 18,840 & 20.350 & 0.330 & 8.220 & 0.190 & 0.000 & 98.840 \\ 0.120 & 3.030 & 10.020 & 20,470 & 32.580 & 27.280 & 0.430 & 5.220 & 0.000 & 0.000 & 98.230\end{array}$

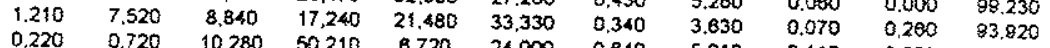
$\begin{array}{llllllllllll}0.220 & 0.720 & 10.280 & 50.210 & 8.720 & 24.000 & 0.840 & 5.210 & 0.110 & 0.000 & 98.110 \\ 0.27 .480 & 4.820 & 4.010 & 21.480 & 42.280 & 0.370 & 2.180 & 0.430 & 0.020 & 82.750\end{array}$ $\begin{array}{lllllllllll}0.380 & 1,830 & 8.510 & 53.010 & 8.750 & 42.280 & 0.370 & 2,180 & 0.130 & 0.020 & 92.750 \\ 0 & 0.810 & 0.240 & 14.090 & 0.150 & 0.000 & 101.150\end{array}$

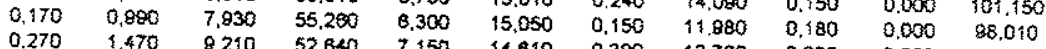
$\begin{array}{lllllllllll}0.190 & 1.670 & 8.210 & 52.640 & 7.150 & 14.610 & 0.300 & 12.780 & 0.230 & 0.000 & 28.640 \\ 0.740 & 45.240 & 17.890 & 11,070 & 0.180 & 15.870 & 0.220 & 0.000 & 102070\end{array}$ $\begin{array}{llllllllllll}0.280 & 1.010 & 10,780 & 52,480 & 8.710 & 7.400 & 0.230 & 17.380 & 0.190 & 0.000 & 88,470 \\ 0.210 & 0,890 & 10.120 & 52,780 & 8.210 & 14.720 & 0.170 & 12.770 & 0.230 & 0.000 & 100.400\end{array}$

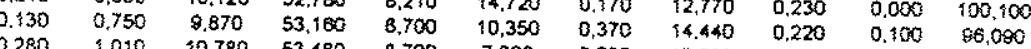

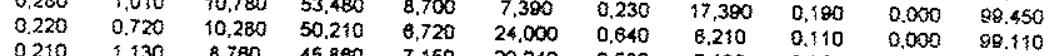

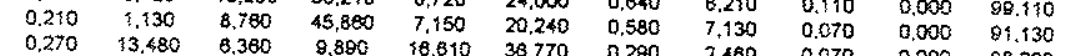
$\begin{array}{lllllllllll}0.170 & 0.840 & 8.450 & 98,890 & 18,810 & 38,770 & 0.280 & 2.480 & 0.070 & 0.000 & 88.200 \\ 0.380 & 8.710 & 21.530 & 0.790 & 5.850 & 0.110 & 0.000 & 81.400\end{array}$ $\begin{array}{llllllllllll}0.3800 & 0.010 & 8,250 & 18.590 & 15,750 & 31,300 & 0,260 & 3.730 & 0.030 & 0.000 & 88.340\end{array}$ $\begin{array}{llllllllllll}0.080 & 10,180 & 8.470 & 8.500 & 30.880 & 24,340 & 0.598 & 8.110 & 0.020 & 0.000 & 88.660 \\ 0.240 & 0.530 & 3.340 & 0.140 & 0.000 & 85.970\end{array}$

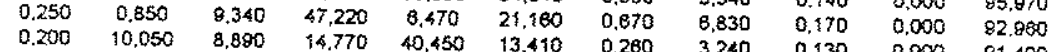
$\begin{array}{lllllllllll}0.190 & 1.080 & 8,800 & 48,830 & 8.280 & 21,310 & 0.510 & 7.620 & 0.130 & 0.240 & 87.470\end{array}$

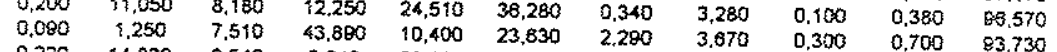

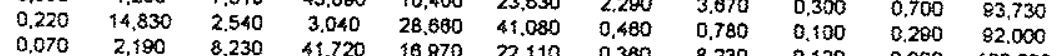

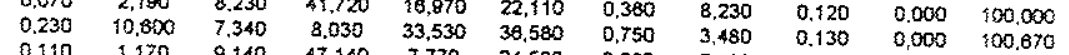

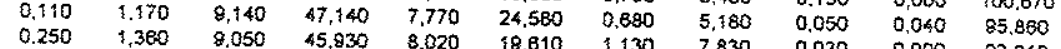
$\begin{array}{lllllllllll}0.250 & 1,380 & 8.050 & 45,830 & 8,020 & 18.810 & 1.130 & 7.830 & 0.030 & 0.000 & 93,210 \\ 0,120 & 12,730 & 7.360 & 12,620 & 15,800 & 34,700 & 0.430 & 3.480 & 0.090 & 0.090 & 37,310\end{array}$

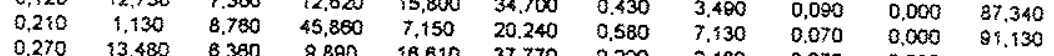

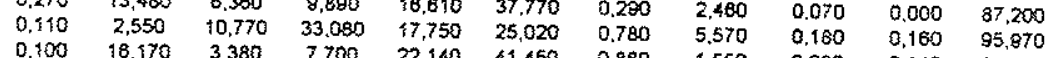

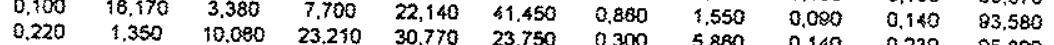
$\begin{array}{llllllllllll}0.480 & 10.810 & 3,120 & 18,300 & 28,120 & 33.750 & 0.300 & 5,860 & 0.140 & 0.230 & 85,880 \\ 0 & 1.840 & 0.930 & 0.040 & 0.000 & 88.890\end{array}$ $\begin{array}{llllllllllll}0,080 & 12,880 & 2,580 & 11,880 & 28,180 & 38,880 & 2,090 & 0.770 & 0.050 & 0,000 & 85.350 \\ 0,180 & 12,700 & 3.270 & 11,080 & 27,790 & 38,870 & 1,800 & 0.850 & 0.010 & 0,000 & 87.850\end{array}$ $\begin{array}{llllllllllll}0.150 & 11,870 & 5.410 & 8,080 & 32,540 & 38,700 & 0.880 & 2.090 & 0.070 & 0,000 & 100,870\end{array}$

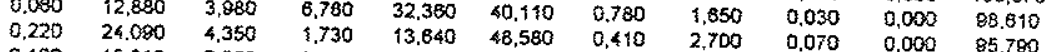

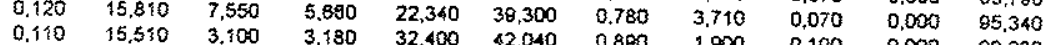
$\begin{array}{lllllllllll}0.11015 & 15,530 & 3.100 & 3.180 & 32,400 & 42.040 & 0.880 & 1.900 & 0.100 & 0.000 & 88.230 \\ 0.015 & 11.970 & 5.410 & 8.080 & 32,510 & 38,720 & 0.860 & 2.070 & 0.070 & 0.000 & 100,505\end{array}$ $\begin{array}{lllllllllll}0.880 & 13,740 & 5.410 & 8.080 & 32.510 & 38,720 & 0.860 & 2,070 & 0,070 & 0.000 & 100,505 \\ 0.480 & 32.760 & 40.870 & 0.810 & 1.510 & 0,020 & 0.000 & 80,480\end{array}$

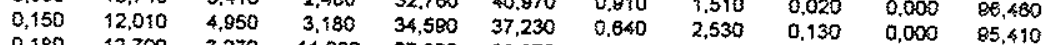

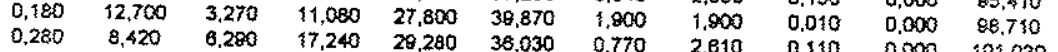

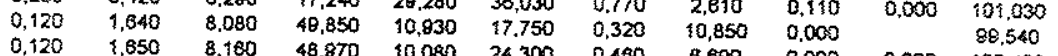
$\begin{array}{lllllllllll}0,120 & 1,650 & 8,180 & 48,870 & 10,080 & 24,300 & 0,430 & 6,690 & 0,000 & 0,000 & 1000,430 \\ 0,300 & 8,630 & 4,550 & 18,040 & 28,120 & 32,800 & 0,540 & 4,540 & 0,020 & 0,000 & 08,630\end{array}$ $\begin{array}{lllllllllll}0,810 & 15,110 & 8.800 & 4,850 & 28,300 & 32,800 & 0 ., 540 & 4,540 & 0,020 & 0,000 & 98,630 \\ 0 & 1,490 & 3,580 & 0.180 & 0,000 & 89,370\end{array}$ $\begin{array}{lllllllllll}0.150 & 12,010 & 4,850 & 3,180 & 34,590 & 37.220 & 0,490 & 3,580 & 0.180 & 0,000 & 89.370 \\ 0.530 & 0,130 & 0.000 & 85,400\end{array}$ $\begin{array}{lllllllllll}0.800 & 18.220 & 1,270 & 0.110 & 33,300 & 44,370 & 1.210 & 0.450 & 0,093 & 0.000 & 95,4020\end{array}$

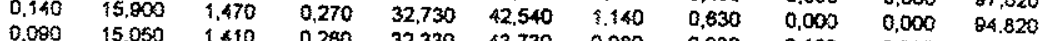
$\begin{array}{lllllllllll}0.080 & 15,050 & 1,410 & 0,280 & 32,330 & 43,730 & 0,880 & 0,830 & 0,180 & 0,000 & 24,840 \\ 0.870 & 17,050 & 0,570 & 0.050 & 30,500 & 44,340 & 1,470 & 0,550 & 0.000 & 0.000 & 95,410\end{array}$ $\begin{array}{lllllllllll}0.070 & 18,470 & 2.130 & 0.050 & 30,500 & 44,340 & 1,470 & 0,550 & 0,080 & 0.000 & 95,410\end{array}$ \begin{tabular}{llllllllllll}
0,180 & 15,840 & 1,230 & 1,380 & 34,210 & 43,380 & 1,480 & 1,680 & 0,2060 & 0,000 & 88.310 \\
\hline & 15,280 & 0.120 & 0,000 & 98.440
\end{tabular}

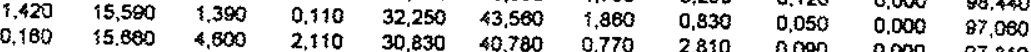

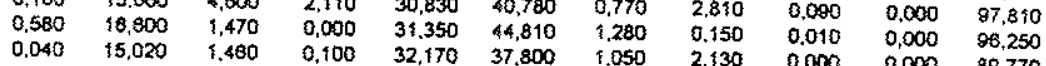

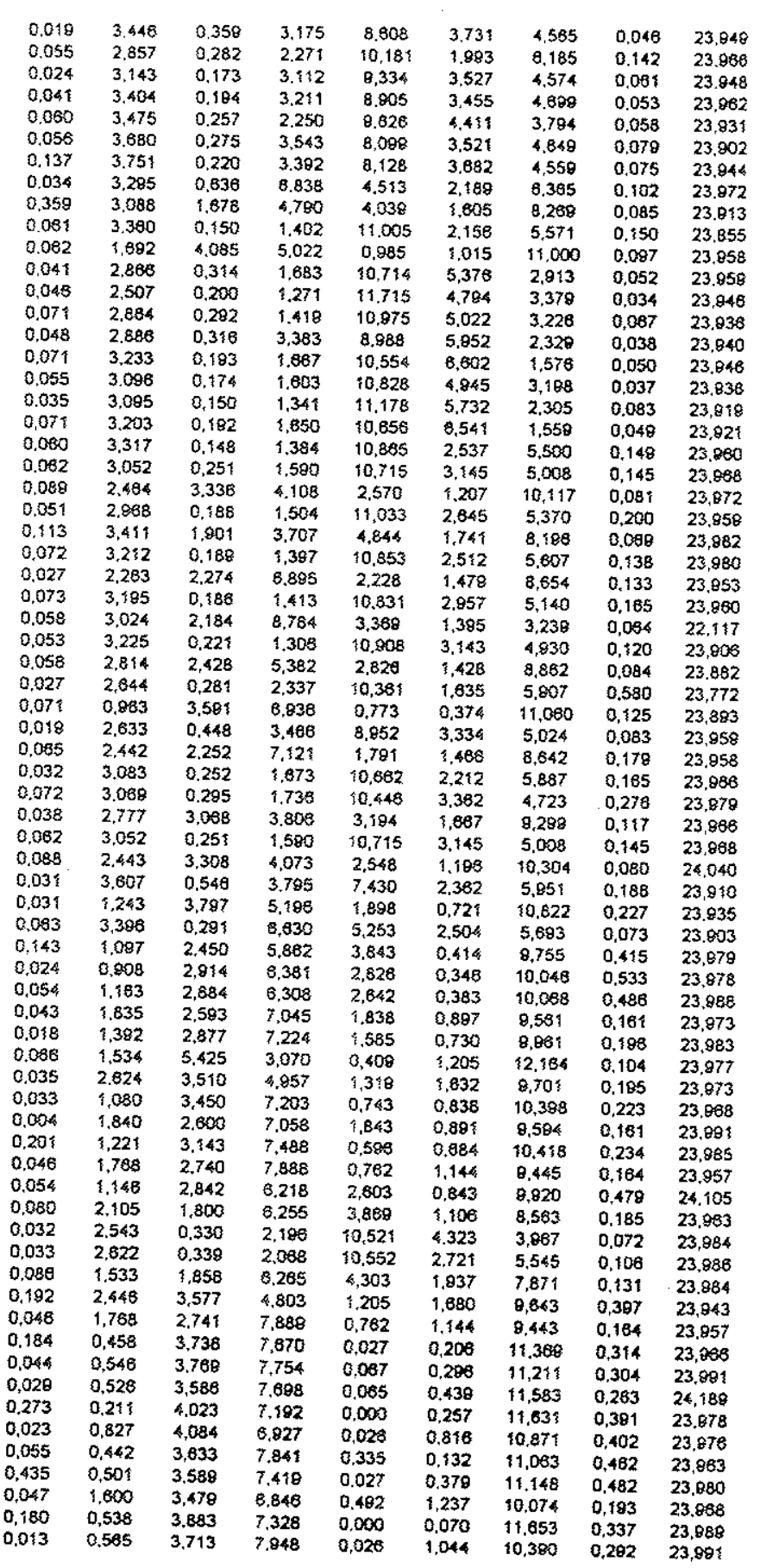


$\begin{array}{lllllllllll}0.380 & 18.030 & 2.200 & 0.050 & 28.070 & 44.340 & 0.890 & 1.800 & 0.130 & 0.000 & 87.583 \\ 0.150 & 17,350 & 3.250 & 0.280 & 28.880 & 43.450 & 0.850 & 1.740 & 0.120 & 0.000 & 87.880\end{array}$

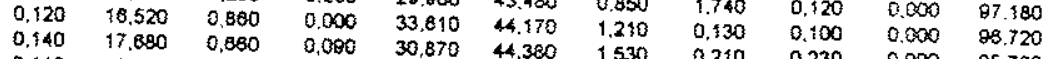
$\begin{array}{lllllllllll}0.110 & 18.750 & 1.750 & 0,080 & 30,870 & 44,360 & 1.530 & 0.210 & 0.230 & 0,000 & 85.790\end{array}$

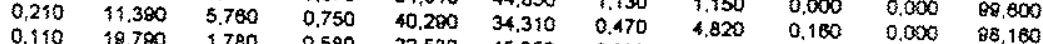

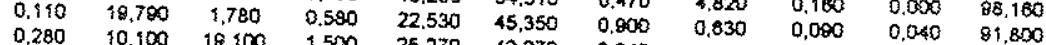

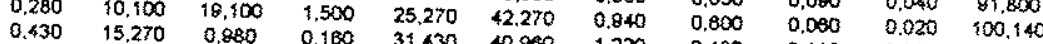
$\begin{array}{lllllllllll}0.110 & 15.510 & 3.100 & 3.180 & 31,430 & 40,280 & 1.220 & 0.480 & 0.110 & 0.230 & 81,280\end{array}$ \begin{tabular}{llllllllll}
17.130 & 0.800 & 0,030 & 28.250 & 42.040 & 0.820 & 1.900 & 0.100 & 0.000 & 88.230 \\
\hline
\end{tabular}

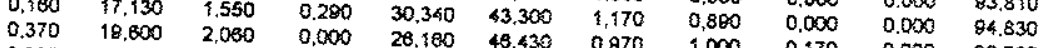
$\begin{array}{llllllllllll}0.200 & 18,180 & 2.500 & 0.450 & 28,790 & 43,810 & 0.870 & 1.000 & 0.770 & 0.000 & 98,780 \\ 0.870 & 17.050 & 0.570 & 0.000 & 3,520 & 2,600 & 0.030 & 0,000 & 98,080\end{array}$

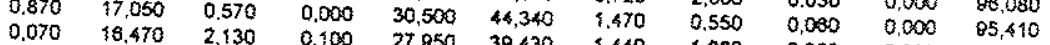
$\begin{array}{lllllllllll}0,180 & 15,840 & 1,230 & 0,390 & 27,850 & 38,430 & 1.440 & 1,360 & 0.080 & 0.000 & 88,330\end{array}$

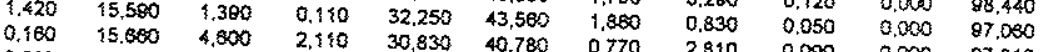
$\begin{array}{llllllllllll}0.580 & 18,800 & 1,470 & 0,000 & 31,350 & 44,810 & 1.280 & 2,310 & 0.090 & 0,000 & 87.810\end{array}$

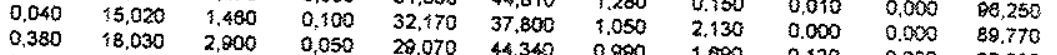

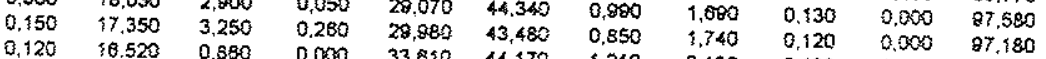

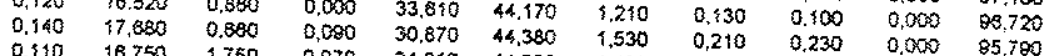

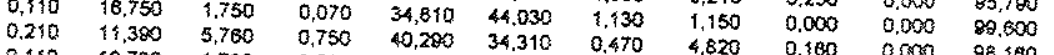

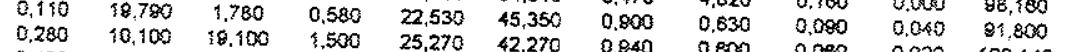

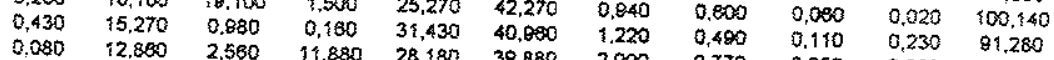

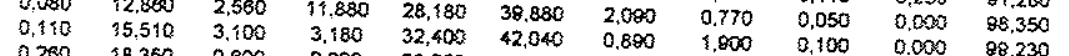

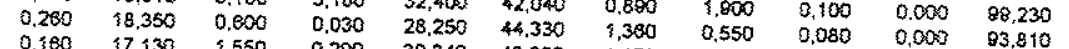

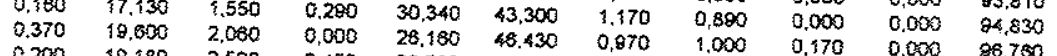

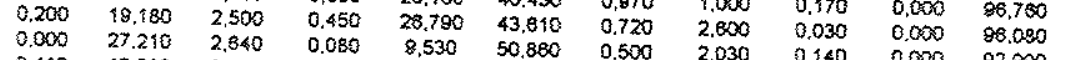

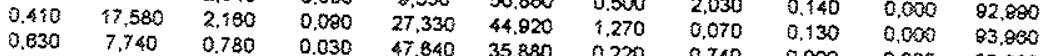

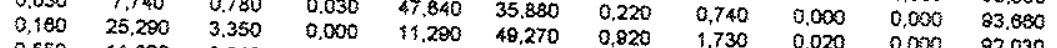

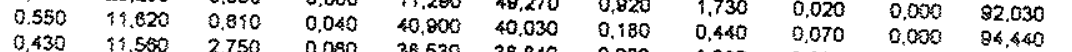

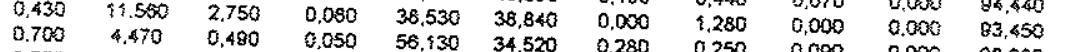
$\begin{array}{lllllllllll}0.770 & 8.470 & 0,480 & 0.050 & 56,430 & 34,520 & 0.280 & 0.250 & 0,090 & 0.000 & 98.880\end{array}$

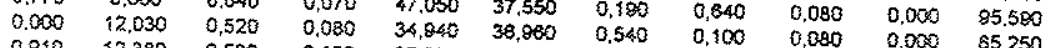

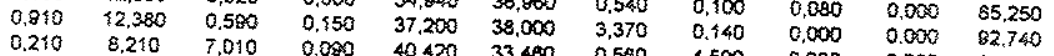

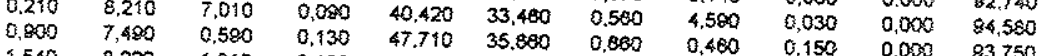
$\begin{array}{llllllllllll}1,540 & 8,220 & 1,810 & 0,100 & 41,840 & 35,300 & 0,330 & 1,860 & 0.140 & 0,0000 & 83.750 \\ 1,020 & 12,870 & 0.720 & 0,000 & 36,300 & 38,440 & 1,400 & 0,140\end{array}$ $\begin{array}{lllllllllll}0.100 & 12,870 & 0.720 & 0,050 & 38,300 & 38,440 & 1,400 & 0.850 & 0,030 & 0,000 & 82.880\end{array}$

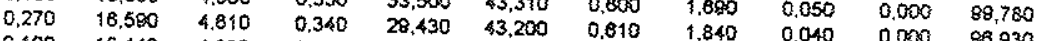

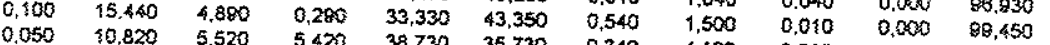
$\begin{array}{lllllllllll}0,110 & 7,300 & 5,050 & 5,420 & 38,730 & 35,730 & 0,340 & 4,100 & 0.080 & 0,0000 & 100,780\end{array}$

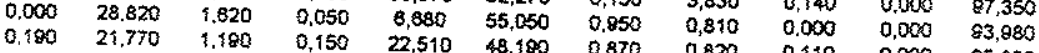
$\begin{array}{lllllllllll}0.170 & 2,770 & 1,180 & 0,150 & 22,510 & 48,480 & 0,870 & 0,820 & 0,110 & 0,000 & 85,800 \\ 0.1,420 & 0,020 & 23,740 & 48,830 & 0,750 & 0,800 & 0,000 & 0,000 & 04,750\end{array}$ $\begin{array}{lllllllllll}0,170 & 0,890 & 7,830 & 55,280 & 63,700 & 48,830 & 0,750 & 0,800 & 0.090 & 0,000 & 84,750 \\ 0 & 1,060 & 0.370 & 5.300 & 0,150 & 11,880 & 0.180 & 0,000 & 88,010\end{array}$

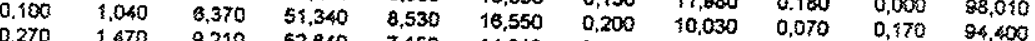

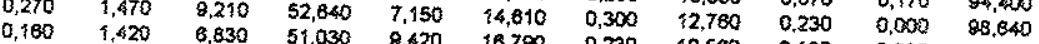

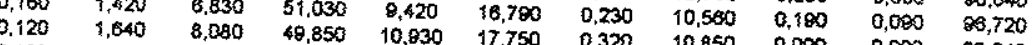

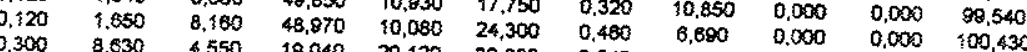
$\begin{array}{lllllllllll}0,210 & 3,850 & 7,550 & 13,040 & 28,120 & 32,800 & 0.540 & 4,540 & 0,020 & 0,000 & 98,630\end{array}$ $\begin{array}{llllllllllll}1,080 & 1,680 & 8,690 & 44,890 & 8,800 & 20,810 & 0.260 & 8,500 & 0,140 & 0.250 & 88,730\end{array}$ $\begin{array}{llllllllllll}0 ., 330 & 18.270 & 2,510 & 0,030 & 27,840 & 44,180 & 0,750 & 2,430 & 0,000 & 0.000 & 87,800\end{array}$ $\begin{array}{lllllllllll}0,460 & 18,800 & 2.330 & 0.250 & 25,770 & 48,120 & 0,830 & 1,480 & 0,000 & 0,000 & 88,8,400 \\ 0.470 & 19,280 & 2,530 & 0,130 & 27,350 & 43,440 & 0,390 & 2,800 & 0,370 & 0,000 & 89,440\end{array}$ $\begin{array}{lllllllll}0.114 & 1.027 & 4.078 & 8.571 & 0.012 & 0.758 & 11.148 & 0.252 & 23.089 \\ 0.045 & 1.155 & 3.837 & 8.700 & 0.002 & 0.783 & 10970 & 0.217 & 23,088\end{array}$ $\begin{array}{lllllllll}0.037 & 0,315 & 3.888 & 8,788 & 0.082 & 0,783 & 10,970 & 0,217 & 23,088 \\ 0.034 & 0.244 & 4,170 & 7,280 & 0.000 & 0.080 & 11,500 & 0,318 & 23,868\end{array}$

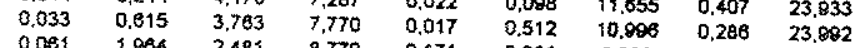

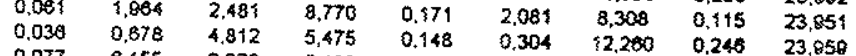
$\begin{array}{llllllllll}0.077 & 8.155 & 2.078 & 5.189 & 0.324 & 0.245 & 9.874 & 0.218 & 23,871 \\ 0,241 & 0,378 & 3.788 & 7.754 & 0.041 & 0.240 & 11.242 & 0.330 & 23,005\end{array}$ $\begin{array}{lllllllll}0,033 & 1,080 & 3,450 & 7,203 & 0,743 & 0,836 & 11,242 & 0,330 & 23,805 \\ 0 & 0,083 & 0.223 & 23,868\end{array}$ $\begin{array}{llllllllll}0.050 & 0.573 & 4.048 & 7.158 & 0.072 & 0.418 & 11.389 & 0.388 & 23.872\end{array}$ $\begin{array}{lllllllll}0.113 & 0.742 & 4.507 & 8.012 & 0.000 & 0.458 & 11.870 & 0.251 & 23.851\end{array}$

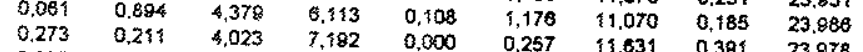
$\begin{array}{lllllllll}0.273 & 0,213 & 4,023 & 7,182 & 0,000 & 0,257 & 13,631 & 0,381 & 23,878 \\ 0.053 & 0,827 & 4,084 & 8,827 & 0,028 & 0,818 & 10,871 & 0,402 & 23,078\end{array}$

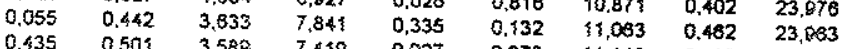
$\begin{array}{llllllllll}0,047 & 1.800 & 3.478 & 6.848 & 0.492 & 1.237 & 1,0.074 & 0,482 & 23,880\end{array}$

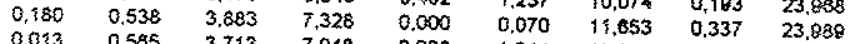

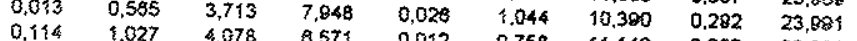

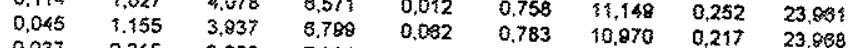
$\begin{array}{llllllllll}0.037 & 0.315 & 3.888 & 7,888 & 0,000 & 0.030 & 10.270 & 0.217 & 23,888 \\ & 0.318 & 23,858\end{array}$

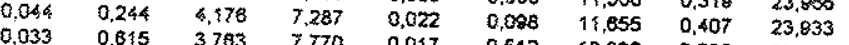

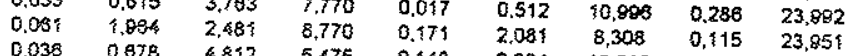

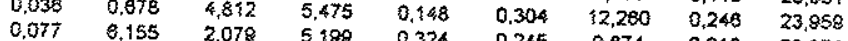
$\begin{array}{llllllllll}0,141 & 0,378 & 2,788 & 5.179 & 0,324 & 0,245 & 8,874 & 0.218 & 23,971\end{array}$

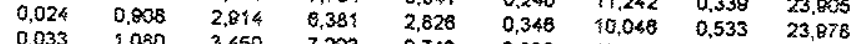

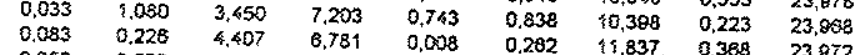
$\begin{array}{llllllllll}0,050 & 0,573 & 4,044 & 7,458 & 0,072 & 0,416 & 11,388 & 0,314 & 23,892 \\ 0.133 & 0,742 & 4,507 & 6,012 & 0,000 & 0,418 & 11,070 & 0,251 & 23,051\end{array}$

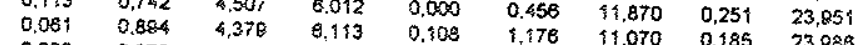
$\begin{array}{lllllllll}0.000 & 0.870 & 8,378 & 8.113 & 0.308 & 1,178 & 11.070 & 0.185 & 23 ., 288 \\ 0.387 & 2.236 & 0.020 & 0.844 & 13.272 & 0.132 & 23.031\end{array}$

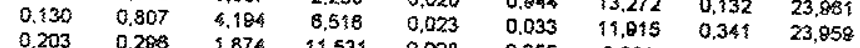

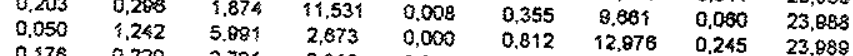
$\begin{array}{lllllllll}0.178 & 0.228 & 2,791 & 8.838 & 0.010 & 0,208 & \$ 0,890 & 0.049 & 23,872 \\ 0.138 & 1.025 & 2.753 & 8.171 & 0.015 & 0.004 & 10.285 & 0.0074 & 23.898\end{array}$ $\begin{array}{lllllllll}0.220 & 0.183 & 1,055 & 1.171 & 0.015 & 0.304 & 10,285 & 0,000 & 23,888\end{array}$ $\begin{array}{lllllllll}0.243 & 0.233 & 2,042 & 13,184 & 0.012 & 0,117 & 8.081 & 0.074 & 23,083\end{array}$

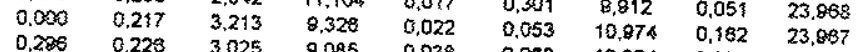
$\begin{array}{lllllllll}0.083 & 0.223 & 3,025 & 8,085 & 0.038 & 0,058 & 10,324 & 0.827 & 23,889 \\ 0 ., 487 & 1,880 & 8,154 & 0,029 & 2,089 & 8,430 & 0.173 & 23,210\end{array}$

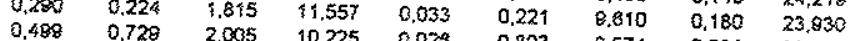
$\begin{array}{lllllllll}0.328 & 0,728 & 2,005 & 10,225 & 0,028 & 0,803 & 8,574 & 0,081 & 23,052\end{array}$ $\begin{array}{llllllllll}0,028 & 1,514 & 3,482 & 8,782 & 0,0000 & 0,458 & 10,815 & 0,382 & 23,078\end{array}$

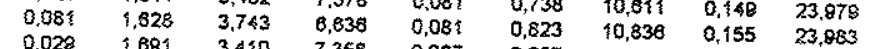

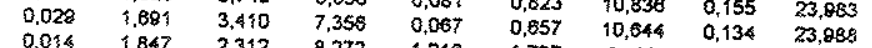
$\begin{array}{lllllllll}0,032 & 1.755 & 1,367 & 8,272 & 1,218 & 1,737 & 8,460 & 0,082 & 23,870 \\ 0 ., 687 & 2,128 & 1,685 & 7,863 & 0,037 & 23,054\end{array}$

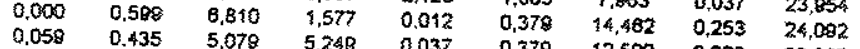

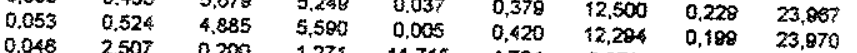
$\begin{array}{llllllllll}0.028 & 2,330 & 0,222 & 1,821 & 11,514 & 4,248 & 3,378 & 0,034 & 23,046\end{array}$ $\begin{array}{lllllllll}0.021 & 2.864 & 0.222 & 1.448 & 10,875 & 5,022 & 3,228 & 0,006 & 23,840\end{array}$

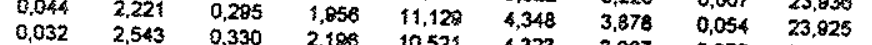
$\begin{array}{lllllllll}0,033 & 2,822 & 0,330 & 2,180 & 10,521 & 4,323 & 3,837 & 0,072 & 23,254\end{array}$ $\begin{array}{llllllllll}0,086 & 1,533 & 1,858 & 2,068 & 10,552 & 2,721 & 5,545 & 0,106 & 23,980 \\ 0 & 2,473 & 0,827 & 3,737 & 4,303 & 1,837 & 7,871 & 0,131 & 23,884\end{array}$ $\begin{array}{lllllllll}0,058 & 2,473 & 0,827 & 3,737 & 8,303 & 1,837 & 7,871 & 0,131 & 23,884\end{array}$ $\begin{array}{lllllllll}0,281 & 2,805 & 0,404 & 2,058 & 8,732 & 3,244 & 4,799 & 0.061 & 23,003\end{array}$

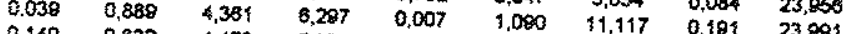
$\begin{array}{lllllllll}0,140 & 0,832 & 4,473 & 5,877 & 0,060 & 0,689 & 11,702 & 0,191 & 23,2831 \\ 0,051 & 0,800 & 4,375 & 8,209 & 0,031 & 1,261 & 10,972 & 0,177 & 23,892\end{array}$ 
$\begin{array}{lllllllllll}0.680 & 18.550 & 2.240 & 0.150 & 24.530 & 46.100 & 0.800 & 1.335 & 0.130 & 0.000 & 85.810 \\ 0.280 & 18.450 & 2.410 & 0.080 & 27.110 & 45.350 & 0.780 & 1.880 & 0.000 & 0.090 & 07.430\end{array}$ $\begin{array}{lllllllllll}0.340 & 18.160 & 2.280 & 0.140 & 27.820 & 45,350 & 0.700 & 1.880 & 0.100 & 0.050 & 87.480 \\ 1.980 & 2.340 & 0.850 & 2.430 & 0.000 & 0.050 & 87.380\end{array}$

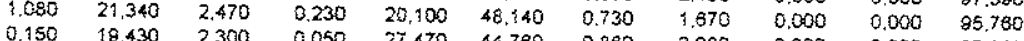
$\begin{array}{llllllllllll}1.330 & 18.430 & 2.300 & 0.050 & 27.470 & 44.780 & 0.880 & 2.080 & 0.000 & 0.000 & 97.080 \\ 18.440 & 2.420 & 0.180 & 24.310 & 45.810 & 0.380 & 1.250 & 0.040 & 0.000 & 84.730\end{array}$ $\begin{array}{llllllllllll}1.180 & 19.850 & 2.880 & 0.010 & 22.580 & 48,940 & 0.740 & 1.250 & 0.040 & 0.000 & 84.760 \\ 0 & & & .580 & 0.080 & 0.000 & 95.870\end{array}$ $\begin{array}{lllllllllll}0.290 & 18.850 & 2.880 & 0.010 & 22.580 & 48,940 & 0.740 & 1.580 & 0.080 & 0.000 & 95.870 \\ & 2.500 & 0.450 & 28.120 & 42.410 & 0.720 & 2.800 & 0.030 & 0.000 & 85.210\end{array}$ $\begin{array}{lllllllll}0.212 & 0.812 & 4.524 & 5.673 & 0.038 & 0.610 & 11.861 & 0.232 & 23,880\end{array}$ $\begin{array}{llllllllll}0.102 & 0.708 & 4.328 & 0.37 & 0.018 & 0.844 & 11.420 & 0.231 & 23.869\end{array}$ $\begin{array}{llllllllll}0.328 & 0.887 & 4.884 & 4.307 & 0.035 & 0.785 & 11.087 & 0.242 & 23.992\end{array}$ $\begin{array}{lllllllllll}0.045 & 0.818 & 4.418 & 6.240 & 0.012 & 0.828 & 11.312 & 0.220 & 23,394\end{array}$ $\begin{array}{lllllllll}0.412 & 0.882 & 4.284 & 5.857 & 0.044 & 0.577 & 11.860 & 0.257 & 23.883\end{array}$ $\begin{array}{llllllllll}0.383 & 0.884 & 4.558 & 5.185 & 0.002 & 0.724 & 11.885 & 0.193 & 23.873 \\ 0.061 & 0.802 & 4.181 & 8.478 & 0.108 & 1.188 & 10.869 & 0.187 & 23.885\end{array}$ 


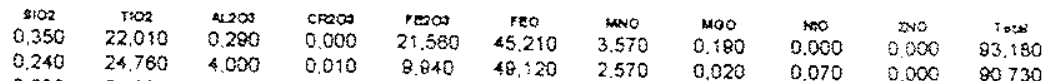

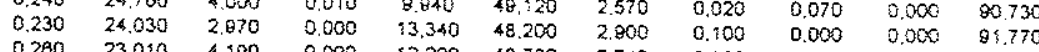
$\begin{array}{llllllllllll}0.280 & 23.010 & 4.180 & 0.000 & 12.280 & 48.780 & 2.740 & 0.080 & 0.170 & 0.000 & 88.520\end{array}$ $\begin{array}{lllllllllll}0.210 & 21,400 & 1.850 & 0.000 & 13.280 & 47.810 & 2.870 & 0.050 & 0.070 & 0.000 & 80.940\end{array}$ $\begin{array}{llllllllllll}0.820 & 22.830 & 3.153 & 1.830 & 0.050 & \$ 2.420 & 48.200 & 2.750 & 0.070 & 0.000 & 0.000 & 91.130\end{array}$ $\begin{array}{llllllllllll}0.310 & 25.430 & 0.980 & 0.080 & 13.030 & 49.000 & 3.840 & 0.180 & 0.020 & 0.000 & 81,180 \\ 0 & 21.90 & 0.000 & 82.880\end{array}$ $\begin{array}{lllllllllll}0.280 & 21,670 & 1.130 & 0.000 & 20.440 & 48.830 & 2.580 & 0.070 & 0.000 & 0.000 & 93,100 \\ 0.280 & 23.730 & 0.940 & 0.000 & 17.490 & 8.90 & 2.30 & 0.30 & 0.000 & 0.000 & 02510\end{array}$ $\begin{array}{llllllllllll}0.390 & 24.030 & 2.780 & 0.000 & 17.180 & 48,810 & 2.480 & 0.150 & 0.000 & 0.000 & 83.850\end{array}$

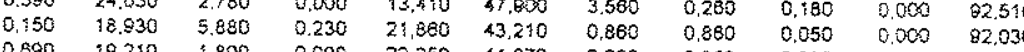

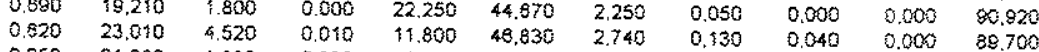

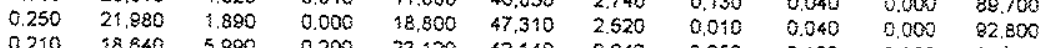
$\begin{array}{lllllllllll}0.210 & 18.840 & 5.980 & 0,200 & 23.120 & 42.140 & 0.340 & 3.250 & 0.160 & 0.000 & 84.350\end{array}$ $\begin{array}{lllllllllll}0.190 & 28.780 & 5.890 & 0.380 & 28.980 & 40.870 & 0.880 & 3.110 & 0.000 & 0.000 & 84.750 \\ 0.720 & 0.130 & 13.680 & 46.110 & 0.730 & 2.850 & 0.040 & 0.000 & 8.030\end{array}$

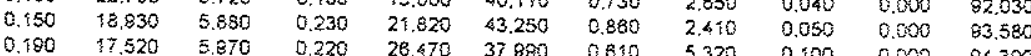
$\begin{array}{lllllllllll}0.250 & 18.180 & 5.810 & 0.220 & 28,470 & 37.820 & 0.810 & 5.320 & 0.100 & 0.000 & 84.380 \\ 0 & 18.130 & 40.580 & 0.810 & 4.220 & 0.120 & 0.000 & 8.5890\end{array}$ $\begin{array}{lllllllllll}0.150 & 24.030 & 2.780 & 0.000 & 13.370 & 48,120 & 3.030 & 0.140 & 0.020 & 0.000 & 85.480\end{array}$ $\begin{array}{llllllllllll}0.200 & 23,570 & 3.240 & 0.000 & \$ 4.440 & 48.820 & 2.580 & 0.490 & 0.020 & 0.000 & 82.820\end{array}$ $\begin{array}{lllllllllll}0.340 & 24.080 & 2.780 & 0,040 & 12.690 & 48.740 & 2.800 & 0.330 & 0.000 & 0.000 & 95.700\end{array}$ $\begin{array}{lllllllllll}0.340 & 24,080 & 2.780 & 0,046 & 12.770 & 48,870 & 2.800 & 0.120 & 0.000 & 0.000 & 81.700\end{array}$

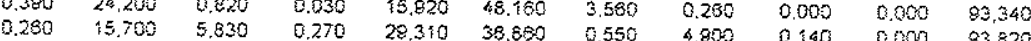

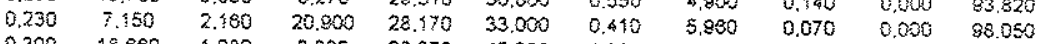
$\begin{array}{lllllllllll}0.300 & 18.850 & 1.080 & 3.380 & 26.070 & 45.530 & 1.330 & 0.780 & 0.410 & 0.500 & 87.280\end{array}$

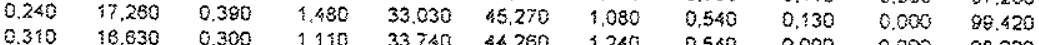
$\begin{array}{lllllllllll}0.280 & 28,030 & 0.300 & 1,110 & 33.740 & 44,250 & 1.240 & 0,540 & 0.090 & 0.000 & 88,220 \\ 0 & 17.270 & 1,020 & 8.440 & 51,740 & 1.350 & 2.330 & 0,080 & 0.000 & 86.080\end{array}$ $\begin{array}{lllllllllll}1.880 & 17.840 & 0.480 & 1.520 & 31.830 & 44.860 & 1.210 & 0.520 & 0.020 & 0.000 & 97.070\end{array}$ $\begin{array}{lllllllllll}0.280 & 24.470 & 0.170 & 1.850 & 17,140 & 45.545 & 1.080 & 3.720 & 0.140 & 0.000 & \approx .600\end{array}$ $\begin{array}{lllllllllll}0.280 & 28,960 & 0.800 & \$, 810 & 11.040 & 44.340 & 1.490 & 7.470 & 0.040 & 0.000 & 96.330\end{array}$ $\begin{array}{lllllllllll}0.210 & 18.320 & 0.270 & 1.330 & 28.820 & 44.070 & 1.130 & 0.510 & 0.220 & 0.000 & 92880\end{array}$ $\begin{array}{lllllllllll}0.180 & 8.520 & 0.170 & 1.310 & 48.870 & 37,840 & 0.450 & 0.380 & 0.000 & 0.000 & 98.820 \\ 0.150 & 17.730 & 0.210 & 1.350 & 28.00 & 43840 & 1.090 & 0.320 & 0.050 & 0.000 & 84.780\end{array}$ $\begin{array}{llllllllllll}0.50 & 17.780 & 0.210 & 1.250 & 28.020 & 43.810 & 1,080 & 0.820 & 0.050 & 0.030 & 84,140 \\ 0.220 & 17.580 & 0.290 & 1.240 & 28,870 & 43.880 & 1.200 & 0.580 & 0.180 & 0.000 & 84.780\end{array}$

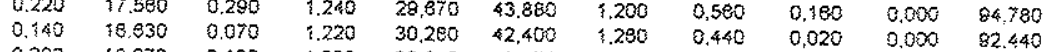
$\begin{array}{lllllllllll}0.200 & 18.070 & 0.130 & 1.200 & 32.840 & 42,470 & 1.270 & 0.520 & 0.130 & 0.000 & 84,830\end{array}$

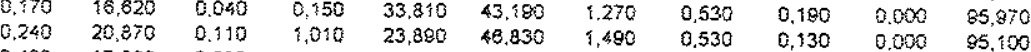

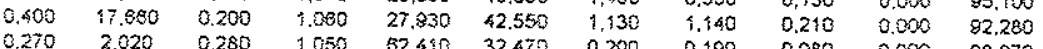

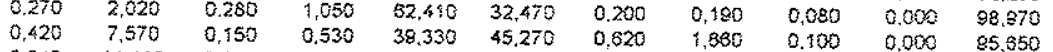

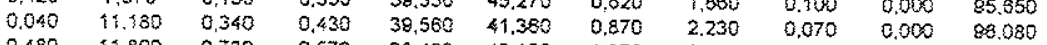
$\begin{array}{lllllllllll}0.480 & \$ 1.800 & 0.730 & 0.570 & 38.480 & 40.150 & 1.870 & 0.430 & 0.080 & 0.000 & 84,880\end{array}$ $\begin{array}{lllllllllll}0.040 & 11,450 & 0.280 & 0.840 & 40,150 & 40,760 & 0.840 & 2,360 & 0.070 & 0.000 & 88,580\end{array}$

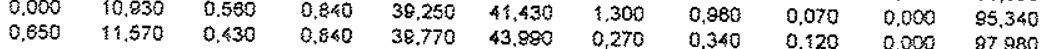

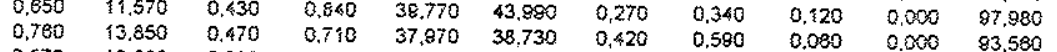

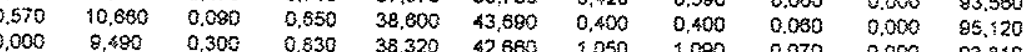

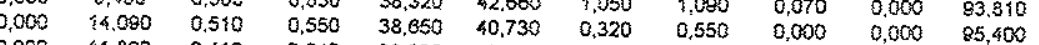
\begin{tabular}{llllllllllll}
0.060 & $\$ 1,890$ & 0,410 & 0,540 & 38,000 & 43,200 & 0,620 & 0.380 & 0,050 & 0,000 & 88,200 \\
\hline
\end{tabular} $\begin{array}{lllllllllll}0.020 & 12,000 & 0.780 & 0.740 & 38,810 & 44.170 & 0.240 & 0.310 & 0.080 & 0.000 & 88.120\end{array}$ $\begin{array}{llllllllllll}0.020 & 9.220 & 0.330 & 0,530 & 40,800 & 45,200 & 0.780 & 1,810 & 0.100 & 0,000 & 98,680 \\ 0.320 & 8,770 & 0,300 & 0,470 & 38,340 & 48,570 & 0.520 & 1,370 & 0.070 & 0.000 & 05.730\end{array}$ $\begin{array}{lllllllllll}0.290 & \{2.800 & 0.950 & 0,630 & 38.280 & 42,280 & 0,430 & 0,680 & 0.080 & 0.000 & 95,730 \\ 98,210\end{array}$

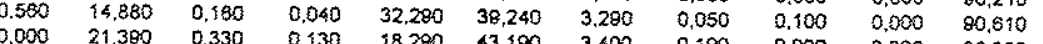
$\begin{array}{lllllllllll}0.470 & 20.110 & 0.280 & 0,370 & 18,280 & 43,490 & 3,400 & 0.180 & 0.000 & 0.000 & 86,820 \\ & 2,3,880 & 43,510 & 3,210 & 0,300 & 0.080 & 0,000 & 88,870\end{array}$

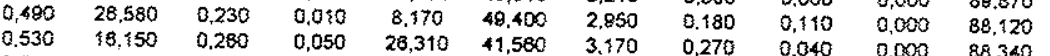

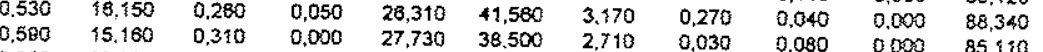
$\begin{array}{lllllllllll}0.350 & 30.030 & 0.210 & 0,000 & 1,030 & 52,100 & 2,890 & 0.130 & 0,100 & 0,000 & 85,110 \\ 0.440 & 18,700 & 0.180 & 0,010 & 23,340 & 43,130 & 3,700 & 0,330 & 0,000 & 0.000 & 86,840\end{array}$

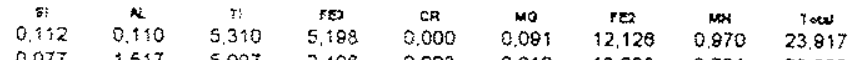
$\begin{array}{lllllllll}0.077 & 1.517 & 5.897 & 2.408 & 0.003 & 0.010 & 13.228 & 0.701 & 23.838 \\ 0.074 & 1.121 & 5.794 & 3.214 & 0.000 & 0.048 & 12.820 & 0.787 & 23.858\end{array}$ $\begin{array}{llllllllll}0.085 & 1.809 & 5.845 & 3.013 & 0.000 & 0.038 & 12.759 & 0.757 & 23.907 \\ 0.085 & 1.079 & 5.838 & 3.175 & 0.000 & 0.024 & 12.070 & 0.787 & 23.945\end{array}$ $\begin{array}{llllllllll}0.088 & 0.710 & 5.248 & 4.728 & 0.000 & 0.029 & 12.282 & 0.872 & 23.943 \\ 0.135 & 1.497 & 5.824 & 3.004 & 0.003 & 0.04 & 12.871 & 0.750 & 23.771\end{array}$ $\begin{array}{llllllllll}0.200 & 0.733 & 5.828 & 3.004 & 0.013 & 0.034 & 12.871 & 0.750 & 23.828\end{array}$

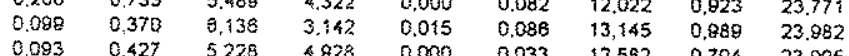

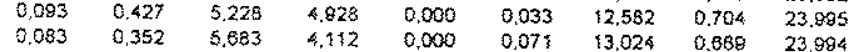
$\begin{array}{llllllllll}0.124 & 1.042 & 5.750 & 3.207 & 0.000 & 0.123 & 12.744 & 0.058 & 23.984 \\ & 0.048 & \end{array}$ $\begin{array}{llllllllll}0.047 & 2.186 & 4.454 & 5.440 & 0.057 & 0.401 & 11.303 & 0.22 \varepsilon & 23.796\end{array}$ $\begin{array}{lllllllll}0.226 & 0.883 & 4.722 & 5.488 & 0.000 & 0.024 & 12.209 & 0.823 & 23.983 \\ 0.201 & 1.722 & 5.001 & 2.870 & 0.003 & 0.083 & 12.873 & 0.751 & 23.984\end{array}$ $\begin{array}{lllllllll}0.080 & 0.713 & 5.027 & 2.870 & 0.003 & 0.083 & 12.873 & 0.759 & 23.284 \\ 0.528 & 0.000 & 0.005 & 12,677 & 0.884 & 23.984\end{array}$ $\begin{array}{lllllllll}0.083 & 2.127 & 4.227 & 5,240 & 0.048 & 1,481 & 10,524 & 0.183 & 23.953 \\ 0.093 & 2.058 & 3.789 & 8.112 & 0.038 & 1.397 & 10,325 & 0.188 & 23980\end{array}$ $\begin{array}{llllllllll}0.048 & 2.083 & 5.288 & 3,175 & 0.044 & 1.221 & 11,823 & 0.181 & 23,984\end{array}$ $\begin{array}{llllllllll}0.048 & 2.118 & 4.358 & 5.018 & 0.056 & 1.088 & 11,084 & 0.223 & 23,080 \\ 0.058 & 2.088 & 3.814 & 5.911 & 0.052 & 2.358 & 0.037 & 0.153 & 23.957\end{array}$ $\begin{array}{llllllllll}0.074 & 2.082 & 4.055 & 5.597 & 0.084 & 1.384 & 10.079 & 0.153 & 23.964 \\ 0.048 & 3.055 & 5.527 & 3.192 & 0.000 & 0.097 & 12.973 & 0.027 & 23.075\end{array}$ $\begin{array}{lllllllll}0.083 & 1.205 & 5,013 & 3,437 & 0.000 & 0.087 & 12.973 & 0.827 & 23.889 \\ 0 & 1.052 & 5.030 & 3.008 & 0.010 & 0.090 & 12.872 & 0.882 & 23.975\end{array}$ $\begin{array}{llllllllll}0.108 & 1.052 & 5.818 & 3.084 & 0.010 & 0.057 & 13.074 & 0.788 & 24.001 \\ 0.393\end{array}$ $\begin{array}{lllllllll}0.124 & 0.308 & 5.803 & 3.817 & 0.008 & 0.124 & 12.847 & 0.862 & 23.288\end{array}$ $\begin{array}{lllllllll}0.068 & 0.750 & 3.548 & 8.817 & 0.084 & 2.184 & 8.257 & 0.140 & 23.858 \\ 0.002 & 0.388 & 8.248 & 4.888 & 2.820 & 8.138 & 0.302 & 26.378\end{array}$

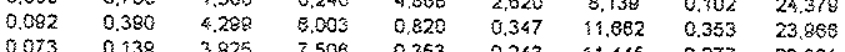

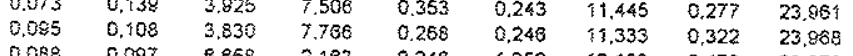
$\begin{array}{lllllllll}0.088 & 0.097 & 8.858 & 2.183 & 0.246 & 1.059 & 13.788 & 0.478 & 23,278 \\ 0.084 & 0.022 & 4.060 & 7.416 & 0.287 & 0.240 & 11578 & 0.313 & 23007\end{array}$

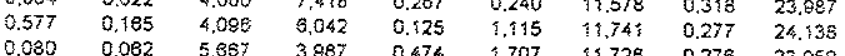

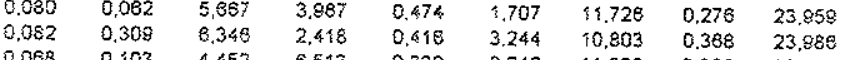
$\begin{array}{llllllllll}0.055 & 0.082 & 1.871 & 11.555 & 0.318 & 0.174 & 0.734 & 0.308 & 23.836\end{array}$ $\begin{array}{lllllllll}0.048 & 0.078 & 4.285 & 6.874 & 0.315 & 0.285 & 11,711 & 0.282 & 23.878\end{array}$ $\begin{array}{lllllllll}0.070 & 0.108 & 4.385 & 7.066 & 0.310 & 0.284 & 11.828 & 0.322 & 23.851\end{array}$ $\begin{array}{llllllllll}0.054 & 0.048 & 3.039 & 7.411 & 0.314 & 0.214 & 11.552 & 0.348 & 23.987\end{array}$ $\begin{array}{llllllllll}0.053 & 0.075 & 3.828 & 7.882 & 0.037 & 0.248 & 11,278 & 0.342 & 23.880 \\ 0 & 0.0248 & 11344 & 0.338 & 23.843\end{array}$ $\begin{array}{llllllllll}0.128 & 0.041 & 4.847 & 5.658 & 0.251 & 0.248 & 12.340 & 0.338 & 23.861 \\ 0 & 4.297 & 6.793 & 0.279 & 0.550 & 1.512 & 0.310 & 23.036\end{array}$

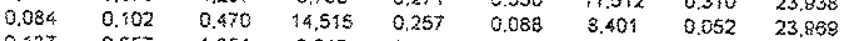
$\begin{array}{lllllllll}0.137 & 0.057 & 1.851 & 0.510 & 0.138 & 0.804 & \$ 2.305 & 0.171 & 25.071\end{array}$ $\begin{array}{lllllllll}0.154 & 0.275 & 2.535 & 8.388 & 0.107 & 1.048 & 10.818 & 0.233 & 24.490 \\ 0.254 & 0.444 & 0.205 & 10.738 & 0.534 & 24.343\end{array}$ $\begin{array}{lllllllll}0.000 & 0.211 & 2.634 & 8.440 & 0.207 & 1.110 & 10.881 & 0.170 & 24,381\end{array}$ $\begin{array}{lllllllll}0.202 & 0.157 & 2.705 & 8.281 & 0.208 & 0.458 & 1,1.083 & 0.352 & 24.401 \\ 0.032 & 0.071 & 24.222\end{array}$ $\begin{array}{lllllllll}0.242 & 0.176 & 3.315 & 8.083 & 0.178 & 0.280 & 10,307 & 0.113 & 23.684\end{array}$ $\begin{array}{lllllllll}0.000 & 0,116 & 2,587 & 8,384 & 0,788 & 0,182 & 11,787 & 0,109 & 24,420\end{array}$ $\begin{array}{lllllllll}0.2000 & 0.138 & 3.340 & 8.158 & 0.243 & 0.534 & 11,734 & 0.283 & 24,716\end{array}$

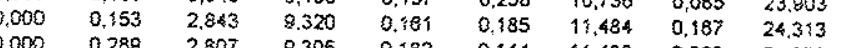
$\begin{array}{llllllllll}0.008 & 0.122 & 2.188 & 8.544 & 0.131 & 0.890 & 11.820 & 0.083 & 24.278 \\ 0 & 0.1307 & 24.889\end{array}$ $\begin{array}{lllllllll}0,105 & 0,1118 & 1,886 & 8.878 & 0.121 & 0.888 & 12,743 & 0.144 & 25,239\end{array}$ $\begin{array}{lllllllll}0.088 & 0.343 & 2.878 & 8.218 & 0.553 & 0.311 & 10,547 & 0.112 & 24,048\end{array}$ $\begin{array}{lllllllll}0.187 & 0.013 & 3.728 & 8.088 & 0.011 & 0.025 & 10.834 & 0.928 & 23.895 \\ 0.000 & 0.134 & 5.545 & 4.738 & 0.035 & 0.098 & 12.449 & 0.908 & 23.05\end{array}$ $\begin{array}{lllllllll}0.157 & 0.1302 & 5.545 & 4.738 & 0,035 & 0.098 & 12,448 & 0.083 & 23.883\end{array}$

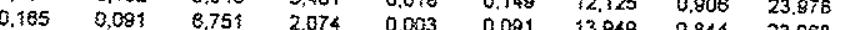
$\begin{array}{llllllllll}0,189 & 0.105 & 4,160 & 8,773 & 0.014 & 0,138 & 11,802 & 0.844 & 23,888\end{array}$

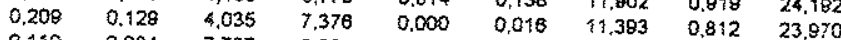
$\begin{array}{llllllllll}0,118 & 0.084 & 7,707 & 0.284 & 0.000 & 0.068 & 14.868 & 0.864 & 23,870 \\ 0.148 & 0.070 & 4.808 & 5.813 & 0.003 & 0.084 & 11.950 & 1.038 & 23.893\end{array}$ 


\title{
A5
}

Composição química, em porcentagem em peso, de anfibólios de rochas "lamprofíricas" do Paraguai.

(ANF)

"Lamprófiros"

Ymi-1 (10.000-10.011, 10c.000-10c.003);

Ymi-4 (14.000-14.005);

Ymi 7 (17.000-17.004);

Yzu-1 (21.000).

\author{
"Lamproitos" \\ Ymi-5 (15.000-15.005); \\ Yzu-2 (22.000-22.005); \\ Yzu-3 (23.000); \\ Yzu-6 (26.001-26.007).
}




\begin{tabular}{|c|c|c|c|c|c|c|c|c|c|}
\hline Sample & 10.000 & 10.001 & 10.002 & 10.003 & 10.004 & 10.005 & $10.006 a$ & $10.0006 \mathrm{~b}$ & 10.007 \\
\hline Anzalysis & gan & gm & $g n$ & $g n$ & gm & $\mathrm{gm}$ & fen & fen & $g m$ \\
\hline Location & $Y M[-1-p]$ & YMI-1-d & YMI-1-p2 & $Y M 1-1-p 2$ & YM:-1-p2 & $\mathrm{XMI}-1-\mathrm{pl}$ & YMI- ]-d & YMI-1-d & YMI-1-p2 \\
\hline Mineral & ANF & ANF & ANF & ANE & $\mathrm{ANF}$ & ANF & ANE & ANF & ANF \\
\hline $\mathrm{SiO} 2$ & 50.14 & 39.28 & 46.12 & 39.17 & 45.23 & 37.16 & 48.94 & 48.61 & 47.35 \\
\hline $\mathrm{TiO}_{2}$ & 2.59 & 3.85 & 0.11 & 0.06 & 1.38 & 0.28 & 1.10 & 1.35 & 1.38 \\
\hline $\mathrm{Al}_{2} \mathrm{O}_{3}$ & 16.59 & 15.02 & 0.29 & 3.13 & 4.86 & 7.54 & 4.08 & 5.09 & 4.55 \\
\hline $\mathrm{F} \infty \mathrm{O}$ & 8.50 & 16.28 & 25.11 & 18.10 & 7.80 & 21.10 & 7.50 & 7.65 & 7.66 \\
\hline $\mathrm{Cr}_{2} \mathrm{O} 3$ & 0.00 & 0.00 & 0.00 & 0.00 & 0.04 & 0.00 & 0.00 & 0.02 & 0.01 \\
\hline $\mathrm{MnO}$ & 0.12 & 0.23 & 0.11 & 0.09 & 0.14 & 0.11 & 0.16 & 0.15 & 0.20 \\
\hline $\mathrm{M} 8 \mathrm{OO}$ & 9.25 & 8.38 & 19.27 & 24.19 & 14.42 & 21.23 & 14.80 & 15.34 & 14.12 \\
\hline $\mathrm{CaO}$ & 0.19 & 1.74 & 0.41 & 1.45 & 22.38 & 0.31 & 21.47 & 20.69 & 22.51 \\
\hline $\mathrm{Na} 2 \mathrm{O}$ & 1.54 & 1.27 & 0.36 & 0.27 & 0.41 & 0.94 & 0.52 & 0.35 & $0.4\}$ \\
\hline $\mathrm{K} 2 \mathrm{O}$ & 8.81 & 6.59 & 1.29 & 1.05 & 0.00 & 1.76 & 0.00 & 0.04 & 0.00 \\
\hline $\mathrm{F}$ & 0.00 & 0.00 & 0.00 & 0.00 & 0.00 & 0.00 & 0.00 & 0.00 & 0.00 \\
\hline $\mathrm{Cl}$ & 0.00 & 0.00 & 0.00 & 0.00 & 0.00 & 0.00 & 0.00 & 0.00 & 0.00 \\
\hline Todel & 97.73 & 92.64 & 93.07 & 87.51 & 96.62 & 90.43 & 98.57 & 99.27 & 98.18 \\
\hline O_F_Cl & 0.00 & 0.00 & 0.00 & 0.00 & 0.00 & 0.00 & 0.00 & 0.00 & 0.00 \\
\hline O_F & 0.00 & 0.00 & 0.00 & 0.00 & $0 . \infty$ & 0.00 & 0.00 & 0.00 & 0.00 \\
\hline $\mathrm{O}_{-} \mathrm{Cl}$ & 0.00 & 0.00 & 0.00 & 0.00 & 0.00 & 0.00 & 0.00 & 0.00 & 0.00 \\
\hline $\mathrm{H} 2 \mathrm{O}$ & 0.00 & 0.00 & 0.00 & 0.00 & 0.00 & 0.00 & 0.00 & 0.00 & 0.00 \\
\hline Crotal & 97.73 & 92.64 & 93.07 & 87.51 & 96.62 & 90.43 & 98.57 & 99.27 & 98.18 \\
\hline $\mathrm{TSi}$ & 7.126 & 6.252 & 7.349 & 6.541 & 6.769 & 6.112 & 7.091 & 6.979 & 6.938 \\
\hline TAl & 0.874 & 1.748 & 0.054 & 0.616 & 0.857 & 1.461 & 0.696 & 0.861 & 0.785 \\
\hline TFe3 & 0.000 & 0.000 & 0.000 & 0.000 & 0.000 & 0.000 & 0.000 & 0.000 & 0.000 \\
\hline Tri & 0.000 & 0.000 & 0.013 & 0.008 & 0.155 & 0.035 & 0.120 & 0.146 & 0.152 \\
\hline Sum_ $T$ & 8.000 & 8.000 & 7.416 & 7.164 & 7.781 & 7.608 & 7.908 & 7.985 & 7.875 \\
\hline CAl & 1.903 & 1.067 & 0.000 & 0.000 & 0.000 & 0.000 & 0.000 & 0.000 & 0.000 \\
\hline $\mathrm{CCr}$ & 0.000 & 0.000 & 0.000 & 0.000 & 0.005 & 0.000 & 0.000 & 0.002 & 0.001 \\
\hline $\mathrm{CF} 3$ & 0.000 & 0.000 & 0.000 & 0.000 & 0.000 & 0.000 & 0.000 & 0.000 & 0.000 \\
\hline $\mathrm{Cri}$ & 0.277 & $0.46 !$ & 0.000 & 0.000 & 0.000 & 0.000 & 0.000 & 0.000 & 0.000 \\
\hline $\mathrm{CMg}$ & 1.960 & 1.988 & 4.577 & 5.000 & 3.217 & 5.000 & 3.197 & 3.283 & 3.084 \\
\hline $\mathrm{CF} e 2$ & 0.860 & 1.484 & 0.42 .3 & 0.000 & 0.976 & 0.000 & 0.909 & 0.919 & 0.939 \\
\hline CMn & 0.000 & 0.000 & 0.000 & 0.000 & 0.018 & 0.000 & 0.020 & 0.018 & 0.025 \\
\hline $\mathrm{CCa}$ & 0.000 & 0.000 & 0.000 & 0.000 & 0.784 & 0.000 & 0.874 & 0.778 & 0.951 \\
\hline Sum C & 5.000 & 5.000 & 5.000 & 5.000 & 5.000 & 5.000 & 5.000 & 5.000 & 5.000 \\
\hline $\mathrm{BMg}$ & 0.000 & 0.000 & 0,000 & 1.022 & 0.000 & 0.206 & 0.000 & 0.000 & 0.000 \\
\hline $\mathrm{BFe} 2$ & 0.150 & 0.683 & 2.923 & 2.528 & 0.000 & 2.903 & 0.000 & 0.000 & 0.000 \\
\hline $\mathrm{BMn}$ & 0.014 & $0.03 !$ & 0.015 & 0.013 & 0.000 & 0.015 & 0.000 & 0.000 & 0,000 \\
\hline $\mathrm{BCa}$ & 0.029 & 0.297 & 0.000 & 0.000 & 2.000 & 0.000 & 2.000 & 2.000 & 2.000 \\
\hline Bha & 0.424 & 0.392 & 0.000 & 0.000 & 0.000 & 0.000 & 0.000 & 0.000 & 0.000 \\
\hline $\mathrm{Stun}_{n} \mathrm{~B}$ & 0.618 & 1.403 & 2.938 & 3.563 & 2.000 & 3.124 & 2.000 & 2.000 & 2.000 \\
\hline $\mathrm{ACa}$ & 0,000 & 0.000 & 0.070 & 0.259 & 0.804 & 0.055 & 0.459 & 0.405 & 0.583 \\
\hline $\mathrm{ANa}$ & 0.000 & 0.000 & 0.111 & 0.087 & 0.119 & 0.300 & 0.146 & 0.097 & 0.116 \\
\hline $\mathrm{AK}$ & 1.597 & 1.338 & 0.262 & 0.224 & 0.000 & 0.369 & 0.000 & 0.007 & 0.000 \\
\hline Sum_A & 1.597 & 1.338 & 0.443 & 0.571 & 0.923 & 0.724 & 0.605 & 0.510 & 0.699 \\
\hline Sum_cast & 15.215 & 15.741 & 15.798 & 16.298 & 15.704 & 16.455 & 15.512 & 15.495 & 15.574 \\
\hline $\mathrm{CCl}$ & 0.000 & 0.000 & 0.000 & 0.000 & 0,000 & 0.000 & 0.000 & 0.000 & 0.000 \\
\hline $\mathrm{CF}$ & 0.000 & 0.000 & 0.000 & 0.000 & 0,000 & 0.000 & 0.000 & 0.000 & 0.000 \\
\hline $\mathrm{OH}$ & - & - & - & - & " & $"$ & - & - & - \\
\hline Sum_oxy & 22.996 & 22,996 & 23.000 & 22.999 & 22.999 & 22.998 & 22.999 & 22.999 & 22.999 \\
\hline
\end{tabular}




\begin{tabular}{|c|c|c|c|c|c|c|c|c|c|}
\hline Semple & 10.008 & 10.010 & 10.011 & 10.0000 & 10.0001 & 10.0002 & 10.0003 & 12.001 & 14.000 \\
\hline Anglysis & gाm & $\mathfrak{g m}$ & $g m$ & gen & $\mathrm{gm}$ & gm & gn? & $g n$ & bormica \\
\hline Location & $Y M 1-1-p 2$ & YMI I-d & YMI- \} d & YMI-IC & $\mathrm{YMI} / \mathrm{C}$ & YMl-1C & YMa-1C & & YMI-4-I \\
\hline Mineral & ANF & $A N E$ & ANF & ANF & ANF & ANF & ANF & ANE & ANF \\
\hline $\mathrm{SiO} 2$ & 34.09 & 58.77 & 53.91 & 4.3 .53 & 53.85 & 42.24 & 40.39 & 53.75 & 39.23 \\
\hline $\mathrm{TiO} 2$ & 1.80 & 0.06 & 0.70 & 0.00 & 0.19 & 4.62 & 0.89 & 0.82 & 0.03 \\
\hline $\mathrm{Al} 2 \mathrm{O} 3$ & 17.41 & 25.67 & 7.50 & 4.49 & 22.27 & 5.25 & 12.04 & 15.03 & 30.75 \\
\hline $\mathrm{F} \in \mathrm{O}$ & 14.19 & 0.98 & $4.4 \mathrm{i}$ & 22.82 & 2.23 & 31.70 & 14.45 & 9.41 & 0.09 \\
\hline $\mathrm{CrOO}$ & 0.00 & 0.00 & 0.11 & 0.00 & 0.00 & 0.00 & 0.09 & 0.07 & 0.00 \\
\hline $\mathrm{MnO}$ & 0.15 & 0.02 & 0.08 & 0.16 & 0.13 & 0.54 & 0.28 & 0.07 & 0.07 \\
\hline $\mathrm{MgO}$ & 16.57 & 0.77 & 12.72 & 15.66 & 1.48 & 6.67 & 17.30 & 1.56 & 0.09 \\
\hline $\mathrm{CeO}$ & 0.85 & 0.55 & 18.32 & 1.25 & 1.21 & 3.98 & 1.72 & 7.51 & 12.34 \\
\hline $\mathrm{Na} 2 \mathrm{O}$ & 0.22 & 4.92 & 1.02 & 0.49 & 7.87 & 0.86 & 0.65 & 0.88 & 2.56 \\
\hline$\times 20$ & 4.38 & 1.87 & 0.02 & 0.28 & 4.71 & 2.46 & 8.74 & 8.08 & 0.00 \\
\hline $\mathrm{F}$ & 0.00 & 0.00 & 0.00 & 0.00 & 0.00 & 0.00 & 0.00 & 0 & 0.00 \\
\hline $\mathrm{Cl}$ & 0,00 & $0 . \infty$ & 0.00 & 0.00 & 0.00 & 0.00 & 0.00 & 0 & 0.00 \\
\hline Totas & 89.665 & 93.61 & 98.68 & 88.68 & 93.94 & 98.32 & 96.46 & 97.11 & 85.16 \\
\hline $\mathrm{O}_{m} \mathrm{Cl}$ & 0.00 & 0.00 & 0.00 & 0.00 & 0.00 & 0.00 & 0.00 & 0.00 & 0.00 \\
\hline$O F$ & 0.00 & 0.00 & 0.00 & 0.00 & 0.00 & 0.00 & 0.00 & 0.00 & 0.00 \\
\hline $\mathrm{O}_{-} \mathrm{Cl}$ & 0.00 & 0.00 & 0.00 & 0.00 & 0.00 & 0.00 & 0.00 & 0.00 & 0.00 \\
\hline $\mathrm{H} 2 \mathrm{O}$ & 0.00 & 0.00 & 0.00 & 0.00 & 0.00 & 0.00 & 0.00 & 0 & 0.00 \\
\hline CTotal & 89.66 & 93.61 & 98.68 & 88.68 & 93.94 & 98.32 & 56.46 & 97.11 & 85.16 \\
\hline $\mathrm{TSi}$ & 5.510 & 7.879 & 7.487 & 7.174 & 7.576 & 6.733 & 6.207 & 7.741 & 6.062 \\
\hline TA] & 2.490 & 0.121 & 0.513 & 0.826 & 0.424 & 0.986 & 1.793 & 0.259 & 1.938 \\
\hline $\mathrm{TFe} 3$ & 0.000 & 0.000 & 0.000 & 0.000 & 0.000 & 0.000 & 0.000 & 0.000 & 0.000 \\
\hline TTi & 0.000 & 0.000 & 0.000 & 0.000 & 0.000 & 0.554 & 0.000 & 0.000 & 0.000 \\
\hline Sum $T$ & 8.000 & $8.000)$ & 8.000 & 8.000 & 8.000 & 8.272 & 8.000 & 8.000 & 8.000 \\
\hline $\mathrm{CAl}$ & 0.825 & 3.932 & 0.71 .3 & 0.045 & 3.266 & 0.000 & 0.38 .5 & 2.290 & 3.657 \\
\hline $\mathrm{CCr}$ & 0.000 & 0.000 & 0.012 & 0.000 & 0,000 & 0.000 & 0.011 & 0.008 & 0.000 \\
\hline $\mathrm{CF}$ e3 & 0.000 & 0.000 & 0.000 & 0.000 & 0.000 & 0.000 & 0.000 & 0.000 & 0.000 \\
\hline CTi & 0.219 & 0.006 & 0.073 & 0.000 & 0.020 & 0.000 & 0.103 & 0.089 & 0.003 \\
\hline $\mathrm{CMg}$ & 3.956 & 0.154 & 2.633 & 3.847 & 0.310 & 1.585 & 3.963 & 0.335 & 0.021 \\
\hline $\mathrm{CFe} 2$ & 0.000 & 0.110 & 0.512 & 1.107 & 0.262 & 3.415 & 0.538 & 1.133 & 0.012 \\
\hline $\mathrm{CMn}$ & 0.000 & 0.002 & 0.009 & 0.000 & 0.015 & 0.000 & 0.000 & 0.009 & 0.009 \\
\hline $\mathrm{CCa}$ & 0.000 & 0.079 & 1.046 & 0.000 & 0.182 & 0.000 & 0.000 & 1.136 & 1.298 \\
\hline Sum $C$ & 5.000 & 4.283 & 5.000 & 5.000 & 4.057 & 5.000 & 5.000 & $S .000$ & 5.000 \\
\hline $\mathrm{BMg}$ & 0.036 & 0,000 & 0.000 & 0.000 & 0.000 & 0.000 & 0.000 & 0.000 & 0.000 \\
\hline $\mathrm{BF} \mathrm{C} 2$ & 1.918 & 0.000 & 0.000 & 2.038 & 0.000 & 0.811 & 1.319 & 0.000 & 0.000 \\
\hline BMn & 0.021 & 0.000 & 0.000 & 0.022 & 0.000 & 0.073 & 0.036 & 0.000 & 0.000 \\
\hline $\mathrm{BCa}$ & 0.025 & 0.000 & 1.680 & 0.000 & 0.000 & 0.680 & 0.283 & 0.023 & 0.745 \\
\hline $\mathrm{BNa}$ & 0.000 & 1.279 & 0.275 & 0.000 & 2000 & 0.266 & 0.194 & 0.246 & 0.767 \\
\hline Surn_B $B$ & 2.000 & 1.279 & 1.954 & 2.060 & 2.000 & 1.829 & 1.833 & 0.268 & 1.512 \\
\hline $\mathrm{ACa}$ & 0.122 & 0.000 & 0.000 & 0.221 & 0.000 & 0.000 & 0.000 & 0.000 & 0.000 \\
\hline ANa & 0.069 & 0.000 & 0.000 & 0.157 & 0.147 & 0.000 & 0.000 & 0.000 & 0.000 \\
\hline AK & 0.903 & 0.320 & 0.004 & 0.059 & 0.845 & 0.500 & 1.713 & 1.485 & 0.000 \\
\hline Surs A & 1.095 & 0.320 & 0.004 & 0.436 & 0.992 & 0.500 & 1.713 & 1.485 & 0.000 \\
\hline Sum_cat & 16.095 & 13.882 & 14.958 & 15.497 & 15.049 & 15.602 & 16.546 & 14.753 & 14.512 \\
\hline $\mathrm{CCl}$ & 0.000 & 0.000 & 0.000 & 0.000 & 0.000 & 0.000 & 0.000 & 0.000 & 0.000 \\
\hline $\mathrm{CF}$ & 0.000 & 0.000 & 0.000 & 0.000 & 0.000 & 0.000 & 0.000 & 0.000 & 0.000 \\
\hline OKI & - & $\sim$ & - & - & - & - & - & - & $\cdot$ \\
\hline Sum $a x y$ & 22.995 & 22.994 & 22.998 & 22.999 & 22.994 & 22.999 & 22.997 & 22996 & 22.992 \\
\hline
\end{tabular}




\begin{tabular}{|c|c|c|c|c|c|c|c|c|c|}
\hline Sample & 14.001 & 14.002 & 14.003 & 14.004 & 14.005 & 17.000 & 17.001 & 17.002 & 17.003 \\
\hline Analysis & $\mathrm{gm}$ & $g m$ & $\mathrm{gm}$ & $\mathrm{gm}$ & $\mathrm{gm}$ & $\mathrm{gm}$ & gm & $\mathrm{gm}$ & $\mathrm{gm}$ \\
\hline Location & YMI-4nd & YMI-4-d & $Y M I-4-d$ & YMI-4d & $Y M Y-4-d$ & $\mathrm{YMI}-7$ & YMI-7 & YMl-7 & YMY-7 \\
\hline Mineral & ANF & ANF & ANF & ANF & ANE & ANF & ANF & ANE & ANF \\
\hline $\mathrm{SiO} 2$ & 39.81 & 38.82 & 34.14 & 59.79 & 42.86 & 47.28 & 42.70 & 30.48 & 29.60 \\
\hline TiO2 & 0.31 & 0.06 & 0.25 & 0.08 & 2.35 & 1.26 & 0.00 & 0.01 & 0.00 \\
\hline $\mathrm{Al} 2 \mathrm{O}_{3}$ & 17.24 & 15.28 & 10.06 & 21.96 & 12.10 & 3.29 & 5.99 & 0.01 & 0.00 \\
\hline $\mathrm{FeO}$ & 13.77 & 8.82 & 25.00 & 1.13 & 7.85 & 9.18 & 19.57 & 12.43 & 16.74 \\
\hline $\mathrm{C} 203$ & 0.00 & 0.00 & 0.03 & 0.00 & 0.00 & 0.05 & 0.00 & 0.06 & 0.07 \\
\hline $\mathrm{MnO}$ & 0.18 & 0.31 & 0.54 & 0.00 & 0.10 & 0.22 & 0.00 & 0.19 & 0.32 \\
\hline $\mathrm{MgO}$ & 12.32 & 17.33 & 16.03 & 0.94 & 19.11 & 14.76 & 18.19 & 48.94 & 44.32 \\
\hline $\mathrm{CaO}$ & 1.14 & 1.35 & 1.20 & 0.39 & 0.00 & 21.29 & 1.53 & 0.18 & 0.17 \\
\hline $\mathrm{Na}_{2} \mathrm{O}$ & 0.13 & 0.09 & 1.95 & 3.56 & 1.39 & 0.37 & 0.12 & 0.00 & 0.03 \\
\hline $\mathrm{K} 2 \mathrm{O}$ & 6.70 & 0.98 & 0.10 & 5.12 & 9.53 & $0.0 !$ & 0.31 & 0.00 & 0.00 \\
\hline $\mathrm{F}$ & 0.00 & 0.00 & 0.00 & 0.00 & 0.00 & 0.00 & 0.00 & 0.00 & 0.00 \\
\hline $\mathrm{Cl}$ & 0.00 & 0.00 & 0.000 & 0.00 & 0.00 & $0 .(x)$ & 0.00 & 0.00 & 0.00 \\
\hline Totesl & 91.60 & 83.04 & 89.27 & 92.97 & 95.29 & 97.66 & 88.41 & 92.24 & 91.18 \\
\hline $\mathrm{OF}_{-\mathrm{Cl}}$ & 0.00 & 0.00 & 0.00 & 0.00 & 0.00 & 0.00 & 0.00 & 0.00 & 0.00 \\
\hline $\mathrm{O}_{-} \mathbf{F}$ & 0.00 & 0.00 & $0 .(0)$ & 0.00 & 0.00 & 0.00 & 0.00 & 0.00 & 0.00 \\
\hline $\mathrm{O}_{\ldots} \mathrm{Cl}$ & 0.00 & 0.00 & 0.00 & 0.00 & 0.00 & 0.00 & 0.00 & 0.00 & 0.00 \\
\hline $\mathrm{E2O}$ & 0.00 & 0.00 & 0.00 & $0 . \infty$ & 0.00 & 0.00 & 0.00 & 0.00 & 0.00 \\
\hline Crotal & 91.60 & 83.04 & 89.27 & 92.97 & 95.29 & 97.66 & 88.41 & 92.24 & 91.18 \\
\hline $\mathrm{TSi}$ & 6.262 & 6.360 & 5.817 & 8.380 & 6.434 & 6.099 & 6.944 & 4.842 & 4.869 \\
\hline TAl & 1.738 & 1.640 & 2.019 & 0.000 & 1.566 & 0.574 & 1.056 & 0.002 & 0.000 \\
\hline $\mathrm{TFe} 3$ & 0.000 & 0.000 & 0.000 & 0.000 & 0,000 & 0.000 & 0.000 & 0.000 & 0.000 \\
\hline$T \mathrm{Ti}$ & 0.000 & 0.000 & 0.032 & 0.000 & 0.000 & 0.140 & 0.000 & 0.001 & 0.000 \\
\hline Sum $T$ & 8.000 & 8.000 & 7.868 & 8.180 & 8.000 & 7.713 & 8.000 & 4.845 & 4.869 \\
\hline CAl & 3.455 & 1.308 & 0.000 & 3.538 & 0.573 & 0.000 & 0.091 & 0.000 & 0.000 \\
\hline $\mathrm{CCr}$ & 0.000 & 0.000 & 0.004 & 0.010 & 0.000 & 0.006 & 0.000 & 0.008 & 0.009 \\
\hline CFe3 & 0.000 & 0.000 & 0,000 & 0.000 & 0.000 & 0.000 & 0.000 & 0.000 & 0.000 \\
\hline $\mathrm{Cri}$ & 0.037 & 0.007 & 0.000 & 0.008 & 0.265 & 0.000 & 0.000 & 0.000 & 0.000 \\
\hline CMg & 2.889 & 3.684 & 4.072 & 0.192 & 4.162 & 3.257 & 4.410 & 4.992 & 4.991 \\
\hline $\mathrm{CrO} 2$ & 0.619 & 0.000 & 0.924 & 0.129 & 0.000 & 1.136 & 0.499 & 0.000 & 0.000 \\
\hline$C M n$ & 0.000 & 0.000 & 0.000 & 0.000 & 0.000 & 0.028 & 0.000 & 0.000 & 0.000 \\
\hline $\mathrm{CCa}$ & 0.000 & 0.000 & 0.000 & 0.057 & 0.000 & 0.573 & 0.000 & 0.000 & 0.000 \\
\hline $\operatorname{Sum}_{\ldots} \mathrm{C}$ & 5.000 & 5.000 & 5.000 & 3.934 & 5.000 & 5.000 & 5.000 & 5.000 & 5.000 \\
\hline $\mathrm{BMg}$ & 0.000 & 0.549 & 0.000 & 0.000 & 0.115 & 0.000 & 0.000 & 6.599 & 5.876 \\
\hline $\mathrm{BF} 22$ & 1.192 & 1.208 & 2.638 & 0.000 & 0.985 & 0.000 & 2.163 & 1.651 & 2.303 \\
\hline $\mathrm{BMn}$ & 0.024 & 0.043 & 0.078 & 0,000 & 0.013 & 0.000 & 0.000 & 0.026 & 0.045 \\
\hline $\mathrm{BCa}$ & 0.192 & 0.200 & 0.000 & 0.000 & 0.000 & 2.000 & 0.000 & 0.000 & 0.000 \\
\hline $\mathrm{ENa}$ & 0.040 & 0.000 & 0.000 & 0.944 & 0.405 & 0.0000 & 0.000 & 0.000 & 0.000 \\
\hline Sum_B & 1.448 & 2.000 & 2.716 & 0.944 & 1.518 & 2.000 & 2.163 & 8.276 & 8.224 \\
\hline $\mathrm{ACa}$ & 0.000 & 0.037 & 0.219 & 0.000 & 0.000 & 0.804 & 0.267 & 0.031 & 0.030 \\
\hline ANa & 0.000 & 0.029 & 0.644 & 0.000 & 0.000 & 0.106 & 0.038 & 0.000 & 0.010 \\
\hline $\mathrm{AK}$ & 1.344 & 0.205 & 0.022 & 0.894 & 1.825 & 0.002 & 0.064 & 0.000 & 0.000 \\
\hline Stun_A & 1.344 & 0.271 & 0.885 & 0.894 & 1.825 & 0.912 & 0.369 & 0.031 & 0.040 \\
\hline Sum_cat & 15.792 & 15.271 & 16.469 & 13.952 & 16.343 & 15.624 & 15.532 & 18.152 & 18.132 \\
\hline $\mathrm{CCl}$ & 0.000 & 0.000 & 0.000 & 0.000 & 0.000 & 0.000 & 0.000 & 0.000 & 0.000 \\
\hline $\mathrm{CF}$ & 0.000 & 0.000 & 0.000 & 0.000 & 0.000 & 0.000 & 0.000 & 0.000 & 0.000 \\
\hline $\mathrm{OH}$ & $\cdot$ & - & $r$ & - & - & - & - & $\cdot$ & - \\
\hline Sum_oxy & 22.995 & 22.996 & 22.997 & 22.995 & 22.997 & 22.999 & 22.998 & 23.000 & 23.000 \\
\hline
\end{tabular}




\begin{tabular}{|c|c|c|}
\hline Sample & 17.004 & 20.0001 \\
\hline Aralysis & $g m$ & घूग \\
\hline Location & YMI-7 & YZU-1 \\
\hline Minesal & ANF & $\mathrm{AN}]$ \\
\hline $\mathrm{SiO}_{2}$ & 46.25 & 42.76 \\
\hline TiO2 & 1.84 & 1.18 \\
\hline $\mathrm{Al} 2 \mathrm{O} 3$ & 6.30 & 11.52 \\
\hline $\mathrm{FeO}$ & 11.28 & 26.22 \\
\hline $\mathrm{Cr} 2 \mathrm{O}_{3}$ & 0.00 & 0.00 \\
\hline $\mathrm{MnO}$ & 0.22 & 0.45 \\
\hline$M B O$ & 13.06 & 5.40 \\
\hline $\mathrm{CaO}$ & 18.71 & 0.23 \\
\hline $\mathrm{Na} 2 \mathrm{O}$ & 0.41 & 2.83 \\
\hline $\mathrm{K} 2 \mathrm{O}$ & 0.91 & 5.41 \\
\hline F & 0.00 & 0.00 \\
\hline $\mathrm{Cl}$ & 0.00 & 0.00 \\
\hline Total & 98.98 & 96.00 \\
\hline $0, \mathrm{Fal}$ & 0.00 & 0.00 \\
\hline $0 . F$ & 0.00 & 0.00 \\
\hline $\mathrm{O}_{-} \mathrm{Cl}$ & 0.00 & 0.00 \\
\hline 120 & 0.00 & 0.00 \\
\hline CTotal & 98.98 & 96.00 \\
\hline TSi & 6.796 & 6.808 \\
\hline TAl & 1.090 & 1.192 \\
\hline $\mathrm{TFe}$ & 0.000 & 0.0000 \\
\hline $\mathrm{MTi}$ & 0.203 & 0.000 \\
\hline $\operatorname{Sum}_{-.} \mathrm{Y}$ & 8.090 & 8.000 \\
\hline $\mathrm{CAl}$ & 0.000 & 0.968 \\
\hline $\mathrm{CCr}$ & 0.000 & 0.000 \\
\hline CFe3 & 0.000 & 0.000 \\
\hline $\mathrm{Cri}$ & 0.000 & $0.14 !$ \\
\hline $\mathrm{CMg}_{\mathrm{g}}$ & 2.861 & 1.282 \\
\hline $\mathrm{CF} e 2$ & 1.386 & 2.609 \\
\hline CMn & 0.027 & 0.000 \\
\hline $\mathrm{CCa}$ & 0.725 & 0.000 \\
\hline Sum_C & 5.000 & 5.000 \\
\hline $\mathrm{BM} \mathrm{Mg}$ & 0.000 & 0.000 \\
\hline BFe2 & 0.000 & 0.882 \\
\hline $\mathrm{BMn}$ & 0.000 & 0.061 \\
\hline $\mathrm{BCa}$ & 2.000 & 0.039 \\
\hline $\mathrm{BNa}$ & 0.000 & 0.874 \\
\hline $\operatorname{Sum}_{, B} B$ & 2.000 & $1.85 S$ \\
\hline $\mathrm{ACa}$ & 0.220 & 0.000 \\
\hline $\mathrm{ANa}$ & 0.117 & 0.000 \\
\hline AK & 0.171 & 1.099 \\
\hline Sum_A & 0.508 & 1.099 \\
\hline Sum_cot & 35.597 & 15.954 \\
\hline $\mathrm{COI}$ & 0.000 & 0.000 \\
\hline$C F$ & 0.000 & 0.000 \\
\hline OH & - & - \\
\hline Sum_oxy & 22.998 & 22.997 \\
\hline
\end{tabular}




\begin{tabular}{|c|c|c|c|c|c|c|c|c|c|}
\hline Sample & 15.000 & $15, \infty 01$ & 15.002 & $15.00 \mathrm{~s}$ & 22.000 & 22001 & 22002 & 22.003 & $22.0 \mathrm{KH}$ \\
\hline \multicolumn{10}{|l|}{ Analysis } \\
\hline Location & YM1-S & YMI-S & YMI-5 & YMA-S & YZU-2 & YZU.2 & $\mathrm{YZU}-2$ & $\mathrm{YZU}-2$ & $\mathrm{Y} Z \mathrm{~N}=2$ \\
\hline Mineral & ANF & ANE & ANF & $\mathrm{ANF}$ & ANI: & $A N T^{2}$ & $\mathrm{ANF}$ & ANF & ANF \\
\hline $\mathrm{SiO} 2$ & 47.42 & 49.53 & 53.75 & 42.26 & 53.75 & 48.69 & 48.77 & 47.23 & 54.74 \\
\hline $\mathrm{TiO} 2$ & 2.82 & 2.96 & 0.82 & 3.85 & 0.82 & 7.84 & 905 & 682 & 3.37 \\
\hline $\mathrm{Al} 2 \mathrm{O} 3$ & 14.81 & 16.20 & 15.03 & 13.71 & 15.03 & 1.45 & 1.45 & 2.12 & 11.62 \\
\hline $\mathrm{FoO}$ & 15.58 & 14.91 & 9.41 & 18.55 & 9.41 & 17.71 & 17.30 & 17.14 & 10.04 \\
\hline $\mathrm{Cr} 2 \mathrm{O}_{3}$ & 0.05 & 0.00 & 0.07 & 0.00 & 0.07 & 006 & 0.00 & 0.07 & 0.00 \\
\hline $\mathrm{MnO}$ & 0.19 & 0.12 & 0.07 & 0.24 & 0.07 & 0.19 & 0.21 & 0.16 & 0.15 \\
\hline $\mathrm{MgO}$ & 5.61 & 4.02 & 1.56 & 5.12 & 1.56 & 7.69 & 5.96 & 9.97 & 3.14 \\
\hline $\mathrm{CaO}$ & 0.22 & 0.30 & 7.51 & 0.07 & 7.51 & 0.69 & 2.70 & 1.26 & 0.91 \\
\hline $\mathrm{Na} 2 \mathrm{O}$ & 0.87 & 0.89 & 0.88 & 0.93 & 0.88 & 8.67 & 10.59 & 7.89 & 4.05 \\
\hline $\mathrm{K} 2 \mathrm{O}$ & 11.15 & 11.29 & 8.08 & 10.48 & 8.08 & 3.60 & 1.32 & 3.44 & 9.46 \\
\hline$F$ & 0.00 & 0.00 & 0.00 & 0.00 & 0 & 0.00 & 0.00 & 0.00 & 000 \\
\hline $\mathrm{Cl}$ & 0.00 & 0.00 & 0.00 & 0.00 & 0 & 0.00 & 0.00 & 0.00 & $0.0)$ \\
\hline Toral & 98.67 & 100.22 & 97.11 & 95.21 & 97.11 & 96.53 & 97.35 & 96.03 & 97.48 \\
\hline O. F.Cl & 0.00 & 0.00 & 0.00 & 0.00 & 0.00 & 0.00 & 0.00 & 0.00 & 0.00 \\
\hline $\mathrm{O}_{-} \mathrm{F}$ & 0.00 & 0.00 & 0.00 & 0.00 & 0.00 & 0.00 & 0.00 & 0.00 & 0.00 \\
\hline O... & 0.00 & 0.00 & 0.00 & 0.60 & 0,00 & 0.00 & 0.00 & 0.00 & 0.00 \\
\hline $\mathrm{H} 2 \mathrm{O}$ & 0.00 & 0.00 & 0.00 & 0.00 & 0 & 0.00 & 0.00 & $0.0)$ & 0.00 \\
\hline Crotal & 98.67 & 100.22 & 97.11 & 95.21 & 97.11 & 96.53 & 97.35 & 96.03 & 97.48 \\
\hline TSi & 7.033 & 7.160 & 7.741 & 6.677 & $7.74)$ & 7.481 & 7.416 & 7.287 & 7.907 \\
\hline TAl & 0.967 & 0.840 & 0.259 & 1.323 & 0.259 & 0.262 & 0.2600 & 0.385 & 0.093 \\
\hline $\mathrm{TFe}, 3$ & 0.000 & 0.000 & 0.000 & 0.000 & $0.000)$ & 0.000 & $0.0 \times 0$ & 0.000 & 0.000 \\
\hline $\operatorname{TTi}$ & 0,000 & 0.000 & 0.000 & 0.000 & 0.000 & $0.96 x$ & 1.035 & 0.791 & 0.000 \\
\hline Sum_T & 8.000 & 8.000 & 8.000 & 8.000 & 8.600 & 8.650 & 8.711 & 8.463 & 8000 \\
\hline $\mathrm{CAl}$ & 1.620 & 1.918 & 2.290 & 1.228 & 2.290 & 0.000 & 0.000 & 0.000 & 1.883 \\
\hline $\mathrm{CCr}$ & 0.006 & 0.000 & 0.008 & 0.000 & 0.008 & 0.007 & 0.000 & 0.009 & 0.000 \\
\hline $\mathrm{CFe} 3$ & 0.000 & 0.000 & 0.000 & 0.000 & $0.000)$ & 0.000 & 0.000 & 0.000 & 0.000 \\
\hline $\mathrm{CTi}$ & 0.315 & 0.322 & 0.089 & 0.458 & 0.089 & $0.000)$ & 0.000 & 0.000 & 0.366 \\
\hline $\mathrm{CMg}$ & 1.240 & 0.866 & 0.335 & 1.206 & 0.335 & 1.761 & 1.351 & 2293 & 0.676 \\
\hline $\mathrm{CFe}_{2}$ & 1819 & 1.802 & 1.133 & 2.108 & 1.133 & 2.276 & 2.200 & 2211 & 1.213 \\
\hline $\mathrm{CMn}$ & 0.000 & 0.015 & 0.009 & 0.000 & 0.009 & 0.025 & 0.027 & 0.021 & 0.018 \\
\hline $\mathrm{CCa}$ & 0.000 & 0.046 & 1.136 & 0.000 & 1.136 & 0.114 & 0.440 & 0.208 & 0.141 \\
\hline Sum $c$ & 5.000 & 4.969 & 5.000 & 5.000 & 5.000 & 4.183 & 4.018 & 4.742 & 4.297 \\
\hline $\mathrm{BMB}$ & 0.000 & 0.000 & 0.000 & $0.0 \times 0$ & 0.000 & 0.000 & 0.000 & 0.000 & 0.000 \\
\hline $\mathrm{BFe} 2$ & 0.113 & 0.000 & 0.000 & 0.343 & 0.000 & 0.000 & 0.000 & 0.000 & 0.000 \\
\hline $\mathrm{BMn}$ & 0.024 & 0.000 & 0.000 & 0.032 & 0.000 & 0.000 & 0.000 & 0.000 & 0.000 \\
\hline $\mathrm{BCa}$ & 0.035 & 0.000 & 0.023 & 0.012 & 0.023 & 0.000 & 0.000 & 0.000 & 0.000 \\
\hline $\mathrm{BNa}$ & 0.250 & 0.249 & 0.246 & 0.285 & 0.246 & 2.000 & 2.000 & 2.000 & 1.134 \\
\hline $\operatorname{Sum} B$ & 0.422 & 0.249 & 0.268 & 0.672 & 0.268 & 2.000 & 2.000 & 2.000 & 1.134 \\
\hline $\mathrm{ACa}$ & 0.000 & 0.000 & 0.000 & 0.000 & 0.000 & 0.000 & 0.000 & 0.000 & 0.000 \\
\hline ANa & 0.000 & 0.000 & 0.000 & 0.000 & 0.000 & 0.583 & 1.123 & 0.360 & 0.000 \\
\hline $\mathrm{AK}$ & 2.110 & 2.082 & 1.485 & 2.112 & 1.485 & 0.706 & 0.256 & 0.677 & 1.743 \\
\hline $\operatorname{Sum}_{\ldots} \mathrm{A}$ & 2.110 & 2.082 & 1.485 & 2.112 & 1.485 & 1.289 & 1.379 & 1.037 & 1.743 \\
\hline Sum cat & 15.532 & 15.301 & 14.753 & 15.784 & 14.753 & 16.122 & 16.108 & 16.243 & 15.175 \\
\hline $\mathrm{CCl}$ & 0.000 & 0.000 & 0.000 & 0.000 & 0.000 & 0.000 & 0.000 & 0.000 & $0.0 \times 0$ \\
\hline $\mathrm{CF}$ & 0.000 & 0.000 & 0.000 & 0.000 & 0.000 & 0.000 & 0.000 & 0.000 & 0.000 \\
\hline $\mathrm{OH}$ & - & - & - & . & - & $\cdot$ & - & . & - \\
\hline Sum_axy & 22.9966 & 22.996 & 22.996 & 22.996 & 22.996 & 23.000 & 23.000 & 22.999 & 22.997 \\
\hline
\end{tabular}




\begin{tabular}{|c|c|c|c|c|c|c|c|c|c|}
\hline Location & YZU.Z & YZU-3 & $Y M]-6$ & YM1-6 & YM- 6 & YMLO & YMl-6 & YMQ6 & YMI-6 \\
\hline Mineral & ANF & ANF & ANF & ANF & $\mathrm{ANI}$ & ANF & ANF: & ANF: & ANF: \\
\hline $\mathrm{SiO} 2$ & $48.2 !$ & 41.27 & 44.45 & 46.06 & 44.53 & $43 \% 6$ & 43.96 & 44.34 & 42.19 \\
\hline $\mathrm{TiO}_{2}$ & 8.71 & 7.98 & 0 & 0.01 & 0.13 & 0 & 0 & 0 & 0 \\
\hline $\mathrm{A} 22 \mathrm{O} 3$ & 2.25 & 13.29 & 6.26 & 7.48 & 7.25 & 6.88 & 6.88 & 6.96 & 8.20 \\
\hline $\mathrm{F} C \mathrm{O}$ & 15.43 & 8.78 & 5.78 & 8.39 & 8.26 & 8.24 & 8.24 & 8.08 & 9.92 \\
\hline $\mathrm{C} 203$ & 0.00 & 0.05 & 0.14 & 0 & 0 & 0 & 0 & 0.03 & 0 \\
\hline $\mathrm{MnO}$ & 0.20 & 0.08 & 0.08 & 0.02 & 0 & 0 & 0 & 0 & 0.08 \\
\hline $\mathrm{MgO}$ & 9.10 & 1530 & 22.52 & 21.57 & 21.01 & 21.52 & 21.52 & 22.29 & 23.07 \\
\hline $\mathrm{CaO}$ & 1.92 & 0.02 & 1.40 & 1.32 & 2.73 & 1.88 & 1.88 & 1.37 & 1.65 \\
\hline $\mathrm{Na2}$ & 8.45 & 1.99 & 0.03 & 0 & 0.09 & 0.04 & 0.04 & 0.03 & 0.03 \\
\hline $\mathrm{K} 2 \mathrm{O}$ & 2.33 & 8.41 & 0.06 & 0.09 & 0.08 & 0.12 & 0.12 & 0.02 & 0.05 \\
\hline$F$ & 0.00 & 0.00 & 0 & 0 & 0 & 0 & 0 & 0 & 0 \\
\hline $\mathrm{Cl}$ & 0.00 & 0.00 & 0 & 0 & 0 & 0 & 0 & 0 & 0 \\
\hline Total & 96.60 & 97.12 & 80.58 & 84.94 & 84.08 & 82.64 & 82.64 & 83.09 & 85.19 \\
\hline $\mathrm{O}_{-} \mathrm{F}_{-} \mathrm{Cl}$ & 0.00 & 0.00 & $0 .(x)$ & 0.00 & 0.00 & 0.00 & $0.0)$ & 0.00 & 0.00 \\
\hline $\mathrm{OF}_{-}$ & 0.00 & 0.00 & 0.00 & 0.00 & 0.00 & 0.00 & 0.00 & 0.00 & 000 \\
\hline $\mathrm{O}_{-} \mathrm{Cl}$ & 0.00 & 0.00 & 0.00 & 0.00 & 0.00 & 0.00 & 0.00 & 0.00 & 0.00 \\
\hline $\mathrm{12} 2 \mathrm{O}$ & 0.00 & 0.00 & 0 & 0 & 0 & 0 & 0 & 0 & 0 \\
\hline CTotal & 96.60 & 97.12 & 80.58 & 84.94 & 84.08 & 82.64 & 82.64 & 83.09 & 85.19 \\
\hline $\mathrm{TSi}$ & 7.301 & 6.099 & 7.293 & 7.255 & 7.144 & 7.161 & 7.161 & 7.156 & 6.764 \\
\hline TAl & 0.401 & 1.901 & 0.707 & 0.745 & 0.856 & 0.839 & 0.839 & 0.844 & 1.236 \\
\hline TFe 3 & 0.000 & 0.000 & 0.000 & 0.000 & $0.00(x)$ & 0.000 & $0.0 \times 1$ & 0.000 & 0.000 \\
\hline $\operatorname{TTi}$ & 0.992 & 0.000 & 0.000 & 0.000 & 0.000 & 0.000 & 0.000 & 0.000 & 0.000 \\
\hline Sum_ $Y$ & 8.694 & 8.000 & 8.000 & 8.000 & 8.000 & $80(0 \times)$ & 8.000 & 8.006 & 8.0003 \\
\hline $\mathrm{CAl}$ & 0.000 & 0.412 & 0.503 & 0.642 & 0.514 & 0.481 & 0.481 & 0.478 & 0.312 \\
\hline $\mathrm{CCr}$ & 0.000 & 0.006 & 0.018 & 0.000 & 0.000 & 0.000 & 0.000 & 0.004 & 0.000 \\
\hline $\mathrm{Cre} 3$ & 0.000 & 0.000 & 0.000 & 0.000 & 0.000 & 0.000 & 0.000 & 0.000 & 0.000 \\
\hline $\mathrm{cri}$ & 0.000 & 0.887 & 0.000 & 0.001 & 0.016 & $O(x)$ & 0.000 & 0.000 & 0.000 \\
\hline $\mathrm{CM}_{B}$ & 2.054 & 3.371 & 4.479 & 4.356 & 4.471 & 4.519 & 4.519 & 4.518 & 4.688 \\
\hline $\mathrm{CFe}_{2}$ & 1.954 & 0.325 & 0.000 & 0.000 & 0.000 & 0.000 & 0.000 & 0.000 & 0.000 \\
\hline CMn & 0.026 & 0.000 & 0.000 & 0.000 & 0.000 & 0.000 & 0.000 & 0.000 & 0.000 \\
\hline $\mathrm{CCa}$ & 0.312 & 0.000 & 0.000 & 0.000 & 0.000 & 0.000 & 0.000 & 0.000 & 0.000 \\
\hline Sum_ C & 4.346 & $5.000)$ & 5.000 & 5.000 & 5.000 & 5.000 & 5.000 & 5.000 & 5.000 \\
\hline $\mathrm{BMg}$ & 0.000 & 0.000 & 1.030 & 0.708 & 0.554 & 0.707 & 0.707 & 0.845 & 0.826 \\
\hline $\mathrm{BF} / 2$ & 0.000 & 0.760 & 0.793 & 1.105 & 1.108 & 1.123 & 1.123 & 1.091 & 1.330 \\
\hline $\mathrm{BMn}$ & 0.000 & 0.010 & 0.011 & 0.003 & 0.000 & 0.000 & 0.000 & 0.000 & 0.011 \\
\hline $\mathrm{BCa}$ & 0.000 & 0.003 & 0.166 & 0.184 & 0.338 & 0.170 & 0.170 & 0.065 & 0.000 \\
\hline $\mathrm{BNa}$ & 2.000 & 0.570 & 0.000 & 0.000 & 0.000 & 0.000 & 0.000 & 0.000 & 0.000 \\
\hline $\operatorname{Stan}_{-} B$ & 2.000 & 1.344 & 2.000 & 2.000 & 2.000 & 2.000 & 2.000 & 2.000 & 2.167 \\
\hline $\mathrm{AC} 3$ & 0.000 & 0.000 & 0.080 & 0.039 & 0.131 & 0.158 & 0.158 & 0.172 & 0.283 \\
\hline $\mathrm{ANa}$ & 0.481 & 0.000 & 0.010 & 0.000 & 0.028 & 0.013 & 0.013 & 0.009 & 0.009 \\
\hline AK & 0.450 & 1.586 & 0.013 & 0.018 & 0.016 & 0.025 & 0.025 & 0.004 & 0.010 \\
\hline $\mathrm{Sum}_{+} \mathrm{A}$ & 0.931 & 1.586 & 0.102 & 0.057 & 0.176 & 0.196 & 0.196 & 0.186 & 0.303 \\
\hline Sun_cat & 15.971 & 15.929 & 15.102 & 15.057 & 15.176 & 15.196 & 15.196 & 15.186 & 15.470 \\
\hline $\mathrm{CCl}$ & 0.000 & 0.000 & 0.000 & 0.000 & 0.000 & 0.000 & 0.000 & 0.000 & 0.000 \\
\hline$C F$ & 0.000 & 0.000 & 0.000 & 0.000 & 0.000 & 0.000 & 0.000 & 0.0000 & 0.000 \\
\hline OH & - & . & $\cdot$ & - & $\cdot$ & 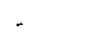 & - & $\cdot$ & . \\
\hline Sum_axy & 22.999 & 22.997 & 22.998 & 22.998 & 22.998 & 22.998 & 22.998 & 22.998 & 22.998 \\
\hline
\end{tabular}




\begin{tabular}{|c|c|c|c|c|}
\hline $\begin{array}{l}\text { Sample } \\
\text { Analysis }\end{array}$ & 26.008 & 26.000 & 26.010 & 26,011 \\
\hline Location & YMI-6 & $\mathrm{YZU} \cdot 6$ & YMI-6 & YML-6 \\
\hline Mineral & ANIF & $\mathrm{ANF}$ & ANF: & ANI: \\
\hline $\mathrm{SiO} 2$ & 44.80 & 43.26 & 42.67 & 42.05 \\
\hline TiO2 & 0.14 & 0.08 & 0 & 0 \\
\hline $\mathrm{Al} 2 \mathrm{O} 3$ & 8.33 & 7.14 & 7.86 & 8.16 \\
\hline $\mathrm{FOO}$ & 8.93 & 8.92 & 9.11 & 9.34 \\
\hline $\mathrm{Cr} 203$ & 0 & 0.08 & 0 & 0 \\
\hline $\mathrm{MnO}$ & 0.05 & 0.08 & 0 & 0.09 \\
\hline $\mathrm{MgO}$ & 19.11 & 21.10 & 20.52 & 17.85 \\
\hline $\mathrm{CrO}$ & 1.64 & 1.60 & 220 & 212 \\
\hline $\mathrm{Na} 2 \mathrm{O}$ & 0.03 & 0.08 & 0 & 0 \\
\hline $\mathrm{K} 2 \mathrm{O}$ & 0.97 & 0.07 & 0.08 & 0.12 \\
\hline $\mathrm{F}$ & 0 & 0 & 0 & 0 \\
\hline $\mathrm{Cl}$ & 0 & 0 & 0 & 0 \\
\hline Total & 84.00 & 82.33 & 82.44 & 79.73 \\
\hline $\mathrm{O}_{-} \mathrm{F}_{-} \mathrm{Cl}$ & 0.00 & 0.00 & 0.00 & $0 .(x)$ \\
\hline$O_{-} F$ & $0 . \infty$ & 0.00 & 0.00 & 0.00 \\
\hline $\mathrm{O} \mathrm{Cl}$ & 0.00 & 0.00 & 0.00 & 0.00 \\
\hline$\$ 20$ & 0 & 0 & 0 & 0 \\
\hline Clotsl & 84.00 & 82.33 & 82.44 & 79.73 \\
\hline TSi & 7.208 & 7.098 & 7.017 & 7.144 \\
\hline TAJ & 0.792 & 0.902 & 0.983 & 0.856 \\
\hline TFe 3 & 0.000 & 0.000 & $0.0 \times 0$ & 0.000 \\
\hline TTi & 0.000 & 0.000 & 0.000 & 0.000 \\
\hline Susm_T & 8.000 & 8.000 & 8.000 & 8.000 \\
\hline CAl & 0.787 & 0.478 & 0.540 & 0.777 \\
\hline $\mathrm{CCr}$ & 0.000 & 0.010 & 0.000 & 0.000 \\
\hline $\mathrm{CF} \times 3$ & 0.000 & 0.000 & 0.000 & 0.000 \\
\hline $\mathrm{Cri}$ & 0.017 & 0.010 & 0.000 & 0.000 \\
\hline $\mathrm{CMB}_{8}$ & 4.196 & 4.502 & 4.460 & 4.223 \\
\hline $\mathrm{CFe}_{2}$ & 0.0000 & 0.000 & 0.000 & 0.000 \\
\hline CMn & 0.000 & 0.000 & 0.000 & 0.000 \\
\hline $\mathrm{CCa}$ & 0.000 & 0.000 & $0.000)$ & 0.000 \\
\hline Sum_C & 5.000 & 5.000 & 5.000 & 5.000 \\
\hline $3 \mathrm{Mg}$ & 0.388 & 0.659 & 0.570 & 0.298 \\
\hline $\mathrm{BF} 2$ & 1.202 & 1.224 & 1.253 & 1.327 \\
\hline $\mathrm{BMn}$ & 0.007 & 0.011 & 0.000 & 0.013 \\
\hline $\mathrm{BCa}$ & 0.283 & 0.106 & 0.177 & 0.362 \\
\hline $\mathrm{BNa}$ & 0.009 & 0.000 & 0.000 & 0.000 \\
\hline Sum_B & 1.888 & 2.000 & 2.000 & 2.000 \\
\hline $\mathrm{ACa}$ & 0.000 & 0.175 & 0.211 & 0.024 \\
\hline ANa & 0.000 & 0.025 & 0.000 & 0.000 \\
\hline$A K$ & 0.199 & 0.015 & 0.017 & 0.026 \\
\hline Sum $A$ & 0.199 & 0.215 & 0.228 & 0.050 \\
\hline Sum_cat & 15.087 & 15.215 & 15.228 & 15.050 \\
\hline $\mathrm{CCl}$ & 0.000 & 0.000 & 0.000 & 0.000 \\
\hline $\mathrm{CF}$ & 0.000 & 0.000 & 0.000 & 0.000 \\
\hline $\mathrm{OH}$ & $\cdot$ & - & - & - \\
\hline Sun_oxy & 22.998 & 22.998 & 22.998 & 22.998 \\
\hline
\end{tabular}


Composição química, em porcentagem em peso, de feldspatoide/zeólitas de rochas "lamprofíricas" do Paraguai. (Lc, ZEO)

"Lamprófiros"

Ymi1 (10.000-10.101; 10c.000-10c.004);

Ymi-4 (14.000-14.019);

Ymi-7 (17.000-17.006);

Yzu-1 (21.000-21.003).

"Lamproitos"

$\ddot{Y} \mathrm{mi}-5(15.002-15.006)$;

Yzu-2 (22.00-22.004). 


\begin{tabular}{|c|c|c|c|c|c|c|c|c|c|c|c|c|c|}
\hline SAMPIE & ANALYSSSS & LOCATION & WINERAL & S102 & AL203 & FEO & $m \infty$ & MGO & $C A O$ & NA2O & $k 20$ & BAO & TOtal \\
\hline 21.000 & $\mathrm{gm}$ & YZU.1 & LC & 55,25 & 24,62 & 0,03 & 0,04 & 0,07 & 0,11 & 10,43 & 0,12 & 0,04 & 90,71 \\
\hline 21.001 & $\mathrm{gm}$ & YZU.1 & Lc & 56,38 & 24,70 & 0,20 & 0,00 & 0,04 & 0,13 & 9,22 & 0,14 & 0,13 & 90,94 \\
\hline 21.002 & $\mathrm{gm}$ & YZU.1 & Lc & 55,92 & 24,89 & 0,13 & 0,03 & 0,08 & 0,19 & 10,26 & 0,08 & 0,00 & 91,58 \\
\hline 21.003 & $\mathrm{gm}$ & YZU.1 & Lc & 55,80 & 24,55 & 0,07 & 0,00 & 0,03 & 0,15 & 10,36 & 0,11 & 0,00 & 91,07 \\
\hline 10.002 & $\mathrm{gm}$ & YML-1-p\} & LC & 58,20 & 25,35 & 0,24 & 0,00 & 0,15 & 0,09 & 5,21 & 0,25 & 0,00 & 89,49 \\
\hline 10.003 & $\mathrm{gm}$ & YM|-1-p| & Lc & 56,67 & 24,94 & 0,34 & 0,01 & 0,09 & 0,14 & 5,36 & 0,29 & 0,00 & 87,84 \\
\hline 10.004 & $\mathrm{gm}$ & $Y M|-1-p|$ & Lc & 58,25 & 25,10 & 0,44 & 0,00 & 0,15 & 0,16 & 5,76 & 0,28 & 0,19 & 90,33 \\
\hline 10.007 & $\mathrm{gm}$ & YMl1-1-p1 & Lc & 59,28 & 24,83 & 0,26 & 0,00 & 0,12 & 0,20 & 4,70 & 0,17 & 0,00 & 89,56 \\
\hline 10.009 & $\mathrm{gm}$ & YM1-1-p & Lc & 58,63 & 25,22 & 0,18 & 0,00 & 0,10 & 0,23 & 4,46 & 0,17 & 0,11 & 89,10 \\
\hline 10.010 & $\mathrm{gm}$ & YM1-1-p2 & LC & 57,61 & 25,93 & 0,29 & 0,03 & 0,20 & 0,41 & 4,33 & 1,41 & 0,00 & 90,21 \\
\hline 10.013 & $\mathrm{gm}$ & YMI-1-p2 & Le & 58,77 & 25,05 & 0,33 & 0,04 & 0,12 & 0,39 & 3,95 & 1,61 & 0,07 & 90,33 \\
\hline 10.014 & $\mathrm{gm}$ & $Y M \mid-1-p 2$ & Lc & 58,32 & 25,15 & 0,32 & 0,03 & 0,16 & 0.44 & 3,59 & 1,65 & 0,04 & 89,70 \\
\hline 10.018 & $\mathrm{gm}$ & $Y M \mid-1-d$ & LC & 59,58 & 23,82 & 0,30 & 0,06 & 0,09 & 4,94 & 6,54 & 2,58 & 0,34 & 98,26 \\
\hline 10.019 & $\mathrm{gm}$ & YML-1-d & LC & 58,57 & 25,56 & 0,38 & 0,00 & 0,15 & 0,16 & 4,99 & 0,26 & 0,00 & 90,07 \\
\hline 10.020 & $\mathrm{gm}$ & YMI-1-d & LC & 58,47 & 25,11 & 0,37 & 0,04 & 0,11 & 0,13 & 4,76 & 0,22 & 0,02 & 89,23 \\
\hline 10.021 & $\mathrm{gm}$ & $Y M I-1-d$ & Lc & 58,58 & 25,03 & 0,38 & 0,00 & 0,11 & 0,10 & 5,57 & 0,24 & 0,09 & 90,10 \\
\hline $10 \mathrm{c} .000$ & $\mathrm{gm}$ & $Y M-1 C$ & Lc & 56,52 & 25,12 & 0,35 & 0,00 & 0,12 & 0,20 & 11,46 & 0,22 & 0,00 & 93,99 \\
\hline $10 \mathrm{c} .001$ & $\mathrm{gm}$ & YML-1C & LC & 57,84 & 18,10 & 0,61 & 0,05 & 0,10 & 5,83 & 3,25 & 10,40 & 0,26 & 96,44 \\
\hline $10 \mathrm{c} .002$ & $\mathrm{gm}$ & YM1-1C & Lc & 57,13 & 22,52 & 0,63 & 0,00 & 0,06 & 0,98 & 5,62 & 8,04 & 0,48 & 95,46 \\
\hline $10 \mathrm{c} .003$ & $\mathrm{gm}$ & $Y M \mid-1 C$ & LC & 54,36 & 24,01 & 0,57 & 0,00 & 0,04 & 0,73 & 12,99 & 0,44 & 0,10 & 93,24 \\
\hline $10 \mathrm{c} .004$ & $\mathrm{gm}$ & YMI-1C & Lc & 53,85 & 22,27 & 2,23 & 0,13 & 1,48 & 1,21 & 7,87 & 4,71 & 0,00 & 93,75 \\
\hline 17.000 & $\mathrm{gm}$ & YMl-7 & Lc & 54,18 & 16,92 & 4,12 & 0,04 & 5,05 & 9,28 & 5,37 & 0,20 & 0,00 & 95,16 \\
\hline 17.001 & $\mathrm{gm}$ & YML-7 & LC & 58,32 & 25,23 & 0,67 & 0,02 & 0,09 & 0,22 & 8,52 & 0,20 & 0,00 & 93,27 \\
\hline 17.002 & $\mathrm{gm}$ & $Y M 1-7$ & LC & 58,19 & 25,03 & 0,32 & 0,01 & 0,04 & 0,14 & 9,33 & 0,17 & 0,00 & 93,23 \\
\hline 17.005 & $\mathrm{gm}$ & YML-7 & LC & 55,95 & 24,14 & 0,23 & 0,09 & 0,00 & 0,23 & 10,71 & 0,20 & 0,00 & 91,55 \\
\hline 17.004 & $\mathrm{gm}$ & YMI-7 & Lc & 54,72 & 24,98 & 0,37 & 0.00 & 0,08 & 0,30 & 12,20 & 0,19 & 0,03 & 92,87 \\
\hline 17.006 & $\mathrm{gm}$ & $Y M \mid-7$ & LC & 55,25 & 24,25 & 0,30 & 0,11 & 0,02 & 0,97 & 8,89 & 4,21 & 0,55 & 94,55 \\
\hline 14.000 & ad. & YMII-4-d & ZEO & 44,73 & 29,57 & 0,07 & 0,00 & 0,07 & 8,13 & 4,25 & 0,04 & 0,00 & 86,86 \\
\hline 14.001 & ad. & YMI-4-d & ZEO & 56,80 & 24,63 & 0,00 & 0,00 & 0,00 & 0,11 & 9,57 & 0,08 & 0,00 & 91,19 \\
\hline 14.002 & ad. & $Y M \mid-A-d$ & ZEO & 41,79 & 30,41 & 0,06 & 0,01 & 0,56 & 10,88 & 2,26 & 0,05 & 0,11 & 86,13 \\
\hline 14.003 & ad. & $Y M \mid-4-d$ & ZEO & 46,31 & 28,86 & 0,00 & 0,04 & 0,77 & 5,65 & 2,97 & 0,08 & 0,07 & 84,75 \\
\hline 14.004 & ad. & YMI-4-1 & ZEO & 56,81 & 23,60 & 0,00 & 0,01 & 0,08 & 0,05 & 11,20 & 0,01 & 0,02 & 91,78 \\
\hline 14.007 & ad. & YMI-4-1 & ZEO & 49,67 & 29,81 & 0,00 & 0,03 & 0,08 & 3,95 & 6,11 & 0,00 & 0,00 & 89,65 \\
\hline 14.006 & $\mathrm{ad}$ & YMI-4-1 & ZEO & 40,38 & 23,94 & 0,05 & 0,00 & 0,02 & 3,16 & 4,00 & 0,01 & 0,18 & 71,74 \\
\hline 14.008 & $\mathrm{gm}$ & YM1-4-d & ZEO & 39,39 & 30,30 & 0,34 & 0,07 & 0,16 & 12,02 & 2,67 & 0,31 & 0,00 & 85,26 \\
\hline 14.009 & $\mathrm{gm}$ & YMI-4-d & ZEO & 42,71 & 30,00 & 0,30 & 0,05 & 0,13 & 10,68 & 2,15 & 1,45 & 0,15 & 87,62 \\
\hline
\end{tabular}




\begin{tabular}{|c|c|c|c|c|c|c|c|c|c|c|c|c|}
\hline 14.010 & $\mathrm{gm}$ & YMI-4-d ZEO & 39,15 & 31,16 & 0,28 & 0,06 & 0,11 & 12,22 & 2,96 & 0,04 & 0,19 & 86,17 \\
\hline 14.011 & $\mathrm{gm}$ & YMI-4-d ana & 56,11 & 24,79 & 0,1 & 0,00 & 0,01 & 0,05 & 10,62 & 0,08 & 0,00 & 91,77 \\
\hline 14.012 & $\mathrm{gm}$ & $Y M 1-4-d$ & 55,86 & 24,25 & 0,03 & 0,00 & 0,04 & 0,04 & 10,68 & 0,05 & 0,00 & 91,05 \\
\hline 14.013 & $\mathrm{gm}$ & $Y M \mid-4-d$ & 56,81 & 24,11 & 0,00 & 0,00 & 0,06 & 0,07 & 10,40 & 0,08 & 0,15 & 91,78 \\
\hline 14.014 & $\mathrm{gm}$ & $Y M \mid-4-d$ & 56,61 & 24,15 & 0,01 & 0,00 & 0,10 & 0,07 & 10,64 & 0,08 & 0,00 & 91,66 \\
\hline 14.015 & $\mathrm{gm}$ & YMI-4-d & 56,54 & 23,90 & 0,04 & 0,00 & 0,04 & 0,04 & 9,98 & 0,07 & 0,04 & 90,65 \\
\hline 14.016 & $g m$ & YM1-4-1 & 56,66 & 23,98 & 0,00 & 0,00 & 0,10 & 0,02 & 11,16 & 0,03 & 0,07 & 92,02 \\
\hline 14.017 & $\mathrm{gm}$ & YMI-4-1 & 57,38 & 24,22 & 0,05 & 0,01 & $0, \uparrow 1$ & 0,13 & 10,25 & 0,03 & 0,04 & 92,22 \\
\hline 14.018 & $\mathrm{gm}$ & YM1-4-1 & 57,06 & 24,69 & 0,11 & 0,00 & 0,08 & 0,14 & 10,32 & 0,08 & 0,19 & 92,67 \\
\hline 14.005 & $\mathrm{ad}$ & YMl-4-1 ZEO & 56,38 & 24,16 & 0,42 & 0,00 & 0,15 & 0,69 & 8,40 & 0,77 & 0,19 & 91,16 \\
\hline 14.019 & $\mathrm{gm}$ & YMl-4-I ana & 57,69 & 24,71 & 0,12 & 0,00 & 0,06 & 0,06 & 10,23 & 0,09 & 0,22 & $93, \uparrow 8$ \\
\hline 10.000 & $\mathrm{gm}$ & YMl-1-p2 LC & 57,35 & 24,99 & 0,30 & 0,00 & 0,08 & 3,34 & 7,81 & 1,88 & 0,00 & 95,85 \\
\hline 10.100 & $\mathrm{gm}$ & YM-1-d ana & 61,22 & 10,18 & 0,83 & 0,00 & 1,34 & 1,80 & 3,99 & 8,98 & 0,00 & 97,34 \\
\hline 10.010 & gm & YMl-1-d LC & 58,79 & 25.37 & 0,55 & 0,06 & 0,38 & 6,31 & 6,36 & 1,20 & 0,00 & 99,02 \\
\hline 10.011 & $\mathrm{gm}$ & YMI-A-p1 LC & 59,35 & 23,46 & 0,42 & 0,01 & 0,28 & 4,32 & 5,59 & 3,79 & 0,00 & 97,22 \\
\hline 10.005 & $\mathrm{gm}$ & YMI-1-p1 LC & 61,48 & 18,26 & 0,61 & 0,04 & 0,13 & 2,20 & 3,20 & 11,38 & 0,00 & 97,30 \\
\hline 10.006 & $\mathrm{gm}$ & YMl-1-p1 LC & 49,86 & 32,40 & 1,17 & 0,04 & 0,16 & 0,27 & 10,53 & 3,77 & 0,00 & 98,30 \\
\hline 10.101 & $\mathrm{gm}$ & YMl-1-d ana & 51,33 & 22,36 & 0,56 & 0,00 & 0,46 & 5,07 & 4,62 & 0,19 & 0,00 & 84,59 \\
\hline 10.022 & $\mathrm{gm}$ & YMI-1-d LC & 58,93 & 24,91 & 0,50 & 0,00 & 0,18 & 0,34 & 4,90 & 0,14 & 0,00 & 89,90 \\
\hline
\end{tabular}




\begin{tabular}{|c|c|c|c|c|c|c|c|c|c|}
\hline Sampie & $15 \% 2$ & $15: x_{2} 3$ & $15 \mathrm{~mm}$ & 15005 & $1 \varsigma \mathrm{s}$ & $22 \mathrm{ar}$ & 22001 & 22.002 & 22003 \\
\hline Amalysis & pssite & $m s d-l c$ & $\mathrm{ps} \dot{a} \cdot \mathrm{l} \cdot \mathrm{c}$ & gim & $g m$ & & & psad-ic & psdictc \\
\hline Location & $\mathrm{M}-5$ & YMI-5 & YMa.5 & YMz-5 & YMI.5 & Y2:13 & $Y Z 7 \% 2$ & $Y \geq \backslash, 2$ & Yzt:-2 \\
\hline Mineral & $1, c$ & Lc & l.c & Le & $\mathrm{t} . c$ & 280 & ZEO & ZEO & $Z E O$ \\
\hline $\mathrm{SiO} 2$ & 56.87 & 56.81 & 55.93 & 48.11 & 5427 & 6015 & 59.85 & 39.86 & 49.93 \\
\hline $\mathrm{T}_{102}$ & $0 \infty$ & 0.02 & 0.12 & 0.00 & 000 & 008 & 0.05 & 002 & 005 \\
\hline $\mathrm{A} 2 \mathrm{OO}$ & 25.51 & 25.88 & 26.65 & 3010 & 25.67 & 25.03 & 25.99 & 30.85 & 26.94 \\
\hline $\mathrm{Fe} 203$ & 0.25 & 0.33 & 0.26 & 0.01 & 839 & 0.79 & 0.20 & 1.14 & 0.46 \\
\hline $\mathrm{MnO}$ & 0.01 & $00 \mathrm{i}$ & 000 & 0.01 & 001 & 0.00 & 0.07 & 0.00 & 0.02 \\
\hline $\mathrm{NgO}$ & 0.62 & 0.06 & 0.10 & 0.05 & 0.11 & 000 & 0.10 & 0.14 & 0.30 \\
\hline $\mathrm{CaO}$ & 0.11 & 0.26 & 0.28 & 0.65 & 009 & 1.74 & 101 & 11.72 & 0.30 \\
\hline $\mathrm{Na} 20$ & 5.85 & 7.53 & 6.13 & 9.54 & 870 & 280 & 3.34 & 2.19 & 2.77 \\
\hline $\mathrm{K} 20$ & 0.36 & 0.54 & 0.73 & 005 & 0.42 & 531 & 1.95 & 0.32 & 0.26 \\
\hline $\mathrm{RaO}$ & 0.00 & 0.00 & 0.00 & 0.00 & 0.00 & 0.24 & 0.14 & 0.12 & 0.04 \\
\hline $\mathrm{sro}$ & 000 & $0 \infty$ & 0.00 & 0.00 & 00 & 0.09 & 0.00 & 0.00 & 0.00 \\
\hline Total & 89,98 & 91,44 & 90,21 & 88.52 & 89,75 & 96,23 & 92.70 & 86,36 & 90,07 \\
\hline Si & 10.953 & 10,833 & 10.760 & 9,653 & 10,626 & 11.077 & 11,149 & 8,462 & 9.900 \\
\hline A.l & 5,786 & 5,812 & 6,040 & $7, \mathrm{i} 1 \mathrm{i}$ & 5.910 & $5,4,28$ & 5,702 & 7.713 & 6,291 \\
\hline $\mathrm{Fe}$ & 0,036 & 0,047 & 0,038 & 0,002 & 0,057 & 0,109 & 0.028 & 0,182 & 0.069 \\
\hline $\mathrm{Ti}$ & 0,000 & 0,003 & 0.017 & $0,0 \infty 0$ & 0,000 & 0,011 & 0,007 & 0.003 & 0,007 \\
\hline $\mathrm{Mn}$ & 0,002 & 0,02 & 0,000 & 0.002 & 0,092 & 0.600 & 0,011 & 0,000 & 0,003 \\
\hline $\mathrm{Mg}_{3}$ & 0005 & $0,01 ?$ & 0.029 & 0.015 & 0,032 & 0,025 & 0.028 & 0,044 & 0,089 \\
\hline $\mathrm{ca}$ & 0.023 & 0.053 & 0,058 & 0,140 & 0,019 & 0,343 & 0,202 & 2.666 & 1,976 \\
\hline $\mathrm{Niz}$ & 2,558 & 2,784 & 2,287 & 3,711 & 3,337 & 1,000 & 1,206 & 0,902 & 1,065 \\
\hline K & 0,088 & 0,131 & 0,179 & 0,013 & 0,105 & 1.248 & 0,463 & 0,087 & 0,066 \\
\hline $\mathrm{Ba}$ & 0,000 & 0,000 & 0,000 & 0,000 & 0,000 & 0,017 & 0.010 & 0,010 & 0,003 \\
\hline$S_{\pi}$ & 0,000 & 0.000 & 0,000 & 0,000 & 0,000 & $0,0 \times 0$ & $0,0 \infty 0$ & 0,000 & 0,000 \\
\hline Cations & 17.000 & 17,000 & 18,000 & $\{9,000\}$ & 18,000 & 18,000 & 17,000 & 17,000 & 17,000 \\
\hline$A b$ & 100,0 & 100,0 & 100.0 & 100,0 & 100,0 & 50.0 & 100,0 & 0,0 & 50,0 \\
\hline Ans & 0,0 & 0,0 & 0,0 & 0,0 & 0,0 & 0,0 & 0,0 & 100,0 & 50,0 \\
\hline Or & 0,0 & 0.0 & 0,0 & 00 & 0.0 & 50.0 & 0,0 & 0,0 & 0,0 \\
\hline
\end{tabular}




\begin{tabular}{|c|c|}
\hline Samplc & $22 \mathrm{k} / \mathrm{s}$ \\
\hline Anahysis & psidit \\
\hline Location & $Y Z 12$ \\
\hline Minesal & ZEO \\
\hline $\mathrm{SiO} 2$ & 54.08 \\
\hline TiO2 & 607 \\
\hline $\mathrm{A} 2 \mathrm{O}_{3}$ & 2439 \\
\hline $\bar{F} \in 20 ?$ & 343 \\
\hline $\mathrm{MrO}$ & $0(0)$ \\
\hline $\mathrm{MgO}$ & 039 \\
\hline 60 & $2 \$ 3$ \\
\hline $\mathrm{N} 220$ & 971 \\
\hline $\mathrm{k} 20$ & 10.12 \\
\hline $\mathrm{B} \approx \mathrm{O}$ & 1.29 \\
\hline 950 & 0.00 \\
\hline Total & 97.01 \\
\hline $\mathrm{Si}$ & 10.412 \\
\hline AI & 5,530 \\
\hline $\mathrm{Fe} 3$ & 0.496 \\
\hline $\mathrm{Ti}$ & 0.010 \\
\hline $\mathrm{Mn}$ & 0,000 \\
\hline$M_{B}$ & 0.112 \\
\hline $\mathrm{Ca}$ & 0,522 \\
\hline $\mathrm{Nz}$ & 0.265 \\
\hline $\mathrm{k}$ & 2.486 \\
\hline $\mathrm{Ba}$ & 0.097 \\
\hline Sr & 0,000 \\
\hline Cations & $17,0 \times 0$ \\
\hline$A b$ & 0,0 \\
\hline An & 0,0 \\
\hline$\pi$ & 100,0 \\
\hline
\end{tabular}




\section{A7}

Composição química, em porcentagem em peso, de feldspatos de rochas "lamprofíricas" do Paraguai.

(SAN)

\section{"Lamprófiros"}

$Y \operatorname{mi-1}(10.000-10.026,10 \mathrm{c} .001-10 \mathrm{c} .007) ;$

Ymi-4 (14.000-14.003);

Ymi-7 (17.001-17.002);

Yzu-1 (21.000-21.015).

\section{"Lamproitos"}

Ymi-5 (15.000-15.012);

Yzu-2 (22.000-22.017);

Ymi-3 (23.000-23.013);

Ymi-6 (26.000-26.014).

Ricos em Fe: $10.010,21.001,21.004-21.006,21.008,21.010-21.012,21.015$, $15.001,22.000-22.005,22.007-22.009,22.012-22.014,22.016,23.000,23.002$, 26.000-26.012, 26.014.

Ricos em Ba: 21.002, 21.003, 21.007, 21.008, 21.010-21.012, 21.015, 15.001, $15.004-15.006,15.008,15.011,15.012,22.000,22.001,22.003,22.005,22.007$, $22.009,22.012-22.014,23.006,23.010,26.003,26.004,26.006$. 


\begin{tabular}{|c|c|c|c|c|c|c|c|c|c|}
\hline Sample & POCB & $10, x+1$ & 10002 & 10003 & bogen & $16(k) s$ & 10006 & frotor & 10.008 \\
\hline \multicolumn{10}{|l|}{ Analysis } \\
\hline Location & $Y_{\operatorname{mil}}-d$ & $Y_{m i-i p i}$ & $Y m i n-\{n\}$ & $\dot{Y} \mathrm{mi}-\mid-\mathrm{pl}$ & Yma-i-p? & $x m i-1-p l$ & $Y m i-1-n$ & $Y_{m i-3-p^{2}}$ & $Y_{\mathrm{min}-\mathrm{p} 2}$ \\
\hline Mineral & SAN & SAN & SAN & $\operatorname{SAN}$ & $\operatorname{san}$ & SAN & SAN & SAN & SAN \\
\hline $\mathrm{SiO}_{2}$ & 60.05 & 62.86 & 62.92 & 63.16 & 5486 & 65.34 & 63.24 & 64.45 & 63.89 \\
\hline $\mathrm{T} \% 2$ & 0.06 & 0.03 & 0.22 & 0.02 & 0.09 & 0.69 & 0.07 & 0.10 & 0.10 \\
\hline $\mathrm{A} 2 \mathrm{OO}$ & 25.03 & 20.31 & 20.85 & 20.16 & 19.92 & 19.45 & 18.52 & 20.60 & 2011 \\
\hline $\mathrm{FeO}$ & 0.38 & 0.10 & 0.24 & 0.54 & 0.21 & 0.25 & 0.16 & 0.25 & 0.16 \\
\hline $\mathrm{MnO}$ & 0.04 & 0.00 & 0.00 & 0.00 & 0.00 & 000 & 0.00 & 0.00 & 0.00 \\
\hline $\mathrm{MgO}$ & 0.20 & 0.05 & 0.04 & 0.02 & 00 & 0.01 & 0,00 & 0.06 & 0.07 \\
\hline 820 & 0.00 & 0.80 & 0.78 & 0.00 & 007 & 0.00 & 0.15 & $0.6 \mathrm{t}$ & 0.15 \\
\hline $\mathrm{CaO}$ & 602 & 000 & 1.12 & 101 & 0.37 & 0.34 & 2.76 & $1 \mathrm{n}$ & 6.83 \\
\hline $\mathrm{Na2O}$ & 6.94 & 0.26 & 5.08 & 4.96 & 4.71 & 4.48 & 3.73 & $s \$ 4$ & 4.85 \\
\hline $\mathrm{K} 2 \mathrm{O}$ & $m$ & 16.75 & 7.76 & 8.50 & 0.56 & 9.92 & 10.43 & 7.57 & 8.76 \\
\hline Total & 99.83 & 101.17 & 99.01 & 98.37 & 99.77 & 9988 & 99.06 & 100.19 & 98.92 \\
\hline Si & 10736 & 11.620 & 11.526 & 11.630 & 11.768 & 11.849 & 11.714 & 11.630 & 11.685 \\
\hline $\mathrm{Al}$ & 5.270 & 4.422 & 4.498 & 4.371 & 4.256 & 4.154 & 4.040 & 4.378 & 4.331 \\
\hline Fe3 & 0.00 & 0.00 & 0.00 & 0.00 & 0.00 & 0.00 & 000 & 0.00 & 0.00 \\
\hline $\mathrm{Ti}_{\mathrm{i}}$ & 0.008 & 0.004 & 0.030 & 0.003 & 0.012 & 0.012 & 0.010 & 0.014 & 0.014 \\
\hline $\mathrm{Fe} \hat{z}$ & 0.057 & 0.015 & 0.037 & 0.083 & 0.032 & 0.038 & 0.025 & 0.038 & 0.024 \\
\hline $\mathrm{Mn}$ & 0.006 & 0.000 & 0.000 & 0.000 & 0.000 & 0.000 & 0.000 & 0,000 & 0.000 \\
\hline $\mathrm{Mg}$ & 0.053 & 0.017 & 0.011 & 0005 & 0.011 & 0.003 & 0.000 & 0.016 & 0.019 \\
\hline $\mathrm{Bz}$ & 0.000 & 0.058 & 0.056 & 0.000 & 0.005 & 0,000 & 0.011 & 0.043 & 0.013 \\
\hline $\mathrm{Cg}$ & 1.153 & 0.000 & 0.220 & 0.199 & 0.072 & 0.066 & 0.548 & 0.215 & 0.163 \\
\hline Na & 2.406 & 0.093 & 1.804 & 1.771 & 1.657 & i. 575 & 1340 & 1.938 & 1.720 \\
\hline K & 0.253 & 3.950 & 1.814 & 1.997 & 2.99 & 2.295 & 2.465 & 1.720 & 2.044 \\
\hline Cations & 19.942 & 20.237 & 20.052 & 20.059 & 20.017 & 19.992 & 20.164 & 20.035 & 20.022 \\
\hline $\mathrm{x}$ & 16.014 & 16.046 & 16.054 & 16.004 & 16.636 & 16,015 & 15.764 & 16.022 & 16.030 \\
\hline z & 3.928 & 4.133 & 3.942 & 4.055 & 3976 & 3.977 & 4.389 & 3.970 & 3.981 \\
\hline Ab & 63.1 & 2.3 & 47.0 & 44.6 & $4 \hat{x} .2$ & 40.0 & 30.8 & 50.0 & 43.8 \\
\hline An & 30.2 & 0.0 & 5.7 & 5.0 & 1.8 & 1.7 & $\lceil 2.6$ & 5.6 & 4.2 \\
\hline or & 6.6 & 97.7 & 47.3 & 50.3 & 56.0 & 58.3 & 56.6 & 44.4 & 52.0 \\
\hline
\end{tabular}




\begin{tabular}{|c|c|c|c|c|c|c|c|c|c|}
\hline $\begin{array}{l}\text { Sample } \\
\text { Aralyssis }\end{array}$ & 10,090 & 1000 & 1001 & 10012 & 50013 & 10014 & 10.917 & 10018 & 1000 \\
\hline Location & $y_{\min }-\mathrm{p}^{2}$ & Ymi-1d & $Y_{\operatorname{mi} i-1-p^{2}}$ & $Y$ mi-1-pl & $x \rightarrow-1-d$ & $Y m i-1 \alpha$ & $Y_{\mathrm{mi}-1-\mathrm{d}}$ & $X_{m i-1}$ & $Y m i-1-p 1$ \\
\hline Mintral & SAE: & SAN & SAN & SAN & $\operatorname{san}$ & $\mathrm{SAN}$ & SAN & $\mathrm{SAV}$ & SAN \\
\hline $\mathrm{SiO}_{2}$ & 64.47 & 6416 & 64.69 & 63.36 & 64.54 & .64 .42 & 66.09 & 62.38 & 61.26 \\
\hline $\mathrm{TiO} 2$ & 0.09 & 0.15 & 0,00 & 0.10 & 036 & 0.18 & 0.15 & 0.15 & 0.11 \\
\hline $\mathrm{Al}_{2} \mathrm{O}_{3}$ & 21.29 & 19.16 & 19.01 & 19.28 & 20.11 & 2046 & 19.89 & 18.59 & 23.28 \\
\hline FeO & 0.20 & 1.20 & 0.30 & 0.56 & 024 & 0.15 & 0.34 & 0.65 & 0.37 \\
\hline $\mathrm{MnO}$ & 0.00 & 0.00 & 0.00 & 0.60 & $\theta(x)$ & 0.00 & 0.00 & 0.65 & 000 \\
\hline $\mathrm{MgO}$ & 0.03 & 0.00 & 0.29 & 0.43 & $6 \infty$ & 0.15 & 0.06 & 0.96 & 0.19 \\
\hline $8 \mathrm{BO}$ & 0.87 & 0.00 & 0.00 & 0.00 & $a \infty$ & 045 & 000 & 0.00 & 0.00 \\
\hline $\mathrm{CaO}$ & 1.52 & 0.00 & 1.58 & 0.82 & 0.68 & 116 & 0.39 & 1.18 & 3.43 \\
\hline $\mathrm{Na} 2 \mathrm{O}$ & 5.75 & 2.92 & 2.48 & 2.22 & 5.35 & 4.70 & 4.41 & 3.86 & 6.67 \\
\hline $\mathrm{K} 2 \mathrm{O}$ & 6.79 & 12.54 & 11.94 & 12.45 & 8.84 & 8.86 & 10.00 & 9.95 & 3.18 \\
\hline Total & 101.01 & 100.13 & 100.29 & 99.23 & 99.92 & 100.53 & 101.33 & 97.78 & 98.49 \\
\hline $\mathrm{Si}$ & 11.538 & 11.782 & 11.803 & 11.716 & 11.692 & 11.629 & 11.814 & 11.657 & 11.100 \\
\hline Ai & 4.487 & 4.144 & 4.085 & $\$ .199$ & 4.290 & 4.350 & 4.187 & 4.091 & 4.967 \\
\hline $\mathrm{Fe} 3$ & 0.00 & 0.00 & 0.00 & 0.00 & $0 . \infty$ & 0.00 & 000 & 0.00 & 0.00 \\
\hline Tí & 0.012 & 0.021 & 0.000 & 0.014 & 0.622 & 0.024 & 0.020 & 0.022 & 0.015 \\
\hline $\mathrm{Fe} 2$ & 0030 & 0.184 & 0.046 & 0.087 & 0.036 & 0,023 & 0.051 & 0.102 & 0.056 \\
\hline Mrn & $0 n \infty)$ & 0.000 & 0.000 & 0.000 & 0000 & 0.000 & 0.000 & 0.008 & 0.000 \\
\hline Mǵg & 0.008 & 0.000 & 0.079 & 0.119 & 0.000 & 0.040 & 0.016 & 0.267 & 0.051 \\
\hline $\mathrm{Ba}$ & 0,061 & 0.000 & 0.000 & 0.000 & 6000 & 0.032 & 0.000 & 0.000 & 0.000 \\
\hline $\mathrm{Ca}$ & 0.291 & 0.000 & 0.309 & 0.162 & 0.132 & 0.224 & 0.075 & 0.236 & 0.666 \\
\hline $\mathrm{N} 2$ & 1.995 & 1.040 & 0.877 & 0.796 & 1.879 & 1645 & 1.528 & 1.399 & 2.343 \\
\hline $\mathrm{K}$ & 1.550 & 2.938 & 2.779 & 2.939 & 2.043 & 2.040 & 2.280 & 2.372 & 0.735 \\
\hline Cations & 20.033 & 20.109 & 19.978 & 20.032 & 20.094 & 20,039 & 19.971 & 20.154 & 19.933 \\
\hline $\mathrm{x}$ & 16.037 & 15.947 & 15.888 & 15.929 & 16.004 & 16.003 & 16.021 & 15.770 & 16.082 \\
\hline Z & 3.935 & 4.162 & 4.090 & 4.103 & 4,000 & 4.004 & 3.950 & 4.384 & 3.851 \\
\hline$A b$ & 52.0 & 26.1 & 22.1 & 20.4 & 46.3 & 42.1 & 39.4 & 34.9 & 62.6 \\
\hline An & 7.6 & 0.0 & 7.8 & 4.2 & 3.3 & 5.7 & 1.9 & 5.9 & 17.8 \\
\hline Or & 40.4 & 73.9 & 70.1 & 75.4 & 50.4 & 52.2 & 58.7 & 59.2 & 19.6 \\
\hline
\end{tabular}




\begin{tabular}{|c|c|c|c|c|c|c|c|c|c|}
\hline Sample & 10,021 & 10,025 & 10.026 & $10 \mathrm{~cm}$ & 100002 & 10.0003 & $10 . c 104$ & 100005 & $10 . c^{\prime} \times 16$ \\
\hline \multicolumn{10}{|l|}{ Analysis } \\
\hline Location & $Y_{\pi i-1} d$ & Ymi-1-d & $Y \operatorname{mi}-1-\dot{d}$ & Ymi-lc & $x_{m-1 c}$ & $Y_{m i-1 C}$ & $Y_{\mathrm{mi}-1 \mathrm{C}}$ & $Y_{m i-i c}$ & $Y_{m i-1 C}$ \\
\hline Mineral & SAN & SAAV & SAN & SAN & SAN & SAN & $\mathrm{SAN}$ & $\sin$ & SAN \\
\hline $\mathrm{S} \mathrm{SO}_{2}$ & 60.41 & 62.39 & 59.68 & 62.22 & 64.23 & 62.84 & 54.26 & 54.28 & 62.54 \\
\hline $\mathrm{THO} 2$ & 0.05 & 0.07 & 0.08 & 0.11 & 0.12 & 0.10 & 0.08 & 0.17 & 0.11 \\
\hline $\mathrm{Al}_{2} \mathrm{O} 3$ & 24.48 & 18.98 & 23.82 & 20.00 & 19.63 & 20.44 & 39.49 & 27.91 & 28.53 \\
\hline $\mathrm{FeO}$ & 0.40 & 0.24 & 0.30 & 0.36 & 0.36 & 0.27 & 0.25 & 0.90 & 0.40 \\
\hline $\mathrm{MnO}$ & 006 & 0.04 & 0.06 & 0.02 & 0.06 & 0.06 & 0.00 & 0.03 & 0.07 \\
\hline $\mathrm{MgO}$ & 0.07 & 0.07 & 0.09 & 0.08 & 0.04 & 0.07 & 0.05 & 0.12 & 0.00 \\
\hline $\mathrm{BaO}$ & 0.00 & 0.00 & 0.34 & 0.06 & 0.23 & 6.79 & 0.26 & 0.23 & 0.00 \\
\hline $\mathrm{C} 2 \mathrm{O}$ & 5.19 & $2.4 \mathrm{i}$ & 4.94 & 108 & 0.70 & 0.86 & 0.96 & 8.47 & 2.25 \\
\hline $\mathrm{Na} 2 \mathrm{O}$ & 6.60 & 3.09 & 6.54 & 4.69 & 5.44 & 3.73 & 3.92 & 6.24 & 6.41 \\
\hline $\mathrm{K} 2 \mathrm{O}$ & 2.10 & 11.31 & 2.59 & 9.78 & 8.65 & 10.49 & 10.83 & 0.74 & 6.42 \\
\hline Total & 99.36 & 98.60 & 98.44 & 98.40 & 99.46 & 99.65 & 100.10 & 99.10 & 99.73 \\
\hline $\mathrm{Si}$ & 10.862 & 31.636 & 10.885 & 31.551 & 13.718 & 11.564 & 11.735 & 9.937 & 11.343 \\
\hline $\mathrm{A}$ & 5.184 & 4.169 & 5.116 & 4.372 & 4.218 & 4.430 & 4.192 & 6.016 & 4.599 \\
\hline$\overline{\mathrm{Fe}} 3$ & 0.00 & 0.00 & 0.00 & 0.00 & 0.00 & 0.00 & 0.00 & 0.00 & 0.00 \\
\hline Ti & 0.007 & 0.010 & 0.011 & 0.015 & 0.016 & 0.014 & 0.011 & 0.023 & 0.015 \\
\hline$F \subset 2$ & 0.060 & 0.037 & 0.046 & 0.056 & 0.055 & 0.042 & 0.038 & 0.138 & 0.061 \\
\hline$M n$ & 0.009 & 0.006 & 0.009 & 0.003 & 0.000 & 0.009 & 0.000 & 0.005 & 0.011 \\
\hline $\mathrm{Mg}$ & 0.019 & 0.019 & 0.024 & 0.022 & 0.01 & 0.019 & 0.016 & 0.033 & 0.000 \\
\hline $\mathrm{Ba}$ & 0.000 & 0.000 & 0.024 & 0.004 & 0.016 & 0.057 & 0.019 & 0.016 & 0.000 \\
\hline $\mathrm{Cz}$ & 1.000 & 0.482 & 0.965 & 0.215 & 0.137 & 0.170 & 0.188 & 1.661 & 0.437 \\
\hline $\mathrm{N} / \mathrm{z}$ & 2.301 & 1.117 & 2.313 & 1.688 & 1924 & 1.331 & 1.388 & 2.235 & 2.254 \\
\hline $\mathrm{K}$ & 0.482 & 2.691 & 0.603 & 2.316 & 2.013 & 2.463 & 2.523 & 0.173 & 1.486 \\
\hline Cations & 19.924 & 20.167 & 20.020 & 20.246 & 20.133 & 20.156 & 20.127 & 20.233 & 20.206 \\
\hline$x$ & 16.053 & 15.815 & 16.012 & 15.938 & 15.952 & 36.008 & 15.938 & 15.976 & 15.957 \\
\hline$z$ & 3.871 & 4.352 & 3.984 & 4.304 & 4.165 & 4.091 & 4.170 & 4.241 & 4.249 \\
\hline $\mathrm{Ab}$ & 60.8 & 26.0 & 59.6 & 40.0 & 47.2 & 33.6 & 33.9 & 56,7 & 54.0 \\
\hline$A_{i \pi}$ & 26.4 & 11.2 & 24.9 & 5.1 & 3.4 & 4.3 & 4.6 & 41.0 & 10.5 \\
\hline Or & 12.7 & 62.7 & 15.5 & 54.9 & 49.4 & 62.1 & 61.6 & 4.3 & 35.6 \\
\hline
\end{tabular}




\begin{tabular}{|c|c|c|c|c|c|c|c|c|c|}
\hline $\begin{array}{l}\text { Sample } \\
\text { Aralysis }\end{array}$ & $\left.10_{c}, \alpha\right) 7$ & $1400 \%$ & $14 \%$ & 1462 & $1+603$ & 17,001 & 17.002 & 2.118 & $2 \log$ \\
\hline Location & $Y \mathrm{mi}-\mathrm{lC}$ & Ymi-4-1 & $\min -4$ & $Y_{\text {mil- }}$-d & Ym-4-d & $Y_{\mathrm{min}-7}$ & $Y_{\mathrm{mi}-7}$ & YZU & YZLi- \\
\hline Mineral & SAN & SAN & SAN & SAN & $\sin$ & SAN & SAN & $S A N$ & SAN \\
\hline $\mathrm{SiO} 2$ & 64.16 & 57.94 & 63.09 & 61.83 & $0: 80$ & 63.79 & 61.71 & 64.40 & 63.15 \\
\hline $\mathrm{niO} 2$ & 0.15 & 0.05 & 0.02 & 0.00 & $O(0)$ & 0.03 & 0.00 & 0.00 & 0.00 \\
\hline $\mathrm{Al} 2 \mathrm{O} 3$ & 20.04 & 26.13 & 18.8 .3 & 18.81 & 20.88 & 19.95 & 19.85 & 18.42 & 21.47 \\
\hline $\mathrm{FeO}$ & 0.56 & $0.5]$ & 0.14 & 0.09 & 0.18 & 0.88 & 0.22 & 0.38 & 0.54 \\
\hline Mno & 0.00 & 0.00 & 0.02 & 0.04 & 0.03 & 0.01 & 0.01 & 0.00 & 0.00 \\
\hline $\mathrm{MgO}$ & 0.17 & 0.18 & 0.06 & 0.03 & 0.05 & 0.37 & 0.07 & 0.00 & 0.10 \\
\hline $\mathrm{BaO}$ & 0.29 & 0.15 & 0.00 & 0.00 & 0.34 & 0.13 & 0.16 & 0.19 & 1.27 \\
\hline $\mathrm{CaO}$ & 0.94 & 0.10 & 0.00 & 2.02 & 000 & 1.9 & 0.92 & 0.10 & 1.27 \\
\hline $\mathrm{N} 22 \mathrm{O}$ & 5.57 & 4.70 & 0.08 & 0.86 & 169 & 4.20 & 3.49 & 2.87 & 5.89 \\
\hline $\mathrm{K} 20$ & 8.26 & 6.67 & 16.83 & 13.71 & 13.02 & 9.61 & 11.74 & 12.37 & 5.30 \\
\hline Total & 100.14 & 96.43 & 99.07 & 97.39 & 96.99 & 100.16 & 98.17 & 98.73 & 99.09 \\
\hline $\mathrm{Si}$ & 11.633 & 10.790 & 11.838 & 11.720 & 11.523 & 0.616 & 11.566 & 11.944 & 11.488 \\
\hline A! & 4.279 & 5.731 & 4.161 & 4.199 & 4.660 & 4.278 & 4.381 & 4.023 & 4.600 \\
\hline $\mathrm{F} e \hat{3}$ & 0.00 & 0.00 & 0.00 & 0.00 & 0.00 & 0.00 & 0.00 & 0.00 & 0.00 \\
\hline $\mathrm{Ti}$ & 0.020 & 0.007 & 0.003 & 0.000 & 0.000 & 0.004 & 0.000 & 0.000 & 0.000 \\
\hline $\mathrm{Fe} 2$ & 0.085 & 0.079 & 0.022 & 0.014 & 0.029 & 0.134 & 0.034 & 0.059 & 0.097 \\
\hline Mn & 0.000 & 0.000 & 0.003 & 0.005 & 0.005 & 0.002 & 0.002 & 0.000 & 0.000 \\
\hline $\mathrm{M}_{\mathrm{B}}$ & 0.046 & 0.050 & 0.017 & 0.008 & 0.014 & 0.100 & 0.020 & 0.000 & 0.027 \\
\hline $\mathrm{Ba}$ & 0.021 & 0.011 & 0.000 & 0.000 & 0.025 & 0.009 & 0.012 & 0.014 & 0.091 \\
\hline $\mathrm{Ca}$ & 0.183 & 0.020 & 0.000 & 0.410 & 0.000 & 0.232 & 0.185 & 0.020 & 0.248 \\
\hline $\mathrm{Na}$ & 1.958 & 1.697 & 0.029 & 0.316 & 0.621 & 1.483 & 1.268 & 1.032 & 2.078 \\
\hline $\mathrm{K}$ & 1.911 & 1.585 & 4.029 & 3.315 & 3.148 & 2.233 & 2.807 & 2.927 & 1.230 \\
\hline Cettions & 20.157 & 19.981 & 20.102 & 19.988 & 20.050 & 20.100 & 20.287 & 20.033 & 19.950 \\
\hline $\mathrm{x}$ & 15.932 & 16.528 & 16.002 & 15.919 & 16.183 & 15.898 & 15.947 & 15.867 & 16.088 \\
\hline$z$ & 4.204 & 3.442 & 4.100 & 4.069 & 3.842 & 4.193 & 4.328 & 4.052 & 3.771 \\
\hline $\mathrm{Ab}$ & 48.3 & 51.4 & 0.7 & 7.8 & 16.5 & 37.6 & 29.8 & 25.9 & 58.4 \\
\hline$A n$ & 4.5 & 0.6 & 0.0 & 10.1 & 0.0 & 5.9 & 4.3 & 0.5 & 7.0 \\
\hline Or & 47.2 & 48.0 & 99.3 & 82.0 & 83.5 & 56.6 & 65.9 & 73.6 & 34.6 \\
\hline
\end{tabular}




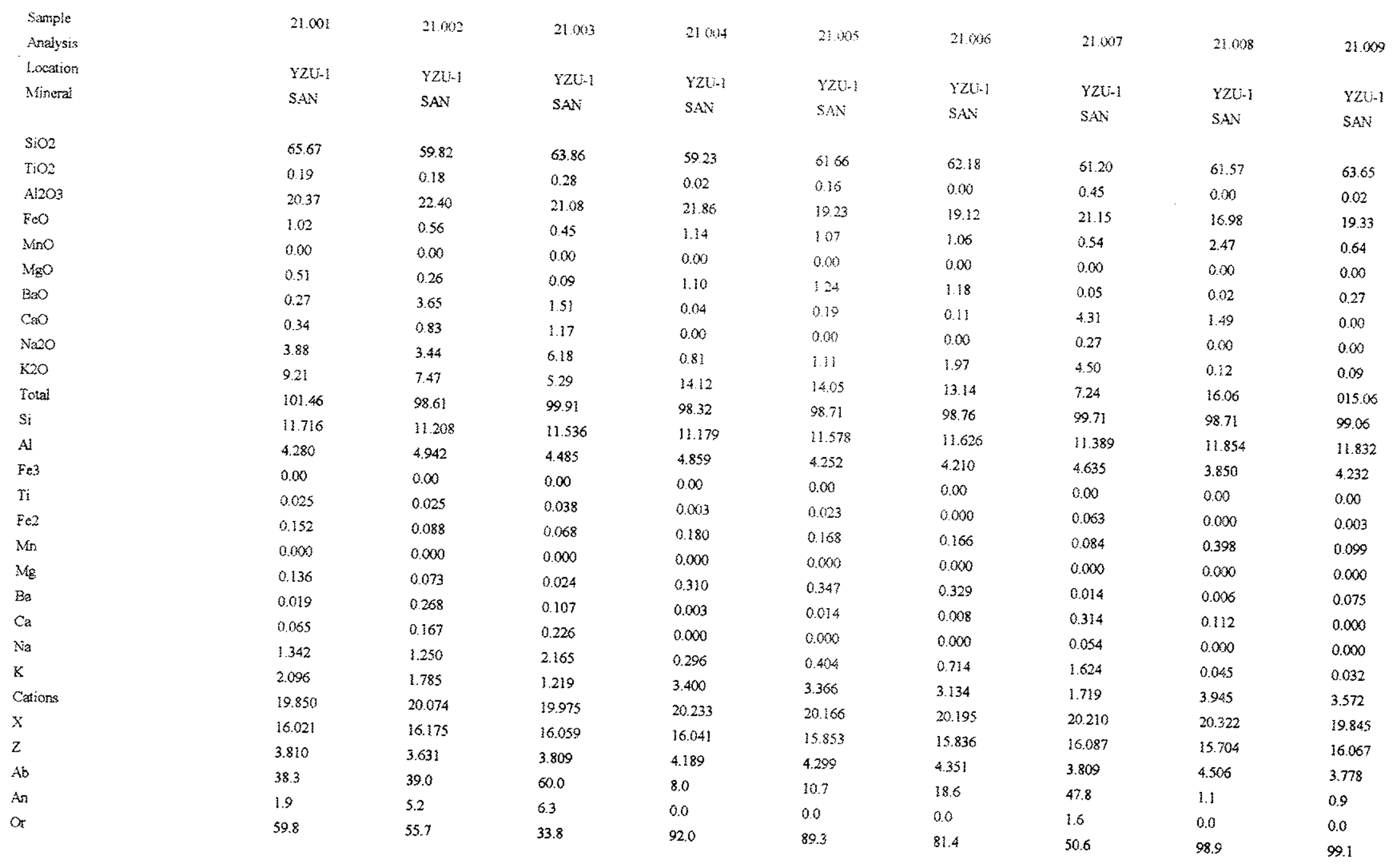




\begin{tabular}{|c|c|c|c|c|c|c|}
\hline $\begin{array}{l}\text { Samule } \\
\text { Analysis }\end{array}$ & 21.010 & 21011 & 21.012 & 21013 & 21014 & 21015 \\
\hline Location & $Y Z Z-1$ & $Y Z U-1$ & $Y Z Z=1$ & $Y Z Z-1$ & $\mathrm{XZZi-3}$ & $Y Z Z_{1-1}$ \\
\hline Minera! & $\mathrm{SAN}$ & SAN & SAN & SAN & $\operatorname{sen}$ & SAN \\
\hline $\mathrm{SL}_{2}$ & 61.56 & 61.11 & 63.37 & 67.69 & 66.47 & 64.12 \\
\hline TiO2 & 0.02 & 0.00 & 0.00 & 0.00 & 0,02 & 0.10 \\
\hline $\mathrm{A} 1203$ & 17.32 & 17.24 & 17.13 & 20.09 & 20.64 & 16.37 \\
\hline $\mathrm{FeO}$ & 2.53 & 2.88 & 2.37 & 0.18 & 0.15 & 3.12 \\
\hline Mo & 0.00 & 0.00 & 0.00 & 0.00 & $0 m$ & 0.00 \\
\hline Mgo & 0.06 & 0.08 & 0.37 & 0.08 & 0.07 & 0.08 \\
\hline $\mathrm{BaO}$ & 1.79 & 2.60 & 1.08 & 0.12 & 0.00 & 1.21 \\
\hline $\mathrm{c}$ & 0.00 & $0, \infty$ & 0.00 & 0.00 & 0.00 & 0.00 \\
\hline $\mathrm{N} 22 \mathrm{O}$ & 0.00 & 0.18 & 0.36 & 0.12 & 021 & 0.17 \\
\hline $\mathrm{K} 2 \mathrm{O}$ & 15.35 & 15.27 & 14.74 & 13.22 & 13.85 & 15.15 \\
\hline Total & 98.63 & 99.36 & 99.22 & 101.50 & 101.41 & 100.32 \\
\hline Si & 11.833 & 11.768 & 11.968 & 12.049 & 11.901 & 12.044 \\
\hline $\mathrm{Ai}$ & 3.921 & 3.910 & 3.810 & 4.211 & 4.352 & 3.621 \\
\hline$F_{0} 3$ & 0.00 & 0.00 & 0.00 & 0.00 & 0.0 & 0.00 \\
\hline $\mathrm{Ti}$ & 0.003 & 0.000 & 0.000 & 0.000 & 0.003 & 0.014 \\
\hline$F_{e 2}$ & 0.407 & 0.464 & 0.374 & 0.027 & 0.022 & 0.490 \\
\hline Mn & 0.000 & 0.000 & 0.000 & 0.000 & 0,000 & 00000 \\
\hline $\mathrm{Mg}$ & 0.017 & 0.023 & 0.048 & 0.021 & 0.019 & 0.022 \\
\hline $\mathrm{Ba}$ & 0.135 & 0.196 & 0.080 & 0.008 & 0.000 & 0.089 \\
\hline $\mathrm{Ca}$ & 0.000 & 0.000 & 0.000 & 0.000 & 0.000 & 0.000 \\
\hline $\mathrm{Nz}$ & 0.000 & 0.067 & 0.132 & 0.041 & 0.073 & 0.062 \\
\hline $\mathrm{x}$ & 3.764 & 3.752 & 3.551 & 3.002 & 3.163 & 3.630 \\
\hline Cations & 20.215 & 20.376 & 20.043 & 19.367 & 19.533 & $20.06 ?$ \\
\hline$x$ & 15.757 & 15.678 & 15.778 & 16.260 & 16.256 & 15.679 \\
\hline$z$ & 4.323 & 4.502 & 4.185 & 3.099 & 3.277 & 4.293 \\
\hline $\mathrm{Ab}$ & 0.0 & 1.8 & 3.6 & 1.3 & 2.3 & 1.7 \\
\hline$A n$ & 0.0 & 0.0 & 0.0 & 0.0 & 0.0 & 0.0 \\
\hline Ot & 100.0 & 98.2 & 96.4 & 98.7 & 97.7 & 98.3 \\
\hline
\end{tabular}




\begin{tabular}{|c|c|c|c|c|c|c|c|c|c|}
\hline $\begin{array}{l}\text { Saxnple } \\
\text { Analysis }\end{array}$ & $1500 \times 0$ & $15 \mathrm{~mm}$ & 15002 & $15(x) 3$ & 15004 & 15.005 & 15.006 & 15.007 & 15008 \\
\hline Location & Ymi-5 & $Y_{m i-5}$ & $Y_{\mathrm{mi}-5}$ & Ymi-5 & $y$ mi-5 & $Y_{\min -5}$ & Ymi-s & $Y_{\text {mi-S }}$ & Ymi-5 \\
\hline Mineral & SAN & SAN & SAN & SAN & $\mathrm{SAN}$ & SAN & SAN & $\mathrm{SAN}$ & SAN \\
\hline $\mathrm{SiO} 2$ & 61.90 & 61.67 & 61.45 & 61.30 & 62.31 & 63.62 & 63.09 & 61.12 & 63.93 \\
\hline $\mathrm{THO} 2$ & 0.07 & 0.27 & 0.14 & 0.05 & 0.03 & 0.10 & 0.13 & 0.05 & 0.02 \\
\hline $\mathrm{A} 120,3$ & 19.40 & 19.88 & 19.41 & 20.83 & 19.28 & 19.79 & 19.69 & 18.64 & 19.06 \\
\hline $\mathrm{FeO}$ & 0.44 & 1.23 & 0.33 & 0.43 & 0.50 & 0.68 & 0.60 & 0.43 & 0.58 \\
\hline $\mathrm{MnO}$ & $0 . \infty$ & 0.00 & 0.00 & 0.00 & 0.00 & 0.00 & 0.00 & 0.00 & 0.00 \\
\hline $\mathrm{MgO}$ & 0.04 & 0.04 & 0.05 & 0.02 & 0.01 & 0.04 & 0.07 & 0.02 & 0.02 \\
\hline $\mathrm{B} 2 \mathrm{O}$ & 0.00 & 2.40 & 0.00 & 0.00 & 3.26 & 1.86 & 2.69 & 0.00 & 1.28 \\
\hline $\mathrm{CaO}$ & 0.00 & 0.00 & 0.00 & 0.00 & 0.00 & 0.00 & 0.00 & 1.10 & $0, \infty$ \\
\hline $\mathrm{N} 22 \mathrm{O}$ & 0.74 & 1.85 & $1.6 \mathrm{~S}$ & 1.80 & 2.36 & 2.02 & 2.52 & 1.19 & 1.35 \\
\hline $\mathrm{K} 20$ & 13.64 & 12.53 & 13.60 & 12.50 & 1263 & 13.00 & 12.13 & 1506 & 14.65 \\
\hline Total & 96.23 & 99.87 & 96.63 & 96.93 & 99.78 & 01.11 & 100.92 & 97.61 & 100.89 \\
\hline $\mathrm{Si}$ & 11.787 & 11.560 & 11.701 & 11.565 & 11.699 & 11.701 & 11.668 & 11.669 & 11.807 \\
\hline AJ & 4.350 & 4.389 & 4.352 & 4.628 & 4.263 & 4.286 & 4.288 & 4.191 & 4.146 \\
\hline $\bar{F} \in 3$ & 0.00 & 0.00 & 0.00 & 0.00 & 0.00 & 0.00 & 0.00 & 0.00 & 0.00 \\
\hline $\mathrm{Ti}$ & 0.010 & 0.038 & 0.020 & 0.007 & 0.004 & 0.014 & 0.018 & 0.007 & 0.003 \\
\hline $\mathrm{Fe} 2$ & 0.070 & 0.193 & 0.053 & 0.068 & 0.079 & 0.105 & 0.093 & 0.069 & 0.090 \\
\hline $\mathrm{Mg}$ & 0.000 & 0.000 & 0.000 & 0.000 & $0, \infty 00$ & 0.000 & 0.000 & 0.000 & 0.000 \\
\hline $\mathrm{Mg}$ & 0.011 & 0.011 & 0.014 & 0.006 & 0.003 & 0.011 & 0.019 & 0.006 & 0.006 \\
\hline $\mathrm{B} a$ & 0.000 & 0.176 & 0.000 & 0.000 & 0.240 & 0.134 & 0.195 & 0.000 & 0.093 \\
\hline $\mathrm{Cz}$ & 0.000 & 0.000 & 0.000 & 0.000 & 0.000 & 0.000 & 0.000 & 0.225 & 0.000 \\
\hline $\mathrm{N} \hat{a}$ & 0.273 & 0.672 & 0.609 & 0.658 & 0.859 & 0.720 & 0.904 & 0.441 & 0.483 \\
\hline $\mathrm{K}$ & 3.313 & 2.996 & 3.304 & 3.009 & 2.882 & 3.050 & 2.862 & 3.668 & 3.452 \\
\hline Cacions & 19.814 & 20.211 & 20.053 & 19.941 & 20.259 & 20.155 & 20.242 & 20.276 & 20.173 \\
\hline $\mathrm{x}$ & 16.147 & 15.987 & 16.073 & 16.200 & 15.966 & 16.001 & 15.974 & 15.867 & 15.956 \\
\hline 2 & 3.667 & 4.048 & 3.980 & 3.741 & 4.063 & 4.020 & 4.073 & 4.409 & 4.124 \\
\hline $\mathrm{Ab}$ & 7.6 & 18.3 & 15.6 & 17.9 & 23.0 & 19.1 & 24.0 & 10.2 & 12.3 \\
\hline $\mathrm{An}_{\mathrm{n}}$ & 0.0 & 0.0 & 0.0 & 0.0 & 0.0 & 0.0 & 0.0 & 5.2 & 0.0 \\
\hline Or & 92.4 & 81.7 & 84.4 & 82.1 & 77.0 & 80.9 & 76.0 & 84.6 & 87.7 \\
\hline
\end{tabular}




\begin{tabular}{|c|c|c|c|c|c|c|c|c|c|}
\hline $\begin{array}{l}\text { Sample } \\
\text { Analysis }\end{array}$ & 15.009 & 15010 & 15011 & 15012 & 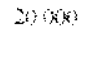 & $22(k)\}$ & 22002 & 22.003 & 226064 \\
\hline Location & Ymi-5 & Ymi-5 & $Y_{\mathrm{min}}=5$ & $Y_{\mathrm{mi}-\mathrm{S}}$ & $x 2012$ & $Y Z U-2$ & $\mathrm{YZU}-2$ & $Y Z X=2$ & YZt-2 \\
\hline Mincral & SAN: & SAN & SAN & SAN & $\operatorname{SAN}$ & SAN & $S A N$ & SAN & SAN \\
\hline $\mathrm{S}: \mathrm{O} 2$ & 63.93 & 62.20 & 61.50 & 61.53 & 63.12 & 61.31 & 63.08 & 62.80 & 63.11 \\
\hline $\mathrm{T}: 02$ & 0.00 & 0.10 & 0.03 & 0.03 & 013 & 0.38 & 0.09 & 0.14 & 0.06 \\
\hline $\mathrm{A} 12 \mathrm{O}$ & 18.54 & 18.13 & 19.45 & 20.49 & 17.21 & 15.62 & 17.59 & 17.75 & 17.18 \\
\hline $\mathrm{FeO}$ & 0.29 & 0.39 & 0.62 & 0.68 & 2.10 & 3.27 & 1.65 & 1.36 & 2.65 \\
\hline $\mathrm{MrO}$ & 0.00 & 0.00 & 0.00 & 0.00 & 0.00 & 0.04 & 0.14 & 0.03 & 0.00 \\
\hline $\mathrm{MgO}$ & $0 x$ & 0.00 & 0.01 & 0.05 & 0.10 & 0.11 & 0.00 & 0.11 & 0.06 \\
\hline $\mathrm{B} 20$ & 0.07 & 0.11 & 1.88 & 4.10 & 109 & 1.73 & 0.48 & 1.45 & 0.95 \\
\hline $\mathrm{CaO}$ & 0.00 & 1.36 & 0.00 & 0.00 & 0.01 & 0.10 & 0.02 & 0.00 & 0.03 \\
\hline $\mathrm{N} 220$ & 1.80 & 1.74 & 0.99 & 2.04 & o.s & 0.25 & 0.16 & 0.24 & 0.08 \\
\hline $\mathrm{K} 2 \mathrm{O}$ & 14.52 & 14.22 & 14.21 & 11.28 & 16.14 & 15.01 & 16.48 & 15.64 & 16.40 \\
\hline Total & 99.15 & 98.25 & 98.69 & 100.20 & 100.05 & 97.82 & 99.70 & 100.02 & 100.52 \\
\hline Si & 11.899 & 11.764 & 11.663 & 11.531 & 11.906 & 11.938 & 11.889 & 11.841 & 11.884 \\
\hline A) & 4.064 & 4.038 & 4.344 & 4.522 & 3.823 & 3.582 & 3.904 & 3.941 & 3.810 \\
\hline $\mathrm{Fe} 3$ & 0.00 & 0.00 & 0.00 & 0.00 & 0.00 & 0.00 & 0.00 & 0.00 & 0.00 \\
\hline Ti & 0.000 & 0.014 & 0.004 & 0.004 & 0.018 & 0.056 & 0.013 & 0.020 & 0.008 \\
\hline $\mathrm{Fe} .2$ & 0.045 & 0.062 & 0.098 & 0.107 & 0.331 & 0.532 & 0.262 & 0.293 & 0.417 \\
\hline Mn & 0.000 & 0.000 & 0.000 & 0.000 & 0.000 & 0.007 & 0.022 & 0.005 & 0.000 \\
\hline $\mathrm{Mg}$ & 0.000 & 0.000 & 0.003 & 0.014 & 0.028 & 0.032 & 0.000 & 0.031 & 0.017 \\
\hline $\mathrm{Ba}$ & 0.005 & 0.008 & 0.140 & 0.301 & 0.081 & 0.132 & 0.035 & 0.107 & 0.070 \\
\hline $\mathrm{Ca}$ & 0.060 & 0.276 & 0.000 & 0.000 & 0.002 & 0.021 & 0.004 & 0.000 & 0.005 \\
\hline Na & 0.650 & 0.638 & 0.364 & 0.741 & 0.055 & 0.094 & 0.058 & 0.088 & 0.029 \\
\hline K & 3.448 & 3.431 & 3.438 & 2.697 & 3.884 & 3.729 & 3.963 & 3.762 & 3.940 \\
\hline Cations & 20.116 & 20.239 & 20.194 & 20.218 & 20.209 & 20.255 & 20.185 & 20.195 & $20.25 \mathrm{I}$ \\
\hline $\mathrm{x}$ & 15.963 & 15.816 & 16.011 & 16.057 & 15.747 & 15.576 & 15.806 & 15.802 & 15.702 \\
\hline z & 4.148 & 4.415 & 4.043 & 3.860 & 4.381 & 4.547 & 4.344 & 4.286 & 4.479 \\
\hline$A B$ & 15.9 & 14.7 & 9.6 & 21.6 & 1.4 & 2.4 & 1.4 & 2.3 & 0.7 \\
\hline $\mathrm{An}$ & 0.0 & 6.4 & 0.0 & 0.0 & 0.1 & 0.5 & 0.1 & 0.0 & 0.2 \\
\hline$\sigma_{\pi}$ & 84.1 & 79.0 & 90.4 & 78.4 & 98.6 & 93.0 & 98.5 & 97.7 & 99.1 \\
\hline
\end{tabular}




\begin{tabular}{|c|c|c|c|c|c|c|c|c|c|}
\hline $\begin{array}{l}\text { Sample } \\
\text { Antalysis }\end{array}$ & 22005 & $22 \sin$ & $22(10) 7$ & 22008 & $220 \% 9$ & 22010 & 22.011 & 22.012 & 22.013 \\
\hline Location. & $Y Z L=2$ & $Y Z Z=2$ & $\mathrm{YZC}=2$ & YZU-2 & $Y A L=2$ & YZU-2 & YZU-2 & $Y Z U-2$ & $Y Z U-2$ \\
\hline Minerai & SAN & SAN & SAN & Sin & $\mathrm{SAN}$ & SAN & SAN & SAN & SAN \\
\hline $\mathrm{SiO}_{2}$ & 61.57 & 63.65 & 61.56 & 61.11 & 63.37 & 67.69 & 66.47 & 64.12 & 63.37 \\
\hline $\mathrm{roz}$ & $0 \infty$ & 0.02 & 0.02 & 0,00 & $0(x)$ & 0.00 & 0.02 & 0.10 & 0.08 \\
\hline $\mathrm{A} 2 \mathrm{O} 3$ & 16.98 & 19.33 & 17.32 & 17.24 & 17.13 & 20.09 & 20.64 & 16.37 & 15.86 \\
\hline $\mathrm{FeO}$ & 2.47 & 0.64 & 2.53 & 2.88 & 2.37 & 0.18 & 0.15 & 3.12 & 3.69 \\
\hline $\mathrm{MnO}$ & 0.02 & 0.27 & 0.00 & 0.00 & 600 & 0.00 & 0.00 & 0.00 & 0.00 \\
\hline Mgo & 0.00 & 0,0 & 0.00 & 0.18 & 0.37 & 0.18 & 0.97 & 0.08 & 0.06 \\
\hline $\mathrm{BaOC}$ & 1.49 & 0.00 & 1.79 & 2.60 & 108 & 012 & 0.00 & 1.21 & 1.95 \\
\hline $\mathrm{COO}$ & 0,0 & 0.0 & 0.00 & 0.00 & 000 & 0.00 & 0,00 & 0.00 & 0.00 \\
\hline $\mathrm{N}_{2} 2 \mathrm{O}$ & 0.12 & 0.09 & 0.00 & 0.18 & 0.36 & 0.12 & 0.21 & 0.17 & 0.26 \\
\hline $\mathrm{K} 2 \mathrm{O}$ & 16.06 & 15.06 & 15.35 & 15.27 & 14.74 & 13.22 & 13.85 & 15.15 & 14.77 \\
\hline Total & 98.71 & 99.06 & 98.57 & 99.36 & 99.22 & 101.60 & 101.41 & 100.32 & 100.04 \\
\hline si & 11855 & 11.844 & 11.840 & 11.768 & 11.968 & 12.039 & 11.901 & 12.044 & 12.033 \\
\hline As & 3.850 & 4.236 & 3.923 & 3.910 & 3.810 & 4.208 & 4.352 & 3.621 & 3.547 \\
\hline Fe3 & 0.00 & 0.00 & 0.00 & 0.00 & 0.00 & $0 . \infty$ & 0.00 & 0.00 & 0.00 \\
\hline $\mathrm{TI}$ & 0.000 & 0.003 & 0.003 & 0.000 & 0.000 & 0.000 & 0.003 & 0.014 & 0.011 \\
\hline $\mathrm{Fe2}$ & 0.398 & 0.100 & 0.407 & 0.464 & $0.37 a_{1}$ & 0.027 & 0.022 & 0.490 & 0.586 \\
\hline $\mathrm{Mn}$ & 0.003 & 0.043 & 0.000 & 0.000 & 0.000 & 0.000 & 0.000 & 0.000 & 0.000 \\
\hline$M_{g}$ & 0.000 & 0.000 & 0.000 & 0.023 & 0.048 & 0.048 & 0.019 & 0.022 & 0.017 \\
\hline $\mathrm{Ba}$ & 0.112 & 0.000 & 0.135 & 0.196 & 0.080 & 0.008 & 0.000 & 0.089 & 0.145 \\
\hline $\mathrm{Cz}$ & 0.000 & 0.000 & 0.000 & 0,000 & 0.000 & 0.000 & 0.000 & 0.000 & 0.000 \\
\hline $\mathrm{Na}$ & 0.045 & 0.032 & 0.000 & 0.057 & 0.132 & 0.041 & 0.073 & 0.062 & 0.095 \\
\hline K & 3.945 & 3.575 & 3.766 & 3.752 & 3.551 & 3.000 & 3.163 & 3.530 & 3.578 \\
\hline Cations & 20.320 & 19.833 & 20.209 & 20.376 & 20.043 & 19.379 & 19.533 & 20.061 & 20.158 \\
\hline$x$ & 15.705 & 16.083 & 15.766 & 15.678 & 15.778 & 16.247 & 16.256 & 15.679 & 15.591 \\
\hline$z$ & 4.503 & 3.750 & 4.308 & 4.502 & 4.185 & 3.124 & 3.277 & 4.293 & 4.422 \\
\hline$A b$ & 1.1 & 0.9 & 0.0 & 1.8 & 3.6 & 1.3 & 2.3 & 1.7 & 2.6 \\
\hline An & 0.0 & 0.0 & 0.0 & 0.0 & 0,0 & 0.0 & 0.0 & 0.0 & 0.0 \\
\hline Or & 98.9 & 99.1 & 100.0 & 98.2 & 96.4 & 98.7 & 97.7 & 98.3 & 97.4 \\
\hline
\end{tabular}




\begin{tabular}{|c|c|c|c|c|c|c|c|c|c|}
\hline $\begin{array}{l}\text { Sample } \\
\text { Analysis }\end{array}$ & 22014 & $\begin{array}{l}22015 \\
\text { psd-lc }\end{array}$ & $\begin{array}{l}22.016 \\
\text { psdalc }\end{array}$ & $\begin{array}{l}22017 \\
\text { psd-kc }\end{array}$ & $236 x$ & $23(x)$ & 23012 & 23003 & 23004 \\
\hline Exation & YZU:2 & YZL:2 & $\mathrm{YZl}_{-2}-2$ & $Y Z \mathrm{U}-2$ & YZU.-3 & $\mathrm{YZU}-3$ & $Y Z U-3$ & $\because 201-3$ & $\mathrm{YZU}-3$ \\
\hline Mineral & $\mathrm{SAN}$ & SAN & SAN & SAN & $S A N$ & $\mathrm{SAN}$ & $\mathrm{SAN}$ & SAN & SAN \\
\hline $\mathrm{Sin} 2$ & 62.85 & 6376 & 60.83 & 61.97 & 6402 & 64.12 & 64.27 & 64.38 & 63.19 \\
\hline $\mathrm{TiO} 2$ & 0.00 & 0.07 & 0.23 & $0 . \infty$ & 0.23 & 0.27 & 0.22 & 0.22 & 0.29 \\
\hline $\mathrm{ALO} 3$ & 16.98 & 21.11 & 18.60 & 19.99 & 17.85 & $18.6 \mathrm{l}$ & 18.97 & 18.72 & 19.22 \\
\hline $\mathrm{FeO}$ & 2.24 & 0.23 & 2.51 & 0.41 & 1.32 & 0.82 & 1.16 & 0.86 & 0.99 \\
\hline $\mathrm{MrO}$ & 0,00 & 0.02 & 0.04 & 0.04 & 0,00 & 0.03 & 0.00 & 0.00 & 0.02 \\
\hline Mgo & 0.04 & 0.26 & 2.73 & 0.90 & 0.01 & 0,00 & 0.00 & $0.0 \mathrm{I}$ & 0.00 \\
\hline $\mathrm{Ba} 3 \mathrm{O}$ & 2.25 & 024 & 0.20 & 0.70 & 052 & 0.09 & 0.06 & $0.0 \mathrm{t}$ & 1.58 \\
\hline $\mathrm{CO}$ & $0(0)$ & $0,0 \mathrm{i}$ & 0.11 & 0.00 & 0,00 & 0.00 & 0.08 & 0.02 & 0.01 \\
\hline $\mathrm{N} 22 \mathrm{O}$ & 0.12 & 0.59 & 0.43 & $0.3 \mathbf{i}$ & 1.78 & $1.4 \hat{3}$ & 1.12 & 1.66 & 2.01 \\
\hline $\mathrm{k} 2 \mathrm{O}$ & 13.70 & 15.26 & 11.60 & 14.45 & 12.92 & 14.19 & 14.22 & 13.32 & 12.24 \\
\hline Total & 98.18 & $10\} .55$ & 97.28 & 98.78 & 98.65 & 99.56 & 300.10 & 99.20 & 99.55 \\
\hline $\mathrm{Si}$ & 12.015 & 11.595 & 11.511 & 11.610 & 11.954 & 11.878 & 11.844 & 11.904 & 11.754 \\
\hline Al & 3.823 & 4.521 & 4.145 & 4.410 & 3.928 & 4.060 & 4.117 & 4.076 & 4.210 \\
\hline $\mathrm{F}: 3$ & 0.00 & 0,00 & 0.09 & 0.60 & 0.00 & 0.00 & 0.00 & 0.00 & 0.00 \\
\hline $\mathrm{Ti}_{\mathrm{i}}$ & 0.000 & 0.010 & 0.033 & 0.000 & 0.032 & 0.038 & 0.030 & 0.031 & 0.041 \\
\hline $\mathrm{Fe} 2$ & 0.358 & 0.035 & 0.397 & 0.064 & 0.206 & 0.127 & 0.179 & 0.133 & 0.154 \\
\hline $\mathrm{Mn}$ & 0.000 & 0.003 & 0.006 & 0.006 & 0,000 & 0.005 & 0.000 & 0.000 & 0.003 \\
\hline$M g$ & 0.011 & 0.070 & 0.770 & 0.251 & 0.003 & 0.000 & 0.000 & 0.003 & 0.000 \\
\hline $\mathrm{B} 3$ & 0.169 & 0.017 & 0.015 & $0.05 i$ & 0.038 & 0.007 & 0.004 & 0.001 & 0.115 \\
\hline $\mathrm{Ca}$ & 0.000 & 0.002 & 0.022 & 0.000 & 0000 & 0.000 & 0.016 & 0.004 & 0.002 \\
\hline $\mathrm{Na}$ & 0.044 & 0.208 & 0.158 & 0.113 & 0.645 & 0.514 & 0.400 & 0.595 & 0.725 \\
\hline $\mathrm{x}$ & 3.341 & 3.540 & 2.800 & 3.456 & 3080 & 3.354 & 3.343 & 3.142 & 2.905 \\
\hline Cations & 19.930 & 20.018 & 19.872 & 20.012 & 19.934 & 19.990 & 19.937 & 19.890 & 20.024 \\
\hline $\mathrm{x}$ & 15.838 & 16.126 & 15.689 & 16.020 & 15.924 & 15.976 & 15.991 & 16.011 & 16.005 \\
\hline$z$ & 3.923 & 3.875 & 4.168 & 3.941 & 3.972 & 4.007 & 3.942 & 3.878 & 3.904 \\
\hline$A \dot{b}$ & 1.3 & 5.5 & 5.3 & 3.2 & 17.3 & 13.3 & 10.6 & 15.9 & 20.0 \\
\hline An & 0.0 & 0.1 & 0.7 & 0.0 & 0.0 & 0.0 & 0.4 & 0.1 & 0.1 \\
\hline or & 98.7 & 94.4 & 94.0 & 96.8 & 82.7 & 86.7 & 88.9 & 84.0 & 80.0 \\
\hline
\end{tabular}




\begin{tabular}{|c|c|c|c|c|c|c|c|c|c|}
\hline Sample & 23605 & 23006 & 23.007 & $23 \% 8$ & $23 \mathrm{~kg}$ & 23010 & 23.011 & 233612 & 23013 \\
\hline Analysis & & & & & & & & $\mathrm{D} 2 \mathrm{M} \operatorname{Min} 93$ & De:Min93 \\
\hline Location & YZU-3 & YZU.3 & $\mathrm{YZU}-3$ & $Y Z U-3$ & $Y Z Z+3$ & $Y Z U-3$ & YZU-3 & YZU:3 & YZU-3 \\
\hline Nineral & SAN & $\mathrm{SAN}$ & $\mathrm{SAN}$ & SAN & $\mathrm{SAN}$ & SAN & SAN & $\sin$ & SAN \\
\hline $\mathrm{SiO}_{2}$ & 62.93 & 60.98 & 64.82 & 62.62 & 65.45 & 62.97 & 61.81 & 64.90 & 64.98 \\
\hline $\mathrm{TOO}_{2}$ & 0.17 & 0.25 & 0.27 & 0.25 & 0.25 & 0.17 & 0.30 & 0.00 & 0.00 \\
\hline $\mathrm{A} i 203$ & 18.92 & 18.72 & 19.09 & 18.94 & 18.88 & 19.61 & 18.13 & 18.36 & 13.38 \\
\hline $\mathrm{FeO}$ & 0.01 & 0.63 & 0.87 & 0.71 & 0.70 & 0.70 & 0.81 & 0.00 & 0.00 \\
\hline $\mathrm{MnO}$ & $a, 0$ & 0.00 & 0.00 & 0.00 & $0(x)$ & 0.00 & 0.01 & 0.00 & 0.00 \\
\hline $\mathrm{MgO}$ & 0.02 & 0.00 & 0.03 & 0.04 & 0.01 & 0.01 & $n(k)$ & 0.00 & 0.00 \\
\hline $13: 0$ & 0.90 & 1.18 & 0.16 & 0.58 & 0.28 & 1.34 & 0.07 & 0.00 & 0.00 \\
\hline $\mathrm{CaO}$ & 0.00 & 0.02 & 0.14 & 0.02 & 0.00 & 0.01 & 0.01 & 0.00 & 0.09 \\
\hline $\mathrm{N} 2 \mathrm{O}$ & 2.19 & 1.78 & 1.50 & 1.86 & 1.83 & 1.82 & 1.67 & 0.25 & 0.57 \\
\hline $\mathrm{k} 20$ & 12.33 & 12.59 & 13.85 & 12.85 & 13.27 & 12.74 & 12.72 & 16.60 & 16.22 \\
\hline Total & 97.47 & 96.15 & 100.73 & 97.87 & 100.67 & 99.37 & 95.53 & 10.11 & 95.15 \\
\hline $\mathrm{Si}$ & 11.849 & 11.741 & 11.848 & 11.787 & 11.926 & 11.722 & 11.873 & 11.998 & 12.639 \\
\hline AI & 4.195 & 4.245 & 4.109 & 4.198 & 4.052 & 4.299 & 4.101 & 3.997 & 3.065 \\
\hline $\mathrm{F} \in 3$ & 0.00 & 0.00 & 0.00 & 0.00 & 0.00 & 0.00 & 0.00 & $0 . \infty$ & 0.00 \\
\hline $\mathrm{Ti}$ & 0.024 & 0.036 & 0.037 & 0.035 & 0.034 & 0.024 & 0.043 & 0.000 & 0.000 \\
\hline$F \in 2$ & 0.002 & 0.301 & 0.133 & 0.112 & 0.107 & 0.109 & 0.130 & 0.000 & 0.000 \\
\hline $\mathrm{Mn}$ & 0.000 & 0,000 & 0.000 & 0.000 & 0.000 & 0.000 & 0.002 & 0.000 & 0000 \\
\hline $\mathrm{Mg}$ & 0.006 & 0.000 & 0.008 & 0.011 & 0.003 & 0.003 & 0.000 & 0.000 & $0.0 \times 0$ \\
\hline $\mathrm{B} a$ & 0.060 & 0.089 & 0.011 & 0.043 & 0.020 & 0.098 & 0.005 & 0.000 & 0.000 \\
\hline $\mathrm{Ca}$ & 0.000 & 0.004 & 0,027 & 0.004 & $0.0 \times 0$ & 0.002 & 0.002 & 0.000 & 0.000 \\
\hline NB & 0.800 & 0.665 & 0.532 & 0.679 & 0.647 & 0.657 & 0.622 & 0.090 & 0.215 \\
\hline $\mathrm{x}$ & 2.962 & 3.092 & 3.230 & 3.086 & 3.085 & 3.026 & 3.117 & 3.915 & 4.025 \\
\hline Cations & 19.970 & 20.062 & 19.946 & 19.998 & 19.894 & 20.038 & 19.900 & 20.000 & 19.944 \\
\hline$x$ & 16.058 & 16.022 & 15.994 & 16.020 & 16.012 & 16.045 & 16.017 & 15.995 & 15.704 \\
\hline$z$ & 3.836 & 3.951 & 3.941 & 3.935 & 3.862 & 3.895 & 3.878 & 4.005 & 4.240 \\
\hline $\mathrm{Ab}$ & 21.3 & 17.7 & 14.0 & 18.0 & 17.3 & 17.8 & 16.6 & 2.2 & 5.1 \\
\hline $\mathrm{A}_{\mathrm{n}}$ & 0.0 & 0.1 & 0.7 & 0.1 & 0.0 & 0.1 & 0.3 & 0.0 & 0.0 \\
\hline Or & 38.7 & 82.2 & 85.2 & 81.9 & 82.7 & 82.1 & 83.3 & 97.8 & 94.9 \\
\hline
\end{tabular}




\begin{tabular}{|c|c|c|c|c|c|c|c|c|c|}
\hline $\begin{array}{l}\text { Sansple } \\
\text { Araalysis }\end{array}$ & 26,000 & 26.001 & $26 .(\alpha) 2$ & 26.1003 & 260104 & 2660105 & 26.006 & 25.007 & $26.0 \% 8$ \\
\hline Location & YZU-6 & YZU-6 & YZU -6 & $Y Z \mathrm{ZU}-6$ & YZV 6 & $y 20-6$ & YZLi-6 & YZY -6 & YZU-6 \\
\hline Mineral & $\mathrm{SAN}$ & SAN & $\mathrm{SAN}$ & SAN & SAN & SAN & SAN & SAN & SAN \\
\hline $\mathrm{SiO}_{2}$ & 64.33 & 64.07 & 64.11 & 64.79 & 6.31 & 62.47 & 63.43 & 64.22 & 63.18 \\
\hline $\mathrm{riO2}$ & 0.27 & 0.17 & 0.26 & 0.20 & 0.11 & 0.88 & 0.24 & 0.02 & 0.19 \\
\hline $\mathrm{A} 2 \mathrm{O} 3$ & 17.80 & 17.98 & 17.92 & 17.21 & 17.90 & 17.42 & 18.20 & 17.88 & 18.14 \\
\hline $\mathrm{FeO}$ & 1.41 & 1.17 & 1.27 & 1.45 & 1.55 & $3.2 !$ & 1.40 & 1.46 & 1.12 \\
\hline $\mathrm{M} n \mathrm{O}$ & 0.04 & 0.12 & 0.12 & 0.02 & 0.00 & 0.11 & 0.00 & 0.00 & 0.07 \\
\hline $\mathrm{MgO}$ & 0.09 & 0.00 & 0.10 & 0.00 & 0.05 & 0.04 & 0.02 & 0.00 & 0.05 \\
\hline $\mathrm{B} 2 \mathrm{O}$ & 0.69 & 0.55 & 0.48 & 1.40 & 1.21 & 0.00 & 130 & 0.57 & 0.45 \\
\hline $\mathrm{CaO}$ & 0.00 & 0.00 & 0.03 & 0.00 & 0.00 & 0.16 & 0.01 & 0.03 & 0.05 \\
\hline $\mathrm{Na} 2 \mathrm{O}$ & 2.15 & 2.07 & 1.99 & 2.03 & 2.30 & 2.02 & 2.11 & 2.01 & 2.14 \\
\hline $\mathrm{K} 20$ & 13.37 & 13.63 & 13.62 & 13.35 & 13.26 & 13.15 & 13.44 & 13.85 & 13.74 \\
\hline Total & 100.15 & 99.76 & 99.88 & 100.45 & 100.10 & 99.46 & 99.95 & 190.04 & 98.75 \\
\hline Si & 11.915 & 11.907 & 11.898 & 12.014 & 11.868 & 11.730 & 11.824 & 11.924 & 11.842 \\
\hline Ai & 3.883 & 3.935 & 3.917 & 3.758 & 3.927 & 3.852 & 3.995 & 3.910 & 4.004 \\
\hline $\mathrm{Fe} 3$ & 0.00 & 0.00 & 0.00 & 0.00 & 0.00 & 0.00 & 0.00 & 0.00 & 0.00 \\
\hline $\mathrm{Ti}$ & 0.038 & 0.024 & 0.036 & 0.028 & 0.015 & 0.124 & 0.034 & 0.003 & 0.027 \\
\hline$F \bullet 2$ & 0.218 & 0.182 & 0.197 & 0.225 & 0.243 & 0.504 & 0.218 & 0.227 & 0.176 \\
\hline Mn & 0.006 & 0.019 & 0.019 & 0.003 & 0.000 & 0.017 & 0.000 & 0.000 & 0.011 \\
\hline Mig & 0.025 & 0.000 & 0.028 & 0.000 & 0.014 & 0.015 & 0.006 & 0.000 & 0.017 \\
\hline $\mathrm{Ba}$ & 0.050 & 0.040 & 0.035 & 0.102 & 0.088 & 0.000 & 0.080 & 0.041 & 0.004 \\
\hline $\mathrm{Cz}$ & 0.000 & 0.000 & 0.002 & 0.000 & 0,000 & 0.032 & 0.002 & 0.006 & 0.010 \\
\hline $\mathrm{Na}$ & 0.772 & 0.745 & 0.716 & 0.730 & $0.83 !$ & 0.735 & 0.763 & 0.724 & 0.778 \\
\hline $\mathrm{K}$ & 3.159 & 3.232 & 3.225 & 3.158 & 3.151 & 3.150 & 3.196 & 3.281 & 3.286 \\
\hline Cations & 20116 & 20.125 & 20.108 & 20.120 & 20.225 & 20.155 & 20.198 & 20.157 & 20.159 \\
\hline $\mathrm{x}$ & 15.836 & 15.866 & 15.851 & 15.800 & 15.810 & 15.706 & 15.853 & 15.837 & 15.873 \\
\hline$z$ & 4.230 & 4.219 & 4.222 & 4.218 & 4.327 & 4.449 & 4.265 & 4.279 & 4.282 \\
\hline Á & 19.6 & 18.8 & 18.2 & 18.8 & 20.9 & 18.8 & 19.3 & 18.1 & 19.1 \\
\hline $\mathrm{A} \Omega$ & 0.0 & 0.0 & 0.1 & 0.0 & 0.0 & 0.8 & 0.1 & 0.1 & 0.2 \\
\hline $\mathrm{O}_{\tau}$ & 80.4 & 81.2 & 81.8 & 81.2 & 79.1 & 80.4 & 80.7 & 81.8 & 80.7 \\
\hline
\end{tabular}




\begin{tabular}{|c|c|c|c|c|c|c|}
\hline Sample & $26 \times 1 \times 9$ & 26000 & 26.001 & 26012 & 26013 & 26014 \\
\hline \multicolumn{7}{|l|}{ Analysis } \\
\hline Lacation & YZU-6 & $Y Z 20-6$ & $Y Z E=6$ & $Y Z 1-6$ & $Y Z L-6$ & YZU 6 \\
\hline Mineral & SAN & $\mathrm{SAN}$ & SAN & $\mathrm{SAN}$ & SAN & $\mathrm{SAN}$ \\
\hline $\mathrm{SiOz}$ & 63.97 & 63.29 & 63.64 & 6418 & 62.92 & 64.29 \\
\hline $\mathrm{TiO} 2$ & 0.26 & 0.10 & 0.23 & 0.30 & 0.06 & 0.20 \\
\hline $\mathrm{A} 2 \mathrm{OO}$ & 17.95 & 17.81 & 17.97 & 18.05 & 18.56 & 18.01 \\
\hline$F e O$ & 1.36 & 1.40 & 137 & 1.47 & 0.52 & 1.64 \\
\hline $\mathrm{M}=\mathrm{O}$ & 0.00 & 0.00 & 0.00 & 0.02 & 0.10 & 0.08 \\
\hline $\mathrm{M} 8 \mathrm{O}$ & 0.07 & 0.00 & 0.06 & 0.00 & 0.09 & 0.06 \\
\hline $\mathrm{BaO}$ & 0.00 & 0.35 & 0.58 & 0.23 & 000 & 0.54 \\
\hline $\mathrm{COO}$ & 0.00 & 0.02 & 0.03 & 0.00 & 0.00 & 0.00 \\
\hline $\mathrm{N}_{22} \mathrm{O}$ & 2.17 & 2.03 & 2.48 & 2.19 & 0.20 & 1.94 \\
\hline $\mathrm{k} 20$ & 13.76 & 13.76 & 13.62 & 13.55 & 16.40 & 13.68 \\
\hline Totai & 99.54 & 98.76 & 99.98 & 99.99 & 98.85 & 100.44 \\
\hline $\mathrm{Si}$ & 11.888 & 11.893 & 11.841 & 11.883 & 11840 & 11.887 \\
\hline A & 3.928 & 3.941 & 3.937 & 3.936 & 4.113 & 3.921 \\
\hline $\mathrm{Fe} 3$ & 0.00 & 0.00 & 0.00 & 0.00 & 0.00 & 0.00 \\
\hline $\mathrm{Ti}$ & 0.036 & 0.014 & 0.032 & 0.042 & 0.008 & 0.028 \\
\hline $\mathrm{Fe} 2$ & 0.211 & 0.220 & 0.213 & 0.228 & 0.082 & 0.254 \\
\hline$M n$ & 0.000 & 0.000 & 0.000 & 0.003 & 0.015 & 0.013 \\
\hline $\mathrm{Mg}$ & 0.019 & 0.000 & 0.017 & 0.000 & 0.025 & 0.017 \\
\hline $\mathrm{Bz}$ & 0.000 & 0.026 & 0.042 & 0.017 & 0.000 & 0.039 \\
\hline $\mathrm{Ca}$ & 0.000 & 0.004 & 0.006 & 0.000 & 0,000 & 0.000 \\
\hline $\mathrm{Ng}$ & 0.782 & 0.740 & 0.895 & 0.786 & 0.073 & 0.696 \\
\hline $\mathrm{K}$ & 3.262 & 3.299 & 3.233 & 3.201 & 3.937 & 3.227 \\
\hline Cations & 20.126 & 20.163 & 20.258 & 20.113 & 20.004 & $20.12 \mathrm{i}$ \\
\hline $\mathrm{x}$ & 15.852 & 15.848 & 15.810 & 35.861 & 15.961 & 15.836 \\
\hline$z$ & 4.274 & 4.289 & 4.406 & 4.235 & 4.133 & 4.246 \\
\hline$A b$ & 19.3 & 18.3 & 21.6 & 19.7 & 1.8 & 17.7 \\
\hline$A_{n}$ & 0.0 & 0.1 & 0.3 & 0.0 & 0.0 & 0.0 \\
\hline $\mathrm{G}$ & 80.7 & 81.6 & 78.2 & 80.3 & 98.2 & 82.3 \\
\hline
\end{tabular}




\section{A8}

Composição química, em porcentagem em peso, de minerais de titânio das rochas "lamprofíricas" do Paraguai: pseudobrookitas: $\mathrm{TiO}_{2}>55 \%$ IImenitas: $\mathrm{TiO}_{2}<55 \%$, (ambos como $\| \mathrm{lm}$ ), rutilos (RUT, rut), perovsquita (Per).

"lamprofiros"

Ymi-1 (10.001-10.031 e sem numeração rutilo de Nb);

Ymi-8 (pipe) (18.001-18.028).

"Tamproitos"

Yzu-2 (22.000-22.012)

Yzu $3(23.000-23.003)$;

Yzu-6 (26.000-26.001)

Ymi-5 (15.001-15.002) e Três Ranchos 4: 001.= perovskita. 


\begin{tabular}{|c|c|c|c|c|c|c|c|}
\hline Sexnple & 10.020 & 10.021 & 10.022 & 10.023 & 10.024 & 10.030 & 10.031 \\
\hline \multicolumn{8}{|l|}{ Artalysis } \\
\hline Locration & YM-1-ES & YMI-1-f5 & YMI-1 & $\mathrm{YM}-1$ & $\mathrm{YMa}-1$ & YMA-1 & YM-1 \\
\hline Mineral & rut & rot & rut & nut & rot & tut & nt \\
\hline $\mathrm{THO}^{2}$ & 99.60 & 98.87 & 92.70 & 93.14 & 99.16 & $\$ 3.65$ & 52.41 \\
\hline $\mathrm{C} 2203$ & 0.09 & 0.37 & 0.00 & 0.00 & 000 & 0.00 & 9.00 \\
\hline $\mathrm{A} 1203$ & 0.13 & 0.02 & 0.10 & 0.11 & 0.13 & 0.27 & 0.27 \\
\hline $\mathrm{F} \in \mathrm{O}$ & 0.18 & 0.12 & 2.53 & 2.44 & 0.13 & 1.85 & 2.27 \\
\hline $\mathrm{F} e 2 \mathrm{O} 3$ & 0.00 & 0.00 & 0.00 & 0.00 & 0.00 & 9.46 & 9.33 \\
\hline Mro & 0.00 & 0.07 & 0.00 & 0.01 & 0.00 & 0.45 & 0.52 \\
\hline $\mathrm{MgO}$ & 0.10 & 0.07 & 0.06 & 0.00 & 0.16 & 0.04 & 0.04 \\
\hline NiO & 0.02 & 0.00 & 0.04 & 0.00 & 0.00 & 0.15 & 0.05 \\
\hline Total & 100,12 & 99,52 & 95,43 & 95,70 & 99,58 & 65,87 & 64,89 \\
\hline
\end{tabular}

TiO2

$\mathrm{ZrO2}$

54,7
0,87

55,08

54,52

45,83

54,85

$\mathrm{Al} 2 \mathrm{O} 3$

$\mathrm{Ce} 2 \mathrm{O} 3$

0,26

0,58

47,85
1,19

1,28

54,85
1,21

$\mathrm{Fe} 2 \mathrm{O} 3$

0,6

8,47

$\mathrm{FeO}$

1,89

$\mathrm{MnO} \quad 0,41$

$\mathrm{MgO}$

$\mathrm{NiO}$

$\mathrm{BaO}$

$\mathrm{PbO}$

$\mathrm{Na} 2 \mathrm{O}$

$\mathrm{K} 2 \mathrm{O}$

$\mathrm{Nb2O5}$

Total

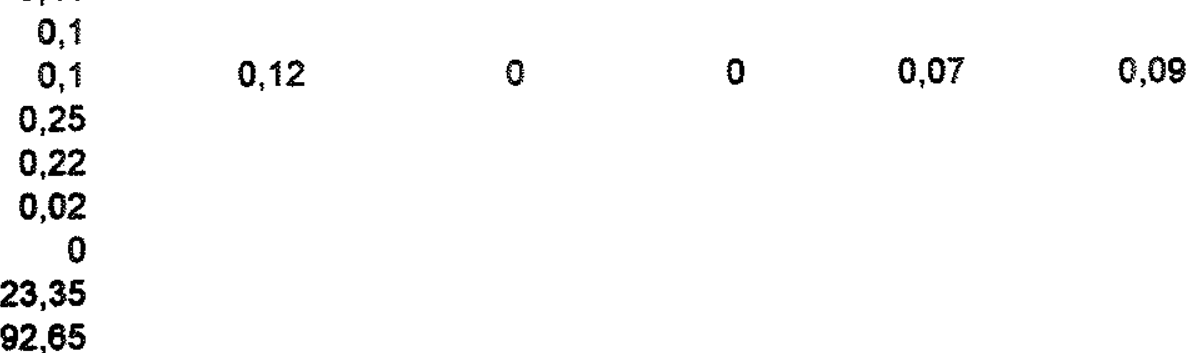




\begin{tabular}{|c|c|c|c|c|}
\hline Sample & 18.000 & 18.020 & 18.021 & 18.028 \\
\hline \multicolumn{5}{|l|}{ Anslysis } \\
\hline Locsition & YMI-8 & YMI-8 & YMI-8 & YMa-8 \\
\hline Minered & RUT & RUT & RUT & RUT \\
\hline $\mathrm{TiO2}$ & 100.39 & 98.69 & 95.17 & 97.36 \\
\hline $\mathrm{C}_{2}^{2} 203$ & 0.06 & 0.00 & 0.10 & 0.05 \\
\hline $\mathrm{Al} 2 \mathrm{O} 3$ & 0.09 & 0.13 & 0.23 & 0.10 \\
\hline $\mathrm{F} C \mathrm{O}$ & 0.32 & 0.37 & 1.67 & 0.93 \\
\hline $\mathrm{Fe} 2 \mathrm{O} 3$ & 0.00 & 0.00 & 0.00 & 0.00 \\
\hline Mano & 0.06 & 0.05 & 0.00 & 0.07 \\
\hline $\mathrm{MgO}$ & 0.13 & 0.13 & 0.07 & 0.08 \\
\hline $\mathrm{NiO}$ & 0.06 & 0.00 & 0.00 & 0.10 \\
\hline Total & 100,91 & 99,37 & 97,24 & 98,69 \\
\hline
\end{tabular}




\begin{tabular}{|c|c|c|c|c|c|c|c|c|c|}
\hline Sample & 10.001 & 10.002 & 10.003 & 10.004 & 10.005 & 10.006 & 10.007 & 10.008 & 10.013 \\
\hline Analyzis & & & & & & & & & 173 \\
\hline Locrtion & $\mathrm{YM}-\mathrm{I}-\mathrm{fs}$ & YMII-1-is & YML-1-5 & $\mathrm{YM}=1-1.5$ & YMI-1-fs & $Y M S-1-$-SS & YMII-ES & VM-1-EB & YMLI \\
\hline Mineral & $\operatorname{Im}$ & Iin & IIn & $\mathrm{Im}$ & Inm & In & $\mathrm{Im}$ & $\mathrm{Ilm}$ & $\mathrm{Inm}$ \\
\hline $\mathrm{THO} 2$ & 57.52 & 58.68 & 53.89 & $61.0 \%$ & 63.05 & 63.83 & 55.67 & 60.37 & 59.27 \\
\hline $\mathrm{Cr} 203$ & 0.06 & 0.11 & 0.00 & 0.04 & 0.15 & 0.02 & 0.05 & 0.00 & 0.02 \\
\hline $\mathrm{A} 2203$ & 0.28 & 0.14 & 0.22 & 0.35 & 124 & 0.27 & 0.23 & 0.45 & 0.56 \\
\hline FeO & 21.7 & 21.27 & 27.14 & 11.68 & 13.36 & 17.12 & 25.28 & 19.87 & 21.34 \\
\hline 50203 & 13.91 & 14.12 & 14.16 & 14.00 & 13.58 & $\$ 4.10$ & 14.68 & 14.22 & 14.29 \\
\hline $\mathrm{MnO}$ & 0.69 & 1.33 & 2.77 & 7.86 & 0.80 & 0.76 & 0.85 & 1.70 & 1.07 \\
\hline $\mathrm{M} B \mathrm{O}$ & 0.20 & 0.24 & 0.35 & 0.18 & 0.23 & 0.12 & 1.54 & 0.15 & 0.25 \\
\hline $\mathrm{NiO}$ & 0.00 & 0.00 & 0.00 & 0.13 & 0.00 & 0.00 & 0.00 & 0.00 & 0.00 \\
\hline Total & 94,36 & 95,89 & 98,53 & 95,25 & $\$ 2.31$ & 96,22 & 98,30 & 96,76 & 96,80 \\
\hline
\end{tabular}

\begin{tabular}{|c|c|c|c|c|}
\hline Sample & 10.012 & 10.017 & 18.013 & 18.016 \\
\hline Arrasysis & 173 & & & \\
\hline Location & YMH & YMI-1-E & YMI-8 & YM-8 \\
\hline Mineral & $\mathrm{IIm}$ & In & $\mathrm{m} \mathbf{m}$ & Illm \\
\hline $\mathrm{TiO} 2$ & 58.68 & 59.96 & 52.96 & 55.06 \\
\hline $\mathrm{Cr} 2 \mathrm{O} 3$ & 0.00 & 0.12 & 0.04 & 0,00 \\
\hline $\mathrm{Al}_{2} 2 \mathrm{O}_{3}$ & 0.27 & 0.34 & 0.23 & 0.36 \\
\hline $\mathrm{F} \in \mathrm{O}$ & 19.77 & 21.37 & 27.56 & 21.80 \\
\hline $\mathrm{Fe} 203$ & 14.14 & 14.29 & 14.22 & 13.51 \\
\hline Aro & 2.96 & 0.60 & 0.50 & 0.51 \\
\hline $\mathrm{MgO}$ & 0.17 & 0.29 & 0.47 & 0.40 \\
\hline NiO & 0.09 & 0.03 & 0.03 & 0.00 \\
\hline Total & 96,08 & $97, \infty 0$ & 96,01 & 91,64 \\
\hline
\end{tabular}




\begin{tabular}{|c|c|c|c|c|c|c|c|c|c|}
\hline Sample & 10.009 & 10.010 & 10.013 & 10.014 & 10.016 & $18.00\}$ & 18.002 & 18.003 & 18.004 \\
\hline Anziysis & & & 173 & & & & & & \\
\hline Location & YMa-1 & YM-1 & na-1 & nM-1-is & YMl-! & YM-8 & YMI-8 & YMa-8 & YMI-8 \\
\hline Mineral & $\mathrm{nth}$ & $\mathrm{nm}$ & $\mathrm{Iim}$ & Ilm & $\rrbracket_{m}$ & tllm & 19 & $1 \mathrm{~lm}$ & $\mathrm{Im}$ \\
\hline $\mathrm{TiO} 2$ & 40.35 & 40.50 & 46.52 & 48.27 & $4 \$ .44$ & 50.44 & 50.73 & 51.00 & 49.69 \\
\hline $\mathrm{Cr} 203$ & $0.0 \mathrm{t}$ & 0.05 & 0.01 & 0.02 & 0.00 & 0.01 & 0.00 & 0.01 & 0.09 \\
\hline $\mathrm{Al} 2 \mathrm{O} 3$ & 0.25 & 0.22 & 0.56 & 0.17 & 0.29 & 0.12 & 0.11 & 0.19 & 0.10 \\
\hline $\mathrm{F}=\mathrm{O}$ & 37.13 & 38.74 & 30.83 & 33.01 & 37.81 & 33.35 & 32.84 & 31.58 & 33.31 \\
\hline $\mathrm{Fe} 203$ & $\{4.44$ & 14.80 & 15.58 & 14.58 & $14.8 \mathrm{I}$ & 14.58 & 14.91 & 14.63 & 14.76 \\
\hline $\mathrm{MnO}$ & 1.12 & 3.36 & 0.39 & 3.51 & 1.27 & 0.58 & 0.49 & $0.5 z$ & 0.60 \\
\hline $\mathrm{MgO}$ & 1.69 & 1.72 & 5.71 & 0.32 & 1.73 & 0.18 & 0.84 & 0.49 & 0.51 \\
\hline $\mathrm{NiO}$ & 0.07 & 0.00 & 0.03 & 0.01 & 0.04 & 0.06 & 0.03 & 0.00 & 0.09 \\
\hline Totial & 95,06 & 97,39 & 99,63 & 97,89 & 97.39 & 99,32 & 99,95 & 98,41 & 99,15 \\
\hline
\end{tabular}

\begin{tabular}{|c|c|c|c|c|c|c|c|c|c|}
\hline Sample & 18.005 & 18.006 & 18.007 & 18.008 & 18.009 & 18.010 & 18.011 & 18.012 & 18.014 \\
\hline \multicolumn{10}{|l|}{ Analysis } \\
\hline Locestion & YMI-8 & YMa-8 & YMI-8 & YMA-8 & YMa-8 & YMa-8 & YaMa-8 & YMA-8 & YMI-8 \\
\hline Mineral & $\mathrm{ym}$ & $\mathrm{Im}$ & $\mathrm{nm}$ & $\mathrm{nlm}$ & $\mathrm{Im}$ & Ilm & Itm & Ilm & $\mathrm{Im}$ \\
\hline $\mathrm{TiO} 2$ & 48.80 & 50.08 & 49.04 & 49.09 & 49.80 & 48.57 & 48.08 & 49.30 & 49.42 \\
\hline $\mathrm{C} 203$ & 0.68 & 0.03 & 0.02 & 0.01 & 0.00 & 0.09 & 0.05 & 0.00 & 0.0 \\
\hline $\mathrm{A} 2 \mathrm{O}_{3}$ & 0.06 & 0.15 & 0.04 & 0.14 & 0.14 & 0.13 & 0.14 & 0.20 & 0.12 \\
\hline $\mathrm{F} \oplus \mathrm{O}$ & 33.54 & 33.34 & 32.53 & 32.97 & 33.23 & 32.54 & 29.48 & 32.20 & 33.06 \\
\hline $\mathrm{Fe} 2 \mathrm{OO3}$ & 14.60 & 15.02 & 14.52 & 14.60 & 14.80 & 14.53 & 13.74 & 14.45 & 14.69 \\
\hline Mino & 0.45 & 0.61 & 1.34 & 0.41 & 0.51 & 0.58 & 0.48 & 0.39 & 0.58 \\
\hline $\mathrm{M} B \mathrm{O}$ & 0.08 & 1.11 & 0.20 & $0.6 \mathrm{I}$ & 0.60 & 0.83 & 0.48 & 0.53 & 0.60 \\
\hline NiO & 0.00 & 0.00 & 0.08 & 0.14 & 0.12 & 0.01 & 0.00 & 0.00 & 0.13 \\
\hline Totol & 98,21 & 100,34 & 97,77 & 97,97 & 99,30 & 97,28 & 92,45 & 97,07 & 98,60 \\
\hline
\end{tabular}




\begin{tabular}{|c|c|c|c|}
\hline Stomple & 18.015 & 18.018 & 18.019 \\
\hline \multicolumn{4}{|l|}{ Anglysis } \\
\hline Location & YMA-8 & Mal-8 & YM18 \\
\hline Mineral & $\mathrm{ln}$ & $\mathrm{Ins}$ & IIm \\
\hline $\mathrm{TiO} 2$ & $\$ 1.38$ & 49.61 & 49.41 \\
\hline $\mathrm{Cr} 203$ & 0.11 & 0.05 & 0.08 \\
\hline $\mathrm{A} 1203$ & 0.12 & 0.03 & 0.06 \\
\hline$F=0$ & 32.18 & 33.93 & 34.13 \\
\hline $\mathrm{Fe} 2 \mathrm{O} 3$ & 14.95 & 14.77 & 14.81 \\
\hline $\mathrm{MinO}$ & 0.63 & 0.43 & 0.59 \\
\hline $\mathrm{MgO}$ & 0.84 & 0.41 & 0.44 \\
\hline $\mathrm{NiO}$ & 0.07 & 0.05 & 0.00 \\
\hline Total & 100,28 & 99.28 & 99,52 \\
\hline
\end{tabular}




\begin{tabular}{|c|c|c|c|c|c|c|c|c|c|}
\hline Sempie & 22.000 & 22.001 & 22.002 & 22.003 & 22.004 & 22.005 & 22.006 & 22.007 & 22.008 \\
\hline \multicolumn{9}{|l|}{$\begin{array}{l}\text { Sampic } \\
\text { Anglysis }\end{array}$} & $Y_{z 3-2}$ \\
\hline Locstion & $\mathrm{Y}_{\mathrm{zu} \mathrm{U}-2}$ & $Y_{z t-2}$ & $Y z x-2$ & $Y_{z \mathrm{zu}-2}$ & $Y z x-2$ & $Y z \mathrm{ul}-2$ & In & $\mathrm{nm}$ & Im \\
\hline Mineral & $\ln$ & $\mathrm{Im}$ & Inm & Ilm & Ifrm & $\mathrm{Ilm}$ & & & \\
\hline $\mathrm{THO} 2$ & 46.65 & 49.71 & 47.62 & 47.85 & 47.86 & 48.94 & 49.45 & 48.68 & 48.79 \\
\hline$C \times 203$ & 0.02 & 0.05 & 0.02 & 0.00 & 0.00 & 0.00 & 0.08 & 0.00 & 0.04 \\
\hline $\mathrm{A} 2203$ & 0.53 & 0.06 & 0.53 & 0.96 & 0.05 & 0.26 & 1.38 & 0.07 & 0.04 \\
\hline$F \infty O$ & 21.82 & 28.09 & 28.70 & 25.62 & 30.04 & 33.75 & 38.22 & 27.09 & 27.29 \\
\hline $\bar{F}=203$ & 13.35 & 14.47 & 8.00 & 14.16 & 14.38 & 4.90 & 1.32 & 14.12 & 14.70 \\
\hline $\mathrm{M}=\mathrm{O}$ & 3.77 & 3.07 & 3.77 & 2.74 & 2.25 & 2.76 & 4.23 & 2.82 & 4.70 \\
\hline 180 & 1.73 & 1.13 & 1.73 & 2.24 & 1.20 & 1.40 & 1.98 & 1.17 & 1.94 \\
\hline $\mathrm{NiO}$ & 0.00 & 0.00 & 0.00 & 0.00 & 0.00 & 0.07 & 0.00 & 0.00 & 0.00 \\
\hline Totai & 87,87 & $\$, 58$ & 90,37 & 93,57 & 95,78 & 92,08 & 96,66 & 93,95 & 97,50 \\
\hline
\end{tabular}

\begin{tabular}{|c|c|c|c|c|c|c|c|c|c|}
\hline Sexpole & 22.009 & 22.010 & 22.011 & 22.012 & 23.000 & 23.001 & 23.002 & $\begin{array}{l}23.003 \\
\text { DeNking3 }\end{array}$ & 26.000 \\
\hline Arabyis & & & & & $Y_{02-3}$ & $Y z x-3$ & $Y_{z t-3}$ & $Y_{z 2 t-3}$ & You-6 \\
\hline & & & & & & & 48.45 & & \\
\hline TiO2 & 48.78 & 49.16 & 49.59 & 49.23 & 45.95 & 47.78 & 0.09 & 0.05 & $\begin{array}{l}51.40 \\
0.00\end{array}$ \\
\hline $\mathrm{C}_{2203}$ & 0.00 & 0.00 & 0.05 & 0.10 & 0.06 & 0.13 & 0.01 & 0.00 & 0.29 \\
\hline $\mathrm{A} 203$ & 0.10 & 0.14 & 0.27 & 0.15 & 0.00 & 0.00 & & 0.00 & 0.29 \\
\hline$F \infty$ & 27.66 & 28.31 & 36.58 & 22.76 & 40.68 & 40.92 & 41.37 & & 32.82 \\
\hline $8<203$ & 14.68 & 14.70 & 6.33 & 13.7 & 5.37 & 5.76 & 5.01 & 40.99 & 14.85 \\
\hline $\mathrm{N} \times \mathrm{O}$ & 6.60 & 5.23 & 4.05 & 5.74 & 1.12 & 1.01 & 1.08 & 1.07 & 0.33 \\
\hline $\mathrm{MBO}$ & 0.59 & 0.80 & 2.08 & 0.69 & 5.63 & 5.47 & 5.66 & 3.63 & 0.23 \\
\hline NiO & 0.00 & 0.02 & 0.06 & 0.07 & 0.00 & 0.01 & 0.00 & 0.00 & 0.13 \\
\hline Toust & 98,41 & 98,36 & 99,01 & 92,51 & 99,82 & 101,08 & 101,67 & 98,58 & 100,05 \\
\hline
\end{tabular}




\begin{tabular}{|c|c|c|c|c|c|}
\hline Sertaple & 26.001 & & & & \\
\hline Analysis & & Sample & $\infty 1$ & 15.001 & 15.002 \\
\hline Locetion & $Y_{\operatorname{man} 6}$ & Aratysis & & & \\
\hline \multirow[t]{2}{*}{ Minerad } & $\mathrm{Im}$ & Location & $3 R^{4}$ & YMi-S & YMats \\
\hline & & Mineral & Per & Per & Per \\
\hline $\mathrm{TiO} 2$ & 49.95 & & & & \\
\hline $\mathrm{C} 203$ & 0.08 & $\mathrm{SiO} 2$ & 0.16 & 0.16 & 0.98 \\
\hline A1203 & 1.38 & $\mathrm{THO} 2$ & 51.03 & 61.91 & 49.01 \\
\hline FeO & 22.87 & $\mathrm{~A}_{2} 2 \mathrm{O} 3$ & 0.12 & 0.11 & 0.92 \\
\hline $\mathrm{Fe} 203$ & 14.27 & $\mathrm{~F} \infty \mathrm{O}$ & 1.42 & 0.96 & 0.96 \\
\hline MnO & 4.23 & $\mathrm{Cr}_{2} \mathrm{O}_{3}$ & 0.17 & 0.03 & 0.00 \\
\hline $\mathrm{MgO}$ & 1.98 & $\mathrm{MnO}$ & 0.05 & 0.00 & 0.63 \\
\hline NiO & 0.00 & $\mathrm{NiO}$ & 0.00 & 0.07 & 0.01 \\
\hline \multirow[t]{7}{*}{ Toxal } & 94,76 & $\mathrm{MBO}$ & 0.27 & 0.06 & 0.23 \\
\hline & & $\mathrm{CrO}$ & 31.22 & 22.44 & 18.92 \\
\hline & & $\mathrm{Na} 2 \mathrm{O}$ & 1.72 & 0.20 & 0.14 \\
\hline & & $\mathrm{K} 2 \mathrm{O}$ & 0.13 & 0.02 & 0.12 \\
\hline & & $\mathrm{B} \times \mathrm{O}$ & 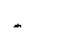 & 0.18 & - \\
\hline & & Sro & - & 0.29 & - \\
\hline & & REE & - & . & - \\
\hline
\end{tabular}




\section{A9}

Composição química, em porcentagem em peso, de carbonatos e turmalinas de rochas "lamprofíricas" do Paraguai.

(car, CAR, tur)

"Lamprofiros"

$Y$ mi-1 (10.000-10.007=carbonato), (10.002-10.043=turmalina);

Yzu-6 (26.000-26.002=carbonato)

"Lamproltos"

20.00-20.41 = turmalinas (tirados de Fipke, 1994). 


\begin{tabular}{|c|c|c|c|c|c|c|c|c|}
\hline Somple & 10.000 & 10.001 & 10.002 & 10.003 & 10.004 & 10.005 & 10.006 & 10.007 \\
\hline Mineral & $\cos$ & $\begin{array}{l}Y M I-1-\infty \\
C\end{array}$ & $\begin{array}{l}Y M 1-l-d \\
C\end{array}$ & $\begin{array}{l}Y M I-1-\alpha \\
c a\end{array}$ & $\begin{array}{l}\text { Min-i-ph } \\
c a r\end{array}$ & $\begin{array}{l}Y \mathrm{M} 1=1-\mathrm{d} \\
\mathrm{cos}\end{array}$ & Cas & $\cos$ \\
\hline $\mathrm{SiO} 2$ & 0.08 & 0.61 & 0.11 & 0.08 & 0.19 & 0.13 & 0.11 & 3.37 \\
\hline 100 & 21.10 & 21.37 & 22.96 & 21.48 & 0,13 & 25.52 & 23.46 & 22.44 \\
\hline $\mathrm{M}$ ino & 0.60 & 0.42 & 0.83 & 0.69 & 0.84 & 1.12 & 0.78 & 0.98 \\
\hline $\mathrm{M} 8 \mathrm{O}$ & 31.94 & 31.78 & 30.87 & 32.24 & 0.79 & 26.19 & 27.89 & 27.89 \\
\hline SrO & 0.00 & 0.00 & 0.00 & 0.00 & 0.00 & 0.00 & 0.00 & 0.00 \\
\hline $\mathrm{C} \infty$ & 0.52 & 0.41 & 0.53 & 0.48 & 58.28 & 1.63 & 0.57 & 1.53 \\
\hline $\mathrm{Na} 2 \mathrm{O}$ & 0.08 & 0.03 & 0.04 & 0.00 & 0.11 & 0.05 & 0.00 & 0.13 \\
\hline $\mathrm{K} 20$ & 0.00 & 0.04 & 0.00 & 0.01 & 0.03 & 0.03 & 0.03 & 0.00 \\
\hline P205 & 0.00 & 0.00 & 0.00 & 0.00 & 0.00 & 0.00 & 0.00 & 0.00 \\
\hline $\mathrm{SO3}$ & 0.00 & 0.00 & 0.00 & 0.00 & 0.00 & 0.00 & 0.00 & 0.00 \\
\hline $\mathrm{F}$ & $0 . \infty$ & 0.00 & 0.00 & 0.00 & 0.00 & 0.00 & 0.00 & 0.00 \\
\hline $\mathrm{Cl}$ & 0.00 & 0.00 & 0.00 & 0.00 & 0.00 & 0.00 & 0.00 & 0.00 \\
\hline Tatb! & 54,32 & 54,66 & $55,3 / 4$ & 54,98 & 60,37 & 54,67 & 52,84 & 56,34 \\
\hline
\end{tabular}

\begin{tabular}{|c|c|c|c|}
\hline Saxnple & 26.000 & 25.001 & 26.002 \\
\hline Analysis & & mig. & $\mathrm{C} / \mathrm{tog}$ \\
\hline Locertion & YZU-6 & YZU-6 & $x Z v-6$ \\
\hline Minaral & CAR & CAR & CAR \\
\hline $\mathrm{SiO} 2$ & 0.05 & 0.03 & 0.13 \\
\hline$F \infty$ & 0.69 & 4.93 & 0.08 \\
\hline MnO & 1.17 & 0.66 & 0.01 \\
\hline $\mathrm{M} 8 \mathrm{O}$ & 1.12 & 17.07 & 0.28 \\
\hline 350 & 0.00 & 0.00 & 0.00 \\
\hline$\infty$ & 53.39 & 29.87 & 55.82 \\
\hline $\mathrm{Na} 2 \mathrm{O}$ & 0.00 & 0.00 & 0.01 \\
\hline$x 20$ & 0.02 & 0.00 & 0.18 \\
\hline P2OS & 0.00 & 0.00 & 0.00 \\
\hline$s a$ & 0.00 & 0.00 & 0.00 \\
\hline $\boldsymbol{F}$ & 0.00 & 0.00 & 0.00 \\
\hline $\mathrm{Cl}$ & 0.00 & 0.00 & 0.00 \\
\hline Totoi & 56,46 & 5256 & 56,52 \\
\hline
\end{tabular}




\begin{tabular}{|c|c|c|c|c|c|c|c|c|c|}
\hline Sample & 10.002 & 10.013 & 10024 & 10.027 & 10.029 & 10.030 & $10.03 i$ & 10.032 & 10033 \\
\hline Aralysis & 173 & & & & & 102 & 102 & 502 & 302 \\
\hline Locaxion & $\mathrm{YM}-1$ & YMI-I & YMa-1 & YMI-1 & YMA- & YMO-1 & $Y M N-1$ & $\mathrm{YMI}-1$ & YMI-3 \\
\hline Mineral & tur & torr & เต็ & tor & tur & tar & tor & tors & tur \\
\hline $\mathrm{SiO} 2$ & 36.86 & 36.21 & 37.47 & 35.55 & 34.65 & 36.35 & 35.31 & 35.94 & 34.06 \\
\hline $\mathrm{THO}_{2}$ & 0.44 & 0.00 & 0.23 & 0.23 & 0.65 & 0.85 & 0.68 & 0.15 & 0.89 \\
\hline $\mathrm{Al} 2 \mathrm{O}^{3}$ & 32.64 & 20.03 & 37.34 & 36.69 & 31.55 & 31.89 & 33.84 & 36.06 & 34.87 \\
\hline $\mathrm{C}: 203$ & 0.05 & 0.00 & 0.00 & 0.04 & 0.00 & 0.03 & 0.01 & 0.00 & 0.00 \\
\hline $\mathrm{F} \times 0$ & 8.84 & 21.34 & 3.86 & 14.14 & 13.31 & 8.47 & 8.56 & 8.46 & 18.12 \\
\hline $\mathrm{MnO}$ & 0.11 & 0.72 & 0.00 & 0.27 & 0.12 & 0.00 & 0.03 & 0.05 & 0.06 \\
\hline $\mathrm{MgO}$ & 6.42 & 1.9 & 6.67 & 0.95 & 3.89 & 6.66 & 5.41 & 4.46 & 2.84 \\
\hline$B \infty O$ & 0.00 & 0.00 & 0.14 & 0.00 & 0.00 & 0.03 & 0.01 & $0 . \infty$ & 0.00 \\
\hline $\mathrm{CoO}$ & 0.53 & 0.78 & 0.23 & 0.08 & 0.36 & 0.56 & $0.2 \xi$ & 0.06 & 0.19 \\
\hline $\mathrm{Na} 2 \mathrm{O}$ & 1.91 & 0.08 & 1.39 & 1.72 & 2.25 & 2.08 & 2.02 & 1.57 & 1.75 \\
\hline $\mathrm{x} 2 \mathrm{O}$ & 0.06 & 0.02 & 0.03 & 0.03 & 0.04 & 0.03 & 0.03 & 0.02 & 0.05 \\
\hline$F$ & 0.00 & 0.00 & 0.00 & 0.00 & 0.00 & 0.00 & 0.00 & 0.00 & 0.00 \\
\hline $\mathrm{Cl}$ & 0.00 & 0.00 & 0.00 & 0.00 & 0.00 & 0.00 & 0.00 & 0.00 & 0.00 \\
\hline $\mathrm{H} 2 \mathrm{O}$ & 0.00 & 0.00 & 0.00 & 0.00 & 0.00 & 0.00 & 0.00 & 0.00 & 0.00 \\
\hline Total & 87,86 & 81,08 & 87.36 & 89.70 & 86,82 & 86,95 & 86,11 & 86,77 & 85,83 \\
\hline Sampie & 10.034 & 10.035 & 10.036 & 10.037 & 10.038 & 10.039 & 10.040 & 10.041 & 10.042 \\
\hline Analysis & $\mathrm{J02}$ & 502 & 502 & $\mathrm{~J} 02$ & 102 & 502 & 302 & 502 & 102 \\
\hline Location & YMI-1 & YMI-1 & YMA-1 & YMA-1 & $Y M A-1$ & YMI-1 & YMI-1 & YMI-1 & YM-1 \\
\hline Minteras & bur & tur & thrs & torr & tor & מ⿰氵 & tur & tur & $\operatorname{tar}$ \\
\hline $\mathrm{SiOZ}$ & 34.46 & 35.41 & 35.36 & 34.50 & 35.98 & 35.72 & 33.75 & 34.91 & 35.37 \\
\hline $\mathrm{TiO2}$ & 0.25 & 0.68 & 0.26 & 0.64 & 0.49 & 0.29 & 1.04 & 0.70 & 0.65 \\
\hline $\mathrm{A} 203$ & 35.35 & 33.74 & 34.51 & 34.45 & 34.78 & 35.39 & 33.53 & 34.54 & 34.20 \\
\hline$C 2203$ & 0.00 & 0.00 & 0.01 & 0.00 & 0.03 & 0.03 & 0.01 & 0.00 & 0.00 \\
\hline FeO & 11.37 & 10.47 & 12.93 & 12.38 & 10.12 & 11.75 & 11.28 & 13.08 & 9.75 \\
\hline MinO & 0.10 & 0.14 & 0.23 & 0.01 & 0.13 & 0.17 & 0.11 & 0.10 & 0.05 \\
\hline 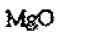 & 2.65 & 3.87 & 2.31 & 2.81 & 3.58 & 2.26 & 3.65 & 1.88 & 4.54 \\
\hline $\mathrm{BeO}$ & 0.02 & 0.00 & 0.06 & 0.10 & 0.00 & 0.00 & 0.02 & 0.00 & 0.00 \\
\hline $\mathrm{Cos}$ & 0.11 & 0.15 & 0.12 & 0.15 & 0.18 & 0.11 & 0.45 & 0.14 & 0.31 \\
\hline $\mathrm{Ne2O}$ & 1.51 & 1.94 & 2000 & 1.85 & 1.7 & 1.64 & 2.00 & 1.63 & 1.97 \\
\hline$x 20$ & 0.05 & 0.05 & 0.04 & 0.02 & 0.03 & 0.03 & 0.05 & 0.04 & 0.01 \\
\hline $\bar{z}$ & 0.00 & 0.00 & 0.00 & 0.00 & 0.00 & 0.00 & 0.00 & 0.00 & 0.00 \\
\hline $\mathrm{Ci}$ & 0.00 & 0.00 & 0.00 & 0.00 & 0.00 & 0.00 & 0.00 & 0.00 & 0.00 \\
\hline 320 & 0.00 & 0.00 & 0.00 & 0.00 & 0.00 & 0.00 & 0.00 & 0.00 & 0.00 \\
\hline Tosel & 85,87 & 86,45 & 87,83 & $86,9 ?$ & 87,03 & 87,39 & 85,89 & 87,02 & 26,85 \\
\hline
\end{tabular}




\begin{tabular}{|c|c|c|c|c|c|c|c|c|c|}
\hline Semple & 10.043 & 20.00 & 20.01 & 20.02 & 20.03 & 20.034 & 20.035 & 20.040 & 20.041 \\
\hline $\begin{array}{l}\text { Aralysis } \\
\text { Location }\end{array}$ & 302 & & & & & & & SK & SK \\
\hline $\begin{array}{l}\text { Location } \\
\text { Mineral }\end{array}$ & YMI-I & AK! & AKI & AKI & $\mathrm{AKK}$ & AK! & AK1 & SK & SR \\
\hline Mirietal & tart & tor & tur & tur & tars & tur & sart & tur & turs \\
\hline $\mathrm{SiO} 2$ & 36.01 & 35.82 & 34.99 & 34.87 & 34.90 & 35.43 & 35.03 & 35.59 & 34.61 \\
\hline TiO2 & 0.41 & 0.95 & 1.04 & 0.90 & 0.70 & 0.24 & 0.99 & 0.11 & $0.8 \mathrm{I}$ \\
\hline $\mathrm{Al} 203$ & 34.25 & 33.44 & 33.22 & 33.93 & 33.74 & 34.56 & 33.03 & 34.57 & 32.64 \\
\hline $\mathrm{Cr} 203$ & 0.02 & 0.00 & 0.00 & 0.00 & 0.00 & 0.00 & 0.00 & 0.00 & 0.00 \\
\hline$F \in O$ & 9.52 & 7.36 & 9.57 & 7.68 & 9.54 & 10.17 & 8.12 & 11.15 & 12.15 \\
\hline $\mathrm{MnO}$ & 0.08 & 0.02 & $0 . \infty$ & 0.02 & 0.10 & 0.05 & 0.02 & 0.02 & 0.09 \\
\hline $\mathrm{M} 8 \mathrm{C}$ & 4.47 & 5.82 & 4.26 & 5.44 & 4.08 & 3.06 & 4.76 & 2.69 & 3.06 \\
\hline $\mathrm{B} \approx \mathrm{O}$ & 0.00 & 0.00 & 0.00 & 0.00 & 0.00 & 0,00 & 0.00 & 0.00 & 0.00 \\
\hline$C \approx$ & 0.36 & 0.80 & 0.62 & 0.70 & 0.41 & 0.15 & 0.59 & 0.05 & 0.51 \\
\hline $\mathrm{N} 22 \mathrm{O}$ & 1.82 & 1.79 & 1.86 & 1.83 & 1.92 & 1.61 & 1.75 & 1.52 & 1.91 \\
\hline $\mathrm{K} 20$ & 0.04 & 0.06 & 0.05 & 0.04 & 0.04 & 0.04 & 0.04 & 0.02 & 0.05 \\
\hline$F$ & 0.00 & 0.00 & 0.00 & 0.00 & 0.00 & 0.00 & 0.00 & $0 . \infty 0$ & 0.00 \\
\hline $\mathrm{Cl}$ & 0.00 & 0.00 & 0.00 & 0.00 & 0.00 & 0.00 & 0.00 & 0.00 & 0.00 \\
\hline $\mathrm{H} 2 \mathrm{O}$ & 0.00 & $0 . \infty 0$ & 0.00 & 0.00 & 0.00 & 0.00 & 0.00 & 0.00 & 0.00 \\
\hline Totel & 86.78 & 86.06 & 85,61 & 85,41 & 85,43 & 85,31 & 84,33 & 85,72 & 85,83 \\
\hline
\end{tabular}




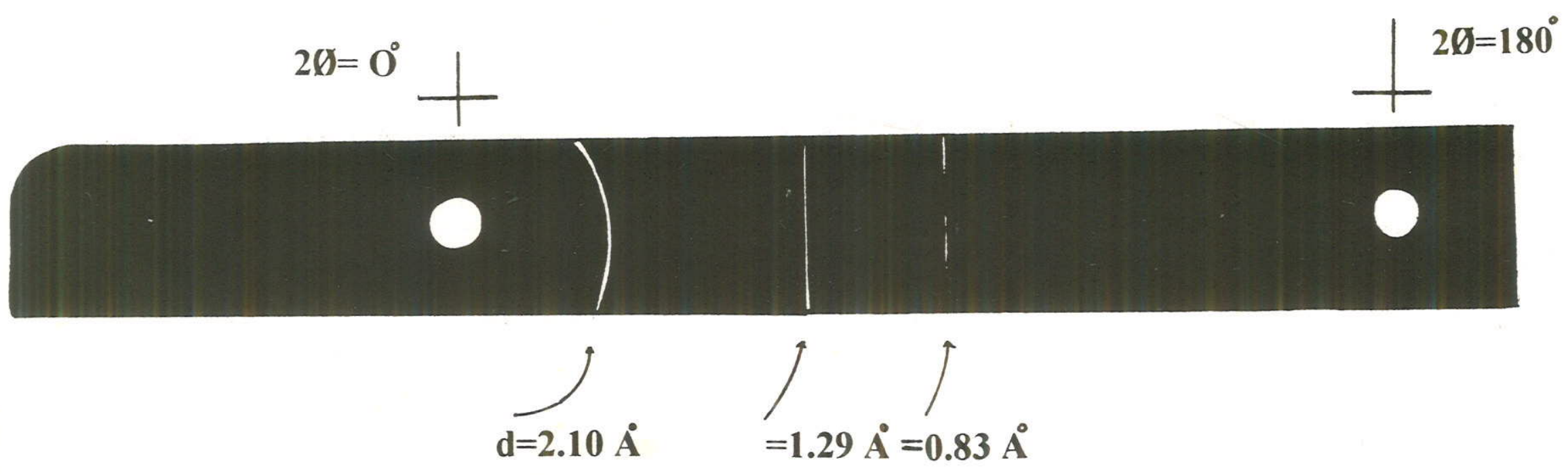

Apêndice 10. Difratograma de raios $\mathrm{X}$ de um cristal de diamante do pipe Ymi-1. Câmara de Gandolfi, radiação CuK $\alpha$ e filtro de Ni por $2+$ horas de exposição. 